BIRDS

OF

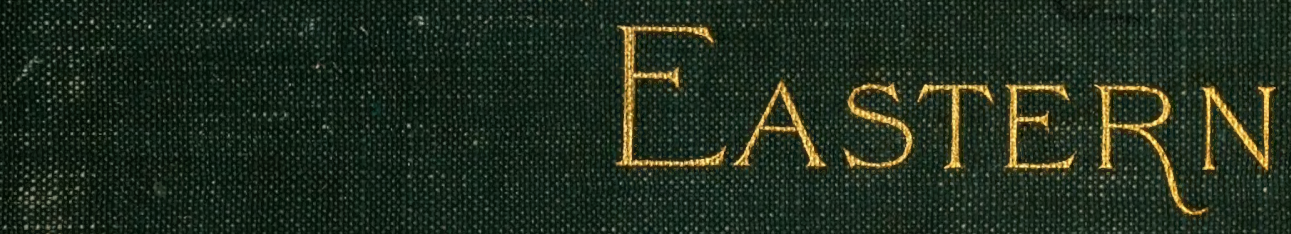

North America

FRANK M. CHAPMAN 



$$
\text { A - Z }
$$

Harvey Riley, 7 alls b hurch, fet. 12, 1896 fa 






PLATE I.

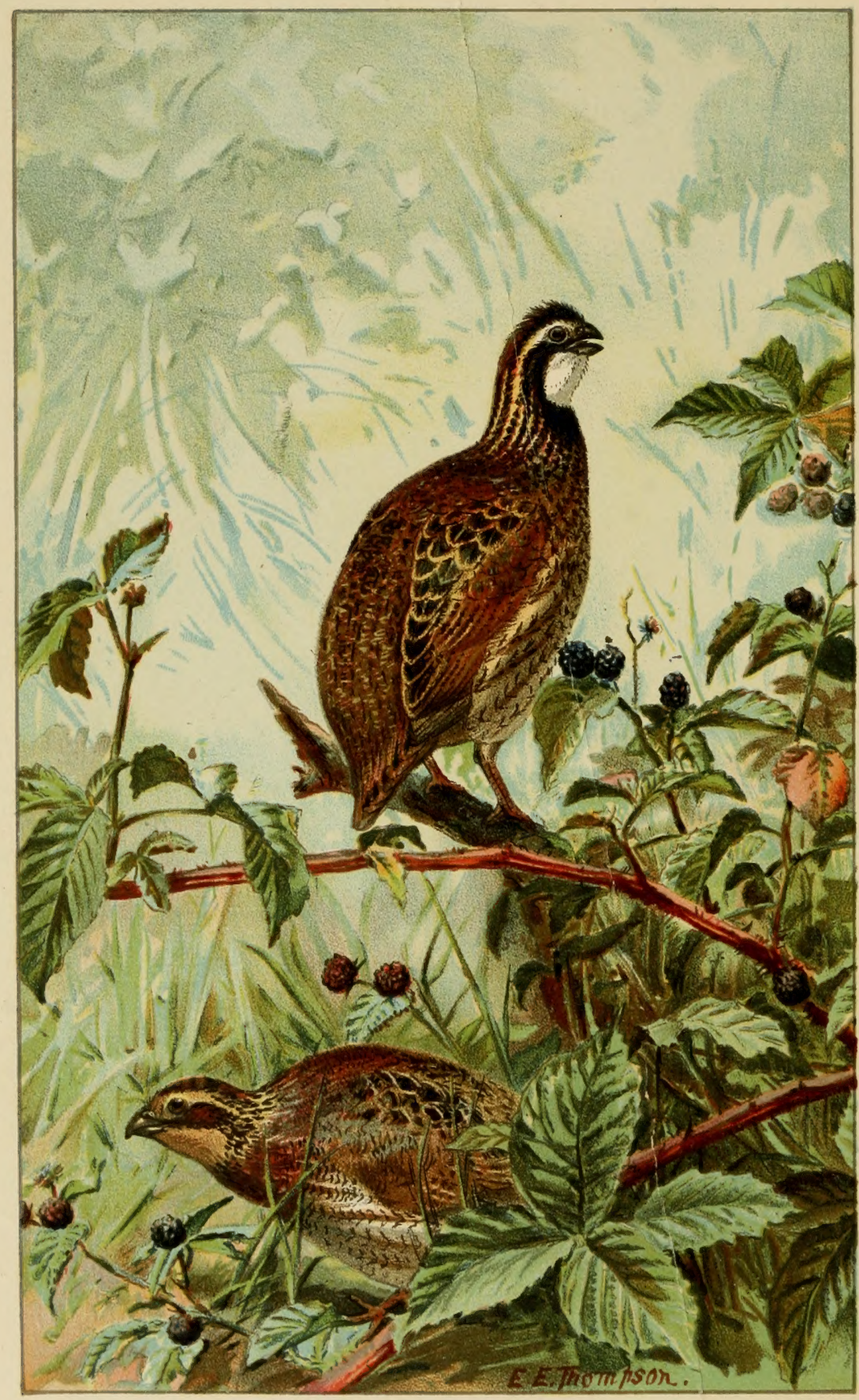




\section{HANDBOOK OF BIRDS}

\section{OF EASTERN NORTH AMERICA}

WITH KEYS TO THE SPECIES

AND DESCRIPTIONS OF THEIR PLUMAGES, NESTS, AND EGGS

THEIR DISTRIBUTION AND MIGRATIONS

AND A BRIEF ACCOUNT OF THEIR HAUNTS AND HABITS

WITH INTRODUCTORY CHAPTERS ON THE

STUDY OF ORNITHOLOGY, HOW TO IDENTIFY BIRDS

AND HOW TO COLLECT AND PRESERVE BIRDS

THEIR NESTS, AND EGGS

\section{BY \\ FRANK M. CHAPMAN}

ASSISTANT CURATOR OF THE DEPARTMENT OF MAMMALOGY AND ORNITHOLOGY IN THE AMERICAN MUSEUM OF NATURAL HISTORY, NEW YORK CITY; MEMBER OF THE AMERICAN ORNITHOLOGISTS' UNION, ETC.

WITH FULL-PAGE PLATES IN COLORS AND BLACK AND WHITE AND UPIVARD OF ONE HUNDRED AND FIFTY CUTS

IN THE TEXT

THIRD EDITION

$$
269450
$$

NEW YORK

D. APPLETON AND COMPANY

I 896 
CoPYRight, 1895 ,

BY D. APPLETON AND COMPANY. 


\section{TO MY MOTHER}

WHO HAS EVER ENCOURAGED HER SON IN HIS NATURAL HISTORY STUDIES

THIS BOOK IS AFFECTIONATELY DEDICATED 



\section{P R E F A C E.}

IF this book had been written in the last century it might have been entitled "Ornithology made Simple, or How to Identify Birds with Ease, Certainty, and Dispatch." It may be unworthy so comprehensive a title, nevertheless I have made an honest endeavor to write a book on birds so free from technicalities that it would be intelligible without reference to a glossary, and I have tried to do this in a volume which could be taken afield in the pocket.

I have not addressed an imaginary audience, nor have I given my prospective readers what, theoretically, I thought they ought to have, but what personal experience with students of birds has led me to believe would meet their wants.

The preparation of this work has firmly convinced me that the poet would have been nearer the truth had he written "One touch of nature makes the whole world kind." In the suceeding pages I have attempted to express my appreciation of the assistance which naturalist friends and associates have generously given me, but here I desire to especially thank Miss Florence A. Merriam, Dr. J. A. Allen, and Mr. Ernest E. Thompson for much valuable criticism and advice.

Frank M. Cuaphan.

American Museum of Natural History,

NEW YoRk CiTY, January, 1895. 



\section{CONTENTS.}

PAGE

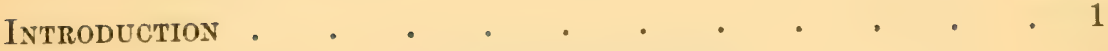

Cimapter 1.-The Study of Ornithology . . . . . 1

Systematic Ornithology • • . • . . . . 2

Philosophic Ornithology . . . . . . . 3

Economic Ornithology . • . . . . . . 6

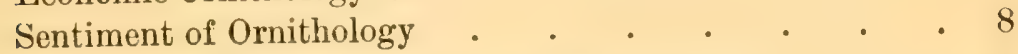

Chapter II.-The Study of Birds Out-of-Doors . • . 10

How to Identify Birds . . . . . . . 10

How to Find Birds . . . . . . . . 11

When to Find Birds . . . . . . . 12

Tables of Migration . . . . . . . . . 15

The Nesting Season . . . . . . . . 1!

Note-books and Journals . . . . . . . 20

Chapter III.-Collecting Birds, their Nests, and Eggs • 23

Collecting Birds . • . . . . . . . 23

Making Birdskins. . . . . . . . 24

Sexing Birds . . . . . . . . . 27

Cataloguing and Labeling . . . . . . . . 28

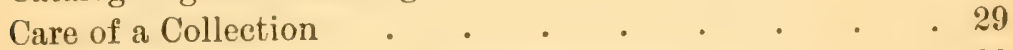

Collecting and Preserving Nests and Eggs . . . . 29

PlaN OF THE WORK. . . . . . . . 32

Nomenclature adopted . . . . . . . 32

Definition of 'Terms . . . . . . . 32

The Key to Families . . . . . . 32

The Keys to Species . . . . . . . . 34

Measurements . . . . . . 37

Range . . . . . . 37

Biographies . . . . . . . 38

Illustrations . . . . . . . . 39

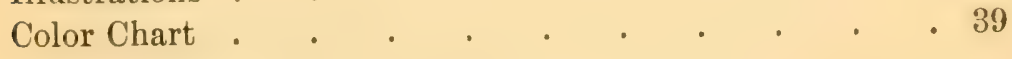

List of AbBreviations . . . . . . . . . 40 
THE BIRDS OF NORTH AMERICA EAST OF THE NINETIETH MERIDIAN • . • . . . . . 41

Key to Orders and Families . . . . . . . 41

I. Order Pygopodes: Diving Birds . . . . . 56

1. Family Podicipidx: Grebes . . . . . 56

2. Family Urinatoridæ: Loons . . . . . 58

3. Family Alcidæ: Auks, Murres, and Puffins . . 60

II. Order Longipennes: Long-winged Swimaiers . . 65

4. Family Stercorariidæ: Skuas and Jaegers . . . 65

5. Family Laridæ: Gulls and Terns . . . . 67

6. Rynchopida: Skimmers . . . . . . 85

III. Order Tubinares: Tube-nosed Swimmers . . . 86

7. Family Diomedeidæ: Albatrosses . . . . 86

8. Procellariidæ: Petrels, Fulmars, and Shearwaters . 86

IV: Order Streganopodes: Totipalmate Swimmers • . 91

9. Family Phaëthontidæ: Tropic Birds . . . . 91

10. Family Sulidæ: Gannets . . . . . . 92

11. Family Anhingidæ: Darters . . . . . 93

12. Family Phalacrocoracidæ: Cormorants . . . 94

13. Family Pelecanidæ: Pelicans . . . . . 95

14. Family Fregatidæ: Man-o'-War Birds . . . . 97

V. Order Anseres: Lamellirostral Swimmers • . 97

15. Family Anatidæ: Ducks, Geese, and Swans . 97

VI. Order Odontoglosse : Lamellirostral Grallatores . 125

16. Family Phœenicopteridæ: Flamingoes . . . 125

VII. Order Herodiones: Herons, Storks, Ibises, etc. . . 125

17. Family Plataleidæ: Spoonbills . . . . . 125

18. Family Ibididæ: Ibises . • • • • . 126

19. Family Ciconiidæ: Storks and Wood Ibises . . 127

20. Family Ardeidæ: Herons, Egrets, and Bitterns 128

Vili. Order Paludicolaz: Cranes, Rails, etc. • • . 137

21. Family Gruidæ: Cranes . . . . . . 137

22. Family Aramidæ: Courlans . . . • . 138

23. Family Rallidæ: Rails, Gallinules, and Coots • . 139

IX. Order Limicol : Shore Birds . . . . . 147

24. Family Phalaropodidæ: Phalaropes . . . . 147

25. Family Recurvirostridæ: Stilts and Avocets . . 149

26. Family Scolopacidæ: Snipes, Sandpipers, etc. . . 150 
27. Family Charadriidæ: Plovers . . . . . 171

28. Family Aphrizida: Turnstones, etc. . . . . 176

29. Family Hæmatopodidæ: Oyster-catchers . . . 177

X. Order Galline: Gallinaceous Birds . . . . 1:9

30. Family Tetraonidæ: Grouse, Bob-whites, etc. . . 178

31. Family Phasianidæ: Pheasants, etc. . . . 185

XI. Order Columbe: Pigeons and Doves . . . . 187

32. Family Columbidx : Pigeons and Doves . . . 187

XII. Order Raptores: Birds of Prey . • . . . . 191

33. Family Cathartidæ: American Vultures . . . 191

34. Family Falconidæ: Falcons, Hawks, Eagles, etc. 193

35. Family Strigidæ: Barn Owls • . . . . 213

36. Family Bubonidæ: Horned Owls, Hoot Owls . . 213

Xili. Order Psittaci : Parrots, Macaws, Paroquets, etc. . 222

37. Family Psittacidæ: Parrots and Paroquets . . 222

XIV. Order Coccyges: Guckoos, Kingfishers, etc. . . 224

38. Family Cuculidæ: Cuckoos . . . . . 224

39. Family Alcedinidæ: Kingfishers . . . . 226

XV. Order Pici: Woodpeckers, Wrynecks, etc. . . . 227

40. Family Picidx: Woodpeckers . . . . . 227

XVi. Order Macrochires: Goatsuckers, Hummingbirds,

SWIFTS, ETC. .

41. Family Caprimulgidie: Nighthawks, Whip-poor-

wills, etc. • . • • • . • . . . 236

42. Family Micropodidæ: Swifts . . . . . 239

43. Family Trochilidæ: Hummingbirds . . . . 240

XVII. Order Passeres: Perching Birds . . . . . 24 ?

44. Family Tyrannidæ: Flycatchers . . . . 242

45. Family Alaudidæ: Larks . . . . . . 252

46. Family Corvidæ: Crows and Jays . . . . . 253

47. Family Sturnidæ: Starlings . . . . . 259

48. Family Icteridx: Blackbirds, Orioles, etc. . . 260

49. Family Fringillidæ: Finches, Sparrows, etc. . . 271

50. Family Tanagridæ: Tanagers . . . . . . 316

51. Family Hirundinidæ: Swallows . . . . 318

52. Family Ampelidæ: Waxwings . . . . . . 323

53. Family Laniidæ: Shrikes . . . . . . 325

54. Family Vireonidæ: Vireos . . . . . . 327

55. Family Mniotiltidæ: Wood Warblers . . . 383 
56. Family Motacillidae : Wagtails and Pipits

57. Family Troglodytidæ: Thrashers, Wrens, etc. . . 37f

58. Family Certhiidæ: Creepers . . . . . 35.j

59. Family Paridæ: Nuthatches and Titmice. . . 85;

60. Family Sylvidie: Kinglets and Gnateatehers . . 991

61. Family Turdidie: Thrushes, Bluebirds, etc. . . . 394

Appexdis: A Field Key to our Commriner Eastern Taard Birds . 404 List of Prixcipal Works Referred to . . . . . 411

INDEX . . . . . . . . . • • . 41j 


\title{
IAT DE ILLTSTRATIOSE.
}

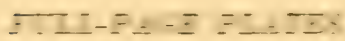

E. $=0 \times 100$

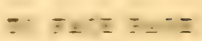

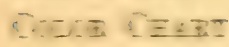

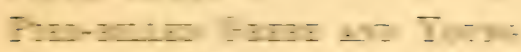

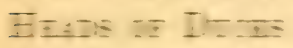

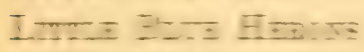

Cratzes Bur

Whande art Twos

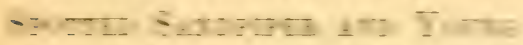

Burse Gevese an Tures.

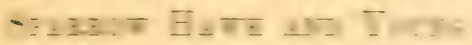

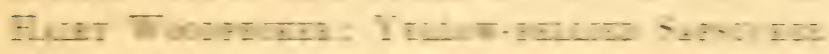

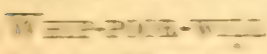

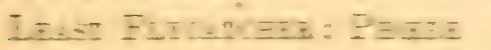

Bis:-

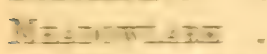

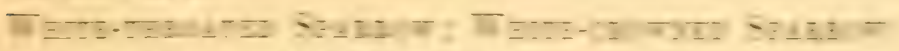

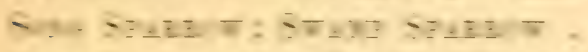

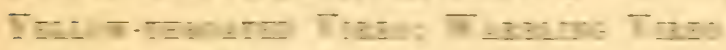

L.

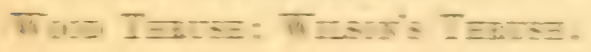

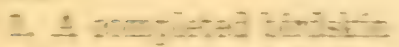

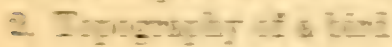

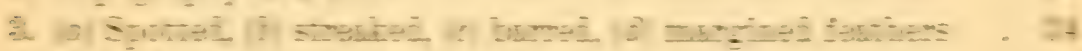

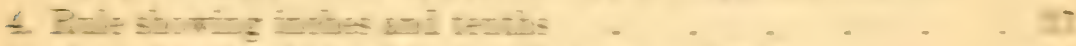

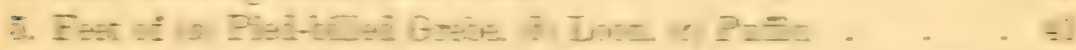

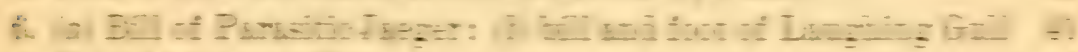

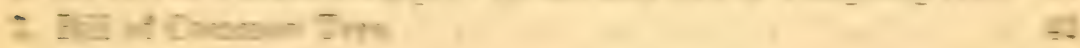

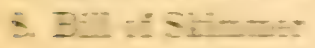


9. (a) Bill and foot of Black-footed Albatross; (b) bill and foot of Fulmar

10. Foot of Cormorant

11. Bill of Yellow-billed Tropic Bird

12. Bill of Gannet .

13. Bill of Anhinga

14. Bill of Cormorant

15. Bill of Man-o'-War Bird

16. Bill of Merganser . . . . . . . . . 4 44

17. (a) Bill and foot of Mallard; (b) foot of Canvasback . . 44

18. Bill of Flamingo . . . . . . . . . 45

19. Bill and toe-nail of Little Green Heron . . . . . 45

20. Bill of White Ibis . . . . . . . . . 45

21. Bill of Roseate Spoonbill . . . . . . . . 45

22. (a) Bill and foot of Clapper Rail : bills of (b) Yellow Rail, (c) Sora, (d) Florida Gallinule; (e) bill and foot of Coot . 46

23. Bill of Sandhill Crane . . . . . . . . 46

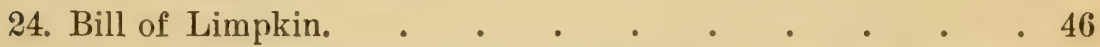

25. Bills of (a) Dowitcher, (b) Knot, (c) Black-bellied Plover, (d) Semipalmated Plover . . . . . . . 47

26. Feet of (a) Red Phalarope, (b) Knot, (c) Dowitcher. (d) Black-

bellied Plover, (e) Semipalmated Plover . . . . 47

27. Bill of Ruffed Grouse . . . . . . . . . . . 48

28. Bill of Wild Pigeon . . . . . . . . . . 48

29. Feet of (a) Barred Owl, (b) Red-shouldered Hawk . . 48

30. Head of Barn Owl . . . . . . . . . . 48

31. Head of Barred Owl. . . . . . . . . 48

32. Head of Turkey Vulture . . . . . . . . . 49

33. Head of Red-shouldered Hawk . . . . • . 49

34. Bill and foot of Carolina Paroquet . . . . . . 49

35. Bill and foot of Belted Kingfisher . . . • . . 49

36. Bill and foot of Yellow-billed Cuckoo . . . . . 49

37. (a) Bill and foot of Hairy Woodpecker, $(b)$ foot of Arctic

Three-toed Woodpecker . . . . . . . 50

38. Bill and foot of Nighthawk . . . . . . . 50

39. Bill and tail-feather of Chimney Swift . . . . . 50

40. Bill of Hummingbird . . . . . . . . 50

41. Foot of Robin . . . . . . . . . . 51

42. Bill and wing of Phøebe . . . . . . . . . 51

43. Bill and hind-toe of Horned Lark . . . . . . 51

44. (a) Bill and wing of Blue Jay, $(b)$ bill of Crow _ . . 51

45. Bill and wing of Starling . . . . . . . . 52 
46. (a) Bill and wing of Baltimore Oriole; bills of (b) Meadowlark, (c) Purple Grackle . . . . . . . 52

47. Bills of $(a)$ Cardinal, (b) Pine Grosbeak, (c) Purple Finch, $(d)$ Red Crossbill, $(e)$ Seaside Finch, $(f)$ Goldfinch . . 52

48. Bill of Scarlet Tanager . . . . . . . . 52

49. Bill and foot of Cliff Swallow . . . . . . . 53

50. Head of Cedar Waxwing . . . . . . . . 53

51. Bill of Loggerhead Shrike . . . _ . . . . 53

52. Bill of Blue-headed Vireo . . . . . . . 53

53. (a) Bill of Tennessee Warbler; (b) bill, wing, and hind-toe of Pine Warbler; bills of $(c)$ Redstart, $(d)$ Water-Thrush; (e) Chat . . . . . . . . . . . 53

54. Bill and hind-toe of American Pipit . . . . 54

50. (a) Bill of Brown Thrasher, (b) bill and wing of Catbird; bills of $(c)$ Carolina Wren, $(d)$ House Wren. . . . 54

56. Bill and tail of Brown Creeper. . . . . . . 54

57. (a) Bill of White-breasted Nuthatch, $(b)$ bill and wing of Chickadee . . . . . . . . . .

58. (a) Bill and wing of Golden-crowned Kinglet, $(b)$ bill of Blue Gray Gnatcatcher . . . . . . . . . 55

59. ( $a$ ) Bill of Robin, $(b)$ bill and wing of Bluebird . . . 55

60. First primaries of $(a)$ American Herring Gull, $(b)$ Ring-billed Gull, (c) Laughing Gull, $(d)$ Franklin's Gull, $(e)$ Bonaparte's Gull . . . . . . . . . .

61. First primaries of ( $a$ ) Caspian Tern, (b) Royal Tern, (c) Common Tern, $(d)$ Aretic Tern, $(e)$ Royal Tern . . . . 78

62. Head of Least Sandpiper . . . . . . . 4160

63. Head of Red-backed Sandpiper . . . . . . . 161

64. Wing of Solitary Sandpiper . . . . . . . . . 166

65. Head of Semipalmated Plover . . . . . . . . . 174

66. Head of Wilson's Plover . . . . . . . . . 176

67. Tail of Sharp-shinned Hawk . . . . . . . . . . 198

68. Tail of Cooper's Hawk . . . . . . . . . . 199

69. Primaries of Red-shouldered Hawk. • . . . . 202

70. Primaries of Broad-winged Hawk . . . . . . 204

71. Foot of Golden Eagle . . . . . . . . . 206

72. Foot of Bald Eagle . . . . . . . . . 207

73. 'Tail-feathers of Yellow-billed Cuckoo . . . . . . 225

74. Tail-feathers of Black-billed Cuckoo . . . • . . 226

75. Head of Crested Flycatcher . . . . . . . . 245

76. Head of Prairie Horned Lark . . . . . . . . 253

77. Head of Cowbird . . . . . . . . . . 262 
78. Head of Orchard Oriole . . . . . . . . . 267

79. Head of Purple Finch . . . . . . . . . 281

80. Head of Redpoll . . . . . . . . . . 285

81. Hind-toe of Lapland Longspur . . . . . . . . 289

82. Tail-feathers of Vesper Sparrow . . . . . . . . 290

83. Tail of Grasshopper Sparrow . . . . . . . . 293

84. Head of Seaside Sparrow . . . . . . . . . . 297

85. Head of Lark Sparrow . . . . . . . . . 299

86. Head of Chipping Sparrow . . . . . . . . . . . . . . 302

87. Head of Fox Sparrow . . . . . . . . . . . . . . . . . . . .

88. Head of Dickcissel . . . . . . . . . . 315

89. Barn, Cliff, Tree, and Bank Swallows . . . . . . 318

90. Section of primary of Rough-winged Swallow . . . 323

91. Head of Red-eyed Vireo . . . . . . . . 328

92. Wing of Warbling Vireo . . . . . . . . . . 329

93. Head of Black and White Warbler . . . . . . . 351

94. Head of Worm-eating Warbler . . . . . . . 351

95. Head of Blue-winged Warbler . . . . . . . . 351

96. Head of Golden-winged Warbler . . . . . . . 351

97. Head of Parula Warbler . . . . . . . . . 351

98. Head of Myrtle Warbler . . . . . . . . . 351

99. Head of Magnolia Warbler . . . . . . . 351

100. Head of Chestnut-sided Warbler . . . . . . 351

101. Black-throated Blue Warbler . . . . . . . 354

102. Head of Black-poll Warbler . . . . . . . . . . . 366

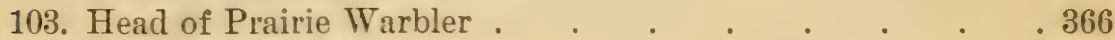

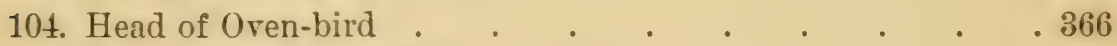

105. Head of Kentucky Warbler . . . . . . . . 366

106. Head of Maryland Yellow-throat . . . . . . . . . . . . . . . . .

107. Head of Wilson's Warbler . . . . . . . . 366

108. Head of Hooded Warbler. . . . . . . . . . 366

109. Head of Canadian Warbler . . . . . . . . . 366

110. Head of Yellow-breasted Chat . . . . . . . 372

111. Head of Short-billed Marsh Wren . . . . . . 383

112. Head of Long-billed Marsh Wren . . . . . . 344

113. Head of Red-breasted Nuthatch . . . . . . 38s

114. Head of Tufted Titmouse. . . . . . . . . . 389

115. Head of Golden-cromned Kinglet . . . . . . . 392 


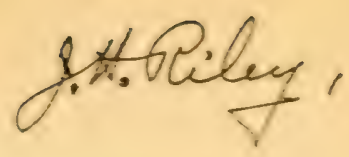

\title{
A HANDBOOK OF THE \\ BIRDS OF EASTERN NORTH AMERICA.
}

\author{
INTRODUCTION.
}

\author{
CHAPIER I. \\ THE STLDY OF ORITTHOLOGT.
}

Brads, hecause of their beauty, the charm of their songs, and the Ease with whiwh they mas be obserred. are dhubtless the foms of animal life which first atract the poung naturalist $s$ attention. His interest in them gires eridence of an inborn lore of Xature. Too often this priceless gift is lnst simply through lach of encouragement and instruotion. Properly leveloped it should ywre a never-failing snurce of nleasure and inspiration, if indech its influence does not become the most potent factor in our lires.

Let us hope that the lay is nut distunt when the impurtance of introducing natural-histary stulise into sur schonls will he generally recngnized. The young student of Xature will then be helpol over the rerelling technicalities which ruder so difficult the first steps to a knowledge of his chusen subject. Withunt a guile he now either Inses his way empletely or travels unler disalvantages whiwh handicap him for the whole journer.

The uninstruoted beginner in ornitholopy usually expends his enercies in forming a wollection, and he knows no beter way of pursuine hi- stuly of birls than to kill and stuff them! Collecting srecimens is a step in the scientifis study of hinls. but omithology would have small chaim to our consderation if its posibiliticesnded here. Properly considerd, it inelules what mat be termel the science of ormitholog! and the sentiment of ornithology. As a science it treats of

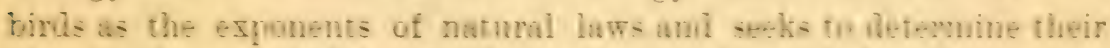
place in the scale wi life. In the sontiment of ornithology Name apreals to us through the mot interesting and beutiful of her onimate forms. 
The Science of Ornithology. - The science of ornithology may be divided into three branches-systematic, philnsophic, and economic. The systematist aims to classify birds according to what are apparently their true relationships. He is the ornithological storekeeper, and having taken an account of stock it is his duty to keep the books of the firm in order. The philosophic ornithologist accepts as a fact the statement of affairs given him by his fellow-worker the systematist, and tries to explain the wherefore and why. He is a seeker of causes. The economist is of a more practical turn of mind. He is impressed by the incalculable influence which birds exert over our agricultural interests, and the necessity for learning with exactness whether this influence is for good or evil. But let us describe these three departments of scientific ornithology more fully.

Systematic Ornithology.-The first step in the scientific study of any group of animals is to name and classify them. Orders, families, genera, species, and subspecies are to be described and arranged in what appears to be the most natural manner. Thus all the Perching Birds, for example, are placed in the order Passeres, and this order is divided into numerous families-for instance, the Thrushes or family Turdida. But how are we to know which are Perching Birds and which of the Perching Birds are Thrushes? The systematist answers, by studying a bird's structure. Generally speaking, orders and families are based on skeletal, muscular, and visceral characters which may be termed internal characters. Genera are based on the form of bill, feet, wings, and tail, or on external characters. while species and subspecies are based mainly on color and size. Thus all the members of a family or order agree more or less in their principal internal characters: those of a genus agree in external characters, and the individuals of a species or subspecies resemble one another in color and size.

The object of classification is to aid us in understanding not alone the relationships of one bird to another bird, or of one family or order of birds to another family or order, or even of living to extinct birds, but also to assist us in explaining the relationships of all the classes of the animal and regetable kingdoms-mammals, birds, reptiles, fishes-and thus down the scale to the lowest forms of life.

This systematic study of the relationships of birds has taught us that they have been evolved from reptilian ancestors. There is much evidence in support of this fact, but the most conclusive is furnished by the discovery in the lithographic slate of Solenhofen. Bavaria, of several specimens of a remarkable fossil, a reptilelike bird, which has been named Archceopteryx lithographica. It is the earliest known direct progenitor of the great class Aves. 
The importance of systematic classification is also shown in the necessity of naming objects before we can study them to advantage. As the alphabet is the foundation of a written language, so this great series of scientific names, which appears so formidable to the student, is the groundwork for all ornithological research.

Philosophic Ornithology.-Having learned the alphabet of ornithology, we may pass from the systematic to the philosophic study of birds; from the study of dead birds to that of living ones. A study of specimens shows their relationships through structure, but a study of the living bird in its haunts may tell us the cause of structure. In classifying birds we have taken note of their form and coloration; our object now is to determine how these characters were acquired.

As Prof. E. S. Morse has said, "There is no group of animals which exceeds birds in varied and suggestive material for the evolutionist." Compare a Hummingbird with an Ostrich, a Swallow with a Penguin, and the enormous variation in the structure and habits of birds is bronght very forcibly to our minds. When we remember that these widely divergent types descended from a reptilian ancestor, we are impressed anew with the truth of Prof. Morse's remark.

A brief review of the more important branches of philosophic ornithology will show how rich a field is open to the student of birds. They are: (1) 'The origin of birds and their place in Nature; $(2)$ their distribution in time and space, and the influences which determine their present ranges; $\uparrow$ (3) the migration of birds, its origin. object, extent, and mauner; $\ddagger$ (4) the nesting of birds, including a study of the significance of sexual differences in form, color, and voice, the location and construction of the nest, the number and color of the eggs, together with the habits of birds during the entire nesting season; (5) the effect

* See Newton's Dictionary of Birds (London : Adam and Charles Black, 1893) ; articles, "Anatomy of Birds" and "Fossil Birds" ; Coues's Key to N. A. Birds.

† Read The Geographical Distribution of North American Mammals, by J. A. Allen, Bull. Am. Mus. Nat. Hist., iv, 1892, pp. 199-241; four maps. The Geographical Origin and Distribution of North American Birds, considered in Relation to Faunal Areas of North America, by J. A. Allen, The Auk, x, 1893, pp. $97-150$; two maps. The Geographic Distribution of Life in North America with Special Reference to the Mammalia, by C. Hart Merriam, M. D., Proc. of the Biological Soc. of Washington, vii, 1892, pp. 1-64; one map. Laws of Temperature Control, by Dr. C. Hart Merriam, Nat. Geog. Mag., vi, 1894, pp. 229-238 ; three maps.

$\ddagger$ On this subject read articles by the following authors: J. A. Allen, Scribner's Magazine, xxii, 1881, pp. 932-938 ; Bull. Nuttall Orn. Club, v, 1880, pp. 151154 ; Scott, ibid.. vi, 1881. pp. $97-100$; Brewster, Memoirs Nuttall Orn. Club (Camhridge, Mass.), No. 1, pp. 22; Cooke and Merriam, Bird Migration in the Mississippi Valley (Washington. 1888) ; Chapman, Auk, v, 1888, pp. 37-39; xi, 1894, pp. 12-17 ; Loomis, Auk, ix, 1892, pp. 28-39 ; xi, 1894, pp. 26-39, 94-117 ; Stone, Birds of E. Penn. and N. J., Bird Migration, pp. 15-28. 
of climate upon the color and size of birds ;* (6) the relation of a bird's color to its haunts and habits. $\nmid$ Besides these general subjects which enter into our study of the life-history of every bird, we have the special instances of intelligent adaptation to changed conditions of life, and, most interesting of all, the relation between structure and habits, or the part played by a bird's habits in determining the form of its bill, feet, wings, and tail. Thus the Crook-billed Plover of New Zealand turns over or probes under stones and shells in search of food, not because its crooked bill makes an excellent lever or probe, but it has acquired a crooked bill through this habit. Again, the Gallinules of certain islands in southern seas are flightless, not because their wings are too small to support them, but because after having flown to these islands they had no further use for wings, which in time, through disuse, became so small that the birds have lost the power of flight. In other words, it is not because their wings are small that they do not fly, but because they do not fly their wings are small.

But to enlarge upon these problems which confront the philosophic ornithologist would require a volume. It is important, however, that the student should have in the beginning at least a general idea of the effect of climate on the size and color of birds and the migration of birds. The first is well illustrated by our Bob-white or Quail. In New England, at the northern limit of its range, it is a fine, large bird with a light-brown back and a white breast narrowly barred with black. As we proceed southward it becomes smaller, the brown is of a deeper shade, the black bars of greater extent. Finally, when we have reached the humid region of southern Florida, the minimum in size is attained, the back is dark, rich chestnut barred with black, and the breast is almost wholly black. No one who compared this small, dark Florida Quail with the large, pale Quail of New England would consider them the same species. But on examining a series of Quails from all the Atlantic States one sees how gradually this change in color and decrease in size occurs, and that nowhere would it be possible to draw a line separating the two extremes. They are species in process of formation still connected by a chain of natural links.

Ornithology presents many similar cases. They illustrate two laws in the evolution of animals-decrease in size southward and greater

* Read Part III of Dr. J. A. Allen's Mammals and Winter Birds of East Florida, Bull. Mus. Comp. Zoöl., vol. ii, No. 3. Cambridge, 1871.

† Consult Poulton's Colors of Animals (D. Appleton \& Co., 1890) ; Beddard's Animal Coloration (Macmillan \& Co.) ; Keeler's Evolution of the Colors of North American Land-birds (Occasional Papers of California Academy of Sciences, iii, 1893) ; also reviews of last two works in The Auk, x, 1893, pp. 189199, 373-380. 
intensity of color in regions of greatest rainfall. They are thus evidences of an evolution so recent that we can assign its cause.

In nomenclature these partly formed species are termed subspecies or races. Under the trinomial system they are distinguished by a third name: thus Colinus virginianus floridanus is a subspecies or race of Colinus virginianus. But if through any change in the earth's surface the regions occupied by the large, light Quail and the small, dark one should be separated, the intermediates would disappear and instead of a race or subspecies we would have a full species-Colinus floridanus.

The Nigration of Birds.-Certain insects, fishes, and mammals migrate, but no animals compare with birds in the extent of their migrations. Some birds nest within the Aretic Circle and winter in the southern parts of the southern hemisphere, performing this journey of thousands of miles year after year and returning to their summer or winter haunts with marvelous certainty and regularity.

Not only is the migration of birds an interesting subject in itself, but the almost constant changes it causes in the bird-life of the same region gives an interest to the study of ornithology which is erer renewed with the changing seasons. Indeed, to the lover of Nature birds are a living calendar. "What was that sound that came on the softened air? It was the warble of the Bluebird from the scraggy orchard yonder. When this is heard, then has spring arrived."

A discussion of the origin of bird migration will be found in the books and papers on this subject to which reference has been given. Here it is possible only to outline its principal features as they exist to-day. Generally speaking, birds migrate at the approach of winter, in search of food. The reason why they leave a land of plenty in the tropics and follow the fontsteps of retreating winter to nest in the comparatively barren north is as yet not satisfactorily explained.

As a rule, the extent of a bird's migration depends upon the nature of its foorl. Insect-eating birds are forced to extend their migrations much farther than the seed-eaters, many of which are permanent residents at their place of birth. The land-birds of the Western States winter in Mexico. A few cross the Isthmus of Tehuantepee into Central America, but practically no species cross the Isthmus of Panama. Our Eastern birds have a longer and more perilous journey to perform. They leave the mainland by way of Florida, and some species find congenial winter haunts in the West Indies or Central America, while others go as far south as the Argentine Republic.

Birds of strong flight, like Swallows, can easily escape from birdkilling Hawks, and so migrate boldly by day. But the shy, retiring inhabitants of woods and thickets await the coming of darkness, and 
then, mounting high in the air, pursue their journey under cover of the night. Birds direct their flight by coast lines and river valley's which are easily distinguishable in clear weather. On favorable nights these natural highways of migration are thronged by a continuous stream of aërial voyagers passing from dusk until dawn.

Looking through a telescope at the moon, one may see numbers of birds cross its glowing surface. From such observations it is computed that migrating birds fly at a height of from one to three miles.

The eyesight of birds is so far superior to ours that we do not realize its value to them while migrating. The height at which they fly gives them command of a wide range of country. and on clear nights they can undoubtedly distinguish its prominent features with ease. But when fogs or clouds obscure these landmarks, they lose their way. It is then that lighthouses prove beacons luring them to destruction. The Bartholdi Statue, at the mouth of the Hudson River, is directly in the path of the great streams of migrants which flow up and down this natural highway of migration, and for this reason is particularly destructive to birds which travel at night. On one occasion after a storm no less than fourteen hundred birds were picked up at its base, haring been killed by striking the statue or pedestal upon which it rests.

But while sight is of the first importance to the older and more experienced birds who know the way, young birds, who are making the journey for the first time, doubtless rely on their hearing to guide them. Birds' ears are exceedingly acute. 'They readily detect sounds which to us would be inaudible. Almost invariably they respond to an imitation of their notes, and, when under way, frequently chirp and call. When we consider their power of hearing and their abundance in routes of migration, it seems probable that at no time during the night is a bird beyond the hearing of his fellow-travelers. The line of flight once established, therefore, by the older birds, who leave first, it becomes a comparatively easy matter for the younger birds to join the throng.

Economic Ornithology.-This branch of the study of ornithology treats of the relationships of bird to man from the standpoint of dollars and cents. Civilized man is Nature's worst enemy. He is a disturbing element whose presence is a constant menace to the balance of life. It is of the utmost importance, therefore, that we should acquaint ourselves with the conditions which make a true equilibrium and endeavor to sustain them when it proves to our advantage to do so.

The disastrous results which have followed man's introduction of the English or House Sparrow in America, the mongoose in the West 
Indies, and the rabbit in Australia, clearly show that our attempts to improve upon Nature must be directed, not by haphazard methods, but by knowledge gained through a careful study of Nature"s laws.

Few persons realize the value of birds to man. They are the natural check upon the increase of insect life. Consider the incalculable number of insects destroyed by the birds which pass the greater part of each day hunting through our lawns, orchards, fields, and woods for the pests that destroy regetation. Of almost equal importance are the birds of prey whose food consists largely of the small rodents which are among the farmer's worst enemies. Indeed. it is not too much to say that without birds the earth would not long be habitable.

As yet we are on the threshold of an exact knowledge of the ralue of birds to man; but let us cite one easily demonstrable case where ignorance of birds' habits resulted in direct pecuniary loss. Quoting from the report for 1886 of Dr. C. Hart Merriam, Ornithologist and Marnmalogist of the United States Department of Agriculture: "On the 2:3d of June, 1885, the Legislature of Pennsylrania passed an act known as the 'scalp act,' ostensibly 'for the benefit of agriculture,' which provides a bounty of fifty cents each on hawks, owls, weasels, and minks killed within the limits of the State, and a fee of twenty cents to the notary or justice taking the affidarit.

"By rirtue of this act about $\$ 90,000$ has iseen paid in bounties during the year and a half that has elaysed since the law went into effect. This represents the destruction of at least $128,5 \% 1$ of the abore-mentioned animals, most of which were hawks and owls.

"Granting that 5,000 chickens are killed annually in Pennsylvania by hawks and owls, and that they are worth twenty-fire cents each (a liberal estimate in view of the fact that a large proportion of them are killed when rery young), the total loss would be 1.250 , and the poultry killed in a year and a half would be worth \$1.8\%. Hence it appears that during the past eighteen months the State of Pennsrltania has spended $\$ 90,000$ to save its farmers a loss of $\$ 1, \$ 75$. But this estimate by no means represents the actual loss to the farmer and the taxpayer of the State. It is within bounds to say that in the course of a sear every hawk and owl destroys at least a thousand mice or their equivalent in insects, and that each mouse or its equiralent so destroyed would cause the farmer a loss of two cents per annum. Therefore, omitting all reference to the enormous increase in the numbers of these noxious animals when Nature's means of holding them in check has been remored, the lowest possible estimate of the ralue to the farmer of each hawk, owl, and weasel would be $\$ 20$ a year, or $\$ 30$ in a year and a half. 
"Hence, in addition to the $\$ 90,000$ actually expended by the State in destroying 128,571 of its benefactors, it has incurred a loss to its agricultural interests of at least $\$ 3,857,130$, or a total loss of $\$ 3,947,130$ in a year and a half, which is at the rate of $2,631,420$ per annum. In other words, the State has thrown away $\$ 2,105$ for every dollar saved! And even this does not represent fairly the full loss, for the slaughter of such a vast number of predaceous birds and mammals is almost certain to be followed by a correspondingly enormous increase in the numbers of mice and insects formerly held in check by them, and it will take many years to restore the balance thus blindly destroyed through ignorance of the economic relations of our common birds and mammals."

To their credit be it said, the legislators of Pennsylvania were not slow to recognize the error which a lack of proper information had caused them to make. A State ornithologist was appointed, and through his efforts this ruinous and absurd law was repealed.

In 1893 the Division of Economic Ornithology and Mammalogy of the Department of Agriculture issued a report upon the food of the Hawks and Owls of the United States based upon the examination of the contents of 2,690 stomachs. It proves conclusively the value of most of these misjudged birds to the agriculturist. It is needless to draw a comparison between legislation based upon information derived from such reports and that based solely on ignorant prejudices.

The Sentiment of Ornithology.-We may accept as true Prof. Morse's estimate of the value of birds to the scientist; we need not question their importance in the economics of Nature, but we are still far from recognizing the possibilities of their influence upon our lives. An inherent love of birds is an undeniable psychological fact which finds its most frequent expression in the general fondness for cagebirds. If we can learn to regard the birds of the woorls and fields with all the affection we lavish on our poor captives in their gilded homes, what an inexhaustible store of enjoyment is ours!

It is not alone the beauty, power of song, or intelligence of birds which attract us, it is their human attributes. Man exhibits hardly a trait which he will not find reflected in the life of a bird. Love, hate; courage, fear; anger, pleasure ; vanity, modesty; virtue, vice ; constancy, fickleness : generosity, selfishness; wit, curiosity, memory, reason-we may find them all exhibited in the lives of birds. Birds have thus become symbolic of certain human characteristics, and the more common species are so interwoven in our art and literature that by name at least they are known to all of us. Shakespeare makes uver six hundred references to birds or bird-life. If we should rob 
Wordsworth's verses of their birds, how sadly mutilated what remained would be!

But why leave a knowledge of birds to poets and naturalists? Go yourself to the field and learn that birds do not exist solely in books, but are concrete, sentient beings, whose acquaintance may bring you more unalloyed happiness than the wealth of the Indies. John Burroughs understands this when he writes of the study of birds: "There is a fascination about it quite overpowering. It fits so well with other things-with fishing, hunting, farming, walking, camping out-with all that takes one to the fields and woods. One may go a blackberrying and make some rare discovery; or while driving his cow to pasture, hear a new song, or make a new observation. Secrets lurk on all sides. There is news in every bush. What no man ever saw before may the next moment be revealed to you. What a new interest the woods have! How you long to explore every nook and corner of them!"

II uman friends may pass beyond our ken, but our list of acquaintances in the bird world increases to the end and shows no vacancies. The marsh the Blackbirds loved may become the site of a factory, but no event on the calendar is more certain than that in due time and place we shall hear the tinkling chorus of the epauleted minstrels rising and falling on the crisp morning air.

". . . Time may come when never more

The wilderness shall hear the lion roar;

But, long as cock shall crow from household perch

To rouse the dawn, soft gales shall speed thy wing,

And thy erratic voice be faithful to the spring!"

The woods of our youth may disappear, but the Thrushes will always sing for us, and their roices, endeared by cherished associations, arouse echoes of a hundred songs and awaken memories befcre which the years will vanish. 


\section{CHAPTER II.}

\section{THE STUDY OF BIRDS OUT-OF-DOORS.}

How to Identify Birds.- Whether your object be to study birds as a scientist or simply as a lover of Nature, the first step is the sameyou must learn to know them. This problem of identification has been given up in despair by many would-be ornithologists. We can neither pick, press, net, nor impale birds; and here the botanist and the entomologist have a distinct advantage. Even if we have the desire to resort to a gun its use is not always possible. But with patience and practice the identification of birds is a comparatively easy matter, and in the end you will name them with surprising ease and certainty. There is generally more character in the flight of a bird than there is in the gait of a man. Both are frequently inclescribable but perfectly diagnostic, and you learn to recognize bird friends as you do human ones-by experience.

If you confine your studies to one locality, probably not more than one third of the species described in this volume will come within the field of your observation. To aid you in learning which species should be included in this third, the paragraphs on Range are followed by a statement of the bird's standing at Washington, D. C., Sing Sing, N. Y., and Cambridge, Mass., while the water-birds of Long Island are treated specially. Take the list of birds from the point nearest your home as an index of those you may expect to find. This may be abridged for a given season by considering the times of the year at which a bird is present.*

* It is sometimes possible to secure a list of birds of your own vicinity. These "local lists" are generally published in scientific journals, but one may frequently secure a copy of the author's edition. On this subject correspond with L. S. Foster, 35 Pine Street, New York city. Among the local lists of eastern birds which were issued as separate publications and are now for sale are-

1. A Catalogue of the Birds of the Virginias, by WVm. C. Rives, M. A., M. D. Proc. Newport [R. I.] Nat. Hist. Soc., Document VII. 1890, 8vo, pp. 100, one map, 305 species.

2. The Birds of Eastern Pennsylvania and New Jersey, with Introductory 
After this slight preparation you may take to the field with a much clearer understanding of the situation. 'Two quite different ways of identifying birds are open to you. Either you may shoot them, or study them through a field- or opera-glass. A "bird in the hand" is a definite object whose structure and color can be studied to such advantage that in most cases you will afterward recognize it at sight. After learning the names of its parts, its identity is simply a question of keys and descriptions.

If you would "name the birds without a gun," by all means first visit a museum, and, with text-book in hand, study those species which you have previously found are to be looked for near your home. This preliminary introduction will serve to ripen your acquaintance in the field. A good field- or opera-glass is absolutely indispensable. A strong opera-glass with a large eye-piece is most useful in the woods, while a field-glass is more serviceable in observing water-birds. Study your bird as closely as circumstances will permit, and write on the spot a comparative description of its size, the shape of its bill, tail, etc., and a detailed description of its colors. In describing form take a Robin, Chipping Sparrow, or any bird you know, which best serves the purpose, as a basis for comparison. A bird's bill is generally its most diagnostic external character. A sketch of it in your note-book wili frequently give you a good clew to its owner's family. It is of the ntmost importance that this description should be written in the field. Not only do our memories sometimes deceive us, but we really see nothing with exactness until we attempt to describe it. Haunts, actions, and notes should also be carefully recorded. This account is your "bird in the hand," and while you can not hope to identify it as easily as you could a specimen, you will rarely fail to learn its name, and experience will render each attempt less difficult than the preceding.

How to Find Birds.-The best times of the day in which to look for birds are early morning and late afternoon. After a night of fasting and resting, birds are active and hungry. When their appetites are satisfied they rest quietly until afternoon, hunger again sending them forth in search of food.

Chapters on Geographical Distribution and Migration, prepared under the Direction of the Delaware Valley Ornithological Club, by Witmer Stone, Conservator Ornithological Section Academy of Natural Sciences of Philadelphia. 8vo, pp. 185 , two diagrams, two maps, 352 species. Price, $\$ 1$.

3. An Annotated List of the Birds known to occur within Fifty Miles of New York City, by Frank M. Chapman. Published by the American Museum of Natural History, New York city, as a guide to its collection of local birds. 8vo, pp. 100, 36 cuts, 4 full-page plates, 348 species. For sale at the Museum. Price, 15 cents. 
Experience will soon show you the places where birds are most abundant. The more varied the nature of the country the greater number of species you may expect to find inhabiting it. An ideal lucality would be a bit of tree-dotted meadow with a reed-hordered pond or stream, surrounded by woods, rolling uplands, and orchards.

Common sense will tell you how to act in the field. Birds are generally shy creatures and must be approached with caution. You must not, therefore, go observing or collecting dressed in flaming red, but in some inconspicuous garb and as quietly as a cat. Furthermore, go alone and keep the sun at your back-two apparently unrelated but equally important bits of advice.

The collector generally has the instincts of a hunter, and practice will develop them. The "squeak" is one of his most valuable aids. It is made by placing the lips to the back of the hand or finger and kissing vigorously. The sound produced bears some resemblance to the cries of a wounded or young bird. In the nesting season its utterance frequently creates much excitement in the bird world, and at all times it is useful as a means of drawing bush- or reed-haunting species from their retreats. One may enter an apparently deserted thicket, and, after a few minutes' squeaking, find himself surrounded by an anxious or curious group of its feathered inhabitants.

The observer of birds will find that by far the best way to study their habits is to take a sheltered seat in some favored locality and become a part of the background. Your passage through the woods is generally attended by sufficient noise to warn birds of your coming long before you see them. They are then suspicious and ill at ease. But secrete yoursèlf near some spot loved by birds, and it may be your privilege to learn the secrets of the forest.

When to Find Birds.-During the year the bird-life of temperate and boreal regions fluctuates with the changing seasons. Birds may thus be classed in the following groups according to the manner of their occurrence: Permanent residents are birds found in one locality throughout the year. Summer residents come from the south in the spring, rear their young, and leave in the fall. Winter visitants come from the north in the fall, pass the winter, and leave in the spring. Transient visitants pass through a given place in migrating to and from their summer homes north of it. Accidental visitants are birds which have lost their way. They are generally young and inexperienced, and are usually found in the fall.

The best time of the year to begin studying birds is in the winter, when the bird population of temperate regions is at the minimum. The problem of identification is thus reduced to its simplest terms, and should be mastered before spring introđuces new elements. 
The commoner permanent residents of the middle Eastern States are the following:

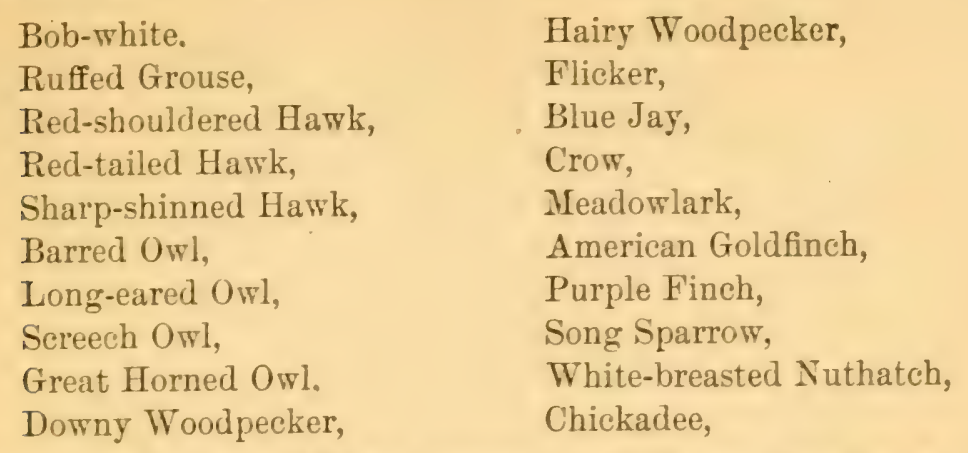

and occasionally the Waswing, Bluebird, and Robin pass the winter. To these should be added the following more or less common winter visitant land-birds :

$\begin{array}{ll}\text { Saw-whet Owl, } & \text { Tree Sparrow, } \\ \text { Horned Lark, } & \text { Junco, } \\ \text { Snowflake, } & \text { Northern Shrike, } \\ \text { Lapland Longspur, } & \text { Winter Wren, } \\ \text { Redpoll, } & \text { Golden-clowned Kinglet, } \\ \text { American Crossbill, } & \text { Brown Creeper. } \\ \text { White-throated Sparrow, } & \end{array}$

Let us now begin with the opening of the spring migration and briefly review the ornithological year. In the vicinity of New York city the first birus arrive from the south late in February or early in March. There is much variation in the coming of these early birds. Later, when the weather is more settled, migrants arrive within a few dars of a given date. In April most of our winter risitants leave for the north. The current of migration grows steadily stronger until ahout May 12 , when high-water mark is reached. Then it rapidly subsides and the spring migration is practically over by June 1 . The winter risitants have gone. the great army of transients has prassed us, and our bird propulation is now composed of permanent residents with the addition of about ninety summer residents.

Nesting-time has arrived, and birds which for nearly a sear have been free to go and come as inclination directed. now have homes where, day after day, they may be found in tireless attendance upon the nest and its treasures. Courtship, the cronstruction of a dwelling, the task of incubation. ant care of the young, all tend to stimulate the characteristic traits of the bird, and at no other time can its habits be studied to better adrantage.

But resident birds begin building long before the migration is con- 
cluded. The Great Horned Owl lays in February, other birds in March and April; still, the height of the breeding season is not reached until June 1.

Another period in the arian year closely connected with the spring migration and nesting-time is the song season. Near New York city it is inaugurated late in February by the Song Sparrow. Voice after voice is added to the choir, and in June our woods and fields ring with the chorus so dear to lovers of Nature. By the middle of July it is on the wane, and early in August it is practically over. Some birds have a brief second song season in the fall, but as a rule it lasts only a few days-it is a farewell to their sumner homes.*

August is a most discouraging month to the student of birds. Birds leave their accustomed haunts and retire to secluded places to renew their worn plumages. They are silent and inactive, and therefore difficult to find. Late in the month they reappear clad in traveling costumes and ready for their southern journey. One by one they leave us, and there are days late in August and early in September when the woods are almost deserted of birds. Later the fall migration becomes continuous, and each night brings a host of new arrivals.

The spring migration is scarcely concluded before the fall migration begins. July 1, 'Tree Swallows, which rarely nest near New York city, appear in numbers from the north and gather in immense flocks in our marshes. Later in the month they are joined by Bobolinks. Early in August the careful observer will detect occasional small flights of Warblers passing southward, and by September 10 the great southern march of the birds is well under way; it reaches its height between the 20th and last of the month, when most of the winter residents arrive, and from this time our bird-life rapidly decreases. Some of the seed-and berry-eaters remain until driven southward by the cold weather in December. When they have gone our bird population is again reduced to the ever-present permanent residents and hardy winter visitants.

The appended tables graphically illustrate the rise and fall of the migrations and of the nesting season. The first is based on my own observations at Englewood, N. J., kindly revised and supplemented by Mr. Eugene P. Bicknell from extended observations at Riverdale, on the opposite side of the Hudson River.

The second was compiled from data accompanying the collections of the American Museum of Natural History.

* See a series of papers by Mr. E. P. Bicknell entitled "A Study of the Singing of our Birds." The Auk, i, 1884, pp. 60- $11,126-140,209-218,322-332$; ii, 1885, pp. 144-154, 249-262. 
Date of arrival.

Feb. 15-Mar. 10.

March 20-31.

April 1-10.

April 10-20.

April 20-30.

March 10-20.

\section{SPRING MIGRATION.}

Purple Grackle.

Rusty Blackbird

Date of departure.

November 1-30.

Red-winged Blackbird............. November 1-30.

Robin ...................... November 1-30.

Bluebird .................... November 1-30.

Woodeock

November 1-30.

Phobe ..................... October 20-30.

Meadowlark ................... November 1-30.

Cowbird..................... November $1-30$.

Fox Sparrow .................... April 1-15.

Wilson's Snipe................. May 1-10.

Kingtisher................... November 1-30.

Mlourning Dove................. November 1-30.

Swamp Sparrow................ November 1-30.

Field Sparrow................. November 1-30.

Great Blue Heron ............... November 1-30.

Purple Finch .................. November 1-30.

Vesper Sparrow .................. November 1-30.

Savanna Sparrow................. May 1-15.

Chipping Sparrow............... November 1-30.

Tree Swallow .................. May 15-31.

Myrtle Warbler................ May 10-20.

American Pipit ................ April 15-25.

Hermit Thrush ................ April 25-May 10.

Yellow-bellied Woodpecker......... A pril 20-30.

Barn Swallow.................. October 1-10.

Yellow Palm Warbler.............. April 25-May 10.

Pine Warbler................. May 1-10.

Louisiana Water Thrush............ September 20-30.

Ruby-erowned Kinglet............ May 1-15.

Green Heron.................. October 10-20.

Spotted Sandpiper.............. September 20-30.

Whip-poor-will................ October 10-20.

Chimney Swift................. October 1-10.

Least Flycatcher................. October 1-10.

Towhee....................... Uctober 20-30.

Blue-headed Vireo............... May 10-20.

Purple Martin ................... September 20-30.

Cliff Swallow ................. October 1-10.

Bank Swallow................. October 1-10.

Rough-winged Swallow............. September 1-10.

Black and White Warbler.......... October 1-10.

Black-throated Green Warbler........ May 15-25.

Oven-bird .................... October 1-10.

House Wren ................... October 10-20.

Brown Thrasher .............. October 10-20. 

April 20-30.

May 1-10.
May 10-20.

\section{Date of arrival.}

May $1-10$.
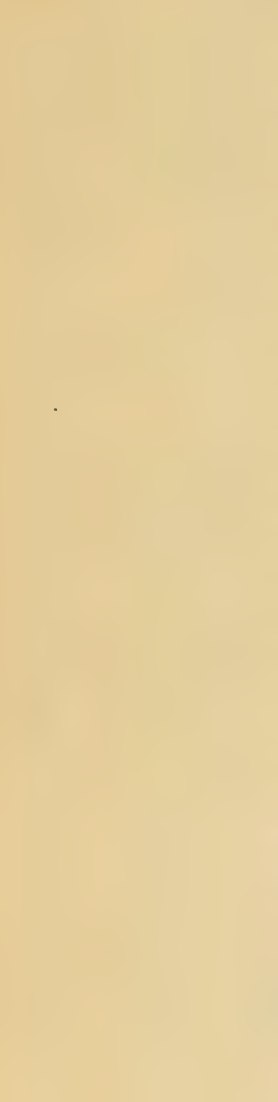

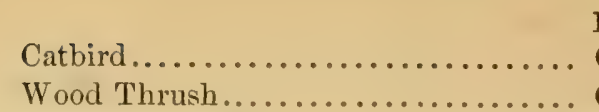

Date of departure.

Uctober 10-20.

Wood Thrush................... October 1-10.

Solitary Sandpiper............... May 15-25.

Yellow-billed Cuckoo.............. October 1-10.

Black-billed Cuckoo............... October 1-10.

Nighthawk.................. October 10-20.

Ruby-throated Hummingbird........ September 20-30.

Crested Flycatcher.............. September 20-30.

Kingbird ...................... September 20-30.

Baltimore Oriole................ September 10-20.

Orchard Oriole................... Septenber 1-10.

Bobolink...................... October 1-10.

Yellow-winged Sparrow ............. October 1-10.

Indigo Bunting................... October 1-10.

Rose-breasted Grosbeak ........... September 20-30.

Scarlet Tanager.................. October 1-10.

Red-eyed Vireo.................. October 10-20.

Warbling Vireo.................. September 20-30.

Yellow-throated Vireo............. September 20-30.

White-eyed Vireo.................. October 1-10.

Nashville Warbler.............. May 20-30.

Blue-winged Warbler ............. September 1-10.

Parula Warbler................ May 20-30.

Yellow Warbler.................. September 10-20.

Black-throated Blue Warbler........ May 15-30.

Magnolia Warbler............... May 15-30.

Chestnut-sided Warbler.......... May 20-30.

Prairie Warbler... ............ May 20-30.

Maryland Yellow-throat............. October 10-20.

Small-billed Water Thrush......... May 15-30.

Hooded Warbler................ September 20-30.

Yellow-breasted Chat............... September 10-20.

Redstart.................... October 1-10.

Wilson's Thrush................. September 20-30.

Wood Pewee..................... September 20-30.

Acadian Flycatcher ................ September 1-10.

Yellow-bellied Flycatcher .......... May 20-30.

White-crowned Sparrow ............ May 15-25.

Golden-winged Warbler........... May 15-25.

Tennessee Warbler.............. May 15-25.

Worm-eating Warbler.............. September 1-10.

Cape May Warbler................ May 15-25.

Blackburnian Warbler............. May 15-25.

Bay-breasted Warbler............ May 20-30.

Blackpoll Warbler............... May 25-June 5.

Wilson's Warbler.............. May 20-30.

Canadian Warbler............... May 25-June 5. 
Date of arrival.

May 10-20.

May 20-30.

Date of arrival. August 1-15.

August 15-31.

September 1-10.

September 10-20.

September 20-30.

October 1-10.
Long-billed Marsh Wren

Date of departure.

Short-billed Marsh Wren

Olive-backed Thrush.

October 10-20

Gray-cheeked Thrush............ May 25-June 5.

I'raill's Flycatcher................

Mourning Warbler................ May 30-June 5.

Bicknell's Thrush ...............

\section{FALL MIGRATION.}

MIGRANTS ARRIVING FROM THE NORTH.

Yellow-bellied Flycatcher...

Date of departure.

Golden-winged Warbler. September 20-30.

Chestnut-sided Warbier............. Sept. 30-Oct. 10.

Canadian Warbler................ September 20-30.

Small-billed Water T'hrush.......... Sept. 25-Oct. 5.

Olive-sided Flycatcher ............ September 10-20.

Tennessee Warbler................ Sept. 25-Oct. 5 .

Nashville Warbler............... Sept. 25-Oct. 5 .

Parula Warbler................. October 15-25.

Cape May Warbler............... Sept. 25-Oct. 5.

Black-throated Green Warbler........ October 15-25.

Black-throated Blue Warbler........ October 15-25.

Magnolia Warbler................ October 10-20.

Blackburnian Warbler............ September 20-30.

Wilson's Warbler............... September 20-30.

Canadian Nuthatch . ............ November 1-30.

Red-headed Woodpecker........... November 1-30.

Blackpoll Warbler............... October 15-25.

Connecticut Warbler............. September 20-30.

Blue-headed Vireo.............. October 15-25.

Philadelphia Vireo............... September 20-30.

Olive-backed Thrush.............. October 1-10.

Bicknell's 'Thrush................ October 1-10.

Yellow-bellied Woodpecker.......... October 20-30.

Junco ....................... April 10-\Гаy 10.

White-throated Sparrow ............ May 1-25.

Myrtle Warbler............... May $5-20$.

Yellow Palm Warbler.............. October $15-30$.

Brown Creeper.................. April 1-30.

Golden-crowned Kinglet.......... April 1-20.

Ruby-crowned Kinglet............ October 20-30.

Winter Wren.................. April 1-30.

Gray-cheeked Thrush............. October 15-25.

Bronzed Grackle................ December 1-30.

Rusty Blackbird................ December 1-30.

American Pipit.................. Oct. 25-Nov. 5. 
Date of arrival.

Oct. 1-10.

October 10-20.

Hermit Thrush

Date of departure.

October 20-31.

Fox Sparrow.

November $1-30$.

Pine Finch Nov. 25-Dec. 5.

Tree Sparrow

May 1-31.

Northern Shrike.

April 1-30.

March 1-31.

SUMMER RESIDENTS LEAVING FOR THE SOUTH.

Date of departure.

September 1-10.

Acadian Flycatcher

Orchard Oriole.

Rough-winged Swallow

Worm-eating Warbler

Blue-winged Warbler

September 10-20.

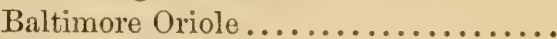

Purple Martin

Yellow Warbler.

Yellow-breasted Chat.

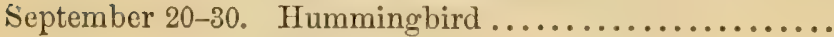

Kingbird.

Great-crested Flycatcher.............

Wood Pewee......................

Rose-breasted Grosbeak.............

Yellow-throated Vireo..............

Warbling Vireo..................

Hooded Warbler..................

Louisiana Water Thrush.............

Wilson's Thrush

October 1-10. Yellow-billed Cuckoo..............

Black-billed Cuckoo................

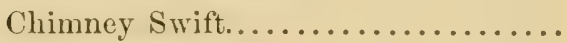

Least Flycatcher.................

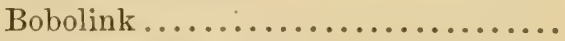

Yellow-winged sparrow .............

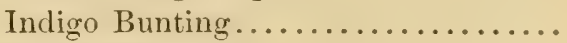

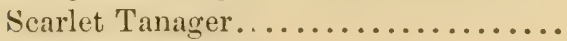

Barn Sivallow

Cliff swallow

Bank Swallow

White-eyed Vireo..................

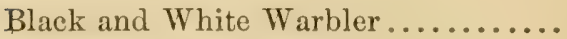

Redstart........................

Oven-bird

Wood Thrush

October 10-20. Whip-poor-will.

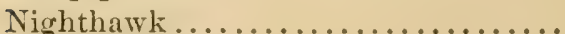

Red-eyed Vireo

Maryland Yellow-throat. 
Date of departure.

\begin{tabular}{|c|c|}
\hline Oct. $10-20$. & Long-billed Marsh Wren............ \\
\hline & Short-billed Marsh Wren............ \\
\hline & House Wren ..................... \\
\hline & Brown 'Thrasher .................. \\
\hline & 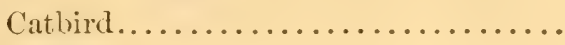 \\
\hline October $20-31$. & Phobe ...................... \\
\hline & 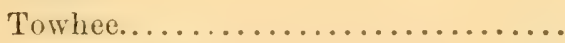 \\
\hline & Tree Swallow.................... \\
\hline November $1-30 . *$ & 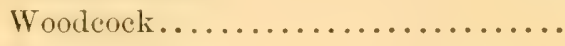 \\
\hline & 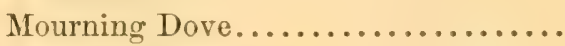 \\
\hline & 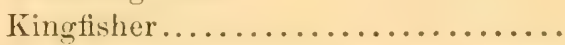 \\
\hline & Red-winged Blackbird ............ \\
\hline & Purple Grackle ................. \\
\hline & 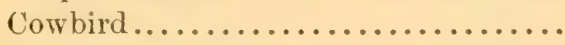 \\
\hline & Vesper Sparrow ................ \\
\hline & Field Sparrow ................ \\
\hline & Chipping Sparrow.............. \\
\hline & 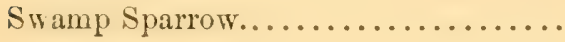 \\
\hline
\end{tabular}

\section{DATES AT WHICH BIRDS BEGIN TO NEST IN THE VICINITY OF NEW YORK CITY.}

Feb. 28. Great Horned Owl.

Mar. 12. Barred Owl.

April 1. Woodeock.

3. Screech Owl.

5. Red-shouldered Hawk.

6. Red-tailed Hawk.

9. American Crow.

9. Long-eared Owl.

10. Bluebird.

17. White-bellied Nuthatch

18. Broad-winged Hawk.

19. Duck Hawk.

20. Robin.

25. Purple Grackle.

26. Mourning Dove.

May 1. Cooper's Hawk.

2. Fish Hawk.

2. Song Sparrow.

3. Cardinal.

5. Cowbird. [In Song Sparrow's nest.]
May 5. Black-crowned Night Heron.

6. Green Heron.

6. Wood Duck.

7. Kingfisher.

8. Barn Swallow.

8. Phøbe.

10. Clapper Rail.

10. Killdeer.

10. Ruffed Grouse.

10. Sparrow Hawk.

10. Savanna Sparrow.

10. Vesper Sparrow.

11. Flicker.

11. Louisiana Water Thrush.

13. Red-headed Woodpecker.

14. Chipping Sparrow.

14. 'Towhee.

15. King Rail.

15. Virginia Rail.

15. Meadowlark.

15. Field Sparrow.

* The time of the departure of these birds varies greatly during different years. Should the season be an exceptionally mild one, many of them will remain until late in December. 
May 15. Swamp Sparrow.

18. Red-winged Blackbird.

19. Tree Swallow.

19. Bank Swallow.

19. Thrasher.

20. Yellow Warbler.

20. Oven-bird.

20. Wood Thrush.

20. Veery.

20. Chickadee.

21. Downy Woodpecker.

21. Sharp-shinned Hawk.

22. Parula Warbler.

23. Hairy Woodpecker.

23. Chat.

23. House Wren.

24. Purple Finch.

24. Catbird.

24. Spotted Sandpiper.

24. Black and White Warbler.

25. Hummingbird.

25. Fish Crow.

25. Purple Martin.

25. Maryland Yellow-throat.

25. Chimney Swift.

25. Blue Jay.

26. Bob-white.

26. Marsh Hawk.

27. Baltimore Oriole.

28. Red-eyed Vireo.

28. White-eyed Vireo.

28. Redstart.

29. Black-billed Cuckoo.

29. Bobolink.
May 29. Indigo Bunting.

29. Chestnut-sided Warbler.

30. Least Flycatcher.

30. Acadian Flycatcher.

30. Orchard Oriole.

30. Rose-breasted Grosbeak.

30. Rough-winged Swallow.

30. Warbling Vireo.

30. Cliff Swallow.

30. Blue-winged Warbler.

31. Seaside Finch.

31. Sharp-tailed Finch.

31. Hooded Warbler.

31. Long-billed Marsh Wren.

31. Least Bittern.

June 1. Bartramian Sandpiper.

1. Piping Plover.

1. Nighthawk.

1. Kentucky Warbler.

2. Yellow-winged sparrow.

2. Worm-eating Warbler.

3. Scarlet Tanager.

3. Whip-poor-will.

3. Great-crested Flycatcher.

4. Kingbird.

5. Wood Pewee.

5. Yellow-throated Vireo.

7. Short-billed Marsh Wren.

7. Yellow-billed Cuckoo.

8. Laughing Gull.

12. Common Tern.

20. Goldfinch.

20. Cedar Waxwing.

IIints on keeping Note-Books and Journals.-The necessity of a well-kept journal can not be too strongly urged. Specimens may be duplicated, but no one can erer see with your eyes. Do not attempt to trust to your memory-a willing servant of the mind too frequently imposed upon. It may receive and retain one impression clearly, but as others are added the earlier ones lose their distinctness or become entirely effaced.

The system adopted for recording notes should be simple to keep and easy of reference. The one here recommended has stood the test of ten years' experience. After returning from the field I enter in my "roll-book," at once, a record of the weather, temperature, direction and force of the wind, locality visited, time of starting and returning, 
and incidental observations on the blooming of flowers, appearance of certain insects, calling of frogs, etc. Then follows a statement of the numbers of every species of birds seen, with various remarks concerning them. One might suppose that much time would be required to make a detailed record of this kind, but, on the contrary, it seldom takes five minutes.

Almost any stationer can supply you with a "roll-" or "time-book" having a space at the left side of the left-hand page for the entry of names, and the rest of both pages ruled in squares. The best plan is to have sheets of paper ruled in this way. These sheets should hare holes punched in their margins for binding in covers, when new sheets can be inserted as desired. Some idea of their appearance may be gathered from the appended part of a left-hand page:

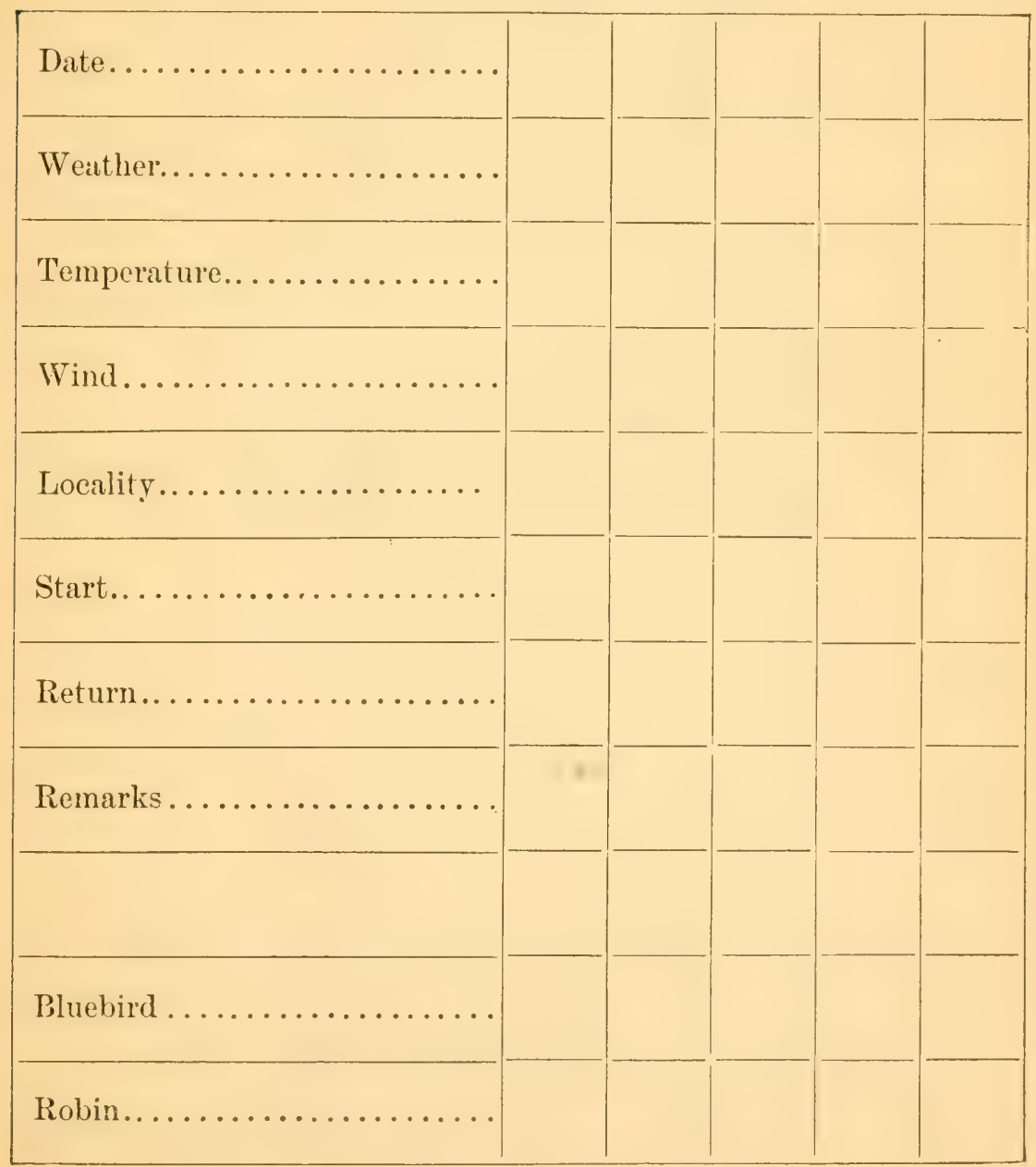


After filling in the preliminary data I write after the name of each bird either the exact or approximate number of individuals seen, or else the letters "A.," "C.," or "T. C.," meaning abundant, common, or tolerably common. This is accompanied by an " $\mathrm{s}$ " if the bird is in song, or "calls" if it is simply heard calling. The possibilities of abbreviation are unlimited, but use no abbreviation which is not fully explained.

If you wish to make a record of some length concerning a certain species, place a cross or asterisk in its square. This refers to your journal of the same date.

Read from left to right, the roll-book gives in a graphic, condensed form the standing of a species during the period of observation. Read from the top to the bottom of the page, it gives in an easily comparable way the complete record of each day, and at the same time it becomes an index to the bird-notes in your journal.

To prevent needlessly multiplying your roll-books the series of birds' names should be made to last at least during an entire season. To this end do not completely fill the right-hand page, but when you have used all of it but a space equal in width to the space occupied by the column of birds' names, cut this part of the page-the extreme right-off; the part remaining will, when turned over to the left, just meet the column of names, and the lines of this column and the new page will thus run continuously. As before remarked, the roll-book should be attended to immediately on returning from the field, while your impressions are fresh. The journal may wait, when a reference to the roll-book will aid in recalling the day's experiences. In addition to these two books, both of which should be quarto size, you need a small, leather-covered, pocket note-book for use in jotting memoranda in the field. 


\section{CHAPTER III.}

\section{COLLECTING BIRDS, THEIR NESTS, AND EGGS.}

Collecting Birds.-With few exceptions, the plumages of the birds of the eastern Lnited States are well known to science. You will collect them, therefore, purely for the purpose of self-education. To this end it is not necessary that you should acquire the large series of specimens found in museums. From two to five specimens of each kind are enough, and when through their medium you have become familiar with the appearance of the species they represent, use the gun only to add to your list of acquaintances. If you wish to make a detailed, critical study of changes in the plumage of species due to age, sex, or season, or to compare some apparently abnormal specimen, risit the nearest museum, the collections of which should be accessible to every earnest student.

Our eastern birds have been measured and described, their rariations noted and recorded, and there is little left to learn in studying their skins from a local standpoint. What we want now is knowledge of the living, not the dead, bird. A thoroughly exhaustive account of the habits of any one of our commonest birds is still to be written. Remember, then, that collections are a means, not the end, of ornithological research.

When armed and ready for the field, you should have a canras hunting-coat, a pair of field-or opera-glasses, a fisherman's basket or "creel," a discarded octaro pamphlet or catalogue of rather beary paper, cotton, a small bottle of corn-meal, and a 16-bore shot-gun with a 0.32 auxiliary barrel, and the necessary complement of shells. The auxiliary barrel can be purchased of dealers in natural history supplies; it should not exceed ten inches in length. The shells for it should be of brass, center-fire, and strong enough to stand reloading many times. Load them with a fine-grained powder and No. 12 shot -about three fifths powder and two fifths shot. For killing birds from the size of a Blue Jay downward they will be effective at a distance of twenty to twenty-five yards. In other words, fully three fourths of your shooting will be done with them. Of 16-bore shells 
carry some loaded with two and a half drachms of powder and three fourths of an ounce of No. 10 shot, and a few others loaded with the same charge of powder and an ounce of No. 6 shot.

On killing a bird, pick it up by the bill or feet, and at once sprinkle meal or dry earth on any blood which may be visible. When this is saturated, scrape it off with a knife-blade and repeat the operation until all the blood is absorbed. Sprinkle some meal at the base of the feathers about the shot-holes from which the blood appears, or, if necessary, plug these holes with bits of cotton. Place a large plug of cotton in the mouth and force it well down the throat to prevent bleeding at the mouth from an internal wound. In some cases it is necessary to also plug the nostrils. Now make a cornucopia from a leaf of the pamphlet, drop the bird in it head foremost, taking care that the bill is not turned forward on to the throat, and, if the bird is not too large, fold in the edges of the cornucopia and place the specimen in your basket. In the case of very large specimensHawks, Owls, etc.-it is advisable to skin out the body in the field, when they can be packed in much smaller space.

Making Birdskins.-If you have fully decided to make a collection of birds, the very best and cheapest way to begin it is to get some one to give you two or three lessons in the art of preparing birdskins. With proper instruction it is not difficult to learn to skin birds. I have known beginners who had closely watched experts at work, make fair skins at their first attempt-better skins, indeed, than the person who learns only from written directions may ever make. I am speaking from experience. Only too clearly do I remember my own first attempts at skinning birds and their hopelessly wretched results. In despair I at last sought the assistance of a distant ornithological friend. In one lesson he made the process so clear to me that I was at once enabled to make skins twice as quickly and twice as well. However, we unfortunately are not all blessed with ornithological friends to whom we can turn for advice, and I therefore append the following directions for making birdskins :

First procure a scalpel with a well-rounded end, a pair of sharppointed scissors with rather long handles, a pair of blunt-ended, rather strong scissors, and a pair of flat-ended forceps. These may be purchased of any dealer in naturalists supplies or at a surgical instrument maker's. Procure also a quart or so of fine corn-meal to use as an absorbent, a pound or two of powdered arsenic and alum mixed in equal parts. and an abundance of the best cotton batting money will buy. Now we are ready to begin with a bird, say, the size of a Robin: 1 . Plug the bird's throat and nostrils tightly with fresh cotton. If the eyeball is ruptured, pull it out with the forceps and fill the carity 
with meal. 2. Lay the bird before you on its back, its bill pointing to the left; place your open left hand lengthwise on it, so that the base of your first and second fingers rests on the middle of the breastbone; use these fingers and the handle of the scalpel to separate the feathers from near the end of the breastbone to the vent, and when the parting is made use the same fingers to hold the feathers aside. 3. With the scalpel make an incision in the skin from just in front of the end of the breastbone, or at the base of the $\mathrm{V}$ formed by the spread fingers, to the vent, being careful not to cut through into the abdomen. 4. Sprinkle a pinch of meal along the cut. 5. Lift the skin at the front end of the cut and insert the end of the scalpel handle between it and the breastbone. If you try to do this lower down on the cut, over the belly, you will find it difficult to separate the skin on which the feathers grow from the immediately underlying skin which covers the abdomen. Separate the skin from the body the whole length of the cut and as far down toward the backbone as possible, thus exposing the bare knee. 6. Take hold of the foot and push the knee farther up into view, then take the blunt-ended scissors and, on the inside of the skin, clip the leg entirely in two. 7. Repeat operations 5 and 6 on the other side of the body. 8. Press away the skin as much as possible on either side of the rump, and place the thumb at the left side (left, seen from above) of the base of the tail or "pope's nose," with the first finger on the other side (both inside the skin) and the second finger behind (above) on the rump; now with the blunt scissors eut through the flesh between the thumb and first finger toward the second finger, which serves the purpose of a guard to prevent you from cutting through the skin. 9. Stand the bird on its breastbone, the belly toward you, and with both thumbs press the tail and skin of the rump over and down off the stump from which you have just cut it. 10. When the stump is free from the skin, take hold of it with the right hand and with the fingers of the left gently press the skin from the body, keeping it constantly turned inside ont and using an abundance of meal. 11. Soon the wing-bones (humerus) will appear. Clip them off at either side close to the body, and resume skinning as before. 12. The skin will slip easily over the neck, and you will then meet with an obstruction in the head. 13. Work the skin carefully over the head, using the tips of the first two fingers of either hand, placing the thumbs as a brace farther forward over the eyes.* 14. Pull the ears carefully from their sockets. 15. The eyes

* In large-headed birds, like Ducks and Woodpeckers, this is impossible, and it is necessary to slit the skin down the back of the neck and push the skull through the opening. 
will now appear; carefully cut the membrane joining the skin and eyeball, making the incision as far back as possible, in order to avoid cutting the skin, which should be pulled forward until it is entirely free of the eyeball. 16. Remove the eyes with the forceps. 17. With the sharp-pointed scissors make an incision directly across the roof of tire mouth, inside the branches of the lower mandible, just back of the skin, and below the eye-sockets. 18. With the sharp-pointed scissors make incisions from either end of this cut back along the branches of the lower mandible through the base of the skull on either side of the neck at its junction with the skull. 19. Connect these cuts by a fourth, which passes through the base of the skull just above the neck, and pull the body and neck from the skull. 20. Scoop out what brains remain with the handle of the scalpel. 21. Pull the end of the wingbone (humerus) inward, skinning the feathers off the bones of the forearm (radius and ulna), and remove the flesh. 22. Do the same thing for the legs, but, after cleaning, do not in either case pull the bones back. 23. Remove as much flesh as possible from the base of the tail, including the oil-gland at the base of the tail above. 24. Hold the skin over the arsenic and alum box, and with a bit of fluffy cotton at the end of a stick, or held in the forceps, dust it thoroughly with the poison, giving an extra allowance to the base of the tail and bones of the skull, wings, and legs. 25. Pull the legs back into place. 26. Place a fluff of cotton on the end of a wire and roll it into a firm, smooth ball, placing one in each eye-socket. 2\%. Coax the skin back over the head, using the first two fingers of each hand and placing the thumbs at the base of the skull. When the tip of the bill appears through the feathers, use the fingers outside, on the feathers, pressing the skin back over the head, and keeping the thumbs in the same position. When the bill is free, take it with the right hand, and use the fingers of the left to urge the skin over the skull, being careful to get it in its former place so that the feathers of the head will lie smoothly. 28. Dress the feathers of the head, particularly those about the eye. 29. Take hold of the tip of the bill and shake the skin gently but vigorously to aid in settling the plumage. 30. Lay the skin on its back, the bill pointing from you, and turn back the feathers about the opening on the belly. 31. See that the wing-bones lie flat on the back of the skin, with their ends touching each other.* 32 .

* The most difficult part in making a birdskin is to induce the wings to assume anything like their natural position when closed. This is because the artificial, cotton body is apt to force them outward on to the sides rather than on the back, where they belong.

In the bird in the flesh the wings are held in place by being attached to the body; in the skin they are loose and hanging. To remedy this, after drawing 
Take a bit of fluffy cotton, press it lightly together, and draw out one end to form a neck. When released from your grasp this cotton body should be but little larger than the body you have removed from the skin. 33. Take the end of the neck with the forceps and insert it gently into the neck of the skin, working the skin down on to it in order to avoid stretching the neck, until the points of the forceps appear in the mouth, then hold the cotton there and withdraw the forceps. 34. Carefully fit the cotton body into the skin. 35. Put one or two stitches in the incision on the belly. 36. Ascertain the sex of the bird (see beyond). 37. Cross the legs, and at the point of intersection attach a label (see beyond). 38. Squeeze the wing-bones together until you feel the tips of your fingers meet over the bird's back. 39. Prepare a sheet of cotton about five inches square and as thin as you can make it; lay the bird on this on its right side, the bill pointing to your right hand. 40. Put the left wing in place and dress the feathers about it. 41. Take hold of the sheet of cotton, and turn the bird over in it in order that you may dress the right wing. 42. Roll the bird on to its belly, holding the wings in position with the thumb and first finger of the left hand, and with the right hand bring the tips of the wingfeathers into their proper place over the back. 43. Roll the bird back on to its back, the bill pointing to your right hand; take the end of the sheet of cotton farthest from you and draw it lightly over the bird to the side nearest you. 44. Draw the end nearest you in the opposite direction. 45 . See that the feet, tail, and tips of the wings are in their proper position, and place your specimen out of harm's way to dry.

It will doubtless take you from half an hour to an hour to make your first birdskin. It will probably be a sorry-looking olject, perhaps minus a head or tail or half its feathers; but do not let this discourage you. An expert can make ten birdskins an hour, and you need only practice to approach this.

There are endless variations of the method here described. It is not possible to go into further details here, and if you have taxidermic ambitions I would advise you to procure a copy of Mr. W. T. Hornaday's excellent Taxidermy and Zoölogical Collecting (Scribner, $\$ 2.50)$.

Sexing.-A specimen without a sex mark on its label is of comparatively little value. The sex in many birds can of course be dis-

the wing-bones in to remove the flesh from them, they should be pushed back only far enough to enable one to see plainly the elbow or bend of the wing outside of the skin. This prevents the wings from hanging, and, to further keep them in place, it will be well at first to tie the ends of the bones (humeri) together. 
tinguished by their color, but the young male frequently resembles the female, while in some instances the female has been known to assume the plumage of the male. Dissection, therefore, is the only safe way to determine sex. Upon reaching stage 36 , in the operation of making a birdskin, cut through the left side of the body from the rent to the neck, taking care not to disturb the internal organs. Force the edges of the opening apart, and, pressing the intestines gently to

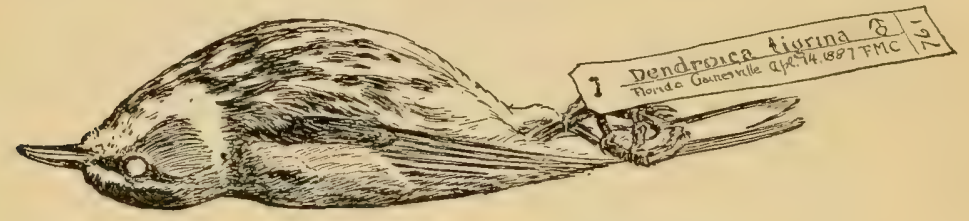

FIf. 1.-A completed birdskin. (Reduced).

one side, look for the sexual organs, which will be found on the walls of the small of the back rery near to the backbone. The male organs (testes), two in number, are usually dull-white, elongate bodies lying side by side. The female organs (ovaries) are composed of numerous round bodies lying in a mass or cluster. In the breeding season the sexual organs of birds become much enlarged, and at this season the testes of a male Chipping Sparrow are about the size of a pea, while the oraries of the female have been likened to a bunch of grapes, the largest being the size of the yolk of the egg of this species. After the breeding season the sexual organs decrease in size, and in adults in the winter and young birds are sometimes difficult to find. The testes of a male Chipping Sparrow at that season are about as large as a small pinhead, while a hand-lens is required to plainly distinguish the ovaries of the female. The arrow of Mars ( $\hat{b}$ ) is used to indicate the male sex; the mirror of Venus ( $q$ ) the female sex.

Cataloguing and Labeling.-Before skinning your birds you should catalogue them. The catalogue should have columns giving (1) the date, (2) your serial collection number, (3) name of the bird, (4) sex, (5) place of capture, (6) name of collector, and (7) remarks. In the last column enter any notes on the color of the eyes, or parts which will change color when drying, contents of the stomach, and other notes. In addition to this "day-book" or "blotter" some ornithologists open a ledger account with their collection, and devote a folio to each species where are posted the entries made in the collection register.

Labels should be of strong bond paper, two inches and a half long and half an inch wide. They are attached to the crossed legs of the bird by linen thread strung through their left end. The face of the label bears the name and sex of the bird, place and date of capture, 
name of collector, and serial collection number. The label shown in Fig. 1 is small, but will illustrate the appearance and manner of attachment. The name of the owner of the collection is printed on the back of the label, preceded by the words "Collection of."

Many collectors prefer to use as a field label a small jeweler's tag upon which the collection number, sex, and date are written. The large label is added after the specimen is dry.

Care of a Collection.-The best cases in which to keep a collection of birdskins are known as "Cambridge cans." They are made of tin with covers which fit into grooves lined with rubber tubing, and are practically air-tight. The smaller sizes cost from five dollars to seven dollars and a half each, and can be obtained of Muller and Wood, 731 Seventh Avenue, New York city.

A wooden cabinet with tight-fitting drawers and door is less expensive, and with ordinary care will preserve specimens for a practically indefinite period. The drawers should be thirty inches long by sixteen inches in width. For birds the size of a Robin a depth of one inch and three quarters is sufficient, while drawers four inches deep will take the largest Hawks or Owls. These drawers will hold about thirty birds the size of a Robin, eighty the size of a Chickadee, and eight to ten Hawks and Owls.

Well cleaned and thoroughly poisoned specimens of small birds are not likely to be attacked by the moth (Tinea) or beetles (Dermestes and Anthrenus) which so often infest poorly prepared or nonpoisoned skins. Naphthaline crystals or camphor gum should be placed in each drawer of the cabinet, the door of which should not be left open needlessly. If a specimen falls a victim to insects, the better plan is to discard it at once. If, however, it is rare, it may be taken out-ofdoors and placed in an air-tight box with a few tablespoonfuls of bisulphuret of carbon.

Collecting and Preserving Nests and Eggs.-No one, I think, will venture to dispute the assertion that Captain Charles Bendire, Honorary Curator of the Department of Oölogy in the United States National Museum, is our leading authority on the study of birds' eggs. 'The following quotation, therefore, from Captain Bendire's Instructions for Collecting, Preparing, and Preserving Birds' Eggs and Nests * may be taken as the opinion of one who knows whereof he speaks: "Unless the would-be collector intends to make an especial study of oiblogy and has a higher aim than the mere desire to take and accumulate as large a number of eggs as possible regardless of their proper identification, he had better not begin at all, but leave the nests and

* Part D, Bull. U. S. Nat. Mus., No. 39, 1891, pp. 3-10. 
eggs of our birds alone and undisturbed. They have too many enemies to contend with, without adding the average egg collector to the number. The mere accumulation of specimens is the least important object of the true oölogist. His principal aim should be to make careful observations on the habits, call notes, song, the character of the food, mode and length of incubation, and the actions of the species generally, from the beginning of the mating season to the time the young are able to leave the nest. This period comprises the most interesting and instructive part of the life-history of our birds." Very heartily do I indorse every word of this, and to the concluding sentence I would add: and there can be no better way to avoid increasing our knowledge of a bird's domestic life than to rob it of its eggs, and destroy its home and our own opportunities at the same time. Studied from a local standpoint, I confess I can see only two points of interest in a bird's egg-one is what the egg is in, the other is what is in the egg.

Nevertheless, I can understand the pleasure attending the legitimate formation of what Captain Bendire calls " a small, thoroughly identified, well-prepared, and neatly cared for collection," which, as the same author adds, "is worth far more scientifically and in every other way than a more extensive one gained by exchange or purchase."

An egg-collector's outfit consists of several drills, an embryo-hook, a blowpipe, forceps, and scissors. A fresh egg should be blown through a hole slightly larger than the tip of the blowpipe. Drill the hole in the side of the egg, and, after inserting the blowpipe about one sixteenth of an inch, blow gently and steadily until the contents have been removed. Then rinse the egg thoroughly with water and lay it hole downward on corn-meal to drain.

In eggs containing embryos it is necessary to make a hole large enough to permit of the use of the embryo-hook, scissors, or forceps, as the case may be.

Each egg should be marked with the number of the species in the Check List of the American Ornithologists' Union, the number of the set in your collection, and the number of eggs in the set. Thus, if I were going to label my second set of four eggs of the Bluebird, I should write with a lead pencil on each egg, near the hole, $766_{4}^{2}$.

There are many ways of displaying collections of eggs. Some collectors place their eggs in little boxes or partitions filled with sawdust or cotton; Captain Bendire uses small pasteboard trays lined, bottom and sides, with cotton wadding. and divided into partitions for each egg by strips of cotton wadding set on edge. It is, however, very largely a matter of taste, and collectors generally have their own ideas on these matters. 
A collection of birds' nests is a telling object lesson in the study of ornithology. Familiar as I am with them, I never see the nests of some birds without feeling the most intense admiration for the marvelous skill which has aided them in forming a structure man would find it difficult, if not impossible, to duplicate. A bird's nest in its original site is a concrete expression of the intelligence of its maker; for the foresight displayed in the choice of a situation, and the ingenuity shown in the construction of the nest, even if largely instinctive now, originated in the intelligence of a line of ancestors.

Nests may be collected before they have been used, when the birds will generally build again; or you may wait and take them after the birds have left them, labeling each nest with what you have learned of the history of its owners. For example: Time required for its construction; whether made by one or both sexes; notes on the laying of the eggs; period of incubation; whether both sexes assisted in incubation; care of the young; number of days they were in the nest, etc.

Some nests, for example the pendent "baskets" of Vireos or such as are placed in crotches, should be taken with the crotch or branch to which they are attached.

With others it is obviously impossible to do this. They should therefore be placed in a frame of wire and wrapped about with fine wire thread. To make this irame, twist two pieces of annealed wire, painted brown, into the shape of a letter $\mathrm{X}$. About midway from the point of intersection and the end of the arm, bend the wires upward at right angles. Now take the fine hair or thread wire and wind it about the four horizontal arms of the frame until its bottom looks like a spider's web; place the nest in this half-formed basket, bend the upright wires inward or outward as the case requires, and continue winding until the nest is bound firmly. The size of the frame and the wire used in its construction may be varied to suit the nest. 


\section{PLAN OF THE WORK.}

Nomenclature.-The nomenclature of the American Ornithologists' Union's* Check-List of North American Birds has been adopted. The number preceding the name of each species is its permanent number in the Union's "Check-List."

Definition of Terms. - The accompanying figure with its named parts will explain the meaning of the terms used in the following descriptions of birds. 'The words, upper parts and under parts, mentioned so frequently, refer respectively to the whole upper or under surfaces of the body of the bird from the base of the bill to the root of the tail, but are not applied to either wings or tail.

'There are infinite variations in the markings of feathers, and those figured present only the patterns most frequently met with. The shaft of the feather is the midrib, to either side of which the ranes or webs are attached.

The Keys. - It is of the utmost importance to thoroughly understand the use of the keys. At first sight they will, no doubt, appear confusing, but in reality they are exceedingly simple. The system upon which they are arranged may be mastered in a few minutes, and you will then be surprised at the ease and rapidity with which, even in large families, you can "run a bird down."

The Key to Families.-Strictly speaking this is not one key but a series of keys, one under each order.

The orders are placed in a natural sequence-that is, we begin with the oldest or lowest forms of birds, Loons, Grebes, etc., and end with

* The American Ornithologists' Union is the leading society of its kind in this country. Its membership includes the foremost ornithologists of the world, and is divided into four classes: 1 . Honorary members, limited to 25 in number. 2. Active members, limited to 50 in number, who must be residents of North America. 3. Corresponding members, limited to 100 in number; and 4. Associate members, who must be residents of North America, and are not limited as to number. The total membership of the Union in December, 1894, was 616. Annual meetings are held, usually in Washington, New York, or Cambridge. The Auk, the official organ of the Union, is a quarterly journal under the editorship of Dr. J. A. Allen, at the American Museum of Natural History. 
the most highly developed ones, Thrushes, Bluebirds, etc. Two main divisions are giren: first, Water Birds; second, Land Birds. In no

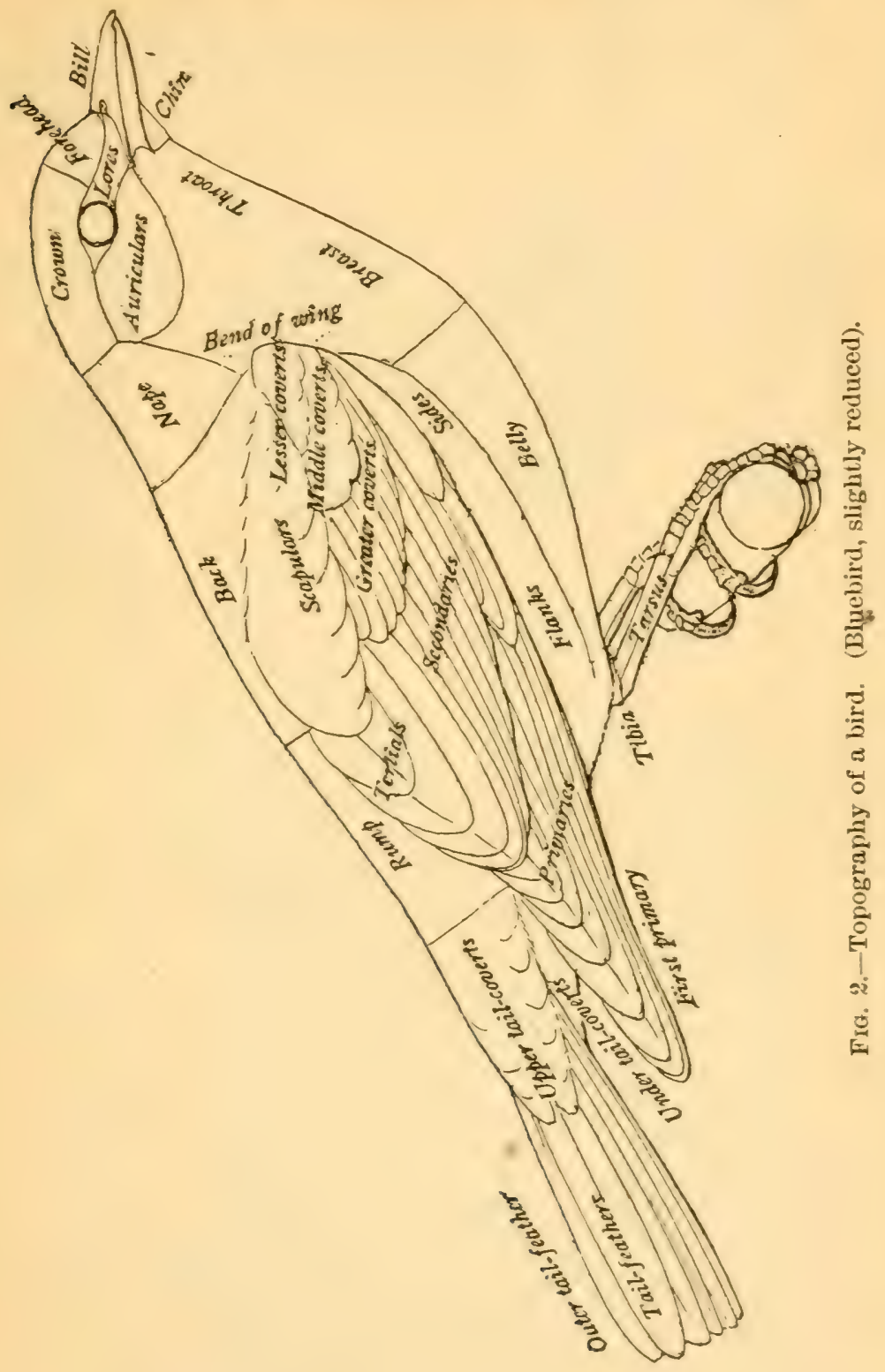

case will it be difficult to decide in which of these groups a bird belongs. Now glance orer the illustrations and select the one which you think most nearly resembles the bird you are identifying. At 
each step test your decision by reading the brief diagnoses of orders and families. In this way you may readily place your bird in its proper family.

The Keys to Species. -If a bird always wore the same plumage it would be a comparatively easy matter to place it in a certain section
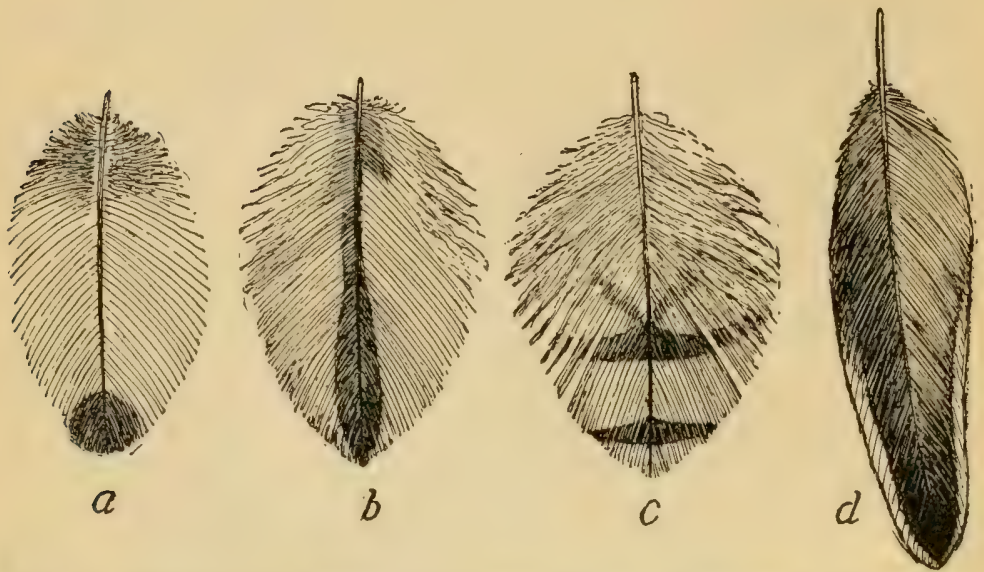

Fra. 3.-Spotted (a), streaked $(b)$, barred (c), and margined $(d)$ feathers.

of a key and keep it there. But, unfortunately, not only are the males and females of the same species frequently quite unlike, and the young different from either, but their plumages may vary with the season. Thus, you see, a bird's color is a most uncertain quantity. An individual of a given species may not only wear two very different costumes, but, in doffing one for another, he does it gradually, and in the meantime appears in changing or transition plumage.

For this reason it has been customary to base keys on only adult males. Such keys do very well in the nesting season, when birds are in song, and when males constitute probably nine tenths of the birds one sees. But at other times of the year young birds outnumber the old ones, and the adults themselves may lose their breeding plumage and wear quite a different one. I have, therefore, attempted to make keys which will identify a bird in any plumage. To do this it was necessary to use many more specimens than there were species. For example, the key to our some 40 species of Warblers is based on 110 specimens representing as many phases of plumage.

With identification as the sole end in view I have, in the keys, abandoned all attempts to follow the current system of classification, and, taking color as the most tangible character, have to a great extent arranged the species on this character alone. The result, from the systematist's standpoint, is most unnatural. Species of different genera 
are brought into the same subsections, and the more variable species may be placed in several widely separated sections.

The maker of keys, however, should not try to serve two masters. If the keys will identify, they will have accomplished their purpose. The classification of our birds is shown in the body of the book, where the species are arranged according to the system adopted by the American Ornithologists' Union.

In making these keys the birds are first assorted into several major sections or groups, according to the markings of some one part of the body. Each one of these sections is preceded by the same kind of number or letter. The heading of a group or section applies to all the species included in it. Thus, if I does not apply to the bird you are identifying, you must pass at once to II, or III, or IV, as the case may be. In like manner, if the bird does not fall into sections $1, A$, or $a$, we go to $2, B$, or $b$, respectively. Even should the first section describe your bird, it is well to read the sections which are contrasted with it.

As a model to show how the keys are used, let us identify, first, a male adult Red-winged Blackbird-a black bird with a red and buff shoulder-patch. Turning to the key to the family Icterida, or Blackbirds, Orioles, etc., we read:

"I. With yellow or orange in the under parts.

"II. Under parts black, with or without metallic reflections.

"III. Under parts grayish, slate color, chestnut, or buffy.

"IV. Under parts biack and white, or black tipped and margined with rusty."

Our bird has the under parts entirely black, so it evidently belongs in Section II. Under this section we read: " $A$. Outer tail-feather $0 \cdot 75$ or more shorter than middle ones; bill 1.00 or more in length." Our bird has all the tail-feathers of nearly equal length, the bill less than an inch long. It can not therefore belong in $A$, so we go to $B$ and read: "Outer tail-feather little if any shorter than middle ones; bill less than 1.00 in length." There is no other section, and we conclude that our bird belongs here. Now we find $a, b, c, d$, each one placed directly beneath the other, and each one leading to the name of a species. This means that the statement following these letters refers to some mark or character by which one of these species may be known from the other, and that we should read them all. First comes "a. Entire plumage bluish black." That will not do. Second, "b. A red and buff shoulder-patch." Evidently this refers to our bird, but we confirm our belief by glancing at $c$ and $d$, neither of which can apply to our specimen; we decide, therefore, that it is a Red-winged Blackbird, and turning to the extended description of Agelaius phoniceus verify our identification. 
Now let us take a somewhat less simple case-a male English Sparrow. This bird, you will doubtless remember, has a black patch on the throat and breast, a slate-colored crown, chestnut marks on the sides of the head, and a streaked back. Turning to the key to the family Fringillidoc, or Finches, Sparrows, etc., we read first the headings to the main divisions which, in the larger families, are placed at the beginning of the key in order that they may be more readily compared.

"I. Under parts with red.

"II. Under parts with no red, and without distinct streaks; throat or breast sometimes with a patch or spot.

"III. Under parts without red, and with numerous streaks."

Our bird undoubtedly belongs in Section II. Under this section we read first: " 1 . Tail with white spots, bars, or patches." Our bird has no white in the tail, so we go to " 2 " and read: "Without large white spots or patches in the tail." There is no number 3 , so we have no hesitation in placing our bird in Section " 2." The first subsection here is " $A$. Back without distinct streaks." Our bird is unquestionably streaked, and we therefore go to " $B$. Back distinctly streaked." There is no Section $C$, and it follows that our bird belongs in "B." Under $B$ we hare " $a$. Bend of the wing yellow" and " $b$. Bend of the wing not yellow." Our bird has no yellow on the wing, and we therefore place it in subsection $b$. This subsection is subdivided into " $b$. Crown bright reddish brown," etc., " $c$. Crown streaked or spotted," etc., and " $d^{1}$. Crown mixed grayish brown and rufous, ashy, or slate-color, without black streaks." Evidently our bird belongs in the group headed $d^{1}$, which we find includes four species, $d^{2}, d^{3}, d^{4}$, and $d^{5}$. After reading the characters assigned to each of these, we have no hesitation in deciding that those under $d^{4}$ apply to our bird, and we prove our identification by turning to the description of Passer domesticus.

I have purposely taken a comparatively complicated case. If I have made it clear, you will have no further difficulty in using the keys, so far as their construction goes. It might be supposed, from this somewhat lengthy description, that the process required much time; but as you become familiar with the use of the keys it should never take you more than five minutes to identify a bird with them.

Descriptions of Plumage.-The descriptions, with quoted exceptions, are from specimens in the American Mnseum of Natural History, and my thanks are due the authorities of that institution for permission to use its valuable collections. I have tried to make them as concise and simple and, at the same time, as detailed as seemed necessary for the purpose of identification. 
Measurements.-All the measurements given are in English inches and hundredths. Those of birds are average measurements, taken for the most part from specimens in the American Museum of Natural History. I have also, with the author's permission, made use of the excellent series of measurements in Dr. E. A. Mearns's Birds of the Hudson Highlands. A variation of about ten per cent from the figures given may be expected.

The total length $\left(=\mathrm{L}_{\text {. }}\right.$ ) of a bird is found by gently stretching the specimen, laying it on its back, and measuring the distance from the end of its bill to the tip of its longest tail-feather. The length of the wing $(=\mathrm{W}$.$) is the distance from the "bend of the wing" to$ the end of the longest primary. The length of the tail $(=\mathrm{T}$.) is the distance from the base, or insertion of the middle feather, to the end of the longest feather. The length of the tarsus (=Tar.) is the distance from the base, or insertion of the toes, to the end of the tibia, or what in reality is the heel. The "tarsus" is therefore the true foot of the bird, while the part to which this name is generally applied consists only of the toes. "The length of the bill (= B.), or "culmen," is the distance from the anterior base of the feathers on the forehead to the tip of the upper mandible. With the exception of total length these measurements are generally taken with a pair of dividers.

Range.-The paragraphs under this heading have been prepared with special reference to the bird's distribution in eastern North America. They are supplemented by a concise statement of the bird's manner of occurrence and the usual times of migration of the nonresident species at three or four localities. This information is the best it is possible to obtain, and has not been previously published. Each locality is treated by a recognized authority on its bird-life from notes based on observations extending over many years.

The data from Washington, D. C., were supplied by Mr. C. W. Richmond, of the Smithsonian Institution. Not only has Mr. Richmond given years to field work in the District of Columbia, but he has had access to the notes of the numerous ornithologists who have observed in the same region.

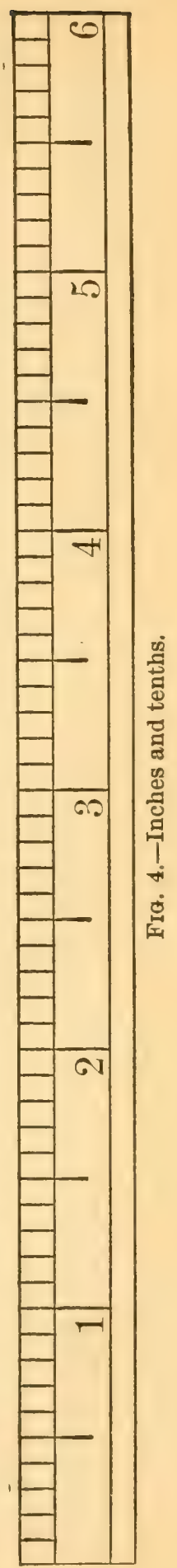


The water-birds of Long Island are treated by Mr. William Dutcher, of New York city, who has for years made our coast birds a subject of especial investigation. Sportsmen, lighthouse-keepers, and ornithologists have all aided him in acquiring an unrivaled series of observations upon the movements of waterfowl and bay birds.

Dr. A. K. Fisher, of the Division of Ornithology in the U. S. Department of Agriculture, has supplied the notes from Sing Sing, N. Y. 'This locality formed the field of his ornithological labors for fifteen years. Within the limits of the town of Ossining Dr. Fisher has observed no less than two hundred and thirty-six species of birds. Probably no area of similar extent in the United States has been more carefully studied or vielded better results.

Cambridge, Mass., is historic ground in the annals of ornithology. From the time of Nuttall it has never lacked for earnest students of its bird-life. Nevertheless, no list of Cambridge birds has ever appeared. It is with unusual pleasure, therefore, that I include annotations on the birds of this region by Mr. William Brewster, who has made a lifelong study of New England birds, and particularly of those found in the vicinity of his home at Cambridge.*

The value of their contributions renders it evident that I am under deep obligations to these gentlemen, and I thank them most sincerely for their generous assistance.

Nests and Eggs.-The brief descriptions of nests and eggs are based on the collections of the American Museum of Natural History, supplemented by the use of Baird, Brewer, and Ridgway's History of North American Birds, Davie's Nests and Eggs of North American Birds, Ridgway's Manual, and Captain Bendire's Life Histories of North American Birds. In describing the eggs the color chart was used when possible; but it was designed with particular reference to the plumages of our birds, and is of less assistance in describing their eggs. The measurements of eggs are mostly from series of measurements made by Mr. H. B. Bailey, accompanying the Bailey collection in the American Museum, supplemented by reference to the works mentioned above.

Biographies.-After devoting separate paragraphs to the bird's general range, its manner of occurrence, comparative numbers, times of migration at several specific points, and its nest and eggs, the space remaining is given to a brief sketch of its haunts, notes, and disposition, with the particular object of aiding in its identification in the field.

* Strictly maritime birds whose occurrence within five miles of Cambridge is casual or accidental are, as a rule, cxcluded. 


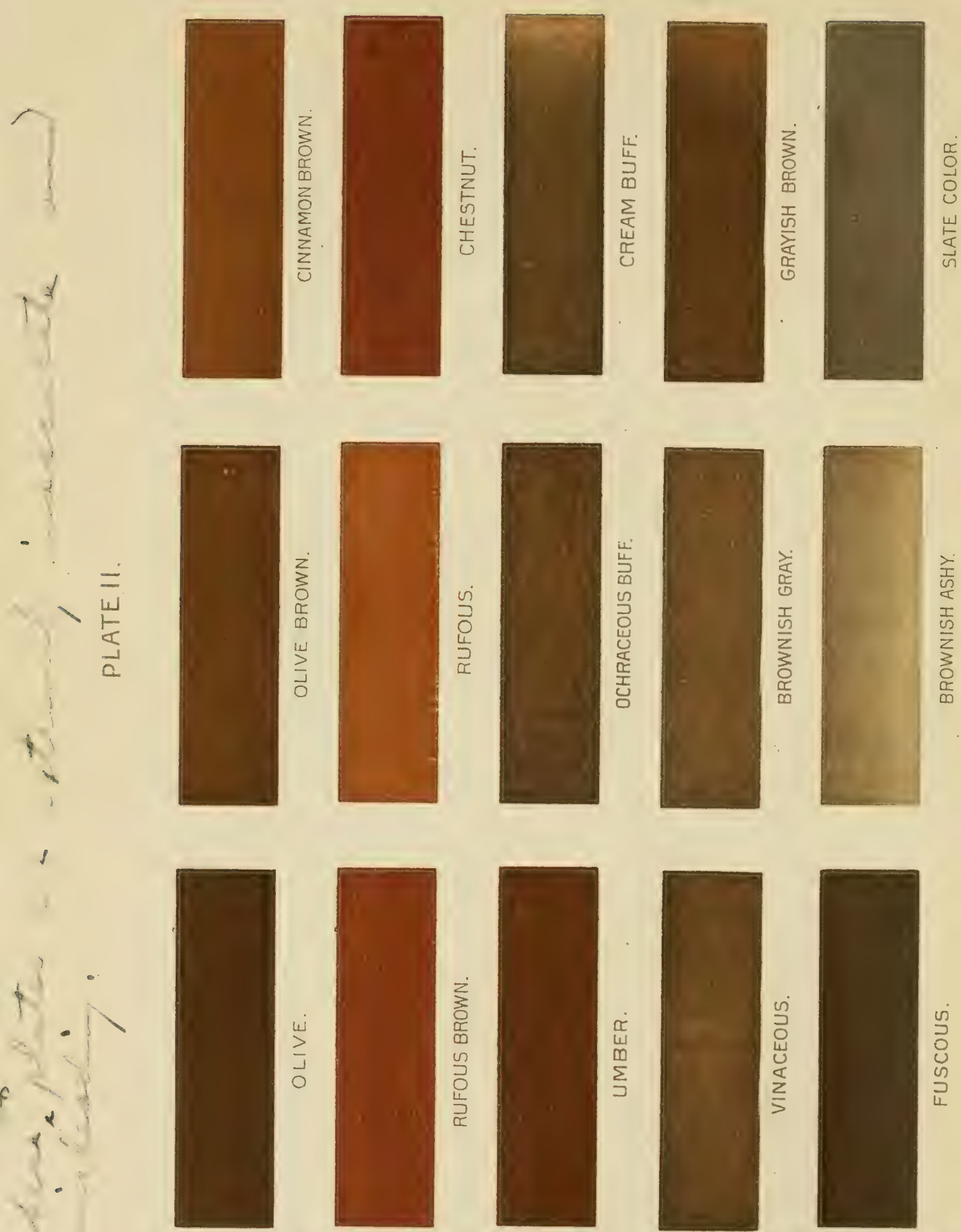

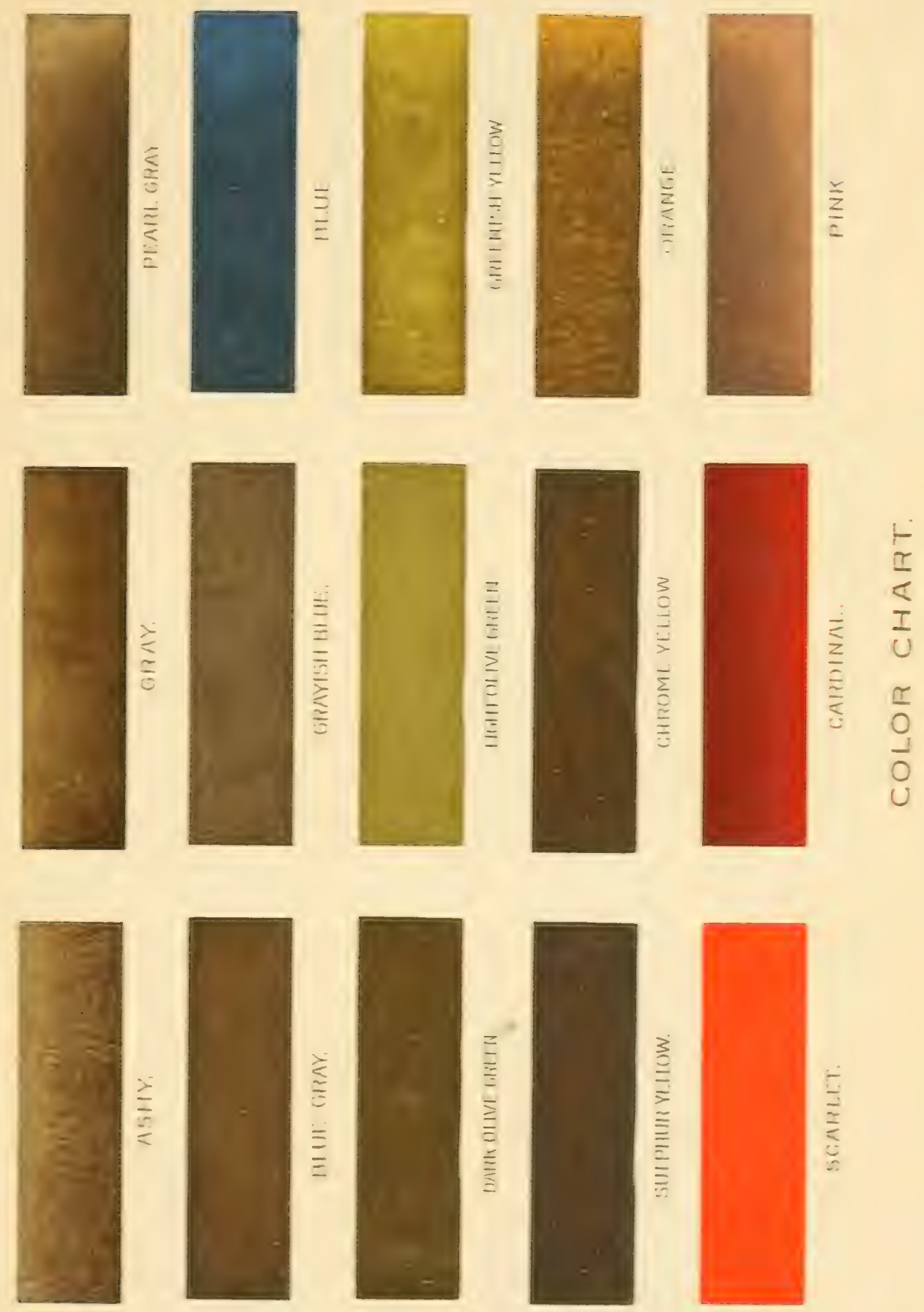

In preparing these biographical sketches I have aimed to secure the best material possible, using my own notes only when I felt they were based on adequate observations. Not only have I carefully examined the literature relating to the habits of our birds, selecting what seemed to be the most trustworthy accounts of their appearance in life, but through the generous co-operation of fellow-students of living birds I am able to present character sketches of some of our birds, written by observers who are everywhere known for their sympathy with birds out-of-doors. Thus I have to thank Mrs. Miller, Miss Merriam, Mr. Bicknell, Mr. Brewster, Dr. Dwight, Mr. Thompson, and Mr. Torrey for pen pietures of birds with which they are especially familiar, each sketch being signed by its author.

Illustrations.- The colored frontispiece is by Mr. Ernest E. Thompson, whom I have to thank for assistance in preparing the color chart and Key to Families. The numerous pen-and-ink drawings, which add so largely to the value of the work, were made by $\mathrm{Mr}$. Tappan Adney from specimens in the American Museum of Natural History. Some of the full-page half-tone plates are from photographs of groups in the American Ifuseum of Natural History; the larger number, however, were especially designed for this work, with the assistance of Mr. J. Rowley, Jr.

The Color Chart.-It must not be supposed for a moment that the colors on the Plate II. represent the colors of all the birds of eastern North America. It does not do so any more than an artist's palette shows all the colors of his picture-in fact, I have called this plate my mental palette, and have frequently used two and even three terms to describe a given shade or tint.

It should be clearly understood, therefore, that when grayish brown, for example, is mentioned, it does not follow that the feathers to which the term is applied are of exactly the same color as the plate, but that they are nearer to this color than to any other in the plate. Used even in this general way, the plate will prove a far more definite basis for description than if every one were left to form his own idea of the colors named. 


\section{LIST OF ABBREVIATIONS.}

Ad. Adult; a fully matured bird.

A. V. Accidental visitant (see page 12).

B. Bill.

B. from N. Bill from nostril.

\& The sign employed to designate female sex (see page 27 ). Im. Immature; the term is generally applied to birds less than a year old, or to those which have not acquired the plumage of the adult.

L. Total length.

f The sign employed to designate male sex (see page 2?).

P. R. Permanent resident (see page 12).

S. R. Summer resident (see page 12).

T. Tail.

Tar. Tarsus.

T. V. Transient visitant (see page 12).

W. Wing.

W. V. Winter visitant (see page 12). 


\title{
THE BIRDS OF NORTH AMERICA EAST OF THE NINETIETH MERIDIAN.
}

\author{
KEY TO ORDERS AND FAMILIES.
}

THE WATER BIRDS.

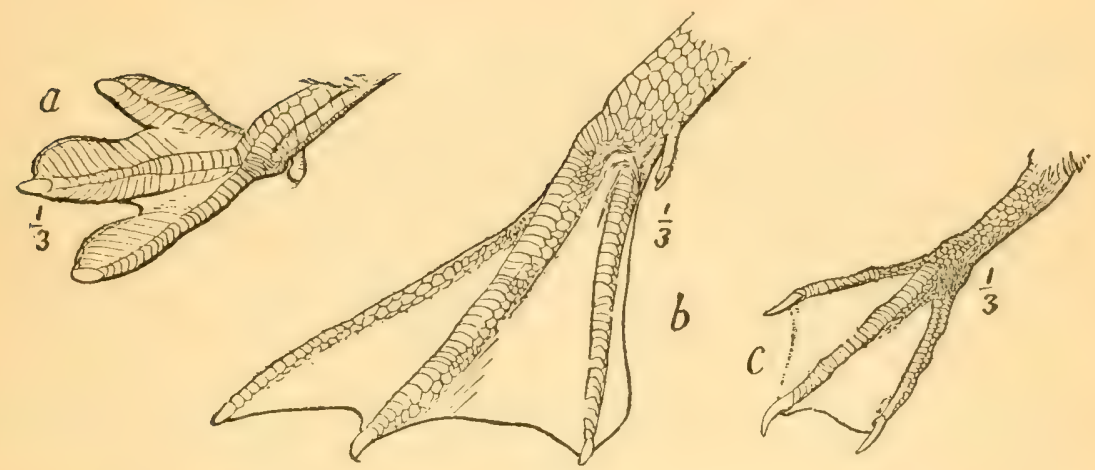

FiG. 5.

Order I. Pygopodes.-Grebes, Loons, and Auks.

Ducklike birds with generally sharply pointed bills; feet webbed, placed far back near the tail; tarsus much flattened; hind toe, when present, with a lobe or flap; bill without toothlike projections; tail very short and sometimes apparently wanting.

A. Toes four, tipped with a broad nail.

a. Toes with lobate webs.... Family Podicipida: Grebes (Fig. 5, a), p. 56.

b. Toes webbed. . . Family Urinatorida: Loons (Fig. $5, b)$, p. 58 .

B. Toes three, tipped with a sharp nail. . . Family Alcida: Auks, Murres, and Puffins (Fig. 5, c), p. 60.
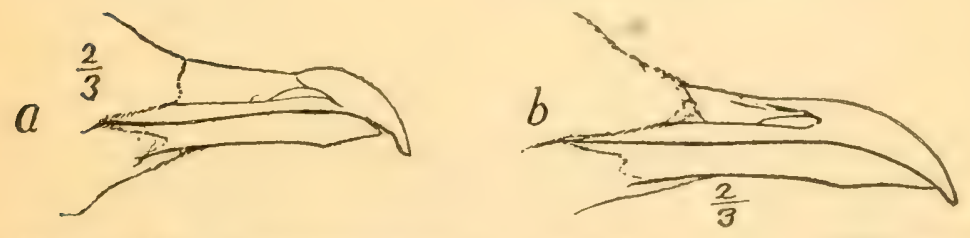

Order II. Longipennes. - JAEGERS, Gulls, and Terns.

Birds with sharply pointed and frequently hooked or hawklike bills; toes four (except in one genus-Kissa), the front ones webbed; wings long and pointed.

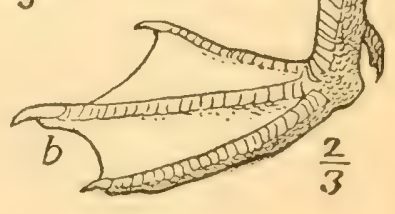

FIG 6. 
A. Tip of the upper mandible more or less swollen, rounded, and sharply pointed; upper parts, including wings, and sometimes the entire plumage, dark sooty blackish, sometimes irregularly barred; tail always dark, the middle feathers longest. ... Family Stercorariido: SkUAS and JAEgers (Fig. $6, a$ ), p. 65.

B. Upper mandible curved but not swollen at the end; tail generally white, sometimes tipped with black; the tail-feathers usually of about equal length. .. . Subfamily Larina: Gulls (Fig. 6, b), p. 67 .

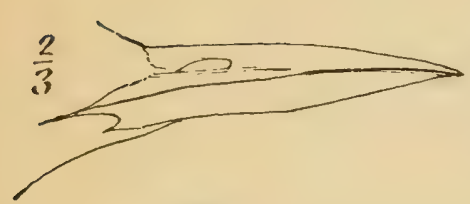

Frg. 7.

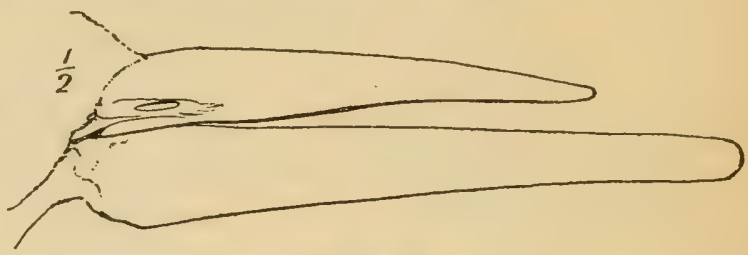

FiG. 8.

C. Bill straight, not hooked and sharply pointed; outer tail-feathers generally longer than the middle ones. Subfamily Sternina: 'Terns (Fig. 7), p. 76 .

$D$. Bill thin and bladelike, the lower mandible much longer than the upper one. ... Family Rynchopida: Skmmers (Fig. 8), p. 85.
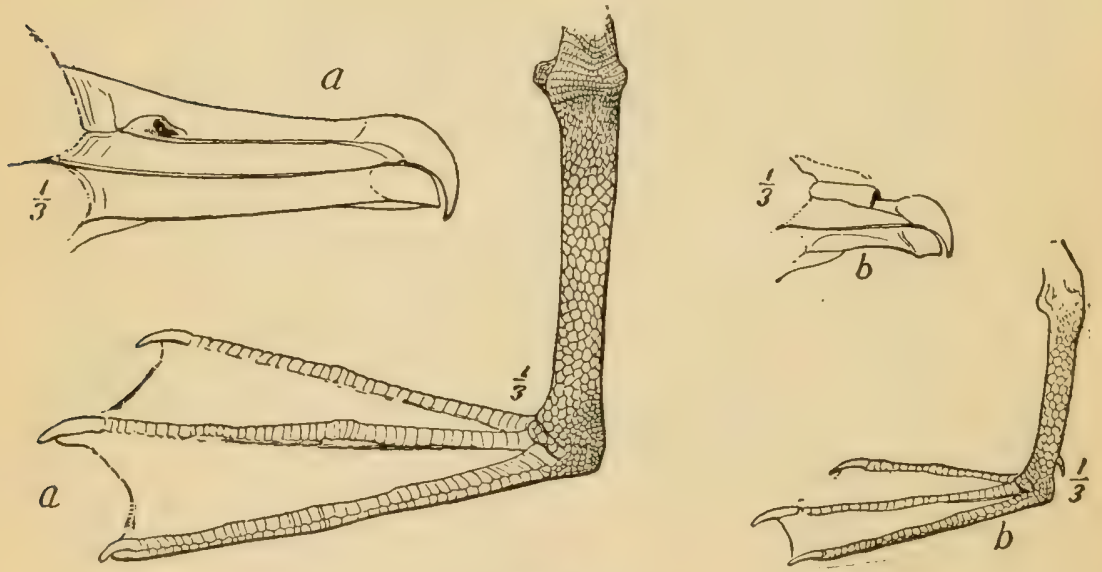

Fig. 9.

Order III. Tubinares.-Albatrosses, Petrels, and Fulmars.

Bill hawklike, the tip of the upper mandible generally much enlarged; nostrils opening through tubes; hind toe reduced to a mere nail, and sometimes entirely wanting.

A. Size very large, nostrils separated and on either side of the bill. . . .

Family Diomedeida: Albatrosses (Fig. 9, a), p. 86.

$B$. Size smaller, nostrils joined and placed on top of the bill. ...

Family Procellariida: Petreds, Fulmars, and Shearwaters (Fig. $9, b)$, p. 86. 
Order V. Anseres.-Ducks, GeEse, and Swans.

Toes four, the front ones fully webbed; tarsus not strikingly fiattened as in the Grebes; tail always well developed; bill with toothlike projections, fluted ridges, or gutters along its sides.

1. Bill very long, narrow, and rounded, with numerous toothlike projections along its sides. ... Subfamily Mergince: Mergansers (Fig. 16), p. 98.

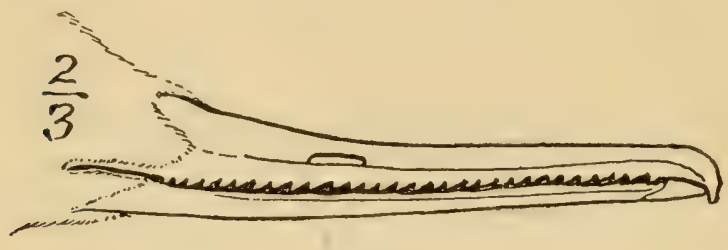

FIG. 16.

2. Bill more or less flattened and ducklike.

A. Lores feathered.

a. Tarsus shorter than the middle toe, without nail; scales on its front transverse, more or less square.

$a^{\mathbf{1}}$. Hind toe without a flap or lobe.... Subfamily Anatina;

River Ducks (Fig. 17, a), p. 100.

$a^{2}$. Hind toe with a flap or lobe.... Subfamily Fuligulina; SeA and Bay Ducks (Fig. 17, b), p. 107.

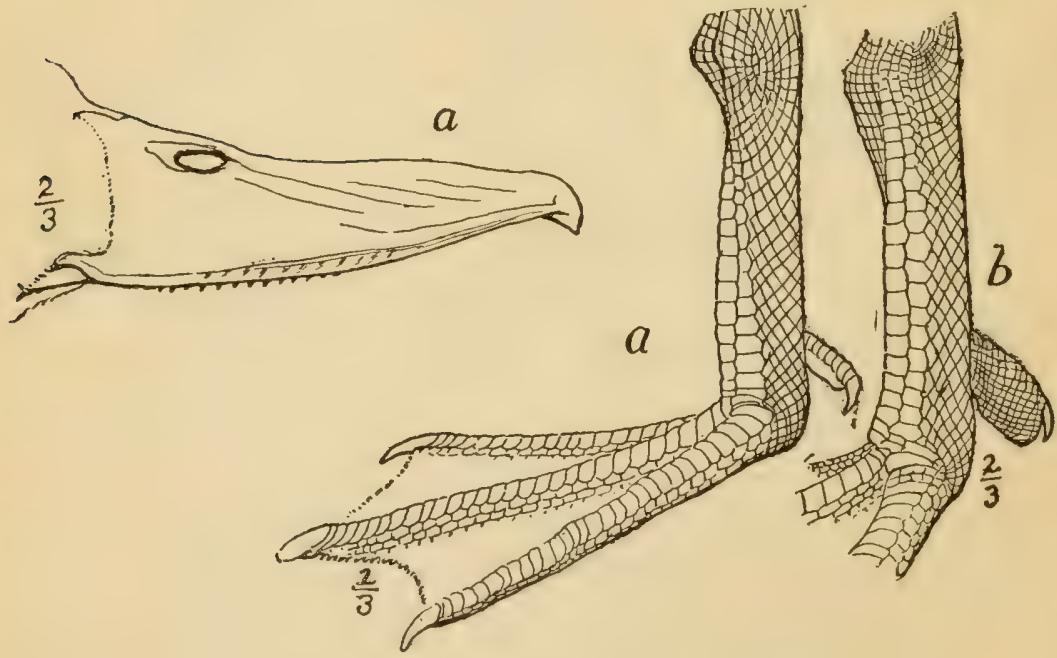

FIG. 17.

b. Tarsus generally longer than the middle toe, without nail; scales on its front rounded. . . Subfamily Anserin $\propto$ : GeEse, p. 119.

B. Lores bare. . . Subfamily Cygnince: Swans, p. 124. 
Order VI. Odontoglossæ.-Flamingoes.

Large red or reddish birds; bill with toothlike ridges as in some Ducks, the end half bent downward; tarsus $12 \cdot 00$ or more in length. ... Family Phonicopterida: $\mathrm{F}_{\mathrm{LA}-}$ MINGOES, p. 125.

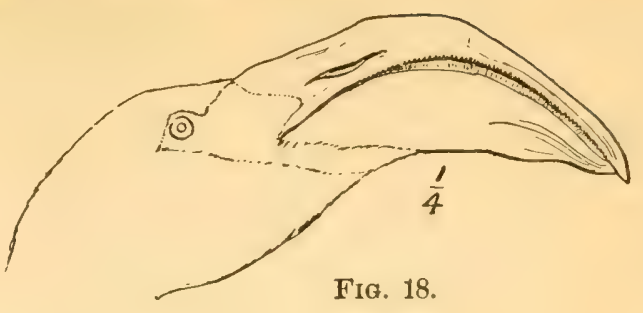

Order VII. Herodiones.-Ierons, Storks, Ibises, etc.

Toes four, all on the same level, slightly or not at all webbed; lores bare; legs and neck generally much lengthened.

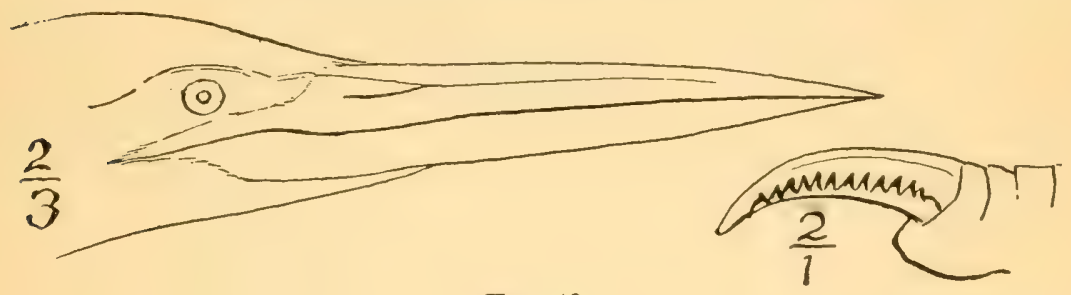

FIG. 19.

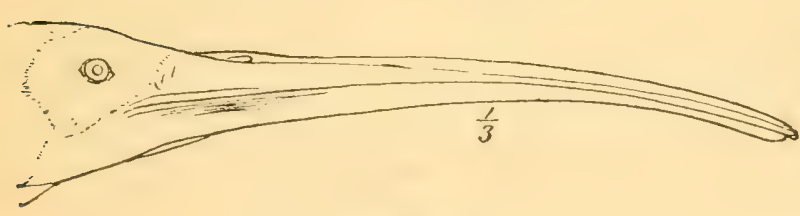

FIG. 20.

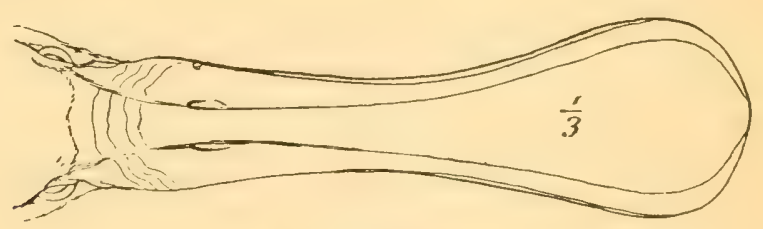

FIG. 21.

$A$. Bill straight and sharply pointed; inner border of the middle toenail with a comblike edge.... Family Ardeida: Herons, Egrets, and Bitterns (Fig. 19), p. 128.

$B$. Bill rounded, more or less eurved downward; no comb on the middle toe-nail.

a. Size large, tarsus over 5.00.... Family Ciconiida: Storks and Wood Irises, p. 127.

b. Size smaller, tarsus under 5•00. . . Family Ibidida: IBises (Fig. $20)$, p. 126.

C. Bill Hattened and much broadened at the end. . . Family Plataleida: Spoonbills (Fig. 21), p. 125. 


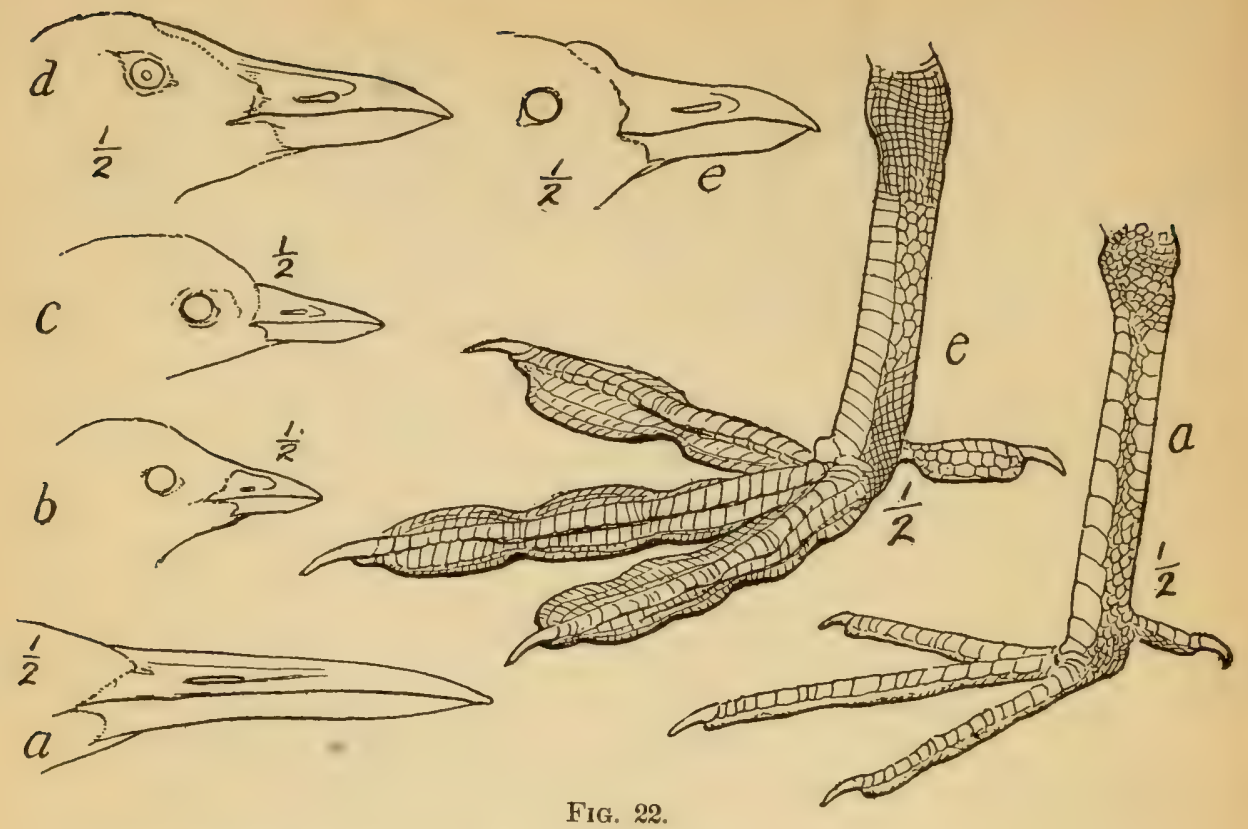

Order VIII. Paludicolæ.-Cranes, RaIls, etc.

Toes four; middle toe without a comb, generally not webbed; hind toe generally small, higher than the front ones, or, if on the same level (Gallinules and. Coots only), the bill is then comparatively short and stout and the forehead has a bare shield; lores feathered, or (Cranes) with hairlike bristles.

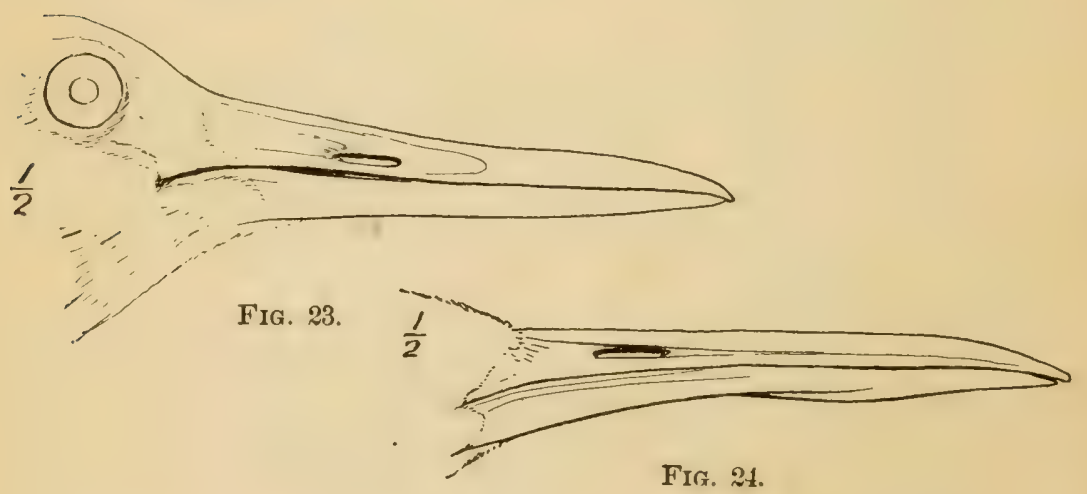

A. Smaller, bill under $3 \cdot 00 \ldots$ Family Rallide: Rails, Gallintees, and Coots (Fig. 22), p. 139.

$B$. Larger, bill over $3 \cdot 00$.

a. Tarsus over 6.00. . . Family Gruidce: Cranes (Fig. 23), p. 137.

b. Tarsus under $6.00 \ldots$ Family Aramidce: Courlans (Fig. 24), p. 138. 

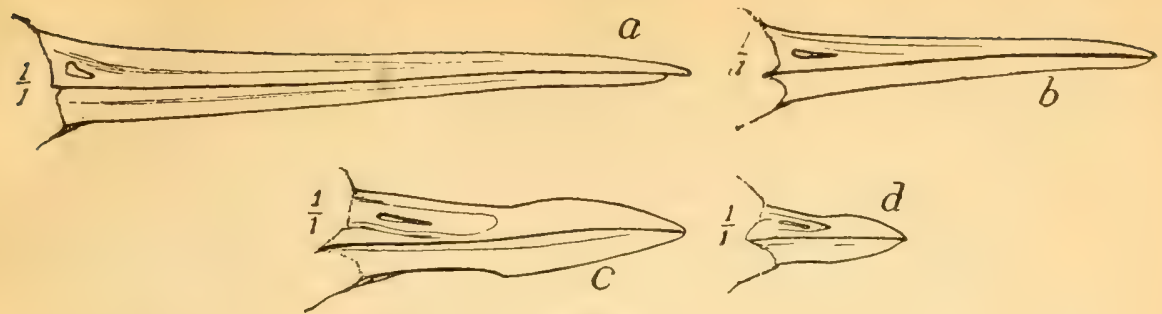

FI\%. 25.

Order IX. Limicolze-Phalaropes, Snipes, Plovers, etc.

Toes four, or (Plovers) three; the hind toe, when present, less than half the length of the inner one, and always elevated above the others; legs generally long and slender, the lower half of the tibiæ bare; bill, except in the Plovers, generally long, slender, and soft, the nostrils opening through slits or grooves; wings long and pointed, the first primary generally the longest.

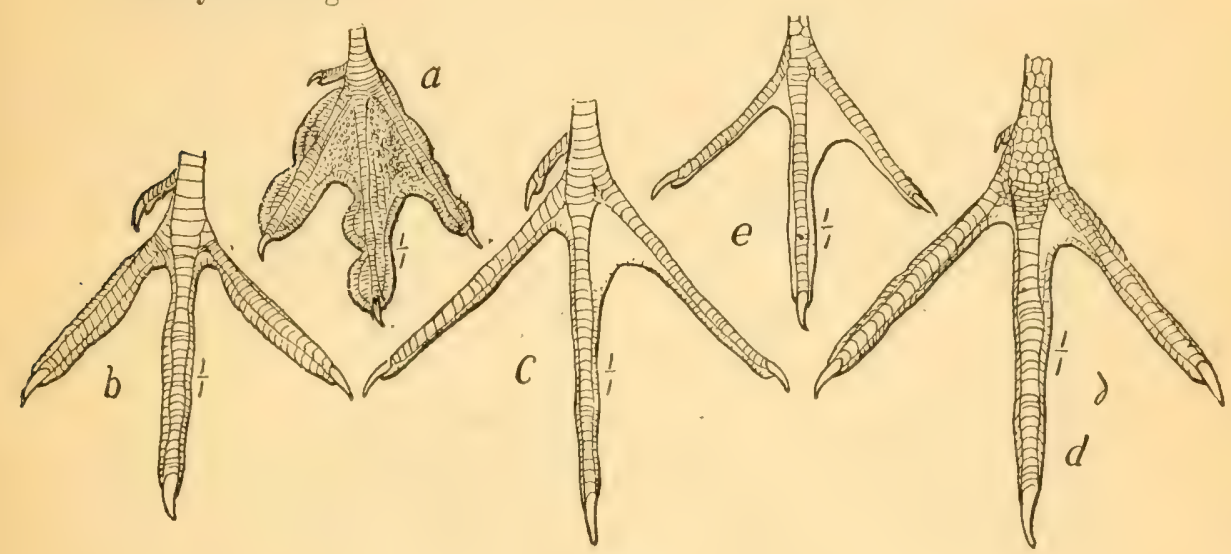

FIG. 26.

I. Tarsus over $3.50 \ldots$ Family Recurvirostrida: Struts and Avocets, p. 149.

II. 'Tarsus under $3 \cdot 50$.

A. Sides of the toes with lobes or webs. . . Family Phalaropodida:

Phalaropes (Fig. 26, $a$ ), p. 147.

$B$. Sides of the toes without lobed webs.

a. Toes four (except in the Sanderling); front of the tarsus with transverse, more or less square, scales. . . Family S'colopacido: Snipes, Sandpipers, etc. (Fig. 25, $a, b$; Fig. 26, $b, c$ ), p. 150.

b. Whole lower back white, a black band across the rump. . . . Family Aphrizida: 'T'urnstones, ete., p. 176.

c. Toes three (except in the Black-bellied Plover): front of the tarsus with small, rounded scales.

$c^{1}$. Bill under 2.00. . . Family Charadriida: Plovens (Fig. 25, $c, d$; Fig. 26, $d, e)$, p. 171 .

$c^{2}$. Bill over $2 \cdot 00 \ldots$ Family Homatopodide: Oyster-CATCHers, p. 177 . 


\section{THE CAND BIRDS.}

Order X. Gallinæ.-Turkers, Grouse, Bob-wintes, etc.

Toes four, the hind one small and elevated above the front ones; bill generally short, stout, hard, and horny; wings rather short, the outer primaries curved and much stiffened.

A. Size very large. ... Subfamily Meleagrince: TuRkeys, p. 186.

B. Size smalier. . Family Tetraonido: Grouse, Вов-whites, etc. (Fig. 27), p. 178.

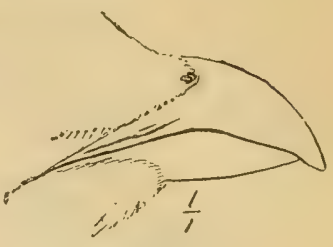

FIG. 2\%.

Order XI. Columbre.-Pigeons and Doves.

Toes four, all on the same level, the hind one about as long as the shortest front one; bill rather slender, deeply grooved, the nostrils opening in a soft, tleshy membrane or skin. ... Family Columbida: Pigeons and Doves (Fig. 28), p. 187.

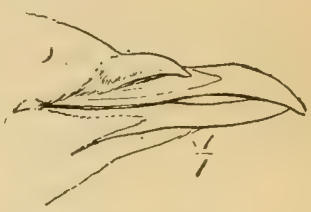

FIG. 28.
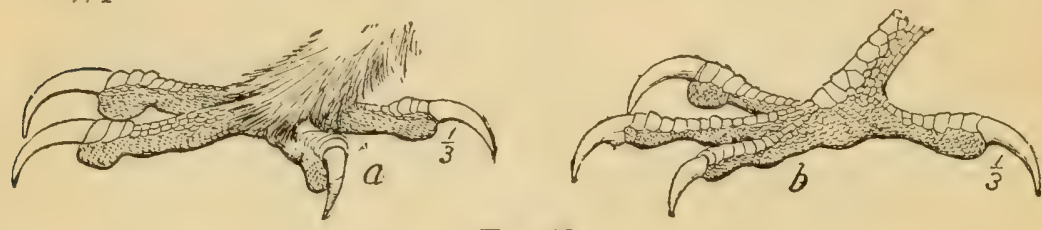

FIG. 29.

Order XII. Raptores.-Vultires, Hawks, and Owls.

Toes four, three in front, the hind one, except in the Vultures, generally as long as or longer than the shortest front one; all the toes armed with strong, sharp, curved nails or talons; bill with a cere, or covering of skin, at its base, through which the nostrils open, very stout and strong, the tip of the upper mandible with a sharply pointed hook.

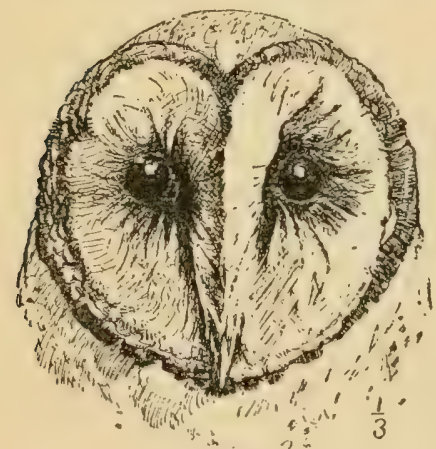

FIG. 30 .

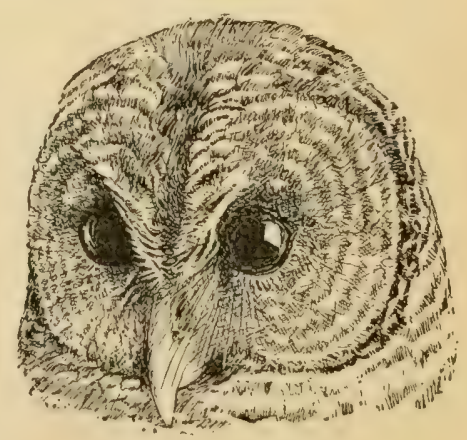

FIG. 31.

A. Eyes set in a striking facial disk; tarsus generally feathered; plum age soft and tluffy. 
a. Middle toe-nail with a comblike edge.... Family Strigida: BArN Ow Ls (Fig. 30), p. 213.

b. Middle toe-nail without a comblike edge. . . Family Bubonida: Horned Owls, Hоot Owls (Fig. 29, a), p. 213.
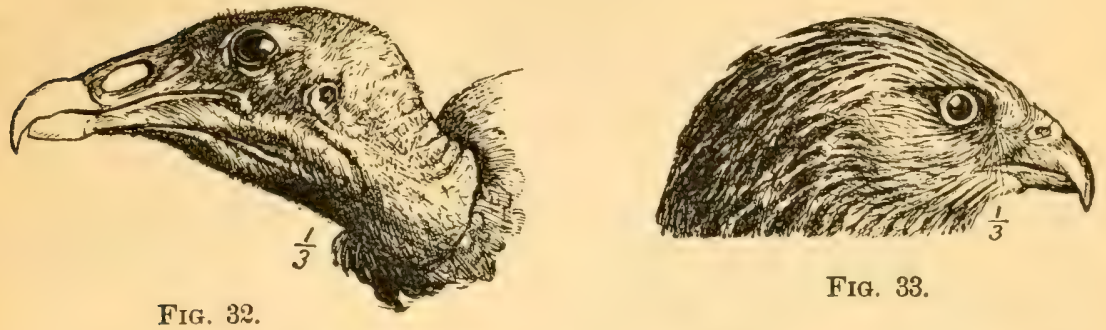

Fia. 33.

$B$. Eyes not set in a striking facial disk; tarsus mostly bare, plumage firm and close.

a. Plumage, in our species, black; hind toe small, claws blunt; bill not sharply hooked; head generally bare. . . . Family Cathartida: American Vultures (Fig. 32), p. 191.

b. Hind toe generally as long as or longer than the shortest front one; toes armed with sharp, curved nails or talons; bill with a sharp hook, head not bare.... Family Falconida: Falcons, Krtes, Hawks, Eagles (Figs. 29, b, 33), etc., p. 193.

\section{Order XIII. Psittaci.-}

Parrots, Paroquets, etc. Toes four, two in front and two behind; bill with a cere. ... Family Psittacida: Parrots and Paroquets (Fig. 34), p. 222.

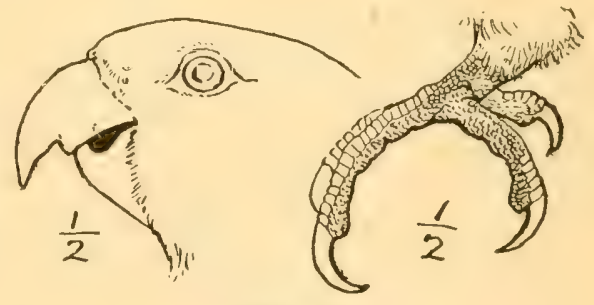

FIG. 34.

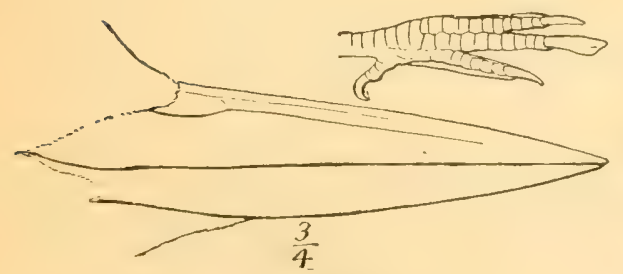

Fig. 35.

Order XIV. Coceyges.-Cuckoos and KINGFISHERS.

Toes four, the middle and outer ones joined for half their length (Kingfishers), or two in front and two behind (Cuckoos); bill without a cere; tail-feathers not stiff

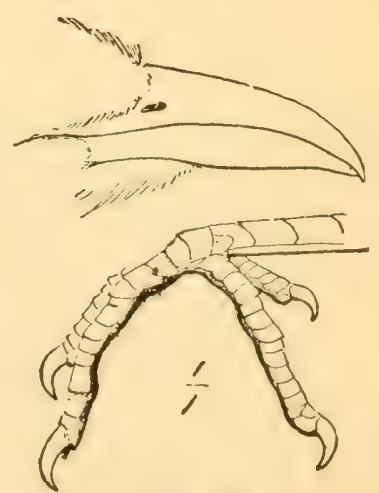

FIG. 36. and pointed. 
$A$. Middle and outer toes joined for half their length. . . F Family $A Z$ cedinidoe: KingFishers (Fig. 35), p. 226.

B. Two toes in front and two behind. . . Family Cuculida: Crckoos (Fig. 36), p. 224.

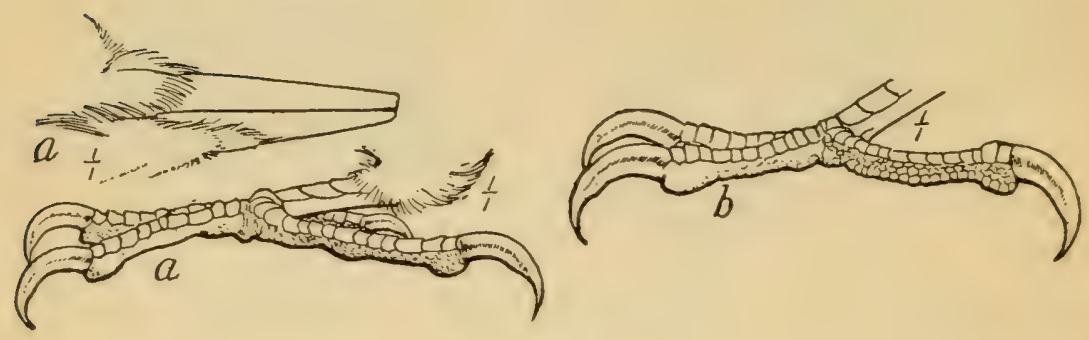

FIG. 37.

\section{Order XV. Pici.-Woodpechers.}

Toes four, two in front and two behind, or toes three, two in front and one behind; bill strong; tail-feathers stiff and pointed; nostrils more or less concealed by bristles.... Family Picida: Woodpeckens (Fig. 37), p. 227.

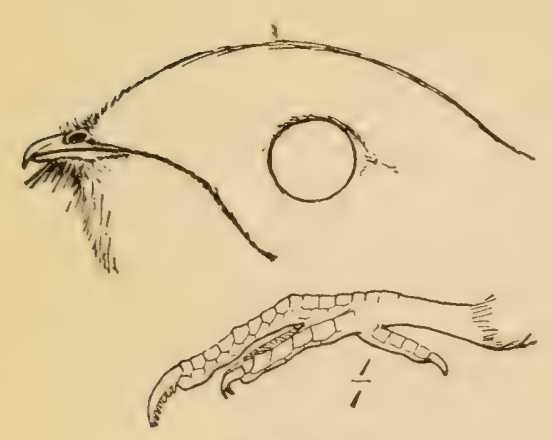

FIG. 38.
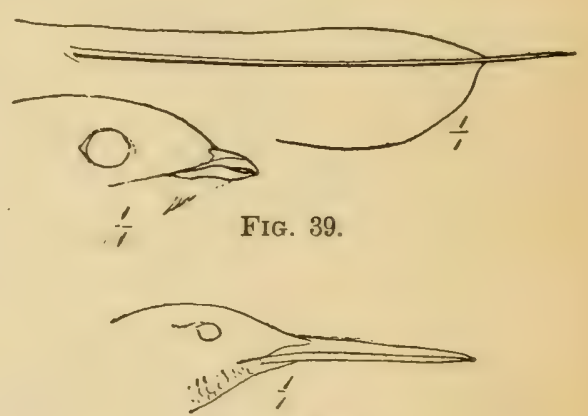

Fig. 40.

Order XVI. Macrochires.-Goatstchers, STIFTs, and HLMMINGBIRDS. Feet very small and weak; bill short and small and mouth large, or bill long and exceedingly slender and mouth small; wings generally long and pointed.

A. Size comparatively large; plumage variegated, black and brown; middle toe-nail with a comblike edge. ... Family Caprimulgidce: Nighthawks, Whip-Poor-Twills, etc. (Fig. 38), p. 236.

$B$. Size medium; plumage sooty black; no comb on the middle toenail; tips of the tail-feathers with spines. . . Family Nicropodida: Swifts (Fig. 39), p. 239.

C. Size rery small; upper parts shining green; bill long and slender. ... Family Trochilide: : Huaningairds (Fig. 40), p. 240. 
Order XVII. Passeres.-Perching Birds: Flycatchers, Blackbirds, Jays, Orioles, Sparrows, Finches,

Swallotis, Vireos, Warblers, Wrexs, Thrushes, ete. Toes four, without webs, all on the same level; hind toe as large as the middle one, its nail generally longer than that of the middle one; tail of twelve feathers.

[The following synoptical table of the characters of the eighteen families which we have in this order seens more satisfactory than an artificial key.]

Family 1. Tyrannidce.-Furcatchers (Fig. 42).

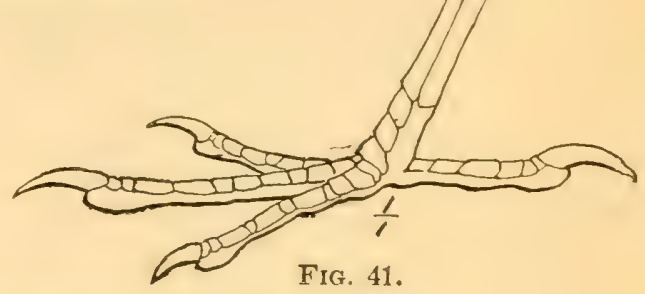

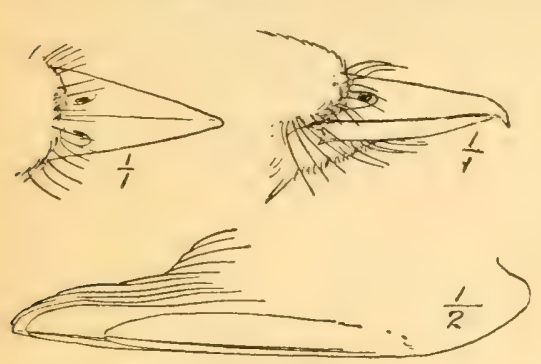

FIG. 42.

Family 2. Alaudidde.-Larks (Fig. 43). Bill rather stout and rounded; nostrils with bristly tufts; nail of hind toe much lengthened, as long as the middle toe without nail; back of the tarsus rounded like the front, p. 252 .

Bill wider than high at the base, slightly hooked at the tip; base with conspicuous bristles; wings longer than the tail, the second to fourth primaries longest, the first but little shorter and generally equal to the fifth or sixth; back of tarsus rounded, like the front; plumage generally olive-green or grayish; tail, except in the Kingbird, without white spots, p. 242.
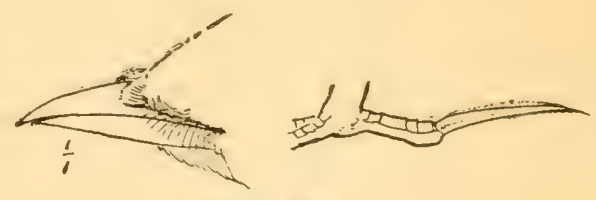

FIG, 43.

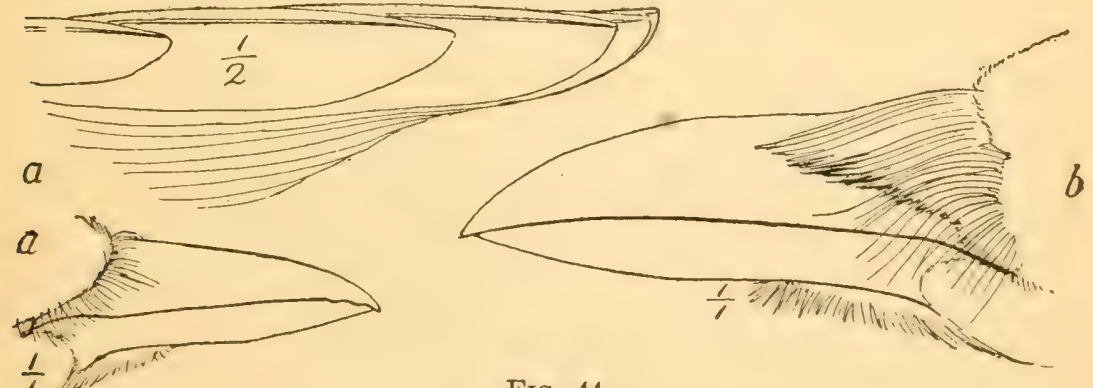

FIG. 44.

Family 3. Corvida.-Crows and JAYs (Fig. 44).

Large birds, over 10.00 in length; bill stout, the nostrils concealed hy tufts of bristly feathers; fourth to fifth primary the longest, the first about half as long; outer tail-feathers shortest; feet and legs stout, p. 253. 


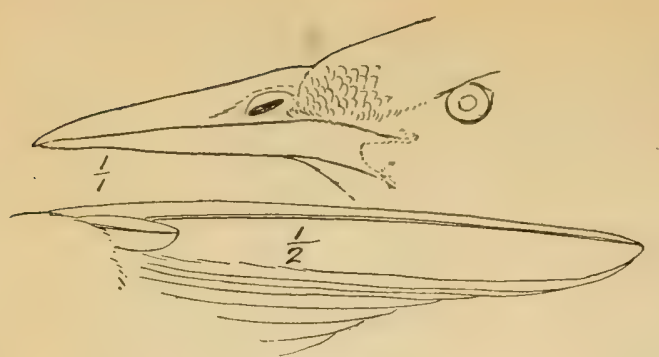

FIG. 45.
Family 4. Sturnida.-STARLINGS (Fig. 45).

Bill flattened, wider than high at the buse; tail short and square; wings long and pointed, second primary longest, the first very small, less than half an inch in length, p. 259.

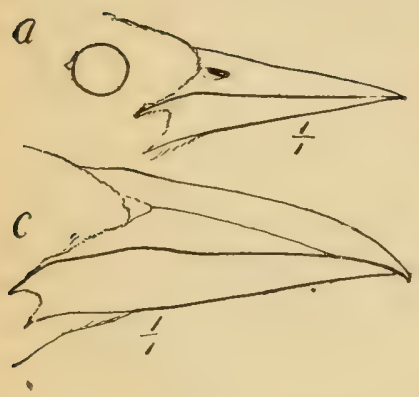

b

FIG. 46.

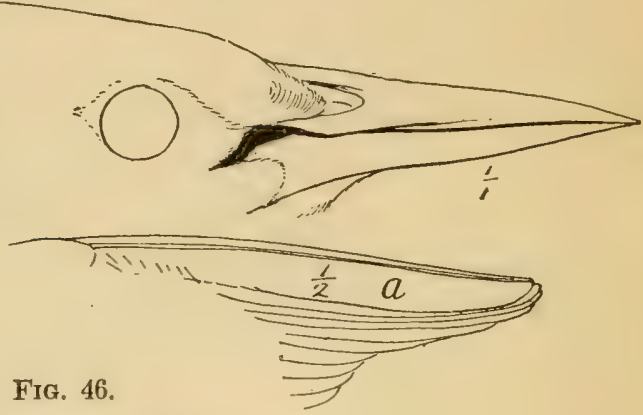

Family 5. Icterido.-Blackbirds, Orioles, etc. (Fig. 46).

Length 7.00-17.00; base of the bill, between the nostrils, extending backward and dividing the feathers of the forehead; nostrils not concealed by bristles; first three primaries of about equal length: outer tail-feathers generally shortest, p. 260.

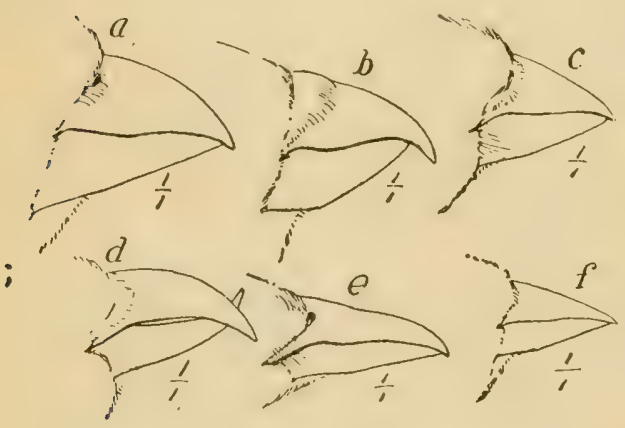

FIG. 47.

Family 6. Fringillida.-Sparrows, Finches, GrosBEAKs, etc. (Fig. 47).

Length $4 \cdot 75-9 \cdot 00$, generally under 8.00 ; bill short, stout, and conical, admirably fitted to crush seeds; third and fourth primaries generally about the same length, the first never more than half an inch shorter than the longest, p. 271.

Family 7. Tanagrida.-T'ANAGERs (Fig. 48).

Length about 7.00 ; the males of our species mostly red; bill finchlike, but less conical, somewhat swollen, the outline of the upper mandible curved, its sides with a slight but generally evident "tooth" near the middle; tail-feathers of equal length, p. 316.

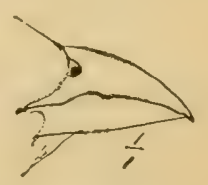

FIG. 48. 
Family 8. Hirundinida.-Swallows (Fig. 49).

Bill short and flattened, much wider than high at the base; no bristles at the base of the bill; wings long and pointed, tips, when closed, generally reaching beyond the end of the tail; first primary the longest; outer tailfeathers longest; feet small, tarsus short, round in front, narrower and sharper in the back, p. 318.
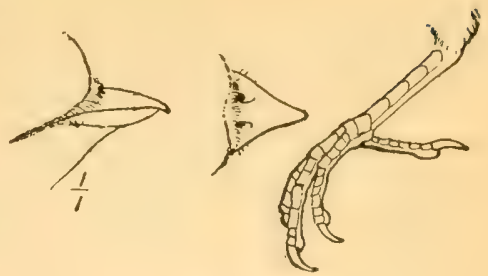

FIG. 49.

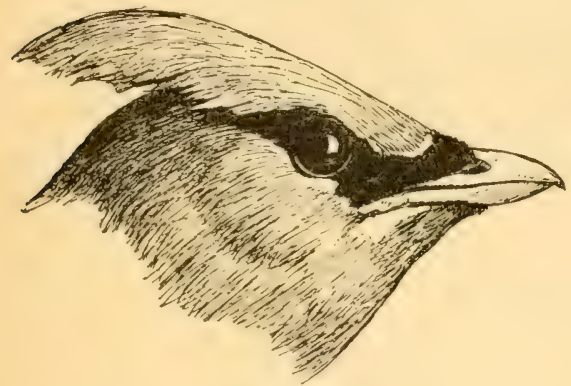

Family 9. Ampelido.-WAXwings

(Fig. 50).

Plumage generally soft, brownish gray or grayish brown; a black band across the forehead and through the eyes; tail tipped with yellow; bill short, notehed at the tip; head conspicuously crested, p. 323.

FIG. 50.

Family 10. Laniida.-SHrikes (Fig. 51).

Grayish birds, $8 \cdot 00-9 \cdot 00$ in length, most of the tail-feathers tipped with white; bill hooked and hawklike, p. 325 .

Family 11. Vireonida.-Vireos (Fig. 52).

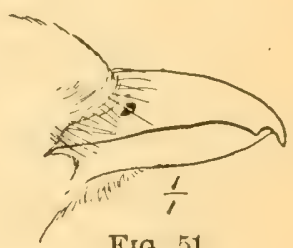

Fra. 51.

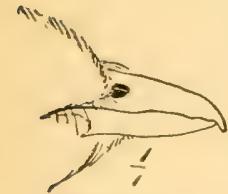

FIG. 52. Small birds, 5.00$7 \cdot 00$ in length, with generally olivegreen backs; tailfeathers without white spots; bill rather stout, higher than broad at the base, the tip of the upper mandible notched and hooked, bristles at the base of the bill barely evident; tarsi scaled, round in front, narrower and sharper behind; toes united at the base, p. 327.

Family 12. Mriotiltida.-WoOD WARBLERS (Fig. 53).

Small birds, length generally under 6.00 , but in four species $6.50-7.50$, with, as a rule, brightly colored

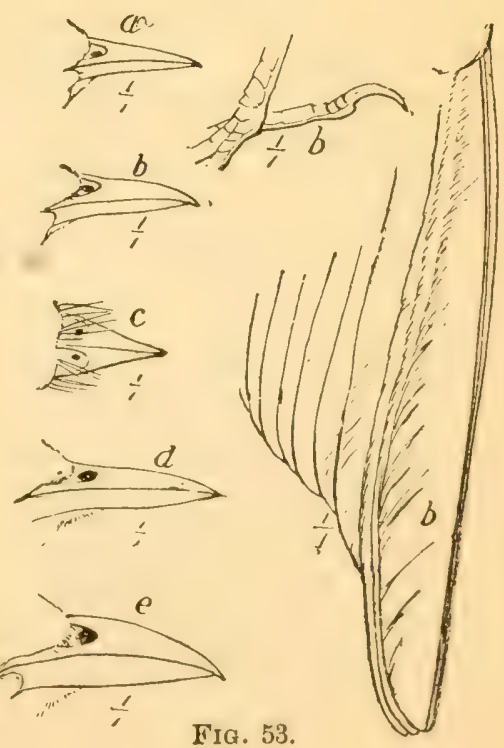


plumage, olive-green or yellow being the most frequent; bill various, never notched at the tip, usually slender and sharply pointed, without conspicuous bristles, but sometimes flattened and broader than high at the base, when the bristles are evident (thus resembling the bill of a true Flycateher, but the back of the tarsus is always thin and narrow, and never rounded as in front); rarely the bill is heavier, more thrushlike or finchlike; second or third primary longest, the first little if any shorter; tail generally square, sometimes rounded, the outer feathers frequently blotched with white, p. 333 .

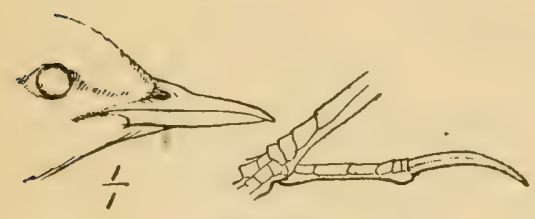

FIG. 54.

Family 13. Motacillida.-WAGTAILS and Pipits (Fig. 54).

No bristles over the nostrils; bill slender, much as in the preceding ; hind toe-nail much lengthened, as long as or longer than the toe; first three primaries of equal length, p. 375.

Family 14. Troglodytida. - ThrasuERs, Wrens, etc. (Fig. 55).

Subfamily Mimince. - 'Thrashers, Mockingbirds, and Catbirds.

Length 8.00-12.00; tarsus scaled; tail rounded, the outer feathers at least half an inch shorter than the middle ones, third to fifth primary longest, the first about half as long, p. 376.

Subfamily Troglodytino.-W -Wens.

Length 4.00-6.00; bill moderate, the upper mandible slightly curved, no bristles at its base; third to fourth primary longest, first about half' as long; tail short and rounded; brown or brownish birds with indistinctly barred wings and tail, p. 376.

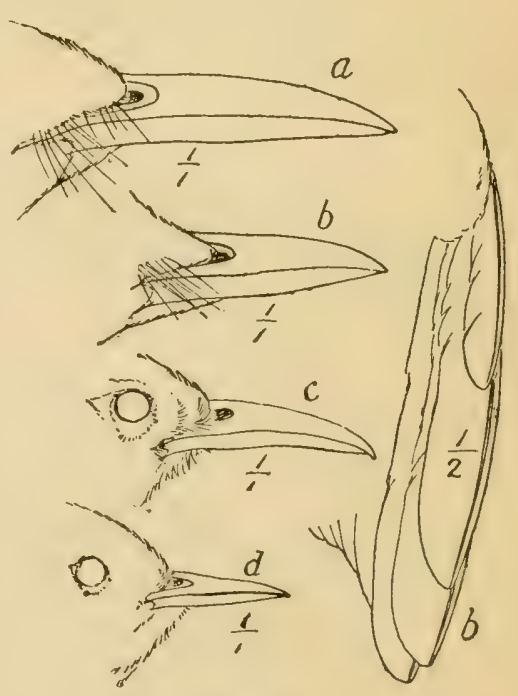

Fig. 55.

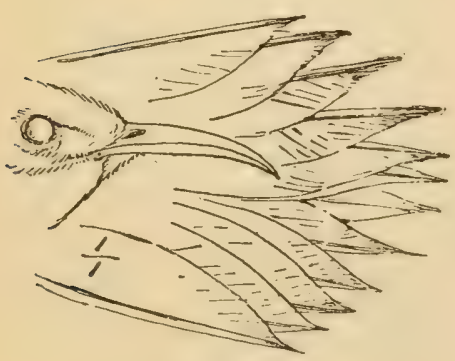

Family 15. Certhiida.-Creepers (Fig. $56)$.

Bill slender and much curved; tailfeathers pointed and slightly stiffened, p. 385 .

Fig. 56. 
Family 16. Parida.-Nuthatches and Titmice (Fig. 57).

Subfamily Sittina.-Nuthatches.

Bill rather long and slender, the end of the lower mandible slanting slightly upward; wings long and pointed, the third or fourth primary the longest, the first very small, not an inch in length; tail short and square, the outer feathers blotched with white, p. 386 .

Subfamily Parina.-Tiтmice.

Length 4:50-6.50; bill short, stout, and rounded, less than half an inch in length; fourth or tifth prinary longest, first very short, not more than one third as long; tail rather long, dull ashy gray without white blotches, p. 389.

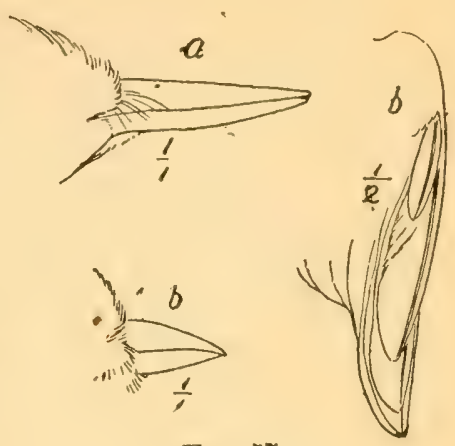

FIG. 5\%.

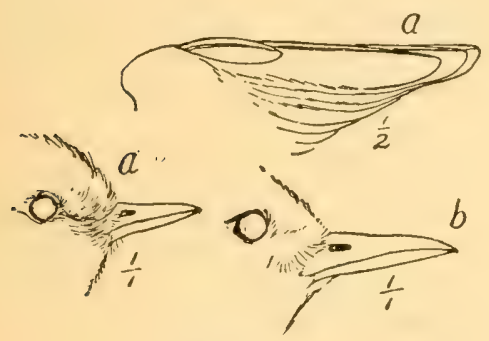

Family 17. Sylviidoe.-Kinglets and Gnatcatchers (Fig. 58).

Length $3 \cdot 50-5 \cdot 00$; bill slender, resembling that of some Warblers, but the first primary is very short, only about one third as long as the longest, p. 391.

FIG. 58.

Family 18. Turdida. Thrushes, Bluebirds, etc. (Fig. 59).

Length over 5.50 ; bill moderate, the tip of the upper mandible notched; tarsus smooth, the scales, if any, fused and indistinct; tail square: wings long and pointed, 3.75 or over, third primary the longest, the first very short, less than one inch in length, p. 394.

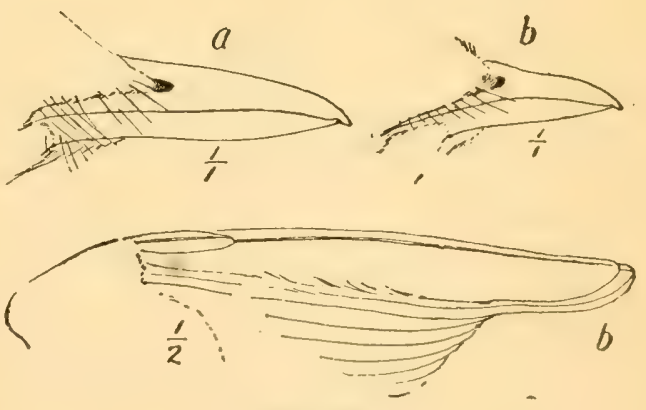

Fig. 59. 


\section{ORDER PYGOPODES. DIVING BIRDS.}

\section{FaMilu Podicipida. Grebes.}

The Grebes, or lobe-footed divers, number about thirty species, distributed throughout the world. Six species are found in North America. Grebes are eminently aquatic birds, and rarely if ever venture upon land, where they are almost helpless. The marvelous rapidity with which Grebes dive, and the ease with which this power formerly enabled them to escape the shot of the fowler, have won for them their various popular names of "Hell-diver," "Water-witch," etc. The cartridges of the modern breech-loader do not give the warning of the discarded flint-lock or percussion cap, and "to dive at the flash" is an expression which now has lost half its meaning. Grebes possess the power of swimming with only the tip of the bill above water, a habit which accounts for many mysterious disappearances. They feed largely on fish, which they pursue and catch under water, progressing by aid of the feet alone.

KEY TO THE SPECIES.

A. Depth of bill at nostril over 35 .

a. Wing over 6.00 . . . . . . 2. Holbell's Grebe.

b. Wing under 6.00 . . . . . 6. Pied-Billed Grebe.

B. Depth of bill at nostril less than 35. . . . . 3. Horned Grebe.

2. Colymbus holbœllii (Reinh.). Holbell's Grebe. Ad. in summer.-Top of the head, small crest, and back of the neek, glossy black; back blackish; throat and sides of the head silvery white; front and sides of the neck rufous, changing gradually over the breast into the silvery white belly; sides tinged with rufous. $A d$. in winter.-Upper parts blackish brown; throat and under parts whitish; front and sides of the neck pale rufous. Im. -Upper parts blackish; throat and under parts silvery white; neck and sides grayish. L., 19.00; W., 7.50; Tar., $2 \cdot 20 ;$ B., 1.90.

Range.-Breeds in the interior of North America, from northern Minnesota northward; in winter migrates southward as far as South Carolina and Nebraska.

Washington, uncommon W. V., Sept. 30 to Mch. or Apl. Long Island irregular W. V., Oct. to Apl. Sing Sing, rare T. V., Oct. to Dec. Cambridge, casual.

Nest, a mass of water-soaked, decaying vegetation floating among rushes in a slough, generally attached to its surroundings. Eggs, two to five, dull white, more or less soiled, $2 \cdot 25 \times 1 \cdot 35$.

"In common with others of the family, this Grebe is an expert diver. Often it will sink into the water without any apparent effort, though more generally it jumps forward, throwing the head into the 



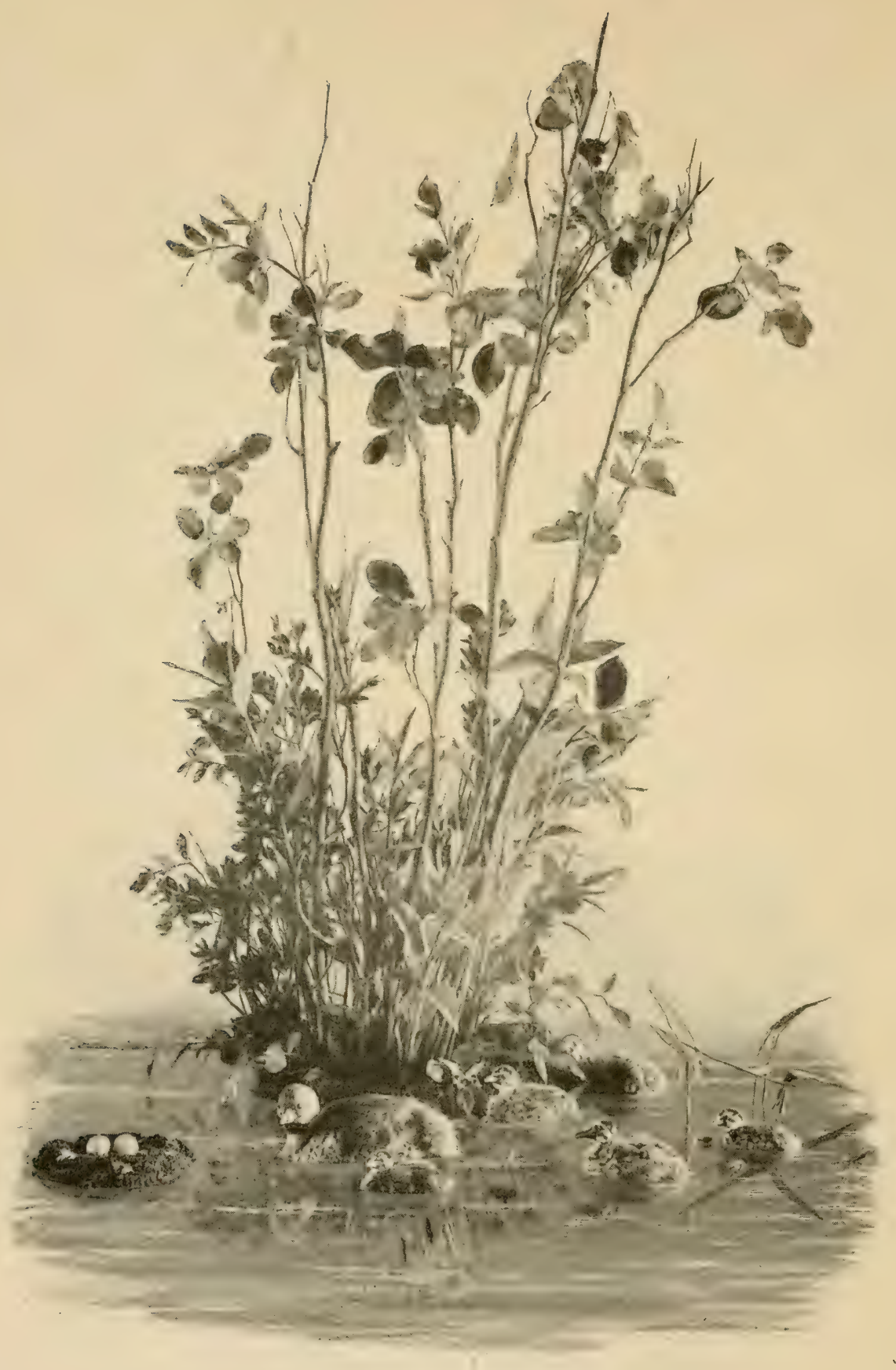

Pied-billed Grebe and young. 
water and the body into the air. It is an expert and rapid swimmer also, and all its morements on the water are exceedingly graceful. When pursued, these birds invariably endeavor to escape by diving, though when on the wing they fly rapidly, their necks and feet stretched at full length" (Chamberlain).

3. Colymbus auritus Linn. Horned Greee. Ad. in summer.Top of the head, hind neck, and throat, glossy blackish; lores pale chestnut; stripe, and plumes behind the eye, butfy ochraceous, deeper posteriorly; back and wings blackish; secondaries white; foreneck, upper breast, and sides chestnut; lower breast and belly white. Ad. in winter and Im.-Cpper parts grayish black; under parts silvery white, sometimes washed with grayish on the throat and breast. L., 13.50 ; W., 5.40 ; Tar., $1.75 ;$ B., 90 .

Kange.-Breeds from northern United States (northern Illinois, St. Clair Flats) northward; winters south ward to the Gulf States.

Washington, common W. V., fall to Apl. 25. Long Island, abundant T. V., rare W. V., Oct. to Apl. Sing Sing, common T. V., Oct. to Dec.; Meh. Cambridge, casual.

Nest, a mass of water-soaked, decaying vegetation, floating among rushes in a slough, generally attached to its surroundings. Eggs, two to seven, dull white, more or less soiled, $1.74 \times 1.15$.

This species and the next are probably frequently mistaken for each other in life, and the same common names are in some instances applicable to both. Mr. Enest E. Thompson writes of a captive individual: "When ordinarily swimming, the feet strike out alternately, and the progression is steady; but sometimes both feet struck together, and then the movement was by great bounds, and was evidently calculated to force the bird over an expanse of very weedy water, or through any tangle of weeds or rushes in which it might have found itself. When lifted out of the water, the feet worked so fast as to be lost to the eye in a mere haze of many shadowy feet with one attachment. When placed on the ground, it was perfectly helpless" (Birds of Manitoba, p. 466).

6. Podilymbus podiceps (Limn.). Pien-billen Grebe; Dabchick; Diedapper; Hell-diver; Water-witch. (See Fig. 5, a.) Ad. in summer.Upper parts glossy, brownish black; throat black; upper breast, front and sides of the neek, and sides of the body, washed with brownish and indistinctly mottled with blackish; lower breast and belly white; a black band across the bill. Ad. in winter and Im.-Much like the above, but throat white and no black band on the bill. L. $13.50 ;$ W., 5.10; Tar., $1 \cdot 45$; B., 85 .

Range.-Argentine Republic northward through Mexico and the West Indies to Hudson Bay and Great Slave Lake, breeding locally throughout its range; winters from New Jersey southward.

Washington, common W. V., Aug. 25 to Apl. or May. Long Island, uncommon T. V., Sept. to Apl. Sing Sing, common T. V., Apl. 6 to Apl. 20; 
Sept. 3 to Oct. 28; a few summer. Cambridge, T. V. in Apl.; very common Sept. to Nov.; breeds in one locality.

Nest, a mass of water-soaked, decaying vegetation, sometimes built up from the bottom in shallow water, sometimes floating among rushes in a slough, when it is generally attached to its surroundings. Eggs, four to eight, dull white, more or less soiled or stained, $1.74 \times 1 \cdot 19$.

This is probably the best known of our Grebes, and is the one which most frequently tempts the shot of would-be sportsmen. Its common names may stand as an expression of its aquatic powers. It dives head foremost, or sinks slowly beneath the water. Iike other Grebes, it can swim easily and for an indefinite period with only its bill above the water, and its sometimes mysterious and apparently complete disappearance is explained by this habit.

\section{Family URInatorid $A$. Loons.}

A family containing only five species, inhabiting the northern half of the northern hemisphere. The Loons are scarcely less aquatic than the Grebes, and are their equals as divers and swimmers. They visit the land only to nest, when their clumsy progress is assisted by the use of bill and wings. Their food consists of fish, which they procure by diving, progressing when under water by aid of the feet alone.

A. Throat black.

KEY TO THE SPECIES.

a. Head black . . . . . . . . . . . . . 7. Loon.

b. Head ashy . . . . . . . 9. Black-THRoated Loon.

B. Throat gray, foreneck chestnut . . . 11. RED-Throated Loon.

$C$. Throat white or whitish; back fuscous, margined with grayish.

$a$. Wing over 13.00 ; base of bill to anterior end of nostril 75 or over.

7. Loon (Im.).

b. Wing under $13 \cdot 00$; base of bill to anterior end of nostril less than ${ }^{\circ} 75$.

9. Black-throated Loon (Im.).

$D$. Throat white or whitish; back fuscous, spotted with white.

11. Red-throated Loon (Im.).

\%. Urinator imber (Gunn.). Loon. (See Fig. 5, b.) Ad. in summer. - Cpper parts, wings, tail, and neek black with bluish or greenish reffections; spaces on the throat and sides of the neck streaked with white; back and wings spotted and barred with white; breast and belly white; sides and a band at the base of the under tail-coverts black spotted with white. $A d$. in winter and Im.-Upper parts, wings, and tail blackish margined with grayish not spotted with white; under parts white; throat sometimes washed with grayish. L., $32 \cdot 00$; W., 14.00 ; Tar., $3 \cdot 40 ;$ B., $2 \cdot 80$.

Range.-Breeds from northern Illinois, Minnesota, and northern New England to the Aretic Cirele; winters from the southern limit of its breeding range to the Gulf of Mexico. 
Washington, common W. V., Sept. to Apl. 25. Long Island, abundant T. V., common W. V., Sept. to June. Sing Sing, common T'. V., Mch. and Oct. Cambridge, not common 'T. V., Apl. to early May; Sept. to Nov.

Nest, a slight depression in the ground within a few feet of the water. Eggs, two, grayish olive-brown, thinly spotted with blackish, 3.50 × 2.20.

This wild inhabitant of our northern lakes and ponds possesses all the characteristic traits of the Divers. Its remarkable notes are thus described by Mr. J. H. Langille:

"Beginning on the fifth note of the scale, the voice slides through the eighth to the third of the scale above in loud, clear, sonorous tones, which on a dismal evening before a thunderstorm, the lightning already playing along the inky sky, are anything but musical. He has also another rather soft and pleasing utterance, sounding like who-whowho-who, the syllables being so rapidly pronounced as to sound almost like a shake of the voice-a sort of weird laughter."

Loons may be seen migrating by day singly or in small companies, generally at a considerable height. Their flight is strong, rapid, and direct.

9. Urinator arcticus (Linn.). Black-turoated Loon. Ad. in summer.-Throat, foreneck, back, wings, and tail black, with purplish and bluish reflections; a band of white streaks on the throat; sides of the neck, back, and wings streaked, barred, or spotted with white; top of head and nape gray; breast and belly white; a blackish band at the base of the under tail-coverts. Ad. in winter and $I m$.- Similar in color to $U$. imber, not spotted above with white. L., $27^{\circ} 00$; W., 11.00; Tar., $2 \cdot 60$; B., $2 \cdot 00$.

Remarks.-Immature and winter birds may be distinguished from the corresponding stage of imber by their small size; from lumme by grayish margins instead of white spots, bars, or margins on the upper parts.

Range.-Breeds in the northern parts of the northern hemisphere; in North America migrates southward in winter to the northern United States, casually to Ohio and Long Island.

Long Island, A. V., one record.

Nest, a slight depression in the ground within a few feet of the water. Eggs, two, grayish olive-brown, spotted or scrawled with blackish, $3.20 \times 2 \cdot 10$.

This species is a very rare winter visitant to the northern border of the United States. The most southern record of its occurrence is Long Island (Dutcher, Auk, x, 1893, p. 265).

11. Urinator lumme (Gunn.). ReD-THRoAted Loon. Ad. in summer.-Back, wings, and tail fuscous, more or less spotted with white; head and neck ashy gray; foreneek chestnut; back of the neck black, streaked with white; breast and belly white; longer under tail-coverts and band at the base of shorter ones fuscous. Ad. in vinter and Im.-Similar to U. imber, but back spotted with white. L., $25 \cdot 00$; W., $11 \cdot 00$; 'Tar., $2 \cdot 60 ;$ B., $2 \cdot 00$.

Runge.-Found throughout the northern parts of the northem hemisphere, 
breeding in North America from New Brunswick and Manitoba northward, and migrating irregularly southward as far as South Carolina.

Washington, rare W. V. Long Island, common T. V., rare W. V., Oct. to May. Sing Sing, casual T. V. Cambridge, one instance, Oct.

Nest, a slight depression in the ground within a few feet of the water. Eggs, two, grayish olive-brown, sometimes tinged with green and spotted with blackish, $2.80 \times 1 \cdot 75$.

This is a more northern species than Urinator imber, which it doubtless closely resembles in habits.

\section{Family Alcid Ae. Auks, Murres, and Puffins.}

This family contains about thirty species, confined entirely to the northern parts of the northern hemisphere. Nearly all of these are found in North America, most of them, however, on only our Pacific coast. Without exception they are maritime birds, passing the greater part of their lives on the open sea. They nest in colonies, sometimes in enormous numbers, generally upon rocky, precipitous shores. Their progress on land is slow and awkward; but they are, as a rule, strong fliers, and accomplished swimmers and divers. Unlike the Grebes and Loons they use their wings in diving. Their food consists of fish, crustacea, and other forms of sea life.

KEY TO THE SPECIES.

I. Bill under 75

II. Bill over 75 .

1. Depth of bill at nostril over 60 .

a. Bill yellowish, depth at nostril over $1 \cdot 00$.

13. Puffin. 13a. Large-billed Puffin. b. Bill black, depth at nostril under 1.00 . . 32. Razor-bILLEd Auk.

2. Depth of bill at nostril under 60 .

A. Wing-coverts white or tipped with white.

a. Greater wing-coverts entirely white . 28. MаNDT's GuILlEmot.

b. Basal half of greater wing-coverts black. 27. Black Guillemot. $B$. No white on wing-coverts.

a. Bill over 1660. . . . . . . . 30. Murre.

b. Bill under 1.60 . . . . . 31. Brtnnnich's Murre.

13. Fratercula arctica (Linn.). PUffin; $\mathrm{SeA}_{\mathrm{P}} \mathrm{P}_{\mathrm{ARR}}$ (see Fig. 5, c). $A d$.-Upper parts, wings, tail, and foreneck blackish, browner on the head and foreneck; nape with a narrow grayish collar; sides of the head and throat white, sometimes washed with grayish; breast and belly white. (Breeding birds have the bill larger and brighter, and a horny spine over the eye.) L., 13.00 ; W., 6.10 ; Tar., 1.05; B., 1.85; depth of B. at base (in winter), 1.50.

Range.- "Coasts and islands of the North Atlantic, breeding on the North American coast from the Bay of Fundy northward" (A. O. U.). Migrates southward in winter, rarely to Long Island. 
Long Island, A. V. in winter.

Nest in a burrow in the ground or in crevices among rocks. Egg, one, dull white, sometimes with obscure markings, $2.49 \times 1.68$.

Mr. Brewster, in describing his experience with this species in the Gulf of St. Lawrence, writes: "The first report of our guns brought dozens tumbling from their nests. Their manner of descending from the higher portions of the cliff was peculiar. Launching into the air with heads depressed and wings held stiffly at a sharp angle above their backs, they would shoot down like meteors, checking their speed by an upward turn just before reaching the water. In a few minutes scores had collected about us. They were perfectly silent and very tame, passing and repassing over and by us, often coming within ten or fifteen yards. On such occasions their flight has a curious resemblance to that of a Woodcock, but when coming in from the fishing grounds they skim close to the waves, and the wings are moved more in the manner of a Duck" (Proc. Bost. Soc. Nat. Hist., xxii, 1883, p. 407).

13a. F. a. glacialis $\left(T_{e} m m\right.$. $)$. Large-Billed PUffin.-Similar to the preceding, but larger. W., 6.80-7:40; B., 2.00-2.30 (B., B., and R.).

Range.- "Coast and islands of the Aretic Ocean from Spitzbergen to Baffin's Bay" (A. O. U.).

The Tufted Puffin (12. Lunda cirrhath) inhabits the North Pacific from California to Alaska. The specimen tigured by Audubon was said by him to have been procured at the mouth of the Kennebec River, Maine. There is no other record of its occurrence on the Atlantic coast.

2\%. Cepphus grylle (Linn.). Black Gullemot; Sea Pigeon. $A d$. in summer.-Sooty black, lighter below and with slight greenish reflections above; lesser wing-coverts and terminal half of the greater wing-coverts white, the basal half of the greater coverts black; linings of the wings white. $A d$. in winter.-Upper parts gray or black, the feathers all more or less tipped with white; wings as in summer; under parts white Im.-Upper parts as in winter adults; under parts white, mottled with black; wing-coverts tipped with black. L., 13.00 ; W., 6.25; Tar., 1.25; B., 1.20.

Range.-Breeds in North America from the Bay of Fundy (Grand Menan) northward, and migrates south ward regularly to Cape Cod, and rarely to Connecticut and Long Island; accidental in Pennsylvania.

Long Island, A. V. in winter.

Nest, in the crevices and fissures of cliffs and rocky places. Eggs, two to three, dull white, sometimes with a greerish tinge, more or less heavily spotted with clear and obscure dark chocolate markings, more numerous and sometimes confluent at the larger end. $2 \cdot 18 \times 1 \cdot 40$.

"They were wary and alert, but allowed me to paddle within easy shooting distance without displaying much alarm. When they finally concluded I was an unsafe neighbor, they lost no time in getting out of sight, diving with surprising suddenness. They usually swam a 
long distance under water with great rapidity, using their wings as well as their feet, and coming to the surface far beyond gunshot range.

"The Sea Pigeons are met usually in small flocks of half a dozen or more, and generally feed in the open sea at the base of bold cliffs. When on the wing they proceed rapidly and in a straight line, and rarely more than a few feet from the surface of the water. On approaching their nesting-site they rise rather abruptly, and fly directly to their nests" (Chamberlain).

28. Cepphus mandtii (Licht.). Mannt's Guillemot.-Resembles the preceding, but the bases of the greater wing-coverts are white instead of black.

Runge.-"Aretic regions of both continents" (A. O. U.); in America breeding from Labrador and Hudson Bay northward, migrating southward as far as Massachusetts.

Nest, in crevices and fissures of cliffs and rocky places. Eggs, two to three, not distinguishable from those of $C$. grylle, $2.34 \times 1 \cdot 15$.

A more northern species than the preceding, which it doubtless resembles in habits.

30. Uria troile $(\operatorname{Linn}$.). MLRRe. Ad. in summer.-Upper parts, wings, tail, and neck all around, dark sooty brown, blacker on the back, wings, and tail; tips of secondaries, breast, and belly white, the sides more or less streaked with blackish. Ad. in winter and Im.-Upper parts, wings, and tail much as in summer; under parts white, the throat more or less washed with sooty brown, the flanks sometimes streaked with brownish, and the feathers of the belly more or less lightly margined with blackish. L., 16.00 ; W., 8.00 ; Tar., 1.40 ; B., $1 \cdot 75$; depth of B. at nostril, $\cdot 50$.

Remarks.-Some specimens have a white ring around the eye and a white stripe behind it. They have been named U. ringvia (Brünn.), but it is uncertain as to whether the species is a distinet one or is based on a mere variation of plumage.

Range._- "Coasts and islands of the North Atlantic" (A. O. U.). In North America, breeding from Nova Scotia northward, and migrating southward as far as Massachusetts.

Nests in communities, side by side on the bare ledges of rocky cliffs. 'Egg, one, pyriform, varying from pale blue or greenish blue to whitish or buffy, singularly spotted, scrawled, or streaked with shades of chocolate, rarely unmarked, $3.25 \times 2.00$.

"These birds begin to assemble on their customary cliffs in England early in May, and erowd together in such numbers that it is not uncommon to see hundreds sitting upon their eggs on the ledge of a rock, all in a line, and nearly touching each other" (Nuttall).

"The bird usually sits facing the cliff, holding the egg between her legs, with its point outward; if robbed, she will lay at least one more, 
similar in character. ... Considerable force is exercised in diving, and the wings are used for propulsion under water" (Saunders).

31. Uria lomvia (Linn.). Brinnicu's Mitrre. Ad. in summer.Upper parts, wings, and tail sooty black, foreneck somewhat browner; tips of secondaries, breast, and belly white; base of the upper mandible greenish, rounded outward beyond the edge of the lower mandible. L., 16.50; W., $8 \cdot 40$; Tar., 1.30 ; B., 1.25 ; depth of B. at nostril, $\cdot 47$.

Remarks.-Adults are to be distinguished from adults of $U$. troile by the darker color of the head, which in lomvia is darker than the throat, by the size of the bill and thickening of its cutting edge at the base. Winter and immature birds can be distinguished from those of $C$. troile only by the size of the bill, which, as the measurements show, is longer in that species.

Range._- Coasts and islands of the North Atlantic and eastern Arctic Oceans" (A. O. U.). Breeds from the Magdalen Islands northward; in winter migrates us far south as New Jersey.

Long Island, irregular W. V. sing Sing, A. V.

Texts in communities, side by side on the bare ledges of rocky cliffis. Eyg, one, not distinguishable from that of $U$. troile.

"During the winter it lives on the open sea, and in the breeding season assembles in large flocks on bold cliffs and rocky headlands. It is an expert diver, using wings and feet to get under water and to swim through it." (Chamberlain).

32. Alca torda Liun. Razor-billed Atr; Thinker. Ad. in summer.- - Tpuer parts, wings, and tail sooty black; foreneck somewhat browner; tips of the secondaries, a line from the eye to the bill, breast, and belly white; bill black, crossed by a white band. Ad. in winter.-Similar to ad. in the summer, but with the sides and front of the neck white. Im.-Similar to ad. in winter, but with the bill smaller and without the white bar. L., 16.50; W., $7 \cdot 90$; Tar., $1 \cdot 35 ;$ B., $1 \cdot 25$.

Range.- "Coasts and islands of the North Atlantic" (A. O. U.). Breeds from the Magdalen Islands northward; in winter migrates southward regularly to Long Island and rarely to Virginia and North Carolina.

Long Island, irregular W. V.

Nest, in the crevices and fissures of cliffs and rocky places. Eggs, one to two, pale bluish white or buffy, thickly spotted and speckled with chocolate markings most numerous and sometimes confluent at the larger end, $3 \cdot 00 \times 1.90$.

"When brooding, it crouches along, not across, the egg, its mate often standing near; and both sexes incubate, though the male may be seen bringing food to the sitting female. . . The young flutter from the rocks to the sea, or are taken by the neck and carried down by the parents. They are at first very loath to follow the old bird in diving, and remain crying plaintively on the surface of the water. The food consists of small fish, which are carried diagonally in the bill -not at right angles, as by the Puffin-and crustaceans. The Razor- 
bill utters a peculiar grunting or groaning, especially when sitting. On the water it may be distinguished from the Guillemot, at a distance, by its upturned tail" (Saunders).

33. Plautus impennis (Linn.). Great Avr.-Upper parts fuscous black, a large white spot before the eye; secondaries tipped with white; sides of the neck and throat seal-brown, rest of the under parts silvery white. L., $28 \cdot 00-30 \cdot 00$; W., $5 \cdot 75$; B., 3.15-3.50; greatest depth of B., 1.50 (Ridgw.).

Range.- "Formerly the coasts and islands of the North Atlantic, from Massachusetts and Ireland northward nearly to the Aretic Circle" (A. O. U.). Now extinct.

Egg, pyriform-orate, pale olive buffy, variously marked with brown and black, $4^{\circ} 67 \times 2 \cdot 91$ (Ridg w. $)$.

The Great Auk was flightless. Like other birds of this family, it frequented certain localities in large numbers each year to breed. Early voyagers and fishermen visited its nesting grounds, killing the helpless birds in enormous numbers for their flesh, feathers, and oil. The result was extinction, and no living Great Auk has been observed since 1842. About serenty specimens are known to be preserved in collections. (See Lucus, Rep. Smith. Inst., 1891, pp. 638-641.)

34. Alle alle (Linn.). Doverie; Sea Dove. Ad. in summer.-Upper parts, wings, and tail sooty black; sides and front of the neck and upper breast somewhat browner; secondaries tipped and scapulars streaked with white; lower breast and belly white. Ad. in winter and Im.-Similar to the above, but throat whiter or washed with dusky, and sometimes a gray collar on the nape. L., $8 \cdot 00 ;$ W., 4.50 ; Tar., ${ }^{7} 70 ;$ B., ${ }^{\circ} 50$.

Range.- "Coasts and islands of the North Atlantic and eastern Aretic Oceans" (A. O. U.). Breeds from latitude $69^{\circ}$ northward ; in winter migrates southward, rarely to Long Island and New Jersey; accidental in Pennsylvania and Virginia.

Long Island, irregular W. V. Sing Sing, A. V.

Nest, on the ledges and in the crevices of rocky cliffs. Egg, one, pale bluish white, $1.85 \times 1 \cdot 27$.

"On the approach of a vessel this bird has a peculiar way of splashing along the surface of the water, as if unable to fly, and then diving through the crest of an advancing wave; it swims rather deep and very much 'by the stern.' . . "' (Saunders).

"Its wings are small, but they are moved almost as rapidly as a Hummingbird's, and propel the bird through the air with great rapidity. This bird is an expert diver too, and, though awkward on land, swims with ease and grace. ..." (Chamberlain). 


\section{ORDER LONGIPENNES. LONG-WINGED SWIMIMERS.}

\section{Family Stercoraridde. Jaegers and Skuas.}

Two of the six known members of this family are found in the antarctic regions, while the remaining four inhabit the northern parts of the northern hemisphere. Except during the nesting season, the Jaegers are as a rule pelagic, though they sometimes visit large bodies of water inland. They generally obtain their food by robling Gulls and Terns, and have been well named the IIawks of the sea. Their greater power of fiight enables them to successfully pursue these birds and force them to disgorge their recently captured prey.

KEY TO THE SPECIES.

A. Bill over $1 \cdot 35$; tarsus over 1.70 ; middle tail-feathers never pointed.

a. Bill over $1 \cdot 90$. . . . . . . . . . . . . 35. SKUA.

b. Bill under 1.90. . . . . . . . . . 36. Pomarine Jaeger.

$B$. Bill under 1.35 ; tarsus under 1.70 ; middle tail-feathers generally pointed.

$a$. Scaly shield on the bill longer than the distance from its end to the tip of the bill . . . . . . . . . 37. Yarasitic JaEger.

b. Scaly shield on the bill shorter than the distance from its end to the tip of the bill . . . . . . . . . 38. LONG-TAILED JAEGER.

35. Megalestris skua (Brïnn.). Sк̌̀. Al.-Upper parts, tail, and wings dark, dirty brown; shafts of the wing and tail-feathers white, except at the tip; outer wing-feathers with inner vanes white at the base: under parts somewhat lighter; neck more or less streaked with whitish. Im.-"Similar to adult, but more distinctly streaked with yellowish, especially on the head and neek." L., 22.00; W., 15.91; 'Tar., 2.63; B., 2.06 (Ridgw.).

Range.-"Coast and islands of the North Atlantic, chiefly northwarl. South to Spain and Massachusetts. Apparently rare off the coast of North America" (A. O. U.).

Long Island, A. V., one record.

Test, on rocky cliffs. E!!!s, two, pale olive-brown or greenish gray spotted with chocolate, $2.80 \times 1 \cdot 90$.

36. Stercorarius pomarinus $(T(m)$. ). PoMARINE JAEgFr. Ad., light phase.-Very similar in color to corresponding phase of S. parasiticus, but with the upper parts darker, nearly black. Ad., darl phase and Im.Similar in color to corresponding staces of $S$ furasiticus. L., 2.200; W., 13.50; T., Ad., 8.00, Im., 5.40; Tar., 2.00; B., 1.55.

Remarks. - This species is to be distinguished from the two following by its larger size and the rounded ends of its central tail-fenthers.

Range._" Resident during the summer in high northern latitudes, chiefly within the Aretic Circle, and extending from Siberia in eastern Asia entirely around the zone" (B., B., and R.). Migrates southward along the Atlantic 
coast, and more rarely through the Great Lakes, and winters from Long Island southward.

Long Island, regular from June 15 to Oct. 30. Sing Sing, A. V.

Nest, on the ground. Eggs, two to three, deep olive-drab sparingly spotted with slate color, and light and dark raw-umber markings and black dots, chicfiy at the larger end, where they become confluent, $2.25 \times 1.70$ (Brewer).

3\%. Stercorarius parasiticus (Linn.). PAIAsitic JAEGER (see Fig. 6, a). Ad, light phase.-Back, wings, and tail slaty fuscous; top of the head and lores nearly black; sides of the head and back of the neck strawyellow, this color sometimes spreading down the sides of the neck and on the throat; breast and belly white; sides of the breast, flanks, lower belly, and crissum slaty fuscous; tarsi and feet (in dried specimens) black; middle tail-feathers pointed and extending about $3 \cdot(00$ beyond the others. Ad., dark phase.-Lntire plumage dark, slaty brown, darker on the top of the head; muler parts slightly lighter; sometimes a trace of straw-yellow on the sides and back of the neck; tarsi, feet, and tail as in the preceding. Im. light phase--Upper parts, wings, and tail fuscous; the feathers of the back, neck, and head more or less bordered, tipped, or barred with bufty; hind-neck and head sometimes buffy, streaked or barred with fuscous, and varying from this color to plain fuscous; longer, lateral upper tail-coverts barred with bufly; tail butly, whitish at the base; under wing-eoverts barred with buffy; under parts white, washed with buffy, and irregularly barred with sooty fuscous; these bars sometimes very numerous when the under parts looked as if washed with sooty fuscous; again, they may be less numerous and confined to the breast and sides, leaving the belly white; central tail-feathers pointed, projecting more or less beyond the rest. Im., dark phase.-Sooty fuscous, the feather, particularly on the under parts, more or less marked with ochraceous-buff. L., 17.00; W., 13.00: 'T., Ad., 8•60, Im., 6.40; B., 1·15.

Remarks. - This species closely resembles S. longicaudus. Adults of both species, whether in the dark or light phase of plumage, may always be distinguished from eath other by the difference in the length of their central tail-feathers, in addition to the characters given in the key. Young birds can not be distinguished by color, but may be identified by the differences in relative proportions of the bill.

Range.-" Northern parts of the northern hemisphere, southward in winter to South Africa and South America" (A. O. U.). In America breeds in the Barren Grounds and Greenland; migrates southward through the Great Iakes and along the Atlantic coastis, and winters from the Middle States southward.

Long Island, regular from June 15 to Oct. 30 .

Nest, on the moors or tundras, a slight depression in the ground scantily lined with grasses, etc., or on rocks by the sea. Eggs, two to four, light olivebrown, with frequently a strong greenish tinge and chocolate markings, more numerous and sometimes confluent at the larger end, $2.25 \times 1.65$.

38. Stercorarius longicaudus Fieill. Long-TAnfed JaEger. Ad., light please.-Back, wings, and tail slaty fuscous; top of head and lores nearly black; sides of the head, back and sides of tho neck straw-yellow; 
throat sometimes washed with the same color; under parts white; sides, lower belly, and crissum slaty fuscous; central tail-feathers extending about $7 \cdot 00$ beyond the others, the projecting ends narrow and pointed. (No dark phase of this species has been deseribed.) Im.- Similar in plumage to im. of $S$. parasiticus, but diftering otherwise as pointed out under that species. L., 21.00; W., 12.50; T., Ad., 12.00, Im., 5.50; B., 1.08.

Range.-Northern part of the northern hemisphere; in America nests in Greenland and quite abundantly "along the Anderson, in the 'Barrens,' and also on the aretic coast" (Macfarlane); migrates southward along the coasts, and rarely through the Great Lakes, to the Gulf of Mexico and West Indies.

Nest, a slight depression in the ground, sometimes scantily lined with grasses. Eygls, two to three, similur in color to tlose of the preceding, $2 \cdot 10 \times 1.50$.

\section{Family Laride. Gulls and Terns.}

This fumily contains about one hundred species divided equally between the subfamily Larince (Gulls) and subfamily Sternine (Terns). They are distributed throughout the world. Some forty species inhabit North America. With few exceptions they agree in possessing the marked characters of their respective subfamilies, under which they may be more conveniently treated.

\section{Subfamily Larince. Gulls.}

Generally speaking, Gulls are maritime and pelagie, though some species are found inland. As eompared with Terns, Gulls are less graceful and actire on the wing. In flight the bill points forward in the plane of the body, not downward toward the earth, as in the Terns. They procure their food largely by picking it from the surface of the water or land with their strongly hooked bills, not by plunging or darting, as do the Terns. Some of the species are true birds of prey, and feed on small mammals and the eggs and young of other birds. Gulls are better swimmers than Terns, and pass much time resting on the water. They nest in colonies, generally on the ground, sometimes on rocky ledges, and rarely in trees.

I. Wing over $15 \cdot 00$.

KEY TO THE SPECIES.

A. Back dark slaty black .

47. BlaCk-BaCEed Gull.

B. Back pearl-uray.

a. Outer primaries marked with black.

51a. Am. Hering Gull. 51. Ierring Gull.

b. No black on primaries.

h. Bill under $2 \cdot 00$.

$b^{2}$. Primaries light pearl-gray, fading gradually into white at their tips. . . . . . . . . 43. ICeland Gull. 
b3. Primaries pearl-grav, tipped with white, and with well-defined gray spaces on the outer webs of the two outer primaries and on both webs of the third and fourth primaries.

45. Kumlien's Gull. c. Bill over 2.00 . . . . . . . 42. Glandous Gull.

$C$. Back grayish, whitish, or brownish, or mottled or spotted with grayish or brownish.

a. 'Tail black or blackish, with or without irregular white markings.

$a^{1}$. Wing over 17.50 ; depth of bill at nostril over 70 .

47. Black-BaCked Gull (Im.).

$a^{2}$. Wing under 17.50 ; depth of bill at nostril under $\cdot 70$.

51a. Adr. IIerring Guld (Im.). 51. Herring Gulu (Im.).

b. Tail white or whitish or grayish brown, with or without black markings.

b1. Bill under 2.00 . . . . . . 43. Iceland Gull (Im.).

62. Bill over 2.00 . . . . . . . 42. Glaucous Gull (Im.).

II. Wing under $15^{\circ} 00$.

1. 'Tail pure white.

$A$. Head and throat slaty black.

a. Outer primary black or mostly black.

$a^{1}$. Outer primary entirely black . . . 58. Lavgung Gull. $a^{2}$. Inner half of inner webs of first primary white.

b. Outer primary mostly white.

62. Sabine's Gull.

$b^{1}$. Tip of first primary white . . . . 59. Franklin's Gull.

b2. 'Tip of first primary black . . . . 60. Bonaparte's Guld.

$B$. Head white, sometimes washed with pearl-gray.

a. Wings white . . . . . . . . 39. Ivory Gulu.

b. Primaries with more or less black.

$b^{1}$. Wing over 11.00 .

b. Hind toe very small, without a nail . . 40. Kiтtiwake.

$b^{3}$. Hind toe normal, with a nail . . 54. RING-BILled Guld。 1. Wing under $11 \cdot 00$. . . . . . . 61. Ross's Gull.

2. 'Tail marked with black.

A. Wing over $13 \cdot 25$.

a. Primaries mostly white . . . . . 39. Ivory Gull (Im.).

b. Primaries black or mostly black -54. RiNG-BILled Gull (Im.).

B. Wing under 13.25 .

a. Hind toe very small, without a nail . . 40. Kiтtiwake (Im.).

b. Hind toe normal, with a nail.

b2. Tarsus 1.50 or over . . . . 58. Laughing Gull (Im.).

$c^{1}$. Tarsus under $1 \cdot 50$.

$c^{3}$. Secondaries pearl color, tail square.

$c^{3}$. Secondaries mostly white, tail rounded.

60. Bonaparte's Guli (Im.).

61. Ross's Gulu (Im.).

39. Gavia alba (Gunn.). Ivory Gíl. Ad.-Entire plumage pure white; bill yellow, feet black. Im.-Similar to ad, but the wing and tail 
feathers, and sometimes the wing-coverts, with a black spot at their tips, L., $17 \cdot 00 ;$ W., $13 \cdot 25 ;$ T., $5.50 ;$ B., $1 \cdot 35$.

Range.- "Arctic seas, south in winter on the Atlantic coast of North America to Labrador and Newfoundland, casually to New Brunswick, and on the Pacific side to Bering Sea" (A. O. U.).

Long Island, A. V., one record.

Nest, of grass, moss, and feathers on rocky cliffs. Eggs, light. yellowish olive, marked with small blotches of brown and larger cloudings of lilac, $2 \cdot 45 \times 1 \cdot 70$ (Brewer).

"The Ivory Gulls appear to spend most of the time amid the packice, often at a long distance from land" (Chamberlain).
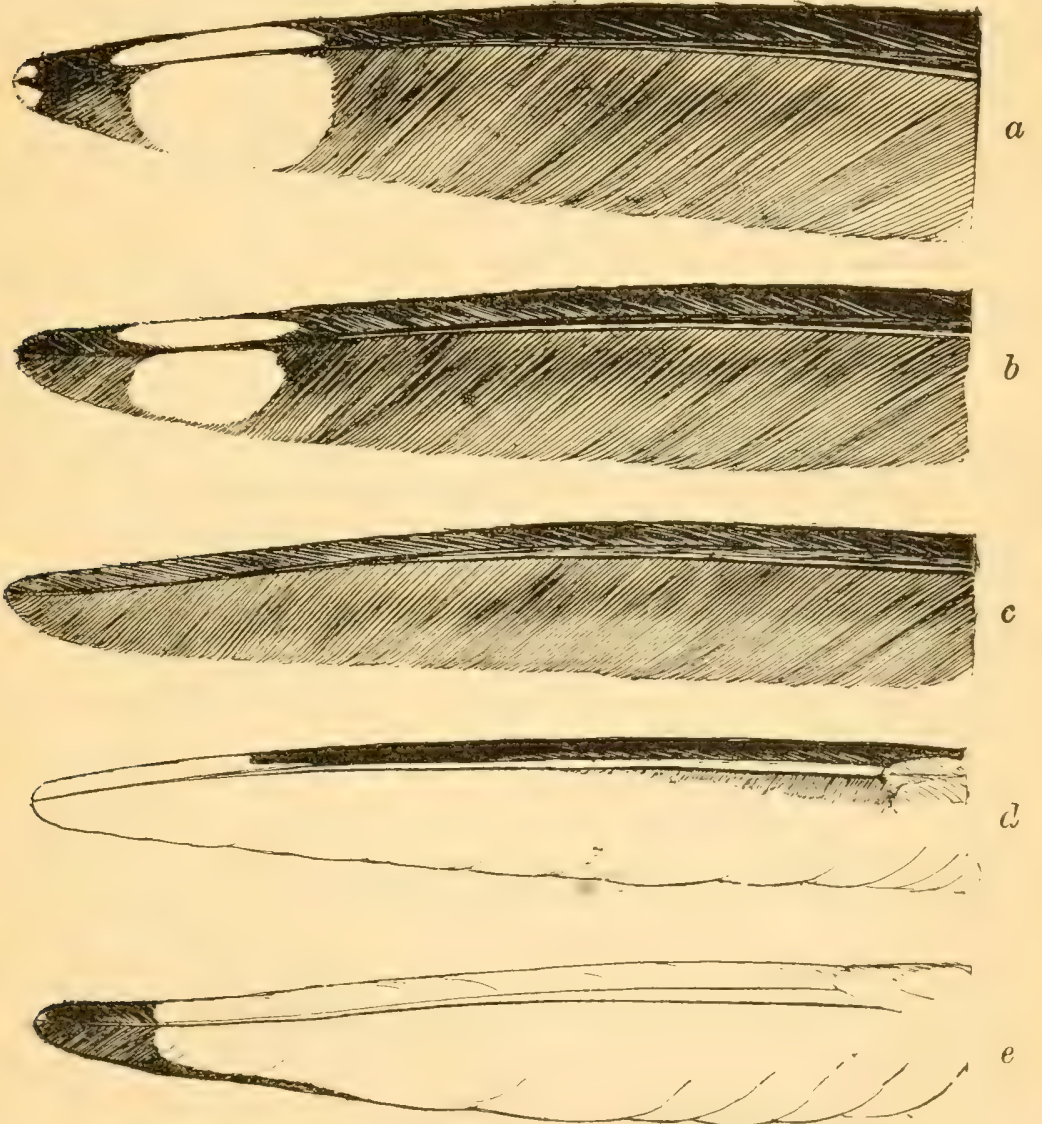

Fig. 60.-First primaries of adult Gulls, seen from below: (a) Am. Herring Gull : (b) Ring-billed Gull ; (c) Laughing Gull ; (d) Franklin`s Gull ; (e) Bonaparte's Gull.

40. Rissa tridactyla (Linn.). Kiтtiwake. Ad. in summer.-IJend, neck, tail, and under parts pure white; back and wings pearl-gray; outer web of first primary and $3 \cdot 00$ of the ends of first and second primaries black; 
third to fifth primaries black at the ends and with white tips; hind toe rery small, a mere knob without a nail; bill yellowish, feet black. Ad. in winter. -Similar to above, but the top of the head and back of the neck washed with pearl-gray, and a dark spot about the eye. Im.-Similar to winter adults, but with the back of the neck, lesser wing-coverts, and part of the tertials black; tail, except outer pair of feathers, with a black band at its tip; four outer primaries black, except the inner half or more of their inner webs; fifth and sixth tipped with black and white; bill black, feet yellowish. L., $16^{\circ} 00$; W., 12.00 ; T., $4.50 ;$ B., 1.30 .

Kemarks.-This species can always be distinguished by the small size of the hind toe.

Range.-Northern parts of the northern hemisphere; in America, breeding commonly from the Magdalen Islands northward, and wintering as far south as the Great Lakes in the interior, and, on the coast, commonly to Long Island, and rarely to Virginia.

Long Island, commion T. V., a few winter, Nov. to Mch.

Nest, of grass, moss, and seaweed on the ledges of rocky eliffs. Eggs, three to four, varying from shades of buffy to grayish brown, distinctly and obscurely marked with chocolate, $2.25 \times 1 \cdot 60$.

"Our bird differs but little in its habits from other oceanic Gulls. Feeding chiefly on fish, but accepting any diet that drifts within range of its keen sight; drinking salt water in preference to fresh; breasting a gale with ease and grace-soaring in midair, skimming close above the crested waves, or swooping into the trough for a coveted morsel; resting upon the rolling billows, and sleeping serenely as they roll, with head tucked snugly under a wing; wandering in loose flocks; and making comrades of other wanderers; devoted to mate and young, and attached to all its kin-wherever seen or howerer employed, the Kittiwake is revealed as a typical gleaner of the sea.

"The name is derived from the bird's singular cry, which resembles the syllables kitti-aa, kitti-aa" (Chamberlain).

42. Larus glaucus Brïnn. Glatcous Gild; Brogomster. Ad. in summer.-Back and wings pale pearl-gray; primaries lightly tinted with pearl, inner half of their inner webs and tips fading gradually into white; rest of the plumage pure white. $A d$. in winter.-Similar to the above, but with the head and neck lightly streaked with grayish. Im.-Upper parts varying from ashy gray to white, the feathers widely barred, mottled, or streaked with buffy or ashy gray: primaries varying from pale smoky gray to pure white; tail ashy or brownish gray; under parts varying from dirty whitish to ashy gray, generally darker on the belly, sometimes mottled with buffy or grayish. (Birds of the second year are said to be pure white.) $I_{\text {. }}$, 28.00 ; W., $17 \cdot 10 ;$ B., 2.35 ; depth of B. at projection on the lower mandible, .75 to $1.00 ;$ Tar., $2 \cdot 60$.

Range.-Northern parts of the northern hemisphere: in North America breeding commonly from southern Labrador north ward and migrating southward to the Great Lakes and Long Island. 
Long Island, irregular W. V.

Nest, of grasses, moss, etc., on the ground. Eggs, two to three, varying from pale olive-brown to grayish white, spotted or speckled with shades of chocolate, $3 \cdot 10 \times 2 \cdot 20$.

Mr. Chamberlain remarks that this species combines "with some gull-like traits many of the coarse characteristics of both Falcon and Vulture."

"Some observers have reported that flocks are at times very noisy, particularly when settling for the night; but those I have met with in winter have been rather silent. Their ery is harsh and at times very loud; it sounds something like the syllables $k u k$-lak. I have seen it written cut-leek."

43. Larus leucopterus Fuber. Iceland Guld. Resembles the preceding species in color, but generally is much smaller; specimens occur, however, which appear to be intermediate. W., 15.40-16.50; B., 1.65-1.90; depth of $B$. at projection on the lower mandible, $\cdot 60-70$; Tar., $2 \cdot 05-2 \cdot 20$ (B., B., and R.).

Range-Aretic regions; in North America migrates south in winter, rarely to Long Island.

Long Island, A. V. in winter.

Nest, of grasses, moss, ete., on the ground. Eggs, clay-color with numerous chocolate markings, $2.79 \times 1.89$.

"The flight of the Iceland Gull, its feeding habits. and its manners generally, suggest a close affinity to the Herring Gull rather than to the Burgomaster" (Chamberlain).

45. Larus kumlieni Brev'st. Krmulex's Guld. Very similar in general color to the two preceding species, but differs from them in the color of the primaries. These, instead of being uniformly pure white or but lightly tinted with gray, are marked with sharply defined spaces of ashy gray. The first primary is tipped with white and marked with ashy gray on the outer web and shaft part of the inner web; the second primary is ashy gray on only part of the outer web; the third and fourth primaries have smaller white tips and are marked with ashy gray near their ends on both webs. W., $155^{\circ} 0-$ 17.00 ; B., $1.65-1.88$; depth of $\mathrm{B}$. at projection on the lower mandible, $\cdot 60-66$; Tar., $2 \cdot 10-2 \cdot 35$ (Brewster).

Kange.-North Atlantic coast of North America; south in winter to Massachusetts.

Nest, on "the shelving rocks of high cliffs."

"Mr. Kumlien found this bird breeding in considerable numbers near the head of Cumberland Gulf," but, owing to the difficulty of distinguishing immature specimens from those of $L$. leucopterus, its status on our coast in winter is not clearly determined.

47. Larus marinus Linn. GrFat BLACK-BACKed Getli; SAtDLEBACk. Ad. in summer.-Back and wings slaty black; wing-feathers tipped 
with white; rest of plumage white; tail sometimes mottled with dusky. $A d$. in winter.-Similar to the above, but with the head and neck streaked with grayish. I $m$.- Head and nape whitish, streaked with grayish; back and wings, except primaries, brownish, the feathers margined and irregularly marked with pale buffy; primaries dark brownish black, the inner ones with small white tips; tail mottled with black and white; under parts whitish, more or less streaked or barred with grayish. L., $29 \cdot 00$; W., 18.50; T., 8.00; B., $2 \cdot 50$.

Range.-North Atlantic; breeds in North America from the Bay of Fundy northward; migrates southward in winter regularly to the Great Lakes and Virginia, and less frequently to South Carolina.

Long Island, common W. V., Sept. to Apl.

Nest, of grasses, seaweed, etc., on the ground. Eggs, two to three, claycolor, brownish ashy or buffy, rather evenly spotted with chocolate, $3 \cdot 00 \times 2 \cdot 15$.

A more northern species than the Herring Gull. Mr. Brewster, who observed it in numbers in the island of Anticosti in July, writes:

"The Black-backs are exceedingly noisy birds, especially when their young are in danger, as well as toward evening. . . . I identified four distinct cries : a braying $h a-h a-h a$, a deep keow, keow, a short barking note, and a long-drawn groan, very loud and decidedly impressive.... At all times of the year, during the breeding season as well as in winter, it is by far the wariest bird that I have ever met."

'The Siberian Guld (50. Larus affinis) - a large Gull inhabiting northern Asia-is sometimes found in Greenland.

51a. Larus argentatus smithsonianus Cones. AMERICAN HERRING GULL. Ad. in summer.-Back and wings deep pearl-gray; first primary tipped with white, then crossed by a small black mark, then a much larger white one; this is followed by a black space; the black runs down the outer web of the feather to near its base and the shaft part of the inner web nearly as far, leaving the inner two thirds of the web below the black mark white (Fig. 60, $\alpha$ ); the second primary is similar, but the second white mark is a round spot on the inner web and the black occupies a greater space near the tip, but does not continue so far down on the feather; the third to sixth primaries are tipped with white, which is succeeded by a gradually diminishing black band which extends farther down on the outer web of the feather than on the inner; the rest of the plumage is pure white. Ad. in vinter.Similar to the above, but with the head and neck streaked or spotted with grayish. Im.-Upper parts ashy fuscous; head and nape more or less streaked with pale buffy; back and wings margined or irregularly marked with the same color; primaries brownish black; tail the same, sometimes tipped or margined with buffy; under parts ashy fuscous, sometimes lightly barred or streaked. L., $24 \cdot 00 ;$ W., $17 \cdot 50$; T., $7 \cdot 50 ;$ B., $2 \cdot 30$.

Range.-." North America generally, breeding on the Atlantic coast from Maine northward" (A. O. U.). In the interior breeds from Minnesota northward; winters from Nova Scotia to Cuba. 
Washington, common W. V., Uct. to Mch. Long Island, abundant W. V., Sept. to May, a few in summer. Sing Sing, common T. V., Sept. 21 to May 9 ; common W. V. when river is open. Cambridge, abundant W. V., Nov. to Apl.

Nest, of grusses, moss, seaweed, etc., on the ground, but, where the birds have been persistently robbed, it is more compactly built and placed in trees, sometimes fifty feet or more from the ground. Eggs, two to three, grayish olive-brown, rarely whitish, spotted, blotehed, and scrawled with distinct and obscure chocolate markings, $2.85 \times 1.90$.

This species is by far the most abundant winter Gull along the coasts of the Middle and Southern States. Unlike the more pelagic species, it frequents our rivers and harbors, feeding about piers and wharves, and near the eities showing comparatively little fear of man. Sometimes one may see them "bedded" in flocks on the water, where they alight to rest. It is generally this species which follows in the wake of our coastwise vessels, sailing astem, when the wind is from ahead, without the slightest perceptible movement of the wings. (For an interesting life-history of the Herring Gull see Mackiay, Auk, ix, 1892, pp. 221-228.)

The European Herring Gull (51. Larus argentatus) differs from our species in being slightly smaller and in having the two white spaces at the tip of the first primary joined, the black spot, therefore, being broken or entirely absent. It is of rare occurrence on the Atlantic coast of North America.

54. Larus delawarensis Ord. RiNG-Ihlen Gull. Ad. in summer.-Back and wings pearl-gray; first primary black, with a white spot near the tip, the base of the inner half of the inner web pearl-gray (Fig. 60,b); second primary black, the basal half of the inner web pearl-gray; on the third to sixth primaries the black decreases rapidly, and each one is tipped with white; rest of the plumage pure white; bill greenish yellow with a black band in front of the nostril. Ad. in winter.-Similar to the above, but the head and nape streaked with grayish. Im.-Upper parts varying from ashy fuscous, the feathers margined with whitish, to pearl-gray, the feathers more or less mottled, spotted, or, on the head and neck, streaked with ashy fuscous; outer primaries black, tail varying from pearl-gray, more or less mottled with blackish, to white, and crossed near the end by a wide band of black: basal half of the bill yellowish, end black. L., 18.50; W., 14.00; T., 6.00; B., $1 \cdot 60$.

Kange.-North America, more common in the interior; breeds from southern Minnesota and Newfoundland northwarl; winters from Long Island to Cuba and Mexico.

Washington, very common T.V., Feb. to Apl. 5; Oct. to Nov.; rare in winter. Long Island, common W. V., Aug. to Apl. Sing Sing, casual 'T. V.

Nest, of grasses, etc., on the ground. Eggs, two to three, clay-color, buffy, or whitish, rather evenly spotted with chocolate, $2 \cdot 30 \times 1 \cdot 65$. 
'The coast-inhabiting individuals of this species resemble the Herring Gull in habits, and are not easily identifiable from that species unless the two be seen together, when the smaller size of the Ring-bill is noticeable.

In the interior, where the species is locally common, it feeds on insects, which it catches both on the ground and in the air.

The MEw Gull (56. Larus canus)-a European species-has been tound once in Labrador.

58. Larus atricilla Linn. Lafghix Gell; Black-heated Gull. (See Fig. $6, b$. .) Ad. in summer.-Back and wings dark pearl-gray ; primaries black, the inner ones with small white tips (Fig. $60, c)$; whole head and throat deep slate-color; rest of the plumage, including the nape, pure white, the breast sometimes suffused by a delicate peach-blossom tint; bill dark reddish, brighter at the tip. Ad. in winter.-Resembles the above, but has the head and throat white, the crown and sides of the head and sometimes the nape spotted or streaked with grayish. Im.-Upper parts light ashy fuscous, the feathers margined with whitish; primaries black; forehead and under parts white, sometimes washed in places with dusky; tail dark pearl-gray, broadly tipped with black. L., 16.50 ; W., 12.50 ; T., 4.90; B., 1.65.

Range.-Breeds from Texas and Florida to Maine; rare in the interior; winters from South Carolina to northern South America.

Washingtón, irregular in fall. Long Island, rare S. R., irregular T. V., Apl. to Sept.

Nest, of grasses, seaweed, etc., on the ground in grassy marshes. Eggs, three to five, varying from grayish olive-brown to greenish gray, spotted, blotched, and scrawled with chocolate, $2.15 \times 1.55$.

"From the hoarse clatter of the Terns one could distinguish its long-drawn, clear note on a high key, sounding not unlike the more excited call-note of the Domestic Goose; and every now and then it would give its prolonged, weird laughter, which has given rise to its common name. To one who has heard it, it might be imitated by the syllables $h a h-h a-h a-h a-h a, h a h-h a h-h a h$, all of which are uttered on a high, clear tone, the last three or four syllables, and especially the last one, being drawn out with peculiar and prolonged effect, the whole sounding like the odd and excited laughter of an Indian squaw, and giving marked propriety to the name of the bird "(Langille).

59. Larus franklini Su. and Rich.. FranKLIN's (ivLl. Ad. in summer.-Whole head and throat sooty black, nape, sides of the neck, and under parts, except throat, white, generally suffused (in fresh specimens) with an exquisite peach-blossom tint; tail white; back and wings pearl-gray; first primary white, the outer web black, except at the tip, the shaft part of the inner web grayish on the basal half (Fig. 60, $d$ ); second primary white, with a black mark on the inner web and a black stripe on the outer web near the tip, the rest of the outer web and shaft part of the inner web pearl-gray; t'ind 
to sixth primaries tipped with white, then banded with gradually diminishing bars of black, which are succeeded by a whitish space, while the rest of the feather is pearl-gray; bill dark coral-red. Ad. in winter.- "Similar, but head and neck white, the occiput, with orbital and aurieular regrions, grayish dusky; bill and feet dusky, the former tipped with orange reddish." Young, first plumage.- " T'op and sides of the head (except forehead and lores), back and scapulars grayish brown, the longer scapulars bordered terminally with pale grayish buff; wing-coverts bluish gray tinged with grayish brown; secondaries dusky, edged with pale grayish blue and broadly tipped with white; primaries dusky, the inner more plumbeous, all broadly tipped with white. Central portion of the rump uniform light bluish gray; lateral and posterior portions of the rump, upper tail-coverts, entire lower parts, forehead, lores, and eyelids white. Bill brownish, dusky terminally ; feet brown (in skin)." W., 11.25 ; B., 1.30; depth through nostrils, 35 ; Tar., 1.60 (B., B., and R.).

Kange._-"Breeds from southern Minnesota and Dakota northward; winters in the Southern States, and migrates principally west of the Mississippi River" (Cooke and Merriam). Not found on the Atlantic coast.

Nest, of grasses, etc., in reedy or bush-grawn marshes. Eggs, one to three, varying from dark chocolate to creamy brown and sooty white, irregularly marked with small spots or large blotehes of umber, and with obsolete lilac shell markings, $2.12 \times 1.40$ (Preston).

This inland species reaches our western limits. An excellent account of its habits, by J. W. Preston, will be found in the Ornithologist and Oölogist, xi, pp. 54, 55.

60. Larus philadelphia (Orl). Bonaparte's GLll. Ad. in summer. -Whole head and throat dark, sooty slate-color; nape and sides of the neck, under parts, except throat, and tail white: back and wings pearl-gray; first primary, seen from above, white, the outer web and tip black (Fig. 60, e); second and third primaries white, tipped with black; third to sixth primaries with small whitish tips, then large black spaces, the rest of the feather white or pearl-gray; bill black. Ad. in winter.-Similar to the preceding, but head and throat white, the back and sides of the head washed with grayish. Im. - Top of the head and nape and a spot on the auriculars more or less washed with grayish; back varying from brownish gray to pearl-gray; lesser wingcoverts grayish brown, secondaries mostly pearl-gray; first primary with the outer web, tip, and most of the shaft part of the inner web black; inner margin of the inner web at the end of the feather narrowly bordered with black; second and third primaries much the same, but with slightly more black at the ends; tail white, banded with black and narrowly tipped with white; under parts white. L., 14.00; W., 10.30; T., 4.00; B., 1.15.

Kange.-Breeds from Nanitoba northward; apparently no record of its breeding on the Atlantic coast; winters southward to the Gulf of Mexico.

Washington, common T. V., Meh. to May 5; Oct. and Nov. Long Island, common T. V., a few winter, Oct. to Apl. Sing Sing, rather rare 'T. V., Apl. and Oct.

Nest, of sticks lined with grasses, ctc., on stumps, in bushes or trees four 
to twenty feet from the ground. Eggs, three to four, grayish olive with a greenish tint and small clove-brown spots, chiefly about the larger end, 1.97 $\times I \cdot 40($ B., B., and R.).

"The flight is easy and graceful, each stroke of the long, pointed wings throwing the body up a little, while the bird peers this way and that in quest of its small prey. If it fly toward one, the white front of its wings, added to its white breast and neck, gives it the appearance of a white bird with a black head. It often has a noticeable way of turning partly around or cutting backward as it drops in securing some object detected on or near the surface of the water, thus making it appear decidedly lithe and agile on the wing" (Langille).

The Litrle Gull (601. Larus minutus), a European species, has been taken only once in America-on Long Island, in September, 1887 (Dutcher, Auk, v, 1888, p. 171).

Ross's Gull (61. Rhodostethia rosea), an aretic species, is known from Point Barrow, Alaska; Melville Peninsula; England, Faroes, and Heligoland; but has been found in numbers only at the first-mentioned locality. (See Murdoch, Rep. of the Exp. to Point Barrow, p. 123.)

62. Xema sabinii (S'ab.). Sabine's Guld. Ad. in summer.-Whole head and throat slate-color, bordered posteriorly by black; back and sides of the neck, under parts, except throat, and slightly forked tail pure white; back and wings dark pearl-gray ; secondaries tipped with white ; first primary black, the inner half of the inner web, except at the end, white; second to fourth primaries similar, but tipped with white; bill black, the end yellow. Ad. in winter.--"Similar to the summer plumage, but the head and neck white, except occiput, nape, and auricular region, which are dull, dusky plumbeous" (B., B., and R.). Im.-Forehead and lores white, rest of the upper parts ashy brown, the feathers slightly tipped with whitish; tail white, broadly tipped with blackish; under parts white. L., 14.00; W., 10.50; T., $4.50 ;$ B., 95 .

Range.-Aretic regions, in winter migrating only a short distance southward and rarely reaching the United States.

Long Island, A. V., one record.

Nest, of grasses, ete., on the ground. Eggs, two to five, deep olive (varying in intensity, however), rather indistinctly spotted or blotehed with brown, $1.78 \times 1.26$ (Ridgw.).

This boreal species is of rare occurrence in the northern United States in the winter.

\section{Subfamily Sterninc. Terns.}

Terns are littoral; never, I believe, pelagic. They inhabit the shores of bodies of both fresh and salt water, but are more abundant on the seacoast than in the interior. Their principal characters, as compared with the Gulls, are mentioned under the subfamily Larina. Their 
power of flight has deservedly won for them the name of Sea Swallows. They capture their prey of small fish by plunging into the water, frequently disappearing and swimming a few feet beneath the surface. They nest in colonies. The nest is usually on the ground. Generally it is simply a slight depression in the sand, shells, or pebbles of a beach, or in the near-by seaweed, moss, or grasses. Sometimes it. is scantily lined with bits of grass, seaweed, moss, etc., but these are frequently wanting.

KEY TO THE SPECIES.

I. Wing under $13 \cdot 00$.

1. Entire top of the head jet-black.

A. Bill black, or mostly black.

a. Feet black or blackish.

$a^{1}$. Under parts black or blackish . . . . 77. Black TERn. $a^{2}$. Under parts white; bill black . . . 63. Gull-billed 'Tern. $a^{3}$. Under parts white; bill black, broadly tipped with yellow.

67. Cabot's Tern.

b. Feet yellowish or orange.

$b 1$. Outer tail-feathers pure white; outer web of first primary black.

72. Roseate T'ern.

62. Inner web of outer tail-feather gray; outer web of first primary gray . . . . . . . . . . . 69. Forster's T'ern.

B. Bill mostly or entirely yellowish, reddish, brownish, or orange.

a. Under parts tinged with grayish; outer web of outer tail-feather gray; inner web white.

$a^{1}$. Bill broadly tipped with blackish; tarsus generally over 70 .

70. CoMmon 'T'ERN.

$a^{2}$. Bill without a distinct black tip; tarsus generally under 70 .

71. Arctic Tern.

b. Under parts pure white; inner web of outer tail-feather gray; outer web white. . . . . . . . . 69. Forster's Tern.

2. Forehead white; lores black; crown jet-black.

A. Wing under 8.00; back pearl-gray. . . . . 74. Least Tern.

$B$. Wing over 8.00 ; back grayish brown or blackish.

a. Back grayish brown; a white stripe from the forehead over the eye.

76. Bridled Tern.

b. Back blackish; white of forehead not reaching over the eye.

75. Sooty Terr.

3. Forehead or crown white or grayish, sometimes speckled with black; lores not entirely black.

A. Wing pearl-gray, over $9 \cdot 00$.

a. Outer tail-feather entirely pure white.

$a^{1}$. Bill over 1.75, tipped with yellowish . . 67. Caвot's Tern.

$a^{2}$. Bill under 1755, without a yellow tip . 72. Roseate Terv (Im.).

b. Outer tail-feather not pure white.

$b^{\mathbf{x}}$. Inner web of outer tail-feather darker than outer web; outer web 
mostly or entirely white; a black space generally on the side of the head inclosing the eye . . . . 69. Forster's Tern (Im.). $b^{2}$. Outer web of outer tail-feather darker than inner web; tarsus over 70 . . . . . . . 70. Common 'T'ern (Im.).

$b^{3}$. Outer web of outer tail-feather darker than inner web; tarsus

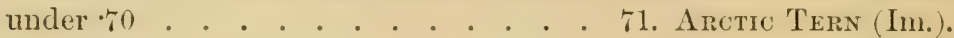

$B$. Wing blackish, over 9.00 .

a. Under parts blackish . . . . . . . 75. Sootr Terv (Im.).

b. Under parts white . . . . . . . 7 6. Brideed Tern (Im.).

4. Crown silvery gray; lores black; rest of plumage sooty black.

II. Wing over 13.00 .

79. Noddy.

A. Wing 15.00 or over; outer primary mostly gray. 64. Caspian T'ern. $B$. Wing under 15.00 ; inner half of inner web of first primary white.

65. Royal Tern.
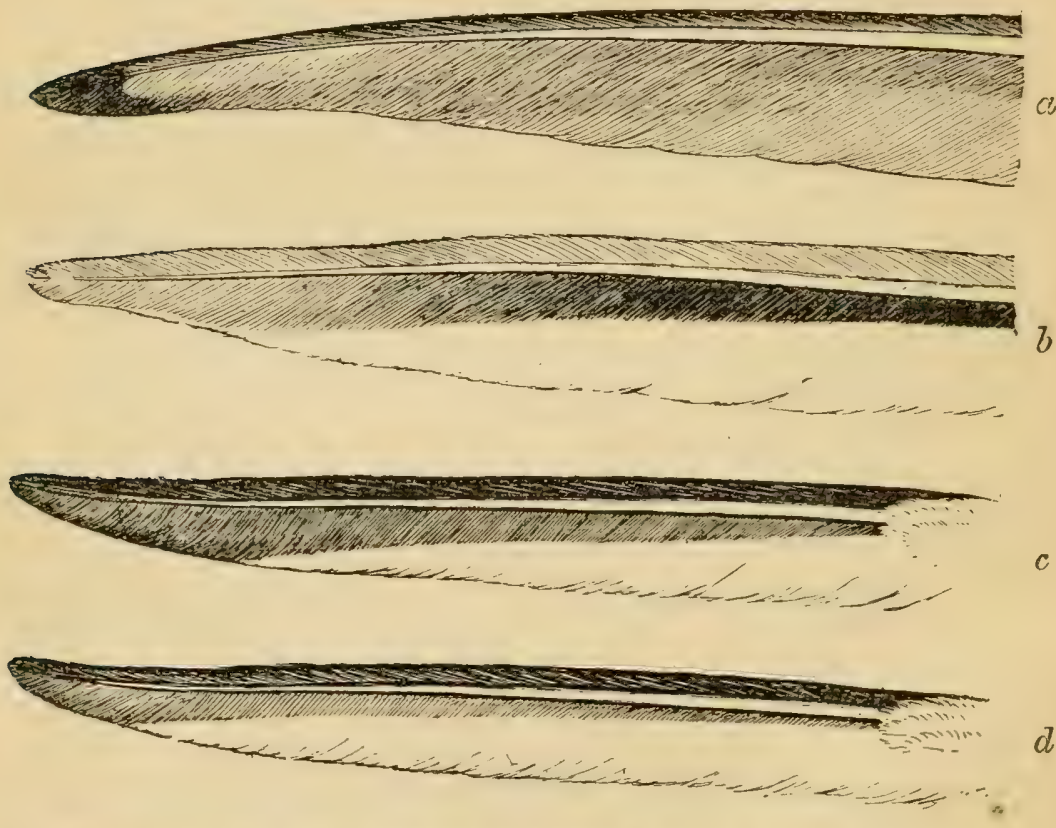

$\ell$

Fig. 61.-First primaries of adult Terns, seen from below. $(a)$ Caspian Tern ; (b) Royal Tern; (c) Common Tern; (d) Arctic Tern; (e) Roseate Tern.

63. Gelochelidon nilotica Hasselq. GLli-billen Tern; MArsu Terv. Ad. in summer.-Top of the head and nape black; back and wings pale pearl-gray; outer web of outer primaries silvery; tip and shaft part of the inner web darker; inner part of the inner web, except for a narrow mar- 
gin at the end of the feather, white; tail white, slightly forked, the middle feathers grayish; under parts white; bill and feet black, the former rather short and stout. Ad. in winter.-Similar to the above, but top of the head white, auriculars grayish, and a space in front of the eye blackish. L., 14.50; W., 12.00 ; T., $5 \cdot 50 ;$ B., $1 \cdot 40$; depth of B. at base, ${ }^{\circ} 50$.

Range.-Cosmopolitan; in North America breeds along the Gulf coast from Mexico to Florida, and on the Atlantic coast north to Virginia, straying northward rarely to Maine.

Washington, casual. Long Island, A. V. in summer.

$E g g s$, three to five, rather uniform buffy white, with numerous distinct and obscure chocolate markings, $1.80 \times 1.30$.

This is a common species on the coast of our Southern States. It is said to prefer insects, which it catches on the wing, to fish. Its roice is harsh and easily distinguishable from that of other Terns, while its heary black bill will also serve to identify it.

64. Sterna tschegrava Lepech. Caspian Terw. Ad. in spring. -Top and back of the head shining black, the feathers lengthened to form a crest; back of the neck, under parts, and tail white; back and wings pearlgray; primaries dark slaty, silvery on the outer web (Fig. 61, a); bill coralred, darker near the tip; feet black. Ad. after the breeding season and in winter.-Similar to the above, but top of the head streaked with black. Im. - Top of head streaked with black and white; back of neck and under parts white; back, wing-coverts, and tertials pearl-gray, spotted or barred with brownish black; primaries dark slaty, silvery on the outer web; tail pearlgray, more or less barred with brownish black; bill orange-red; feet blackish brown. L., $21 \cdot 00$; W., 16.20; T., $6.00 ;$ B., $2 \cdot 80$.

Range.-A cosmopolitan species of irregular distribution; in North America, breeds locally from Texas to Great Slave Lake; migrates through the interior and on the coast, and apparently does not winter within our limits.

Long Island, uncommon 'I'. V., Aug. and Sept.

Eqgs, two to three, grayish white or buffy white, with rather small, distinct, and obscure chocolate markings, $2.70 \times 1.83$.

This large Tern of local distribution is to be known by its size and red bill. Unless the two were seen together, however, I do not believe it could with certainty be distinguished in life from the Royal Tern.

65. Sterna maxima Bold. Royal Ters. Ad. in spring.-Top and back of the head shining black, the feathers lengthened to form a erest: back of the neck, under parts, and tail white; back and wings pearl-gray; inner web of primaries, except at the tip, white; tip, outer web, and shaft part of inner web dark, silvery slate-color (Fig. 61, b). Ad. after the breeding season and in winter.-Similar to the above, but top of the head streaked with black and white. Im.-Resembling the young of $S$. tschegrava, but smaller and with the inner half of the inner web of the primaries white. L., 19.00: W., 14.00: T., $7.00 ;$ B., 2.50 .

Range.-Brecling in North America along the Gulf coast from Texas to 
Florida, and on the Atlantic coast to Virginia; occasionally wanders northward to the Great Lakes and Massachusetts.

Long Island, A. V. in summer.

Eygls, one to four, more pointed than those of the preceding, grayish white, with rather small, distinct, and obscure chocolate markings, $2.65 \times 1 \cdot 75$.

A common species on our southern coasts. During the winter it is about the only Tern one sees in Florida waters. It is a strong, active bird on the wing, and a reckless, dashing diver, frequently disappearing beneath the surface in eatching its prey. The slow-flying Pelicans are at its mercy, and it often deftly robs them of their wellearned gains.

Both this species and the preceding, and indeed all the Terns, are to be known from the Gulls by the very different manner in which they hold their bills. A Tern points its bill directly downward, and looks, as Coues says, like a big mosquito, while a Gull's bill points forward in the plane of its body.

67. Sterna sandvicensis acuflavida (Cabot). CABOT's 'TERN; SANDWich 'T'ern. Ad. in spring.-Whole top of the head and crest black: back and wings light pearl-gray; primaries silvery gray; the shaft part of the inner web white except at the tip; rest of the plumage white; feet and bill black, the latter with a conspicuous yellowish tip. Ad. after the breeding season and in winter.-Similar to the above, but crown white, sometimes spotted with black; back of the head and crest more or less streaked with white. Im.-Similar to the preceding, but back spotted with blackish; tail slaty gray and much shorter; bill slightly if at all tipped with yellow. L., 16.00 ; W., $10.50 ;$ T., 5.50; B., 2.05 .

Range.-Tropical America, breeding on the Gulf coast from Texas to Florida, and on the Atlantic coast to South Carolina; accidental in Massachusetts.

Eggs, two to three, buffy white, spotted, speckled, and scrawled with distinct and obseure chocolate markings, $2.05 \times 1 \cdot 40$.

This is an abundant summer resident on the coasts of southern Florida, and in winter is common as far north as Key West.

It is said by Audubon to snmewhat resemble the Marsh Tern on the wing, and to have a loud, sharp, grating voice, which can be heard half a mile or more. I have never seen it alive, but I believe its yellow-tippel, black bill would enable one to identify it at some distance.

'I'rudeau's Terx (68. Sterna trudeaui) is a South American species which has been taken once on Long Island and onee on the New Jersey coast.

f 69. Sterna forsteri Tutt. Fonster's TErs. d l. in summer.-Whole top of the head black; back and wings pearl-gray; inner border of inner web of the outer primaries white, except at the tip; rump and entire 
under parts white; tail light pearl-gray, the outer feather darker toward the end, where the inner web is always darker than the outer; bill dull orange, the end third blackish; feet orange. Ad. in winter.-Similar to the above, but head white, more or less washed with grayish or spotted with black, a large black spot on the side of the head inclosing the eye; bill mostly black; feet brownish. Im.-Similar to the preceding, but the back and wings more or less mottled or washed with light brownish, and the tail much shorter. L., 15.00; W., 10.25; T., 7.00; Tar., 90; B., 1.50.

Range.-Of more or less general distribution throughout North America, breeding in the east locally from Texas northward through the Mississippi Valley to St. Clair Flats and Manitoba-recorded from Lake Mistassini-apparently not breeding on the Atlantic coast north of Virginia, but wandering irregularly to Massachusetts.

Washington, rare and irregular ' $\mathrm{I}$. V. Long Island, rare T. V. in fall.

Nest; of seaweed, flags, or weeds on a slight elevation in grassy marshes. Eggs, three, very variable, olive-gray, or olive brownish ashy, more rarely whitish or buff, heavily marked with chocolate, $1.80 \times 1 \cdot 30$.

Dr. Brewer, writing of Mr. Rilgway's experience with this species on Cobb's Island, Virginia, where it was found breeding in numbers, says: "It was only less abundant than the Anglica [= nilotica], and quite as numerous as the hirundo, frequenting especially grassy marshes, in which it nests. He found it pre-eminently a marsh Tern. It nested in company with, or in close proximity to, colonies of the Black-headed Gull. It could be readily distinguished from the Common Tern, which it closely resembles when on the wing, by its grating monotonous note, which very closely resembles one frequently uttered by the Loggerhead Shrike" (B. B., and R.).

y0. Sterna hirundo Limn. CoMmon TerN; Wilson's Tern; Sen Swallow (see Fig. 7). Ad. in summer.-Whole top of the head black; back and wings pearl-gray; inner border of inner web of outer primaries white, except at the tip (Fig. 61, c); throat white; breast and belly pale pearl-gray; tail white, the outer webs of the outer feathers gray or pearl-gray; bill red at the base, the end third black; feet orange-red. $A d$. in winter.-Similar to the above, but front part of the head and under parts white: bill mostly black. Im.-Similar to the preceding, but the back more or less washed or mottled with light brownish; lesser wing-coverts slaty gray, and tail much shorter. L., 15.00; W., 10.25; T., 5־0 ; Tar., $75 ;$ B., $1 \cdot 40$.

Remarks.- The Common Tern is closely related to Forster's Tern and also to the Aretic Tern. From the former it is to be distinguished by the color of the long outer tail-feathers. In the Common Tern the outer web of these feathers is always darker than the inner web; in Forster's Tern the inner web is always darker than the outer one. Adult Common Terns have the breast and belly washed with pearl-yray, while in Forster's Tern these parts are pure white.

The Common Tern differs from the Arctic Tern in having the bill tipped 
with black instead of being entirely red; in having longer tarsi, and in the color of the primaries.

Kange.- "Greater part of the northern hemisphere and Africa; in North America chiefly confined to the eastern province" (A. O. U.). Breeds locally both on the coast and in the interior from the Gulf States to the Barren Grounds and Greenland.

Washington, irregular T. V., sometimes common. Long Island, common S. R., May through Sept. Sing Sing, casual in late summer. Cambridge, casual in Sept.

Eggs, three to four, not distinguishable with certainty from those of the preceding, but averaging paler and greener, and less heavily marked, $1.60 \times 1.20$.

It is five years since I visited the breeding grounds of the colony of Common Terns on Gull Island, L. I., but I can close my eyes and still feel the air vibrate with the harsh, half-threatening, half-pleading chorus of nearly two thousand excited voices. There is a dull, heavy, hopeless monotone, broken only by the scream of some half-maddened bird who fearlessly darts downward to protect its nest at my feet. A shot is fired; there is a moment of awe-struck silence, then, with renewed violence, the screaming is resumed. Pandemonium reigns: tearr, terrr, swish! the air is full of darting, diving, crying Terns. It was useless to attempt to secrete myself. At no time during my stay did the outcry cease or hovering flock disperse.

This little, barren, uninhabited, sandy island-only a few acres in extent-and Muskeget Island, off the Massachusetts coast, are the only localities, from New Jersey to Maine, where the once abundant Common 'Tern, or Sea Swallow, can be found in any numbers. What an illustration of the results of man's greed and woman's thoughtlessness ! 'The fickle fashion which indorsed the poor 'Tern's spotless plumage has long since found new favorites, and the sally mangled pearl-gray feathers have gone to graves in the ash-heap. Now it is the Egret's turn.

Even the protection afforded by an insular home was not sufficient. Feather hunters, egg robbers, and self-styled oölogists came in boats to drive the Sea Swallows from their last resort; but the law interfered, and both Gull and Muskeget Islands now have a paid keeper whose duty it is to protect the Terns.

y1. Sterna paradisaea Brünn. Arctic Tern.-Very similar in color to the Common Tern, from which it differs in having less gray on the shaft part of the inner web of the outer primaries (Fig. 61, d); in having the tail somewhat longer, the tarsi and bill shorter, while the latter, in the adult, is generally without a black tip. L., 15.50 ; W., 10.25; T., 7.50 ; Tar., 65 ; B., $1 \cdot 30$.

Kange._- Northern hemisphere ; in North America, breeding from Massa- 
clusetts to the aretic regions, and wintering southward to Virginia and California" (A. U. U.).

Long Island, rare in summer.

Eggs, three to four, not distinguishable with certainty from those of the preceding, $1.62 \times 1.15$.

Comparing the notes of this bird with those of the Common Tern, Mr. Brewster writes: "Their notes are similar, but several of them can be distinguished. The usual cry of S. macrura [= paradiscer] corresponds to the tearr of $S$. hirmudo, but is shriller, ending in a rising inflection, and sounding very like the squeal of a pig. The bird also has a short, harsh note similar to that of Forster's 'Tern. At any distance within fair gun-range I could usually separate it from Wilson's [= Common] Tern by its longer tail, and by the uniform and deeper color of the bill. In flight and habits the two seemed to me identical" (Birds Observed on the Gulf of St. Lawrence, Proc. Bost. Soc. Nat. Hist., xxii, 1883, p. 402).

y2. Sterna dougalli Hontaq. Roseate Tern. Al. in summer.Whole top of the head black; back and wings pearl-gray; outer web of primaries and shaft part of the inner web slaty black (Fig. 61,e); under parts white, generally delicately tinted with pinkish; tail pure white; bill black, the base reddish: feet red. Ad. in winter.-Similar to the above, but front of the head white, more or less streaked or spotted with black; under parts pure white. Im., first plumage._- Pileum and nape pale buffy grayish, finely mottled or sprinkled with darker, and streaked, especially on the crown, with dusky; orbital and auricular regions dusky blackish; remainder of the head, extreme lower part of the nape, and entire lower parts white, the nape, and sometimes the breast, finely mottled with buffy gray; back, scapulars, wingcoverts, rump, upper tail-coverts, and tail pale pearl-blue, the back and scapulars overlaid with pale buff irregularly mottled with dusky, each feather with a submarginal dusky $\mathrm{V}$-shaped mark; primary coverts and primaries dark bluish-gray edged with paler, the inner webs of the latter broadly edged with white; tail-feathers marked near their ends much like the longer scapulars, their outer webs rather dark grayish; bill brownish dusky ; feet dusky." L., 15.50 ; W., 9.50 ; T., 7.50 ; B., 1.50 (B., B., and R.).

Range.-Temperate and tropical regions; in America apparently confined to the Atlantic coast, breeding from Florida northward to Maine: comparatively rare north of southern New Jersey; winters south of the United States.

Long Island, uncommon but regular S. R., May through Sept.

Eggs, three, not distinguishable with certainty from those of $S$. forsteri or S. hirundo, but averaging paler and less heavily marked, 1.65 × 1*20.

This species is found associated with colonies of Common Terns, apparently making its nest among theirs. It is a less excitable, wilder hird than hirmudo, and its single harsh note, erect, may be distinctly heard above the uproar of Common 'Terns, as it hovers somewhat in 
the background. Its white breast and long outer tail-feathers also aid in distinguishing it.

74. Sterna antillarum (Less.). Least Tern. Ad. in summer.Forehead white, lores and crown black; back, tail, and wings pearl-gray; outer web of outer primaries and shaft part of the inner web slaty black; under parts white; bill yellow, generally tipped with black; feet orange. $A d$. in winter.-Top of head white, more or less spotted with black; back of head black; bill blackish. Im.-Upper parts and tail at the end mottled with blackish and buffy, primaries as in the adult, under parts white, bill blackish. L., $9 \cdot 00$; W., 6.90; T., 3.50 ; B., 1.10.

Range.-Northern South America northward to California, Dakota, and Massachusetts, rarely to Lalorador; breeds locally throughout its range, and winters south of the United States.

Washington, casual T. V. Long Island, rare in summer.

Eggs, three to four, buffy white, speckled or spotted with chocolate, $1.25 \times 9.90$.

This, the smallest of our Terns, resembles its congeners in habits, though it is said to add insects to its usual fare of fish. Its voice is described as "a sharp squeak, much like the cry of a very young pig following its mother."

y5. Sterna fuliginosa Gmel. Soотr TERN. Ad.-Forelead and a line reaching to the eye white, lores and rest of the head black; nape, back, and wings brownish black, nearly as dark as the head; outer tail-feathers white, brownish on the end half of the inner web; rest of tail-feathers of the same color as the back; under parts white; bill and feet black. Im., first plumage.-Sooty slate-color; linings of the wings and under tail-coverts whitish; wing-coverts, scapulars, upper tail-coverts, and tail-feathers more or less tipped with white. L., 17.00; W., 11.50; T., 7.25; B., 1.75.

kange.-Tropical and subtropical regions; in North America breeds rarely as far north as North Carolina; oceasionally wanders northward to Maine; winters south of the United States.

Long Island, A. V. in summer.

Eggs, one to three, whitish or buff, speckled or spotted with chocolate, $2 \cdot 00 \times 1 \cdot 45$

A regular summer visitant to our southern coasts and occasionally wandering northward. It breeds in colonies in little-frequented islands in the West Indies, and may be seen fishing in flocks, which hover low over the water.

The Bridurd Tern (76. Sterna ancethetus), a tropical species, has been taken once in Florida, but may prove to be a regular summer visitant to some of the Florida keys.

yy. Hydrochelidon nigra surinamensis (Gmel.). B A ACK TERx. Ad. in summer.-Whole head and under parts, except under tail-coverts, black; back, wings, and tail slate-color; bill and feet black. Ad . in winter. 
-Forehead, nape, and under parts white; back of the head black mixed with white; back, wings, and tail deep pearl-gray. Im.-Similar to the preceding, but upper parts more or less washed and tipped with brownish; sides washed with grayish. L., 10.00; W., 8.30; T., 3.30; B., 1.00.

Range.-Temperate and tropical America; breeds in the interior from Kansas and Illinois to Alaska; not known to breed on the Atlantic coast, where it is found from Prince Edward's Island southward as an irregular migrant, oceurring at times in considerable numbers.

Washington, irregular T. V., Sept. Long Island, irregular T. V. in varying numbers, Aug. and Sept. Sing Sing, A. V., Sept.

Nest, of reeds, grasses, ete., rather closely woven, in grassy marshes or vegetation floating in a slough. Eggs, two to three, grayish olive-brown, rarely whitish, heavily spotted and blotched with chocolate markings, frequently confluent about the larger end, $1.35 \times \cdot 98$.

This is an abundant species at favorable localities in the interior.

"It seems not to subsist on fish at all, but chiefly on dragon flies and various aquatic insects. It finds both its home and its food in the marshes usually, but its powers of flight are so great that it may also be seen far out on the dry open plains, scouring the country for food at a distance of miles from its nesting ground. . . .

"The bird may frequently be seen dashing about in a zigzag manner so swiftly, the eye can offer no explanation of its motive until, on the resumption of its ordinary flight, a large dragon fly is seen hanging from its bill. ..." (Thompson).

The White-Tinged Black Tern (78. Hydrochelidon leucoptera), an Old World species, has been taken once in Wisconsin, and is recorded as "seen" on a lake near Winnipeg.

y9. Anous stolidus (Lim.). Nondr. Ad.--Top of the head silvery whitish, lores black; rest of the plumage dark sooty brown; tail rounded, the central tail-feathers longest. Im.- Similar, but the top of the head is like the rest of the plumage and the silvery whitish appears as a line from the bill to above the eye. L., $15.00 ;$ W., $10 \cdot 25 ;$ T., $5.90 ;$ B., 1.70 .

Range._-"Tropical and subtropical regions; in America, from Brazil and Chili north to the Gulf and South Atlantic States" (A. O. U.).

Nest, of sticks, grasses, etc., on a mangrove bush, in a tree, sometimes on the beach or in erevices of rocks. Egg, pale buffy white, sparingly marked with rufous, $2.05 \times 1.35$.

This is a summer visitant to our South Atlantic and Gulf coasts, and nests on some of the Florida keys.

\section{Family Rynchopid}

The three closely allied species constituting this small but distinct family are found in the warmer parts of the earth. Only one species 
inhabits the western hemisphere. Skimmers are unique both in the form of the bill and in their manner of feeding. Upening the mouth, the bladelike lower mandible is dropped just beneath the surface of the water; then, flying rapidly, they may be said to literally "plow the main" in search of their food of small aquatic animals.

80. Rynchops nigra Linn. B Back Skimmet; Scissor-bill (see Fig. 8). Ad.-Forehead, sides of the head, under parts, and tips of the secondaries white; upper parts and wings black; outer tail-feathers white, inner ones more or less brownish. L., 18.00 ; W., 14.50; T., 475; B., $2 \cdot 60$.

Range.-Coasts of the warmer parts of America, breeding regularly as far north as southern New Jersey, and, after the breeding season, occasionally wandering northward as far as the Bay of Fundy.

Washington, A. V. Long Island, occasional in summer.

Nest, a slight depression in the sand or shells of a beach. Eggs, three to four, white or buffy white, heavily blotched with chocolate, $1.80 \times 1.35$.

A not uncommon species on our southern coasts, resembling other members of this family in habits.

\section{ORDER TUBINARES. TUBE-NOSED SWIMMERS.}

\section{FAMLY DiOMEDEID AE: AlBatrosses.}

The Albatrosses, numbering eight or ten species, are confined chiefly to the seas of the southern hemisphere. They are eminently pelagie birds, possessed of untiring powers of flight. Four species visit our Pacific coast, but on the Atlantic coast of North America Albatrosses are almost unknown, and there are but few records of their occurrence.

The Wandering Albatross (80.1. Diomedea exulans), the largest of all sea birds, with an expanse of wing which measures from twelve to fourteen feet, inhabits antaretic seas, but sometimes wanders northward, and is said to have been seen in Tampa Bay, Florida.

The Yellow-nosed Albatross (83. Thalassogeron culminatus) is also a southern species which is said to have been taken once in Quebee (Chamberlain, Nuttall's Manual, $2 d$ ed., ii, p. 277).

\section{Fhimly Proceliaritd}

The serenty known species of Petrels are distributed over the seas of the world. Some thirty species have been found in North America, of which seven cceur regularly on our Atlantic coast. Like their large relatives, the Albatrosses, they are strictly pelagic, and visit the land only to nest. The strong, swift flight of Shearwaters, and the gracefui movements of the smaller "Mother Carey's Chickens," are familiar sights to those who go "down to the sea in ships." 
I. Wing over $10^{\circ} 50$.

KEY TO THE SPECIES.

$A$. Under parts dusky

94. Sooty Shearwater.

$B$. Under parts white.

a. Bill under $1 \cdot 50$

b. Bill over $1 \cdot 50$.

61. Under tail-coverts white. . . . . 88. Cory's Shenrwater.

$b^{2}$. Under tail-coverts grayish brown . . 89. Greater Shearwater.

II. Wing under $10^{\circ} 50$.

A. Wing over $7 \cdot 25$.

a. Depth of bill at base over 50. . 86. Fulmar. 86a. Lesser Fuluar.

$b$. Depth of bill at base under 50 .

b1. Upper parts bluish gray . . . . . 99. Scaled Petrel.

$b^{2}$. Upper parts sooty black . . . 92. Audubon's Shearwater.

$B$. Wing under $7 \cdot 25$.

a. Upper tail-coverts more or less white.

$a^{1}$. Tail forked

b1. Tail square.

$b^{2}$. Webs of fect marked with yellow; upper tail-coverts not tipped with black . . . . . . . . . 109. Wilson's Y'ETrel.

$b^{3}$. Webs of feet without yellow; tail-coverts tipped with black.

104. Stormy Petrel.

b. Upper tail-coverts grayish or brownish.

b1. Entire under parts brownish . . . . 101. Bulwer's Petrel.

$b^{2}$. Breast grayish . . . . . . 110. White-bellied Petrel.

$b^{3}$. Entire under parts white. . . . 111. White-faced Petrel.

86. Fulmarus glacialis (Lim.). Flumar; Nonny (see Fig. 9, わ). Light phase.-Head, neck, and under parts white or whitish; back, wings, and tail slaty gray. Dark phase.-Entire plumage nearly uniform dark, slaty gray. L., 19.00 ; W., 13.04; B., 1.50; depth of B. at base, 75 (Ridgw.).

Range.-North Atlantic; south in winter on the American coast to Massachusetts; accidental in northern New Jersey.

Nest, on the ledges of rocky clift's. Egg, one, dull white, $2.85 \times 2.01$.

"The Fulmar is a constant attendant on whalers, sealers, etc.-who know it as the 'Mollimoke'-in order to obtain fatty substances and animal offal; but I never saw it take any while on the wing. and it always settles on the water to feed, like an Albatross. The pinions are often flapped slowly in an owl-like manner, but in scudding they are held very straight-a peculiarity by which it may easily be distinguished from a Gull at a distance" (Saunders).

86a. F. g. minor Kijaerb. Lesser Fuluar; Noddy. "Similar in color to $F$.glacialis, but much smaller. W., 11.80-12.00; B., 1.30-1.38; depth of B. at base, '60-· $70 . "$

Range.- "North Atlantic, south on American side to coast of New England" (Ridgw.). 
88. Puffinus borealis Cory. Corr's Shearwater. Ad.-Upper parts ashy fuscous, wings and tail darker; sides of head and neck slightly lighter; under parts white, sometimes washed with grayish on the breast; under wing-coverts and under tail-coverts white, the latter more or less mottled with grayish; bill yellowish. L., 21.00 ; W., 14.00; Tar., 2.20; B., 2.10.

Range.-Known as yet only off the Atlantic coast from Massachusetts to Long Island.

Long Island, uncommon from Aug. to Oct.

Nest and eygs unknown.

Cory's Shearwater has been found as a not uncommon summer visitant off the coast of Massachusetts, but its range is unknown.

89. Puffinus major Faber. Greater Sheartater; Hagdon. $A d$. -Upper parts fuscous, wings and tail slightly darker; longer upper tailcoverts tipped with whitish; under parts white; belly more or less ashy gray ; under tail-coverts ashy gray; bill blackish. L., 20.00; W., 12.25; Tar., 2.20; B., 1.85.

Range.-"Atlantic Ocean, south to Cape Horn and Cape of Good Hope" (A. O. U.); north to Greenland.

Long Island, uncommon in summer.

Nest and eggs unknown.

"The long, narrow wings are set stiffly at right angles with the body, and the bird frequently glides half a mile at a time without moving them perceptibly. It usually follows a direct course, and invariably skims close over the waves. I know of no other sea bird whose movements are as easy and graceful. Indeed, at times, especially during a gale, its evolutions will compare in grace and spirit with those of the Mississippi or Swallow-tailed Kites" (Brewster).

Manx's Shearwater (90. Puffinus puffinus) resembles the next in color, but is larger. W., $8 \cdot 50-9 \cdot 25$; B., 1.35-1.40; depth of B. through base, $\cdot 40-\cdot 45$; Tar., 1.70-1.80" (B., B., and R.). It is a European species of exceedingly rare or accidental occurrence on the North Atlantic coast.

92. Pufiinus auduboni Finsch. Audebon's Shearwater. Ad.-. Upper parts, wings, and tail dark, sooty, brownish black; under parts white; sides of the breast grayish ; a patch on the flanks and under tail-coverts sooty hrownish black; inner side of tarsi yellowish, outer brownish; bill blackish. L., 12.00 ; W., 8.00; Tar., 1.60; B., 1*20.

Range.-Warmer parts of the Atlantic, north rarely to Long Island; breeds in the Antilles and Bahamas, but not, so far as known, on our coasts.

Long Island, A. V., one record.

Nest, of a few bits of sticks in a hole in the rocks. Egg, one, chalky white, $2.05 \times 1.40$.

An abundant West Indian species which breeds in the Bahamas and Antilles, and is doubtless not uncommon off our southern coasts. 
Its flight, low over the water, is strong and swift, five or six rapid wing-beats being followed by a short sail.

94. Puffinus stricklandi liidgw. Sonty Sheniwater; Black HAGDON. Ad.-Upper parts, wings, and tail dark, sooty, brownish black; under parts somewhat grayer; bill blackish. L., 17.00; W., 12.00; Tar., 2:10: B., $1 \cdot 65$.

Range.-As far as known, North Atlantic; south on the American coast to South Carolina.

Long Island, uneommon in summer.

Nest and eggs unknown.

"Its flight and habits seem to be identical with those of major, but its uniform dark coloring gives it a very different appearance. At a distance it looks as black as a Crow" (Brewster).

The Black-capped Petrel (98. Astrelata hasitata) is a southern species, which has been found on Long Island, in Florida, West Virginia, and Vermont. It bears a general resemblance to Puffinus major, but is much smaller and has the upper and under tail-coverts white.

The Scaled Petrel (99. Estrelata scalaris) is known from one individual which had wandered to western New York. Its true home has not been discovered, but is doubtless in the Antaretic Ocean.

Bulwer's Fetrel (101. Bulweria bulweri) inhabits the eastern Atlantic Ocean, including the coasts of Europe and Africa, and is of accidental occurrence in Greenland.

104. Procellaria pelagica Linn. Stomi Petrel. Ad.-Upper parts, wings, and tail sooty black; under parts slightly browner; upper tailcoverts white, the longer ones broadly tipped with black; under tail-coverts mixed with whitish; bill and feet black. L., 5.50 ; W., $4 \cdot 80 ;$ T., $2.50 ;$ B., 45 .

Range.- "Atlantic Ocean, south on the American side to the Newfoundland Banks, west coast of Africa and coast of Europe" (A. O. U.).

Nest, of a few bits of sticks and grasses in a burrow in the ground or beneath a rock. Eyg, one, dull white, sometimes with a wreath of minute or obscure markings at the larger end, $1 \cdot 10 \times \cdot 80$.

This is the common Stormy Petrel of the east side of the Atlantic. It nests in numbers on the small islands along the coast of Great Britain, but is only a transient visitant in our waters. It resembles the two following species in habits.

106. Oceanodroma leucorhoa (tieill.). Leach's P'etret. $A d$. - Upper parts, wings, and tail sooty brown; under parts slightly browner; wing-coverts grayish brown; longer upper tail-coverts white, shorter ones mixed with sooty brownish; tail forked, outer feathers more than 50 longer than middle pair; bill and feet black. L., $8 \cdot 00$; W., $6 \cdot 20 ;$ ' T., $8 \cdot 50$; B., $\cdot 62$.

Range.-" North Atlantic and North Pacific Oceans; south on the coast of the United States to Virginia and California; breeds from Maine and the Hebrides northward on the coasts of the Atlantic" (A. O. U.). 
Washington, A. V., several records. Long Island, uncommon T. V., May and June. Cambridge, A. V., one instance, Oct.

Nest, of a few bits of sticks and grasses in a burrow in the ground, or heneath a rock. Egg, one, creamy white, sometimes with a wreath of minute or obscure markings at the larger end, $1.34 \times 1 \cdot 00$.

"This is a bird of the northern hemisphere, being as common on the Pacific Ocean as on the Atlantic. Its chief breeding station on our shores is among the islands at the mouth of the Bay of Fundy; but the open ocean is the bird's true home.

"Leach's Petrels are seldom seen about their nesting site during the day, though in the evening they assemble there; and when fluttering through the twilight or under the moon's guidance they have the appearance of a foraging squad of bats, though the birds' wild, plaintive notes betray their race. The Petrels are not strictly nocturnal, however, for while one of a pair sits close on the nest all day-and this one has been generally the male, in my experience-the mate is out at sea.

"When handled, these birds emit from mouth and nostrils a small quantity of oil-like fluid of a reidish color and pungent, musklike odor. The air at the nesting site is strongly impregnated with this odor, and it guides a searcher to the nest" (Chamberlain).

109. Oceanites oceanicus ( $\hbar u h l)$. Wilson's Petrel. Ad.-Upper parts, wings, and tail sooty black; under parts somewhat lighter; under tail-coverts mixed with whitish, longer upper tail-coverts white, shorter ones marked with sooty black; wing-coverts grayish, margined with whitish; bill and feet black, the webs of the latter mostly yellow. L., 7.00; W., 5.90; 'T., $2 \cdot 80 ;$ B., $\cdot 50$.

Range.-Atlantic Ucean; breeds in southern seas (Kerguelen Island) and migrates northward, spending the summer off our coasts.

Washington, A. V., one record. Long Island, common from May to Sept. Nest, in the erevices of rocks. Egg, one, white.

It is generally known that some birds which nest in the northern parts of our continent, in the winter migrate as far south as Patagonia; but comparatively few are aware that during the summer we receive several visitors from the southern parts of the southern hemisphere. They are all included in the family Procellaridace, and Wilson's Petrel is doubtless the most common. It breeds in the islands of the South Atlantic in February, and after the cares of the breeding season are over migrates northward to pass its winter off our coasts. At this season its home is the sea, and its occurrence on land is generally due to storms. For this reason, and because of its long migration, it is the Petrel most frequently observed in western Atlantic waters during the summer. 
Under the name of "Stormy Petrel," or " Mother Carey's Chicken," they are familiar to most people who have made sea voyages. On tireless wing they follow in the track of a ship, coursing ceaselessly back and forth, now beneath the stern, now hovering over the foamflecked wake, reminding one of white-rumped Martins in their easy, graceful flight. If food be thrown overboard, they are at once at tracted to it, and soon are left far behind, a litcle group of black, fluttering forms on the surface of the ocean. The meal disposed of, a few rapid wing-beats bring them to us, and again they resume their patient beating to and fro.

The White-bellied Petrel (110. Cymodroma grallaria) is a tropical species which has been taken once in North America-at St. Marks, Florida.

The Winte-faced Petrel (111. Pelagodroma marina) inhabits the South Atlantic and southern seas. It is of casual occurrence off the coast of Massaehusetts. It may be distinguished from any of our small Petrels by its white under parts.

\section{ORDER STEGANOPODES. TOTIPALMATE SWIIIMERS.}

\section{Fanily Phä̈thontid at. Tropic Birds.}

The three species composing this small but distinct family are found throughout the tropical and subtropical regions of the world. They are littoral rather than pelagic, but make long journeys across the open sea. Their flight when migrating is strong, rapid, and direct. In feeding, they course over the water, beating back and forth at a height of about forty feet. Their long, willowy tail-feathers add greatly to the grace and beauty of their appearance when on the wing.

112. Phaëthon flavirostris Brandt. Yellow-BILled Tropic Brro (see Fig. 11). Ad.-White; a mark before and through the eye; outer web of primaries, lesser wing-coverts, and tertials black; flanks streaked with slate; bill yellow; tail tinged with salmon, shafts of the feathers black. W., $10 \% 5 ;$ T., $19 \cdot 00 ;$ B., $2 \cdot 00$.

Range.-Tropical coasts; Atlantic consts of tropical America, West Indies, Bahamas, Bermudas; casual in Florida and accidental in western New York and Nova Scotia.

This species breeds abundantly in the limestone eliffs of the Bermudas, but is of rare and probably accidental occurrence on our coasts.

The Red-billed Tropic Bird (113. Phäthon athereus) resembles the preceding species, but has the bill red and the upper parts finely barred with black. Its range in the Atlantic is more southern than that of the Yellowbilled Tropic Bird, and in eastern North Ameriea it is accidental. The only record of its occurrence is off the Newfoundland Banks. 


\section{Family Sulid}

The Gannets number about eight species, of which one is northern while the remaining seven are distributed throughout the tropical and subtropical coasts of the world. They are strictly maritime, but, except when migrating, do not venture far from land. Their flight is strong and rapid, the vigorous strokes of the wing being interrupted at intervals by a short sail. They obtain their food of fish by plunging for it from the air. The northern species is migatory; the others are roving, but all return with regularity to their nesting places, generally on some inaccessible islet, where, during the breeding season, they may be found associated in large numbers.

115. Sula sula (Linn.). Воовт. (See Fig. 12.) Ad.-Breast and belly white, sometimes washed with grayish; rest of the plumage brownish fuscous; head and neek sometimes streaked with grayish brown and white; bill and feet yellowish. Im.-Entire plumage brownish fuscous, lighter below; bill blackish, feet yellow. L., 30.00; W., 15.50: T., 8.00; B., 3.80.

Range._"Coasts of tropical and subtropical America, north to Georgia."

Long Island, A. V., one record.

Nest, on the shore of a barren islet. Eggs, two, chalky white, $2 \cdot 30 \times 1 \cdot 55$.

This inhabitant of barren shores and lonely islets is a summer visitant to the Florida keys. It is a strong flier, and when on the wing reminds one of both a Cormorant and a Gull.

The Blue-faced Booby (114. Sula cyanops) is found in the "South Pacific, West Indies, and northward to Florida," but there are no recent records of its occurrence in the last-named locality.

The RED-Fоотеd Bоoвy (116. Sula piscator) inhabits the coasts and islands of tropical and subtropical seas, north to western Mexico, and is said to occur in Florida, but, like $S$. cyanops, it is of accidental occurrence within our limits.

11\%. Sula bassana ( $\operatorname{Linn}$.). Gannet. Ad.-W hite, head and neck tinged with pale straw-yellow; primaries fuscous. Im.-Throat and upper parts, including wing-coverts, dark grayish brown, each feather with a small white wedge-shaped spot; breast and belly white, margined with grayish brown. L., 35.00 ; W., 19.00 ; T., $9.50 ;$ B., 4.00 .

Range.- "Coasts of the North Atlantie, south in winter to the Gulf" of Mexico and $A$ frica; breeds from Nova Scotia and the British Islands northward."

Long Island, T. V., May; Oct. and Nov.; a few winter.

Nest, on rocky cliffs. Egg, one, pale bluish white, overlaid by a chalky deposit, more or less soiled and stained, $3.20 \times 1.90$.

"The birds are usually associated in small, straggling flocks, and with outstretched necks, and eyes ever on the lookout for fish, they fly at a height of from seventy-five to a hundred feet above the water, or 
occasionally somewhat more. The height at which the Gannet flies above the water is proportioned to the depth at which the fish are swimming beneath, and Captain Collins tells me that when fish are swimming near the surface the Gannet flies very low and darts obliquely instead of vertically upon his prey. Should any finny game be seen within range, down goes the Gannet headlong, the nearly closed wings being used to guide the living arrow in its downward flight. Just above the surface the wings are firmly closed, and a small splash of spray shows where the winged fisher cleaves the water to transfix his prey. Disappearing for a few seconds, the bird reappears, rests for a moment on the water, long enough to swallow his catch, and then rises in pursuit of other game" (Lucas, Rep. U. S. Nat. Mus., 1891, p. 712).

\section{Family AnHingide. Darters.}

There are four species of Darters or Snakebirds, one each in Africa, southern Asia, Australia, and tropical and subtropieal America. They are silent birds. generally living in pairs on bodies of fresh water with wooded shores. They select a perch over the water, and when alarmed sometimes drop into the element below and disappear beneath its surface, or fly upward to a considerable height and circle about like sailing IIawks. They swim well, and when approached too closely quietly sink backward, frequently leaving the long, thin neck and narrow, pointed head above the surface, when one at once observes the origin of the name "Snakebird." They obtain their food by pursuing it under water, and their finely serrated bill assists them in retaining their hold upon it.

118. Anhinga anhinga (Lim.). Anhivga; Snatebird; Water Tunкex. (See Fig. 13.) Ad. o in summer.-General plumage glossy black with greenish reflections; back of the head and neck with scattered grayish plumes; upper back with numerous elongated silvery white spots, which on the scapulars become streaks; lesser wing-coverts spotted like the back; exposed portion of median and greater coverts silvery gray; tail tipped with whitish, the outer webs of the middle pair of feathers with transverse flutings. Ad. of in winter. - Similar, but without the grayish plumes on the head and neck. Ad. $q$. - Similar to $\delta$, but with the whole head, neck, and breast brownish, darker above. Im,-Similar to $q$, but with the black parts of the plumage brownish. L., 34.00; W., 13.50; T., 10.50; B., 3.25.

Range.-Tropical and subtropical America; breeds as far north as southern Illinois and South Carolina; winters from the Gult' States southward.

Nest, of sticks lined with moss, rootlets, etc., over the water in a bush or tree. Eggs, two to four, bluish white with a chalky deposit, $2.15 \times 1.35$.

This singular bird is common in the Gulf States. It has the habits of other members of this small family. 


\section{Fanily Phalacrocoracidar. Cormorants.}

Cormorants are found in all parts of the world. Ten of the thirty known species inhabit North America. As a rule they are maritime, but they also frequent bodies of fresh water far from the seacoast. They are gregarious at all times of the year and breed in large colonies. Their flight is strong and ducklike, but, except when migrating, is generally not far above the surface of the water. They secure their food of fish by pursuing it under water, their hooked bill assisting them in its capture. Unlike the Gannets, they do not dive from the air, but from the water or a low perch.

119. Phalacrocorax carbo (Linn.). Connorant; Shag. (See Fig. 10.) Ad. in breeding plumage.-Region about the base of the lower mandible white or whitish; head, upper neck, and throat glossy black, thickly sprinkled with white; rest of the neck, under parts, and rump glossy black; a white patch on the flanks; upper back, scapulars, and wing-coverts light olive-brown, each feather bordered by glossy black; tail black, composed of fourteen feathers. Ad. in winter. - Similar, but without white on the head. Im.-Top of the head and hind neck brownish black; upper back, scapulars, and wing-coverts grayish brown, the feathers bordered by blackish; rump glossy black; throat and breast grayish brown, changing to white on the belly; sides and under tail-coverts glossy black. L., 36.00; W., 14.00; T., $7 \cdot 00 ;$ B., $3 \cdot 00$.

Range.- "Coasts of the North Atlantic, south in winter on the coast of the United States casually to the Carolinas" (A. O. U.). Breeds from the Bay of Fundy to northern Greenland.

Long Island, regular T. V. in limited numbers.

Nest, of sticks and seaweed, in colonies generally on the ledges of rocky cliffs. Eggs, four to six, pale bluish white, more or less overlaid with a chalky deposit, $2.50 \times 1.50$.

This northern species is of uncommon occurrence on our coast south of its breeding range.

120. Phalacrocorax dilophus (S $w$. and Rich.). Dormle-crested Cormorant. Ad. in breeding plumage.-Head, neck, rump, and under parts glossy black; upper back, scapulars, and wing-coverts light grayish brown, each feather marnined with glossy black; tail black, composed of twelve feathers; a tuft of black feathers on either side of the head. Ad. in winter.Similar, but without tufts on the head. Im.-Top of the head and back of the neck blackish brown; upper back, scapulars, and wing-coverts brownish gray, each feather margined with black; rump glossy black; sides of the head and fore neck grayish white, whiter on the breast and changing gradually to black on the lower belly. L., $30 \cdot 00 ; W_{\text {., }} 12 \cdot 50 ;$ T., $6 \cdot 20 ; B$., $2 \cdot 30$.

Range.-Eastern North America, breeding from Dakota, and the Bay of Fundy northward; winters from southern Illinois and Virginia southward.

Washington, casual, several records. Long Island, common T. V., Apl. 
and May; Aug. to Nov. Sing Sing, A. V., June. Cambridge, casual, one instance, Sept.

Nest, of sticks, seaweed, etc., on the ledges of cliff's, low bushes, bushy trees, or on the ground. Eggs, two to four, similar in color to those of the preceding, $2.40 \times 1.40$.

This is the common Cormorant of the middle Eastern States. We see it chiefly as migrant when in flocks of varying size it passes far overhead, or pauses to rest on our shores. In migrating the flock is formed in a long line, comparatively few birds deep. On the wing they bear a general resemblance to large Ducks.

120a. P. d. floridanus (Aud.). Florida Cormorant. Resembles the preceding species in color, but is smaller. W., 12.00; T., 5.50; B., 2.10.

This is an abundant bird on the Florida coast and westward along the shores of the Gulf. Almost every buoy in the harbors of Florida is capped by a Cormorant. They are shy birds, but may easily be secured by placing traps on the buoys or snags, to which they regularly return to roost.

The Mexican Cormorant (121. Phalacrocorax mexicanus)-a species found on the west Gulf coast and southward-sometimes wanders up the Mississippi as far as Illinois.

\section{Family Pelecanid a. Pelicans.}

The twelve known species of Pelicans are distributed throughout the warmer parts of the world. Three species are North American, of which two are exclusively maritime, while the third is found both on the coast and in the interior. Pelicans are gregarious and nest in large colonies. Their flight is strong but leisurely, six or seven wingstrokes being followed by a short sail, all the members of a flock flapping and sailing in unison. They feed on fish, for which some species plunge from the air, while others capture small fry with their scooplike pouches while swimming.

125. Pelecanus erythrorhynchus Gmel. Anericar WHite Pelican. Ad. in breeding plumage.-White, primaries black, whitish at the base; an occipital crest and a horny prominence on the bill. $A d$. in winter.-Similar, but without the crest or horny prominence. Im.-Similar, but top of the head brownish gray. L., 60.00 ; W., 22.00; Tar., 4.50; B., $14 \cdot 00$.

Range.-North America, now rare or accidental on the Atlantic coast; breeds from southern Minnesota northward; winters along the Gulf coast.

Washington, casual, four records. Long Island, A. V.

Nest, of small sticks, on the ground. Eggs, two to four, creamy or bluish white with a chaliry deposit, more or less stained, $3.45 \times 2.30$. 
The White Pelican winters in numbers on the Gulf coast of Florida and westward, but rarely occurs on the Atlantic coast. Its snc,ry white plumage renders it conspicuous at a great distance, and a faraway Pelican on the water is sometimes mistaken for a distant sail.

The White Pelican catches his food while swimming. A flock of Pelicans will sometimes surround a school of small fry and with beating wings drive them toward the shore, all the time eagerly scooping the unfortunate fish into their great pouches. At the conclusion of a siccessful "drive" they go ashore or rest quietly on the water and devour their prey at leisure.

They migrate by day - and perhaps by night also-flying at a great height, and sometimes pausing to sail in wide circles far up in the sky.

126. Pelecanus fuscus Linn. Brown Pelican. Ad. in breeding plumage.-Top of the head and a spot on the upper breast straw-yellow: line down either side of the breast white; hind head, neck, and a spot on the fore neck seal-brown; sides and back silvery gray bordered by brownish black; scapulars, wing-coverts, secondaries, and tail silvery gray; primaries black; under parts dark blackish brown narrowly streaked with white. $A d$. after the breeding season.-Similar, but with the hind head and whole neck white, more or less tinged with straw-yellow. Im.-Similar to the preceding, but the head and neck grayish and rest of the plumage duller. L., 50.00; W., 19.50; Tar., $2 \cdot 65 ;$ B., $11 \cdot 00$.

Range.-Atlantic coast of tropical and subtropical America; breeds abundantly along the Gulf coast and northward to South Carolina; oceasionally strays to Illinois and Massachusetts.

Long Island, A. V.

Nest, of sticks, in mangrove bushes or on the ground. Eggs, two to fire, similar in color to those of the preceding species, $3.00 \times 1.95$.

Brown Pelicans are abundant residents on the Florida and Gulf coast. They are generally seen in flocks of four to eight birds flying one after the other. The leader beats time, as it were, and they all flap in unison for a certain number of wing-beats, then sail for a short distance, and then flap again. The coast line is their favorite highway to and from their roosts or nesting grounds. They fly low over the water just outside the breakers, following the trough of the seanow disappearing behind the advancing wall of water, now reappearing as the wave breaks on the shore..

Unlike the White Pelican, this species secures his prey by diving. Singly, in pairs, or in small flocks, they beat back and forth, generally about twenty feet above the water, and when opportunity offers plunge downward with such force that the spray dashes high about them, and the resulting splash may be heard a half a mile. They sometimes catch fish twelve to filteen inches in length, but as a rule feed on smaller ones. 


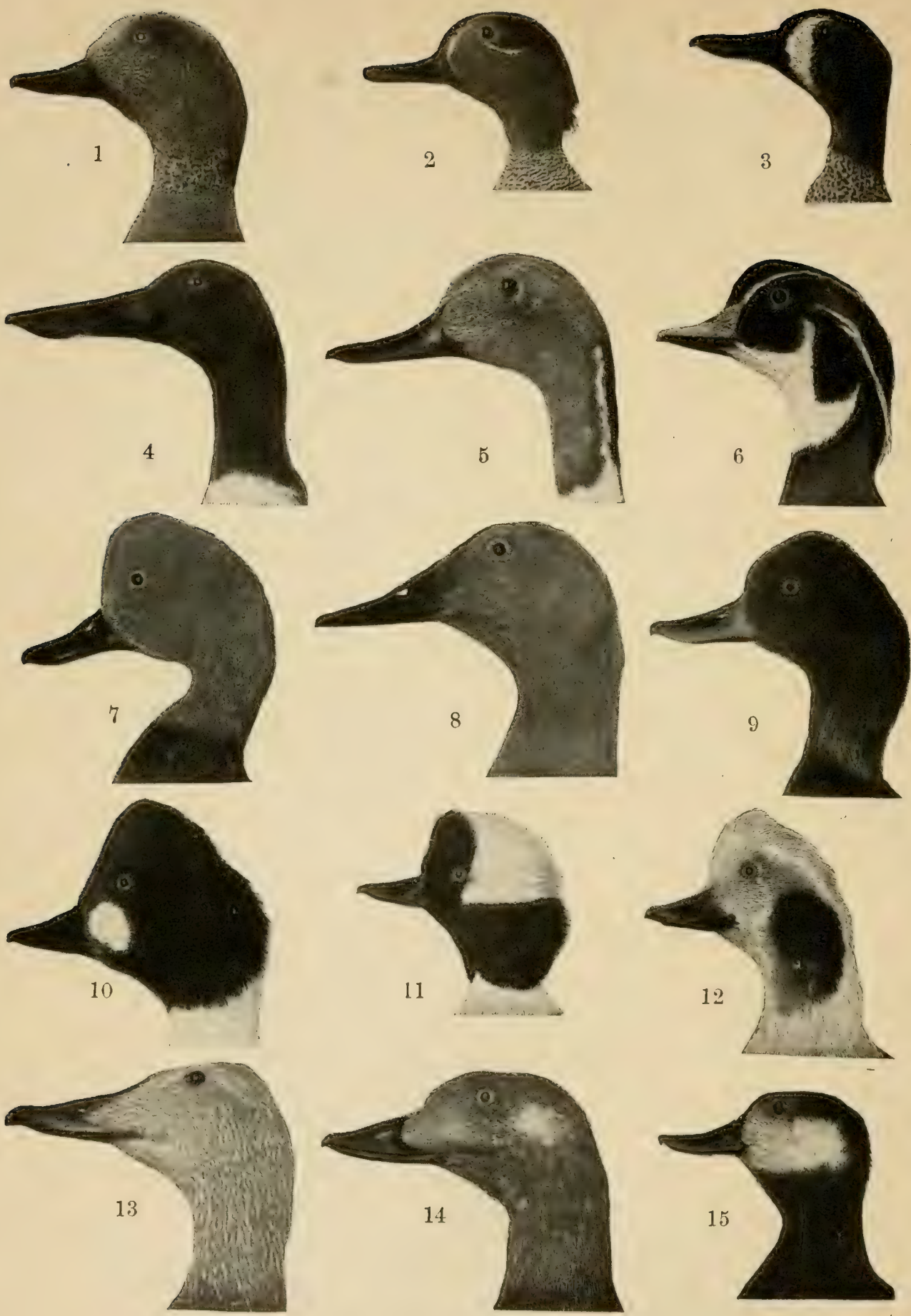

1. Baldpate.

2. Green-winged Teal.

3. Blue-winged Teal.

4. Shoveler.

5. Pintail.
6. Wood Duck.

7. Redhead.

8. Canvasback.

9. Am. Scaup Duck.

10. Am. Golden-eye.
11. Bufflehead.

12. Old Squaw.

13. Greenland Eider.

14. White-winged Scoter.

15. Ruddy Duck. 


\section{Family Fregatid At. MaN-o'-War Birds.}

Man-o'-war Birds, or Frigate Birds, are found throughout intertropical seas. One of the two known species occurs in America. They are strictly maritime, and, while sometimes observed at great distances from the land, are met with in number's only near the coasts. They have a greater expanse of wing in proportion to the weight of their body than any other bird, and in power of flight are unsurpassed. They rarely alight upon the water, but, facing the wind, pass hours resting motionless on outstretched wings, sometimes ascending to great heights and calmly soaring far above storms. It is when feeding that their marvelous aërial powers are displayed to the best advantage. By swift, indescribably graceful darts they secure fish which are near the surface or capture those which have leaped from the water to escape some enemy below. They also pursue Gulls and 'Terns, and, forcing them to disgorge their prey, eatch it in midair. As a rule they are gregarious at all seasons, and nest and roost on bushes near the shore.

128. Fregata aquila ( $(i m m$.). Man-o'-war Bird; Frigate Bird. (Sce Fig. 15.) Ad. ô.-Entire plumage black, more glossy above. \&.-Similar, but browner; lesser wing-eoverts grayish brown; breast and upper belly white. Im.--Similar to the $q$, but whole head and neck white. L., 40.00; W., 25.00; T., $17 \cdot 00 ;$ B., 4:50.

Range.-Tropical and subtropical coasts generally; in America north to Florida, Texas, and California, and easually to Kansas, Ohio, and Nova Scotia.

Long Island, A. V., one record.

Nest, of sticks, in colonies, on bushes or rocks. Egg, one, chalky white, $2 \cdot 65 \times 1 \cdot 75$.

This species is not uncommon on the coasts of southern Florida, but does not, so far as I know, nest there. It resembles other members of the family in habits.

\section{ORDER ANSERES. LAMELLIROSTRAL SWIMMERS.}

Family Anatide. Ducks, Geese, and Swans.

The two hundred species included in this family are placed in the five subfamilies, Mergince or Mergansers, Anatince or River Ducks, Fuligulince or Sea Ducks, Anserince or Geese, and Cygnince or Swans. The characters given in the Key to Families should enable one to easily refer a specimen to its proper group. These subfamilies are so well defined that it seems advisable to treat of each one separately. 
Aside from the general remarks at the head of each subfamily I can add little which will aid in the identification of the species in the field. Ducks are shy creatures, and familiarity with their habits is gained only by long experience.

\section{Subfamily Mergino. Mergansers.}

The Shelldrakes or Sawbills are fish-eating Ducks. They pursue and capture their prey under water, and their serrate bills seem especially adapted to this mode of feeding. The flesh of adult Sheldrakes is rank and fishy; but the Hooded Merganser is an excellent table Duck.

KEY TO SPECIES.

A. Bill under 1.75, wing 8.00 or under . . . 131. Hooded Merganser. B. Bill over 1.75 , wing over 8.00 .

$a$. Head and throat black.

$a^{1}$. Breast and belly white, tinged with salmon.

129. Am. Merannser (o ad.).

$a^{2}$. Breast brownish, thickly streaked and spotted with black.

130. Red-breasted Merganser ( 8 ad.).

$b$. Head and sides of the neck rich rufous-brown; distance from nostril to end of bill less than 1.50 . . . 129. Arr. Merganser ( $q$ and im.).

$c$. Crown grayish brown, more or less washed with cinnamon-rufous; sides of the neck cinnamon-rufous; distance from nostril to end of bill over 150 . . . . . 130. Red-breasted Merganser ( $q$ and im.).

129. Merganser americanus (Cass.). American Merganser; Goosander; Sheldorake. (See Fig. 16.) Ad. of.-Whole head and upper neck glossy greenish black; hind neck, secondaries, lesser wing-coverts, and ends of greater ones white; back black, rump and tail ashy gray; breast and belly white, delicately tinged with salmon. $A d . \&$ and Im.-Chin and upper throat white; lower throat and entire top of the head rufous-brown; rest of upper parts and tail ashy gray; speculum* white; breast and belly white. L., $25 \cdot 00$; W., 10.50; T'ar., 1.85 ; B. from N., 1.50 .

Range.-North America generally; breeds from Minnesota and southern New Brunswick northward; winters from Kansas, Illinois, and Maine southward to South Carolina.

Washington, rare W. V. Long Island, uncommon W. V., Nov. to Mch. Sing Sing, tolerably common T. V., Jan. 1 to Mch. 8. Cambridge, formerly common T. V., Oet. to Dec.

Nest, of leaves, grasses, and moss, lined with down, in a hole in a tree or cliff. Eggs, six to ten, creamy buff, $2.65 \times 1.75$.

"This bird is fond of plunging beneath rushing currents for its food, and should it encounter a raft of floating rubbish or an ice-cake

* A patch in the wing formed by the end half of the secondaries, which in Ducks are generally of a different color from the rest of the wing-feathers. 
it will readily pass underneath it. It swims so deeply as to afford the gunner but a small mark, and dives so quickly at the snap or flash of his gun that he stands but a small chance of killing it.

"On being surprised the Goosander may rise directly out of the water, but more commonly pats the surface with his feet for some yards and then rises to windward. $\Lambda$ whole flock thus rising from some foaming current affords a spirited scene. Once on the wing, the flight is straight, strong, and rapid" (Langille).

130. Merganser serrator (Limu.). Ren-breasted Merganser; SHelldrake. $A d$. of.-Whole head and throat black, more greenish above; a white ring around the neck; a broad cinnamon-rufous band with black streaks on the upper breast and sides of the lower neck; lesser wing-coverts, tips of greater ones, secondaries, breast, and belly white; rump and sides finely barred with black and white. Ad. $\&$ and Im.-Top and back of head grayish brown washed with cinnamon-rufous; sides of the head and throat cinnamon-rufous, paler on the throat; rest of under parts white; back and tail ashy gray; speculum white. L., $22.00 ;$ W., 9.00 ; Tar., 1.70 ; B. from N., 1.80 .

Remarks.-Adults of this and the preceding species may always be distinguished by the color of the breast; females and young, by the differently colored heads, while the position of the nostril is always diagnostic.

Lange.-Northern parts of the northern hemisphere; in America breeds from northern Illinois and New Brunswick northward to the aretic regions: winters from near the southern limits of its breeding range southward to Cuba.

Washington, uncommon W. V. Long Island, abundant 'T. V., Mch. 1 to May 1; Oct. 15 to Dec. 1, a few winter. Sing Sing, common T. V., Dec. to Apl. 30. Cambridge, casual, one instance, Oct.

Nest, of leaves, grasses, mosses, etc., lined with down, on the ground near water, among rocks or serubby bushes. Eggs, six to twelve, creamy buff, $2.55 \times 1.75$.

This is a more common species than the preceding, which it resembles in habits. Its note is described as a "croak."

131. Lophodytes cucullatus (Limn.). Hooded Merganser. Ad. $\delta$. -Front part of large circular crest black; remaining part white, bordered by black; rest of head, the neek, and back black; breast and belly white; sides cinnamon-rufous, finely barred with black. $A d . q .-$ Upper throat white; head, neek, and upper breast grayish brown, more or less tinged with cinnamon, especially on the small erest; lower breast and belly white; sides grayish brown; back fuseous. Im.-Similar, but with no crest. L., $17 \cdot 50 ;$ W., $7 \cdot 50$; Tar., $1 \cdot 10 ;$ B., $1 \cdot 45$.

Range.-North America generally, south in winter to Cuba and Mexico: breeds locally throughout its North American range.

Washington, uncommon W. V. Long Island, uncommon T. V., rare W. V., Nov, to May. Sing Sing, rare 'T. V., Mch. Cambridge, formerly common 'T. V., ()et. to Dee. 
Nest, of grasses, leaves, moss, etc., lined with down, in a hollow tree or stump near water. Eggs, eight to ten, buffy white, $2.10 \times 1.75$.

According to Ernest E. Thompson, both the preceding species frequent chiefly "living" or running water, while this bird prefers "dead" waters, or quiet ponds and lakes. In Florida it lives in small ponds in the hummocks, where one expects to find Wood Ducks, and feeds on roots, seeds, etc. It visits also the lakes frequented by Black Ducks, Mallards, and other Anatince. The male is a striking bird in life, and can not be mistaken for any other species.

\section{Subfamily Anatince. River and Pond Ducks.}

The Ducks of this subfamily are distinguished by the absence of a lobe on the hind toe. They are, for the most part, northern breeding birds, and appear on our waters chiefly as migrants. At this time they differ but little in habits, and as a rule frequent sluggish streams, shallow ponds, arms of bays, and marshes. In comparison with the deep-water Fuligulino they might be called "dabblers" or "tip-ups," and any one who has seen them dabbling along the shore, or with upturned tail and head immersed probing the bottom in shallow water, like a flock of animated tenpins, will recognize the appropriateness of these terms. 'They feed upon mollusks, crustaceans, insects and their larve, seeds and roots of aquatic plants. The "gutters" on the sides of the bill act as strainers, and, after probing the bottom, the mere act of closing the bill forces out the mud and water taken in with the food. As a rule, they feed more commonly by night than by day.

They do not gather in such large flocks as the Sea Ducks, and in our waters are generally found in groups of less than fifty.

They spring from the water at a bound, and on whistling wing are soon beyond the fowler's reach. Their speed is variously estimated for different species at a hundred to a hundred and sixty miles an hour. Doubtless the first-named distance is nearer the truth.

Their nest is composed of twigs, rootlets, grasses, leaves, moss, feathers, etc., lined with down from the breast of the incubating bird. All our species, except the Wood Duck, place their nest on the ground, generally in grassy sloughs or marshes, but sometimes in dry places some distance from the water.

I. Wing under 8.50 .

KEY TO THE SPECIES.

a. Lesser wing-coverts gray.

139. Green-Winged Teal. 138. Europeat Teal.

b. Lesser wing-coverts blue.

$b^{1}$. Cheeks slate-color, a broad white mark near the front of the face.

140. Biue-winged Teal (o ad.). 
12. Cheeks and under parts chestnut-rufous. 141. Cinnamon Teal (o ad.). c. Cheeks finely streaked with blackish.

$c^{2}$. Under parts whitish, sometimes washed with brownish, streaked or spotted with blackish . . . . 140. Blue-Winged Teal \&.

$c^{\text {h }}$. Under parts heavily washed with chestuut-rufous and mottled with black. . . . . . . . . 141. Cinndion T'eal 9.

II Wing over 8.50.

A. Belly white or grayish white, not conspieuously streaked or spotted.

x. Whole head shining dark green . . . . . 132. Mallard (o ad.).

b. Center of head white or whitish, a large streak behind the eye.

137. Baldpate ( $\&$ ad.).

c. Throat white, crown green or grayish green, tips of primaries greenish.

144. Wood Duck.

d. Throat blackish, center of crown buffy, rest of head rufous.

136. WIDGEON ( $\&$ ad.).

e. Throat and sides of head olive-brown, darker on the crown.

143. Pintail ( $q$ ad.).

$f$. Throat, crown, and sides of head more or less finely streaked with blackish.

$f^{2}$. Wing-coverts with more or less chestnut . . . 135. Gadwald.

$g^{1}$. No chestnut in wing-coverts.

$g^{2}$. Axillars* and sices barred with black . . . 143. Pintall \&.

$g^{3}$. Axillars white or speckled with black, sides plain brownish.

137. BALDPATE \&.

$g^{4}$. Axillars white, sides thickly spotted or barred with black.

135. Gadwall $\&$.

$B$. Under parts conspicuously mottled; spotted, or streaked, or feathers margined with chestnut-rufous.

a. With white in wing-coverts.

$a^{\geq}$: Lesser wing-coverts ashy blue . . . . . 142. Shoveler o.

$b^{1}$. Lesser wing-coverts brownish gray, bordered with white or tipped with black.

$b^{2}$. Speculum + purple . . . . . . . 132. Mallaro 9.

$b^{3}$. Speculum gray and white . . . . . 135. Gidwall .

b. No white in wing-coverts.

a. Throat fulvous or buffy without streaks. . . 134. F LORIDA Duck.

b. Throat finely streaked with black..... 133. BLAck Duck.

C. Belly chestnut . . . . . . . . . . 142. Shoveler o

132. Anas boschas Linn. Maland (see Fig. 1\%, a). Al. o.Whole head and throat glossy greenish or bluish black; a white ring around the neck; breast rich chestnut; belly grayish white, finely marked with wavy black lines; under tail-coverts black; upper back dark grayish brown; rump and upper tail-coverts black; longer upper tail-coverts recurved; speculum rich purple, bordered at the base and tip by narrow bauds of blach and white. Ad. \&.- Top and sides of head streaked with fuscous and buft'y ; back fuscous, 
the feathers with internal rings or loops and sometimes borders of pale ochraceous buffy; speculum as in the preceding; breast and belly ochraceous buffy, mottled with dusky grayish brown. L., 23.00; W., 11.00; Tar., $1.75 ;$ B., $2 \cdot 25$.

Range.-Northern parts of the northern hemisphere; in America breeds in the interior from Indiana and Iowa, and on the Atlantic coast rarely south of Labrador, northward to the arctic regions; winters from southern Kansas and Delaware southward to Central America and the island of Granada.

Washington, common W. V. Long Island, uneommon T. V., Sept. to Apl. Sing Sing, rare T. V., Oct., Mch.

Eggs, six to ten, pale grecnish or bluish white, $2.30 \times 1 \cdot 70$.

The Mallard is far more common in the interior than on the coasts. Its loud, sonorous quack is not distinguishable from that of its domesticated descendants.

133. Anas obscura Gmel. Black Duck; Dessir Deck. Ad.Top of the head rich fuscous, slightly streaked with pale buffy; sides of the head and throat pale buffy, thickly streaked with blackish; rest of under parts fuseous brown, the feathers all bordered by ochraceous-buff; back slightly darker and narrowly margined with buffy; speculum rich purple, bordered by black. L., $22 \cdot 00 ;$ W., $11 \cdot 00$; Tar., $1 \cdot 75 ;$ B., $2 \cdot 20$.

Remarks. - Always to be distinguished from the Mallard by the lack of white in the wing.

Range.-North America; breeds from Illinois and New Jersey to Hudson Bay and Labrador; winters southward to the Greater Antilles.

Washington, common W. V. Long Island, abundant W. V., Sept. to May ; a few breed. Sing Sing, tolerably common S. K., Mch. 6 to Nov. 13. Cambridge, very common T. V., Mch. and Apl; late Aug. to Nov.; a few breed.

Eqgs, eight to twelve, pale greenish or bluish white, or creamy buff, $2 \cdot 43 \times 1 \cdot 75$.

This species resembles the Mallard in general habits, and the voices of the two are indistinguishable. The Black Duck, however, is commoner near the seacoasts, and when molested will sometimes pass the day at sea, returning at night to feed in the marshes and ponds near the shore.

134. Anas fulvigula Rillne. Fromina Deck. A4.-Top of head streaked with black and buffy; sides of the head and entire throat buffy, without streaks; rest of under parts rich buffy ochraceous, widely streaked with black; back black, the feathers broally margined and sometimes internally striped with ochraceous-buff; speculum rich purple bordered by black; bill olive-yellow, its nail black. L., 20.00; W., 10.50; Tar., 1.65; B., 2.05.

Remarks.-Easily distinguished from A. obscura by the absence of streaks on the throat.

Range.-Florida and Gulf coast to Louisiana.

Eggs, eight to ten, pale dull buff or pale grayish buff, $2 \cdot 15 \times 1 \cdot 61$ (Ridgw.).

This is a common resident species in Florida. Its habits and voice are practically the same as those of the Black Duck. 
135. Anas strepera Linn. Ginwall; Gray Duck. Ad. o.'Top of the head streaked with rufous-brown and black; sides of the head and neck pale buffy, thickly streaked or spotted with black; breast and neck all around black, each feather with a border and an internal ring of white, giving the plumage a beautifully scaled appearance; belly white or grayish; rump, upper and under tail-coverts black; lesser wing-coverts chestnut. Ad. \&.Ilead and throat as in the male; back fuscous margined with buffy; breast and sides ochraceous buffy, thickly spotted with blackish; belly and under tail-coverts white, more or less thickly spotted with blackish; little or no chestnut on wing-coverts; speculum ashy gray and white; axillars and under wing-coverts pure white. L., 19.50; W., 10.40; Tar., 1.55; B., 1.70.

Range.-Northern hemisphere; in America, breeds in the interior locally from Kansas northward to the aretic regions; known to breed on the Atlantic coast only at Anticosti; winters from Virginia to Florida and Texas.

Washington, common W. V., Sept. to Apl. Long Island, A. V.

Eggs, eight to twelve, pale buff or buffy white, $2.09 \times 1.57$ (Ridgw.).

This species is common in the interior and in Florida, but is rather rare in the other Atlantic States. Its call-note is said to resemble that of the Mallard, "but is rather more shrill, and frequently repeated."

136. Anas penelope Linn. Erropenn WIngeon. At. f.-Crown creamy buff; throat blackish, rest of head and neck rufous-brown; upper breast vinaceous, lower breast and belly white; sides and back finely marked with wavy black and white lines. $A d$. \&.- Head and throat deep ochraceousbuff', finely streaked and barred with black, darker above; upper breast and sides much the same color, but without black markings; lower breast and belly white; back grayish brown, the feathers with small ochraceous buffy bars; tertials fuscous, bordered by deep ochraceous buffy; greater wing-coverts brownish gray, usually whiter on the outer webs and tipped with black. W., $10.50 ; B ., 1 \cdot 40$.

Remarks. - The females of the European and American Widgeons bear a general resemblance to one another. Their distinguishing characters are mainly in the color of the head and throat, which are brown in the European species, and in the color of the greater wing-eoverts, which are whiter in the American bird. I have seen a eaged male in the summer in a plumage elosely resembling that of the female. Probably a similar change of plumage oceurs in our A. americana.

Range.-Northern parts of the Old World; in North America breeds in the Aleutian Islands, and oceurs occasionally in the eastern United States.

Washington, A. V., two records. Long Island, A. V.

Eggs, five to eight, buffy white, $2.23 \times 1.53$.

"The call-note of the male is a shrill, whistling uhēé-yoŭ, whence the local names 'Whew Duck' and 'Whewer'; but the female utters a low purr-ing growl. Both sexes, however, rise in silence" (Saunders).

13\%. Anas americana fimel. Bafipate; Anerican Wingeon. Ad. 8. - Middle of the crown white or buffy; sides of the crown, from the eye 
to the nape, glossy green, more or less sprinkled with black; lores, cheeks, and throat buffy, finely barred with black; upper breast and sides vinaceous, the latter more or less finely barred with wavy black lines; lower breast and belly white; back grayish brown, more or less tinged with vinaceous and finely barred with black. Ad. \&.-Head and throat white or pale, creamy buff, finely streaked and barred with black, darker above; upper breast and sides pale vinaceous washed with grayish; lower breast and belly white; back grayish brown, the feathers with small creamy buff bars; tertials fuscous, bordered with whitish or creamy butf; greater wing-coverts brownish gray, their outer webs mostly or entirely white, their ends black, sometimes tipped with white. L., 19.00; W., 10.50; Tar., 1.50 ; B., 1.40.

Range.-North America; breeds in the interior regularly from Minnesota northward, and casually as far south as Texas; not known to breed on the Atlantic coast; winters from open water south to Central America and northern South America.

Washington, common W. R., Oct. to Apl. Long Island, uncommon T. V., Oct. to Apl. Sing Sing, common T. V., Meh. 11 to Apl. 12; Oct. 4 to Oct. 28.

Eggs, seven to twelve, butty white, $2.05 \times 1.50$.

Colonel N. S. Goss writes that, as a rule, Widgeons are "not shy, and their note, a sort of whew, whew, whew, uttered while feeding and swimming, enables the hunter to locate them in the thickest growth of water plants: and when in the air the whistling noise made by their wings heralds their approach." They are fond of wild celery, which they procure by robbing the Canvasback and other diving Ducks, "snatching their catch from their bills the moment their heads appear above the water."

139. Anas carolinensis Gmel. Green-winged Teal. Ad. $\delta$. -Chin black, sides of the head from the eye to the nape shining green, rest of the head and neck rufous-chestnut; breast washed with vinaceous and spotted with black; belly white; sides finely marked with wavy black and white lines ; middle under tail-coverts black, lateral ones creamy buff; upper back like the sides, lower back grayish fuscous; a white bar in front of the bend of the wing; wing-coverts brownish gray, tipped with ochraceous buffy. Ad. o.- - Top of the head brownish fuscous, margined with cinnamon; throat and sides of the neck white, finely spotted with black; breast and sides washed with cinnamon and spotted or barred with black; belly and under. tail-coverts white, sometimes spotted with black; back fuscous, the feathers with crescent-shaped marks of ochraceous buffy, and bordered with grayish; wings as in the male. L., $14.50 ;$ W., 7.00 ; 'Tar., 1.10: B., 1.35.

Range.-North America; breeds from Minnesota and New Brunswick northward; winters from Kansas and Virginia southward to the West Indies and Central America.

W ashington, common W. V., Sept. to Apl. Long Island, uncommon T. V. and W. V., Oct. to Apl. Sing Sing, common T. V., Apl.; Sept. 11 to Oct. 28. Cambridge, uncommon T. V., Apl.; Sept. to Nov.

Eggs, six to twelve, buffy white or creamy buff, $1.80 \times 1.25$. 
"In autumn the males usually keep in separate flocks from the females and young. 'Their notes are faint and piping, and their wings make a loud whistling during flight. . . ." (B., B., and R.).

The European Teal (138. Anas crecca) is of easual occurrence in North America. The adult male resembles that of $A$. carolinensis, but the white bar in front of the wing is lacking, and the inner scapulars are creamy butf, with a sharply defined black mark on their outer webs. The female can not be distinguished from that of $A$. carolinensis.

140. Anas discors Linn. BlLE-WINGed Teal. Ad. \&.-Crown fuscous, chin and sides of the base of the bill black; a broad white band across the front of the head, its hinder margin bordered by black; rest of the head and throat dark ashy with purplish reflections; breast and belly cinnamon-rufous, thickly spotted with black; back fuscous, the feathers with crescents of ochraceous-buff; lesser and median wing-coverts grayish blue, end half of the greater ones white; speculum green. $A d$. o and of in summer.Crown fuscous, lightly margined with grayish; sides of the head and the neck whitish, fincly spotted with blackish, exeept on the throat; breast and belly with less cinnamon wash than in the preceding; back and wings quite similar to the preceding, but ochraceous bars sometimes wanting; speculum darker and greater coverts with less white. L., 16.00; W., 7.25; Tar., 1·20; B., $1 \cdot 60$.

Range.-Chiefly eastern North America; breeds from Kansas, northern Ohio, and New Brunswick northward; winters from Virginia and the Lower Mississippi Valley to northern South America.

Washington, common W. V., Sept. to Apl. Long Island, common T. V. in Sept., rare T. V. in spring. Sing Sing, common 'T. V. in fall, Sept. 24 to Oct. 17. Cambridge, rare in spring; very common (at least formerly) Aug. to Oct.

Eggs, six to twelve, buffy white or ereamy buff, $1.85 \times 1 \cdot 30$.

This generally silent species flies in densely massed, small flocks, which move as one bird. The white face-mark can be discerned at some distance, and, in connection with the bird's small size, is a good field-mark.

The Crmpamon Teal (141. Anas cyanoptera), a species of western North America, sometimes occurs east of the Mississippi. It has been recorded from Illinois and Florida. The male has the under parts deep cinnamon; the female closely resembles the same sex of our Anas discors.

142. Spatula clypeata $($ Limn.). Shoveleir. Ad. of.- Head and neck fuscous, glossed with bluish green; back and a broken line down the back of the lower neck fuscous; rest of the lower neck and breast white; lower breast and belly rufous-ehestnut; upper and under tail-coverts dark greenish; lesser wing-enverts grayish blue, greater ones brownish gray tipped with white; speculum green. $A d$. $\& .-$ Throat buffy white; head and neck streaked with buffy and black; rest of under parts more or less washed with 
buffy ochraceous, everywhere indistinctly spotted with fuscous except on the middle of the belly; back fuscous, the feathers with margins and internal crescents of whitish and buffy; wing-coverts and speculum much as in the male. Im.-The im. $\delta$ is intermediate between the ad. $\delta$ and $q$; the im. o resemble the ad. $\delta$, but the wing-coverts are slaty gray, the speculum with little or no green. L., 20.00 ; W., 9.50 ; B., 2.50 ; greatest width of B., 1.20.

Range.-Northern hemisphere; in America, more common in the interior; breeds regularly from Minnesota northward and locally as far south as Texas; not known to breed in the Atlantic States; winters from southern Illinois and Virginia southward to northern South America.

Washington, not uncommon W. V. Long Island, rare T. V. Sing Sing, A. V., Oct.

Eggs, six to ten, pale buffy white or bluish white, $2.10 \times 1.50$.

The Shoveler, like most of the members of this subfamily, is more common in the Mississippi Valley than on the coast. It is generally a silent bird, but its note in the breeding season is said to be "took, took:" It feeds largely by tipping in shallow water.

143. Dafila acuta ( $\mathrm{i}$ im. $)$. Pintail; Sprigtail. Ad. o.--Head and throat olive-brown; back of the neck blackish, bordered by white stripes, which pass to the breast; breast and belly white; the abdomen faintly and the sides strongly marked with wavy lines of black and white; back somewhat darker than the sides; seapulars black, bordered or streaked with butfy white; wing-coverts brownish gray, the greater ones tipped with rufous; speculum green; central tail-feathers glossed with green and much elongated. Ad. \&.-Throat white or whitish, crown and sides of the head streaked with blackish and buffy ochraceous, darker above; breast washed with buffy ochraceous and spotted with blackish; belly white; abdomen more or less indistinctly mottled with blackish; sides with bars and lengthened black and white crescents; under wing-coverts fuscous, bordered with whitish; axillars barred or mottled with black; back fuscous, the feathers with borders, bars, or crescents of white or buffy; speculum grayish brown bordered with white. os in breeding plumage.- "Similar to ad. $\&$, but wings as in spring or winter plumage" (Ridgw.). Im.-The im. $\delta$ is variously intermediate between the ad. $\delta$ and $q$; the im. $\%$ resembles the ad. $\&$, but the under parts are more heavily streaked or spotted. L., o, 28.00, \&, 22.00; W., 10.00 ; T., o , $7 \cdot 50$, o, $3 \cdot 60 ;$ B., $2 \cdot 00$.

Remarks. The female of this species is a rather obscure-looking bird, but may always be known by its broad, sharply pointed central tail-feathers and dusky under wing-coverts.

Range.-Northern hemisphere; in America, breeds from Iowa and Illinois to the Aretic Ocean; not known to breed on the Atlantic coast; winters from Virginia southward to the Greater Antilles and Central America.

Washington, W. V., Oct. to Apl. Long Island, very common '1. V., Sept. 15 to Apl. 15 ; a few winter. Sing Sing, common T. V., Mch. 15 to Apl. 10 ; Sept. 26 to Dec. 4. Cambridge, easual T. V., Apl.; Sept. and Oct.

Eggs, eight to twelve, bufly white or pale bluish white, $2 \cdot 20 \times 1.50$. 
The Pintail is frequently found associated with the Black Duck and Widgeon. As a rule it is voiceless, but is said to utter "a lowtoned quack at night." 'The long neck and tail of the male make its identification easy even at a distance.

144. Aix sponsa (Linn.). Woon Duck. Ad. o. $-\mathrm{A}$ 'line from the bill over the eye, a similar line at the base of the side of the crest, and some of the elongated erest-feathers white; throat, a band from it up the side of the head, and a wider one to the nape, white; rest of the cheeks and crown green with purplish reflections; a white band in front of the wings; breast and a spot at either side of the base of the tail purplish chestnut, the former spotted with white; belly white; sides buffy ochraceous, finely barred with black, the longer flank feathers tipped with wider bars of black and white: back greenish brown; scapulars blacker; speculum steel-blue; primaries tipped with greenish blue.- $A d$. $\& .-$ Throat and a stripe from the eye backward white; crown purplish brown; sides of the head ashy brown; breast and sides grayish brown streaked with buffy; belly white; back olive-brown glossed with greenish; inner primaries tipped with greenish blue. Im.-The im. of resembles the o. L., $18 \cdot 50 ;$ W., 9.00; Tar., $1 \cdot 35$; B., 1.30.

Range.-North $A$ merica; breeds from Florida to Hudson Bay, and winters southward to southern Mexico, Cuba, and Jamaica.

Washington, uncommon P. R. Long Island, uncommon T. V. and W. V., Sept. to Apl.; rare S. R. Sing Sing, tolerably common S. R. Cambridge, common T. V., Mch. and Apl.; Aug. to Nov.; a few breed.

Nest, of grasses, leaves, twigs, etc., in a hole in a tree or stump. Eggs, eight to fourteen, pale buffy white, $2.05 \times 1.50$.

Woodland ponds and forest-bordered streams make a proper setting for the grace and beauty of these richly attired birds. Several times it has been my fortune to see them in the unconscious enjoyment of their secluded homes, and I know of no sight in the bird world which so fully satisfies the eye. Alarm them, and with a frightened, plaintive whistle, "oo-eek," they spring from the water and make off through the woods. At other times they will swim ahead of one's canoe, and, rounding a bend in the stream, go ashore and walk rapidly away.

The young are brought from the nest to the ground in the bill of the parent.

\section{Subfamity Fuligulino. Bay and Sea Ducks.}

The members of this subfamily are to be distinguished from those of the preceding by the presence of a lobe or web on the hind toe. They are open-water Ducks, frequenting our large lakes, bays, and seacoasts. Their food consists chiefly of mollusks, crustaceans, and the seeds and roots of aquatic plants. They obtain it principally by diving, sometimes descending one hundred and fifty feet or more. The 
bill, as in the Anatince, acts as a sieve or strainer. As a rule they feed by day and pass the night at a distance from the shore or at sea. Some of the species occur in our waters in large flocks-indeed, our most abundant Ducks are members of this subfamily. With one exception they are northern breeding birds, seldom nesting south of our northern tier of States.

Their nest is composed of twigs, leaves, grasses, stems of aquatic plants, seaweed, etc., lined with down from the breast of the incubating bird.

\section{KEY TO THE SPECIES.}

I. Feathers at the base of the bill not reaching 50 forward along its sides. $A$. Wing over 7.00; axillars and most if not all the linings of the wings white. $a$. Head and neck black, with greenish or purplish reflections.

$a^{1}$. Back black; bill with a bluish band near its tip.

150. RING-NECKED DUCK o .

$b^{1}$. Back finely barred with black and white.

6 2. Back of head generally with purplish reflections; wing generally under 8.25; nail of bill generally under 25 in width.

149. Lesser Scaup Duck of.

$b^{3}$. Back of head generally with greenish reflections; wing generally over 8.25 ; nail of bill over 25 in width.

148. Am. Scaup Duck of.

b. Head and neck rufous or rufous-brown, sharply defined from the black breast.

61. Head and upper neck rich rufous; bill 2.00 or under; flanks finely barred, like the back. . . . . . . 146. Redhead ô.

$b^{2}$. Head and neck rufous-brown; crown blackish; bill over $2 \cdot 00$; flanks very slightly if at all barred . . . . . 147. CANvasback of.

c. Head and neck brownish or grayish.

$c^{1}$. A white patch in the wing.

$c^{2}$. Feathers at base of bill white; wing generally under 8.25: nail of bill generally under 25 in width . . 149. Lesser Scalp Duck o

$c^{3}$. Feathers at base of bill white; wing generally over 8.25 ; nail of bill generally over 25 in width . . 148. AM. Scaup Duck ?. $d^{1}$. No white in wing.

$d^{2}$. An indistinct bluish band near the tip of bill; bill under 2.00 .

$d^{3}$. Wing under 8.00. . . . 150. Ring-NECKed Duck $q$.

$d^{4}$. Wing over 8.00 . . . . . . . 146. REDHEAD \&.

$\epsilon^{2}$. No band on bill; bill over 2.00 . . . . 147. Canvasback $\%$

$B$. Wing over $7 \cdot 00$; axillars and most if not all the under wing-coverts blackish.

a. Head and throat dark steel-blue or steel-green.

$a^{1}$. Head and throat steel-blue; white patch at base of bill 1.00 or more in height . . . . . . . 152. BARRow's GOLDEN-EYE of.

$a^{2}$. Head and throat steel-green; white patch at base of bill less than 1.00 in height . . . . . . . . 151. AM. GoLDEN-EYE \&. 
b. Whole head and throat brown, sharply defined from the gray or white neck; a white patch (speculum) in the wing.

b1. Nostril nearer the tip than the base of the bill.

151. Am. GolDEN-EYE $\subsetneq$. 6.2. Nostril in the middle of the bill - 152. Barrow's GoLden-Exe $q$.

¿. Whole head and neck black . .. . . . 163. Av. Scoter $\delta$.

1. A white patch on the top of the head and another on the back of the neck . . . . . . . . . 166. Surf Scoter of

e. Niddle of crown black, bordered by chestnut; front half of the face white . . . . . . . . . 155. HARLEquin Duck oै

$f$. Head and neck whitish, grayish, or brownish; no white in the wing.

$f^{1}$. Bill over 1.25.

$f^{2}$. Feathers on culmen reaching much further forward than those at the sides of the bill . . . . . 166. Surf Scoter 9 .

$f^{3}$. Feathers on culmen reaching little if any beyond those at the sides of the bill . . . . . . . 163. AM. Scoter $\%$.

$g^{1}$. Bill under 1.25.

$g^{2}$. Central tail-feathers longest, sharply pointed, under tail-coverts 154. Uld SQuaw. $g^{3}$. Central tail-feathers not sharply pointed; under tail-coverts grayish brown

C. Wing under $7 \cdot 00$.

a. Tail-feathers stiff and narrow ; upper tail-coverts very short.

$a^{1}$. Upper parts mostly rich chestnut-rufous.

$a^{2}$. Cheeks white ....... 167. Rudpr Duck o . $a^{3}$. Cheeks black . . . . . . 168. Masked Duck f .

b1. Upper parts grayish or brownish, with sometimes rufous markings. $b^{2}$. Lining of wing blackish; under parts grayish.

168. Masked Duck ?

23. Lining of wing whitish; under parts grayish.

167. Rudpy Duck ?.

b. Tail-feathers normal; upper tail-coverts about half as long as tail.

II. Feathers at sides or top of bill extending forward generally as far as nostril. 153. Bufflehead.

A. Feathers on sides of bill not reaching nostril.

a. Nostril narrow, elongate; feathers on culmen extending forward in a narrow line, a $\mathrm{V}$-shaped mark on throat . . . 162. Kixg Erder.

b. Nostril large, rounded; feathers on culmen not extending forward in a narrow line . . . . . . . 165. White-winged Scoter.

$B$. Feathers on sides of bill extending as far as nostril.

a. Bare base of bill on top narrow, ending posteriorly in a sharp point.

b. Bare base of hill on top broad, the posterior end rounded.

160. AM. EIDER.

The Rurots-crested Dich (145. Netta rufina) is an ()ld-World species which has been taken once in America. The record is based on an immature male found in Fulton Market, New York city, which was supposed to have been shot on Long Island. 
146. Aythya americana (Eyt.). Rediend. $A d$. of.-Head and throat bright rufous; lower neek, breast, back of the neck, and upper back black; rest of the back and scapulars finely barred with wavy black and white lines of equal width; wing-coverts brownish gray; upper tail-coverts black; belly white, the lower belly more or less finely barred with black; under tailcoverts black; sides like the back. $A d$. \&.-Upper parts dark grayish brown, darker on the rump, the feathers more or less margined with buffy or ashy; sides of the head lighter; upper throat white; neck buffy ochraceous; breast and sides grayish brown, more or less washed or margined with butfy or butfy ochraceous; belly white; lower belly and under tail-coverts tinged with ochraceous; an indistinct bluish-gray band across the end of the bill. L., 19.00; W., 8.90; Tar., $1.55 ;$ B., 1.85.

Remarks.-This species is frequently confused with the Canvasback, from which it may be distinguished by the characters given under that species.

The female Redhead is much like the fernale Ring-neck in coloration; the latter is generally browner, but they can be distinguished with certainty only by the difference in their size.

Range.-North America; breeds from California and Minnesota northward to the fur countries; rare on the North Atlantic coast, where it has been found breeding only once (Calais, Me.); winters from Virginia southward to Cuba and Jamaica.

Washington, common W. V. Long Island, T. V. in irregular numbers, Oct. 1 to Apl. 15, few W. V. . Sing Sing, common T. V., Apl. 1 to Apl. 24; Oct. 12 to Oct. 28. Cambridge, casual; one instance, Oct.

Nest, on the ground in grassy sloughs or marshy lake sides. Eggs, six to twelve, buffy white, $2 \cdot 40 \times 1 \cdot 70$.

The Ducks of the genus Aythya possess to some extent the habits of both the River Ducks and true Sea Ducks. They are divers in deep water, but along the shores or in shallow water they are also "dabblers." On our coasts the Redhead is a Bay Duck, and feeds in salt and brackish water.

14\%. Aythya vallisneria (Wils.). Cаnтаsвack. Ad. o.-Head and neck rufous-brown, the chin and crown generally blackish; breast and upper back black; rest of the back and generally wing-coverts finely barred with wavy lines of black and white, the white lines the wider; belly white; lower belly more or less finely barred with black; upper and under tail-coverts black; sides white, much less lightly barred with wavy black lines than the back, or even entirely without bars. $A d$. $q$.- Head, neck, upper breast, and upper back cinnamon, the throat lighter, and, with the front parts of the head, more or less washed with rufous; back grayish brown, the feathers more or less barred with vavyy white lines; belly white or grayish white; sides the same or grayish brown, generally marked like the back. L., 21.00; W., 9.00 ; Tar., $1 \cdot 60 ;$ B., $2 \cdot 40$.

Remarks.-This species is sometimes mistaken for the Redhead, to which it bears a general resemblance. The males of the two species may be distinrouished (1) by the color of the head and neck, which is rufous in the Red- 
head and rufous-brown in the Canvasback; (2) by the generally blackish chin and crown of the Canvasback, these parts in the Redhead being colored like the rest of the head; (3) by the difference in the markings of the back, wing-coverts, and sides; and (4) by the difference in the size and shape of the bill, as shown by the accompanying measurements. 'The females of the two species may be at once distinguished by the color of the back, which in the Canvasback is tinely barred with wavy white lines, markings which do not appear on the back of the female Redhead.

Range.-North America; breeds only in the interior, from Minnesota to the Aretic Circle; rare on the Atlantic coast north of Delaware; winters from the Chesapeake Bay to the Greater Antilles.

Washington, rare W. V. Long Island, rare T. V. Sing Sing, rare T. V., Ocl.

Nest, on the ground, in grassy sloughs or marshy lake sides. Eggs, six to ten, buffy white with a bluish tinge, $2 \cdot 40 \times 1 \cdot 70$.

There's much in a name. The reputation of the Canvasback, among gourmands, is too firmly established to be questioned; but, given the same chef, and half a dozen of our Ducks can be made to do duty for this favorite of epicures. In some parts of the west, where folks have a way of thinking for themselves, the Canvasback is frankly placed second to his cousin the Redhead.

The Canvasback is at its best when the bird has been for some time feeding on wild celery-a diet which equally improves the flesh of other species.

148. Aythya marila nearctica Steju. AM. S Scaup Duck; Broadbill; Bluebill; Blackhead. Ad. o.-Head, neck, breast, and upper back black, the top and sides of the head with generally greenish reflections; back and scapulars with wavy black and white bars; speculum white; upper and under tail-coverts black; belly white; lower belly strongly and sides faintly marked with wavy black bars. $A d$. \&.Region around the base of the bill white; head, neck, breast, and upper back umber, margined with ochraceous on the breast; back and scapulars fuscousbrown; sides dark grayish brown, both generally marked with fine, wavy bars of white; speculum and belly white. \& L., 18.50; W., 8.75; Tar., 1.40; B., 1.65; greatest width of B., 1.00. \& L., 17.50; W., 8.25; Tar., 1.36 ; B., $1 \cdot 65$; greatest width of B., $1 \cdot 00$.

Range.-North America; breeds in the interior rarely from Minnesota and regularly from Manitoba northward to Alaska; reported on the Atlantic from as far north as Greenland, but not known to breed and not common north of Massachusetts; winters from Long Island to northern south America.

Washington, rather common W. V. Long Island, abundant T. V., Sept. 25 to May 1, some winter. Sing Sing, common T. V., Mch. 22 to Apl. 13; Oct. 4 to Dec. 3 * $^{*}$

* The presence or absence of Ducks in the winter depeuds upon whether the river is frozen or open. 
Nest, on the ground, in grassy sloughs or marshy lake sides. Eggs, six to ten, pale olive-buff, $2 \cdot 54 \times 1 \cdot 71$.

This is one of our most common Bay Ducks. While with us it seems to prefer salt and brackish water. It feeds largely on mollusks, which it obtains by diving. Its note is said to be a discordant scaup.

149. Aythya affinis $(E y t$.). Lesser Soatp Deck; Little Blackhead; Little Bluebili; Creek Broanbill. $A d$. $\delta$. - Similar to the preceding species but smaller, the head, as a rule, glossed with purplish instead of greenish, and the flanks strongly instead of faintly marked with wary black bars. $A d$. $q$. - Similar to the of of the preceding species, but smaller. o L., 16.50 ; W., 8.00; Tar., 1.35; B., 1.60; greatest width of B., 95 . \& L., 16.50 ; W., $7 \cdot 60$; Tar., $1 \cdot 30 ;$ B., $1 \cdot 55$; greatest width of B., 90 .

Remarks.-The Scaup Ducks resemble each other so closely that it is sometimes impossible to tell them apart, but they may generally be distinguished by the characters given above.

Range.-North America; breeds only in the interior, rarely from Iowa and commonly from Manitoba northward; not common on the Atlantic coast north of Massachusetts; winters from Virginia to the Greater Antilles.

Washington, not uncommon W. R., Oct. to Apl. Long Island, common T. V. Sing Sing, common T. V., Jan. 28 to Apl. 12; Aug. 31 to Nov. Cambridge, common in Oct. and Nov.; rare in spring.

Nest, on the ground, in grassy sloughs and marshy lake sides. Eggs, six to ten, similar in color to those of the preceding, $2 \cdot 25 \times 1.58$.

This species has much the same habits as the preceding, but is more often found in fresh water, and I think is more southern in its distribution during the winter. It is by far the most abundant Duck in Florida waters at that season, where it occurs in enormous flocks in the rivers and bays along the coasts.

150. Aythya collaris (Donov.). RING-Necked Dick. Ad. of.Chin white; head, neck, breast, and upper back black, the head with bluish reflections, the neck with a not sharply defined chestnut collar; back and scapulars black, speculum gray; upper and under tail-coverts black, belly white, lower belly and sides finely barred with wavy black lines; bill black, the base and a band across the end bluish gray. Ad. \&.-Upper parts fuscous brown, more or less margined with ochraceous; speculum gray; sides of the head and neck mixed grayish brown and white; breast, sides, and lower belly grayish brown, more or less margined with oshraceous; upper belly white or whitish; bill blackish, an indistinet band of bluish gray across its end. L., 16.50; W., 7.50; 'T'ar., 1.25; B., 1.80.

Remarks.- The male Ring-neck may be known from any of its allies by its chestnut collar and other excellent characters; the female resembles the female Redhead, but is smaller and generally browner.

Range.-North America, breeding only in the interior from Iowa northward; not common on the Atlantic const north of Virginia. 
Washington, not rare, W. V. Long Island, A. V. Sing Sing, A. V., Apl. Cambridge, casual; one instance, Nov.

Nest, on the ground, in grassy sloughs or marshy lake sides. Eggs, six to twelve, similar in color to those of the two preceding species, $2 \cdot 28 \times 1 \cdot 63$.

'This is more of a fresh-water bird than either of the preceding. It is not common in the Atlantic States north of Florida, where during the winter il is abundant on fresh-water lakes.

- 151. Glaucionetta clangula americana (Bonap.). AMERICAN Golden-EYe; Whistler. Ad. of.-Head and throat dark, glossy green, a circular white patch at the base of the bill measuring, along the bill, less than half an inch in height; neck all around, breast, belly, exposed part of wing-coverts, speculum, and most of the scapulars white; rest of plumage black. Ad. \%.- Head and throat cinnamon-brown, fore neck white; upper breast, back, and sides ashy gray bordered with grayish; wing-coverts tipped with white; speculum, lower breast, and belly white. L., 20.00; W., 9.00; B. from anterior margin of white patch to anterior margin of nostril, 1.00 ; from anterior margin of nostril to tip, $\cdot 75$.

Range.-North America, breeding from Manitoba and Maine northward, and wintering from the southern limit of its breeding range to Cuba.

Washington, not rare, W. V. Long Island, common T. V. and W. V., Nov. 15 to Apl. 15. Sing Sing, common 'T. V. and W. V., Nov. to May. Cambridge, rather common, Oct. and Nov.

Nest, in a stump or hollow tree. Eggs, six to ten, pale bluish, $2.35 \times 1.75$.

The rapidly moving wings of most Ducks make a whistling sound, but this species excels in wing music. As a diver it can also claim high rank.

152. Glaucionetta islandica (Gmel.). BARROW's GOLDEN-EYE. Ad. s.-Head and throat dark, glossy, purplish blue, an irregular, somewhat spread-rving-shaped white patch at the base of the bill measuring, along the bill, about one inch in height; neck all around, breast, belly, speculum, lesser wing-coverts, ends of greater ones, and the shaft part of the scapulars white; rest of the plumage black. $A d . q$.-Resembles the $q$ of the preceding species in color; there is some difference in the size and proportions of the bill, but the two birds can not always be distinguished with certainty. W., $9 \cdot 25 ; \mathrm{B}$. from anterior maresin of white patch to anterior margin of nostril, 80 ; from anterior margin of nostril to tip, $\cdot 66$.

Kemarks.-The males of this and the preceding species may always be distinguished by the difference in the color of the head and size and shape of the white spot at the base of the bill.

Range--Breeds in the far north-Greenland, Iceland, and Alaska-anc. southward in the Rocky Mountains; winters as far south as Illinois and Virginia.

Washington, A. V.. one record. Long Island, A. V.

Nest, in a stump or hollow tree. Eggs, six to ten, pale bluish, $2.40 \times 1.70$. 
A more northern species than the preceding, which it resembles in habits.

153. Charitonetta albeola (Linn.). Bufflehead; Butter-Ball; Spirit Duck. $A d$. o . - A broad white band passes around the back of the head from eye to eye; rest of the head, upper neck, and throat beautifully glossed with purple, greenish, and bluish ; lower neck all around, breast, belly, wing-coverts, speculum, and outer scapulars white; back black; upper tailcoverts and tail ashy-grayish. $A d . \& .-\mathrm{A}$ white patch on either side of the head, throat, and entire upper parts fuscous-brown; speculum, breast, and belly white. L., 14.75 ; W., 6.50 ; Tar., 1.25; B., 1.05.

Range.-North America; breeds from lowa and Maine northward; winters from near the southern limit of its breeding range to the West Indies and Mexico.

Washington, common W. V., Sept. to Apl. Long Island, common T. V. and W. V., Oet. 1 to Apl. Sing Sing, tolerably common T. V. Cambridge, common in Oct. and Nov.

Nest, in a stump or hollow tree. Eggs, six to twelve, dull light buff, $1.98 \times 1.46$ (Ridgw.).

This small Duck has won deserved distinction through its powers as a diver. Like the Grebes, it "dives at the flash," though this wellworn expression has lost half its meaning since flintlocks and percussion caps have become things of the past. The Bufflehead feeds to some extent on small fish, which it pursues and catches under water.

- 154. Clangula hyemalis (Linn.). OLd SQTaT; Old Wife; Sotth Sovtuerly. Ad. s in winter.-Sides of the front of the head washed with grayish brown; sides of the back of the head and sides of the upper neck black, more or less margined with ochraceous; rest of the head, neck all around, upper back, scapulars, and lower belly white; back, breast, and ipper belly black; tail pointed, the middle feathers very long and narrow; band across the end of the bill yellowish orange. Ad. o in summer.--Sides of the front of the head white; crest of the head, neck, throat, breast, and upper belly black; back and seapulars black, the latter margined with dark buffy ochraceous; lower belly white; tail and bill as in the preceding. $\&$ in winter.-Upper parts black or fuscous; scapulars and upper back more or less margined with grayish $\odot \mathrm{r}$ grayish brown; sides of the head and neck and sometimes the back of the neck white or whitish; breast grayish; belly white; tail pointed, but without the long feathers of the male; under wingcoverts dark. Ad. \& in summer.-Generally similar to the above, but the sides of the head and throat mostly blackish, and the feathers of the upper parts more or less margined with ochraceous. L., of, $21 \cdot 00$, $₹, 16.00$; W., 8.60 ; T., \& , $8 \cdot 00$, \&, $2.50 ;$ B., $1 \cdot 05$.

Remarks. - The male old Squaw is too distinct to be confused with any other species, its long tail-feathers being its most striking character; the female bears some resemblance to the female of the Harlequin Duck, but has the belly nure white instead of grayish dusky. 
Range.-Northern hemisphere; breeds in the far north, and, in America, winters as far south as the upper Mississippi Valley and Virginia.

Washington, rare W. V., Nov, to Apl. Long Island, abundant W. V., Nov. 1 to Apl. 15. Sing Sing, tolerably common W. V., Dec. 4 to Apl. 6. Cambridge, rather common in Oct. and Nov.

Nest, on the ground near water, under low bushes or tall grasses. Eggs, six to twelve, pale bluish tinged with olive, $2.05 \times 1.49$.

In The Auk for 1892, pp. 330-337, Mr. George H. Mackay gives a capital account of the habits of this species in our waters. He speaks of them as the swiftest flying as well as the noisiest (in the spring) of all the sea fowl which tary with us, and gives their curious scolding or talking notes as o-onc-o-onc-ough, egh-ough-egh. Their flight is generally near the water, and when shot at while flying they sometimes dive from the wing. He also mentions their habit of towering, "usually in the afternoon, collecting in mild weather in large flocks if undisturbed, and going up in circles so high as to be scarcely discernible, often coming down with a rush and great velocity, a portion of the flock scattering and coming down in a zigzag course similar to the Scoters when whistled down."

155. Histrionicus histrionicus (Limn.). HARLEQUiN 1 UCK. Ad. oै - Center of the crown black, margined by white and rufous : front of the sides of the head, a spot on the ear, a stripe back of it, and a collar around the back and sides of the neck white; rest of the head and throat rich slaty blue; a band in front of the wing white, margined with black; inner scapulars white; back and breast bluish slate; belly fuscous; sides rufous-chestnut. $A d$.. .Front of the head whitish; a white spot on the ears; upper parts brownish fuscous; throat, breast, and sides lighter; belly grayish brown, margined with whitish. L., 17.00; W., 7.80; Tar., 1.50; B., 1.05.

Range._."Northern North America, breeding from Newfoundland, the northern Rocky Nountains, and the Sierra Nevada, northward; south in winter to the Middle States and California" (A. O. U.).

Long Island, rare W. V.

Nest, on the ground or in hollow stumps near water. Eggs, six to eight, yellowish buff or greenish yellow, $2.30 \times 1.62$ (Davie).

Unlike other members of this subfamily, this species passes the breeding season on rapid dashing streams, but during the winter it occur's as a Sea Duck off our more northern coasts.

156. Camptolaimus labradorius (Gmel.). Laprador Dicr; PIED Duck. Ad. 8 .-Center of crown black; rest of head, throat, and upper neck white; a black band around the lower neck connected behind with the black back; primaries fuscous, rest of wing white; front and sides of the upper breast white, lower breast and belly black. $A d . \&$.-Brownish gray, the speculum white. Im. 8.-Like the $\%$, but with the throat and ends of the greater wing-corerts white. L., $20.00 ;$ W., $8.40 ;$ Tar., $1.50 ;$ B., 1.58 . 
Range.-Formerly, North Atlantic coast, breeding from Labrador northward, and in winter migrating southward to Long Island; doubtless now extinct.

In a recent paper* on this species MIr. William Dutcher quotes the late Mr. George N. Lawrence, as follows: "I recollect that about forty or more years ago it was not unusual to see them in Fulton Market, and without donbt killed on Long Island; at one time I remember seeing six fine males, which hung in the market until spoiled for want of a purchaser; they were not considered desirable for the table, and collectors had a sufficient number, at that time a pair being considered enough to represent a species in a collection."

The cause of this Duck's extinction is unknown. The last specimen, so far as known, was taken at Grand Menan in 1871. F Forty-two specimens have been recorded as existing in collections.

Steller's Duck (15\%. Eniconetta stelleri), an aretic species, was observed by Kumlien in Greenland.

159. Somateria mollissima borealis (BreThm). Greenland EIDEr. Ad. o.-Top of the head black, a greenish white line on the crown; rest of the head, throat, neck, upper breast, back, scapulars, and lesser wingcoverts white, tinged with greenish on the sides and back of the head, and with vinaceous on the breast; middle of the rump, upper and under tailcoverts, lower breast, and belly black. Ad. \&.- Head, throat, and neck buffy ochraceous, darker above and streaked with black; back black, the feathers all widely margined and sometimes partly barred with buffy ochraceous; breast buffy ochraceous, barred with black; belly grayish brown or olivebrown, indistinctly margined or barred, with buffy. Im.-Similar, but distinctly marked with buffy. L., 23.00 ; W., 11.00; Tar., 1.80; B., $2 \cdot 10$.

Range.-Breeds from Labrador northward; winters southward to Maine.

Nest, on the ground, amid coarse herbage and rocks. Eggs, five to eight, pale bluish or greenish, tinged with olive, $2.95 \times 2.00$.

This is the American representative of the Eider Duck of northern Europe, from which it differs only slightly. The highly prized Eider down is taken from the nest of this bird and its allies. As incubation progresses the sitting bird plucks the down from her breast to serve as a nest lining. In Iceland, according to Saunders, the average yield from each nest is about one sixth of a pound. When the females begin to sit the males leave them and, gathering in small flocks, live at sea.

160. Somateria dresseri Sharpe. AuErican Ender. liesembles the preceding in color, but differs in the feathering of the base of the cul- 
men. In both species the culmen is divided by a wedge of feathers reaching forward from the forehead. Looked at from the tip of the bill, the base of the culmen is thus $\mathrm{V}$-shaped. In dresseri the arms of the $\mathrm{V}$ are very broad and rounded at the ends, while in borealis they are much narrower and gencrally pointed at the ends. L., 23.00; W., 11.30 ; Tar., $1 \cdot 70$; B., $2 \cdot 10$.

Kange.-Breeds from the Bay of Fundy to Labrador; winters southward to Delaware; occasional in winter on the Great Lakes.

Long Island, rare W. V. Sing Sing, A. V., Dec.

Nest, on the ground, generally sheltered by rocks. Eggs, five to eight, pale bluish or greenish, tinged with olive, $3.00 \times 2.00$.

This species is of more southern distribution than the preceding, which it resembles in habits. During their visits to the coasts of the United States the Eiders are true Sea Ducks, living some distance off shore, generally over a bed of mussels, which they secure by diving, and which constitute their chief lood.

162. Somateria spectabilis (Linn.). King Entr. Ad. ô.Region about the base of the upper mandible and a large $V$-shaped mark on the throat black; top of the head bluish gray; cheeks greenish; neck all around white; front and sides of the breast creamy buft; upper back, sides of the rump, and wing-coverts white; rest of the plumage black. $A d .+$. Head and throat buffy ochraceous, the former streaked with black; back black, the feathers widely margined with ochraceous or rufous; under parts varying from brownish gray to fuscous, more or less washed, especially on the breast, with ochraceous or rufous. Im.-Paler and with less ochraceous. I., $23 \cdot 00$; W., 10.80 ; Tar., 1.80 ; B., 1.30 .

Remarks. - The adult male of this species may at once be known by its bluish-gray head and the $\mathrm{V}$-shaped mark on its throat. Females and young birds resemble those of the two preceding species, but are to be distinguished by the generally unstreaked throat and the feathering of the side of the base of the bill, which in this species does not, as in the two preceding, reach to the nostril.

Range.-Breeds from Gulf of St. Lawrence northward, and winters southward more or less regularly to Long Island and the Great Lakes; casually as far as Virginia, and on one occasion Georgia.

Long Island. regular W. V.

Nest, on the ground, among rocks or herbage. Eggs, six to ten, light olivegray to grayish green, $3.12 \times 1.92$ (Davie).

While in our waters this species does not differ from the preceding in habits.

163. Oidemia americana $5 w$, and Rich. AMERICAN SCOTER; Black Соот. Ad. \&.-Entire plumage black, feathers on the side of the bill extending little if any forward beyond the corner of the mouth; bill black; upper mandible orange or yellowish at the base. L., 19.00; W., 9.00; Tar., $1 \cdot 70$; B. along culmen, $1 \cdot 75$; B. along side, $1 \cdot 85$.

Range.-Coasts and larger lakes of northern North America; breeds in 
Labrador and the northern interior; south in winter to Virginia, the Great Lakes, and California.

Washington, casual W. V. Long Island, common W. V., Oct. through A pl. Sing Sing, rare T. V., Oct. Cambridge, occasional in fall.

Nest. on the ground, near water. Eggs, "six to ten, pale dull buff or pale brownish buff, $2.55 \times 1.80 "$ (Ridgw.).

All three species of Surf Scoters, or "Coots," are abundant winter residents off the coasts of the New England and northern Middle States. At this time their habits are practically alike-indeed, they are often found associated. As a rule, they frequent only the sea and its estuaries, where they live over beds of mussels, clams, or scallops, which they obtain by diving; but they are sometimes found in ponds near the coast, where food of this nature is abundant.

In The Auk for 1891, pp. 279-290, Mr. George H. Mackay gives the results of a long-continued study of Scoters on the Massachusetts coast.

The Velvet Scoter (164. Oidemia fusca) is an Old-World species which has been recorded from Greenland.

- 165. Cidemia deglandi Bonap. Wntte-minged Scoter; WinteWINGED Соот. Ad. 8.-A spot below the eye and the speculum rohite, rest of the plumage black; bill orange-black at the base, the feathers on it reaching forward far beyond the corners of the mouth. Im. \&.-Grayish or fuscous-brown, lighter below; speculum white, feathers at the base of the upper bill and a spot on the ears whitish. Ad. in winter and Im. \&.- Similar to the preceding, but generally without whitish spots on the head. L., 22.00; W., 11.00 ; Tar., 2.00 ; B. along culmen, 1.50 ; B. along side, 1.55 .

Remarks.-The white speculum and feathering of the bill will always serve to distinguish this speeies from its allies.

Range.-Northern North America, breeding in Labrador and the fur countries; south in winter to Virginia, southern Illinois, and California.

Washington, casual W. V., Oct. to Apl. Long Island, abundant W. V., Sept. 15 to May 15. Sing Sing, tolerably common 'T. V. Cambridge, oceasional in fall.

$N_{\epsilon s t}$, on the ground, beneath bushes, frequently some distance from water. Eggs, "six to ten, pale dull butf, varying to cream-color, $2.68 \times 1.83$ " (Ridgw.).

- 166. Oidemia perspicillata (Linn.). Scrf Scoter; SeA Cont. Ad. o.-A square mark on the crown and a triangular one on the nape white, rest of the plumage black; bill orange-yellow, a large circular black spot on its side at the base; feathers on the culmen extending nearly to a level with the nostril, feathers on the side of the bill not extending forward. $A d$. $\%$ and Im.-A whitish spot at the base of the bill and on the ears; upper parts fuscous brown; throat, breast, sides, and lower belly grayer, belly white. L., 20.00 ; W., 9.30 ; Tar., $1 \cdot 60$; B. along culmen, 1.55 ; B. along side, $2 \cdot 30$.

Remarks.-The forward extension of the feathers on the culmen will 
always distinguish this species from 0 . americana, wilile it ma be known from deglandi by the absence of white in the wings.

Range.-Breeds from the Gulf of St. Lawrence northward; winters southward to the Great Lakes and Virginia, and casually to Florida.

Washington, casual W. V. Long Island, common W. V., Oct. through Apl. Sing Sing, common T. V., Oct. 7 to Oct. 22. Cambridge, occasional in fall.

Nest, in tall grasses near water. Eggs, "five to eight, pale buff or pale creamy buff, $2.47 \times 170 "$ (lidgw.).

16\%. Exismatura rubida (Wils.). Ruddy Duck. Ad. o.- Top or the head black, cheeks and chin white, throat and back rufous-chestnut, lower back blackish; breast and belly silvery white; upper tail-coverts very short, tail-feathers stiff and pointed. Ad. \& and Im.-Upper parts dark grayish brown, the feathers marked with fine wavy bars of buffy; sides of the head and upper throat whitish, lower throat grayish, rest of the under parts silvery white. L., 15.00; W., 5.90 ; Tar., 1.15; B., 1.55 .

Remarks. - The short upper tail-coverts and stitf, pointed tail-feathers will always serve to identify this species.

Kange.-Of general distribution from northern South America to the fur countries, breeding largely northward, but locally throughout its range (Granada, Wells; Guatemala, Salvin; Cuba, Gundlach; Cape Cod, Miller).

Washington, common W. V., Sept. to Apl. Long Island, irregular 'T. V. Sing Sing, common T. V., Meh. 14 to Apl. 6; Oet. 5 to Oct. 28. Cambridge, very common in Oet. and Nov.

Nest, in a slough or marshy place, generally on a mass of floating vegctation. Eggs, six to ten, creamy or buffy white, $2.50 \times 1.80$.

"When rising from the water, it runs on the surface for some dis tance, and generally against the wind. If it can not command a fair - open space for flight, it will dive, using its tail either as a rudder or as a paddle in a vertical motion, and will hide itself away among the grass and sedges. When on the wing, it flies low along the surface of the water, with a rapid beat of its broad wings, making a short, plump figure quite uncommon for a Duck; and it generally flies quite a distance before alighting" (Langille). In swimming, the tail is sometimes held erect at right angles to the body.

The Masked Duck (168. Nomonyx dominicus) is a tropical species of rare accurrence in North America. Single specimens have been taken in Wisconsin, New York, and near Cambridge, Mass.

\section{Subfamily Anserince. Geese.}

Geese are vegetarians. When on the water, they feed largely by tipping, as with head and neck immersed and tail pointing skyward they search for the ronts or seerls of aquatic plants. They are far more terrestrial than Ducks, and visit the land to nip the herbage, 
young corn, or cereals. When wounded, they dive readily and, with their body just below the surface of the water and only the bill exposed, head for the shore, where they attempt to hide in the vegetation.

In migrating, the flock is formed in a V-shaped wedge, the lead, it is said, being taken by an old gander.

KEY TO THE SPECIES.

I. Whole head or forehead white.

A. Bill yellowish.

a. Forehead and feathers at the base of bill white.

171a. Am. White-Fronted Goose (Ad.)。

b. Head and neck white or grayish, sometimes tinged with rusty.

$b^{1}$. Primaries black, rest of plumage white.

169. Lesser Snow Goose. 169a. Greater Snow Goose.

62. Back grayish brown, rump and belly whitish, wing-coverts and tertials widely margined with white. . . 169. Lesser Snow Goose (Im.). 169a. Greater Snow Goose (Im.).

$\iota^{3}$. Back grayish brown, rump, belly, and wing-coverts gray, the latter not conspicuously margined with white.

169.1. Blue Goose (Ad.).

$B$. Bill black, throat and sides of the head white, lores black.

II. Head and neck brown, bill yellow or yellowish.

175. Barnacle Goose.

A. Nail of bill black, rump fuscous.

171a. Am. White-fronted Goose (Im.).

B. Nail of bill yellow, rump gray . . . . 169.1. Blue Goose (In.).

III. Head black or brownish black, bill black.

A. Throat white - . 172. Canada Goose. 172a. Hutchins's Goose.

$B$. Throat black or brownish black, neck speckled with white.

a. Belly white . . . . . . . . . . . 173. Brant.

b. Belly brownish gray ........ 174. Black Brant.

169. Chen hyperborea (Pull.). Lesser Snow Goose. Ad.-Entire plumage, except the primaries with their coverts, white; primaries black, their bases and coverts ashy. Im.- "Head, neck, and upper parts pale grayish, the feathers of the latter with whitish edges and (especially wing-coverts and tertials) striped medially with darker; rump, upper tail-coverts, tail, and lower parts plain white. L., 23.00-28.00; W., 14.50-17.00; B., 1.95-2.30; Tar., 2.80-3.25" (Ridgw.).

Range.-Western North Ameriea, breeding in Alaska and migrating southward to the Gulf; rarely found east of the Mississippi.

Eggs, uniform dirty, chalky white, $3.40 \times 2 \cdot 20$ (B., B., and R.).

169a. C. h. nivalis (Forst.). Greater Snow Guose.-Resembles the preceding in color, but is larger. L., 30.00-38.00; W., 17.35-17.50; B., 2.55$2 \cdot 70$; Tar., 3.15-3.50 (Ridgw.).

Range.-Eastern North America, breeding in the far north (exact breeding range unknown); winters from Chesapeake Bay to Cuba; rare on the Atlantic coast north of Virginia. 
Iong Island, irregular from Oct. to Apl. Sing Sing, A. V., Apl.

Nest and eggs unknown.

The Snow Goose does not appear to be a common bird on any part of the Atlantic coast. It migrates both by night and day, and when on the wing its white plumage and black-tipped primaries render it easily identifiable. It is a noisier bird than the Canada Goose, and its voice is higher and more cackling.

169.1. Chen crerulescens (Linn.). BLuE Goose. Ad.-Head and upper neek white; middle of the hind neck sometimes blackish, lower neck all around fuscous, rest of under parts brownish gray edged with buffy; the lower belly generally paler, sometimes white; upper back and scapulars like the breast; lower back, rump, and upper tail-coverts gray; tail fuscous gray edged with whitish; wing-coverts like the rump or slightly darker, with little or no whitish margins; wing-quills and tertials fuscous, the latter more or less margined with whitish. Im.--"Similar to adult, but head and neck uniform deep grayish brown, only the chin being white. L., 26.50-30.00; W., 15.00$17 \cdot 00$; B., $2 \cdot 10-2 \cdot 30$; Tar., 3*00-3.30" (Ridgw.).

Range.-North America; breeds in the Hudson Bay region and migrates southward, chiefly through the interior, to Texas.

Long Island, A. V.

Nest and eggs unknown.

The Blue Goose is apparently nowhere a common bird, and on the Atlantic coast it is even less common than in the interior. It was at one time supposed to be the young of the Snow Goose, which it doubtless resembles in habits.

191a. Anser albifrons gambeli (Hurtl.). AMericax WhIteFronten Goose. Ad.-Forehead and region bordering the base of the bill white; upper parts and foreneck grayish brown, more or less margined on the back with lighter; longer and lateral upper tail-coverts white; breast somewhat lighter than the throat, more or less irregularly marked with black, and fading gradually into pure white on the lower belly; sides like the back. Im.-Similar, but no white at the base of the bill or black marks on the breast; nail of the bill black. "L., $27 \cdot 00-30 \cdot 00$; W., 14.25-17.50; B., 1.80-2.35 ; depth of mandible at base, $90-1 \cdot 20$; width, $\cdot 85-1 \cdot 05$; Tar., 2.60-3.20" (Ridgw.).

Range.- "North America, breeding far northward; in winter south to Nlexico and Cuba" (A. O. U.); rare on the Atlantic coast.

Long Island, A. V.

Nest, on the ground, of grasses lined with down. Eggs, six to seven, dull greenish yellow with obscure darker tints, $3 \cdot 10 \times 2 \cdot 07$ (Davie).

"These birds are rarely met with on the Atlantic coast, but are quite common in the Mississippi Valley and abundant on the Pacific slope. They prefer low, wet grounds in the vicinity of timber, or where the prairie is dotted here and there with bushes; and, while they occasionally forage off the wheat fields and other grains on the 
bottom lands, they seldom visit the high, dry prairies like the Snow and Canada Geese" (Goss).

The European White-Fronted Goose (171. Anser albifrons) resembles its American representative in color, but averages smaller. It is American only as it occurs in Greenland, where gambeli is apparently unknown.

172. Branta canadensis (Linn.). Canada Goose. Ad.-Throat and a large patch on the side of the head behind the eye white or whitish; chin and rest of the head and neck black; back and wings grayish brown, more or less edged with lighter; tail and shorter upper tail-coverts black, longer and lateral ones white; breast and belly grayish, fading to white on the lower belly; sides like the back. Im.-Similar, but throat and cheeks sometimes mixed with blackish. "L., 35.00-43.00; W., 15.60-21.00; Tar., 2.45-3.70; B., $1 \cdot 55-2 \cdot 70 "$ (Ridgw.).

Range.-Temperate North America; breeds in the northern United States and British provinces; south in winter to Mexico.

Washington, W. V. and rather common 'I. V., Oct. to Apl. Long Island, common 'T. V., Mch. and Apl.; Oct., some W. V. Sing Sing, tolerably com. mon T. V., Mch. 11 to May 21; Oct. Cambridge, common 'T. V., Mch. and Apl.; Oct. to Dec.

Nest, of sticks lined with down, on the ground in the open prairie, on the shores of streams, on tree stumps and sometimes in trees, when a deserted nest of the Osprey is generally used. Eggs, four to five, butty white, $3.50 \times 2.35$.

Probably the migration of no bird attracts more universal interest than that of the Wild Goose. Ornithologists talk of "waves" and "flights" of migrants passing in the night, but the biannual pilgrimage of the Canada Goose appeals to us all with the directness of a personal experience. We see the living wedge of long-necked birds passing high overhead; the unbroken sound-waves bring the sonorous "honks" with unexpected distinetness to our ears; and we receive an impressive lesson in the migration of birds. They are embarked on a journey of several thousand miles, but they come and go as surely as though they carried chart and compass.

172a. B. c. hutchinsii (S'u' \& Rich). II'tcniss's Goose--Resembles the preceding in color, but averages smaller. L., 25.00-34.00; W., 14.75$17 \cdot 75$; Tar., $2 \cdot 25-3 \cdot 20 ;$ B., 1·20-1.90 (Ridgw.).

Range.-" North America, breeding in the aretic regions, and migrating sonth in winter chiefly through the western United States and Mississippi Valley; eastern Asia" (A. O. U.).

Long Island, A. V.

172c. B. c. minima Rílgu. Cackeing Gonse.-To be distinguished from the two preceding by its smaller size and the much darker brownishgray color of the breast and upper belly. "W., 13.60-14.50; Tar., 2.40-2.75; B., $\cdot 95-1 \cdot 15 "$ (Ridgw.). 
Range.-Pacific coast of North America, breeding chiefly about the shores of Norton Sound and the lower Yukon; south in winter to California, and, more rarely, to upper Mississippi Valley (Wisconsin, etc.) (Ridgw.).

193. Branta bernicla (Lim.). Brant. Ad.-Head, neck, throat, and upper breast black; sides of the neck speckled with white; back brownish gray, margined with grayish brown; longer and lateral upper tail-coverts white; lower breast ashy gray fading to white on the lower belly; sides darker. Im.-Similar, but with less white on the sides of the neek and iving-coverts, and secondaries tipped with white. L., 26.00; W., 13.20; Tar., $2 \cdot 20 ;$ B., $1 \cdot 35$.

Range.-Northern parts of the northern hemisphere; breeds within the Arctic Circle; in America, migrates southward along the Atlantic coast, reaching the Carolinas in winter; rare in the interior.

Washington, rare W. V. Long Isiand, common 1. V., Nov. 1 to May 15; a few winter. Sing Sing, A. V.

Nest, of grasses, moss, etc., lined with down, on the ground. Eggs, four, smooth and creamy white in color, $270 \times 1.80$ (Saunders).

"Its manner of flying is different from that of the Canada Goosemoving in more compact bodies. less rapidly, and without seeming to have a chosen leader-that marked characteristic in the flight of the latter.

"While in our bays it appears inactive, seldom taking to wing unless disturbed by a passing boat or the near report of a gun.

"The Brent rises slowly, and when on the wing moves sluggishly for a short distance, and, if not attracted by a distant flock, frequently returns to the place it had left. Its food consists of a marine plant (Zostera marina), commonly called 'eel grass.' At low water it is seen industriously at work tearing up its favorite plant. After the tide has risen to such a height as to compel it to relinquish its rocation, it is seen drifting with the current, feeding sumptuously on the fruits of its labor" (Giraud).

174. Branta nigricans (Lan\%). BLACK BrAnt.-Bears a general resemblance to the preceding species, but may be readily distinguished by its much darker lower breast and upper belly, which are nearly as dark as the back, and by having white markings on the front as well as on the sides of the neck.

Range.- "Arctic and western North America; rare or casual on the Atlantic coast" (A. O. U.). "Breeds in abundance on the arctic coast of Liverpool Bay" (Macfarlane).

Long Island, A. V.

Nest, of grasses, moss, etc., lined with down, on the ground. Eggs, five to seven, dull ivory-white or grayish white, $2.85 \times 1.82$ (B., B., and R.).

This is the western representative of the preceding species. It is of casual occurrence on the Atlantic coast. 
The Barnacle Goose (175. Branta leucopsis) is an Old-World species which visits Greenland regularly in the fall, and is sometimes found on our coasts. It differs from any of the preceding in having the forehead, sides of the head, throat, and chin white, the lores being black.

\section{Subfamily Cygninæ. Swans.}

Swans feed from the surface, either by "tipping" or by simply immersing the long neck and head. Their food consists largely of vegetable matter, but they eat also small mollusks. They migrate in $\mathrm{V}$-shaped flocks. When on the wing, and also when feeding, they utter at times loud, trumpeting notes. When pursued they do not at oncetake flight, but swim rapidly away, and in this manner easily distance a strong rower.

KEY TO TIIE SPECIES.

$A$. With yellow on the lores; distance from the eye to the nostril greater than the distance from the nostril to the tip of the bill . 180. WhistLing Swan. $B$. No yellow on the lores; distance from the eye to the nostril not greater than from the nostril to the end of the bill . . 181. Trumpeter Swan.

180. Olor columbianus $(O r d)$. WhistLing SWAN. Ad.-White; bill and feet black; a small yellow spot on the lores. Im.-Head and neek brownish and rest of plumage more or less washed with grayish; bill and feet light. L., 55.00; W., 22:00; Tar., 4.00. Eye to N., 2*40; N. to tip of B., $2 \cdot 25$.

Range.-North America; breeds on the shores of the Arctic Ocean, and migrates south to the Gulf of Mexico; rare on the Atlantic coast north of Chesapeake Bay.

Washington, rare W. V., Oct. Long Island, A. V.

Nest, of grasses, moss, etc., lined with down, on the ground near water. Eggs, two to five, soiled whitish, $4.25 \times 2 \cdot 70$.

This is a rare bird on the Atlantic coast north of Virginia. "When feeding, or dressing their plumage, this Swan is usually very noisy, and at night these clamors may be heard to the distance of several miles. Their notes are varied, some resembling the lower ones made by the common tin horn, others running through the various modulations of the notes of the clarionet. These differences are presumed to be dependent upon age" (B., B., and R.).

181. Olor buccinator (Rich.). Trumpeter SWAN. Ad.-White, bill and fect black, no yellow on the lores. Im.-Head and neck brownish, rest of plumage more or less washed with grayish. L., 65.00; W., 23.00; Tar., $4 \cdot 25$; Eye to N., $2 \cdot 70 ;$ N. to tip of B., $2 \cdot 20$.

Kange.-"Chiefly the interior of North America, from the Gulf coast to the fur countries, breeding from Iowa and Dakota northward; west to the Pacific, but rare or easual on the Atlantic" (A. O. U.).

$N_{e s t}$, of grasses and down, on the ground. Egys, two to six, soiled whitish, $4.40 \times 2.80$. 
This species rarely occurs east of the Mississippi Valley. Its habits are said to resemble those of the preceding species, "but its cry is very different, resembling the notes of a French horn and being very sonorous."

The Whooping Swan (179. Olor cygnus) is an Old World species which sometimes is found in Greenland. It differs from either of our Swans in having the "basal portion of the bill and entire lores yellow in the adult."

\section{ORDER ODONTOGLOSSA. LAMELLIROSTRAL GRALIATORES.}

\section{Family Phanicopterid a. Flamingoes.}

The seven species included in this family are distributed throughout the tropics. Five species are American, of which one reaches our southern border in Florida. Flamingoes are gregarious at all seasons. They are rarely found far from the seacoasts, and their favorite resorts are shallow bays or rast mud flats which are flooded at high water. In feeding, the bill is pressed downward into the mud, its peculiar shape making the point then turn upward. The ridges along its sides, as in the bills of Ducks, serve as strainers through which are forced the sand and mud taken in with the food.

182. Phøenicopterus ruber (Linn.). Flamingo. (See Fig. 18.) $A d$.-Beautiful rosy vermilion, scapulars and under parts somewhat paler, flanks carmine, primaries and secondaries black; bill yellowish black at the tip. Im.- "Grayish white, the wings varied with grayish and dusky" (Ridgw.). L., 45.00; W., 16.25; Tar., $12 \cdot 50 ;$ B., 5.5Q.

Range.-Atlantic coasts of tropical and subtropical America; resident in southwestern Florida (Monroe County); casual along the Gulf coast to Texas; accidental in South Carolina.

Nest, in mud flats, a truncate cone of mud ten to twenty inches in height, hollowed on top. Eggs, two, soiled whitish with a chalky deposit, $3 \cdot 55 \times 2 \cdot 20$.

The Flamingo is resident in the United States only in the vicinity of Cape Sable, Fla., where in 1890 Mr. W. E. D. Scott observed a flock of about a thousand birds (The Auk, vii, 1890, pp. 221-226).

\section{ORDER HERODIONES. HERONS, STORKS, IBISES, ETC.}

\section{Family Plataleid $\pi$. Spoonbills.}

The Spoonbills inhabit the warmer parts of the world. Only one of the five or six species is found in Amcrica. They frequent the 
shores both on the seacoast and in the interior. They are generally found in flocks and they nest in colonies. Spoonbills have the general habits of Herons, but feed by immersing the bill and swinging it from side to side in their search for food.

183. Ajaja ajaja (Limn.). Roseate Spoonbill; Pink Cirlew. (See Fig. 21.) Ad.-Head and throat bare, neck and upper back white, sometimes tinged with pink; sides of the breast in front of the wings and end half of tail ochraceous-butf; rest of plumage pink; lengthened feathers at the base of the neck darker; lesser wing-coverts, upper and under tail-coverts carmine. Im.--Similar, but head and throat feathered, ochraceous-buff and carmine of the adult replaced by pink. L., $32 \cdot 00$; W., 14.50 ; Tar., 4.00 ; B., $6 \cdot 25$.

Range.-Tropical and subtropical America north to the Gulf States.

Nest, a platform of sticks in mangrove bushes or small trees. Eggs, three to five, white, spotted and speckled with shades of olive-brown, $2.57 \times 1 \cdot 73$.

This was formerly a common species in Florida, but continued persecution has so reduced its numbers that during four winters passed in different parts of the State I did not observe it. It nests in January and February in the extreme southern part of the State, and after the nesting season wanders northward. On the Texas coast it is more numerous.

\section{FAMILy IBIDID A. IBISES.}

Ibises are distributed throughout the warmer parts of the globe; they number about thirty species, of which four occur in North America. They are silent birds, and live in flocks during the entire year. 'I'hey feed along the shores of lakes, bays, and salt-water lagoons, and on mud flats over which the tide rises and falls. Their food consists principally of crustaceans, frogs, and small fish.

\section{KEY TO THE SPECIES.}

A. Plumage deep chestnut . . . . . . . 186. Glossy Iris. B. Plumage scarlet . . . . . . . 185. Scarlet Ibis (Ad.). C. Plumage white . . . . . . . . 184. White Ibis (Ad.).

D. Back brown, belly white.

a. Kump white. . . . . . . . . . 184. White Iris (Im.). b. Kump like the back . . . . . . 185. Scarlet Ibis (Im.).

184. Guara alba (Linn.). White Ibis; Spanisn Curlew (see Fig. 20). $A d$.-White, the tips of the four outer primaries black; bare parts of the head orange-red. Im.-Head and neck white, streaked with grayish brown; upper back and wings grayish brown; rump, breast, and belly white. L., 25.00; W., 11.00; Tar., 3.40; B. from N., 4.60.

Range-Tropical America; breeds as far north as southern Indiana, southern Illinois, and South Carolina; winters from the Gulf southward.

Long Island, A. V. 
Nest, of reeds and weed stalks, in trees, bushes, and reedy marshes. Eggs, three to five, pale greenish white, with chocolate markings gerierally most numerous at the larger end, $2.25 \times 1.50$.

This locally abundant species is generally found in flocks of five or six to as many hundred birds which frequent mud flats, marshes, or the borders of lagoons. They fly in close rank, and when in large flocks, with their snowy plumage glistening in the sunlight and their wing-strokes accented by the black-tipped primaries, form a strikingly beautiful picture.

The Scarlet Ibis (185. Guara rubra), a South American species, has been recorded from Florida, Louisiana, and New Mexico. (See Brewster, Bull. Nutt. Orn. Club, viii, 1883, p. 185̃ ; also Scott, Auk, vi, 1889, p. 15.)

186. Plegadis autumnalis (Ifrsselq.). Glossy Ibrs. At -Rich chestnut, upper and under tail-coverts, back, wings, and front of the head with greenish and purplish reiftections; lores (in skins) blackish. Im.-Head and neck fuscous-brown, the feathers laterally margined with white; rest of under parts dull fuscous-brown; back with greenish reflections. L., 24.00; W., $11 \cdot 50 ;$ 'Tar., $3 \cdot 10 ;$ B., 5.00.

Range.-Tropical and subtropical regions generally; rare and of local distribution in the southeastern United States and West Indies.

Washington, A. V., two records. Long Island, A. V., two records. Cambridge, A. V., one record, May.

Nest, of rushes, plant stems, etc., in reedy swamps or low bushes. Eggs, three, rather deep, dull blue, $2.01 \times 1.47$.

This is a rare species in the eastern United States. Its haunts are of much the same nature as those of the preceding species.

The White-faced Glossy IbIs (18\%. Plegadis guarauna), a locally common species from 'Texas westward and soutliward, has been recorded but once from east of the Mississippi, viz., at or near Lake Washington, Florida, where a female was shot on a nest containing three eggs (Brewster, Auk, iii, 1886, p. 482). This species resembles the Glossy Ibis, but adults have the region about the base of the bill white.

\section{Family Ciconidde. Storks.}

Only two of the twenty-five known species included in this family are found in North America. Storks are both gregarious and solitary. Our species, the so-called Wood Ibis, is as a rule found in flocks and nests in colonies. It feeds in swamps and on the shores of bayous, where it is said to "rake" the bottom with its foot in searching for food. It is a strong flier, a certain number of wing-strokes being followed by a short sail. At times it mounts high in the air and sails about like a Vulture. Sometimes it perches upon trees. Its voice is described as a rough, guttural croak. 
188. Tantalus loculator Linn. Woon Iris. Ad.- Head and neck bare; primaries, secondaries, and tail glossy greenish black, rest of plumage white. Im.-Head more or less feathered; head and neck grayish brown, blacker on the nape; rest of plumage as in the adult, but more or less marked with grayish; wings and tail less greenish. L., 40.00; W., 18.00; Tar., 7•60; B. from N., 8.00.

Range.-Tropical and subtropical America; breeds in the Gulf States, and, after the breeding season, wanders irregularly north ward, sometimes reaching Kansas, Wisconsin, Indiana, Pennsylvania, and New York.

Washington, A. V., two specimens. Long Island, A. V.

Nest, a platform of sticks in trees. Eggs, two to three, dull white with a soft calcareous deposit, $2.75 \times 1.75$.

This is a locally common species in Florida.

\section{Family Ardeid Ae. Herons and Bitterns.}

This family contains about serenty-five species distributed in most parts of the globe, but more numerously in the intertropical regions. Generally speaking, Herons are gregarious, nesting and roosting in flocks. While feeding they are more solitary, but each night they regularly return to ronst with their kind in a "rookery." Bitterns do not associate in flocks, and are generally found singly or in pairs. As a rule, they feed in grassy marshes, while Herons more commonly resort to the shores of lakes, rivers, bays, or salt-water lagoons. Some species secure their food of frogs, fish, small reptiles, ete., by standing rigidly motionless and waiting for it to come within striking distance, or by wading for it with the utmost caution. Others run rapidly and noisily through the water. trusting to their agility and the rapidity of their spearlike thrusts to supply their wants. Herons, unlike our Ikises and Cranes, fly with their folded neck drawn in between their shoulders. Their voice is a hoarse squawk.

I. Wing over $13 \cdot 00$.

KEY TO TIE SPECIES.

A. Plumage pure white.

a. Wing 17.00 or over; feathers on the lower neck long, narrow.

192. Great White Heron.

b. Wing under $17 \cdot 00$; neck-feathers not lengthened 196. Ar. EGrEt. $B$. Upper parts generally slaty or grayish blue.

193. Watid's Heron. 194. Great Blue Heron.

II. Wing under $13 \cdot 00$.

1. Crown without streaks.

A. Crown white or whitish.

a. Wing over $11 \cdot 00$.

$a^{1}$. Plumage entirely or mostly white . . 198. Reddish Egret. $a^{2}$. Plumage gray streaked with black; throat and sides of neck black . . . . . 203. Yellow-crowned Nigit Heron. 
b. Wing under 11.00 .

$b^{1}$. Ylumage pure white; legs and bill black; fect yellow.

197. Snowy Heron.

62. Tips of primaries slate-color; plumage white, somętimes irregularly marked with slaty blue. . 200. Little Blue Heron (Im.). $B$. Crown umber or redish brown.

a. Head and neck reddish brown; body slate-color.

198. Redish Egret.

b. Neck conspicuously streaked; body variegated. 190. Am. Bitrern. $C$. Crown slaty or slate-blue with sometimes a purplish east.

a. Wing-coverts more or less margined with rufous.

199. Luouisiana Heron.

b. Wing-coverts without rufous . 200. Little Blue Heron. D. Crown greenish or bluish black.

a. Wing over $10^{\circ} 00$; entire under parts pure white.

202. Black-crowned Night Heron.

b. Wing under $10 \cdot 00$.

$b^{1}$. Wing-coverts green . . . . 201. Little Green Heron.

$c^{1}$. Wing-coverts rufous-chestnut and buff.

$c^{2}$. Under parts buffy, more or less streaked. 191. Least Bittern. $c^{3}$. Under parts rufous-chestnut - 191.1. Corr's Least Bittern.

2. Crown streaked.

A. Wing under 10.00 ; upper parts greenish 201. Little Green Heron.

$B$. Wing over 1000 ; upper parts brownish or blackish brown streaked with white.

a. Upper parts light brown; outer edge of primaries reddish.

202. Black-crowned Night Heron (Im.).

b. Back dark brown; crown nearly black with white streaks; primaries dark slate-color . 203. Yellow-crowned Night Heron (Im.).

190. Botaurus lentiginosus (Ionterg.). Americax Bittern; Marsh Hen. Ad.-A glossy black streak on either side of the upper neck; top of the head and back of the neck bluish slate, more or less washed with buffy; back brown, bordered and irregularly mottled with buffy, and buffy ochraceous, wing-coverts similarly marked, but the ground color grayer; under parts creamy buff, the feathers all widely streaked with bufty brown, which is finely speckled with buffy aud narrowly margined by brownish gray. Im.- Similar, but the buffy everywhere deeper and more ochraceous. L., $28 \cdot 00$; W., 10.50 ; Tar., $3.50 ;$ B., 3.00 .

Range.-Temperate North America; breeds but rarely south of Virginia; winters from Virginia southward.

Washington, rather common W. V., Aug. to Apl. Long Island, common T. V., Apl. and Sept. to Nov. Sing Sing, rare S. R., Apl. 11 to Oct. 5. Cambridge, not common S. R., Apl. 15 to Nov.

Nest, of grasses, ete, on the ground in marshes. Eggs, three to five, pale olive-buff, $1.90 \times 1.45$.

The Bittern makes its home in extensive grassy meadows with plenty of water, but in the season of migration may be found and 
heard "booming" in smaller and more accessible swampy places. Like the other members of its family, it excels in standing still, and will hold its head erect and motionless amid the tall grass till the watcher tires of looking and pronounces the suspicious object nothing but a stick after all. The Bittern's fame rests upon its rocal performance, or "boom." This is sometimes exactly like the working of an old-fashioned wooden pump, and sometimes-even with the same bird-like the driving of a stake in a bog. It can be heard for a long distance. The performance is best witnessed in spring, while the grass is still low. That it is not so very difficult at that season to steal a march upon the bird may perhaps be considered as established on the testimony of a man who has never lived near a Bittern meadow, and yet has watched the performance at much length and at near range on several occasions. His first experience of this kind is described somewhat fully in The Auk, vol. vi, page 1. The strange notes are delivered with equally strange contortions, as if the bird were horribly nauseated, and are preceded by a succession of quick snappiıg or gulping sounds-"hiccoughs," one observer has called them. No water is employed in the operation, in spite of the circumstantial assertions of several persons who profess to have seen the bird swallowing and then ejecting it.-BradFord Torrey.

191. Ardetta exilis $(G m e l$.). Least Bittern. A $d .8$. - Top of the head, back, and tail shining black; back of the neck chestnut-rufous; most of the greater wing-coverts and outer vanes of the secondaries darker; lesser wing-coverts and part of the greater ones buffy ; under parts, including under tail-coverts, washed with buffy; a blackish patch at either side of the breast. $A d$. \&.- Similar, but head browner and back light, glossy umber; under parts darker and more or less streaked with brownish. Im. 8.- Similar to ad. $\delta$, but the back washed and tipped with chestnut; under parts darker and lightly streaked with black. Im. \&.--similar to ad. \&, but the back rufous, margined with buffy ochraceous. L., 13.00 ; W., $4 \cdot 60$; Tar., 1.60; B., 1.80.

Range.-Temperate and tropical America; breeds in North America as far north as Maine, Ontario, and Manitoba; winters from southern Florida south ward.

Washington, not very numerous S. R., May 5 to Sept. 25. Long Island, common S. R., May to Sept. Sing Sing, tolerably common S. R., to Aug. 10. Cambridge, rather coinmon S. R., May 15 to Aug.

Nest, of grasses, plant stems, etc., in marshes among rushes, sometimes in a small bush. Eggs, three to six, pale bluish white, $1 \cdot 20 \times 992$.

Wet, grassy marshes such as Rail love, or reed-grown ponds that Gallinules frequent, are the resorts of these retiring, secretive little birds. With outstretehed necks and lowered heads they make their way without difficulty through the jungle of roots and stalks. Sometimes they climb up a slender reed, and, hanging on like Marsh Wrens, 
survey their surroundings. They take wing almost from beneath one's feet, and, with a low, frightened qua, fly slowly for a short distance and then drop back into the grass. During the breeding season one may hear what presumably is the voice of only the male-a soft, slowly repeated, dovelike $c 00, c 00, c 00, c 00, c 00$. It floats over the marsh like the voice of a spirit bird.

191. 1. Ardetta neoxena Fory. Corr's Bittern. Ad. s. - "Top of the head, back, and tail dark greenish black, showing a green gloss when held in the light. Sides of the head and throat rufous-chestnut, the feathers on the back of the neck showing greenish-black tips; breast and under parts nearly uniform rufous-chestnut, shading into dull black on the sides; wing-coverts dark rufous-chestnut, all the remiges entirely slaty plumbeous; under tailcoverts uniform dull black. W., 4.30; Tar., 1.40 ; B., 1.80 " (Cory, orig. descr., Auk, iii, 1886, p. 262).

This small Bittern was described from a specimen taken in the Everglades of Florida. Five additional specimens have since been secured in the same region, to which, until recently, the species was supposed to be confined. Within the past few years, however, seven specimens have been taken in the 'Toronto marshes, where A. exilis is common, and one is recorded from Michigan. It seems to me not unlikely that, as Mr. W. E. D. Scott suggests, neoxena may prove to be a color phase of A. exilis. (Cf. Scott, Auk, viii, 1891, p. 309; ix, 1892, p. 141 ; and Chapman, ibid., xiii, 1896, p. 11.)

192. Ardea occidentalis $4 u d$. Great White Heron. Ad.-Entirely white; in breeding plumage, with long, narrow, stiffened feathers on the back and lower foreneck, and two narrow plumes on the back of the crown. "L., 45.00-54.00; W., 17.00-21.00 ; B., 6.00-7.00; Tar, 8.00-8.75" (Ridgw.).

Range.-Jamaica and Cuba north to the consts of southern Florida, casually to Anclote River and Miceo.

Nest, a platform of sticks in colonies in mangrove bushes. Eggs, three to four, pale, dull blue, $2.50 \times 1 \cdot 80$.

This is a common species on the coasts of southern Florida, particularly in the ricinity of Cape Sable. Rarely it is found as far north as the Anclote River on the west coast and Micco on the east coast. This bird is as large as the Great Blue Heron, and must not be confused with Ardea egretta, to which the name Great White IIeron is frequently applied.

Ardea wuerdmanni Baird has been considered to be a color phase of this species, but its true standing is unknown. It is described by Coues as follows:

"Head, with the crest, white, the forehead streaked with black edges of the feathers: under parts white, the sides streaked with black; lower plumes of neek white, mostly streaked with black edges of the feathers; neck purplish 
gray, darker than in $A$. herodias, with a similar throat line of white, black, and rufous. Under wing-coverts streaked with white; rufous of edge of wing less extensive than in $A$. herodias, that of tibir paler. Tibiæ and soles of feet yellow; tarsi and top of toes yellowish green. Im.-Like young A. herodias; top of head dusky, the feathers with whitish shaft lines and bases. Lesser wing-coverts speckled with rusty, the under ones pure white" (Coues). "L., 48.00-50.00; W., 20.00-21.00; B., 5.95-6.50; Tar., 7.95-8.25" (Ridgw.).

193. Ardea wardi Ridgw. WARD's IIERon.--This is the Florida representative of $A$. herodias. It is believed by some ornithologists to be a distinct species, but in my opinion is a peninsular race. The average differences in color between it and $A$. herodias consist in its whiter lower parts, darker neck, and olive instead of black legs. These differences, however, can not always be relied upon, and size is the character by which the two birds can best be distinguished, wardi being the larger, as the following measurements show : L., 52.00; W., 19·75-20.50; B., 6*40-6.80; Tar., 8*00-8.50.

Range.-Florida, from Alachua County southward.

Nest, a platform of sticks, in colonies, generally in cypress trees. Eggs, three to four, pale, dull blue, $2.65 \times 1.85$.

This is the Florida form of the preceling, which it resembles in habits. It is more common than the Great Blue IIeron, and is generally distributed throughout the peninsula from Gainesville southward.

194. Ardea herodias Linn. Great Blye IIeron; Blee Crane; Sandinl Crane. Ad. in breeding plumage.-Center of the crown and throat white, sides of the crown black, this color meeting on the back of the head, where the feathers are lengthened to form an occipital crest: neck pale grayish brown, a narrow black, white, and ochraceous line down the middle of the foreneck; feathers of the lower foreneek narrow and much lengthened, whitish with sometimes black streaks; back, wing-coverts, and tail slaty gray, the scapulars paler, narrow, and much lengthened; bend of the wing chestnut-rufous; a patch of black and white feathers on the side of the breast; breast and belly streaked with black and white and sometimes pale rufous; feathers on legs dull rufous, legs and fect black, upper mandible oliveyellow, the culmen blackish; lower mandible yellow; lores blue. Im.Similar, but entire crown black, throat white, neck brownish gray washed with buffy ochraceous; no black at the sides of the breast or plumes on the lower neck; under parts streaked with black, slaty, white, and ochraceous; bend of wings and feathers on legs puler; back slaty grayish brown without lengthened plumes. "L., 42.00-50.00; W., 17.90-12.85; B., 4.30-6.25; Tar., 6.00-8.00" (Ridgw.).

Range.-Northern South America northward to the aretic regions; breeds locally throughout most of its North American range and winters from the Middle States southward.

Washington, rather common, absent only in midwinter. Long Island, common T. V., A pl. and May; Aug. to Dee. Sing Sing, common T. V., Apl. 4 to Apl. 18; Aug. 16 to Oct. 6. Cambridge, common T. V., Apl. and May; Sept. to Nov.; occasional in summer. 
Nest, a platform of sticks, generally in colonies, in trees. Eggs, three to four, pale, dull blue, $2.50 \times 1.50$.

Is it due to the influence of the artists of the Orient that these long-legged, long-necked birds are so frequently miscalled "Cranes"? With head drawn in and legs trailing on behind, they flap slowly over the water, resembling, no doubt, the "Cranes" of fans. screens, and bronzes; nevertheless, they are Herons. With all a Heron's immovable alertness they watch patiently for passing fish, sometimes wading with extreme caution, placing one foot slowly after the other. They feed both by day and night. Fishes, frogs, reptiles, even small mice, all are welcome; and all are powerless to escape the lightning thrust of the spearlike bill. Their voice is harsh and rasping. When alarmed they utter a croak which is sometimes prolonged into a series of squawks. They nest and roost in colonies, but at other times are solitary birds.

The European Great Blue Ileron (195. Ardea cinerea) is accidental in southern Greenland. It may be distinguished from our species by the white instead of rufous feathers on the legs.

196. Ardea egretta Gmul. American Egret. h. in breding plumage.-Entire plumage pure white; about fifty straight "aigrette" plumes grow from the interseapular region and reach beyond the tail; legs and feet black; bill yellow; lores orange, bordered below by greenish. Ad. after the breeding season and Im.-Without the interseapular plumes. L., 41.00; W., $15 \cdot 00$; Tar., $5 \cdot 60 ;$ B., 4.50 .

Range.-Tropical and temperate America; breeds as far north as southern Illinois and Virginia; after the breeding season sometimes strays northward as fir as Manitoba, Quebee, and New Brunswick.

Washington, not common and irregular S. R., May to August. Long Island, rare from July to Sept. Sing Sing, A. V.

Nest, a platform of sticks, in colonies, in bushes over water. Eggs, three to five, dull blue, of a rathcr deeper shade than those of the preceding, $2.25 \times 1 \cdot 60$.

Tourists who went to Florida thirty years ago have told me of prairies white with Egrets, of bushy islands glistening in the sun like snow banks. Now you may look for miles along a lake shore and perhaps in the distance see a solitary Egret, which, as you approach, with a frightened squaw takes wing a rifle-shot away. The rapid extermination of these plume-bearing birds is startling evidence of man's power in the animal world. At his word a species is almost immediately wiped out of existence. I have heard a "plume-hunter" boast of killing three hundred IIerons in a "rookery" in one afternoon. Another proudly stated that he and his companions had killed one hundred and thirty thousand birds-IIerons, Egrets, and Terns-during one winter. But the destruction of these birds is an unpleasant 
subject. It is a blot on Florida's history. The subject will be found fully treated by W. E. D. Scott in The Auk, iv, 1887, p. 135.

19\%. Ardea candidissima Gmel. Snowy Hleron; SNow EgirTt Ad. in breeding plumage.-Entire plumage pure white; about fifty recurved "aigrette" plumes grow from the interseapular region and reach to or just beyond the end of the tail; legs black, feet yellow, bill black, yellow at the base; lores orange-yellow, Ad. after the breeding season and Im.-Without the interscapular plumes. L., $24 \cdot 00 ;$ W., $9 \cdot 75$; Tar., 3.80; B., $3 \cdot 20$.

Range.-Tropical and temperate America; breeds as far north as southern Illinois and Long Island; after the breeding season sometimes strays northward as far as Ontario and Maine.

Washington, casual; irregular in fall. Long Island, rare S. R., Apl. to Sept. Sing Sing, A. V.

Nest, a platform of sticks, in colonies, in bushes over water. Eggs, three to five, pale, dull blue, $1.80 \times 1.20$.

The "curse of beauty" has numbered the days of this the most dainty and graceful of Herons. Twenty years ago it was abundant in the South, now it is the rarest of its family. The delicate "aigrettes" which it donned as a nuptial dress were its death warrant. Woman demanded from the bird its wedding plumes, and man has supplied the demand. The Florida Ilerons have gone, and now he is pursuing the helpless birds to the uttermost parts of the earth. Mercilessly they are shot down at their roosts or nesting grounds, the coreted feathers are stripped from their backs, the carcasses are left to rot. while the young in the nest above are starving. But then, you know, the little bunch of aigrettes in yonder jaunty bonnet is "so fretty," "so becoming!"

198. Ardea rufescens limel. Rendisil Egiret. Ad., dark phaseHead and neck rufous-chestnut, glossed with vinaceous; rest of the plumage dark bluish slate-color; about thirty "aigrette" plumes grow from the interscapular region and reach beyond the tail; legs and feet black. Im.-Similar, but without the "aigrette" plumes. White phase.-Similar in size and form, but entire plumage white, except the tips of the primaries, which are sometimes very finely speckled with grayish. Im.-Similar, but without the "aigrette" plumes. L., 29.00; W., 12.50; 'Tar., 5·40; B., 3·60.

Remarks. - The two color phases of this bird were supposed to represent two species, the white phase being called Ardea pealei Bonap. They have, however, been found mated together, and intermediates or party-colored specimens are known.

Range.-West Indies and Central America north to coasts of the Gulf States; casually southern Illinois.

Nest, a platform of sticks, in colonies, in bushes generally over water. Eygs, two to four, pale, dull blue, $1.95 \times 1.45$.

This is, or was a few rears ago, a not uncommon species on the coasts of southern Florida, but it is unknown in the interior. It is 



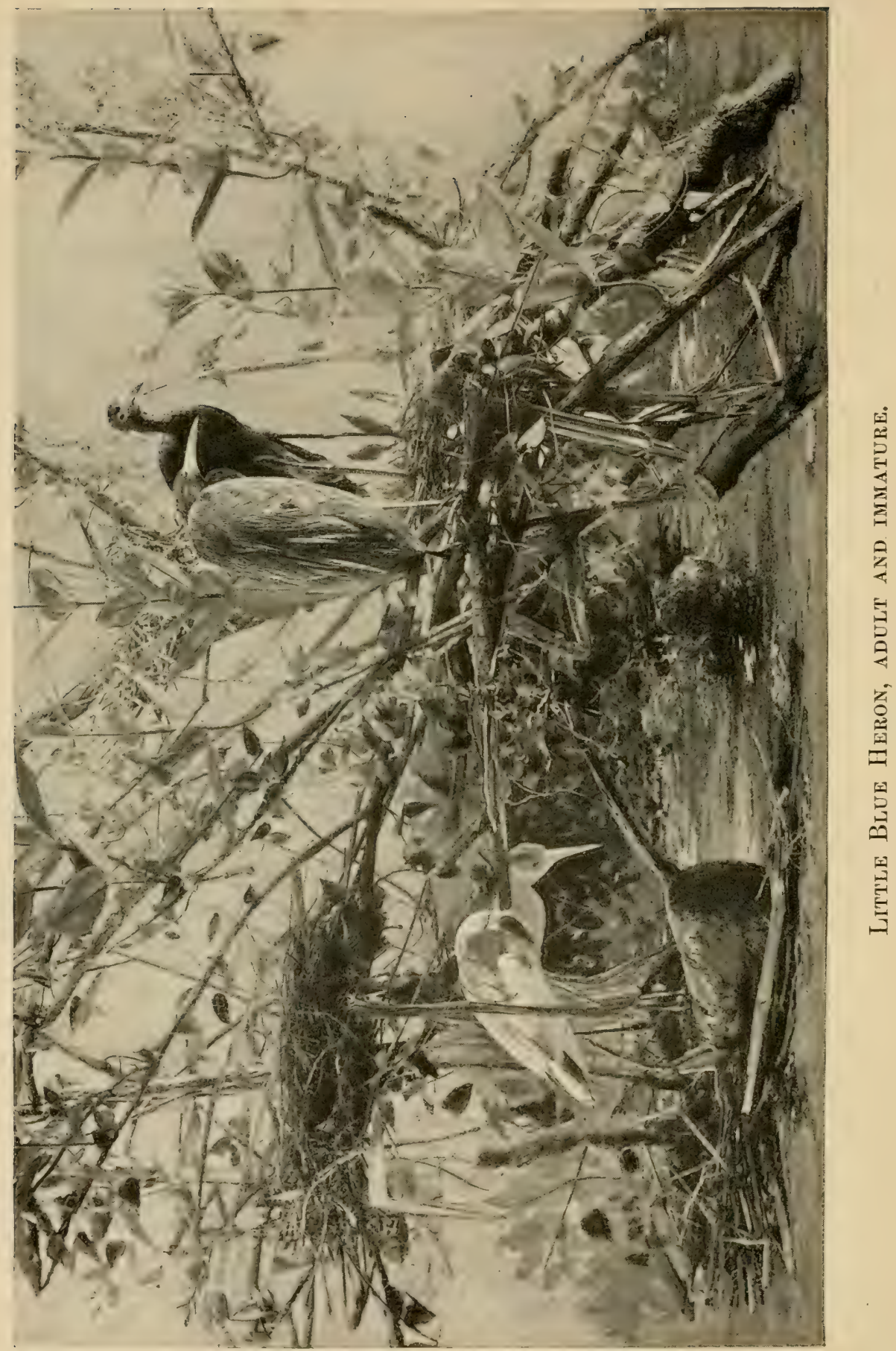


generally seen in flocks. With $A$. candidissima they lack the patience of the larger Herons and pursue their prey in shallow water.

199. Ardea tricolor ruficollis (Gosse), Louisiana Heron. $A d$. - Upper parts dark bluish slate-color; back of the head and upper neck with elongated chestnut-rufous and white feathers; back with pale brownish gray "aigrette" plumes reaching to the tail; lower back, rump, and belly white; neck bluish slate-color; throat white, an indistinct rufous line down the middle of the foreneck ; legs blackish ; base of the bill and lores bluish: Im.Throat, and an indistinct line down the foreneck, white; rest of the head and neck brownish rufous; upper back and wings bluish slate-color, more or less washed with brownish rufous; no plumes; lower back, rump, and belly white; breast with more or less slaty streaks; legs yellow behind, blackish before; lower mandible and lores orange; upper mandible black. L., $26.00 ; \mathrm{W} ., 10 \cdot 00$; Tar., $3.70 ;$ B., 3.90 .

Range.-Central America and West Indies northward to the Gulf States; casually to Long Island.

Long Island, A. V., one record.

Nest, a platform of sticks, in colonies, in bushes over water Eggs, four to five, pale, dull blue, $1.75 \times 1.35$.

A common species in Florida, where it is found both singly and in flocks. It is sometimes a slow, stealthy feeder, and at others dashes for its prey.

200. Ardea cœrulea Lim. Little Blte IIEron. di.-Head and neck maroon-chestnut; rest of the plumage dark bluish slate-color; interscapulars and lower neck feathers lengthened and narrowly pointed; lores blue; legs and feet black. Im. - White, the plumage sometimes more or less washed with slaty; the tips of the primaries always bluish slate-color; legs, feet, and lores greenish yellow. L., 22.00; W., 10.25; Tar., 3.70; B., 3.00.

Remarks.-Between the young and adult there is every stage of intergradation of color, some specimens being irregularly marked with blue and white in about equal proportions. Young birds are sometimes mistaken for Snowy Herons, but can always be distinguished by the greenish yellow legs and slaty tips of the primaries.

Range.-Tropical and temperate America, breeding as far north as southern Illinois and Virginia; after the breeding season wanders northward, sometimes reaching Nova Scotia.

Washington, casual in July and August; sometimes quite common. Long Island, rare from Apl. to Sept.

Nest, a platform of sticks, in colonies, in bushes over water. Eggs, three to four, pale, dull blue, $1.70 \times 1.30$.

Thanks to their lack of "aigrette" plumes Little Blue Herons are probably the most common Ilerons in Florida to-day. They are generally found in flocks, sometimes composed entirely of blue adults, sometimes of white, immature birds, and at others both young and old are associated. The white birds resemble $A$ condidrsima, but the 
color of their legs and feet serves as a distinguishing character at some distance. They are silent when feeding, but when undisturbed in their rookeries each bird seems to have something to say, and the result is a strange chorus of croaking voices. They feed by day, and generally wait for their prey to come within striking distance.

201. Ardea virescens Linn. Littre Green IIeron; Pohe (see Fig. 19). Ad.-Crown and a short line below the eye glossy greenish black; throat buffy white, this color extending down the foreneck as a narrow line mixed with blackish, widening on the breast; rest of the head and neck rufous-chestnut glossed with vinaceous; back, with lengthened interscapulars, green, more or less washed with bluish gray; wing-coverts green, margined with white or buffy; belly ashy gray, more or less washed with buffy. Im.Similar, but with the neck and under parts streaked with blackish; back without lengthened feathers or wash of blue-gray ; wing-coverts widely margined with buffy ochraceous. L., $17 \cdot 00 ;$ W., $7 \cdot 25 ;$ Tar., $1.90 ;$ B., 2.50 .

Range.-Tropical and temperate America; breeds as far north as Manitoba, Ontario, and the Bay of Fundy ; winters from Florida southward.

W ashington, very common S. K., Apl. 15 to Sept. Long Island, common S. R., Apl. to Uet. Sing Sing, common S. R., Apl. 6 to Sept. 26. Cambridge, common S. R., May 5 to Sept.

Nest, a platform of sticks in a bush or low branch of a tree. Eggs, three to six, pale, dull blue, $1.50 \times 1 \cdot 14$.

The shores of wooded streams or ponds are frequented by this small IIeron in preference to more exposed situations. It is most active in the early morning or at nightfall, and during the dicy rests quietly in some sheltered situation. When startled, it springs into the air with a frightened squawk, and, alighting at a safe distance on a tree or on some elevated perch, with upstretched neck watches the intruder, betraying its apprehension by nervous twitehings of the tail. It is a solitary bird, and, unlike most Herons, is never found in flocks.

202. Nycticorax nycticorax nævius (Boll .). BLACK-CRowNED Night Heron; Qunwk. Ad.-Forehead, lores, neck, and under parts white or whitish; crown, upper back, and scapulars glossy, greenish black; lower back, wings, and tail ashy gray; legs and feet yellow; lores greenish; two or three white rounded occipital plumes about 8.00 in length. Im.-Upper parts grayish brown, the feathers streaked or with wedge-shaped spots of white or buffy; outer web of primaries pale rufous; under parts white, streaked with blackish. L., 24.00; W., 12.00; Tar., 3.20; B., 3.00.

Range,-Breeds from Manitoba and New Brunswick southward through South America; winters from the Gulf States southward.

Washington, not uncommon S. R., oceasional in winter. Long Island, common S. R., Apl. to Oct., a few winter. Sing Sing, common S. R., Apl. 6 to Oet. 20. Cambridge, P. R., most common in Aug. and Sept.

Nest, of sticks, in colonies, generally in the upper parts of tall trees, sometimes in bushes or on the ground. Eygs, four to six, pale, dull blue, $200 \times 1 \cdot 40$. 
These birds live in colonies composed sometimes of thousands of pairs. Their day begins after sunset, when they leave their roosts and start for their feeding grounds. Occasionally they utter a loud, hoarse quawk, the origin of their common name; and looking up we may catch a glimpse of them hurrying through the gloom. During the nesting season the demands of the young force them to feed both by day and night.

203. Nycticorax violaceus $(\operatorname{Lin} u$.). YELLOW-CROWNED N HERon. Ad.-Crown white, generally washed with buffy; ear-coverts white; rest of the head and throat black; neek, breast, and belly blue-gray; back the same; the lengthened interscapulars, scapulars, and wing-coverts streaked with black; two or three black and white rounded occipital plumes; lores greenish yellow; legs greenish. Im.-Crown black, the feathers streaked with white or buffy ; rest of the upper parts, including wing-coverts, fuscous-brown with wedge-shaped buffy or white spots; primaries dark bluish slate-color without rufous; under parts white or buffy streaked with blackish. L., 23.00; W., $12 \cdot 00$; Tar., $3 \cdot 55 ;$ B., $3 \cdot 00$.

Remarks.-Young birds bear a general resemblance to those of the preceding species, but differ in being darker, in having the head darker than the back, and the primarias without rufous.

Range.-Breeds from southern Illinois and South Carolina southward to South America, and occasionally strays north as far as Massachusetts.

Long Island, A. V. Cambridge, A. V., one record, July.

Nest, a platform of sticks, in pairs, generally in a low branch overhanging water. Eggk, four to five, pale, dull blue, 1.95 × 1.45.

Enlike the preceding, this is a rather solitary species, and is found singly or in pairs along the borders of wooded streams, and never in colonies. It is also, I think, more diurnal in habits.

\section{ORDER PALUDICOLÆ. CRANES, RAILS, ITC.}

\section{Family Gruid 皮。 Cranes.}

The Cranes number about eighteen species, of which three are North American, while the remaining fifteen inhabit the Old World. They frepuent plains and marshes, and are omnirorous feeders, eating frogs, lizards, field-mice, snakes, etc., and various kinds of regetable food. Our species migrate in flocks, but are solitary rather than gregarious at other times of the year. Their voice is loud and resonant.

204. Grus americana $(\operatorname{Linn}$.). Whonping Crane; White Crane. Ad.-Top of the head, lores, and sides of the throat dull red, with a thin growth of black "hairs"; primaries black, rest of the plumage white. Im.Similar, but whole head feathered, and the plumage more or less washed with buffy ochraceous. L., 50.00; W., 25.00; 'Tar., $11.50 ;$ B., 5.00. 
Range.-Interior of North America; breeds from Illinois northward; winters in the Gulf States.

Washington, A. V, one record.

Nest, of grasses and weed stalks, on the ground in marshy places. Eygs, two, olive-gray, spotted and blotehed with distinct and obseure cinnamonbrown markings, $4.00 \times 2.50$.

A rather rare species east of the Mississippi. "In flight their long necks and stiltlike legs are stretched out in a line with the body to the full extent, moving strongly with slowly beating wings, but not swiftly, ... often circling spiral-like to a great height. They occasionally bunch up, and I have seen them in triangular form; but as a rule they travel in single file, following their leader in a wary line, croaking as they go, like hounds upon a cold trail" (Goss).

The Little Brown Crune (205. Grus canadensis) breeds from IIudson Bay to Alaska, and winters in Texas and Mexico. There are but two instances of its occurrence east of the Mississippi (Rhode Island and South Carolina). It resembles mexican $\alpha$, but is smaller; W. $18 \cdot 50 ; \mathrm{B} ., 4 \cdot 10$.

206. Grus mexicana (Müll.). Sandhll Crane; Brown Chane. Ad.-Whole top of the head to below the eyes covered with rough, minutely warty, dull reddish skin thinly grown with short, black "hairs"; plumage brownish gray, with more or less silvery gray and buffy ochraceous. Im.Similar, but whole head feathered, and with more buffy ochraceous in the plumage. "L., 40.00-48.00; W., 21.83; Tar., 1025 ; B., 5.47" (Ridgw.).

Range-Florida, Georgia, and northward through the Mississippi Valley to Manitoba; breeds locally throughout its range; winters in the Gulf States from Florida to Texas.

Nest, of roots, rushes, weed stalks, etc., on the ground in marshy places. Eggs, two, olive-gray, spotted and blotched with distinct and obscure cinnamon-brown markings, $3.90 \times 2 \cdot 40$.

"These birds in their habits are similar to the Whooping [Crane], but much more numerous. Their loud, modulating, sonorous croak announces their presence, and is often heard during the night as well as the day.

"During courtship and the early breeding season their actions and antics at times are ludicrous in the extreme, bowing and leaping high in the air, hopping, skipping, and circling about with drooping wings and croaking whoop, an almost indescribable dance and din, in which the females (an exception to the rule) join, all working themselves up into a fever of excitement only equaled by an Indian war dance, and, like the same, it only stops when the last one is exhausted" (Goss).

\section{Family aramide. Courlans.}

Courlans might be called large Rails with some of the habits of Herons. Two species are linown, Arcenus scolopaceus of South America, 
and $A$. giganteus of Central America, Mexico, the West Indies, and Florida. They frequent the borders of wooded streams and swamps, and at times the uplands. Their flight is short, and when on the wing their legs dangle below them. Like the Iferons, they perch in trees. Their prolonged, melancholy call has won for them the name "Cryingbird." Their usual note is a loud, rather high wah-ree-ow; the last syllable is drawn out into a wail, and the effect is most grewsome. Courlans feed to a large extent on land shells (Ampulluria), and, as Prof. W. B. Barrows has shown, the tip of the Courlan's bill is sometimes turned slightly to one side. an evident result of forcing it into the spiral opening of the shell to extract the animal.

20\%. Aramus giganteus (Bonap.). Lmpin; Cring-rirn; ( CotrLAN. (See Fig. 24.) Ad.-Glossy olive-brown, the feathers of the head and neck narrowly, those of the body broadly, striped with white; wings and tail more bronzy. Im.-Similar, but paler and duller. L., 28.00; W., 13.00; Tar., $4.50 ;$ B., $4 \cdot 25$.

Range-Central America and West Indies north to Rio Grande Valley and Floridia.

Test, of leares, twigs, etc., in a bush or small tree. Eggs, four to seven, pale buffy white, blotehed, stained, and speckled with light cinnamon-brown, $2 \cdot 30 \times 1 \cdot \% 0$.

This is a locally distributed species in Florida. Its general habits are described in the remarks on the family Aramida.

\section{Family Ratlid ac. Rails, Gallinules, and Coots.}

The one hundred and eighty species contained in this family are distributed throughout the greater part of the world, fifteen species inhabiting North America. Rails and Gallinules are not strictly gregarious, but are generally associated through a community of interests; Coots, however, are usually found in flocks. Rails inhabit grassy marshes, in which they seek safety by running or hiding, taking to wing when pursued only as a last resort. Their flight is then short and labored, and with dangling legs they soon drop back into cover. Nevertheless, they perform extended migrations, traveling hundreds of miles without resting. Gallinules live near the marshy borders of bodies of water, while the more aquatic Coots resemble some Ducks in habits.

I. Bill over $1 \cdot 75$.

KEY TO THE SPECIES.

$A$. Cheeks below the cye cinnamon-rufous, like the breast; flanks black barred with white; upper parts rich olive-brown streaked with black.

208. King RaIl.

$B$. Cheek below the eye gray; flanks generally gray or brownish, barred with white; upper parts generally grayish, streaked with black.

211. Clapper Rail and races. 
1I. Bill under 1.75.

A. Wing over 6.00 .

a. General color blue, feet yellow . . . - 218. Hurple Galdincle.

b. General color slaty, feet dark greenish.

$b^{1}$. Toes with large scalloped webs or flaps at the side. 221. Aм. Соот.

$b^{2}$. Toes without flaps or webs . . . . 219. Florida Gallinule.

B. Wing under 6.00 .

a. Wing under $3 \cdot 50$.

$a^{1}$. Back blackish, with small round, white spots - 216. BLACK RAIL. $a^{2}$. Back blackish, barred with white and margined with buffy.

215. YeLLOW RAIL.

b. Wing over $3 \cdot 50$.

b1. Bill over 1.00 . . . . . . . . 212. Virgrinia RaIl.

c. Bill under $1 \cdot 00$.

$c^{2}$. Wing over 4.50, lesser wing-coverts rufous - 217. Corn Crake.

$c^{3}$. Wing under 4.50, lesser wing-coverts olive . . . 214. 'SorA.

208. Rallus elegans Aud. King RaIL; MaIsh Hen. Ad.-Upper parts varying from olive-brown to black, the back and scapulars widely margined with olive-gray; wings and tail olive-brown; wing-coverts rufous; throat white; neck and breast cinnamon-rufous; belly and sides fuscous, sharply barred with white. Downy Foung-Glossy black. L., 15.00; W., 6.50 ; Tar., $2.20 ;$ B., 2.40 .

Range.-Eastern North America; breeds as far north as Missouri and southern Connecticut, and occasionally strays as far as Wisconsin, Ontario, and Maine; winters from Virginia southward.

Washington, uncommon ${ }^{-}$S. R., almost a P. R. Long Island, rare S. R.

Nest, of grasses, on the ground in fresh-water marshes. Eggs, seven to twelve, buffy white, more heavily spotted and speckled with rufous-brown than those of the next species, $1.68 \times 1.20$.

The King Rail is the fresh-water representative of the Clapper Rail. It is, however, a much less common bird, and less is known of its habits. Like other Rails, it is a skulker, and never flies when it can escape by running or hiding in the dense grass of its home. On three occasions I have heard what I am quite sure was the King Rail's call,

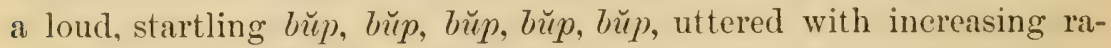
pidity until the syllables were barely distinguishable, then ending somewhat as it began. The whole performance occupied about five seconds.

- 211. Rallus longirostris crepitans (Gmel.). Clapper RAIL; Mansir Hen. (See Fig. 22, a.) Ad.-Upper parts very pale greenish olive, the feathers widely margined with gray; wings and tail grayish brown; wing-coverts pale cinnamon, much washed with gray; throat white; neck and breast pale, between ochraceous and cream-buff, more or less washed with grayish; belly and sides gray or brownish gray, barred with white. Downy Young-Glossy black. L., 14.50; W., 5.00; Tar., 2.00; B., 2.50.

Remarks.-The Clapper Rail may always be known from the King Rail 


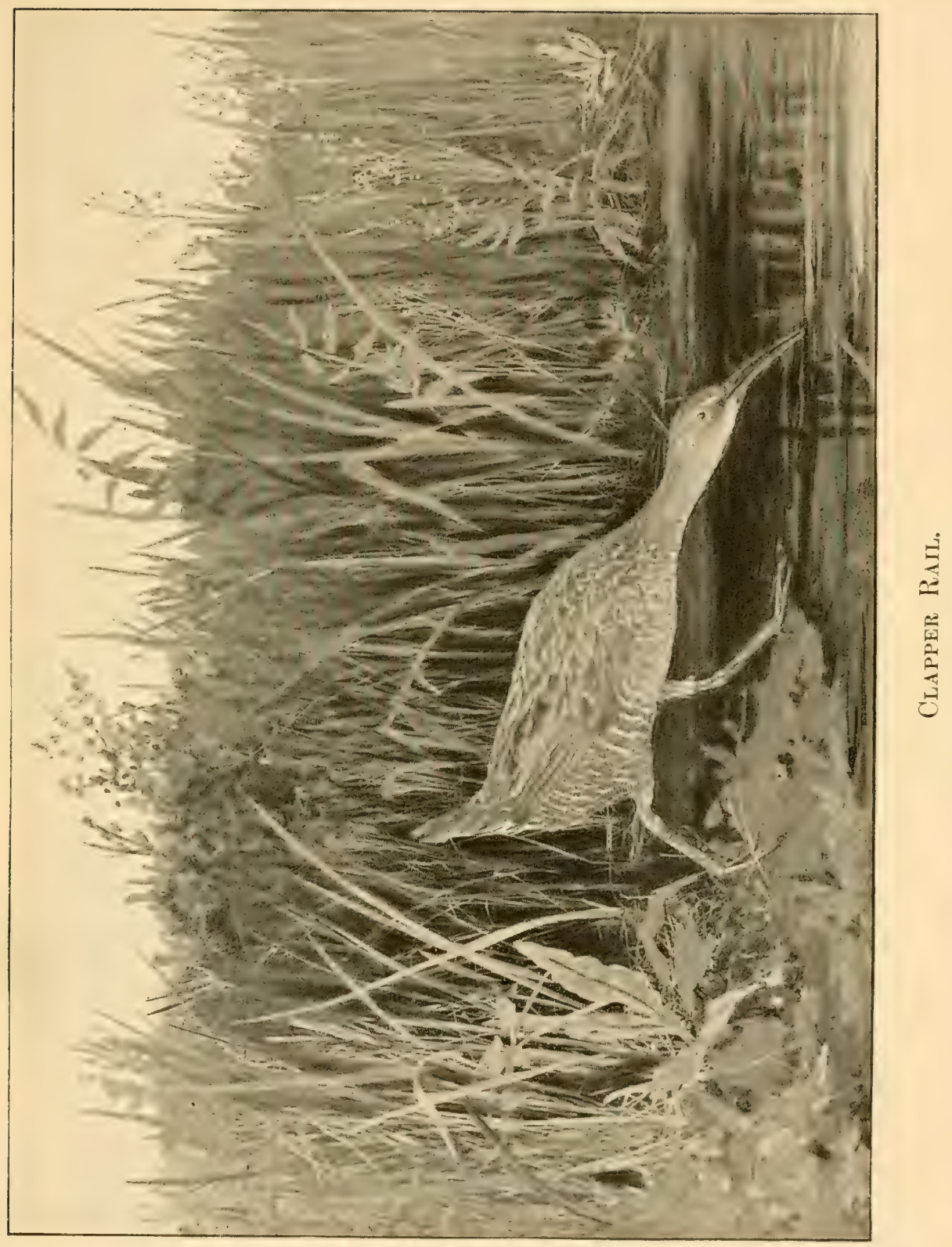



by its generally grayish instead of brownish or blackish upper parts, by its nuuch paler breast and flanks and paler wing-coverts.

k'ange.-Breeds in salt-water marshes of eastern North America from Connecticut to the Gulf of Mexico; winters in small numbers from near the northern limit of its range southward.

Washington, A. V., one record. Long Island, common S. R., Apl. to Oct., a few winter. Sing Sing, A. V.

Nest, of grasses, on the ground, in grass-grown, salt-water marshes. Eggs, eight to twelve, butfy white, spotted and speckled with rufous-brown, $1 \cdot 72 \times 1 \cdot 20$.

The Clapper Rail is an inhabitant of grassy, salt-water marshes, and, in the southern parts of its range, of mangrove swamps. It is almost impossible to flush these birds unless their haunts are invaded by an unusually high tide, when a boat may be pushed through the meadows and the birds forced to take wing. I have heard birds calling in the tall grass within a few feet of me, and have made a wild rush in their direction, only to be mocked a moment later by apparently the same bird calling from a point almost within reach. 'I'hey dodge about over well-traveled pathways like children in a game of blindman's buff.

While not strictly gregarious, they live in colonies, and the long, rolling call of one bird is sometimes taken up and repeated by others until there is a general outcry through the marsh.

211a. R. 1. saturatus Mensh. Louisiana Clapper Rail.-A local race of the Clapper Rail found in the marshes of Louisiana. Its characters appear not to be well understood. It is much darker than crepitans, but not so dark as scottii. "W., 5•65; Tar., 1.97; B., 2.27" (Ridgw.).

kange.-Coast of Louisiana.

211b. R. 1. scottii (Senn.). Florida Clapper Rall.-Differs from crepitans in being black, fuscous, or olive-brown above, with olive-gray margins to the feathers; in having the neck and breast cinnamon-rufous washed with brownish, and in having the belly and tlanks black instead of gray. In fict, the general color of scottii suggests a King Rail, but the latter may always be known by its rufous wing-coverts and clear cinnamon-rufous neck and breast. W., $5.50 ;$ Tar., $1.90 ;$ B., $2 \cdot 40$.

Range.-Gulf coast of Florida.

212. Rallus virginianus Linn. VIR̈̈Lin Rail. Ad.-Upper parts fuscous or black, the feathers bordered by pale grayish brown; wings and tail dark grayish brown; wing-coverts rufous, lores whitish, cheeks gray, throat white, rest of the under parts cinnamon-rufous; Hanks and under tailcoverts barred or spotted with black and white. Downy Young.-Glossy black. L., $9 \cdot 50$; W., $4 \cdot 30$; Tar., $1 \cdot 30 ;$ B., $1 \cdot 50$.

Range.-Breeds from northern Illinois, Pennsylvania, and Long Island to Manitola and Labrador; winters from near the southern linit of its loreeding range southward.

Washington, probably P. R. Long Island, common S. R., Apl. to Oct.; a 
few winter. Sing Sing, tolerably common S. R. to Sept. 29. Cambridge, common S. R., Apl. 20 to Uet. 15.

Nest, of grasses, on the ground in marshes. Eggs, six to twelve, pale buffy white, spotted and speckled with rufous-brown, $1 \cdot 26 \times \cdot 96$.

In almost any extensive fresh or brackish marsh, especially if it has beds of cat-tail flags or scattered thickets of low bushes and briers, one may hear in May and June, particularly in the early morning, late afternoon, or during clnudy weather, a succession of grunting sounds not unlike those of a hungry pig. Although by no means loud, they have a penetrating quality which makes them carry to a considerable distance; and they are apt to attract attention even when, as is usually the case, they mingle with the songs of innumerable Red-winged Blackbirds, Marsh Wrens, and other swamp-loving birds. It is no easy matter to trace them to their author, but if you are persevering and at the same time fortunate, you may at length discover him skulking under a bush or behind a tuft of grass. He is the Virginia Rail, an odd-looking bird about the size of a Snipe. If you remain motionless, he may presently come out into fairer view and walk slowly around the edge of some pool, lifting and putting down his large feet with curious deliberation, cocking up his absurdly short tail at each step, and every now and then stopping to thrust his bill deep into the ooze in search of food. As he pauses to look at you, you are struck by his half-quizzical, half-sinister expression, due, no doubt, to the fact that his eyes are blood-red and deeply sunk in their long, narrow head. Startle him by some sudden movement, and he will do one of three things-dart back into cover as swiftly as a frightened mouse, skip across the pool over the floating leaves cf the water plants, using both wings and feet, or rise with feebly fluttering wings and hanging legs to fly only a few rods before dropping beyond some intervening screen of grass or bushes. In any case you are not likely to find him again on this occasion.

Besides the grunting sound, the Virginia Rail utters during the breeding season, especially at night and in lowering weather, a guttural cut, cutta-cuitta-cutta, often repeated at brief intervals for hours in succession. This ery appears to be peculiar to the male, and is, no doubt, his love song. When hearl at a distance of only a few yords it has a vibrating, almost unearthly quality, and seems to issue from the ground directly beneath one's feet. 'The female, when anxious about her eggs or young, calls $k i-k i$-ki in low tones, and kiu much like a Flicker. The young of both sexes in autumn give, when startled, a short, explosive kep or kil, closely similar to that of the Carolina Rail.

Williail Brewster. 
214. Porzana carolina (Limn.). Sora; Carolina Rail. (See Fig. 22, c.) Ad.-Region about the base of the bill, center of crown, and a line down the middle of the neck black; rest of the breast and throat, sides of the head, and front part of the crown pale blue-gray; rest of the upper parts olive-brown, most of the feathers with black centers, the scapulars and back streaked on either side with white; wings fuscous-brown, their coverts grayish cinnamon, outer edge of first primary white; lower belly white, flanks barred with black and white. Im.-Similar, but without black at the base of the bill or on the throat; breast washed with cinnamon and upper parts darker. L., 8.50; W., 4.30; Tar., $1 \cdot 30 ;$ B., $\cdot 80$.

Kange--Breeds from Kansas, Illinois, and Long Island northward to Ifudson Bay; winters from South Carolina to northern South America.

Washington, common T. V., Mch.; July to Nov. Long Island, common T. V., Apl. and May; Aug. to Oet.; rare S. R. Sing Sing, common T. V., May; Aug. 19 to Oet. 24. Cambridge, very common S. R., Apl. 20 to Oct. 20.

West, of grasses, on the ground in marshes. Eggs, eight to fifteen, buffy white or ochraccous-buff, spotted and speckled with rufous-brown, 1.24 × 90 .

'The Soras' summer home is in fresh-water marshes, where, if it were not for their notes, the reeds and grasses would long keep the secret of their presence. But knowing their calls, you have only to pass a May or June evening near a marsh to learn whether they inhabit it. If there, they will greet you late in the afternoon with a clear whistled ker-wee, which soon comes from dozens of invisible birds about you, and long after night, has fallen it continues like a springtime chorus of piping hylas. Now and again it is interrupted by a high-voiced, rolling whimy which, like a call of alarm, is taken up and repeated by different birds all over the marsh.

They seem so absorbed by their musical devotions that eren when calling continuously it requires endless patience and keen eyes to see the dull-colored, motionless forms in places where one would not suppose there was sufficient growth to conceal them.

Floating silently near the shore on my back in a canoe, I have seen them venture out to feed. With tails erect they step gingerly along. evidently aware of their exposed position, for on the least alarm they dart back to corer. Sometimes they cross small streams by swimming, and they are expert divers.

In the fall they gather in the wild-rice or wild-oat (Zizania aquatiect) marshes, and a well-directed stone or unusual noise may bing a series of protesting interrogative kuks or pepps from the apparently deserted reeds. At this season "gunners" in small flat-bottomed boats are poled through the flooded meadows, and the Soras, waiting until the last moment, rise on feeble wing-a mark which few can miss. Numerous puffi of smoke float over the tall grasses, and the dull reports come bonming across the marsh with fateful frequeney. 
The Spotted Crake (213. Porzana porzana)-an Old World representative of our Sora-is recorded as "occasional in Greenland."

215. Porzana noveboracensis ( $G$ mel.). Yellow RaIl. (See Fig. 22, b.) Ad.-Upper parts black, the feathers bordered with ochraceous-buff and with from one to three narrow white bars; breast ochraceous-buff ; middle of the belly white; sides and lower belly black or brownish, barred with white. L., 7.00; W., $3 \cdot 40$; Tar., $95 ;$ B., 52.

Range._-Eastern North America from Nova Seotia and Hudson Bay west to Utah and Nevada; no extralimital record except Cuba and the Bermudas" (A. O. U.).

Washington, rare T. V., Meh. and Oct. Long Island, uncommon T. V. Cambridge, rare 'T. V., Apl. and May; Oct. and Nov.

Nest, on the ground in grassy marshes. Eggs, six or more, creamy buff, densely sprinkled and speckled on larger end with rusty brown, $1 \cdot 12 \times \cdot 83$ (Ridgw.).

'This little Rail inhabits marshes with others of its family. With them it seems to know that it can escape its enemies much more easily by hiding in the tangled grasses of its home than by taking wing, and it flies only to avoid actual capture. It can be hunted successfully, therefore, only with dogs.

Nuttall describes its notes as "an abrupt and cackling cry, ' $/ r^{\prime} k$, 'krèk, 'krèk, 'krek, 'kuk, 'k'kh," and compares them to the croaking of the tree frog.

216. Porzana jamaicensis (Gmel.). Little Black Rail. Ad.Head, breast, and upper belly slate-color; lower belly, back, and wings brownish black, barred or spotted with white; nape dark reddish brown. L., $5 \cdot 00 ;$ W., $2 \cdot 80 ;$ Tar., $\cdot 80 ;$ B., $\cdot 60$.

Range.- "Temperate North America, north to Massachusetts, northern Illinois, and Oregon; south to West Indies and in western South America to Chili" (A. O. U.). Probably breeds throughout its North America range.

W ashington, rare T. V., several in Sept. Long Island, rare T. V.

Nest, of grasses, on the ground in marshes Eggs, ten, white, thinly sprinkled with reddish brown dots, more numerous at the larger end, $1.00 \times \cdot 80$ (Nelson, Bull. Nutt. Orn. Club, i, 1876, p. 43).

This bird is about as difficult to observe as a field mouse. It is said to prefer grassy meadows, where, like others of its family, it never flies when it can escape by running or hiding. It is apparently not common. The only description of its notes I know of is given by Mr. March, of Jamaica, who, as quoted by Dr. Brewer, writes its call as "chi-chi-cro-croo-croo, several times repeated in sharp, high-toned notes, so as to be audible to a considerable distance."

'The Corn Crake (21\%. Crex crex), a bird of Europe and northern Asia, is casual in Greenland, Bermudas, and eastern North America. It is about the size of a Clapper Rail, but has a bill no larger than that of the Sora. The 
general color of the upper parts is between ochraceous-buff and cream-buff, the feathers with black centers; the wing-coverts and most of the quills are pale rufous; the breast is pale ochraceous-buff; the sides are the same, barred with white; the middle of the belly is white.

218. Ionornis martinica (Linn.). Purple (xallintle. Ad.-Front of the crown with a bare bluish plumbeous plate; rest of the head and under parts rich dark purplish blue; under tail-coverts white; back shining olivegreen; wings light blue, tinged with greenish; bill earmine, tipped with pale greenish (in skins, reddish orange, tipped with yellowish); legs yellow. Im. -Upper parts more or less washed with brownish; under parts more or less mottled with white; plate on the head smaller; bill without orange-red. Downy young.-Glossy black, head with numerous white, hairlike feathers; base of the bill yellowish, end black. L., $13 \cdot 00 ;$ W., $7 \cdot 10$; Tar., $2 \cdot 40$; B. from posterior margin of nostril, $\cdot 80$.

Kange.-Tropical America; breeds as far north as southern Illinois and South Carolina, and rarely strays northward to Wisconsin and Maine; winters from southern Florida southward.

Long Island, A. V.

Nest, a platform of reed stalks built in rushes over the water or in grassy marshes. Eggs, eight to ten, buffy white, finely speckled with rufous-brown, $1 \cdot 60 \times 1.15$.

This is a common bird in the Southern States. It winters from southern Florida southward and migrates northward in April. It is generally found associated with the Florida Gallinule, which it resembles in habits, but its much brighter color is apparent at a distance.

219. Gallinula galeata (Licht.). Flondd Galdinte. (See Fig. $22, d_{\text {. }}$ Ad.-Dark bluish slate-color; back and scapulars washed with olivebrown; belly whitish; flanks with a few conspicuous white streaks; under tail-coverts white; crown with a bare, bright-red plate; bill the same color tipped with yellowish; legs greenish, reddish at the tibiæ. Im.-Similar, but under parts grayish white; crown plate much smaller and with the bill brownish; no red on the legs. Downy young.-- "Glossy black, the lower parts sooty along the median line; throat and cheeks interspersed with silvery white hairs" (Ridgw.). L., 13.50; W., 7.00; Tar., 2.15 ; B. from posterior margin of nostril, 80 .

Range.-Temperate and tropical America; breeds locally as far north as Minnesota and southern Maine; winters from the Gulf States southward.

Washington, rare T. V., Apl.; Aug. to Oet. Long Island, uncommon T. V., May; Sept. and Oct. Sing Sing, rare S. R., June 5 to Nov. 5. Cambridge, uncommon S. R., May 10 to Oct. 1.

Nest, of rushes on a bed of rushes or similar slight elevation in marshes, lagoons, or swampy lake sides. Eggs, eight to thirteen, buffy white or ochraceous-buff, spotted and speckled with rufous-brown, 1.80 × 1.25.

There is something about the appearance and habits of Callinules which always suggests to me the thought that they are chicliens who 
for unknown reasons have been forced to adopt the ways of both Coots and Rails. Indeed, now I think of it, the names Water-hen and Noorhen are applied to near relatives of our bird.

They frequent marshy, reed- or bush-grown shores of ponds and lakes, walking gracefully through the tangled regetation. Their flight is short and, like a Rail, with dangling legs they drop awkwardly to the ground. They swim readily, and when on the water resemble a Coot, though they are by no means so aquatic. Their notes are loud and varied, and during the nesting season they are unusually noisy. Their common note is a loud, explosive chuck; other calls are suggestive of the barnyard, and remind one of the protest of a disturbed brooding hen or even the squawking of a struggling fowl. In The Auk, vol. viii, pages 1-7, Mr. Brewster gives a detailed account of his study of a pair of Gallinules.

221. Fulica americana Gmel. American Coot; Mud-hen; Crow Duck; Blue Peter. (See Fig. 22,e.) Ad.-Head and neck blackish; rest of the plumage dark, bluish slate-color, paler below; edge of the wing, tips of the secondaries, and under tail-coverts white; bill whitish, two spots near its tip and crown plate brownish; legs and feet greenish; toes with scalloped flaps. Im.-Similar, but much whiter below, a slight brownish wash above; crown plate much smaller. Downy young.-Blackish, white below; throat and upper parts with numerous bright orange hairlike feathers; lores red; bill red, tipped with black. L., $15 \cdot 00 ;$ W., $7 \cdot 50$; Tar., $2 \cdot 25 ;$ B. from posterior margin of nostril, $\cdot 80$.

Remarks. - The Coot bears a general resemblance to the Florida Gallinule, but, aside from the differenees in color, the scalloped webbed feet of the Coot will always serve to distinguish them.

Range.-North America as fur north as Alaska and New Brunswick, and casually Greenland; breeds locally throughout its range; rather rare on the Atlantic coast during the nesting season.

Washington, common T. V., Meh. to May; Sept. to Oct. 15. Long Island, uncommon T. V., Apl.; not uneommon, Sept. to Nov. Sing Sing, common T. V., Apl. 28 to May 16 ; Sept. 22 to Nov. 13. Cambridge, T. V., rare in Apl. ; common Sept. to Nov.

Nest, of reeds, grasses, etc., among reeds in fresh-water marshes. Eggs, eight to fifteen, pale, buffy white, finely and uniformly speckled with chocolate or black, $1.85 \times 1.25$.

As one might imagine after seeing their lobed feet, Coots are more. aquatic than either of the Gallinules. In the Middle States they are found in creeks and rivers with marshy and reed-grown shores, while in Florida they resort in enormous numbers to lakes covered with the yellow lilies locally known as "bonnets" (Nuphar); and in some of the large, shallow rivers, like Indian River, they may be found in myriads, associated with Lesser Scaup Ducks.

In $m y$ experience they are as a rule quite shy; but near the long 
railway pier at Titusville, Florida, where shooting is prohibited, they are as tame as domestic Ducks. 'They evidently know the boundary line between safety and danger, however, and whęn beyond the protected limits show their usual caution.

Coots swim easily, with a peculiar bobbing motion of the head and neck. When alamed they patter over the water, using their feet as much as their wings. The sound produced is a characteristic one.

They are noisy birds, and when alarmed break out into a great chorus of high, cackling notes which I have heard at a distance of half a mile. Their irory-white bill is an excellent field mark, and readily serves to distinguish Coots from Gallinules.

The European Соoт (220. Fulica atra) inhabits the northern parts of the Old World, and sometimes oceurs in Greenland. It closely resembles the American Coot, but lacks the white markings on the edge of the wing and under tail-coverts.

\section{ORDER LIMICOL E. SHORE BIRDS.}

\section{Family Phalaropodida. Phalaropes.}

There are three known members of this family: one is confined to the interior of North America, the other two may be called Sea Snipe, and are found in the northern parts of the northern hemisphere. 'The webbed feet of these pelagic species enable them to swim with ease, and during their migrations they may be found in flocks resting upon the sea far from land. Their presence on our shores is largely dependent upon the weather, and during severe storms many are sometimes found upon our coasts. Contrary to the usual rule, the female in this family is the larger and more brightly colored-indeed, in the domestic economy of the Phalarope household the female is male, except in the prime essentials of sex. She does the wooing, takes the lead in selecting the nesting site, and, although she lays the eggs, the duties of incubation fall upon the male.

KEY TO THE SPECIES.

A. Bill over $1 \cdot 10$

221. Wilson's Phalarope.

B. Bill under $1 \cdot 10$.

a. Bill very slender; wing under 4.75. . 223. Northern Phalarope.

b. Bill stout; wing over 475 . . . . . . . 222. Red Phalarope.

222. Crymophilus fulicarius (Linn). Ren Phalarope; (iray Pitalarope. (See Fig. 26, a.) Ad. in summer.--Crown and ehin fuscous; cheeks white; back black, the feathers bordered with cream-buff; wings gray; some of the secondaries and tips of greater corcrts white; upper tail- 
coverts rufous; under parts dull, reddish brown. Ad. in winter.-Top of the head and under parts white; region about the eye and back of the neck fuscous; back and scapulars dark pearl-gray; wings grayish fuscous, the coverts and secondaries tipped with white; rump and tail fuscous. Im. - "6' 'Top of the head, hind neck, back, and seapulars dull black, the feathers edged with ochraceous; wing-coverts, rump, and upper tail-coverts plumbeous, the middle coverts bordered with pale buff, the tail-coverts with ochraceous; head and neek (except as described above) and lower parts white, the throat and chest tinged with brownish buff. L., 8.12; W., 5.37; B., 87 ; Tar., •82" (Ridgw.).

liange.- "Northern parts of northern hemisphere, breeding in the aretic regions and migrating south in winter: in the United States, south to the Middle States, Ohio Valley, and Cape St. Lucas; chiefly maritime". (A. O. U.).

Washington, casual, one record, Uct. Long Island, not uncommon T. V., May ; Aug. to Nov.

Nest, a slight hollow in the ground lined with a few bits of moss and grasses. Eggs, three to four, similar to those of the following species, $1.25 \times \cdot 90$.

This pelagic species is found in numbers some distance off our coasts; it occurs on land rarely, and generally only after storms.

223. Phalaropus lobatus (Linn.). Nortiers l'halarope. Ad. i in summer.-Upper parts slaty gray; back and scapulars edged with ochraceousbuff; sides and front of the neck rufous, more or less mixed with slaty gray; rest of under parts white. $A d$. o in summer.--Similar, but upper parts black, and with more ochriceous; sides and front of the neck mixed with fuscous. $A d s$. in winter.-Upper parts grayish, more or less mixed with white; tips of greater wing-coverts and sometimes part of the secondaries white, occasionally with traces of rufous on the sides of the neck; under parts white, more or less mottled with grayish on the breast. Im.-Upper parts black, edged with straw-color; forehead white; under parts white, breast sometimes lightly washed with buffy. L., 7.75 ; W., 4.50 ; Tar., $\cdot 80$; B., 85 .

Range.-- Northern portions of the northern hemisphere, breeding in aretic latitudes; south in winter to the tropics" (A. O. U:).

Washington, casual, one record, Sept. Long Island, common T. V., Aug. to Nov. ; May.

Nest, a slight hollow in the ground lined with grass and mosses. Eggs, three to four, pale olive-gray heavily blotched with deep chocolate, $1 \cdot 18 \times \cdot 83$.

During its presence off our coasts this species resembles the preceding in habits. It is, however, more common, and under proper conditions sometimes occurs in larger flights. I have seen it in great numbers about one hundred miles off Barnegat. New Tersey, in May. For sereral hours the steamer passed through flocks of these Sea Snipe, which were swimming on the ocean. They arose in a body at our approach, and in close rank whirled away to the right or left in search of new feeding grounds.

224. Phalaropus tricolor (Tieill.). Wirson's Phalarore. $A d$. \& in summer.-Top of the head and middle of the back pearl-gray, nape 
white; a black streak passes through the eye to the side of the neck and, changing to rufous-chestnut, continues down the sides of the back and on the scapulars; neck and upper breast washed with pale, brownish rufous ; rest of the under parts and upper tail-coverts white. Ad. o in summer.-Upper parts fuscous-brown, bordered with grayish brown; upper tail-coverts, nape, and a line over the eye white or whitish; sides of the neck and breast washed with rufous; rest of the under parts white. Ads. in winter.-Upper parts gray, margined with white; upper tail-coverts white; wings fuscous, their coverts margined with butfy; under parts white. Im.- "I'op of head, back, and scapulars dusky blackish, the feathers distinctly bordered with buff; wingcoverts also bordered with pale buff or whitish; upper tail-coverts, supereiliary stripe, and lower parts white, the neck tinged with buff" (Ridgw.). o L., S.75; W., 4.75; Tar., 1*20; B., 1*20. \& L., 9.50; W., 5.25; Tar., 1.30; B., 1.30.

Range.- "Temperate North America, chiefly in the interior, breeding from northern Illinois and Utah northward to the Saskatehewan region; south in winter to Brazil and Patagonia" (A. O. U.).

Long Island, casual, Aug., Sept., and Oet.

Nest, a shallow depression in soft earth lined with a thin layer of fragments of grass. Eggs, three to four, cream-buff or buffy white, heavily blotched with deep chocolate, $1.28 \times 94$. (See Nelson, Bull. Nutt. Orn. Club, ii, 1879, pp. 38-43.)

"These birds are rare in the Eastern States, abundant in the Mississippi Valley, and quite common westward within their range. They inhabit the marshes, swales, and edges of shallow ponds, feeding upon minute snails and other small forms of life that abound in their aquatic haunts, procuring the same chiefly by ruming over the moist ground or wading in the short growths of water grasses. They swim buoyantly, but seldom long at a time or far from the shore, and I never saw one dive or make an attempt to do so, but, when frightened, prefer to escape by flight, which is strong, but at such times in a zigzag and wavy manner, dropping back as soon as out of danger. As a rule they are not timid, and are easily approached. Their motions, whether upon the land or water, are easy and pleasing. gracefully nodding the head or picking from side to side as they go" (Goss).

\section{Faimly Recurvirostrid F.. Avocets and Stilts.}

The eleven species comprising this family are distributed throughout the warmer parts of the world. They are generally found in flocks, and may be called Wading snipe. They feed in shallow water, wading to their heels, and when necessary swimming with ease.

225. Recurvirostra americana (rmel. AMERIN AVOCET. Ad. in summer.-Head and neck cinnamon-rufous, back and tail white, scapulars and primaries black; middle coverts, tips of the greater ones, and part of secondaries white; belly white, bill turned upward. Ad. in winter and Im.- 
Generally similas, but head and neck white or pearl-gray. L., 16.50 ; W., !).00: 'Tar., $3 \cdot 75 ;$ B., $3 \cdot 75$.

Range-Cemperate North Anerica; rare or accidental on the Atlantic coast; breeds from Illinois, and rarely Texas, nerthward to the Saskatchewan; winters along the Gulf coast and southward.

Long Island, A. V.

Nest, a slight depression in the ground in marshy places. Eggs, three to four, pale olive or buffy clay-color, thickly spotted with chocolate, 1.95 × 1.35.

A vocets are common birds in parts of the interior, but are rare on the Atlantic coast. They frequent shores and shallow pools, and in searching for shells, crustaceans, etc., their peculiar recurved bill is used in a most interesting manner. Dropping it beneath the surface of the water until its convexity touches the bottom, they move rapidly forward, and with every step swing their bill from side to side, as a mower does his scythe. In this way they secure food which the muddy water would prevent them from seeing.

226. Himantopus mexicanus ( Müll.). BLA(K-NECKED S'TILT. Al. 8.- A white spot above and another below the eye; front of the head, front of the neck, lower back, rump, and under parts white; tail grayish; rest of the plumage glossy, greenish black. Ad. \&.-Similar, but with the back fuscous-brown. Im.- Similar to the preceding, but head and neck more or less marked with white; back and seapulars bordered with white or whitish. L., $15 \cdot 00$; W., $9 \cdot 00$; Tar., $4 \cdot 15 ;$ B., 2.00 .

Range.-Tropical America, breeding northward to the Gulf coast and "locally and rarely" up the Mississippi Valley as fur as Minnesota; rare on the Atlantic coast north of Florida, but straying sometimes as fur as Maine.

Long Island, A. V.

Nest, a slight depression in the ground lined with grasses. Eqgs, three to four, olive or buffy clay-color, thickly spotted with chocolate, $1.70 \times 1 \cdot 25$.

Stilts are fond of wading in shallow ponds in salt marshes, and are graceful and alert in their movements. During the nesting season they become very noisy, and at nightfall I have heard them utter their froglike croak as they darted erratically about over the marshes.

\section{Fanily Scolopacid Ae. Snipes, Sandpipers, etc.}

About one hundred species are considered as belonging to this family. They are distributed throughout the world, but during the breeding season are mostly confined to the northern parts of the northem hemisphere. Some forty-five species are found in North America. With the Plovers they constitute the great group known as Shore Birds or Bay Birds, and with few exceptions they are rarely found far from the vicinity of water. Generally speaking, they are more abundant on the coast than in the interior, but many species are quite as numerous inland as they are near the sea. As a rule, they migrate 
and pass the winter in flocks, but they are not gregarious during the nesting season.

Their long bills serve the purpose of both probes and forceps. Most of the species probe the soft mud for food, while some are known to have the power of moving the upper mandible independently of the lower one, curving it at the tip as one would a finger.

Snipes are not supposed to be song birds, but during the breeding season many species are highly and peculiarly musical, and at other times of the year they utter characteristic whistles. These are susceptible of imitation, and the birds are quick to respond to an imitation of their notes. The sportsman concealed in his "blind," therefore, calls to passing birds, and with the aid of wooden decoys easily draws them within gunshot.

I. Bill 2:00 or over.

$$
\text { KEY TO THE SPECIES. }
$$

A. Axillars * barred with black.

a. Bill curved downward.

a1. Bill over 3.00, under 4.50 . . . . . 265. Hudsonian Clirlew. $a^{2}$. Bill under 3.00 . . . . . . . . 266. Essmo Curlew. $a^{3}$. Bill over 450 . . . . . . 264. Long-billed Curlew.

b. Bill straight or curved slightly upward.

$b^{1}$. Tail-feathers with numerous black bars.

$l^{2}$. Wing over $7 \cdot 00$, primaries black or fuscous.

254. Greater Yellow-Legs.

$b^{3}$. Wing over $7 \cdot 00$, inner web of primaries buff or rufous.

249. Marbled Godwit.

64. Wing under $7 \cdot 00$, bill widened and pitted at the tip.

231. Dowitcher. 232. Long-Billed Dowitcher.

c. Tail black with a broad rufous tip or marked with rufous.

$c^{2}$. Outer web of primary with rufous bars.

$c^{3}$. Primaries not barred . . . . . 230. Wilson's Snipe.

B. Axillars not barred.

a. Axillars rufous or ochraceous-buff.

$a^{1}$. Bill over 5.00, much curved downward.

264. Long-billed Curlew.

$a^{2}$. Bill nearly straight, between 3.50 and 5.00 .

249. Marbled Godwit. $a^{3}$. Bill straight, under 3.50 . . . . 228. AMERICAN Woodcock.

b. Axillars black.

$b^{1}$. Under parts chestnut-rufous, barred with black.

251. Hudsonian Godwit.

$b^{2}$. Under parts white, with or without blackish bars.

258. Willet. 258a. Western Willet. 
II. Bill under $2 \cdot 00$.

A. Tail with cross-bars.

a. Wing over $5 \cdot 75$.

$a^{1}$. Outer tail-feathers white, more or less barred; outer primary withnut bar's . . . . . . . . . . . 25J. Yellow-legs.

$a^{2}$. Outer primary with numerous black bars.

b. Wing under $5 \cdot 75$.

261. Bartranian Samppiper.

(1. Under parts white, with numerous round blackish spots; upper parts brownish gray, barred with blackish . 263. Spotted SAndpiper.

$b^{2}$. Under parts white, breast streaked with blackish; upper parts fuscous, spotted with white . . . . 256. Solitary Sandpiper.

$b^{3}$. Under parts tinged with buffy, inner web of outer primary speckled with blackish . . . . . . 262. Buff-breasted Sandpiper.

$b^{4}$. Under parts white, breast washed with grayish, inner primaries and secondaries with a concealed white patch.

263. Spotted Sandpiper (Im.).

B. Tail without cross-bars, toes 4 .

a. Bill over $1 \cdot 10$.

$a^{1}$. Middle upper tail-coverts with cross-bars or streaks.

$a^{2}$. 'Tarsus over 1.50 . . . . . . 233. Stmit SAndpiper.

$a^{3}$. Tarsus under 150 , wing under 6.00 . 244. Curlew Sandpiper.

$a^{4}$. Tarsus under 1.50, wing over 6.00 . . . . . 234. Клот.

b1. Middle upper tail-coverts black or fuscous, without bars; bill straight.

$b^{2}$. 'Tarsus under 1.50 ; upper parts blackish, more or less margined with gray . . . . . . . . . 235. Purple Sandpiper.

$b^{3}$. Tarsus under 1.50 ; upper parts more or less margined with rufous. 239. Pectoral Sandpiper.

$b^{4}$. Tarsus over 1.50 . . . . . . . . . 260. Ruff.

c. Middle upper tail-coverts grayish, bill curved slightly downward.

243 $\alpha$. Red-EACKed SANDPIPER.

5. Bill under $1 \cdot 10$.

$b^{1}$. Wing under 4.00 .

$b^{2}$. Toes partly webbed.

246. Semipalmated Sandpiper. 247. Westetin Sandpiper.

$b^{3}$. Toes not webbed . . . . . . 242. Least Sandpiper.

c. Wing over $4 \cdot 00$, inner webs of primaries plain.

$c^{2}$. Breast white or whitish, streaked or spotted with blackish; middle upper tail-coverts white . 240. White-rumped Sandpiper.

$c^{3}$. Breast buffy, heavily spotted or streaked with blackish; middle upper tail-coverts black, slightly margined with rufous.

239. Pectoral SANDPiper.

$c^{4}$. Breast buffy lightly spotted or streaked with black; middle upper tail-coverts fuscous, lightly margined with buffy.

241. Baird's Sandpiper.

d1. Wing over $4 \cdot 00$, inner webs of primaries speckled.

262. Buff-breasted Sandpiper.

C. Tail without cross-bars, toes 3 . . . . . 248. SAnderLing. 



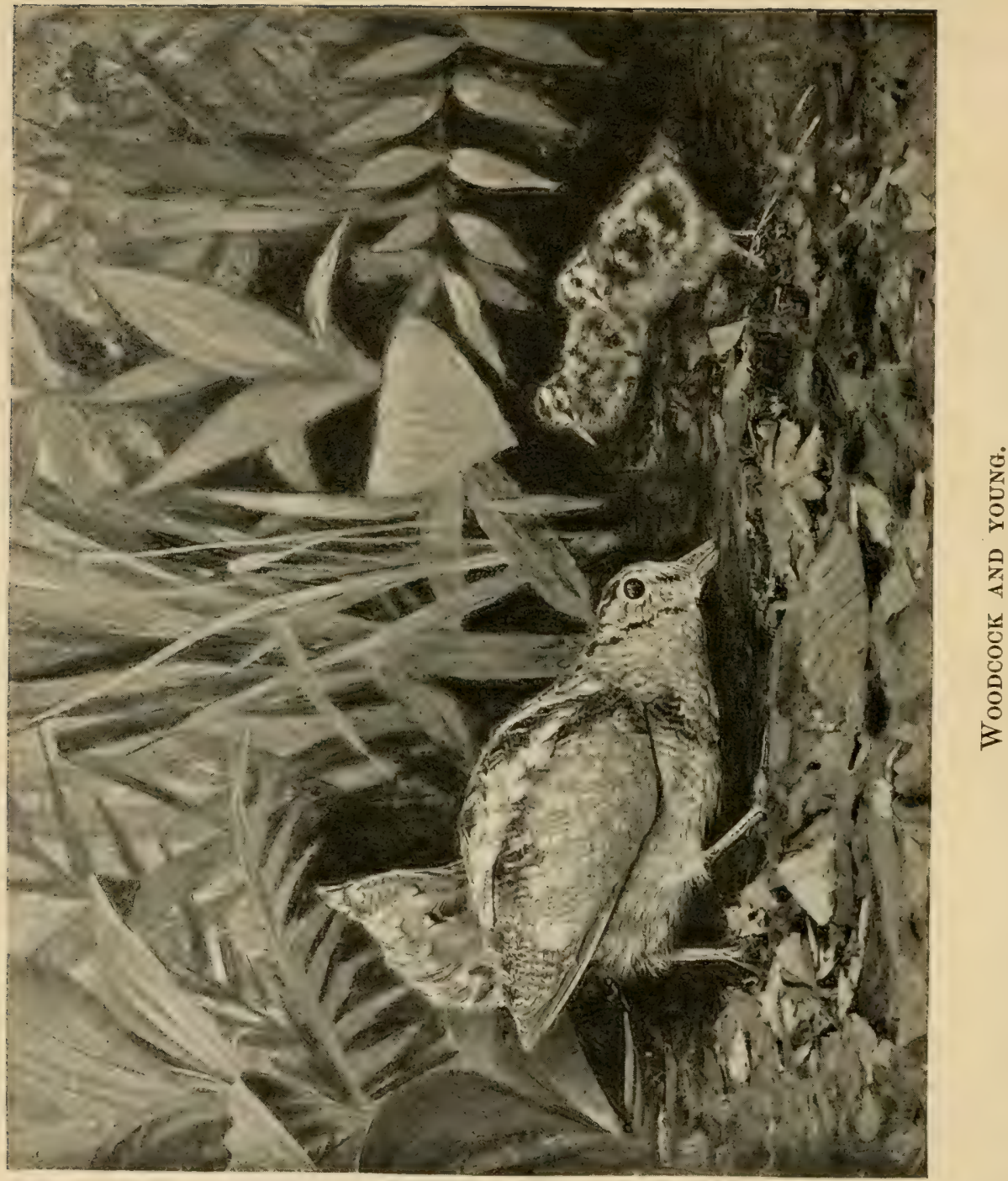


228. Philohela minor (Gmel.). A Merican Woodcock. Ad.-Front of the erown slaty, washed with buff, an indistinct blackish line in its center, and another from the eye to the bill; back of the head black, with two or three bars of ochraceous-buff'; rest of the upper parts black, margined with slaty and barred and mottled with rufous or ochraceous-buff; tip of the tail ashy gray above, silvery beneath; under parts between ochraceous-butf and rufous; three outer primaries very narrow and much stiffened. L., 11.00; W., $5 \cdot 40$; Tar., $1 \cdot 25 ;$ B., $2 \cdot 90$.

Range.-Eastern North America north to Labrador and Manitoba, breeding nearly throughout its range, but not commonly in the southern part of it; winters from southern Illinois and Virginia southward.

Washington, rather common from Feb. to Nov.; a few winter. Long Island, common S. R.; a few winter. Sing Sing, common S. R., Feb. 19 to Dec. 2. Cambridge, S. R., formerly common, fast becoming rare; Ilch. to Nov.

Nest, of a few dry leaves, on the ground in the woods. Eggs, four, butfy, distinctly and obscurely spotted with shades of rufous, $1.60 \times 1.23$.

During the spring and early summer tffis $O$ wl among Snipe haunts low, wooded bottom-lands; in August, while molting, it resorts to cornfields near woods, and in the fall migrating birds frequent wooded uplands. But at all times it requires a soft, moist earth in which it may easily probe with its long bill for its fare of earthworms. The holes it makes are known as "borings." They are generally found in little groups, and are, of course, certain evidence of the presence of Woodcock. It has recently been discovered by Mr. Gurdon Trumbull that the Woodeock can more the tip of its upper mandible independently of the lower one, and this organ is made to act as a finger to assist the bird in drawing its food from the ground.

The flight of the Woodeock is sometimes accompanied by a high, whistling sound produced by its narrow, stiffened primaries in beating the air. When flushed near its nest or young, the parent bird generally feigns lameness or a broken wing, and leads the intruder some distance from its treasures before taking wing.

The cloak of night always lends a certain mystery to the doings of nocturnal birds, and more often than not their habits justify our unusual interest in them. How many evenings have I tempted the malaria germs of Jersey lowlands to watch the Woodcock perform his strange sky dance! He begins on the ground with a formal, periodic peent, peent, an incongruous preparation for the wild rush that follows. It is repeated sereral times before he springs from the ground and on whistling wings sweeps out on the first loop of a spiral which may take him 300 feet from the ground. Faster and faster he goes, louder and shriller sounds his wing-song; then, after a moment's pause, with darting, heallong flight, he pitches in zigzags to the earth, uttering as he falls a clear, twittering whistle. He generally returns to near the 
place from which he arose, and the peent is at once resumed as a preliminary to another round in the sky.

The European Woodcock (22\%. Scolopax rusticola) bear's a general resemblance to our Woodeock, but is much larger; the under parts are barred with black, the wings are barred with rufous, and the outer primaries are not emarginate. It is of accidental occurrence in eastern North America.

230. Gallinago delicata $(O r d)$. Wilson's Snipe; Evglisil Snipe. Ad.-Upper parts black, barred, bordered, and mottled with different shades of cream-butf; wings fuscous ; outer edge of outer primary and tips of greater coverts white; throat white; neck and breast ochraceous-buff, indistinctly streaked with blackish; belly white, sides barred with black; under tailcoverts buffy, barred with black; outer tail-feathers barred with black and white, inner ones black, barred with rufous at their ends and tipped with whitish. L., 11.25; W., 5.00; Tar., 1.20; B., 2.50.

Range.-North America, breeding from southern Minnesota, northern Illinois, northwestern Pennsylvania, and Connecticut north ward to Fludson Bay and Labrador, and wintering from southern Illinois and South Carolina to northern South Ameriea.

Washington, common T. V., Meh. to May 5 ; fall; occasional in winter. Long Island, common T. V., Meh. and Apl.; Aug. to Oct. Sing Sing, tolerably common 'T. V., Meh. 20 to May 6; Oct. 6 to Nov. 20. Cambridge, common T. V., Apl. 5 to May 5 ; Sept. and Oet.

Eggs, three to four, olive, clay-color, or brownish ashy, heavily marked with chocolate, principally at the larger end, $1 \cdot 60 \times 1 \cdot 17$.

Wilson's Snipe frequents fresh-water meadows and swamps, and in spring is often found in low-lying swales in meadows or mowing fields, but, excepting in very dry seasons, it seldom alights on salt marshes. At times, especially in winter or early spring, when the meadows are covered with snow or ice, it resorts to springy runs wooded with alders, birches, and maples, but as a rule it prefers open places. Two things are essential to its requirements-ground so thoroughly water-soaked as to afford slight resistance to its long and highly sensitive bill when probing, and such concealment as tussocks, hillocks, or long grass afford, for, unlike the Sandpipers, the Snipe rarely ventures out on bare mud flats, save under corer of darkness. Although less strictly nocturnal than the Woodcock, it feeds and migrates chiefly by night or in "thick" weather. Its migratory movements are notoriously erratic, and meadows which one day are alive with birds may be quite deserted the next, or the reverse.

Dear to our sportsmen is Wilson's Snipe, partly because of the excellence of its flesh, but chiefly from the fact that it furnishes a mark which taxes their skill to the utmost, and which no mere novice need hope to hit, unless by accident ; for the bird's flight is swift and tortuous, and it springs from the grass as if thrown by a catapult, uttering 
a succession of hoarse, rasping scaipes which have a peculiarly startling effect on inexperienced nerves.

In the springtime-and occasionally in autumn also-Wilson's Snipe mounts to a considerable height above his favorite meadows and darts downward with great velocity, making at each descent a low yet penetrating, tremulous sound which suggests the winnowing of a domestic Pigeon's wings, or, if heard at a distance, the bleating of a goat, and which is thought to be produced by the rushing of the air through the wings of the snipe. 'This performance may be sometimes witnessed in broad daylight when the weather is stormy, but ordinarily it is reserved for the morning and evening twilight and for moonlight nights, when it is often kept up for hours in succession.

Besides this "drumming" or "bleating," as it is called, the Snipe, while mating, sometimes makes another peculiar sound, a liǔk-kiŭkkiǔk-kiŭk-kiŭp, evidently rocal and occasionally accompanying a slow, labored, and perfectly direct flight, at the end of which the bird alights on a tree or fence post for a few moments.-Wildiam Brewster.

The Europeax Snipe (229. Gallinago gallinago) inhabits the northern parts of the Old World, is of frequent occurrence in Greenland, and accidental in the Bermudas.

231. Macrorhamphus griseus (Gmel.). Dowither. (Sce Figrs. 25, a, 26, c.) Ad. in summer.-Upper parts, tertials, and wing-coverts black, the feathers edged or barred with ochraceous-buff' or rufous; rump, upper tailcoverts, and tail barred with black and more or less ochraceous-buff; primaries fuscous; under parts dull, pale rufous, whitish on the belly, more or less spotted and barred with black. Ad. in winter.-Upper parts brownish gray; rump and tail barred with black and white; throat and breast washed with ashy, belly white, sides and under tail-coverts barred with black. Im.-Upper parts black, the feathers edged with rufous; rump and tail barred with black and white, and sometimes washed with rufous; secondaries widely edged with white; under parts more or less washed with ochraceous-buff and obscurely spotted with blackish. L., $10 \cdot 50$; W., $5 \cdot 75$; Tar., $1 \cdot 30 ;$ B., 2.05-2.50.

Remarks.-The barred tail and tail-coverts, with the peculiar flattened, pitted tip of the bill, are characteristic of this and the next species.

Range,-Eastern North America, breeding within the Aretic Cirele, and wintering from Florida to South America.

Washington, easual, one specimen, Sept. Long Island, common T. V., May; July to Sept. 15.

Eggs, four, light buffy olive, distinctly spotted and speckled, especially about the larger end, with deep brown, $1.65 \times 1.13$ (Ridgw.).

The Dowitchers are among our best-known Bay Birds. They migrate in compact flocks which are easily attracted to decors by an imitation of their call. Mud-flats and bars exposed by the falling tide are their chosen feeding grounds. On the Gulf coast of Florida I have 
seen several hundred gathered in such elose rank that they entirely concealed the sandbar on which they were resting.

232. Macrorhamphus scolopaceus (Say). Lovg-BILled DowITCHER; Western DowtToher. Ad. in summer.-Similar to the preceding, but averaging larger; the bill especially is longer, the under parts are more uniformly rufous, and the sides are more heavily barred with black. $A d$. in winter and Im.-To be distinguished from the corresponding stages of $\mathbf{H}$. griseus only by their larger size. W., 6.00; Tar., $1 \cdot 50 ;$ B., 2.10-2.90.

Range.- " Mississippi Valley and western provinee of North America from Nexico to Alaska; less common, but of regular occurrence along the Atlantic coast of the United States" (A. O. U.).

Washington, casual, seven shot in Apl. Long Island, casual, July to Oct.

Eggs, four, not distinguishable from those of the preceding species.

This is a bird of the interior and Western States, and occurs on our coasts as a rare but regular late fall migrant. It resembles the preceding species in habits, but the baymen who "gun" for Snipe say they can recognize it by its somewhat different notes. Like the Woodcock, Wilson's Snipe, and its near ally, M. grisens, the male utters a flight song in the nesting season. It is well described by Mr. E. W. Nelson in his Report on Collections made in Alaska, p. 101.

233. Micropalama himantopus (Bonap.). Stilt SANdpiper. Ad. in summer.-Upper parts black, bordered with grayish and buffy; earcoverts and an indistinct line around the back of the head rufous; secondaries grayish, edged with white; primaries fuscous; rump ashy : upper tailcoverts barred with black and white; outer tail-feathers with broken dusky bars, inner ones with central streaks or margins of brownish gray or white; under parts white, heavily barred with fuscous. Ad. in winter.--Upper parts brownish gray; upper tail-coverts white; tail white, margined with brownish gray; under parts white; the throat, neck, and sides indistinetly streaked or washed with grayish. Im.- Similar to the preceding, but the upper parts blackish, margined with ochraceous-buff. L., $8.25 ;$ W., 5.00; Tar., 1.60; B., 1·55.

Remarks.-The distinguishing characters of this species are the flattened, pitted tip of the bill, in connection with the very long tarsi.

Range.-Eastern North America, breeding within the Arctic Circle, and wintering as far south as South America.

Washington, easual, one record. Long Island, not uncommon T. V., May ; July to Oct. 10.

Eggrs, three to four, pale grayish buff, or grayish buffy white, boldly spotted with fich vandyke-brown and purplish gray, $1.42 \times 1.00$ (Ridgw.).

Colonel N. S. Goss, in his admirable Birds of Kansas, writes that he has observed this species along the edges of old channels of rivers or muddy pools of water, in which it wades while feeding; immersing the head and feeling with its sensitive bill in the thin mud for food. It moves about rather slowly as compared with the true Sandpipers, and at times will try and avoid detection by squatting close to the 
ground, flying only as a last resort, and then darting swiftly away with a sharp tweet, tweet.

† 234. Tringa canutus Linn. Knot; Romin Snipe; Gray Snipe. (See Figs. 25, b, 26, b.) Ad. in summer.-Upper parts barred and streaked with black and white and rufous; tail ashy gray, narrowly margined with whitish ; under parts dull rufous; lower belly white or whitish, sides sometimes with black bars. (According to George H. Mackay, it requires about four years for birds to acquire this plumage. See Auk, x, 1893, p. 25.) Im.-Upper parts plain brownish gray; upper tail-coverts barred with black and white, tail brownish gray; breast and sides barred with black, belly white. Young.Upper parts pale brownish gray; head streaked with blackish; back, wingcoverts, and scapulars with distinct black and white borders; upper tail-coverts barred with blackish; tail ashy gray, narrowly margined with white; under parts white; breast finely streaked or spotted with blackish; flanks barred or streaked with blackish. L., 10.50; W., 6.75; 'Tar., 1.20; B., 1.30.

Range.-Northern hemisphere, breeding within the Aretic Cirele, and in America wintering from Florida to South America.

Long Island, not uncommon T. V., May 15 to June 10; July 15 to Nov.

Eggs, known from only one specimen collected in the vicinity of Fort Conger by General Greely, and described as "light pea-green, closely spotted with brown in small specks about the size of a pinhead," 1'10 × 1.00 (see Merriam, Auk, ii, 1885̃, p. 313).

Knots feed along the beaches on the small crustaceans and molIusca brought in by the wares, and they also frequent muddy places, where, like the true Snipe, they probe the ground for food. They decoy with ease, "bunching" so closely as they wheel into the stools that the entire flock is sometimes killed by a single discharge. Mr. George H. Mackay, in one of his careful and detailed studies of our Shore Birds, describes their notes as a soft wah-quoit and a little honk: The first is particularly noticeable when flocks are coming to the decoys (see Auk, x, 1893, pp. 25-35).

235. Tringa maritima Brïmn. Purple SAndpiper. Al. in summer.-Upper parts black, margined with ochraceous-buff and cream-buff; wings fuscous-gray, greater coverts margined with white and some secondaries entirely white; upper tail-coverts fuscous, outer tail-feathers ashy gray, inner ones fuscous; throat and breast brownish gray, streaked with black; belly white, sides and under tail-coverts streaked with brownish gray. Winter plumage.-Head, neck, breast, and sides ashy, the two latter margined with white; back fuscous, margined with ashy; wings fuscous, the coverts, secondaries, and tertials distinetly bordered with white; upper tail-coverts and middle tail-feathers black or fuscous, outer tail-feathers ashy; belly and linings of the wings white. L., $9 \cdot 00 ;$ W., $5 \cdot 00$; Tar., $9 \cdot 00 ;$ B., 1.40 .

Remarks.-The brownish gray or ashy breast of this species is a good distinguishing character.

Range._-" Northern portions of the northern licwisplere; in North Amer- 
Ica chiefly in the northeastern portion, breeding in the high north," south in winter to the Great Lakes and Long Island, and casually to Florida.

Long Island, uncommon W. V., Nov. 1 to Meh. 1. Cambridge, casual, one instance, Oct.

Eggs, three to four, olive clay-color or brownish ashy, heavily marked with rufous-brown, $1.45 \times 1.08$.

This bird might be called Winter Snipe or Rock Snipe. Indeed, I find the latter name has been applied to it from its habit of frequenting rocky coasts, where it secures its food in the alga attached to rocks exposed by the falling tide.

239. Tringa maculata Tieill. P'Ectoral SANDPIPER; Kirierer. Ad. in summer.-Upper parts black, the feathers all heavily bordered with pale ochraceous-buff; rump and upper tail-coverts black, lightly tipped with ochraceous-buff; middle tail-feathers longest, pointed and margined with butfy; outer tail-feathers brownish gray, narrowly margined with white; throat white, neck and breast heavily streaked with black and buffy; rest of under parts white. Winter plumage.-Similar, but ochraceous-buff of upper parts replaced by rufous, and breast heavily washed with buffy. L., 9.00; W., $5 \cdot 40$; Tar., $1 \cdot 10$; B., $1 \cdot 15$.

Remarks.-This bird somewhat resembles both $T_{\text {. }}$ fuscicollis and T. bairdii, but it differs from them in its larger size, black instead of white or fuscous upper tail-coverts, and longer, more pointed middle tail-feathers.

Range.-North America; breeds in the aretic regions and winters in the West Indies and South America.

Washington, common T. V., Apl.; Aug. to Nov. Long Island, T. V., rare in spring, common from July 15 to Nov. 1. Sing Sing, rare T. V., Sept. 10 to Oct. 16. Cambridge, irregular and uncommon in Sept. and Oct.

Eggs, four, drab, sometimes with a greenish tinge, blotched with clear amber-brown markings, more numerous at the larger end, 1.50 × 1.09 (Murdoch).

The names Grass Snipe and Krieker describe with equal truth and conciseness the haunts and notes of this Snipe. It frequents wet, glassy meadows rather than beaches, and, although it flies in flocks, the birds scatter while feeding and take wing one or more at a time. They thus remind one of Wilson's Snipe. Their note is a squeaky, grating whistle. They will respond to an imitation of it, but do not decoy so readily as the larger Bay Birds. Mr. E. W. Nelson writes* that during the breeding season the male inflates its breast and throat until they are double their normal size, and utters a deep, hollow, resonant note.

240. Tringa fuscicollis rieill. White-rimped SAxmpiper. $A d$. in summer.-Upper parts black, edged with rufous; rump grayish fuscous, margined with ashy; longer upper tail-coverts $w$ hite, with sometimes brownish-

* Rep. on Nat. Hist. Colls. made in Alaska, p. 108. 
gray markings; central tail-feathers fuscous, outer ones brownish gray ; upper throat white; neck, breast, and sides distinctly streaked and spotted with black and more or less washed with ochraceous-buff. Winter plumage."Upper parts plain browuish gray, with indistinct, narrowed, mesial streaks of dusky; otherwise as in summer, but streaks on chest, etc., less distinct" (Ridgw.). Im.-Similar to summer examples, but the feathers of the upper parts with rounded whitish or ochraceous-buft tips; breast less distinctly streaked. L., $7 \cdot 50$; W., 4.90 ; 'Tar., $\cdot 90 ;$ B., 95.

Remarks.-The white upper tail-coverts distinguish this species.

Range.-Eastern North America, breeding in the aretic regions and wintering as far south as the Falkland Islands.

Long Island, not uncommon T. V., July 20 to Oct 10. Sing Sing, casual T. V., Sept.

Eggs, three to four. light olive, or olive brownish, spotted (usually rather finely) with deep brown and duil, purplish gray, 1.37 × 94 (Ridgw.).

"They frequent the sandy beach as well as the marshy shores upon the coast, but inland seem to prefer the edges of pools of water upon the uplands. They move in small flocks, are very social, often associating with other waders, are not as a rule shy or timid, and, when startled, usually fly but a short distance, drop back, and run about in an unconcerned and heedless manner, picking up the minute forms of life that usually abound in such places, occasionally uttering a rather sharp, piping weet, weet. Their flight is swift and well sustained" (Goss).

241. Tringa bairdii ('oues). BAmD's SannpIPER. All. in summer.Upper parts fuscous; feathers of the crown and nape margined laterally with pale buffy; back and scapulars tipped with pale buffy or brownish gray; middle upper tail-coverts fuscous, sometimes tipped with butty ; central tailfeathers fuscous, nargined with whitish, outer ones pale brownish gray ; throat white; breast washed with buffy and lightly spotted or streaked with fuscous; sides and belly white. Im.-Similar, but the back, scapulars, and wing-coverts with rounded white tips. (In the winter these tips are more or less worn off.) L., 7.40 ; W., 4.90 ; Tar., $\cdot 90 ;$ B., $\cdot 85$.

Remarks.-This bird most closely resembles T. fuscicollis. In any plumage it may be known from that species by the fuscous instead of white niddle upper tail-coverts. In summer it differs also in the absence of rufous above, the less heavily spotted throat, and the white instead of spotted sides. In winter the chief distinguishing marks of the two species, aside from the differently colored upper tail-coverts, are the buffy breast and generally paler upper parts of bairdii.

Range-Interior of North America, breeding in the arctic regions and migrating southward to South America; rare on the Atlantic coast.

Washington, casual, one record. Long Island, casual, Aug.

Eggs, three to four, light, creamy buff, sometimes tinged with rusty, thickly speckled and spotted with deep reddish brown or chestnut, $1.30 \times .93$ (Ridgw.). 
"In habits they are similar to the White-rumped (which they so closely resemble), but are more inclined to wander from the water's edge. I have flushed the birds on high prairie lands, at least a mile from the water" (Goss).

242. Tringa minutilla Tieill. Least Sandpiper; Meadow Oxeye; PEeP. Ad. in summer.-Upper parts black or fuscous, edged and tipped with buffy or rufous; rump and middle upper tail-coverts plain black or fuscous; central tail-feathers black or fuscous, outer ones ashy gray; upper throat

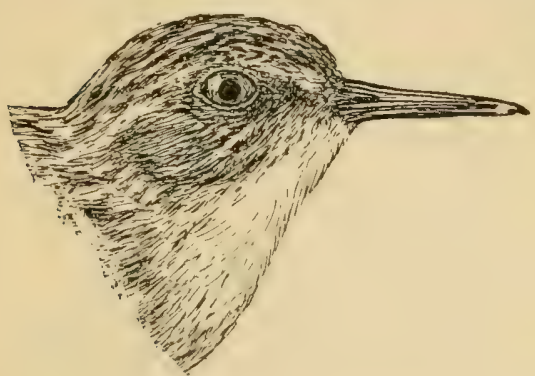

Fig. 62.-Least Sandpiper. (Natural size.) white; neck and breast white or buffy, streaked with fuscous; belly and sides white. Im.- Similar, but feathers of the back with rounded rufous or buffy tips; breast not distinctly streaked. Winter plumage.-Upper parts brownish gray, sometimes with more or less black in the centers of the feathers; breast white or ashy, not distinctly streaked. L., 6.00; W., 3.50; Tar., $\cdot 70 ; \mathrm{B} ., \cdot 75$.

Remarks. - This is the smallest of our Sandpipers, and can be confused only with Ereunetes pusillus, from which, however, it may always be distinguished by the absence of webs between the bases of the toes.

Range.-North America, breeding in the aretic regions and wintering from the Gulf States to South America.

Washington, uncommon T. V., May; Aug. to Oet. Long Island, abundant T. V., Apl. 25 through May; July through Sept. Sing Sing, tolerably common T. V., May 9 to May 22; Oct. 3. Cambridge, very common T. V., May 25 to May 31 ; July 20 to Aug. 31.

Eggs, three to four, pale, grayish buffy, varying to pale brownish, thickly spotted, speckled, or sprinkled with deep chestnut and dull, purplish gray, $1 \cdot 15 \times \cdot 83($ Ridgw.).

This, the smallest of our Sandpipers, is frequently associated with its larger cousin the Semipalmated Sandpiper on the shores and beaches, but it also visits the grassy meadows, and for this reason is known by baymen as the "Meadow Oxeye."

243a. Tringa alpina pacifica (Coues). Red-BACKed SANDPiper; LEADBACK. Ad. in summer. - Upper parts broadly margined with rufous, the centers of the feathers black, wings brownish gray; breast whitish, lightly streaked with blackish; middle of the belly with a large black patch, lower belly white. Im.-Upper parts blackish, the feathers with rounded tips of rufous or buffy; breast washed with buffy and indistinctly streaked with blackish; belly spotted with black. Winter plumage.-Upper parts brownish gray; middle upper tail-coverts fuscous; wing-coverts brownish gray margined with buffy; throat white; breast ashy, indistinetly streaked; belly 
white, the sides sometimes spotted with black. L., 8.00; W., 4.75; Tar., 1.00; B., 1.50 .

Remarks.-There is, of course, every degree of intergradation between summer and winter plumage, but the species may always be known by its slightly curved bill.

Range.-North America, breeding in the arctic regions and wintering from Florida southward: rare in the interior.

Washington, rare T. V., Apl.; Oct. Long Island, T. V., uncommon in

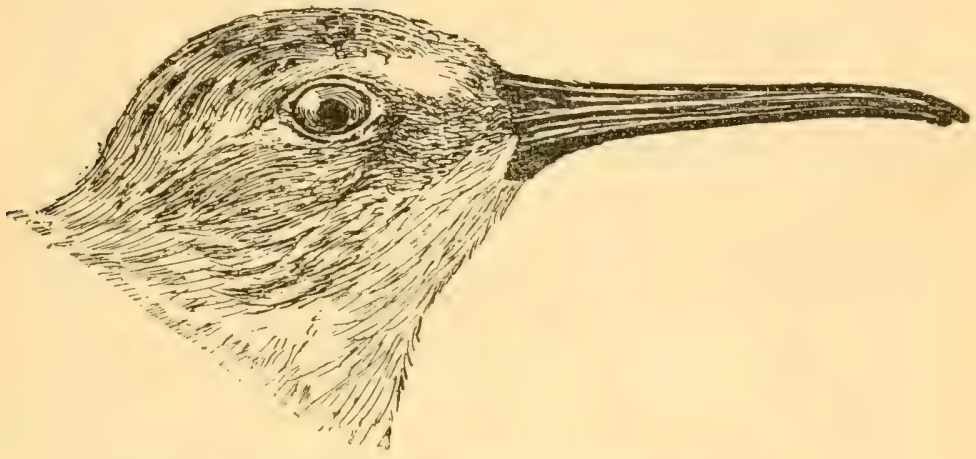

FIG. 63.-Red-backed Sandpiper. (Natural size.)

spring, Apl. 1 to May 15; common in fall, Aug. 31 through Oct. Sing Sing, tolerably common T. V. in fall, Oct. 3 to Oct. 24. Cambridge, casual, one instance, Oct.

Eggs, three to four, varying from pale, bluish white to ochraceous-buff, heavily marked with chocolate, chietly at the larger end, 1.43 × 1.01.

Generally speaking, this is a shore or beach bird, though it also visits grassy marshes. It flies and feeds in flocks, and is an unsuspicious, rather stupid little Snipe, less active than most members of this family. 'The gray-plumaged fall birds are known as "Leadbacks," while in the spring they go by the names "Blackbreast" or "Redback."

The DunLis (243. Tringa alpina) is the Old-World representative of our Red-backed Sandpiper, from which it differs only in being less brightly colored and somewhat smaller. L., about $7 \cdot 40$; W., 4.12-4.50; Tar., $78-90$; B., 1·05-1.25. It is of casual oceurrence in North America.

The Curlew SANDpiper (244. Tringa ferruginea) inhabits the eastern hemisphere, and occurs casually in eastern North America. It has been recorded from Ontario, Nova Scotia, Maine, Massachusetts, and Long Island.

245. Ereunetes pusillus (Limn.). Sempilmated SAxppiper; Sand OXEYE; PEEP. Ad. in summer.-Upper parts black or fuscous, margined with brownish gray and a small amount of rufous; rump grayish brown; upper tail-coverts blackish; tail-feathers brownish gray, central ones darkest; breast streaked or spotted with blackish. Im.-Similar, but upper parts and wingcoverts blackish, with rounded rufous or butfy tips to the feathers; breast un- 
strenked, tinted with buffy. Winter plumage.-Upper parts brownish gray, with darker shaft streaks; upper tail-coverts darker; under parts white, sometimes with faint streaks on the breast. L., $6 \cdot 30$; W., 3.75 ; Tar., $\cdot 75 ;$ B., ${ }^{\circ} 65-\cdot 80$.

Remarks. - The small size of this and the next species prevents their being confused with any other except Tringa minutilla, from which they may always be known by their partially webbed toes.

Range.-Eastern North America; breeds in the arctic regions, and winters from the Gulf States southward through Brazil.

Washington, rare T. V., May; Aug. to Oct. Long Island, abundant T. V., May; July through Sept. Sing Sing, common T. V. in fall, Aug. 14 to Oct. 20. Cambridge, very common in Aug. and Sept.

Eggs, three to four, pale, dull grayish buff, sprinkled, speckled, or spotted with dark brown and purplish gray, $1.21 \times \cdot 85$ (Ridgw.).

The thought of these little Sandpipers always creates a inental picture of a long stretch of dazzling beach with its ever-changing surfline. I hear the oft-repeated booming of the rolling, tumbling breakers, and in the distance see a group of tiny forms hurrying to and fro over the sand smoothed by the frothy waves. With what nimble gracefulness they follow the receding waves, searching for treasures cast up by the sea! What contentment and good-fellowship are expressed by their cheery, conversational twitterings! Up and down the beach they run, now advancing, now retreating, sometimes, in their eagerness, venturing too far, when the waters threaten to ingulf them, and in momentary confusion they take wing and hover back to a place of safety. Suddenly, as though at a signal, they are off ; a compact flock moving as one bird, twisting and turning to right and left, now gleaming white as the sun strikes their snowy bodies, now dark again like a wisp of sunless cloud flying before the wind.

+ 247. Ereunetes occidentalis Laur. Westeri Semipalmated SANDPIPER.-This bird closely resembles the preceding, from which, in summer plumage, it differs in having the upper parts conspicuously margined with rufous and the breast more heavily streaked. In fall and winter plumage the differences in coloration are not so apparent, but the birds are to be distinguished at any season by the size of the bill, which in the western species always averages longer. W., 3.80; 'Tar., 80; B., .85-1.20.

Range.-Western North America; breeds in the aretic regions, and winters from the Gulf States to South America; oceasional on the Atlantic coast.

Long Island, uncommon 'T. V., occurring with E. pusillus.

Eags, three to four, deep cinnamon buffy, sprinkled, speckled, or thickly spotted with bright rusty brown or chestnut, the general aspect decidedly rusty, $1.24 \times .87$ (Ridgw.).

This western representative of the preceding species is sometimes found on our coasts associated with its eastern relative. In Florida, particularly on the Gulf coast, it occurs in numbers during the winter. 
248. Calidris arenaria $(\operatorname{Linn}$.). Sanierling; Surf Snipe. $A d$. in summer.-Feathers of the upper parts with generally black centers, bordered and sometimes barred with pale rufous and tipped with ashy white; wings fuscous, the basal half of the outer web of the inner primaries white; wing-coverts grayish fuscous, the greater one broadly tipped with white; tail brownish gray, narrowly margined with white; throat and upper breast washed with pale rufous and spotted with blackish ; rest of the under parts pure white. Im. in fall.-Similar, but upper parts without rufous, glossy black, the feathers sometimes bordered with white, but generally with two white spots at their tips separated by the black of the central part of the feather; nape grayish white, lightly streaked with blackish; under parts pure white, with oecasionally a few spots on the breast. Winter plumage.Upper parts pale brownish gray, wings as in the preceding; under parts pure white. L., $800 ;$ W., 5.00; Tar., 1.00; B., 1.00.

Remarks.-The Sanderling is the only one of our Snipes or Sandpipers having three toes, and it may always be known by this character in combination with its booted or transversely scaled tarsi.

Range.- "Nearly cosmopolitan, breeding in aretic and subaretic regions; migrating, in America, south to Chili and Patagonia" (A. O. U.).

Washington, casual T. V., two records. Long Island, common 'T. V., Mch. 15 through May; Aug. 1 through Sept. Sing Sing, tolerably common T. V., to June 5; Sept. 9 to Oct. 5. Cambridge, casual, one instance, Sept.

Eggs, three to four, light olive-brown, finely spotted or speckled with darker, the markings larger and more blended on the larger end, 1.41 x.91 (Ridgw.).

This is a true beach bird, and is usually found on shores washed by the sea. It frequently associates with the Semipalmated Sandpiper or Oxeye, which it resembles in habits, but its larger size and lighter colors distinguish it from that species.

249. Limosa fedoa (Limi.). Mlarnled Gonwt; Brown Martin. Ad.- - Tpper parts black, the head and neck streaked with buffy, the back barred or the feathers spotted on the sides and sometimes tipped with buffy or ochraceous-buff; inner web of the outer primaries and both webs of the inner ones ochraceous-buff or pale buffy, speckled with black; tail ochraceousbuff barred with black ; throat white, rest of the under parts pale buffy, spotted or barred with black; bill curved slightly upward, yellowish at the base, black at the end. Im.-Similar, but the under parts with few or no bars excent on the flanks and under tail-coverts. L., $18.00 ; \mathrm{W} ., 875$; Tar., $2.75 ;$ B., 4.00 .

Range.-North America, breeding chiefly in the interior, from western Minnesota, and rarely Iowa and Nebraska, northward, and migrating southward to Central America and Cuba; rare on the Atlantic coast.

Long Island, rare 'T. V., Aug. and Sept.

Eggs, three to four, clay-color or brownish ashy, blotched, spotted, and scrawled with grayish brown, $2 \cdot 15 \times 1 \cdot 60$.

Colonel Goss writes that this species "inhabits the salt- and freshwater shores, marshes, and moist ground upon the prairies. It feeds 
upon crustacea, insects, worms, larvæ, etc., moving about in a horizontal position, picking and probing as it goes. Its flight is easy and well sustained, though not very rapid; in alighting, raises the wings over the back as it touches the ground. These birds as a rule are shy, and keep well out of reach. ..."

251. Limosa hæmastica $($ Linn.). II udontan Godwit; RingTailed Marlin. Ad.-Upper parts black, the head and neck streaked and the back spotted or barred with ochraceous-buff ; primaries black or fuscous; upper tail-coverts white, the lateral ones tipped or barred with black; tail black, with a broad base and a narrow tip of white; throat buffy, streaked with blackish; under parts chestnut-rufous, barred with black and sometimes tipped with whitish ; axillars black. L., 15.00; W., 8.25; Tar., 2.25; B., 3.20.

Range.-Eastern North America; breeds in the arctic regions and migrates southward, chiefly through the interior, as far as Patagonia.

Long Island, rare T. V., Aug. and Sept.

Eggs, three to four, deep olive, hair-brown, or broccoli-brown (sometimes paler), usually more or less spotted with darker brown, but sometimes nearly uniform, $2.20 \times 1.42$ (Ridgw.).

This bird resembles the preceding in habits, and like it is rare on the Atlantic coast.

The Black-Tailed Godwit (252. Limosa limosa) inhabits the northern parts of the Old-World and is of accidental occurrence in Greenland.

- 254. Totanus melanoleucus (Gmel.). Greater Yellow-tegs. $A d$. in summer.-Upper parts black, the head and neck streaked and the back spotted or barred with white or ashy; upper tail-coverts white, more or less barred with black: tail white or ashy, barred with black; breast heavily spotted with black; sides barred with black; middle of the belly white. Winter plumage.-Similar, but upper parts brownish gray, edged with whitish; sides of the scapulars, tertials, and wing-coverts with blackish and whitish spots; breast only lightly streaked with blackish, and sides slightly barred. L., $14.00 ;$ W., $7 \cdot 70$; Tar., $2 \cdot 40 ;$ B., $2 \cdot 20$.

Range.-North America; breeds from Minnesota and rarcly northern Illinois and Anticosti northward; winters from the Gulf States to Patagonia.

Washington, rather common T. V., Apl. and May; July 25 to Nov. Long Island, common T. V., Apl. 10 through May; July 15 through Oct. Sing Sing, common T.V., to June 5 ; - to Oct. 28. Cambridge, common T. V., Apl. 15 to May 25 ; Sept. and Oct.

Eggs, three to four, brownish buffy, distinetly but very irregularly spotted with rich vandyke- or madder-brown, $1.43 \times 1.20$ (Ridgw.).

It needs only the musical notes of the Yellow-leg to recall memories of many days passed along the shore and in the marshes. Half reclining in my blind, I see in fancy the staring decoys, pointing like weatherencks with the wind, and hear the dull booming of surf behind the brown sand dunes. 
Few birds are flying; lulled by the lap, lap of the water, I have almost fallen asleep, when from far up in the gray sky comes a soft, flutelike whistle, wheu, wheu-uheu-wheu-wheu, wheu, wheu-uheu. I respond quickly, and, lying on my back, look eagerly upward. Not a bird can be seen, but the questioning call grows stronger and is repeated more frequently. Finally I distinguish five or six black points sailing in narrow circles so high that I can scarcely believe they are the birds I hear. But no bar or shoal breaks the sound waves. The birds grown larger and on widening circles sweep earthward. Their soft whistle has a plaintive tone; their long bills turn inquiringly from side to side. The stolid decoys give no response, they repel rather than encourage, but the whistling continues, and with murmured notes of interrogation the deluded birds wheel over them, to find too late that they have blundered.

- 255. Totanus flavipes ( $G$ mel.). Yellow-legs; Sumar YellowLEGs. Ad. in summer.-Upper parts generally brownish gray, the head and neck streaked with black and white, the back, scapulars, and wing-coverts with sometimes black centers, spotted or tipped with whitish or brownish gray; upper tail-coverts white, more or less barred with black, tail varying from white to brownish gray, with numerous black or blackish cross-bars; breast heavily spotted or streaked and sides barred with black; belly white, legs yellow. Winter plumage.-Similar, but upper parts brownish gray, the sides of the feathers with whitish spots; tail-bars grayish; breast lightly streaked with ashy. L., $10 \cdot 75 ;$ W., $6 \cdot 40$; Tar., $2 \cdot 05 ;$ B., 1.40 .

Remarks. - This bird closely resembles the Greater Yellow-legs in color, but may always be distinguished by its smaller size.

Range.-North America, breeding chiefly in the interior from Minnesota, northern Illinois, Ontario County, N. Y., northward to the arctic regions; winters from the Gulf States to Patagonia.

Washington, rather common T. V., Apl. to May 15; Aug. to Nov. Long Island, T. V., very rare in spring, abundant in fall; July 15 to Oct. 1 . Sing Sing, tolerably common T. V. in fall; Aug. 25 to Oct. 5 . Cambridge, rare in May; sometimes common in Aug. and early Sept.

Eggs, three to four, buffy (variable as to shade), distinctly (sometimes broadly) spotted or blotehed with dark madder- or vandyke-brown and purplish gray, $1.69 \times 1.15$ (Ridgw.).

This species closely resembles the preceding in notes, habits, and choice of haunts. It decoys, however, more easily, and, generally speaking, is more common.

The Green-shank (253. Totanus nebularius) is an Old-World species, of which three specimens were taken by Audubon, May 28, 1832, near Cape Sable, Florida. It resembles our Greater Yellow-legs, but differs chiefly in having the lower back and rump white.

The Green SANDPiper (25\%. Totanus ochropus) is an Old-Worid species which has been recorded once from Nova Scotia. It resembles our Solitary 
Sandpiper, but is larger (W., 5.75), and has the upper tail-coverts pure white.

256. Totanus solitarius (Wils.). Solitary SANDPIPER. Ad. in summer.-Upper parts olive-fuscous, with a slight greenish tinge, the head and neck streaked and the back spotted with white; upper tail-coverts fuscous, with fine whitish spots on their sides, the lateral ones sometimes barred; central pair of tail-feathers fuscous, the others white, barred with black;

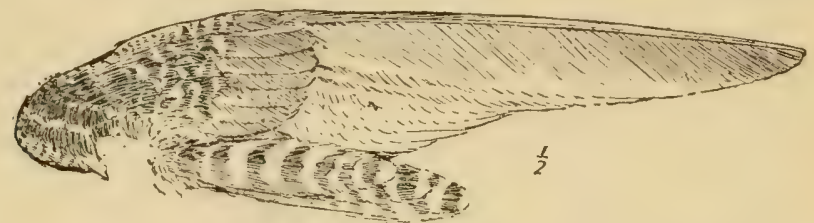

Fig. 64.-Inner view of wing of Solitary Sandpiper, showing barred axillars.

breast streaked, and sides sometimes barred with black; belly white; axillars barred with black and white; legs greenish fuscous. Winter plumage.-Similar, but upper parts grayish brown; head and neck generally unstreaked, and the back only lightly spotted with buffy white; breast streaked with brownish gray. L., 8*40; W., 5.25; Tar., 1·20; B., $1 \cdot 15$.

Range.-Eastern North America; breeds locally and rarely from northern Illinois, western Pennsylvania, and Maine northward; winters in South America.

Washington, common 'T. V., Apl. to May 25; July 25 to Nov. Long Island, common T. V., May: July 15 to Oct. 1. Sing Sing, common T. V., May 3 to 30 ; Aug. 27 to Oct 2. Cambridge, common T. V., May 15 to 25; July 20 to Oet.

Eggs, known from only one example taken by Jenness Richardson, near Lake Bombazine, Vermont, May 28, 1878, and described by Dr. Brewer as light drab, with small, rounded, brown markings, some quite dark, nowhere confluent, and at the larger end a few faint purplish shell-marks, 1.39 × 95 .

This is a wood Sandpiper. It is rarely found on the beaches or salt marshes near the sea, but frequents fresh-water ponds, or lakes and woodland streams, both in the lowlands and mountains. It is genererally observed during the migrations, and although it occasionally breeds in the Middle States its skill in concealing its nest has defied the search of oölogists. It is a quieter, more dignified bird than the Spotted Sandpiper, and as a rule only utters its "]ow, whistling notes" when flushed.

258. Symphemia semipalmata (Gmel.). WILlet. Ad. in summer.-Upper parts brownish gray, the head and neck streaked, and the back bared with black, and sometimes buffy, the centers of the feathers being occasionally wholly black; basal half of the primaries and greater part of secondaries white; upper tail-coverts white wth a few blackish bars; central tail-feathers ashy, indistinctly barre / with blackish ; outer ones whitish, lightly 
mottled with grayish; foreneck heavily streaked; breast and sides heavily barred with dark brownish gray and more or less washed with buffy; belly generally white, with sometimes a few bars. Winter plumage.-Upper parts brownish gray, unmarked; tail without bars ; rump and wings as in the adult; breast washed with grayish ; belly white; axillars black. L., 15.00; W., 8.00; Tar., $2 \cdot 30 ;$ B., $2 \cdot 15$.

Range.-Eastern North America, breeding from Florida to southern New Jersey, and locally and rarely to Maine.

Washington, rare T. V., Aug. Long Island, T. V., rare in May; uncommon in Aug. and Sept. Sing Sing, A. V.

Eygs, three to four, clay-color or buffy, thickly spotted with chocolate, chiefly at the larger end, $2 \cdot 10 \times 1 \cdot 55$.

Willets frequent both fresh- and salt-water marshes, shores, and beaches. If you visit their haunts during the nesting season, on fluttering wings they will hover above your head or fly low over the marsh to draw you away from their home, uttering, with scarce a moment's cessation, their loudly whistled call of pilly-uill-willet, pillywill-willet. All day long, and even at night, I have heard them repeat these notes until, wearied by their persistence, one is thankful to leave them in undisturbed possession of the ground.

258a. S. S. inornata Brevest. Western Willet.-Slightly larger than the preceding, and, in summer plumage, the upper parts are paler and less heavily marked with black; the breast is less heavily streaked and more suffused with buffy, and the middle tail-feathers are without black bars. In winter plumage the two forms can be distinguished only by the slight and inconstant character of size. W., 8.50; Tar., $2.50 ;$ B., 2.40 .

Range.-Western United States, hreeding from Texas to Manitoba; winters on the Gulf coast from Florida to Texas.

The Ruff (260. Pavoncella pugnax) is an Old-World species which oceasionally wanders to eastern North America. It has been taken in Maine, Massachusetts, Ontario, Ohio, Long Island, and New Jersey. The adult male may be known by its enlarged ruff, which varies in color from black, chestnut, and rufous to buffy and whitish. The female is without a ruff; and is otherwise very different from the male. The upper parts are grayish brown, the back, scapulars, and tertials are broadly barred with black, the outer tail-feathers are ashy, the inner ones are barred with buffy and black, the breast is ashy, with concealed black bars, the belly is white. In winter the upper parts are light grayish brown with few or no bars. of L, 12.50; W., 7.50; Tar., 1.90 ; B., 1.50 . \& L., 10.00 ; W., 6.00; Tar., 1.40; B., 1.15 .

261. Bartramia longicauda (Bechst.). Bartraman SANDPiper; Upland Plover; Field Plover. Ad.-Head and neck streaked with black and ochraceous-buff; back and wing-coverts ochraceous-buff; barred with black; tertials olive, barred with black and margined with ochraceous-buff; primaries fuseous, the outer one barred with white: inner tail-feathers brownish gray, outer ones varying from ochraceous-buff to white, all more or less 
barred with black; breast and sides washed with buffy and streaked or barred with black; belly white or whitish. Im.-Similar, but the ochraceous-buff is deeper. L., 11.50 ; W., 6.50 ; Tar., 1.90; B., 1.15 .

Remarks. - The white bars on the outer primary will always serve to identify this species.

Range-Eastern North America; breeds locally from Kansas and Virginia to Alaska and Nova Scotia; winters over most of South America.

Washington, common T. V., Apl.; Aug. to Sept. Long Island, uncommon S. K., Apl. to Sept. Cambridge, not common 'I. V., Apl. 25 to May 5 ; July 30 to Sept. 15.

Eggs, four to tive, creamy buff or white, spotted with reddish brown or chocolate, chiefly at the larger end, $1.80 \times 1.30$.

The Upland "Plover" is at home on grassy plains and pastures. It is usually a shy bird, and can rarely be successfully approached on foot. It shows no fear, however, of a man who is riding or driving, and when on horseback I have passed within a few yards of birds which regarded me with some interest but no alarm. They so closely resemble dried grass in color that it is sometimes exceedingly difficult to distinguish them from their surroundings. One may ride over a prairie upon which, at first glance, not a Plover is visible, and find, after careful scrutiny, that dozens of birds are scattered about him feeding.

In alighting they stretch their wings to the utmost, high over their backs, as if to get the wrinkles out before gently folding them. When flushed they utter a soft, bubbling whistle. I)uring their migrations one may clearly hear these sweet notes from birds traveling beyond the limits of human vision. Mr. Langille describes their alarm

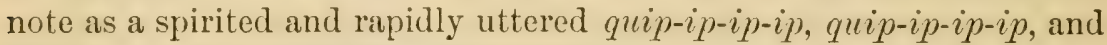
their song, given from the ground, a fence, or even a tree, as $c h r-r-r-r-r$ $e e-e-e-e-e-e-00-0-0-0-0-00$. He remarlis: "This prolonged, mournful, mellow whistle, more like the whistling of wind than a bird's voice, may be heard even in the night, and is one of the most weird and never-tobe-forgotten sounds in Nature."

262. Tryngites subruficollis ( Vieill.). Buff-breastel) SandPIPER. Ad.-Upper parts pale grayish brown, the feathers with olive centers; primaries fuscous, the inner half of their inner webs speckled with black; longer inner wing-coverts conspicuously marked and tipped with black, then white; central tail-feathers fuscous, outer ones becoming buffy, irregularly marked and tipped with black and buffy; under parts pale ochraceous-buff, tipped with whitish, and with generally concealed black markings. Im.Similar, but the upper parts and breast paler. I., $8.50 ;$ W., $5 \cdot 25 ;$ B., $\cdot 80$.

Remarks.-In any plumage this bird may be known by the peculiar speckling on the inner webs of all the primilies, and also the markings of the under wing-coverts.

Range._" North America, especially in the interior; breeds in the Yulson 



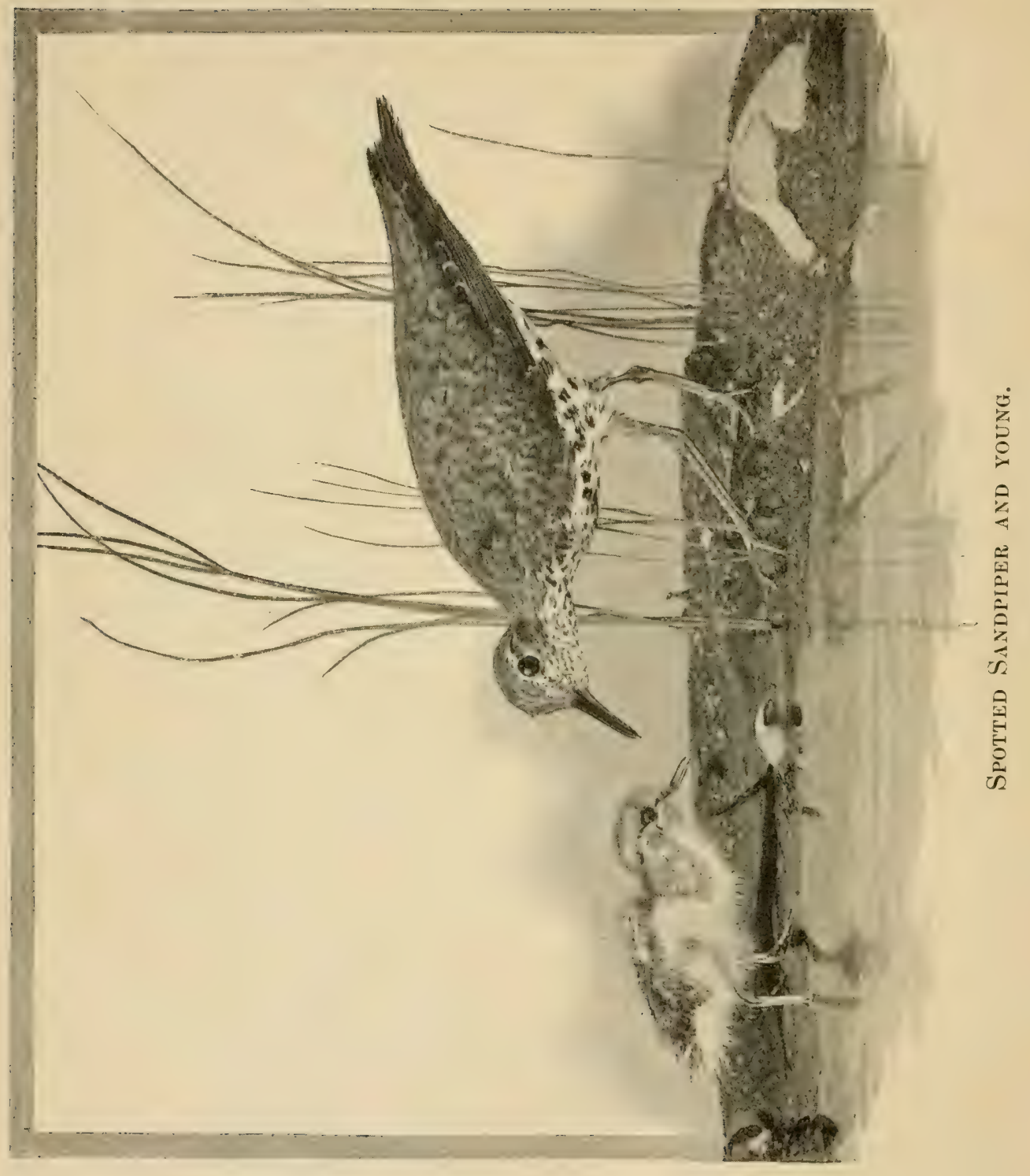


district and interior of British America; northward to the aretic coast; South America in winter; of frequent occurrence in Europe" (A. O. U.).

Long Island, rare 'T. V., Aug. and Sept.

Eggs, three to four, buffy grayish white, varying to pale olive-buff, boldly spotted longitudinally (and somewhat spirally) with dark vandyke- or madder-brown and purplish gray, $1.53 \times 1.04$ (Ridgw.).

This is a rare species on the Atlantic coast. Dr. Hatch writes of it as observed by him in Minnesota: "They are an extremely active species when on the wing, and essentially ploverine in all respects, seeking sandy, barren prairies, where they live upon grasshoppers, crickets, and insects generally, and ants and their eggs specially. I have found them repasting upon minute mollusks on the sandy shores of small and shallow ponds, where they were apparently little more suspicious than the Solitary Sandpipers are notably. 'The flight is in rather compact form, dipping and rising alternately, and with a disposition to return again to the neighborhood of their former feeding places."

263. Actitis macularia (Linn.). Spotted SAndprper. Ad.insummer.-Upper parts brownish gray with a faint greenish luster, the head and neck more or less streaked, and the back barred or spotted with black; inner tail-feathers like the back, outer ones with blackish bars; under parts white, everywhere spotted with black. Im.-Upper parts brownish gray, with a greenish tinge, the back faintly and wing-coverts conspicuously barred with black and buffy; under parts pure white, unspotted, but slightly washed with grayish on the breast. Winter plumage.-Similar, but back browner and without bars. L., $7 \cdot 50$; W., $4 \cdot 20$; Tar., $\cdot 90$; B., $\cdot 95$.

Range.-North America north to Hudson Bay; breeds throughout its range; winters southward to Brazil.

Washington, common T. V., not common S. R., Apl. 5 to Sept. 30. Long Island, abundant S. R., Apl. 25 to Oct. Sing Sing, common S. R., Apl. 29 to Oct. 23. Cambridge, common S. R., Apl. 26 to Sept.

Eggs, four, creamy buff or white, thickly spotted. and speckled with chocolate, chiefly at the larger end, $1 \cdot 25 \times \cdot 95$.

Few Shore Birds are more generally known than this widely distributed little Sandpiper. It frequents the margins of bodies of both fresh and salt water, but is more common inland on the shores of our rivers, ponds, and lakes. During the summer it is practically our only fresh-water Sandpiper, and is familiar to most of us under its common names. It runs rapidly along the beach, then pausing bobs, bows, and "teters" in a most energetic manner. When flushed it takes wing with a sharp weet-weet weet-upet, and after a few wing-strokes scales over the water to the beach beyond. It apparently dislikes to go beyond certain limits, and after several flights makes a wide circle and returns to the starting point. 
264. Numenius longirostris Tils. Long-milled Curlew; SickLE-BILL. $A d_{\text {. }}$-Head and neck streaked, and back barred with buffy and black; wing-coverts, inner webs of primaries, secondaries, and tail varying from buffy to pale rufous, barred or mottled with blackish; under parts ochraceous-buff, breast more or less streaked and sides sometimes barred with black; axillars rufous, generally unbarred. L., 24.00; W., 10.50; Tar., $3 \cdot 10 ;$ B., 6.00 .

Range.-United States, breeding in the interior as far north as Manitoba and on the Atlantic coast to North Carolina; casual northward to New England; winters from Florida and Texas southward to the West Indies.

Washington, rare and irregular 'T. V. Long Island, casual from July to Sept. Sing Sing, A. V.

Eggs, three to four, olive clay-color or brownish ashy, spotted or blotched with chocolate, $2.58 \times 1.85$.

"These birds, as a rule, inhabit the muddy shores and moist grassy fiats and plains, but often frequent and breed upon the uplands remote from water. Their food consists of worms, crickets, beetles, grasshoppers, small snails, crabs, and crawfish; the latter they reach for with their long bills and pull them out of their holes; and I have seen them probe for and unearth the larvæ of the beetles and other forms of life that in the spring come to or near the surface preparatory to transformation. While feeding they move about with an easy carriage.

"Their flight is not rapid but well sustained, with regular strokes of the wings, and when going a distance usually high and in a triangular form, uttering now and then their loud, prolonged whistling note, so often heard during the breeding season; before alighting, suddenly drop nearly to the ground, then gather, and with a rising sweep gracefully alight" (Goss).

265. Numenius hudsonicus Lath. IIrdsonian Curlew; J JCK Curlew. Al.-Upper parts grayish brown, the sides of the feathers with whitish spots; rump and tail barred with buffy and blackish; inner web of outer primaries and both webs of inner ones barred with buffy or whitish and black; under parts buffy or whitish, the neck and breast streaked and the sides and under wing-coverts barred with black. L., 17.00; W., 9.50; Tar., $2 \cdot 20 ;$ B., $3 \cdot 75$.

Range.-Breeds in the arctic regions and winters from the Gulf States to Patagonia.

Long Island, T. V., rare from May 20 to 30 ; common from July to Oct. 1.

Eggs, three to four, pale olive, spotted with dull brown, $2.27 \times 1.57$ (Ridgw.).

This is a much commoner bird on our coasts than the preceding, which it resembles in habits but not in notes.

266. Numenius borealis (Forst.). EsTruo CURLeT; Fute; Dovari-BIrd. Ad.-Upper parts black, margined and tipped with buffy or 
whitish; upper tail-coverts barred with buffy and black; tail brownish gray, edged with buffy and barred with black; primaries fuscous without bars; under parts buffy or whitish, the breast streaked, the sides and under wingcoverts barred with black L., 13.50 ; W., 8.40; Tar., 1.75 ; B., 2.40 .

Range.-Breeds in the arctic regions and migrates southward, chiefly through the interior, to Patagonia.

Long Island, rare T. V., Sept.

Eggs, three to four, pale olive-greenish, olive, or olive-brownish, distinctly spotted, chicfly on the larger end, with deep or dark brown, $2.04 \times 1.43$ (Ridgw.).

This Curlew is far more common in the interior than on the Atlantic coast. It is more of a field bird than either of the two preceding species, and frequents the dry uplands to feed on seeds and insects. Mr. G. H. Mackay, in his biography of this species, ${ }^{*}$ writes: "Most of their habits closely resemble those of the Golden Plover. In migration they fly in much the same manner, with extended and broadside and triangular lines and clusters similar to those of Ducks and Geese at such times. They usually fly low after landing, sweeping slowly over the ground, apparently looking it over, generally standing motionless for quite a while after alighting, which, owing to their general color approximating so closely to the withered grass, renders it difficult at times to perceive them. . . The only note I ever heard them make is a kind of squeak, very much like one of the cries of Wilson's Tern (Sterna hirundo), only finer in tone."

The Whimbrec (26\%. Numenius phoopus), an Old-World species, is of accidental occurrence in Greenland.

\section{Family Charadritd}

The one hundred species contained in this family are, as a whole, of less boreal distribution than the Snipes, and during the nesting season are distributed throughout the world. Only eight species are found in North America. Their habits in a general way resemble those of the true Snipes, but their much shorter, stouter bills are not fitted for probing, and they obtain their food from the surface. Probably for this reason several species are as frequently found on the uplands as near the shores.

I. 'Toes three.

KEY TO THE SPECIES.

A. Back spotted or streaked with black and white, rufous, or golden yellow.

B. Back ashy, gray, brown, or brownish gray.

272. Am. Golden Plover.

a. Rump rufous

2\%3. KilldeEr.

b. Rump not rufous.

* The Auk, vol. ix, 189?, pp. 16-21. 
b1. Bill over $\cdot 50$.

b2. A black or brownish band on the breast. 280. Wilson's Plover.

$b^{3}$. No band on the breast; back grayish brown, margined with rufous. 281. Mountain Plover.

$c^{1}$. Bill under $\cdot 50$.

$c^{2}$. A black line from the eye to the bill.

274. Semipalmated Plover.

$c^{3}$. No line from the eye to the bill.

277. Piping Plover. 277a. Belted Piping Plover.

1I. Toes four.

270. Black-Bellied Plover.

The Lapwing (269. Vanellus vanellus) is an Old-World species of accidental occurrence in America. The only record for eastern North America south of Greenland is based on a specimen shot at Merrick, L. I., in December, 1883 (Dutcher, Auk, iii, 1886, p. 438).

2y0. Charadrius squatarola (Linn.). Black-tellied Plover; Beetle-Head. (See Fig. 25, c, 26, d.) Ad. in summer.-Upper parts black, bordered with white; tail white, barred with black; basal half of the inner web of the primaries white; sides of the head and neck and entire under parts, except the white lower belly and under tail-coverts, black. Im.--Upper parts black, the head and neck streaked, the back spotted with buffy yellow; tail and wings as in the adult; under parts white, the breast and sides streaked with brownish gray. Winter plumage.-Similar to the preceding, but upper parts brownish gray, lightly margined with whitish. L., 11.00; W., 7.50; Tar., $1.90 ;$ B., 1.10.

Remarks.-The rounded scales on the front of the tarsus and the presence of a fourth, although very small, toe distinguish this bird.

Range.-Nearly cosmopolitan; breeds in the arctic regions, and in America winters from Florida to Brazil.

Long Island, common T. V., May 5 to June 5; Aug. 1 to Oct. 15. Sing Sing, A. V.

Eggs, three to four, light buffy olive, spotted and speckled with dark brown and brownish black or deep black, $2.04 \times 1.43$ (Ridgw.).

The following notes are abridged from Mr. Mackay's extended account of the habits of this species (Auk, ix, 1892, pp. 143-152). They are in a great degree tide birds, and seek a large part of their food on sand-flats left by the receding water. As the tide rises they resort to adjoining marshes or uplands, beaches, or the exposed crests of sandbars. In migrating they fly in lines and also in ranks, like Ducks and Geese. When on the ground they usually run very fast for four or five yards, then stop, elevate the head, and look around. They strike at the object they are going to pick up and eat with a very quick motion. They have two calls: one of several notes, with the accent on the second one, is mellow, clear, and far reaching; the other is low, and is uttered when they are at ease and contented. 
2y2. Charadrius dominicus Müll. American Golden Plover; Grennback. Ad. in summer.-Upper parts black, spotted and margined with golden yellow; tail brownish gray, indistinctly barred with whitish ; sides of the breast white; rest of the under parts, including sides of the head, black; under wing-coverts ashy. Winter plumage.-Upper parts and tail fuscous, spotted or barred with whitish or yellow; under parts whitish, more or less streaked or barred with brownish gray. L., 10.50; W., 7.00; Tar., $1 \cdot 60 ;$ B., $\cdot 90$.

Remarks.-Immature birds are sometimes confused with those of the Blackbellied Plover, but, aside from differences of size and color, the absence of the fourth toe in the present species will always distinguish it.

Kange.-Breeds in the arctic regions; winters from Florida to Patagonia.

Washington, rare and irregular T. V. Long Island, T. V., very rare in May; common from Aug. 15 to Nov. 10.

Eggs, three to four, ochraceous-buff or buffy white, heavily marked with chocolate, $1.85 \times 1.28$.

Golden Plovers frequent marshes, sandy hills, old fields, sand-flats exposed by the falling tide, plowed fields, and burned tracts which are free of trees and bushes. When on the ground they run rapidly and gracefully, and after alighting soon scatter. All their movements are quick, and after running a few yards they suddenly stop, hold their head erect, and look about them. In feeding they seem to strike at an object with a motion that reminds one of a Loon or Grebe beginning to dive.

When a flock is approaching decoys, every bird seems to be whistling, uttering a note like coodle, coodle, coodle. Unlike the Blackbellied Plover, the young birds are wary and more difficult to decoy than the old ones. When driven from a favorite resting or feeding ground they generally return in a short time. (Abridged from $\mathrm{Mr}$. George II. Mackay's account of the habits of this species in The Auk, viii, 1891, pp. 17-24.)

The European Golden Plover (271. Charadrius apricarius) occurs in eastern Greenland. It resembles our species, but has the under wing-coverts white instead of gray.

2y3. Aggialitis vocifera (Linn.). KilldeEr. Ad.-Forchead, a spot behind the eye, throat, and a ring around the neek, a band on the breast, lower breast, and belly white; front of the crown, lores, a ring around the neek, and a band on the breast black; erown and back grayish brown tipped with rufous; rump and upper tail-coverts rufous; inner tail-feathers grayish brown, outer ones becoming rufous and white, all tipped with black and white. L., 10.50 ; W., 6.50 ; Tar., 1.35 ; B., 75 .

Range.-North America north to Newfoundland and Manitoba, breeding throughout its range; winters from the lower Mississippi Valley and Virginia to northern South Ameriea. 
Washington, P. R., most abundant in migrations. Long Island, not common T. V., recorded in every month but Jan. Sing Sing, rare T. V. in fall; Sept. 28 to Oct. 25. Cambridge, A. V., two instances, Sept.

Eggs, three to four, buffy white, spotted and scrawled with chocolate, chiefly at the larger end, $1.50 \times 1 \cdot 10$.

In localities where this bird is common it is difficult to get beyond the reach of its notes. Lakesides, meadows, pastures, and cultivated fields all attract it, but it is more numerous in the vicinity of water. It is a noisy, restless bird, running rapidly when on the ground, and when on the wing flying swiftly and sometimes pursuing a most irregular course. As a rule it is found in flocks, which scatter when feeding but unite when taking wing. At the first sign of danger it utter's its half-plaintive, half-petulant kill-dee, kill-dee, and when thoroughly alarmed its outcry increases until, beside itself with fear, it reaches the limit of its rocal powers. Although by no means shy, the Killdeer never seems to gain confidence in man, and at his approach always gives voice to its fear. Even at night I have heard it cry out at some real or fancied danger.

274. Aggialitis semipalmata Bonap. Semipalanated Plover; RingNECK. (See Fig. 25, d, 26,e.) Ad. in summer.-Feathers at the base of the

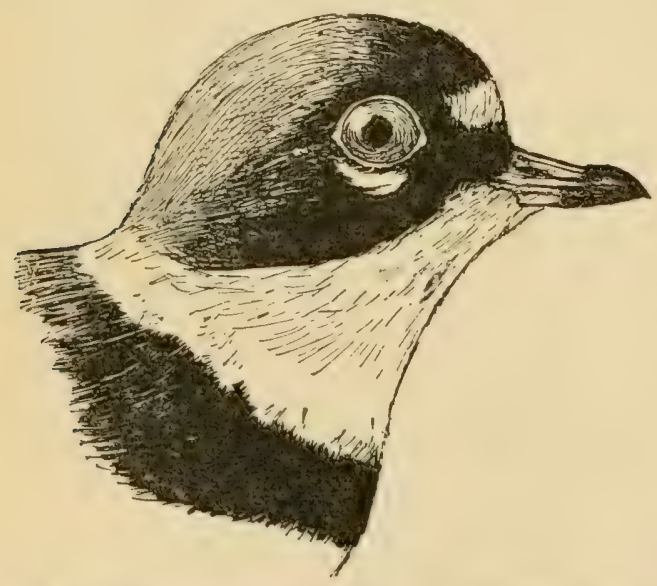

FIG. 65.-Semipalmated Plover. (Natural size.) upper mandible, front of the crown, sides of the head below the eye, and a band on the breast, which generally encireles the neck all around, black; rest of under parts and a ring around the neck white; back of head and back brownish gray; inner tail-feathers brownish gray, outer ones becoming gradually white; toes webbed at the base. Winter plumage.-Similar, but the black replaced by brownish gray. L., $6.75 ;$ W., 4.80 ; Tar., $\cdot 90$; B., 50 .

Range.-Breeds from Labrador to the shores of the Aretic Sea; winters from the Gulf States to Brazil.

Washington, easual, three specimens, May; Aug. Long Island, common T. V., May; Aug. and Sept. Sing Sing, common T. V. in fall; Aug. 23 to Sept. 20. Cambridge, rare in spring; sometimes common in Aug. and Sept.

Eggs, three to four, buffy white or creamy buff, spotted with chocolate, $1.30 \times 90$. 
This species frequents sandy beaches, mud-flats, and marshes. It is found generally in small flocks of five or ten individuals, which, unlike the Sand Oxeyes, do not feed in a compact body, but run rapidly about, independently of one another. When they take wing, however, they close ranks at once and move as though governed by one desire.

Their simple, sweet, plaintire call is one of the most characteristic notes heard on our shores. At noonday, when the heat waves are dancing over the marshes and even the twittering Oxeyes are silent, one may hear the cool, pure notes of this little Plover. 'Tiney may be written

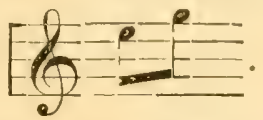

A third, shorter note is sometimes added.

Even a whistled imitation of them takes me to the beaches.

The Rina Plover (275. Agialitis hiaticula), an Old-World species, is found in Greenland. It is similar to the preceding but slightly larger, the black band on the breast is wider, and there is no web between the inner and middle toes.

† 2yy. Fgialitis meloda (Ord). Piping Plover. Ad. in summer. - Upper parts pale whitish ashy; forehead, under parts, and a ring around the neck white: front of the crown and a band on either side of the breast black; inner tail-feathers fuscous, outer ones becoming white. Winter plumage.-Similar, but the black replaced by brownish gray. L., 7•00; W., 4.75; Tar., $85 ;$ B., 50 .

Range.-Eastern North America, breeding from Virginia to Newfoundland; winters from Florida southward.

Long Island, not uncommon S. R., Mch. through Sept. Sing Sing, A. V.

Eggs, three to four, creany white, tinely spotted or speckled with chocolate, $1.24 \times \cdot 95$.

The Piping Plover resembles the Ring-neck in habits but not in notes. Mr. J. H. Langille writes that it " can not be called a 'whistler,' nor even a 'piper,' in an ordinary sense. Its tone has a particularly striking and musical quality. Queep, queep, queep-o, or peep, peep, peep-lo, each syllable being uttered with a separate, distinct, and somewhat long-drawn enunciation, may imitate its peculiar melody, the tone of which is round, full, and sweet, reminding one of a high liey on an Italian hand organ or the hautboy in a church organ. It is always pleasing to the lover of Nature's melodies, and in the still air of the evening it is very impressive."

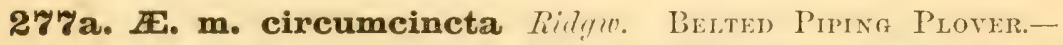
Closely resembles the preceding, from which it differs in having the bands on either side of the breast joined, forming a continuous breastband.

Range.-Breeds from "northern Illinois and Nebraska northward to Lake 
Winnepey," and eastward to the Magdalen and Sable Islands; winters from the Gulf southward. Casual on the $\Lambda$ tlantic coast during the migrations.

Long Island, A. V. in summer.

280. Aggialitis wilsonia $(O r d)$. Wilsox's Plover. Ad. ô.Lores, front of crown, and a band on the breast black; rest of under parts,

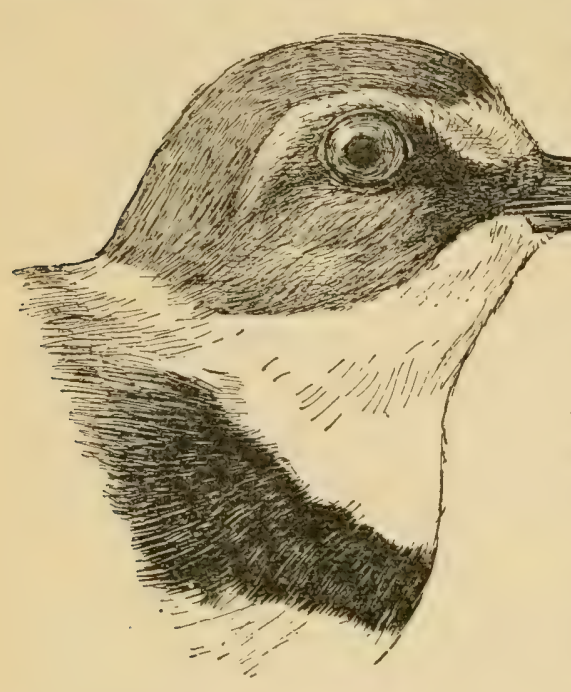
forehead, and an indistinct ring on the nape white; sides of the head and nape sometimes with rufous markings; cheeks, crown, and back brownish gray ; inner tail-feathers fuscous, outer ones becoming white. Ad. . .-Similar, but black replaced by brownish gray. Im.- Similar to ., but upper parts margined with grayish. L., 7.50; W., 4.50; Tar., $1 \cdot 10 ; \mathrm{B} ., \cdot 80$.

Range.-America, breeding from Virginia to Central America; winters southward to Brazil; easual northward to Nova Sentia.

Long Island, $\mathrm{A}$. V., in sum-

FIG: 66.-TVi'son's Plover. (Natural size.) mer.

Eggs, three, creamy white, evenly and rather finely spotted and speckled with chocolate, $1.42 \times 1.03$.

This is a more strictly maritime species than the other representatives of this genus. Sandy beaches are its favorite resorts, but it is also found on mud-flats exposed by the falling tide. Dr. Coues describes its note as half a whistle, half a chirp; quite different from that of the preceding species. It is a gentle, unsuspicious bird, and when its nest is approached it runs about the intruder and begs as plainly as a bird can that he will not disturb its treasures.

The Mountain Plover (281. Egialitis montana), a western species, is of accidental oceurrenee in Florida. The upper parts are grayish brown margined with rufous, the under parts are white tinged with buffy on the breast; in adults the front of the eromn and lores are black. L., about 8.75 ; W., 5.75 ; Tar., $1.50 ;$ B., $\cdot 85$.

\section{Family Apirizide. Surf Birds and Turnstones.}

A small family of four species, three of which are found in North America, though but one of these risits our Eastern States. They are strictly maritime birds, frequenting only the seacoasts, where they prefer the outer beaches. 
283. Arenaria interpres $($ Limn.). Turnstone; Brant Bird; CAlico-BACK. Ad. in summer.-Upper parts, including wings, strikingly variegated with rufous, black, and white; tail white at the base, a black band near its end, and tipped with white; throat and breast black and white; belly white. Winter plumage.-Upper parts blackish, bordered with brownish gray or ashy; lower back white; longer upper tail-coverts white, shorter ones black; tail as in the adult; throat white, breast black margined with white, belly white. L., 9.50 ; W., 6.00 ; Tar., $\cdot 95$; B., 1.00.

Range.-Nearly cosmopolitan; breeds in the aretic regions, and in America migrates southward to Patagonia.

W ashington, rare and irregular T. V. Long Island, common T. V. May ; Aug. and Sept. Sing Sing, A. V.

Eggs, three to four, clay-color, blotched and scrawled with grayish brown, $1 \cdot 60 \times 1.15$.

This strictly maritime species is found singly or in small flocks, generally on the outer beaches, where it obtaius its food by turning over shells and pebbles in search of insects, crustaceans, etc.

\section{Family H minatopodid Æ. Oyster-CatChers.}

The Oyster-catchers number ten species, represented in most of the warmer parts of the globe. But three species are found in North America, and only one of these occurs in the Eastern States. They are strictly maritime birds, and resort to the outer bars and beaches in search of clams, mussels, ete, exposer by the tide. Their strong bill is used as an oyster-knife to force open the shells of these bivalves.

286. Hrematopus palliatus Temm. AMERICAN () yster-CATCHER. Ad.-Head, neck, and upper breast glossy black, back and wing-coverts olivebrown, secondaries white, primaries fuscous, upper tail-coverts white, base of the tail white, end fuscous, lower breast and belly white. Im.-Similar, but head and neck blackish and upper parts more or less margined with buffy. L., 19.00; W., 10.50; Tar., 2.40; B., 3*40.

Range.-Seacoasts of temperate and tropical America, from New Jersey and Lower California to Patagonia; occasional or accidental on the Atlantic coast north to Massachusetts and Grand Menan.

Long Island, A. V.

Eggs, three to four, buffy white or ereamy buff, rather evenly spotted and blotched with chocolate, $2.20 \times 1.55$.

A not uncommon species from southern New Jersey southward; confined exclusively to the coast. It agrees in habits with other members of this small family.

The European Oyster-CATCHER (285. Hamatopus ostralegus) is of accidental occurrence in Greenland. 


\section{ORDER GALLIN ÆE. GALLINACEOUS BIRDS.}

\section{Fanily Tetraonid a. Grouse, Bob-whites, etc.}

Of the two hundred species contained in this family, one hundred belong in the subfarnily Perdicince or Old-World Partridges and Quails, sixty in the subfamily Odontophorince or New-World Partridges and Bob-whites, and twenty-five in the subfamily Tetraonince or Grouse, inhabiting the northern parts of the northern hemisphere. Generally speaking, these birds are non-migratory, though there are some striking exceptions among the Perdicince. Aftel the nesting season they commonly gather in "coveys" or bevies, usually composed of the members of but one family. In some species these bevies unite or "pack," forming large flocks. As a rule, they are terrestrial, but may take to trees when flushed, while some species habitually call and feed in trees. They are game birds par excellence, and, trusting to the concealment afforded by their dull colors, attempt to avoid detection by hiding rather than by flying, or, in sportsman's phraseology, "lie well to a dog." Their flight is rapid and accompanied by a startling whirr, caused by the quick strokes of their small, concave, stifffeathered wings.

KEY TO THE SPECIES.

A. Tarsi bare . . . . 289. Boв-white. 289a. Florida Bob-white. $B$. Upper third or half of tarsi feathered.

300. Ruffed Grouse. 300a. Canada Ruffed Grouse.

C. Tarsi entirely feathered, toes bare.

a. With bunches of elongated, stiffened feathers springing from either side of the neck - . . . . . 305. Prairie Hen. 306. Heath Hen.

b. Feathers of neck normal.

$b^{1}$. Outer web of primaries spotted with white.

308b. Prairie Sharp-tailed Grouse.

$b^{2}$. Primaries not spotted with white... . 298. Canada Grouse.

D. Tarsi and toes entirely feathered . . . . 301. Ptarmigan and races.

289. Colinus virginianus (Linn.). Bob-white; (rail ; Partringe. Ad. o in winter.-Opper parts rarying from reddish brown to chestnut; interscapulars with broken and sometimes complete black bars; inner vane of tertials widely margined with cream-buff; rump grayish brown, finely mottled, and with a few streaks of blackish; tail ashy gray, the inner feathers fincly mottled with buffy; front of the crown, a band from the bill to beneath the eye, and a band on the upper breast black; throat and a broad line from the bill over the eye white; sides rufous-chestnut, margined with black and white; lower breast and belly white barred with black. Ad. \& in winter.-Similar, but the throat and line over the eye, forehead, and lores pale ochraceous-buff; little or no black on the upper breast. Summer examples 
of both sexes have the crown blacker, the buffy markings generally paler. L., 10.00 ; W., 4.50 ; T., 2.50 ; B. from N., 35 .

Range.-Eastern North America, from southern Maine and Minnesota southward to the Gulf of Mexico; resident wherever found.

Washington, common P. R. Sing Sing, common P. R. Cambridge, common P. R.

Nest, on the ground, in grassy fields. Eggs, ten to eighteen, white, $1.20 \times .95$.

Taking the Old-World species of the genera Coturnix and Caccabis as the types respectively of Quails and Partridges, neither of these latter names can properly be applied to our Colinus, which should therefore be known under the distinctive title Bob-white.

During the nesting season Bob-whites are distributed in pairs through clearings and cultivated fields. The members of a brood constitute a bevy or covey, though occasionally two families or broods are found in one bevy. In the fall they frequent grain fields, but as winter approaches draw in toward thickets and wooded bottom-lands, sometimes passing the coldest weather in boggy alder swamps. They roost on the ground, tail to tail, with heads pointing outward; a bunch of closely huddled forms-a living bomb whose explosion is scarcely less startling than that of dynamite manufacture.

Like most grass-inhakiting birds whose colors harmonize with their surroundings, Bob-whites rely on this protective resemblance to escape detection, and take wing only as a last resort. Sometimes they take refuge in trees, but ustally they head for wooded cover, where they remain if the growth is dense, but if it is open they generally run the moment they touch the ground.

About May 1 they begin to pair, and rival males may then be seen battling for mates like diminutive gamecocks.

The name "Bob-white" originated in the spring call of the male. Mounting a fence or ascending to the lower branches of a tree, he whistles the two clear musical, ringing notes Bob-white! Sometimes they are preceded by a lower one which can be heard only when one is near the singer.

After the breeding season, when the birds are in bevies, their notes are changed to what sportsmen term "scatter calls." Not long after a bery has been flushed and perhaps willely seattered, the members of the disunited family may be heard signaling to one another in sweet minor calls of two and three notes. When excited they also utter low, twittering notes.

289a. C. v. floridanus (Fones). Florina Bon-white; Quall; ParTRIDGE.- Similar to the preceding, hut smaller, the plumage throughout darker, the black of the back more extensive, the rump and upper tail-enverts grayer, 
the black throat-band wider and sometimes reaching down upon the breast, the rufous-chestnut of the sides more extensive, the black bars of the breast and belly much wider. L., 8.50; W., 4.40 ; T., 2.50 .

Range.-Florida, except the northern border of the State.

A common bird throughout the pine-grown portions of the Florida peninsula. It is especially numerous on old plantations, where it frequents patches of "cow peas." It resembles the northern Bob-white in habits, but is, I think, more inclined to take to the trees when flushed. I have seen a whole covey fly up into the lofty pine trees, where, squatting close to the limbs, they became almost invisible.

They begin to pair early in March.

The European or Migratory Quall (Coturnix coturnix) has been introduced into this country on several occasions, but does not appear to have survived.

298. Dendragapus canadensis (Linn.). CANAdA Grotse; SPrLce PARTRIDGe. Ad. of.-Upper parts barred with black, ashy, gray, and grayish brown; tertials and wing-coverts irregularly marked with fuscous and grayish brown; tail black, tipped with rufous; the black throat separated from the black breast by a broken circular band of black and white and a band of the same color as the back of the neck; sides mottled with black and grayish brown, the ends of the feathers with white shaft streaks; rest of the under parts black, broadly tipped with white, except on the middle of the lower breast; bare skin above the eye bright red in life. Ad. \&.-Upper parts barred with black and pale rufous and tipped with ashy gray; tail black, mottled and tipped with rufous; throat and upper breast barred with pale rufous and black; sides mottled with black and pale rufous, the ends of the feathers with white shaft streaks; rest of the under parts black, broadly tipped with white and more or less washed with pale rufous. L., 15.00; W., $6.50 ;$ T., $4 \cdot 75$; B. from N., 40 .

Range.-From northern New England, northern New York, and northern Minnesota northwestward to Alaska.

Nest, on the ground. Eggs, nine to sixteen, buffy or pale brownish, more or less speckled or spotted with deep brown, 1.71 × 1.22 (Ridgw.).

This species is a common inhabitant of coniferous forests, and is generally resident wherever found. An excellent account of its habits is given in Captain Bendire's Life Histories of North American Birds, p. 51 .

300. Bonasa umbellus (Limn.). Rufren Grotse; Partridge; Pheasant. A $l$. of.-Prevailing color of the upper parts rufous, much variegated with black, ochraceous, buffy, gray, and whitish; sides of the neck with large tufts of broad, glossy black feathers; tail varying from gray to rufous, irregularly barred and mottled with black, a broad black or brownish band near the end; tip gray; throat and breast ochraceous-buff, a broken blackish band on the breast; rest of the under parts white, tinged with buffy and 



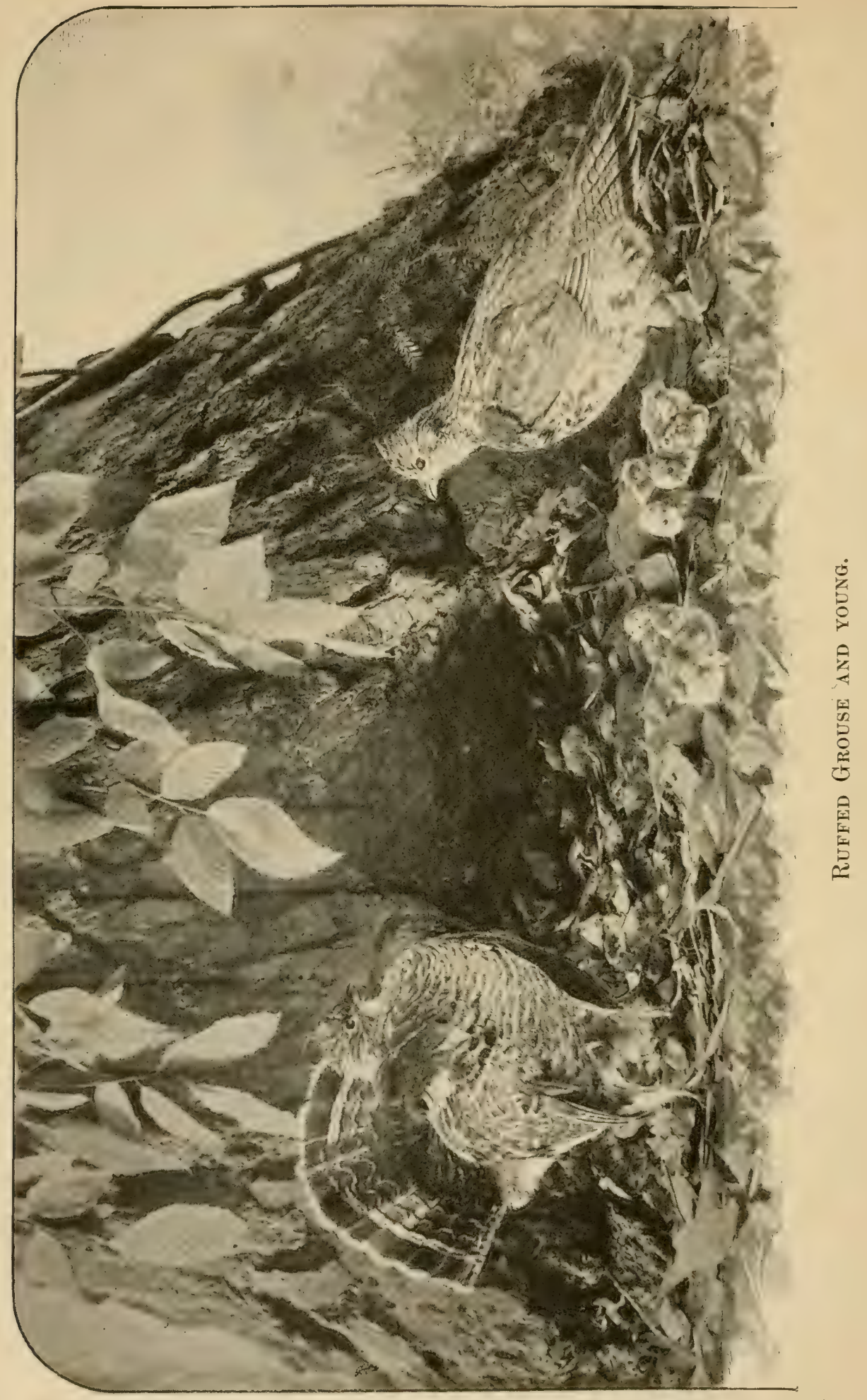


barred with blackish or dark grayish brown, the bars indistinct on the breast and belly, stronger on the sides. $A d$. o . - Similar, but with the neck tufts very small. L., $17 \cdot 00 ; \mathrm{W} ., 7 \cdot 25 ;{ }^{\prime} \mathrm{I}$., $6.25 ;$ B. from N., 52.

Range.-Eastern United States, from Vemont to Virginia, and along the Alleghanies to northern Georgia.

Washington, not common P. R. Sing Sing, common P. R. Cambridge, common P. R.

Nest, on the ground, at the base of a stump or tree, or beneath brush. Eggs, eight to fourteen, pale ochraceous-buff, 1.52 × 1.18.

Of all the characteristics of this superb game bird, its habit of drumming is perhaps the most remarkable. This loud tattoo begins with the measured thump of the big drum, then gradually changes and dies away in the rumble of the liettle-drum. It may be briefly represented thus: Thump_-thump__-thump-thump, thump; thump, thump-rup rup rup rup $r-r-r-r-r-r-r-r-r$. The sound is produced by the male birl beating the air with his wings as he stands firmly braced on some favorite low perch; and it is now quite well known to be the call of the male to the female; an announcement that he is at the old rendezvous-a rendezrous that has perhaps served them for more than one season. and a place that in time becomes so franght with delightful associations that even in autumn or wintur the male, when he finds himself in the vicinity, can not resist the temptation to mount his wonted perch and vent his feelings in the rolling drum-beat that was in springtime his song of love. But now, alas! there is no lady Grouse to come, shy but responsive, at the sound of his reverberating summolls.

There is good reason for supposing that the Ruffed Grouse is polygamous, and that the male, if he drums in vain at one place, will fly to another retreat and there seek the society of some more compliant female.

The young Grouse can run about as soon as they are hatched, and can fly well when about a week old. Their mother is celebrated for the variety of expedients she puts in practice to save her brood from threatened danger, and their father has frequently been known to divide the charge with her. The young usually continue with their parents till the following spring, though it is rare at this time to see more than three or four surviring out of the original twelve or fourteen.

The food of this Grouse is largely insects and berries during the summer; in the autumn it adds seeds to the list, and when the ground is covered with snow the staples are catkins, leaves, and buds.

Its toes are provided during the winter with a curious fringe of strong, horny points which act as snowshoes. In the northeru part of its range this bird commonly burrows into a snowdrift to pass the night during the season of intense cold; but in the summer and in 
the warmer region of its range it roosts habitually among the thickets of evergreen.-Ernest E. Thompson.

300a. B. u. togata (Linn.). Canadian Rlffed Grotse; ParTRIDGE.-To be distinguished from the preceding by the prevailing eolor of thie upper parts, which are gray instead of rufous, and the more distinctly barred under parts, the bars on the breast and belly being nearly as well detined as those on the side; the tail is generally gray.

Range.-Nova Scotia, northern half of Maine, northern Vermont, New Hampshire, and New York northward and westward to Hudson Bay and Oregon.

301. Lagopus lagopus $(\operatorname{Linn}$.). Willow Ptarmigan. Ad. of in summer.-Prevailing color above rufous, or black thickly barred or mottled with rufous and buffy or whitish; tail fuscous, tipped with white; middle tail-feathers like the back; throat, breast, and sides like the head and neck; belly white. $A d . \&$ in summer.-Similar to the male, but the bars both above and below broader and more numerous. Winter plumage.-Outer tail-feathers as in summer, rest of the plumage white. L., $15.00 ;$ W. $7 \cdot 50 ;$ T., 4.40;-B. from N., 42 ; depth of B. at N., ${ }^{4} 44$.

Remarks. - Both this species and its subspecies alleni may be distinguished from our other Ptarmigans by their more rufous eolor and larger bills.

Range. - " Northern portions of the northern hemisphere, south in winter; in America to Sitka, Alaska, the British Provinces, and_oceasionally within the northern border of the United States" (Bendire).

Nest, on the ground. Eggs, seven to eleven, varying from cream-buff to rufous, heavily spotted and blotched with blackish, $1.75 \times 1 \cdot 20$.

This abundant and characteristic aretic bird does not nest south of central Labrador, but migrates southward in winter to the St. Lawrence, and has once been taken in northern New York and once in New Brunswick. An extended account of its habits will be found in Nelson's Report on Natural History Collections made in Alaska, p. 131. It is quoted by Captain Bendire in his Life Histories of American Birds (p. 70), where will be found practically all we know concerning the habits of this and the following members of this genus.

301a. L. 1. alleni Stejn. Allex's Ptamianan.-Differs from the preceding in having the "shafts of secondaries black, and quills (sometimes a few of the wing-coverts also) more or less blotched or mottled with dusky. Summer plumages and young unknown" (Ridgw.).

Range.-Newfoundland.

"It frequents rocky barrens, feeding on seeds and berries of the stunted plants that thrive in these exposed situations" (Merriam, Orn. and Oöl., viii, 1883, p. 43).

302. Lagopus rupestris (Gmel.). Rock Ptaraigan; Rocker. $A d$. o in summer.-General color above grayish, the feathers black basally; head 
and neck barred, and back marked with numerous fine wavy lines of gray and white or buffy; central tail-feathers like the back, outer ones fuscous, generally tipped with white; breast and sides like the head and neck; belly white. Ad. o in summer.-Above black, barred with ochraceous-buff and margined with grayish; middle tail-feathers the same, outer ones as in the male; midale of the belly white, rest of the under parts like the back, but with more ochraceous-buff." Winter plumage-Lores black, outer tail-feathers as in summer, rest of the plumage white. W., $7 \cdot 25$; B. from N., 35 ; depth of B. at N., 32 .

Range.-"Arctic America in general, southeastward to the Gulf of St. Lawrence (Anticosti), except the northern extremity of the peninsula of Labrador, and region thence northward, Greenland and Aleutian Islands" (Bendire).

Nest, usually placed among the dwarf brush or sedge-covered patches of the tundras. Eggs, six to ten, pale cream or yellowish buff, sometimes with a vinaceous-rufous suffusion, spotted and blotched with clove-brown or dark claret-red, $1.65 \times 1.18$ (Bendire).

"In its general manners and mode of living it is said to resemble albus [ = L. lagopus $]$, but does not retire so far into the wooded country in the winter" (B., B., and R.).

302a. L. r. reinhardti (Brehm). Greenland Ptarmaan. "Summer male.-Similar to corresponding stage of L. mpestris, but less regularly and coarsely barred above. Summer female.-Above chiefly black, this varied irregularly with pale grayish buff, mostly in form of borders to the feathers and spots along their edges, or oceasionally imperfect bars, these latter most distinct on wings, where the two colors are in about equal proportion; lower parts light grayish buff, everywhere coarsely barred with black" (Ridgw.).

Range.-Northern parts of Labrador northward to Greenland.

"They prefer more open ground, and rarely straggle even into the skirts of the wooded tracts. The hilltops and barrens (hence often called the Barren Ground Bird) are their favorite resorts" (Turner).

303. Lagopus welchi Prevest. Wercin's Ptirutgan. Al. o in summer.-Upper parts black, the head and neck barred with white and cohraceous-buff, the back and wing-coverts finely and irregularly marked with wavy lines of buffy and white; tail grayish fuscous, the middle feathers tipped with white; throat white, foreneck like the hind neck, breast and sides like the back; rest of the under parts white. \&.-Upper parts black, finely and irregularly barred with ochraceous-buff, grayish, and white; central tail-feathers like the back, others fuscous; foreneck, breast, and sides like the hind neck; belly white. Winter plumage-White, tail fuscous, the central feathers tipped with white; lores black. W., 7.25; B. from N., 35 ; depth of B. at N., 32 .

Remarks.-This species with L. rupestris is to be distinguished from Lagopus lagopus by the ochraceous-butf instead of rufous markings, the fine 
grayish wavy bars on the upper parts, and the smaller bill. For a comparison of welchi with rupestris see Auk, ii, 1885, p. 193.

Range.-New foundland.

N'est and eggs unknown.

"According to $\mathrm{Mr}$. Welch, these Ptarmigan are numerous in Newfoundland, where they are strictly confined to the bleak sides and summits of rocky hills and mountains of the interior" (Brewster, $l$. c.).

305. Tympanuchus americanus (Reich.). Prairie Hen. $A d$. s.-Upper parts barred with rufous and black and spotted with rufous; sides of the neck with tufts generally composed of ten or more narrow, stiffened black feathers marked with bufty and rufous, their ends rounded, the skin beneath these tufts bare; tail rounded, fuscous, the inner feathers somewhat mottled with ochraceous-buff, tip white; throat buffy; breast and belly white, evenly barred with black. Ad. \&.-Similar, but the neck tufts much smaller and the tail barred with ochraceous-buff or rufous. L., 18.00; W., $9.00 ;$ 'T., 4.00 ; B. from N., 52 .

Range.-Prairies of Mississippi Valley, south to Louisiana, west to northern Indian Territory, middle Kansas, Nebraska, and eastern North and South Dakota; east to Kentucky, Indiana, northwestern Ohio, southwestern Michigan, and southwestern Ontario; north to southern Manitoba (Bendire).

Nest, on the ground. Eggs, eleven to fourteen, buffy olive, sometimes finely speckled with brownish, $1.70 \times 1.25$.

"This familiar game birl inhabits our fertile prairies, seldom frequenting the timbered lands except during sleety storms or when the ground is covered with snow. Its flesh is dark, and it is not very highly esteemed as a table bird.

"During the early breeding season they feed largely upon grasshoppers, crickets, and other forms of insect life, but afterward chiefly upon our cultivated grains, gleaned from the stubble in autumn and the cornfields in winter ; they are also fond of tender buds, berries, and fruits. 'They run about much like our domestic fowls, but with a more stately carriage. When flushed they rise from the ground with a less whirring sound than the Ruffed Grouse or Bob-white, and their flight is not as swift, but more protracted and with less apparent effort, flapping and sailing along, often to the distance of a mile or more. In the fall the birds collect together and remain in flocks until the warmth of spring quickens their blood and awakes the passions of love; then, as with a view to fairness and the survival of the fittest, they select a smooth open courtship ground (usually called a 'scratching ground'), where the males assemble at the early dawn to vie with each other in courage and pompous display, uttering at the same time their love call, a loud booming noise: as soon as this is heard by the hen birds desirous of mating they quictly put in an appearance, squat upon the 
ground, apparently indifferent observers, until elaimed by victorious rivals, which they gladly accept, and receive their caresses" (Goss).

306. Tympanuchus cupido (Linn.). IІелth IIEn.-Similar to the preceding, but the seapulars broadly tipped with buffy; the neck tufts of less than ten feathers; these feathers pointed, not rounded, at the ends.

Range.-Island of Martha's Vineyard, Mass.

Nest, "in oak woods, among sprouts at the base of a large stump" (Brewster). Eggs, six to thirteen, "creamy buff in color, with a slight greenish tinge," $1.73 \times 1.29$.

In the early part of this century the Heath Hen was found locally throughout the Middle States, where, unlike its western representative, the Prairie Hen, it lived in wooded districts. It is now restricted to the island of Marthas Vineyard, an excellent illustration of the protection afforded by an insular habitat.

Mr. William Brewster, writing in 1890 (Forest and Stream, p. 188; see also p. 207), estimated that there were from one hundred and twenty to two hundred Heath Hens then on the island, but he has recently informed me that since then, owing to insufficient protection, they have been nearly exterminated.

308b. Pediocætes phasianellus campestris Ridg $\%$. Pratrie Sharp-tailed Grovse. $A d$. of.-Prevailing color of the upper parts ochraceous-buff, barred and irregularly marked with black; no neck tufts; outer web of the primaries spotted with white; middle tail-feathers projecting about an inch beyond the others, ochraceous-buff and black; throat buffy; breast with $\mathrm{V}$-shaped marks of black; sides irregularly barred or spotted with black or buffy; middle of the belly white. $A d . \&$. - Similar, but smaller;

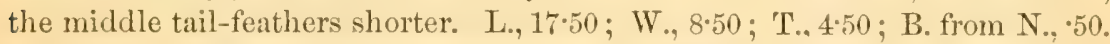

Range.-Western United States from New Mexico northward to Manitoba, east to Wisconsin and northern Illinois.

Nest, on the ground. Eggs, eleven to fourteen, creamy buff or pale olivebrown, generally slightly spotted with fine, reddish brown markings, 1.65 $x$ $1 \cdot 22$ (Bendire).

This partially migratory species lives on the prairies during the summer and in wooded regions in the winter. A capital account of its habits is given by Ernest E. Thompson in his Birds of Manitoba.

\section{Family Phasianid æa. Pheasants, etc.}

With the exception of the Yucatan Turkey and the four races of our Wild Turkey, the some ninety speeies included in this family are inhabitants of the Old World, and are most numerously represented in southern Asia, where are found the Peacocks, many of the Pheasants, and the Jungle Fowl, from which the rarieties of our domesticated fowls have descended. 
310. Meleagris gallopavo Linn. WILd TLRKEY. - The Wid Turkey may be distinguished from the common domestic race chiefly by the chestnut instead of white tips to the upper tail-coverts and tail. " 8 ad. I.., about 48.00-50; W., 21.00; T., 18.50; Weight 16-40 lbs." (Ridgw.).

Range.-Eastern United States from Pennsylvania southward to Florda, west to Wisconsin, the Indian 'Territory, and Texas.

Washington, rare $P . R$.

Nest, on the ground, at the base of a bush or tree. Eggs, ten to fourteen, pale cream-buff, finely and evenly speckled with grayish brown, $2 \cdot 45 \times 1.95$.

This noble game bird is rapidly decreasing in numbers, and in comparatively few years will doubtless be found only in the parts of its range which are unfit for the habitation of man.

Except during the breeding season, Wild Turkeys are found in small flocks of six to twelve or fifteen individuals of both sexes. They roost preferably in the trees in wooded bottom-lands, returning each night to the same locality.

At the opening of the breeding season in March the male begins to gobble. As a rule, he calls only early in the morning, before leaving his roost. Later he sails to the ground and at once begins his search for breakfast, or, attracted by the plaintive piping of some female, he struts and displays his charms before her. It is at this time that battles between the males occur. They are polygamists, and the victor becomes sultan of the harem. During the period of incubation, and while the young require their mother's care, the females do not associate with the males, who then flock together.

The calls of both sexes so closely resemble those of the domestic birds that it requires a practiced ear to distinguish them. In localities where both birds might be expected to occur, I could never be sure whether I was listening to the challenge of some defiant gobbler perched in a cypress in the valley below, or to the vainglorious effort of the lord of the poultry yard.

The Wild Turkey is divided by ornithologists into four closely related races. Meleagris galloparo is the bird of the Eastern States; M. g. osceola, as stated below, is found in southern Florida; M. $g$. ellioti inhabits southeastern Texas and northeastern Mexico; $M . g$. mexicane ranges from western Texas to Arizona, and south over the table lands of Mexico to Vera Cruz. It is this race, with white-tipped upper tail-coverts, which was first introduced into Europe, where it had become established as early as 1530 .

310b. M. g. osceola sicott. Florida Wild Tiriser.-Resembles M. gallopavo, but is smaller, and the primaries, instead of being regularly and widely barred with white, as in that bird, have much smaller, broken white markings. Weight, ô 12-22 lbs.; \& 4 $75-9$ lbs. (Scott, Auk, ix, 1892, p. 115).

Range.-Southern Florida. 


\section{ORDER COLUIMBZE. PIGEONS AND DOVES.}

\section{Family Columbid 开. Pigeons and Doves.}

About one third of the three hundred known species of Pigeons and Doves are found in the New World, but of this number only twelve species occur in North America. The birds of this family differ widely in their choice of haunts. Some are strictly arboreal, others as strictly terrestrial. Some seek the forests and others prefer fields and clearings. Some nest in colonies, others in isolated pairs, but most species are found in flocks of greater or less size after the breeding season. When drinking, they do not raise the head as other birds do to swallow, but keep the bill immersed until the draught is finished. The young are born naked and are fed by regurgitation.

\section{KEY TO THE SPECIES.}

$A$. Tail widely tipped with white or grayish white.

a. Tail pointed.

$a^{1}$. Back or rump bluish slate-color. . . . 315. Passenger Pigeon. $a^{2}$. Back olive grayish brown. . . . . 316. Mourning Dove.

b. Tail square . . . . . . . 317. Zenaida Dove.

$B$. Tail not tipped with white.

a. Upper parts dark slate-color . . . 314. White-crowned Pigeon.

$b$. Upper parts rufous with purplish reflections.

b1. Line below the eye and belly white or whitish . 322. Quatl Dove.

ใ2. Line under the eye and belly buffy ochraceous.

c. Upper parts grayish olive-brown.

322.1. Ruddy Quail Dove.

c. Crown blue, a white line below the eye.

323. Blue-meaded Quail Dove.

$c^{2}$. Crown pinkish or like the back 320. Ground Dove.

314. Columba leucocephala Limn. White-crowned Pigeox. $A d$. o. - Rich slate-color; crown white; back of the head purplish chestnut; back of the neck with greenish reflections, each feather with a black border. Ad. \&.-Similar, but paler; crown ashy, less purplish chestnut: back and sides of the neck brownish ash with metallic reflections and black margins. L., 13.50 ; W., $7 \cdot 50$; T., $5 \cdot 10$; B., 70 .

Range.-Florida Keys, West Indies, and const of Central America.

Nest, in low bushes. Eggs, two, glossy white, $1.41 \times 1.02$.

This Pigeon is locally common in some of the keys off southern Florida, and has been known to oecur on the mainland. According to $\mathrm{Nr}$. J. W. Atkins (Auk, vi, 1889, p. 246), it arrives at Key West early in May and remains until November.

315. Ectopistes migratorius (Limn.). PAssengir Pigeox. (Sce Fig. 28.) $A d$. 0.-Upper parts rich bluish slate-color; back and sides of the 
neck with metallic reflections; middle of the back and scallulars more or less washed with olive-brown; middle tail-feathers fuscous, outer ones black at the base, then slaty blue, fading into a broad, white tip; under parts deep, rich vinaccous; lower belly white; throat bluish slate-color. Ad. $q$.- Similar, but upper parts with less iridescence and more olive-brown; breast pale grayish brown; belly whitish. Im.-Generally similar to the \&, but the feathers of the upper parts and breast tipped with whitish, the primaries edged and tipped with rufous. L., 16.29; W., 7.82; T., 7.53; B., 7.10.

Kange.-Eastern North Amrerica, northward in the interior to Hudson Bay, breeding locally throughout the more northern part of its range.

Washington, rare and irregular ' $\mathrm{T}$. V. or W. V. Sing Sing, formerly rare S. R. and common T. V., Apl. 15 to May 17; Aug. 21 to Oct. 11; last seen Oct. 11, 1888. Cambridge, rare and irregular 'T. V.

Nest, a platform of sticks, in a tree. Eggs, one to two, white, 1.45 × 1.09.

Wilson, writing about $180 \mathrm{~S}$, estimated that a flock of Wild Pigeons observed by him near Frankfort, Kentucky, contained at least 2,230,272,000 individuals. Captain Bendire, writing in 1892, says: “ . . . It looks now as if their total extermination might be accomplished within the present century. The only thing which retards their complete extinction is that it no longer pays to net these birds, they being too scarce for this now, at least in the more settled portions of the country, and also, perhaps, that from constant and unremitting persecution on their breeding grounds they have changed their habits somewhat, the majority no longer breeding in colonies, but scattering over the country and breeding in isolated pairs" (Life Histories of North American Birds, p. 133).

An article by IVilliam Brewster on The Present Status of the Wild Pigeon as a Bird of the United States, with some Notes on its Habits (Auk, vi, 1889, pp. 285-291), gives much information concerning the recent history of the bird in Michigan, one of its last strongholds. According to an informant of Mr. Brewster's, the last nesting in Michigan of any importance was in 1881. "It was of only moderate sizeperhaps eight miles long." The largest known Michigan nesting occurred in 1876 or $187 \%$. It was twenty-eight miles long and areraged three or four miles in width.

In the Atlantic States the Wild Pigeon is now so rare a bird that during the past sixteen years I have seen only one pair.

316. Zenaidura macroura (Linn.). Morrvrng Dore. Ad. ô.-Upper parts olive grayish brown; forehead vinaceous; crown bluish slatecolor; sides of the neck with metallie reflections, a small black mark below the ear; middle tail-feathers like the back, the others, seen from above, slaty gray for the basal half, then banded with black and broadly tipped with ashy and white; breast vinaceous; belly cream-buff. Ad. + .- Similar, but with less iridescence; breast and forehead washed with grayish brown. Im.- 
Much like the $\&$, but the feathers tipped with whitish. L., 11.85; W., 5.72; T., $5.50 ;$ B., $\cdot 53$.

Remarks.-The Dove is sometimes mistaken for the Wild Pigeon, but, aside from the differences in size, may always be distinguished by its olive grayish brown instead of bluish slate-color rump, the black mark below the ear, and other characters.

Range.-North America, breeding from Cuba north to Ontario, Quebec, and southern Maine, and wintering from southern Illinois and New York to tha Greater Antilles and Panama.

W ashington, P. R.; common, except in winter. Sing Sing, common S. R., Mch. 3 to Nov. 27 ; a few winter. Cambridge, oceasional during summer in the immediate vicinity of Cambridge.

Nest, a flat structure of small twigs rather loosely put together, on the lower branches of a tree, generally within ten feet of the ground; rarely on the ground in the Eastern States. Eggs, two, white, $1.07 \times \cdot 83$.

Doves resemble Wild Pigeons, but are much smaller, and their rapid flight is accompanied by the whistling sound of wings, while the flight of the Wild Pigeon is said to be noiseless.

During the nesting season they may be found in pairs, generally in open woodlands or tree-bordered fields. 'They also visit roads and lanes to dust themselves. The sweet, sad call of the male has won for this species its common name; it consists of several soft coos, which may be written : Coo-0-o, $a h-c 00-0-0-c 00-0-0-c 00-0-0$. Under favorable circumstances these notes may be heard at a distance of at least two hundred and fifty yards; they are uttered slowly and tenderly, and with such apparent depth of feeling that one might easily imagine the bird was mourning the loss of his mate, instead of singing a lovesong to her.

At this season one or both birds may be seen performing a peculiar aërial erolution. Ascending to a height of about thirty feet, they fly for some distance in an unnatural manner, and then, after a short sail, return to their perch. When engaged in this performance they very closely resemble a Sharp-shinned Hawk.

After the nesting season Doves gather in flocks of varying size and frequent grain and corn fields. During the day they visit the nearest supply of fine gravel, which they eat in large quantities as an aid to digestion. In some localities, soon after sunset, they regularly remair in numbers to some favorite place to drink, and then retire to their roosts.

31\%. Zenaida zenaida (Bomap.). ZexiInA Dore. Al.--Bears a general resemblance to Zenaidura macroura. but the tail is square and tipped with ashy, and the under parts are deep, rich vinaceous, L., 10.00; W., 6.10; 'T., $3.50 ;$ B., 66 .

Range.-Florida Keys, West Indies, and coast of Yucatan.

Nest, on or near the ground. Eggs, two, glossy white, $1.22 \times \cdot 92$. 
This is a common West Indian species. Audubon found it in numbers in the keys off southern Florida, where he records it as a summer resident, arriving in April and departing in October. The few naturalists who have visited these keys since Audubon's time have $n$ t been there in the summer, and we do not therefore know whether this species still occurs there at that season. It is more terrestrial in habits than the Mourning Dove, and its notes are deeper, louder, and more solemn than the notes of that species.

The White-Winged Dove (319. Melopelia leucoptera) is a species of general distribution from the Mexican border of the United States south to Costa Rica, and it has been recorded from Cuba, Jamaica, and San Domingo. It is of accidental occurrence at Key West, Florida.

320. Columbigallina passerina terrestris Chapm. Ground Dove; Mourning Dove. Ad. 8.-Forehead and under parts vinaceous, the centers of the breast-feathers blackish; top and back of the head bluish slatecolor; back brownish gray; tail blackish, the outer feathers with small white tips; base of the bill coral-red, tip black. Ad. ․ .-Similar, but the forehead and under parts pale brownish gray. Im.-Resembles the $q$, but the feathers are tipped with whitish. L., $6{ }^{\circ} 75 ;$ W., $3.60 ;$ T., $2 \cdot 50 ;$ B., ${ }^{\circ} 50$.

Range.-South Atlantic and Gulf States north to North Carolina, west to Texas; more common near the coast than inland.

Washington, accidental; two records.

Nest, on the ground or in low trees or bushes. Eggs, two, white, $85 \times \cdot 67$.

This diminutive Pigeon frequents both pines and "hummocks," lake-shores and old fields, and in some southern towns is a familiar bird of the quieter streets. It is by no means shy, and runs before one with quick, short steps and a graceful movement of the head. Occasionally it holds its tail upright, giving it a peculiar bantamlike appearance. Its flight is short, and when on the wing it bears an odd resemblance to a short-tailed Japanese kite.

Its favorite roosting places are densely foliaged orange trees, and frequently when the bird is hidden in their depths one may hear its mellow, crooning coos uttered so softly that they float on the air as though born of murmuring winds.

322. Geotrygon martinica (Gmel.). QuaIL Dore.-Upper parts rufous, with brilliant metallic reflections; wings rufous: a white line beneath the eye; breast vinaceous; belly white. L., $11 \cdot 00$; W., $6 \cdot 20$; T., 5.00; B., 50 .

Range.-Florida Keys and West Indies.

Nest, in trees. Eggs, two, ochraceous-white, $1.22 \times \cdot 94$ (Bendire).

A West Indian species which occurs during the summer regularly, but, so far as known, only in small numbers in the Florida Keys.

The Quail Doves inhabit wooded districts, where they live on the ground. Their flight is low and noiseless, and, according to my ex- 
perience with them in Cuba, they are difficult birds to observe unless one can find some tree on the fallen fruits of which they are feeding.

The Ruddy Quall Dove (322.1. Geotrygon montana) is a West Indian and Central American species, which has been once recorded from Key West (Atkins, Auk, vi, 1889, p. 160). It bears a general resemblance to the preceding, but the back is more rufous and the belly is deep cream-buff.

The Blue-Headed Quarl Dove (323. Starnonas cyanocephala), a Cuban species, is of accidental occurrence in the Florida Keys. The back is olivebrown, the crown and sides of the throat are deep grayish blue, throat black, line beneath the eye white.

\section{ORDER RAPTORES. BIRDS OF PREY.}

\section{Fanily Cathartid Æ. American Vultures.}

A New World family of eight species, of which three are North American. Within their range Vultures are found wherever there is food. Far above the earth on firm wing they sail in broad circles, and from this outlook in the sky descend to feast upon the stricken deer in the forest or the cur lying in the gutters of a thoroughfare. Except during the nesting season, they are generally found in flocks, which each night return to a regularly frequented roost. When alarmed, they utter low, grunting sounds, but at other times are voiceless.

325. Cathartes aura ( $\operatorname{linn}$. ). Turkey Vulture. (See Fig. 32.) Ad.-Head and neck naked, the skin and base of the bill bright red; plumage glossy black, edged with grayish brown. Im.-Similar, but the head covered with grayish-brown furlike feathers. L., about 30.00 ; W., 22.00 ; T., $11 \cdot 00 ;$ B., $2 \cdot 30$.

Range.-Temperate North America, from New Jersey southward to Patagonia. Of more or less regular occurrence in New Jersey as far north as Princeton in the interior and Sandy Hook on the coast.

Washington, abundant P. R. Sing Sing, A. V.

Nest, in hollow stumps or logs, or on the ground beneath bushes or palmettos. Eggs, one to three, dull white, generally spotted and blotehed with distinet and obscure chocolate marking, but sometimes plain or but slightly spotted, $2.80 \times 2.00$.

Doubtless one of the first things that attract the attention of a stranger in our Southern States is the Turkey Buzzard. Indeed, there are few moments between sunrise and sunset when these birds are not in sight. On outstretched, immovable wings they soar overhead in graceful circles, perfect pictures of "repose in motion." Without once flapping their broad pinions, they sail in spirals up the sky until thay are hidden by the storm-cloudis they have purposely aroided. 
Again, on sees them winging their way low over fields or through the streets of a town in search of food, which their powers of both sight and smell assist them in finding.

Their services as scavengers are invaluable. The thought of burying a dead horse or cow never occurs to the southern planter. $\mathrm{He}$ simply drags the animal to a more or less retired place and leares it for the Buzzards, who never fail to do justice to the repast.

In some southern towns they make a self-constituted street-cleaning department, and if their efforts were seconded by a corps of goats, to dispose of the more indigestible materials, they would form an admirable branch of the public service.

After a rain it is a common sight to see Buzzards perching with wings held in spread-eagle fashion as they dry their water-soaked plumage. Frequently they stand on the top of a chimney to take advantage of the heat arising with the smoke.

Their only note is a low, hissing sound uttered when they are disturbed. Just after sunset Buzzards may be seen. sailing to their roosting place, generally in the upper branches of a dead tree.

326. Catharista atrata (Bartr.). Black Vllture. Ad.-Iead and neck bare, the skin and base of the bill blackish; plumage glossy black; under surface of the wings silvery. L., about 24.00 ; W., 17.00 ; T., 8.00; B., $2 \cdot 20$.

Range.-Breeds from North Carolina southward, through Mexico to South America, and oceasionally strays as far north as Maine.

Nest, on the ground, under logs, bushes, palmettos, ete. Eggs, one to three, pale bluish white, generally more or less spotted with distinct and obscure chocolate markings, $2 \cdot 95 \times 2 \cdot 00$.

This species is more abundint near the seacoast and less common in the interior than the preceding. It is also more often found living in towns or cities. Any one who has visited the vicinity of the market in Charleston, S. C., will testify to its abundance and semi-domestication there. Indeed, the birds hare become so tame that when engaged in devouring some savory morsel they are in frequent danger of being trodden under foot.

Black Vultures are heavier birds than Turkey Buzzards, and whenever the ownership of food is in question the dispute is invariably settled in the Vulture's favor. Their stretch of wing, however, is not so great, and for this reason their flight is far less easy and graceful than that of the Buzzard. They flap their wings oftener, and this habit, in connection with their black heads, grayish primaries, and comparatively short tails, serves to identify them in the field. The only note I have ever heard from them is a low grunt uttered when they are disturbed. 
Family falconide. Falcons, Hawis, Eagles, etc.

The three hundred and fifty species included in this family are distributed throughout the world. One tenth of the number are found in North America. During the migratory seasons they may sometimes be seen traveling in seattered flocks, which may take hours to pass a given point. At other times of the year, with few exceptions, they are solitary birds, having no intercourse with their kind. During the breeding season many species have definitely bounded haunts, upon which intrusion by individuals of the same species is not permitted. With much regularity they return to the same locality and even the same nest year after year, and some species are known to mate for life. Their days are an unceasing vigil. At all times they are on the alert for food. This consists to a large extent of small mammals and insects, birds and poultry forming a comparatively insignificant part of the diet of most species. Hawks are thus of great value to the agriculturist as the natural check upon the increase of the myriads of small rodents so destructive to crops.

The cries of Hawks are generally loud, startling, and characteristic of their fierce natures. They strike their prey with their feet, and use the bill to tear it into fragments.

Hawks' nests are generally bulky affairs, composed of ecarse twigs and sticks. The presence of downy feathers gives evidence that they are or have been recently occupied.

I. Wing over 19.00 .

KEY TO THE SPECIES.

A. Upper half of tarsus feathered.

a. Whole head and neck white . . . . 352. Bald EAgle (Ad.).

b. Head and neck brown or brownish.

b1. Bill mostly yellow (Greenland) - . 351. Grat SeA EAGLe (Ad.).

b2. Bill black or blackish . . . . . . 352. Bald EAgle (Im.).

B. Whole tarsus feathered....... . 349. Golden EAgle.

II. Wing under $19 \cdot 00$.

\section{Feathers of under parts more or less streaked and spotted, without cross-bars.}

A. Outer primary with numerous black or blackish bars.

a. Wing under $10^{\circ} 00$.

$a^{1}$. Back bright rufous, with or without black bars.

360. AM. Sparrow HatK.

$a^{2}$. Back bluish slate-color. . . . 357. Pigeon Hawk (Ad.).

$a^{3}$. Back fuscous, second primary longest.

357. Pigeon Hawk (Im.).

$a^{4}$. Back fuscous, fourth primary longest, tail-feathers of nearly equal length; wing under $9.00 . . .2332$. Sharp-SHINNED HawI. 
$a^{5}$. Back fuscous, fourth primary longest, outer tail-feathers half an inch or more shorter than the middle ones; wing over $9 \cdot 00$.

b. Wing over $10 \cdot 00$.

333. CoOper's HaWk.

61. Second primary longest, tail generally over $9 \cdot 00$.

62. "Lower tail-coverts immaculate white." 353. White Grrfalcon. $b^{3}$. "Lower tail-coverts always more or less marked with dusky."

354. Gray Grrfalcon and Races.

c. Second primary longest, tail under $9 \cdot 00$.

$c^{2}$. Tarsus shorter than middle toe without nail, upper parts blackish. 356. DuCK Hawk.

$c^{3}$. Tarsus longer than middle toe without nail, upper parts brownish . . . . . . . . 355. Prairie Falcon.

$d^{1}$. Third or fourth primary longest.

$d^{2}$. Upper tail-coverts white. . . . . 331. Marsh Hawk.

$d^{3}$. Upper tail-coverts brownish . . .334. Aм. Gosiawk (Im.).

$B$. Outer primary generally one color, base sometimes whitish or with a few imperfect bars.

a. Tarsus entirely bare, scales on its front large, rounded.

362. Audubon's Caracara.

b. Tarsus entirely feathered . . . 348. Ferruginous Rough-LEG.

c. Tarsus partly feathered, scales on its front small, rounded.

364. Am. Osprex.

d. Tarsus partly feathered, scales on its front transverse, more or less square.

$d$. Three outer primaries emarginate or "notched." *

$d^{2}$. Wing under 12.00 . . 343. BroAD-WINGED HAwK (Im.).

$d^{3}$. Wing over $12 \cdot 00$. . . . 342. Swainson's Hawk (Im.).

$e^{1}$. Four outer primaries emarginate or "notched." +

$\epsilon^{\mathbf{2}}$. Upper tail-coverts pure white . . . 331. Marsa Наwк.

$e^{3}$. Upper tail-coverts not pure white; wing under 13.50 ; lesser wing-coverts conspicuously margined with rufous.

339. Red-SHOUldered HAwK (Im.).

$e^{4}$. Upper tail-coverts not pure white; wing over 13.50 ; lesser wingcoverts not conspicuously margined with rufous.

337. Red-tailed Hawk and Races.

\section{Feathers of under parts with more or less numerous cross-bars.}

A. Scales on front of the tarsus numerous, rounded.

a. Wing under 1500 . . . . . . . 356. Duck HaWk.

b. Wing over 15.00 . . . . . 362. Audubon's Caracara.

$B$. Scales on front of the tarsus sharply defined, transverse, more or less square.

a. Four or five outer primaries emarginate or "notched." + $a^{1}$. Tail white at the base and tipped with whitish.

330. Everglade Kite. 
$a^{2}$. Tail rufous, with sometimes a black band near the end.

337. Red-tailed Hawk (Ad.) and Races.

$a^{3}$. Tail black or blackish, with four to six white or grayish erossbars - 339. Red-Shouldered Hawk (Ad.).

339a. Florida Red-shouldered Hamk (Ad.).

$a^{4}$. Tail 10.00 long, gray, with several indistinct blackish bands.

b. Three outer primaries emarginate or "notched." *

334. An. Goshaw K.

b1. Tail with two or three broad whitish bars.

343. Broad-winged Hawk (Ad.).

$t^{2}$. Tail with numerous narrow, indistinct blackish bars.

342. Swainson's Hawh (Ad.).

$C$. Front of the tarsus smooth, or with the scales not sharply defined; outer primary barred.

a. Wing under $9 \cdot 00$, tail-feathers of nearly equal length.

332. Sharp-shinned Hath (Ad.).

b. Wing over $9 \cdot 00$, outer tail-feathers half an inch shorter than the middle ones; upper tail-coverts not white. 333. Cooper's Hawk (Ad.).

c. Wing over 9.00 ; upper tail-coverts white. 331. MLarsh Hawk (Ad.).

D. Tarsus entirely feathered.

a. Legs rich rufous, heavily barred - 348. Ferrugrous Rodgh-Leg.

$b$. Legs ochraceous-buff, more or less barred.

\section{Under parts wilhout streaks or bars.}

347a. Ar. Rovgh-Legged Hath.

A. Under parts white.

a. Scales on front of tarsus transverse, more or less square.

b. Scales on front of tarsus numerous. rounded.

334. SHORT-TAILED HaWk.

6. Tail barred.

ל2. Upper parts not barred . . . . . . 364. Arr. Osprer.

b3. Upper parts barred. . . . . 353. WHITE GrRfalcon.

$c^{1}$. Tail not barred.

$c^{2}$. Tail square, white . . . . 328. Writte-tailed Kite.

$c^{3}$. Tail forked, bluish black . . 327. Swallow-tailed Kite.

$B$. Under parts dark brown, slate, gray, or black.

a. Tarsus entirely feathered . . 34i $\alpha$. Ar. Rovgir-Legged Hawr.

b. Tarsus partly feathered, scales transverse, more or less square.

b1. Wing over $13 \cdot 00$.

$\iota^{2}$. Upper tail-coverts, base and tip of the tail white; two outer primaries slightly "notehed" . . . 330. Everglade Kite.

b3. Three outer primaries "notehed"*. 342. Swaisson's HAwk.

b4. Four outer primaries "notched" . . 33S. Harlan's Hawk.

$c^{1}$. Wing under $13 \cdot 00$.

$c^{2}$. Primaries more or less distinctly barred; general plumage sooty black . . . . . . . 344. SHORT-TAILed HATK.

$c^{3}$. Primaries not barred; general plumage slaty blue.

329. Mississippi Kite. 
32\%. Elanoides forficatus (Linn.). SWALrow-TAILED KITE. $A d$. -Head, neck, linings of the wings, rump, part of tertials, and under parts white; rest of the plumage glossy bluish black; tail deeply forked, the outer feathers about 8.00 longer than the middle ones. L., 24.00 ; W., 16.50 ; T., $13.50 ;$ B. from N., 80 .

Kange.-Southern United States north to Pennsylvania and casually to Massachusetts; south to South America; breeding locally throughout its range, and wintering in Central and South America.

Nest, in the upper branches of tall trees. Eggs, two to four, white or bufly white, boldly spotted or blotched, chiefly round the larger end, with hazelbrown, chestnut, or rich madder-brown, $1.87 \times 1.49$ (Ridgw.).

The Swallow-tailed Kite winters in Central and South America, and appears in the United States in March. Its home is the air, and it is far more frequently seen on the wing than at rest. It captures its prey, devours it, and drinks while under way. Its flight possesses all the marvelous ease and grace of a Swallow's, made more evident, and consequently more impressive, by the bird's much greater size.

328. Elanus leucurus ( Vieill.). White-taIled Kite. Ad.-Upper parts ashy gray, whiter on the head; wing-coverts black; tail and under parts white. L., 15.50; W., 12.50; T., 7.00; B. from N., 70.

Range.-Breeds from South Carolina, southern Illinois, and Indian Territory southward through Mexico to the Argentine Republic; rare east of the Mississippi.

Nest, in trees. Eggs, three to four, "handsomely marbled or clouded with various shades of rich madder-brown on a paler (sometimes whitish) ground, $1.71 \times 1.31 "$ (Ridgw.).

This species is not often found east of the Mississippi. It frequents open, marshy situations. A pair which I observed in Texas hunted by hovering over the reeds, sustaining a position facing the wind, and about forty feet from the ground, by a gentle movement of the wings.

329. Ictinia mississippiensis (Wils.). MIssissippi Kıте. Ad.-. Head, neck, exposed margins of the secondaries, and under parts gray; back bluish slate-color; primaries streaked or spotted with rufous-chestnut; tail black, without bars. Im.-Head streaked with black and white; back blackish, tipped with rufous or white, the concealed parts of the feathers white and with generally one blackish bar; primaries without rufous; tail with three or four broken white bars; below bufty, streaked with rufous and grayish brown. L., $14 \cdot 00 ;$ W., $11 \cdot 25$ : T., $6 \cdot 50 ;$ B. from N., 60 .

Range.-Breeds from South Carolina, southern Illinois, and Kansas southward to Central America; winters in the tropies.

Nest, in tall trees. Eggs, two, dull white, sometimes with a bluish tinge, $1.63 \times 1.32$.

This bird, like the preceding, is only a summer resident in the United States, arriving from the south in April. It is not common 
east of Louisiana. It migrates in flocks, sometimes flying within gunshot, and at others so far above the earth as to be almost beyond the bounds of vision.

330. Rostrhamus sociabilis (Tieill.). ETERgLade Kite; STALLHuwk. Al. o.-Dark slate-color; under, and longer upper tail-coverts, and base of the tail white, tip of the tail whitish; upper mandible much lengthened and hooked. \& and $\mathrm{im}$.--Upper parts black, tipped with rufous: under parts barred and mottled with rufous, black, and buffy; tail as in the $A d$. $\delta$. L., $18 \cdot 00 ;$ W., 14.00; T., $7 \cdot 75 ;$ B., 1.20.

Range.-Breeds from middle Florida southward to the Argentine Republic.

Nest, in bushes, among reeds or tall grasses. Eggs, two to three, pale bluish white, heavily spotted, blotched, or washed with cinnamon or chocolate, $1 \cdot 85 \times 1 \cdot 47$.

This species is a summer resident in southern Florida. It arrires from the south in February. Mr. W. E. D. Scott writes of it as observed at Lake Panasofkee, Florida: "Their food at this point apparently consists of a kind of large, fresh-water snail, which is very abundant, and the local name of 'Snail-Hawk' is particularly applicable to this bird as I have met with it. They fish over the shallow water, reminding one of Gulls in their motions; and having secured a snail by diving, they immediately carry it to the nearest available perch, where the animal is dexterously taken from the shell without injury to the latter" (Bull. Nutt. Orn. Club, vi, 1881, p. 16).

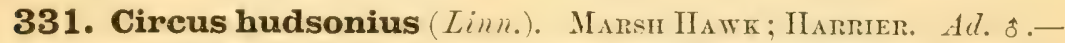
Upper parts gray or ashy; upper tail-coverts white; tail silvery gray, irregularly barred or marked with blackish; upper breast pearl-gray; the lower breast and belly white, spotted or barred with rufous. $A d$.. .- Upper parts fuscous, the head and neck streaked, and the wing-coverts spotted or margined with rufous; longer upper tail-coverts white ; middle tail-feathers barred with ashy and black, others barred with ochraceous-buff and black; under parts ochraceous-buff, widely streaked on the breast and narrowly streaked on the belly with fuscous or light umber. Im.-Similar to the $q$, but somewhat darker above; the under parts darker, almost rufous; the belly without streaks. of L., 1900 ; W., 13.75; T., 9.01) B. from N., •60. \& L., $22 \cdot 00 ;$ W., $15 \cdot 00 ;$ T., $10 \cdot 00$.

Range.-North America in general, south to Panama.

Washington, common W. V., July to Apl. Sing Sing, tolerably common S. R., Mch. 6 to Oct. 30 ; a few winter. Cambridge, common T. V., Mch. 15 to Apl. 15; Sept. and Oct.; a few breed.

Nest, on the ground, in marshes. Egge, four to six, dull white or pale bluish white, $1.75 \times 1 \cdot 40$.

This Hawk is essentially a bird of the unwooded country, and we might as well look for a Grouse in the open marsh as for a IIarrier in the thick woods. It flies low, and may be easily identified by the large 
white patch on its rump. Quartering the country with slow, vacillating flight, it usually captures its living prey by surprising it away from its retreats.

The IIarrier is a low-perching IIawk, and most frequently will be seen alighting on a slight elevation or in the grass. During the nesting season the male may be seen endeavoring to win the admiration of the principal spectator by performing a number of extraordinary aërial evolutions. Sometimes he soars to a great height, then falls straight downward nearly to the ground, turning several somersaults during the descent, and uttering at the same time a reiterated screeching. At other times he flies across the marsh in a course which wonld outline a gigantic saw, each of the descending parts being done in a somersault and accompanied by the screeching notes, which form the only love song within the range of his limited vocal powers.-Ernest E. Thompson.

"Of 124 stomachs examined, 7 contained poultry, or game birds; 34 , other birds; 57 , mice; 22 , other mammals; $\%$, reptiles; 2 frogs; 14, insects; 1 , indeterminate matter, and 8 were empty" (Fisher).

332. Accipiter velox (Wils.). Sharp-shinned Hawk. Ad.-Upper parts slaty gray; primaries barred with blackish; tail nearly square, ashy

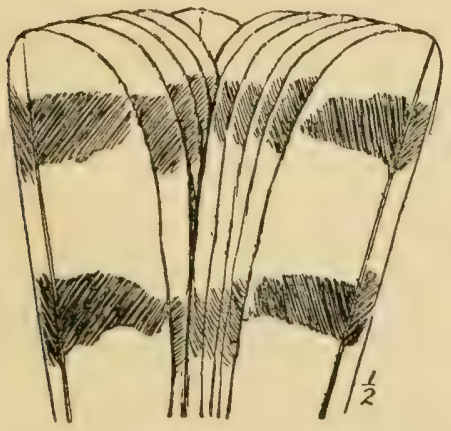

FIG. 6\%.-Square tail of Sharpshinned Hawk. gray, with blackish cross-bars and a whitish tip; throat white, streaked with blackish: rest of under parts barred with white and ochraceous-buff or pale rufous. Im.Upper parts fuscous, margined with rufous; primaries and tail much as in the ad.; under parts white or buffy white, streaked or spotted with blackish or pale rufous-brown. o L., 11.25; W., 6.60; T., 5.50; B. from N., -40. \& L., $13.50 ; \mathrm{W} ., 8 \cdot 00 ; \mathrm{T} ., 7 \cdot 00$.

Remarks.-This species very closely resembles Cooper's Hawk. In adult plunage the black eap characterizes that species, but immature birds may be distinguished only by size and the difference in the shape of the tail; which in velox is nearly square, and in cooperi decidedly rounded.

Range.-Breeds throughout the United States, and winters from Massachusetts to Central Ameriea.

Washington, common P. R. Sing Sing, common P. R. Cambridge, common T. V., Apl. 15 to Apl. 30 ; Sept. and Oet.; rare S. R., uncommon W. V.

Nest, in trees, fifteen to forty feet from the ground. Eggs, three to six, varying from bluish white to pale eream-butf, distinctly spotted, hearily blotched, or even washed with chocolate or cinnamon-rufous, $1.55 \times 1 \cdot 20$.

The generally misapplied names "IIen Hawk" and "Chicken Hawk" should be restricted to the birds of this genus, for they de- 
serve the reputation commonly attributed to the large IIawks of the genus Buteo.

The Sharp-shinned Hawk differs decidedly in habits from the mouse- or insect-eating species, which watch for their prey from a lookout and capture it on the ground. It is a fearless, daring, aggressive bird, and flying swiftly, rather low, either in the open or through woods, it makes sudden dashes at the frightened birds, which hurry to cover to escape its talons. One hears a commotion among the birds; calls of alarm, and a dark form darts through the foliage in close pursuit, or, missing its aim, alights in the center of some thickly leaved tree, there to await in silence a fresh opportunity. Sometimes it may be seen soaring in narrow circles, when its disproportionately long tail forms a good field character.

It is usually a voiceless bird except during the nesting season, when a too close approach to its nest causes it to utter its peculiar notes.

"Of 159 stomachs examined, 6 contained poultry or game birds; 99 , other birds; 6, mice; 5, insects; and 52 were empty" (Fisher).

333. Accipiter cooperi (Bonap.). Cooper's Hawk. Ad.-Similar to adults of the preceding, but larger and with the crown blackish. Im.Similar in color to young of $A$. velox, but larger. \& L., $15 \cdot 50$; W., $9.50 ;$ T., $7.75 ;$ B. from N., $\cdot 55$. \& L., 19.00 ; W., 10.50 ; T., 9.00.

Range--Breeds from the Gulf of Mexico to Newfoundland, and winters from Massachusetts to Mexico.

Washington, common P. R. Sing Sing, tolerably common P. R. Cambridge, common T. V., Apl.; Sept. and Oct.; not uncommon S. R. ; rare W. V.

Nest, in trees, twenty-five to fifty feet from the ground. Eggs, three to six, pale bluish white, sometimes lightly spotted with brownish, $1.90 \times 1.55$.

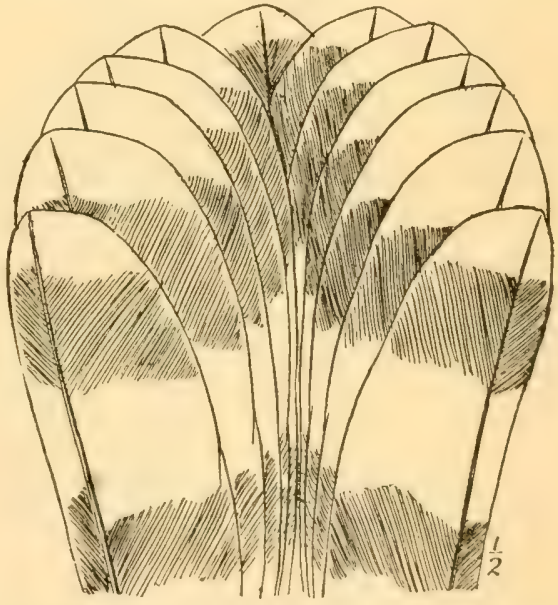

FIG. 68.-Rounded tail of Cooper's Hawk.

This species resembles the preceding in habits, but because of its larger size is more destructive to poultry.

"Of 183 stomachs examined, 34 contained poultry or game birds; 52 , other birds; 11 , mammals; 1 , frog; 3 , lizards; 2 , insects; and 39 were empty" (Fisher).

334. Accipiter atricapillus (Wils.) American Goshamk. Ad.Upper parts bluish slate-color; head blackish, a white line orer and behind 
the eye; inner tail-feathers like the back, outer ones more fuscous, and slightly marked with blackish; tip whitish; entire under parts evenly marked with irregular, wavy bars of gray and white, the feathers of the throat and breast with clarker shaft streaks. Im.-Upper parts fuscous, margined with rufous; primaries barred with black; tail brownish gray, barred with black; under parts white or buffy, streaked with black. \& L., 22.00; W., 13.00; 'T., 10.00; B. from N., 65 . \& L., $21 \cdot 00$; W., $13 \cdot 40$; T., $11 \cdot 50$.

Range.-Breeds from the northern United States northward, and winters as far south as Virginia.

Washiugton, casual in winter. Sing Sing, rare W. V., Oct. 10 to Jan. 14. Cambridge, irregular and uncommon W. V.

Nest, in trees. Eggs, two to five, "white, or glaucous-white, sometimes very faintly marked with pale brownish, $2.31 \times 1 \cdot 74 "$ (Ridgw.).

With the general habits of the two preceding species this larger bird is much bolder than either. Dr. Fisher remarks: "This species is one of the most daring of all the Hawks, and while in pursuit of its prey is apparently less concerned by the presence of man than any other. It will dart down unexpectedly at the very feet of the farmer and carry off a fowl."

"Of 28 stomachs examined, 9 contained poultry or game birds; 2 , other birds; 10 , mammals ; 3 , insects ; 1 , centiped; and 8 were empty" (Fisher).

33\%. Buteo borealis (Gmel.). Red-talled Hawk; HeN IAwK; CHicken HAwк. Ad.-Upper parts dark grayish brown or fuscous-brown, more or less edged with rufous, ochraceous-buft, and whitish ; four outer primaries "notehed," the outer one not regularly barred; wing-coverts not edged with rufous; tail rich rufous, with a narrow black band near its end and a white tip; upper breast heavily streaked with grayish brown and ochraceousbuff, lower breast lightly streaked and sometimes without streaks; upper belly streaked, spotted, or barred with black or blackish, forming a kind of broken band across the belly; lower belly generally white without streaks. Im.-Similar, but the tail of about the same color as the back, crossed by numerous more or less distinct blackish bands; no rufous in the markings of the under parts. of L., $20 \cdot 00$; W., $15 \cdot 50$; T., $9 \cdot 25$; B. from N., 95 . \& L., $23 \cdot 00$ : W., 16.50 ; T., $9 \cdot 75$.

Range.-Eastern North America, breeding throughout most of its range.

Washington, common W. V., rare S. R. Sing Sing, common P. R.; less common in winter. Cambridge, common W. V., Nov. to Apl.; a few S. R.

Nest, in trees, thirty to seventy feet from the ground. Eggs, two to four, dull white, generally seantily and irregularly marked with shades of cinnamon-brown, $2.40 \times 1.85$.

The Red-tailed Hawk resembles its near relative, the Red-shouldered Hawk, in the selection of its haunts, and, to a large extent, in habits. It is to be distinguished in life from that species by its larger size, which, even in the ficld, is noticeable, and by its call. The usual 
note of the Red-tail is a long-drawn "squealing" whistle, which to my ear suggests the sound produced by escaping steam.

" Of 562 stomachs examined, 54 contained poultry or game birds; 51, other birds; 278, mice; 131, other mammals; 37 , batrachians or reptiles; $4 \%$, insects; 8 , crawfish; 1 , centiped; 13 , offal; and 89 were empty" (Fisher).

33ra. B. b. kxiderii Hoopes. Krider's Hawk.-Similar to Buteo borealis, but with much more white in the plumage; the head sometimes almost entirely white; the under parts only lightly streaked, and with the band on the belly sometimes obsolete; the tail in the ad. pale rufous, generally without a terminal black band; in the im., pale rufous, or white washed with rufous, and with numerous blackish bars. of W., 15.00; T., 9.50.

Range.- "Great plains of the United States, from Minnesota to Texas; east irregularly or casually to Iowa and northern Illinois" (Bendire).

337d. B. b. harlani (Aul.). HarLAN's HAWk. Al.-Upper parts dark sooty fuscous, the bases of the feathers more or less barred with grayish; tail closely mottled with black, fuscous, rufous, and whitish ; under parts varying from white more or less spotted across the belly to sooty fuscous. Im.-Similar, but the tail barred with blackish, grayish, rufous, or whitish, tipped with white. of L., about 19.00 ; W., 15.50 ; T., 8.25. \& L., about 21.00 ; W., $17.00 ;$ T., 9.25 .

Runge.--"Gulf States and lower Mississippi Valley; north (casually) to Kansas, Iowa, Illinois, and Pennsylvanía ; east to Georgia and Florida" (Bendire).

Dr. William L. Ralph, in Captain Bendire's Life Iistories of North American Birds (p. 218), reports this species as not uncommon during the winter in St. John's and Putnam Counties, Florida. He writes: "They are exactly like the Red-tailed Hawks except in color, and their call-note is the same, only being longer drawn out. The call of the latter bird, as already stated, sounds like the squealing of a pig, or 'kee-ee-e,' and that of Harlan's Hawk like 'kee-ee-ee-e-e-ee."

'The Western Redtail (337b. B. b. calurus) has been recorded from Illinois, and one specimen of the European Buzzard (396. Buteo buteo) is said to have been taken in Michigan.

339. Buteo lineatus (Gmel.). Red-sirovlderen II Awk; Hen Hawk; Chicken Hawk. Ad.-Upper parts dark grayish fuscous-brown, more or less edged with rufous, ochraceous-buff, and whitish; four outer primaries "notched," all barred with black and white; lesser wing-coverts rufous, forming a conspicuous "shoulder" patch; tail black or fuscous, with four or five white cross-bars and a white tip; throat streaked with blackish; rest of under parts rufous or ochraceous-buff', cverywhere barred with white or whitish. Im.-Upper parts much as in the adult; basal part of the primaries mostly ochraceous-buff, fading to whitish on the inner web, with broken bars of fuscous; lesser wing-coverts conspicuously margined with rufous or rufouschestnut; tail dark grayish brown, indistinctly barred with fuscous, and on 
the basal half with more or less rufous, the inner webs of the feathers with sometimes white bars; under parts white or whitish, streaked or spotted with black or blackish, the legs sometimes barred with rufous. o L., 18.30; W., 12.50 ; 'T., 8.00; B. from N., 75 . क L., 20.35: W., 13.50; 'T., 9.00.

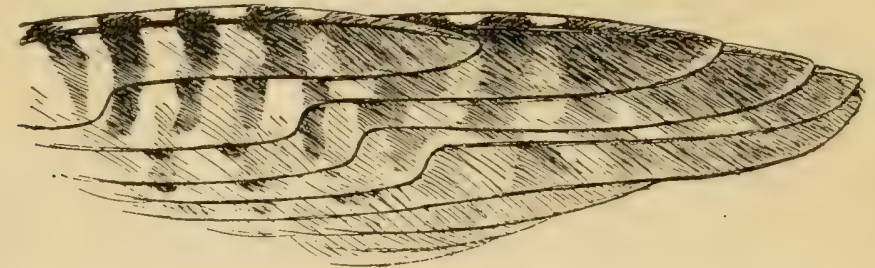

FIG. 69.-Four-notched primaries of Red-shouldered Hawk. (Reduced.)

Remarks.-Adults of this species may always be known by the rich rufous lesser wing-coverts. Immature birds are sometimes confused with the young of the Red-tailed or Broad-winged Hawks. From the former they may be distinguished by their small size, rufous margins of the lesser wing-coverts ochraceous-buff markings on the primaries, and the continuously streaked under parts; from the latter they differ in having four instead of three outer primaries "notched," in being larger, and in having ochraceous-butf on the primaries.

Kange.-Eastern North America, north to Nova Scotia and Manitoba; resident nearly throughout its range.

W ashington, common P. R. Sing Sing, common P. R. Cambridge, common $P . R$., less common in winter.

Nest, in trees, thirty to sixty feet from the ground. Eggs, three to six, dull white, generally more or less sprinkled, spotted, or blotched with cinnamon-brown or chocolate, $2.15 \times 1.65$.

The present species and the Red-tailed Hawk are the birds to which the names Chicken Hawk and Hen Hawk are most frequently misapplied. Being both common species whose habits render them easily observed, they are often unjustly made to suffer for the sins of their bird-killing relatives of the genus Accipiter.

The farmer sees a Hawk sailing in wide circles above him, uttering its fierce, screaming cry of keè-you, keè-you. While he is watching it a sly, low-flying Accipiter slips by him and makes a sudden dash into the poultry yard. The farmer does not discriminate; a Hawk is a Hawk, and, shaking his fist at the bird in the air, he vows vengeance at the first opportunity.

The Red-shouldered Hawk is at most times of the year a bird of the woods. Particularly does it like low woods watered with small streams from which it can obtain its favorite food of frogs. Its note is one of the common sounds of summer, and can be heard when the bird is almost lost to sight far up in the sky. It is frequently imitated by the Blue Jay. 
“ Of 220 stomachs examined, 3 contained poultry; 12 , other birds; 102 , mice; 40 , other mammals; 20 , reptiles ; 39 , batrachians; 92 , insects ; 16 , spiders ; 7, crawfish ; 1 , earthworms ; 2 , offal ; 3 , fish ; and 14 were empty" (Fisher).

339a. B. 1. alleni Ridgw. Florida Red-shov'ldered Hawk-Adults of this species may easily be distinguished from those of $B$. lineatus by their smaller size, grayish white head, with black shaft streaks and no rufous, the smaller fuscous tips on the scapulars and interscapulars, which do not conceal the ashy gray bases of the feathers, by the whitish or grayish cheeks and throat, and the ochraceous-buff, indistinctly barred under parts. Immature birds are very similar to those of $B$. lineatus, and ean be distinguished only by their smaller size and darker color. \& W., 11.00; T., 7.50; B., $1 \cdot 20$.

Range.-Florida, north along the Atlantic coast to South Carolina, west along the Gulf' coast to eastern 'Texas.

342. Buteo swainsoni Bonap. Swanson's IIawk. Ad. o.-Upper parts fuscous-brown, more or less margined with rufous or buffy ; primaries unbarred, three outer ones "notehed"; tail slightly grayer than the back, with numerous indistinet, blackish bars showing more plainly on the under surface; breast covered by a large, cinnamon-rufous patch; belly white or ochraceous-buff, streaked, spotted, or barred with blackish, rufous, or buff. $A d$. \&.-Similar, but larger, the breast patch of the same color as the back. o and o in dark or melanistic plumage.-Entire plumage fuscous, the under tail- and under wing-coverts and the tail sometimes spotted or barred. Im.Upper parts fuscous-brown, widely margined with buffy and rufous; base of the primaries grayish, and sometimes with a few broken bars; tail much as in the ad. ; under parts ochrucenus-buffi, spotted and streaked with blackish. \& L., 20.00 ; W., $15 \cdot 00$; T., 8.50; B. from N., 75.

Remarks.-Between the light and dark phases of coloration there is every degree of intergradation; but in any plumage this IIawk may be distinguished from our other species by having only three outer primaries notched. In this respect it agrees with $B$. latissimus, from which, however, it differs decidedly both in size and color.

Range.-Western North America, eastward to the Mississippi; breeds from Texas to the aretic regions, and occasionally strays eastward to the Atlantic States.

Nest, in trees, thirty to eighty feet from the:ground. Eggs, two to three, varying from dull bluish white to creamy white, sometimes unmarked, but generally more or less spotted or blotehed with shades of cinnamon-brown, $2 \cdot 30 \times 1 \cdot 72$.

Swainson's IIawk is of rare occurrence east of the Mississippi. Dr. Fisher writes: "By preference it frequents the timber in the vicinity of streams, though often it is found far out on the prairie, where its only perch is the earth mound of some mammal, or some other slightly elevated knoll." 
343. Buteo latissimus (Wils.). Brond-Wingro IIAWk. Ad.Upper parts dark grayish brown or fuscous, more or less margined with buffy and rufous: three outer primaries "notched" and without ochraceous-buff markings; tail fus-

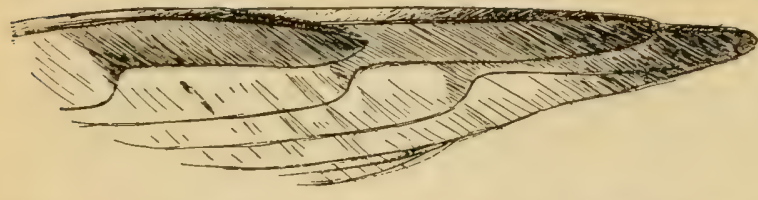

Fig. 70.-Three-notched primaries of Broad-winged Hawk. (Reduced.) cous, with two bars and the tip grayish white; under parts heavily barred with brownish ochraceousbuff:. Im. - Upper parts like the preceding; tail grayish

brown, with three to five indistinct black bars and a narrow whitish tip; under parts white or buffy white, streaked and spotted with fuscous. o L., $15 \cdot 89$; W., 10.68; T., $6 \cdot 75 ;$ B. from N., 70 . \& L., 16.76; W., 11.41; T., $7 \cdot 09$.

Remarks.-Compared with the other members of this genus, the three "notched" primaries and small size are the principal characters of this Hawk.

Range.-Breeds throughout eastern North America, from New Brunswick south ward.

Washington, not common W. V., rare S. R. Sing Sing, tolerably commonS. R., Mch. 15 to Oct. 23. Cambridge, T. V., sometimes common in Sept.; rare in spring.

Nest, in trees, twenty-five to fifty feet from the ground. Eggs, two to four, dull white or buffy white spotted, blotched, or washed with ochraceous-buff or cinnamon-brown, $2 \cdot 10 \times 1 \cdot 60$.

"Of all our Hawks, this species seems to be the most unsuspicious. often allowing a person to approach within a few yards of it, and when startled flies but a short distance before it alights again. During the early summer the Broad-winged Hawk often may be seen sitting for hours on the dead top of some high tree. At other times it is found on the smaller trees in the deep woods, along streams, or on the ground, where its food is more often procured. Although sluggish and unusually heavy in its flight, it is capable of rapid motion, and sometimes soars high in the air. One of its notes resembles quite closely that of the Wood Pewee. ...

"Of 65 stomachs examined, 2 contained small birds: 15 . mice; 13 , other mammals; 11 , reptiles; 13 , batrachians; 30 , insects; 2 , earthworms ; 4, crawfish; and 7 were empty" (Fisher).

344. Buteo brachyurus Fieill. Short-tallen Hawk. Ad.Upper parts slaty gray or fuscous grayish brown; forchead whitish; tail barred with black and narrowly tipped with white, its under surface grayish; sides of the breast with some rufous-brown markings; rest of the under parts pure white. Im.-Similar, but upper parts browner and margined with cream-buff; under parts washed with cream-buff; no rufous-brown on the breast. Dark phase.-Fuscous-black, with a slight mctallic luster; forehead 
whitish; tail lighter than back, barred with black, its under surface and the under surface of the primaries grayish. L., 17.00; W., 12.50; T., 7.00; Tar., $2 \cdot 35$; B. from N., 70 .

Range.-Florida and Mexico southward through South America.

Nest, in trees. Eggs (?), dull white, spotted at the larger end with small spots and blotches of reddish brown over about one fourth the surface, $2 \cdot 16 \times$ 161 (Pennock).

A rare resident in Florida. According to Mr. C. J. Pennock, who found its nest at St. Marks on April 3, its call somewhat resembles the scream of the Red-shouldered Fiawk, but is finer and more prolonged (Auk, vii, 1890, p. 56 ; see also Scott, ibid., vi, 1889, p. 243).

The Mexican Gosuawn (346. Asturina plagiata) is a tropical species which reaches the southwestern border of the United States. An individual seen by Mr. Robert lidgway in southern Illinois, Augrust 19, 18 1 , is the only known instance of its occurrence east of the Mississippi.

34\%a. Archibuteo lagopus sancti-johannis (Gmel.). AMERIcan Rougir-Legged Hawk. Ad., light phase.-Upper parts fuscous-brown, margined with whitish and ochraceous-buff; inner vanes of the primaries white at the base; basal half of the tail white or buffy, end with two or three grayish or whitish bars; under parts varying from white to ochraceous-buff, streaked and spotted with black, these marks uniting to form a broken band across the belly; front of tarsi entirely feathered. Im., normal phase-Similar to the ad., but the end half of the tail without bars except for the white tip, the under parts more heavily marked with black, the belly band being broad and continuous. Black phase.-Plumage more or less entirely black, the primaries and tail barred with whitish and grayish. L., $22^{\circ} 00 ;$ W., $16^{\circ} 00$; T., $9 \cdot 50$.

Remarks.-Its feathered tarsi and heavily marked under parts characterize this species.

Range.-North America, breeding north of the United States and wintering as far south as Virginia.

Washington, rare and irregular W. V. Sing Sing, A. V. Cambridge, not uncommon T. V., Nov.; Mch.; a few winter.

Nest, on rocky ledges or in trees. Eggs, two to five, dull white, sometimes unmarked, but generally more or less spotted, blotehed, or scrawled with cinnamon-brown or chocolate, $2.20 \times 1.75$.

"The Rough-leg is one of the most nocturnal of our Hawks, and may be seen in the fading twilight watching from some low perch or beating with measured, noiseless flight over its hunting ground. It follows two very different methods in securing its food-one by sitting on some stub or low tree and watching the ground for the appearance of its prey, as the Red-tail does; the other by beating back and forth just abore the tops of the grass or bushes and dropping upon its victim, after the manner of the Marsh Hawk. ...

"The flight of the Rough-leg is seldom rapid and often appears 
labored, and when on the wing this Hawk resembles the Osprey more than any other bird of prey. ...

"Of 49 stomachs examined, 40 contained mice; 5 , other mammals; '1, lizards; 1 , insects; and 4 were empty" (Fisher).

348. Archibuteo ferrugineus (Licht.). Ferruginous Rovgh-LEG. Ad., light phase.-Upper parts mostly rufous, the centers of the feathers fuscous; tail grayish white, margined with rufous; legs rufous, barred with black; rest of under parts white, more or less barred with rufous on the sides and belly; tarsi fully feathered in front. Im.-Upper parts dark grayish brown, slightly varied with ochraceous-buff; tail silvery grayish brown, without bars, the base white; under parts white, lightly spotted and streaked with fuscous. Dark phase.-Dark fuscous-brown, more or less varied with rufous; primaries and tail as in the ad. L., 23.00; W., 17.00; T., 10.50 .

Remarks.-This species is to be distinguished from the preceding principally by its much larger bill and differently colored tail and under parts.

Range._-"Western United States; east to and across the great plains (occasionally to Illinois); north to the Saskatchewan; south into Mexico " (Bendire).

Nest, in trees or on the ground in rocky places. Eggs, two to four, "white, or buffy white, usually more or less spotted, blotched, or clouded with brown or grayish purple (or both), $2.42 \times 1.88 "$ (Ridgw.).

This bird is rarely found east of the Mississippi. Dr. Fisher remarks: "The Squirrel Hawk is pre-eminently a bird of the prairie,

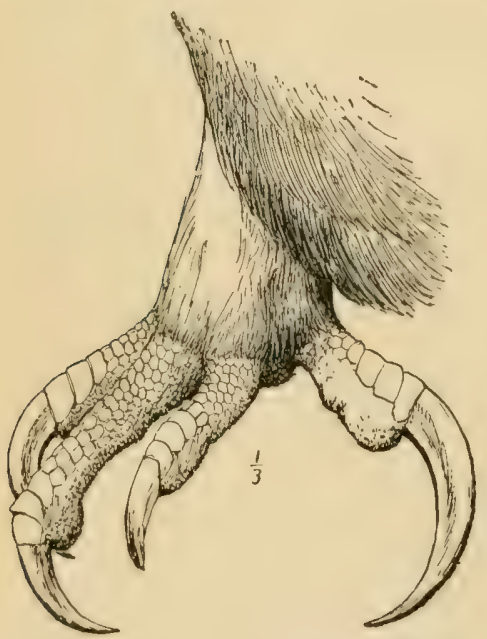

Fig. 71.-Foot of Golden Eagle. and, unlike the common Rough-leg, shows little partiality to the vicinity of water, though in other respects it closely resembles the latter bird in habits."

349. Aquila chrysaëtos (Linn.). Golden Eagle. Ad.-Back of the head and nape pale, buffy ochraceous; basal two thirds of the tail white; tarsus white, entirely feathered; rest of the plumage fuscous-brown ; quills fuscous. Im.Similar, but base of the tail with broken grayish bars; tarsus and under tailcoverts ochraceous-buff. \& L., $30.00-$ $35 \cdot 00$; Ex., $78 \cdot 00-84^{\circ} 00$; W., 22.00-24.70; T., 14.00-15.00; Tar., 3.65-3.80. L., 35.00$40 \cdot 00$; Ex., 84.00-90.00; W., 25.00-27.00; T., 15.00-16.00; Tar., 4.15-4.25 (Kidgw。).

Range.-North America; of rare occurrence east of the Mississippi.

Washington, rare W. V. Sing Sing, A. V.

Nest, on cliffis or rocky ledges. Eggs, two to three, dull white, obscurely or distinctly blotched or speckled with shades of cinnamon-brown, $2.93 \times 2.34$. 
"It seems to be nowhere a common species in the east, but it is much more numerous in the mountainous parts of the far west. It is confined chicfly to the mountains and more northern latitudes, where it breeds. It is able to endure intense cold, and sometimes remains far north in winter. In fact, its movements at that season are more in the form of wandering for food than regular migration to the south.

"The food consists mainly of mammals and birds, of which spermophiles, rabbits, fawns, lambs, turkeys, grouse, waterfowl, and other large birds form the principal part, though offal and carrion are sometimes taken. . . O Of 6 stomachs examined, 1 contained feathers; 2, mammals; 2 , carrion; and 1 was empty" (Fisher).

351. Halizeetus albicilla (Linn.). GraY SEA EAgLE. Ad.-Tail white, rest of plumage varying from grayish brown to fuscous. Im.- "With plumage largely light cinnamon-brown or isabella-color. \& $\mathrm{L}$., 31.00-34.00; W., 23・00-26.00; T., 11·50-12.00" (Ridgw.).

Range.-Northern parts of the Old World; Greenland.

Nest, on clift's or in trees. Eggs, two to three, dull white, "occasionally with sinall, faint spots of light brown " (Davie), $3.00 \times 2.35$.

This is a common species in Greenland.

352. Halizetus leucocephalus (Linn.). BALD EAGLE. Al.Head, neck, and tail white, rest of the plumage fuscous; bill yellow; tarsus not fully feathered. Im.-Fuscous, more or less varied with white; tail fuscous, more or less mottled with white, particularly on the inner vanes of the feathers; bill black. of L., 32.85; Ex., 84'10; W., 22.00 ; T., $11 \cdot 90$; B., 2.48. क L., 35.50; Ex., 89.00; W., 24.00 ; T., 12.25 ; Weight, $12 \mathrm{lbs}$.

Range.-North America, breeding throughout its range.

Washington, not common P. R. Sing Sing, common P. R. Cambridge, of irregular occurrence at all seasons.

Nest, generally in tall trees. Eggs, two to three, dull white, $2 \cdot 85 \times 2 \cdot 20$.

Bald Eagles are seldom found far from the water. Here they may be seen soaring overhead, winging their way to and from their feeding ground, or occupying some favorite perch, generally in an exposed posi-

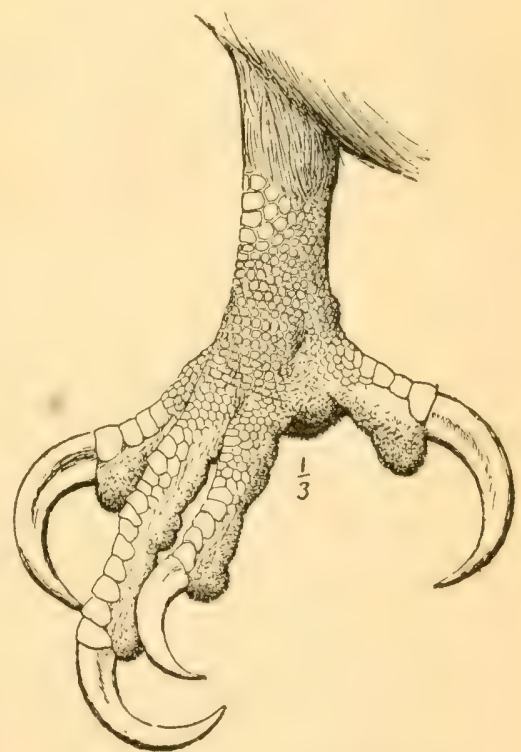

Fig. 72.-Foot of Bald Eagle.

tion. They subsist principally upon fish. As a last resort they sometimes capture these themselves, but dead fish cast up on the shore 
are eagerly taken, and their habit of robbing the Fish Hawk of his well-earned booty is too well known to be commented upon. In some localities, particularly in the south during the winter, they live largely upon water-fowl which they capture themselves.

The voice of the Bald Eagle has a weird, human quality. Dr. Fisher says: "At a distance the note of the Bald Eagle is not altogether unpleasant, resembling somewhat that of Sea Gulls, but near by it is grating and suggests a maniacal laugh." Dr. William L. Ralph writes in Captain Bendire's Life Histories of North American Birds, p. 277: "The cry of the male is a loud and clear cac-cac-cac, quite different from that of the female-so much so that I could always recognize the sex of the bird by it; the call of the latter is more harsh and often broken."

The conspicuous white head and tail of adults of this species render it easy of identification even at a considerable distance. Young birds too closely resemble Golden Eagles to be distinguished with certainty, but the rarity of that species in the east makes it probable that any Eagle observed is a Bald Eagle.

353. Falco islandus Brünn. White Gyrfalcon. Ad.-Head white, finely streaked with black; scapulars, interseapulars, and wing-coverts brownish gray, widely margined with white; tail white, the central feathers with sometimes broken bars; under parts white, lightly streaked with grayish brown; under tail-coverts white. Im.-Similar, but upper parts with narrower white margins; tail barred with brownish gray, under parts heavily streaked with the same color. L., $22 \cdot 00 ;$ W., $16 \cdot 00 ;$ 'T., $10 \cdot 00$; B. from N., $\cdot 95$.

Range. Aretic regions; casually south in winter to Maine.

Nest, on rocky eliffs. Eggs, three to four, varying from creamy white, spotted or blotched with cinnamon-brown, to uniform pale reddish brown, spotted or blotehed with shades of the same color, 2:30 $\times 1.85$.

"The food consists of water-fowl and other birds-largely of various arctic species of Grouse which are captured on the wing. All these northern Falcons were formerly esteemed for hawking, as they still are by the Mongol races; their style of flight is magnificent-much swifter than that of the Peregrine-and both are deadly 'footers' (i. e., tenacious of grip), but they lack spirit and dash" (Saunders).

354. Falco rusticolus Limn. Gray Grifalcon. Ad.-Upper parts grayish fuscous, barred and margined with buffy white; tail with numerous bars of the same colors; under parts white, streaked and spotted with blackish; legs and under tail-coverts barred with brownish gray. I., 20.00; W., $15 \cdot 50 ;$ T., $9.50 ;$ B. from N., $\cdot 90$.

Range-Aretic regions; in America, south in winter to the northern United States.

Nest, on cliffs or in trees. Eggs, three to four, not distinguishable from those of the preceding, $2.37 \times 1.72$. 
354a. F. r. gyrfalco (Limn.). Grrfalcox.-Head streaked with buffy white and fuscous or black; back varying from brownish gray to slaty fuscous, without complete bars and sometimes entirely unbarred; tail of the same color as the back, with indistinct or incomplete lighter bars; under parts heavily streaked with whitish and fuscous.

Range.-" Northern Europe and aretic America, from northern Labrador and coasts of Hudson Bay to Alaska"; Casually south in winter to R. I.

354b. F. r. obsoletus (Gmel.). Black Girfalcon.- Cpper parts uniform slaty fuscous, without bars; tail the same, without or with only broken bars; under parts of the same color as the back; the feathers with partly concealed buffy spots.

Range.-Labrador; southward in winter, easually to Long Island.

Remarks.-Gyrfalcons are so rare in collections that the descriptions here given can not be considered as applying to the species as a whole, but rather to the individuals from which the descriptions were taken. F. islandus is the lightest colored, and $F$.r. obsoletus is the darkest of our supposed four furms, while the others are intermediate between these two.

355. Falco mexicanus Schleg. Prairie Falcon. Ad.-Above, grayish brown; primaries and inner webs of all but the middle tail-feathers with numerous buffy bars or spots; below, white, streaked and spotted with dark grayish brown. Im.-Similar, but with the upper parts margined with ochraceous-buff or buffy. of L., 17.00; W., 12.20; 'T., 7.00.

Range.-Western United States, eastward casually to Illinois.

Nest, on cliffs, sometimes in hollow trees. Eggs, two to five, "creamy white, vinaceous-white, or pale vinaceous-buffy, sprinkled, speckled, or irregularly spotted with madder-brown, $2.06 \times 1.60 "$ (Ridgw.).

"The Prairie Falcon, as the name implies, is a typical plains bird, and inhabits the dry interior. . . .

"The flight of this Hawk is swift and graceful, though in most cases it is carried on at no great distance from the ground. It is not a shy bird, except in sections where it has been persecuted and has learned that man is its worst enemy" (Fisher).

356. Falco peregrinus anatum (Bonap.). D гек II Upper parts dark bluish slate-color; primaries barred with ochraceous; tail indistinctly barred with blackish and tipped with white; under parts creambuff', barred and spotted with black, except on the breast. Im.-Upper parts fuscous, more or less margined with ochraceous or rufous; region below the eye black; ear-coverts buffy; wings as in the ad.; upper surface of the tail barred with grayish, under surface barred with ochraceous-buff; under parts cream-buff' or ochraceous-buff, streaked, spotted, or barred with black. of L., $16 \cdot 00$; W., $12 \cdot 25 ;$ 'T., 6.50; B. from N., $\cdot 68$. \& L., 19.00; W., 14.00; T., 7.50.

Range.-North America and the greater part of South America, breeding locally from our Southern States northward.

Washington, rare and irregular W. V. Sing Sing, casual. Cambridge, rare ' $T$. V., casual in winter. 
Nest, on rocky cliffs and in the hollow limbs of tall trees. Eggs, three to four, varying from creamy white, heavily marked with cinnamon-brown, to pale reddish brown, more or less marked with shades of the same color, $2.05 \times 1.68$.

This species is the "Noble Peregrine" of falconry. It would be difficult to imagine a bird more highly endowed with qualities which make the ideal bird of prey. Its strength of wing and talon is equaled by its courage. No bird flies more swiftly than the Duck Hawk. Even Teal-those winged bullets-can not escape it. No bird is more daring. I have had Duck Hawks dart down to rob me of wounded Snipe lying almost at my feet, nor did my ineffective shots prevent them from returning.

Duck Hawks are generally found near water, where they prey largely on water birds.

"Of 20 stomachs examined, 7 contained poultry or game birds; 9 , other birds; 1, mice; 2, insects; and 4 were empty" (Fisher).

35\%. Falco columbarius Linn. Pigeon HAwк. Ad.-Lpper parts slaty blue, a broken buffy or rusty collar on the neck; primaries barred with white; tail with three or four distinct grayish white bars and a white tip; under parts varying from cream-buff to deep ochraceous, streaked with blackish, except on the throat. Im.-Upper parts fuscous or brownish fuscous, a broken buffy collar on the nape; primaries barred with ochraceous; tail with three or four incomplete buffy bars and a whitish tip; under parts much as in the ad. L., $10.00-13.00 ; \mathrm{W} ., 8 \cdot 00 ;$ T., $5.50 ;$ B. from N., 45.

Remarks.-This little Falcon bears some resemblance to a Duck Hawk, but is much smaller.

Range.-Breeds from the northern United States northward; winters from the Southern States southward to South America.

Washington, not uncommon T. V. Sing Sing, tolerably common T. V., Apl. 1 to May 11; Aug. 10 to Oct. 15. Cambridge, conmon 'T. V., Apl. 10 to May 5 ; Sept. and Oct.; occasional in winter.

Nest, in trees, in hollow limbs, or on cliffs. Eggs, four to five, varying from creamy white, more or less heavily marked with reddish brown or chocolate, to reddish brown marked with shades of the same color, 1.65 × 1.20.

"This Falcon, with the exception possibly of the Broad-winged Hawk, is the least shy of all our diurnal birds of prey, and often may be approached within a few rods. It frequents the more open country and edges of woods, and is common along the shores of large bodies of water. ...

"The flight is very rapid and resembles that of the Wild Pigeon quite closely; nor does the similarity end here, for while sitting on a tree the general poise is that of a Pigeon in repose, and specimens have been mistaken and shot for the latter bird.... 



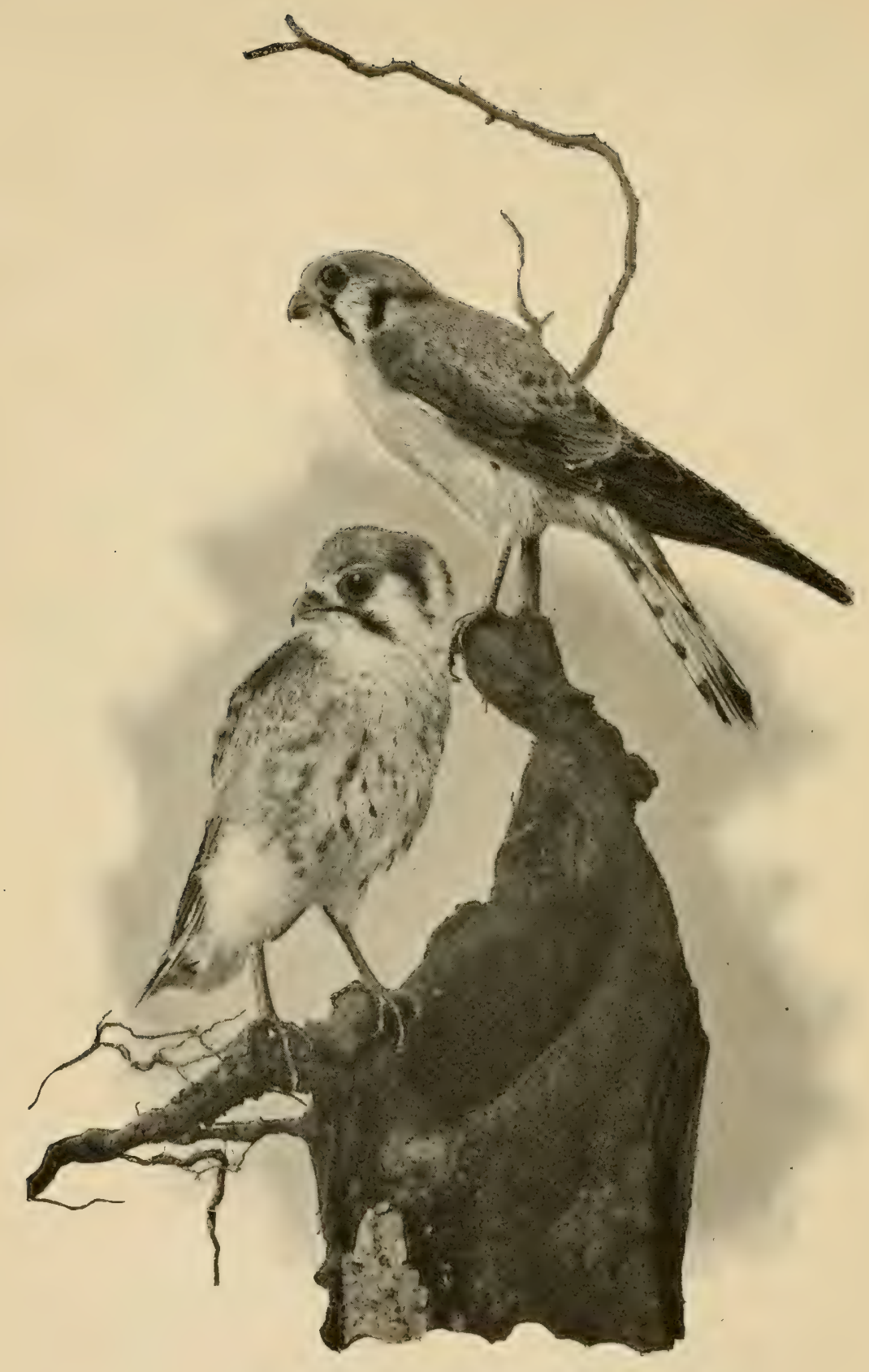

SPARROW HAWK AND YOUNG. 
"Of 56 stomachs examined, 2 contained poultry ; 41 , small birds; 2 , mice; 16, insects; and 5 were empty" (Fisher).

The Meruin (358.1. Falco regulus) and the Kestrel (359.1. Falco tinnunculus), both Old-World species, have each been recorded once from this side of the Atlantic, the Merlin from Greenland, the Kestrel from Massachusett (Cory, Auk, v, 1888, pp. 110, 205).

360. Falco sparverius himl. American Sparrow Hawk. A $d$. of -Back rufous, more or less barred with black; tail rufous, a black band near its end, the tip white; head slaty blue, with generally a rufous spot on the crown; wing-coverts slaty blue, primaries barred with white; a black mark before and behind the white ear-eoverts; under parts varying from creambuff to ochraceous-butf'; belly and sides spotted with black. $A d$.. .-Back, tail, and wing-coverts rufous, barred with black; head as in the male; under parts more or less heavily streaked with dark ochraceous-buff. Im.-Closely resemble the adults. L., $10 \cdot 00 ; \mathrm{W} ., 7 \cdot 30 ;$ T., 4.80; B. from N., '45.

Range.-Breeds from Florida to Hudson Bay, and winters from New Jersey southward.

Washington, common W. V., rare S. R. Sing Sing, rather rare P. R. Cambridge, rather common S. R., Feb. to Nov.

Nest, in a hole in a tree, frequently in a Woodpecker's deserted nest. Eggs, three to seven, varying from crenmy white to rufous, generally tinely and evenly marked with shades of the ground color, $1.40 \times 1 \cdot 12$.

An old stub or branchless trunk of a dead tree standing well out in a field is the kind of perch the Sparrow Hawk most frequently chooses. From this lookout, like a Loggerhead Shrike, he awaits the appearance of gane below. Generally it is a grasshopper which falls his victim. When he detects one, he flies directly orer it and poises on hovering wings until the right opportunity offers, when he drops lightly downwart, clutches his prey in his talons, and then returns to his perch to devour it at leisure.

The Sparrow Ilawl's call is a rather high, quickly repeated killykilly-killy-killy, which in some sections gives it the name of "Killy Hawk."

".Of 320 stomachs examined, 1 contained a game bird; 53 , other birds; 89 , mice: 12 , other mammals ; 12 , reptiles or batrachians; 215 , insects ; 29, spiders ; and 29 were empty" (Fisher).

The Cuban Sparrow Hawk (361. Falco sparverioides) is of accidental occurrence in the Florida Keys. It has two color phases; in one, the under parts, inclucling the under wing-coverts, are white; in the other, these parts are rufous.

362. Polyborus cheriway (.Fu'q.). Auntrox's Caracara. Ad.Face bare; crown, lower back, wings, and belly black; throat buffy; nape, interseapulars, and breast barred with black and buffy; tail white, barred 
and tipped with black. Im.-Similar, but browner, and with few or no bars on the interscapulars and breast. L., 22.00; W., 16.00; B. from N., 1.25.

Range.-Southern Florida and Mexican border of the Lnited States south to the Amazon.

Nest, in a cabbage palmetto or on the tops of dense buslies. Eggs, two to three, varying from crean-buff' to rufous, heavily marked with shades of reddish brown and chocolate, $2.35 \times 1.85$.

Caracaras frequently associate with Vultures and feed on carrion, but they also capture their own food. This consists largely of frogs, lizards, and small snakes, which the birds find while walking about on the ground in search of them. 'Their flight is strong, rapid, and direct, and bears no resemblance to that of a Vulture's.

364. Pandion haliaëtus carolinensis (Gmel.). AnERICAN USPREY; Fish Hawk. Ad. of.-Upper parts fuscous, the head and nape varied with white; tail with six to eight obscure bands, more distinct on the inner web; under parts white, breast sometimes slightly spotted with grayjsh brown. Ad. 9.--Similar, but the breast always spotted with grayish brown. L., $23 \cdot 10$; W., 18.25; 'T., 8.40.

Range.-North America; breeds from Florida to Labrador: winters from South Carolina to northern South America.

Washington, uncommon S. R., Mch. 25 to Oct. Sing Sing, common T. V., rare S. R., Apl. 3 to May 26; Sept. 29 to Oct. 20. Cambridge, common T. V., Apl.; Sept.

Nest, generally in a tree, thirty to fifty feet from the ground, rarely on the ground. Eggs, two to four, extremely variable, sometimes dull white, unmarked, sometimes almost solid chocolate, but generally buffy white, heavily marked with chocolate, chiefly at the larger end, $2 \cdot 45 \times 1.80$.

This species lives in colonies, and also in pairs, along our coasts, returning year after year to the same nesting ground. Its food consists solely of fish, which as a rule it captures alive. Winging its way slowly orer the water, it keeps a keen watch for fish which may appear near the surface. When one is observed it pauses, hovers a moment, and then closing its wings descends with a speed and directness of aim that generally insure success. It strikes the water with great force, making a loud splash, and frequently disappears for a moment lxefore rising with its prey grasped in its powerful talons. As a rule, it carries its food to some favorite perch, there to devour it. It is sair? that Fish Hawks have been known to strike fish so large that, unable to release their hold, they were drawn under water and drowned.

When protected, Fish IIawks, like many other birds, to a large degree lose their fear of man. In The Auk, for October, 1892, will be found a valuable article by Dr. C.S. Allen. on the habits of this species as observed by him on Plum Island, $\mathrm{N}$. Y., where for forty years the birds had been protected by the owner of the islund. 
The note of the Fish Hawk is a high, rapidly repeated, plaintive whistle.

\section{Fanily Strigid Ae. BarN Owls.}

The Barn Owls, numbering some eight or ten species, are found nearly throughout the temperate and tropical regions. They differ from other Owls in structure, but share with them the characteristic habits of the suborder Striges.

- 365. Strix pratincola Bruty). AMERICAN BARN OWL; MoNkeYFACED OWL. (See Fig. 30.) Ad.-Upper parts mixed gray and ochraceousbuff, finely speckled with black and white; tail varying from white to ochraceous-buff, generally mottled with black, and sometimes with three or four narrow black bars; under parts and facial disk varying from pure white to deep ochraceous-buff, the former generally with numerous small, black, round spots, the facial disk narrowly margined by ochraceous-buff or rufous; eyes black. L., 18.00; W., 13.25; T., 5.50; B., 1·30.

Range.-North America; occasionally found as far north as Massachusetts, and breeds from Long Island southward through Mexico.

Washington, not rare P. R. Sing Sing, A. V.

Nest, in a tower or steeple, a hole in a tree or bank. Eggs, five to nine, $1.72 \times 1.30$.

The Barn Owl conceals itself so well during the day that, in my experience, it is a difficult bird to observe, even in localities where it is common. For this reason the capture of one of these odd-visaged birds is frequently the cause of much excitement over the supposed discovery of an animal entirely new to science, and which, by the local press, is generally considered half bird, half monkey!

The only notes I have ever heard from the Barn Owl are a sudden wild, startling scream, a high, rapidly repeated $c r-r$-ree, $c r-r$-ree, cr-r-ree, and, in captive birds, a hissing sound; but Captain Bendire mentions "a feeble, querulous note like quäek-quäek, or äek-äek, sounding somewhat like the call of the Night Hawk (Chordeiles virginianus), frequently repeated, only not so loud."

"Of 29 stomachs examined, 1 contained poultry; 3 , other birds; 17 , mice ; 17 , other mammals ; 4 , insects; and 7 were empty" (Fisher).

\section{Family Bubonid 2 . Horned Owls, Hoot Owls, etc.}

Owls are found in all parts of the world. About two hundred species are known, of which some twenty inhabit North America. With few exceptions Owls are woodland birds, but some species live in grassy marshes or dry plains, while others make theil home in towers, steeples, or outbuildings. Owls are nocturnal birds of prey, and for 
this reason feed more largely on small mammals-most of which are nocturnal-than the diurnal birds of prey. They are therefore of eren greater value to the agriculturist than Hawks.

Their prey is captured with their talons, and, unless too large, is swallowed entire. The bones and hair are afterward ejected at the mouth in matted pellets.

Owls' eyes are so fixed in their sockets that they can not look from one point to another by simply " rolling" the eyeball, but are obliged to turn their head. The weird, almost human, voices of 0 wls add not a little to the superstitious fear with which they are frequently regarded. The eggs of Owls are uniformly white, unmarked.

$$
\text { KEY TO THE SPECIES. }
$$

I. Wing over $10^{\circ} 00$.

A. Belly without bars, striped longitudinally.

a. Upper parts with cross-bars.

$a^{1}$. Toes feathered . . . . . . . 368. Barred OWl. $a^{2}$. Toes bare . . . . . . . 368a. Florida Barred Owl.

b. Upper parts striped longitudinally . . . 367. SHort-Eared OWL.

$B$. Belly with cross-bars.

$\alpha$. With conspicuous horns or ears.

$a^{1}$. Wing over 13.00 . . . 375. Great Horned Owl and races. $a^{2}$. Wing under $13 \cdot 00$. . . . . 366. Am. Long-Eared OWL.

b. Without horns or ears.

$b^{1}$. Plumage white, more or less barred with black. 376. SNowr OwL. $b^{2}$. Plumage fuscous, mottled and barred with whitish.

370. Great Gray OWL.

I1. Wing under $10^{\circ} 00$.

A. Toes heavily feathered.

a. Wing more than 6.00 .

$a^{1}$. Tail more than 6.00 . . . . . . 377 $\alpha$. AM. HAwk OwL.

$a^{2}$. Tail less than 6.00 . . . . . 371. Richardoson's OwL.

b. Wing less than $6.00 . . . . . .372$. SAW-WHeT OWL.

$B$. Toes thinly, if at all, feathered.

a. Tarsi heavily feathered; with conspicuous horns.

373. Screech ()wl. $373 a$. Florida Screech OWl.

b. Tarsi partly bare; no horns . - 378a. Florida Burrowing ()WL.

366. Asio wilsonianus (Less.). AMERICAN LoNg-EARED ()wL. Al. -Ear-tufts conspicuous, an inch or more in length, black bordered by white and buffy; upper parts fuscous-brown mottled with white, the bases of the feathers ochraceous-buff'; tail with six to eight fuscous cross-bars : facial disk bufty bordered by black; under parts mixed white and ochraceous-buff, the breast broadly streaked, the sides and belly irregularly barred with fuscous; eyes yellow. L., 14.80; W., 11.90; 'T., 6.00; B., 1.06.

Range.-North America: breeds from Nova Seotia and Manitoba southward to the Gulf States. 
Washington, common P. R. Sing Sing, common P. R. Cambridge, not common P. R.

Nest, generally in an old Crow's, Hawk's, or Squirrel's nest. Eggs, three to six, $1.65 \times 1.30$.

"This species, like the Screcch Owl, is nocturnal in its habits, and differs from the Short-eared $\mathrm{Owl}$ in never hunting during the daytime. It usually spends the day in some evergreen woods, thick willow copse, or alder swamp, although rarely it may be found in open places. ...

"The bird is not wild, and will allow itself to be closely approached. When conscious that its presence is recognized, it sits upright, draws the feathers close to the body, and erects the ear-tufts, resembling in appearance a piece of weather-beaten bark more than a bird. . . .

"Like the other Owls, its flight is slow and wavering, but in common with them it is buoyant and devoid of any appearance of heaviness. The note of this Owl is said by some to resemble the noise made by kittens, while others state it is like the barking of small dogs.

"Of 107 stomachs examined, 1 contained a game bird; 15, other birds; 84 , mice; 5 , other mammals : 1 , insects ; and 15 were empty" (Fisher).

36\%. Asio accipitrinus ( Pull.). Short-eared OwL. Al.-Ear-tufts very short, difficult to distinguish in a dried skin; upper parts fuscous, the feathers margined with cream-buff or ochraceous-buff, not mottled with white; tail with ochraceous-buff and fuscous bands of about equal width; under parts varying from whitish to ochraceous-buff, the breast broadly and the belly more finely streaked with fuscous; eyes yellow. L., $15 \cdot 50$; W., $12 \cdot 75$; T., $6.05 ; \mathrm{B} ., 1 \cdot 20$.

Range.-Nearly cosmopolitan, breeding in the United States locally from Virginia northward.

Washington, common W. V. Sing Sing, casual. Cambridge, uncommon T. V., Apl.; Oct. and Nov.

Nest, on the ground, in grassy marshes. Eggs, four to seven, 1.60 × 1.25.

This species might well be named Marsh Owl, for, unlike most of our Owls, it does not frequent the woods, but lives in grassy marshes. It is not shy and does not take wing until almost stepped upon, when it arises noiselessly and flies low over the marsh. Sometimes it alights on a knoll or slight elevation and watches the intrucler in the intent, half-human manner of Owls.

During the migrations and in the winter this bird is occasionally found in flocks or colonies containing one or two hundred individuals.

"Of 101 stomachs examined, 11 contained small birds; 7\%, mice; 7, other mammals; 7, insects; and 14 were empty" (Fisher).

o 368. Syrnium nebulosum (Forst.). BarReI) () w: HoOt OWL. (See Fig. 31.) Ad.-No car-tufts; upper parts grayish brown, each feather with 
two or three white or buffy white bars; tail with six to eight similar bars; facial disk gray, finely barred or mottled with fuscous; under parts white, more or less tinged with bufty, the breast barred, the sides and belly broadly streaked with fuscous; bill yellow; legs and feet feathered to or near the bases of the nails; eyes brownish black. L., 20.00 ; W., 13.50 ; T., 9.50 ; B., 1.50 .

Range.-Eastern North America, north ward to Nova Scotia and Manitoba: resident, except at the northern limit of its range.

Washington, not common P. R. Sing Sing, rare P. R. Cambridge, rare P. R., sometimes common in Nov. and Dec.

Nest, in a hollow tree; sometimes in an Old Crow's or Hawk's nest. Eggs, two to four, $2.00 \times 1.65$.

The deep-toned, questioring voice, the absence of "horns," and the dark-brown, nearly black eyes, combine to make Barred Owls appear anong the most human of these strangely human birds. They inhabit large tracts of woodland, and are generally resident in certain localities. Their notes are uttered more or less throughout the year, but are more frequently heard during the nesting reason. As a rule they call only during the first part of the night and again before sunrise, but on moonlight nights they call throughout the night, and occasionally they may be heard during the day. They readily respond to an imitation of their' cries, and even at midiay I have drawn them from their nesting place to meet a supposed intruder on their domain. Under favorable circumstances they may be heard at a distance of at least half a mile.

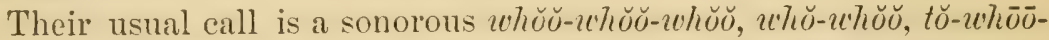
$\bar{a}$. This is varied, both as to relative position and length of the syllables, by the same individuals, and is apparently the cry of question and response. When two birds, perhaps rival males, come together, there ensues a striking medley of whŭ-whŭs mingled with rolling $w h \bar{o} \bar{o}-\breve{u} h s$, the whole reminding one of deep-voiced, mirthless laughter. Sometimes two birds give a concerted performance. One utters about ten rapid hoots, while the other, in a slightly higher tone, hoots half as fast, both performers ending together with a $u h \bar{o} \bar{o}-\breve{u} h$. At times they utter a single, prolonged whōo- $\breve{a} h$, and more rarely a weird, gasping shriek emphasized at its conclusion like a cry of distress.

"Of 109 stomachs examined, 5 contained poultry or game; 13 , other birds ; 46, mice; 18 , other mammals; 4 , frogs; 1 , a lizard ; 2 , fish; 14, insects; 2, spiders; 9, crawfish; and 20 were empty" (Fisher).

368a. S. n. alleni Firlyr. Florida BArRed Owl.-Similar to the preceding, but averaging somewhat darker, and with the toes nearly naked. W., $12.50 ;$ T., 8.50 .

Range.-Florida, and region of the Gulf coast to Texas. 
370. Scotiaptex cinereum (Gmel.). Great Gray Owr. Ad.-No ear-tufts, size very large; upper parts fuscous, everywhere mottled with white, and with little or no buffy; facial disk gray, barred with black; under parts white, the breast broadly streaked, the belly and sides irregularly barred and streaked with fuscous; legs and feet heavily feathered; bill and eyes yellow. L., $27 \cdot 00$; W., $17 \cdot 50 ;$ T., $12 \cdot 00$.

Range.-Breeds from Hudson Bay northward, and wanders southward in winter to the northern border of the United States.

Cambridge, very rare and irregular W. V.

Nest, in coniferous trees. Eggs, two to four, $2.16 \times 1 \cdot 71$.

"Dr. Dall considers it a stupid bird, and states that sometimes it may be caught in the hands. Its great predilection for thick woods, in which it dwells doubtless to the very limit of trees, prevents it from being an inhabitant of the barren grounds or other open country in the north....

"The note of this Owl is said to be a tremulous, vibrating sound, somewhat resembling that of the Screech Owl. . . .

"Of 9 stomachs examined, 1 contained a small bird; 7, mice; and 4 other mammals" (Fisher).

3y1. Nyctala tengmalmi richardsoni (Bondp). Riculinsor's OwL. Ad.-Upper parts grayish brown and the hend and back spotted with white; tail with four or five imperfect white bars; under parts white, heavily streaked with grayish brown; legs and feet heavily feathered, whitish, barred with grayish brown; eyes yellow. Im.--Upper parts dark cinnamon-brown, with a few more or less concealed white spots; tail as in the ad.; breast like the back; belly ochraceous-buff. L., $10 \cdot 00$; W., $6 \cdot 75 ;$ T., $4 \cdot 40$.

Range.-Northern North America; south in winter to the northern United States.

Nest, in holes in trees or in old nests of other birds (?). Eggs, three to seven, $1.35 \times 1 \cdot 14$.

"Richardson's Owl is nocturnal in its habits, remaining quiet during the day in the thick loliage of the trees or bushes. In fact, its vision is apparently so affected by bright light that many specimens have been captured alive by persons walking up and taking them in their hands. On this account the Eskimo in Alaska have given it the name of 'blind one.'

"'The song of this Owl, according to Dr. Merriam (Bull. Nuttall Ornith. Club, vol. vii, 1882, p. 237), is a low, liquid note that resembles the sound produced by water slowly dropping from a height" (Fisher).

ad. 3y2. Nyctala acadica (Gmel.) SAW-WHET OWL; ACADIAN ()WI. Ad.-Upper parts dark cinnamon-brown, the head finely streaked, the back spotted with white; tail with three or four imperfect white bars; under parts white, heavily streaked with cinnamon-brown or dark rufous; legs and feet 
feathered, buffy white, unbarred; eyes yellow. Im.-Upper parts as in the ad., but head and back with little or no white; breast like the back; belly ochraceous-buff. L., $8 \cdot 00 ;$ W., $5.40 ;$ T., $2 \cdot 80 ;$ B., $\cdot 60$.

Remarks.-Its small size and absence of ears at once distinguish this species from any $\mathrm{Owl}$ of eastern North America except $N$.t. richardsoni, from which it may be known by its lighter color, streaked instead of spotted head, and unbarred legs and feet.

Range.-North Ameriea; breeds from northern New York northward, and migrates southward in winter as far as Virginia.

Washington, rare W. V., Oct. to Mch. Sing Sing, rather rare W. V., Oct. 28 to Jan. 13. Cambridge, not uncommon W. V., Nov. to Mch.

Nest, in a hole in a tree; frequently a Woodpecker's, sometimes a Squirrel's deserted nest. Eggs, three to five, $1.19 \times 1.00$.

"The species is not migratory, but is more or less of an irregular wanderer in its search for food during the fill and winter. It may be quite common in a locality and then not be seen again for several years. It is nocturnal, seldom moving about in the daytime, but passing the time in sleeping in some dark retreat. So soundly does it sleep that oftentimes it may be captured alive. . . .

"During the day it frequents the thick evergreen woods, though sometimes it is found in comparatively open groves, but always in dense trees. ...

"The note of this species is peculiar and has a rasping character, resembling the sound made when a large-toothed saw is being filed; hence the name. It is more often heard during March and early A pril, though occasionally it is heard at other times of the year.

"The flight resembles that of the Woodcock very closely-so much so, in fact, that the writer once killed a specimen as it was flying over the alders, and not until the dog pointed the dead bird was he aware of his mistake. ...

"Of 22 stomachs examined, 17 contained mice; 1 , a bird; 1 , an insect; and 3 were empty" (Fisher).

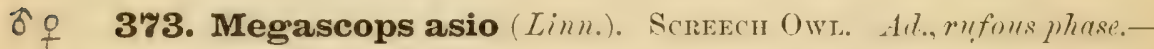
Size small; ear-tufts conspicuous, about an inch in length; upper parts bright rufous, finely streaked with black; under parts white, the feathers centrally streaked with black and irregularly barred with rufous; toes rather seantily feathered; eyes yellow. Gray phase.-Upper parts generally brownish gray, streaked with black and finely mottled with ochraceous-buff; ; under parts white, fincly streaked and more finely and irregularly barred with black, more or less bordered by rufous. Young.-Entire plumage regularly barred with grayish or rufous and white. L., $9 \cdot 40$ : W., $6 \cdot 40 ;$ T., $3 \cdot 09 ;$ B., $\cdot 63$.

Remarks. - This bird may be known by its small size and ear-tufts. Its color phases are not dependent upon. age, sex, or season, and both phases are sometimes represented in the same brood. Between the two there is a complete intergradation. 
Range.-Eastern North America, northward to New Brunswick and Minnesota; generally resident throughout its range.

W ashington, common P. R. Sing Sing, common P. R. Cambridge, common P. R.

Nest, generally in a hollow tree. Eggs, four to six, $1.55 \times 1.22$.

The Sereech Owl frequently makes its home near our dwellings, and sometimes selects a convenient nook in them in which to lay its eggs. But its favorite retreat is an old apple orchard, where the hollow limbs offer it a secure refuge from the mobs of small birds which are ever realy to attack it. A search in the trees of an orchard of this kind rarely fails to result in the discovery of one or more of these feathered inhabitants who may have resided there for years. They attempt to escape capture by a show of resistance and a castanetlike cracking of the bill, but when brought from their hiding place sit quietly, dazzled for a moment by the sudden light. They then elongate themselves and almost close their eyes, thus rendering themselves as inconspicuous as possible. How differently they appear when the western sky fades and their day begins! Is any bird more thoroughly awake than a hungry Screech Owl? With ear-tufts erected and his great, round eyes opened to the utmost, he is the picture of alertness.

When night comes one may hear the Screech Owl's tremulous, wailing whistle. It is a weird, melancholy call, welcomed only by those who love Nature's voice whatever be the medium through which she speaks.

"Of 25\% stomachs examined, 1 contained poultry; 38 , other birds; 91, mice; 11 , other mammals : 2 , lizards : 4, batrachians ; 1 , fish ; 100 , insects; 5, spiders; 9, crawfish; 7, miscellaneous ; 2, scorpions ; 2, earthworms; and 43 were empty" (Fisher).

3y3a. M. a. floridanus (Rirl/u.). FLorInA S'REECI OwL-Much like the preceding, but smaller, with the colors deeper and markings of the under parts heavier. W., $5.95 ;$ T., 2.80 .

liange.-Florida and Gulf coast region to Louisiana.

3y5. Bubo virginianus (Gmel.). GreAt IIOINed OWL. Al.-Size large ; car-tufts conspicuous, nearly two inches in length; upper parts mottled with varying shades of ochraceous-buff and black; facial disk ochraceousbuff; ear-tufts black and ochraceous-buff; $\Omega$ white patch on the throat, rest of the under parts ochraceous-buff, barred with black; legs and feet feathered; eyes yellow. of L., 22.00; W., 15.00; T., 8.50; B., 1.60.

Range.-Eastern North America; northward to Labrador and southward to Costa Rica; resident throughout its range.

Washington, rare P. R. Sing Sing, tolerably common P. R. Cambridge, occasional at all seasons.

Nest, generally in an old Crow's, Ilawk's, or Squirrel's nest. Eggs, two to three, $2.20 \times 1.80$. 
This "tiger among birds" is an inhabitant of heavily forested regions, and is common therefore only in the wilder, less settled portions of our country. It is the only one of our resident Owls which destroys poultry and birds in any numbers, but, in spite of its frequent visits to the farmyard, Dr. Fisher considers that in many localities it is a "beneficial species" because of its great fondness for rabbits.

Its usual call is a loud, deep-toned whōo, hoo-hoo-hoo, whōōo, whōōo. The syllables are all on the same note, and bear some resemblance to a bass-voiced dog barking in the distance.

A much rarer call is a loud, piercing scream, one of the most bloodcurdling sounds I have ever heard in the woods.

"Of 127 stomachs examined, 31 contained poultry or game birds; 8 , other birds; 13 ; mice; 65 , other mammals; 1 , a scorpion; 1 , fish ; 10 , insects, and 17 were empty" (Fisher).

375a. B. v. subarcticus (Hoy). Western ILONEn Ow L.-Similar to the preceding, but much lighter in color, the ochraceous-buff markings largely replaced by gray or white.

Range.-Western United States, east casually to Wisconsin and Illinois.

395c. B. v. saturatus Ridgw. Duskr IIorned Owl--Similar to $B$. virginianus, but much darker, the prevailing color fuscous or dusky.

Range.-- "From Labrador and Hudson Bay; west through the interior to Alaska, and south probably through all the higher regions of the Rocky and Sierra Nevada Míountains; south to Arizona (San Francisco Mountain)" (Bendire).

3y6. Nyctea nyctea $(\operatorname{Linn}$.). SNowy OWL. Ad. \&..-Size large; no ear-tufts; white, more or less barred with dark grayish brown or fuscous; legs and feet heavily feathered; eyes yellow. $A d$. $q$. - Similar, but more heavily barred. L., $25 \cdot 00$; W., $17 \cdot 00$; T., $9 \cdot 50 ;$ B., $1 \cdot 50$.

Range.-Breeds from Labrador northward and wanders southward in winter regularly to the northern United States and occasionally to Texas.

Washington, casual W. V. Sing Sing, A. V. Cambridge, rare and irregular W. V.

Nest on the ground. Eggs, three to ten, $2 \cdot 24 \times 1 \cdot 76$.

"The Snowy Owl is diurnal in its habits, but like most birds is more active in search of prey during the early morning and again toward dusk. Like many of the Hawks, it occupies a commanding perch for hours, watching what is going on about it, occasionally varying the monotony by dropping on a mouse or launching out over the broad country, soon to return to its perch. During its southern wanderings it is very partial to localities in the vicinity of water, especially the barren sand wastes along the seashore or extensive marshy flats bordering the bays and rivers. . . .

"The flight is firm, smooth, and noiseless, and may be long pro- 
tracted. It is capable of rapid flight, and, according to Audubon, is able to capture Ducks, Pigeons, and even Grouse on the wing, striking them down after the manner of the Duck Hawk.

"Of 38 stomachs examined, 2 contained game birds; 9 , other birds; 18, mice; 2, other mammals ; and 12 were empty" (Fisher).

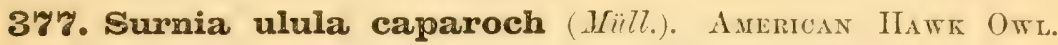
Ad.-Size medium; no ear-tufts; upper parts dark grayish brown or fuscous; head and hind neck spotted with white; back, and especially tertials, barred with white; tail with broken whitish bars, long and rounded, the outer feathers more than an inch shorter than the middle ones; middle of the throat with a fuscous spot and below it a white one; sides of the neck and upper breast streaked with fuscous, rest of the under parts barred with fuscous and white; legs and feet fully feathered. L., $15 \cdot 00 ;$ W., $8 \cdot 75 ;$ T., $7 \cdot 25$.

Range.-Breeds from Newfoundland northward, and occasionally wanders southward in winter as firr as Pennsylvania.

Nest, in coniferous trees or in the holes of dead trees or stubs. Eggs, three to seven, $1.50 \times 1.23$,

"The Hawk Owl is strictly diurnal, as much so as any of the Hawls, and like some of them often selects a tall stub or dead-topped tree in a comparatively open place for a perch, where it sits in the bright sunlight watching for its prey.

"Although the flight is swift and hawklike. it has nevertheless the soft, noiseless character common to the other Owls; when starting from any high place, such as the top of a tree, it usually pitches down nearly to the ground, and flies off rapidly above the tops of the bushes or high grass, abruptly arising again as it seeks another perch.

"The note is a shrill cry, which is uttered generally while the bird is on the wing" (Fisher).

3y8a. Speotyto eunieularia floridana Ridgw. Florida BCRrotring OWL. Ad.-Size small; no ear-tufts; legs and feet nearly naked; upper parts grayish brown, spotted and barred with white; throat white, rest of the under parts barred with grayish brown and white in about equal amounts. L., $9 \cdot 00 ; \mathrm{W} ., 6 \cdot 50 ;$ T., $3 \cdot 00 ;$ Tar., $1 \cdot 75$.

Range.-Southern Florida, ehiefly in the Kissimmee "prairie" region of Osceola, Polk, and De Soto Counties, and also Manatee County.

Nest, in a hole in the ground excavated by the bird. Eggs, five to seven, $1.23 \times 1.03$.

This diurnal Owl is locally abundant in its restricted range. Excellent accounts of its habits will be found under the following references: Rhouls, Auk, ix. 1892, pp. 1-8; Scott, ibid., 216-218; Bendire, Life Histories North American Birds, pp. 400-402.

The Birrowivg OwL (378. Speotyto cunicularia hypogaa), well known in our Western States, has been taken once in Massachusetts. 


\section{ORDER PSITTACI. PARROTS, IMACAWS, PAROQUETS, ETC.}

\section{Family Psittacide. Parrots and Paroquets.}

The order Psittaci is divided into six families containing in all about five hundred species. The American species, some one hundred and fifty in number, are included in the present family. Only one species inhabits the United States, and it is not found south of our boundaries. Parrots and Paroquets-the dividing line between the two can not be sharply drawn-are forest-inhabiting, fruit- and seedeating birds. They are poor walkers, good climbers, and strong fliers, making extended flights in search of food. Their roices in Nature are harsh and discordant; nevertheless, almost all the species possess the power of speech. Some, however, rarely learn to talls, while other's invariably do. The red-tailed, gray African Parrot (Psittacus erytha$c u s)$ takes first rank for ability in this direction, while the Mexican Double Yellow-head (Amazona levaillanti) is usually accorded second place.

382. Conurus carolinensis $($ Lim.). Carolina Paroquet, (See Fig. 34.) $A d$.-Head and neck all around yellow; forehead and cheeks deep orange; bend of the wing and tibie orange; rest of the plumage bright green ; the inner vanes of the wing-feathers fuscous; the under surface of the tail yellowish. Im.-Similar, but the head and neck green like the back; forehead and region in front of the eye orange; tibiæ and bend of the wing without orange. L., $12 \cdot 50 ;$ W., $7 \cdot 40 ;$ T., $6 \cdot 50$.

Range.-Formerly eastern United States north to Maryland, the Great Lakes, and Iowa; west to Colorado, the Indian Territory, and eastern Texas; now restricted to a few localities in the wilder parts of Indian Territory and Florida. (On the extermination of the Paroquet, see Hasbrouck, Auk, viii, 1891, pp. 369-379, with map; and Butler, ibid., ix, 1892, pp. 49-56.)

Nest, said to be in a hollow eypress or sycamore tree, but no exact, detailed account of the nidification of this species has been published. Eggs, two, white, $1 \cdot 44 \times 1 \cdot 12$.

The complete extermination of the Paroruet throughout the greater part of its range is due chiefly to four causes: first, it was destructive to fruit orchards, and for this reason was lilled by agriculturists; seeond, it has been trapped and bagged in enormous numbers by professional bird-catchers; third, it has been killed in myriads for its plumage; and, fourth, it has been wantonly slaughtered by so-called sportsmen. In short, in the present century the Paroquet has always disappeared soon after its haunts were invaded by civilized man.

I made three visits to Florida before learning of a locality where Paroquets could be found. Finally, in March, 1889, while collecting 
in eastern Florida, information was received of their presence near the head waters of the Sebastian River, a small stream flowing into the Indian River near Hicco, and I at once started for this locality. The follcwing notes made on this trip are from the Abstract of the Proceedings of the Linnxan Society of New York city, No. 2, 1890, pp. 5, 6. Since they were written the Paroquet has been found to be a locally common bird in the unsettled parts of Brevard, Osceola, Polk, De Soto, and Dade Counties.

Late on the afternoon of our arrival we started a flock of seven Parnquets from a productive patch of the thistles (Cirsium lecontei) which proved to be their favorite food. Evidently their meal was finished and they were ready to retire, for they darted like startled Doves through the pines, twisting and turning in every direction, and flying with such rapidity they were soon lost to view, the ring of their sharp, rolling call alone furnishing proof it was not all a vision. 'Two days passed before I again met Comums, and this time to better advantage. It was a wet and drizzling morning when we found a flock of six birds feeding on thistles at the edge of a "prairie." Perched on the leafless branches of the tree before us, their brilliant green plumage showed to the best advantage. Several were skillfully dissecting the thistles they held in their feet, biting out the milky seed while the released fluffy down floated away beneath them. There was a sound of suppressed conversation; half-articulate calls. We were only partially concealed behind a neighboring tree, still they showed no great alarm at our presence; euriosity was apparently the dominant feeling. One of the three birds which fell at our fire was but slightly wounded, a single shot passing through the elbow, and his loud outeries soon recalled his companions-a habit which has cost thousands of them their lives, and in part, at least, accounts for the rapidity of their extermination-and one alone of this flock escaped.

There was evident regularity in the habits of the birds we afterward observed-in all about fifty, in flocks of from six to twenty. At an early hour they left their roost in the "hummock" bordering the river and passed out into the pines to feed, always, so far as I observed, selecting thistle patches, and eating the seeds only when in the milky stage. At about ten o'clock they returned to the "hummock" and apparently to some farorite tree, here to pass the rest of the inorning and early afternoon, when they again started ont to feed, returning to the roost just before sunset. A flock of these birds feeding among the thistles is a most beautiful and animated sight; one is almost persuaded not to disturb them. There is constant morement as they fly from plant to plant, or, when securing thistles, they fly with them in their bills to a neighboring tree, there to dissect them at their 
leisure. The loud rolling call was apparently uttered only when on the wing, but when at rest, or feeding, there was a low conversational murmur of half-articulate, querulous notes and calls.

Of their ronsting habits I can say little or nothing. Late one morning (March 15th) we found a flock of eight birds resting on a tall, dead cypress near the center of the "hummock" on the river's bank. On a previous expedition my guide had observed them in this same tree, which was evidently a farorite midday haunt, and it is not impossible they may have roosted in the hole we discovered near its top.

\section{OFDER COCCYGES. CUCKOOS, KINGFISHERS, ETC.}

\section{Family Cuculid}

Only thirty-five of the some one hundred and seventy-five known species of Cuckoos are found in the New World, and they are largely confined to the tropics.

Cuckoos as a rule are rather solitary birds inhabiting wooded areas. The Anis, however, are always gregarious and live in open places. Their flight is weak, generally from tree to tree, and their feet are largely used as a means of progression. Some species hop, others walk, and one is celebrated for his speed as a runner. They are possessed of peculiar vocal powers, and their strange calls are frequently the origin of their popular names. Many species are remarkable for the irregularity of their breeding habits. The Old-World Cuckoo ( $C u$ culus canoms), like our Cowbird, deposits its eggs in the nests of other birds, and leaves to them the duties of inculation and rearing of the young. The Anis are communistic, and build but one nest, in which several females lay and share the task of incubation. The smaller species are insectivorous, but the larger ones add small reptiles and batrachians to their fare.

386. Coceyzus minor (frmel.). Maygrove Crerson. Al.--Tpper parts brownish gray, grayer on the head, with glossy reflections; wings and middle pair of tail-feathers like the back; outer tail-feathers black, broadly tipped with white; ear-coverts black, bill black, the lower mandible yellow except at the tip; under parts ochraceous-buff. L., 12.50 ; W., 5.40; T., 6.50; B. from $\mathrm{N}_{.,}, 80$.

Range--Greater Antilles, west coast of Central America, northward to coast of Gulf States (?); west coast of Florida.

Nest, a platform of sticks, in low trees and bushes. Eggs, three to four greenish blue.

This bird is apparently a rare summer resident on the Gulf coast of Florida, but its relationships in this region to the following race are not known. 
386a. C. m. maynardi (Ridgw.). Marnard's Crekoo.-Similar to the preceding, but with a slightly smaller bill and much paler under parts, the throat and breast being grayish white, very faintly washed with ochraceous, which becomes stronger on the belly. B. from N., 75 .

kange.-Bahamas and Florida Keys.

This bird is a regular summer resident in the Florida Keys and probably adjoining Atlantic mainland (see Scott, Auk, vi, 1889, p. 2i)(1).

38\%. Coceyzus americanus (Li/n.). Yellow-Billed) CuCkon. (See Fig. 36.) Ad.-Upper parts brownish gray with slight greenish gloss; most of the wing-feathers rufous, except at the tip; outer tail-feathers black, conspicuously tipped with white, which extends down the outer vane of the outer feather; under parts dull whitish; bill black, the lower man-

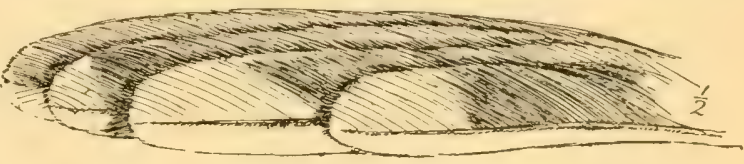

Fig. 73.--Tail-feathers of Yellow-billed Cuckoo. dible yellow, except at the tip. L., $12 \cdot 20 ;$ W., $5 \cdot 70 ;$ T., $6 \cdot 20 ;$ B. from N., $\cdot 76$. Remarks.-This species bears a general resemblance to the Black-billed Cuckoo, but may always be known from that species by its yellow lower mandible, rufous wing-feathers, and black, white-tipped tail-feathers.

Range.-North America; breeds from Florida to New Brunswick, and winters in Central and South America.

Washington, common S. R., May 2 to Oet. 15. Sing Sing, common S. R., May 4 to Oet. 31. Cambridge, common S. R., May 12 to Aug.

Nest, a platform of small sticks, with a few grasses or eatkins, generally in low trees or vine-corered bushes, four to ten feet from the ground. Eggs, three to five, pale greenish blue, $1 \cdot 22 \times \cdot 92$.

A long, slim, dovelike bird slips noiselessly by and disappears in the depths of a neighboring tree. If you can mark his position you will find him perched motionless, and apparently slightly dazed. After a moment he recovers and begins to hop about the tree in an active search for his favorite fare of caterpillars. He is especially fond of the kind which make nests in trees, commonly known as "tent caterpillars." and if you examine the conspicuous homes of these pests you will frecuently find them punctured with many holes made by the Cuckoo's bill. A Cuckoo I shot at six o'clock one September morning had the partially digested remains of forty-three of these eaterpillars in his stomach.

The notes of the Cuckoo are strikingly characteristic, and while subject to much variation may be fairly represented by the syllables tut-tut, tut-tut, tut-tut, tut-tut, cl-uck-cl-uck-cl-uck, cl-uck-cl-uck, cl-uck, cow, cow, cow, cow, cow', cow. It is not usual, however, to hear the whole song given at once. 
388. Coccyzus erythrophthalnus (Tils.). BLACK-BILLED Cuckoo. Ad.-Upper parts grayish brown with a slight green gloss; wings

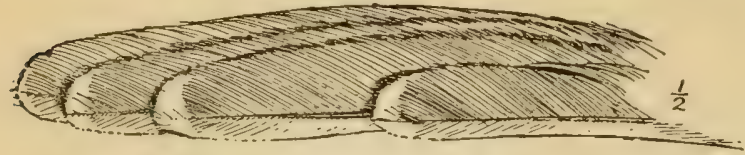

Fig. \%4.-Tail-feathers of Black-billed Cuckoo. and tail the same, the latter narrowly tipped with white; under parts dull white; bill black. L., $11 \cdot 83 ; \mathrm{W}$., $5.50 ;$ T., $9.26 ;$ B. from N., $\cdot 74$.

Remarks.-This species is to be distinguished from the Yellow-billed Cuckoo chiefly by the absence of rufous in the wings, black in the tail, and yellow in the lower mandible.

Range.-Eastern North America; breeds as far north as Labrador, and winters in Central and South America.

Washington, rather rare S. R., May 2 to Oct. 15. Sing Sing, common S. R., Nay 3 to Oet. 7. Cambridge, common S. R., May 15 to Sept. 20.

Nest, similar to that of the preceding, but more compactly built; location the same. Eggs, two to five, greenish blue, of a deeper shade than those of the preceding species, $1 \cdot 14 \times 85$.

This species resembles the preceding in habits. The two birds may be distinguished in life by the differences in the color of their bills and tails. Mr. William Brewster has called my attention to an easily recognizable difference in their calls. The present species has a much softer voice, and the cow, cow notes are connected.

The ANI (383. Crotophaga ani), a common species in the Bahamas and Greater Antilles, is of accidental occurrence in Pennsylvania, Florida, and Louisiana. Its plumage is black with bluish reflections, the tail is rounded, the bill high and thin, the depth at the nostril equaling or exceeding the distance from the nostril to the tip of the bill.

\section{Family Alcedinid A. Kingfishers.}

Kingfishers are most numerous in the Malay Arehipelago, and the majority of the one hundred and eighty known species are found there. Only eight are American, and seven of these are confined to the tropics. They are solitary birds of somewhat local habit. All the American species are, as their name implies, fish-eaters, and are rarely found far from the water. Some of the Old-World species, however, are forestinhabiting and feed on small insects, mollusks, etc.

- 3 390. Ceryle alcyon (Lim.). Belted Kingrisher. (See Fig. 35.) $A d$. o.- Upper parts bluish gray; wings with small white spots, most of the feathers tipped with white, the inner web of the primaries white at the base: tail-feathers with numerous spots and broken bands of white; a white spot before the eye; throat white, this color passing on to the sides of the neck and nearly meeting on the back of the neek; a band across the breast, and 
the sicles bluish gray-in immature specimens tinged with rufous-lower breast and belly white. Ad. \&.-Similar to the male, but the sides and a band on the belly rufous. L., $18 \cdot 02 ;$ W., $6 \cdot 17$; T., $3 \cdot 60 ;$ B., $2 \cdot 00$.

Range.-North America; breeds from Florida to Labrador, and winters from Virginia to South America.

Washington, common P. K. Sing Sing, common S. R., Apl. 1 to Nov. 23 ; casual in winter. Cambridge, common S. R., Apl. 10 to Uct.

Nest, in a hole in a bank, ahout six feet from the entrance. Eggs, five to eight, white, $1.34 \times 1.05$.

The shores of wooded streams or ponds are the chosen haunts of the Kingfisher. Silently he rerches on some limb overhanging the water, ever on the alert for food or foe. Paddle toward him as quietly as you please, just as you reach his danger line he drops from his perch and with loud, rattling call flies on ahead. 'This may be repeated several times, until finally the limits of his wanderings are reached, when he makes a wide detour and returns to the starting point.

The Kingfisher hunts after the manner of the Fish Hawk. In passing over the water it needs only the glint of a shining fin or scale just beneath the surface to catch his watchful eye. On quickly moving wings he hovers over the place, waiting only a fair chance to plunge on the unsuspecting fish below. Emerging from the water with his prey in his bill, he shakes the spray from his plumage, and, with an exultant rattle, flies away to some favorite perch.

\section{ORDER PICI. WOODPECKERS, WRYNECKS, ETC.}

\section{FAmily Picid 2. WoOdPeckers.}

Woodpeckers are found in all the wooded parts of the world except Australia and Madagascar. About three hundred and fifty species are known, of which nearly one half are confined to the New IVordd. Some twenty-five of this number are found in North America. Woolpeckers are mather solitary birds, but are sometimes found associated in scattered companies during their migrations. Above all other birds they are especially adapted to creep or climb. 'The peculiar structure of the foot, with its two toes directed forward and-two backward (except in one genus), assists them in clinging to an upright surface, while the pointed, stiffened tail-feathers serve as a prop when the bird is resting. The stout, chisel-like bill is used to cut away wood and expose the hiding places of grubs, etc., when the long, distensible tongue with its horny, spearlike tip is thrust in, the food impaled and drawn out. The rocal powers of Woodpeckers are limited, and the bill is also used to beat the long. rolling eall which is their love-song. The eggs of Woodpeckers are 
uniformly white, and are placed in a hole, generally in a dead tree or limb, hollowed out by the bird.

KEY TO THE SPECIES.

I. No red on the head or nape.

A. Entire under parts black.

a. Wing about $10 \cdot 00$, bill ivory-white.

392. IYoTY-billed Woodpecker 9.

B. Under parts white, without hlack spots or streaks.

a. Wing under $4 \cdot 00$; outer tail-feathers barred with black.

3:4. DUWNY WOODPECKER \&.

6. Wing over $4 \cdot 00$; outer tail-feathers white, without black bars.

393. Hairy WoODPECKER \&.

393b. SoutIIERN HaIrx WOODPECKer 9.

C. Under parts with black spots, bars, or streaks.

a. Back entirely black . 4 400. Arctic Three-toed Woodpecker.

$b$. Back black and white.

b1. Outer tail-feathers entirely white, crown yellow or spotted with white . . . . . 401. Ax. Three-toed Woodpecker.

62. Outer tail-feathers barred with black, no black patch on the breast, ear-coverts white . 395. RED-COCKADED WOODPECKER \&.

63. Outer tail-feathers black, with generally a narrow white margin; rump white. . . . 406. RED-HEADEd WoodPECKer 9.

64. Outer tail-feathers black and white, a large black patch on the breast . . . . 402. Yellow-Bellied Sapsucker \&.

II. Whole top of the head red.

A. Throat red.

a. Primaries spotted with white, belly yellowish.

402. Yellow-belited Sapsucker o .

b. Primaries black, rump and belly white.

406. RED-MEADED W OODPECKER o.

B. Throat white.

a. Breast and belly black . . 405. Pileated Woonpecker $\delta$.

b. Breast blaek or blackish, sides streaked, belly yellowish white.

402. YelLow-BeLlied SAPSUCKER \&.

$\epsilon$. Under parts tinged with red, without streaks or spots.

409. RED-RELLIED WOODPECKER oे.

III. Crown black, brown, or gray, a red band across the nape, a red crest on the back of the head, or small patches of red on either side of the nape.

A. Under parts black, wing over $8 \cdot 00$.

a. Bill ivory-white . . . 392. Irory-BILLED Wooppecker. る.

b. Bill blackish . . . . 405. Pileated Woodpecker \&.

B. Under parts more or less spotted or streaked with black.

a. A black patch on the breast, throat brown, rump white.

412. Fitcker.

b. Head black, ear-coverts white, a few red feathers on either side of the nape . . . . 395. Ren-COCKaded WoodPecker of. 



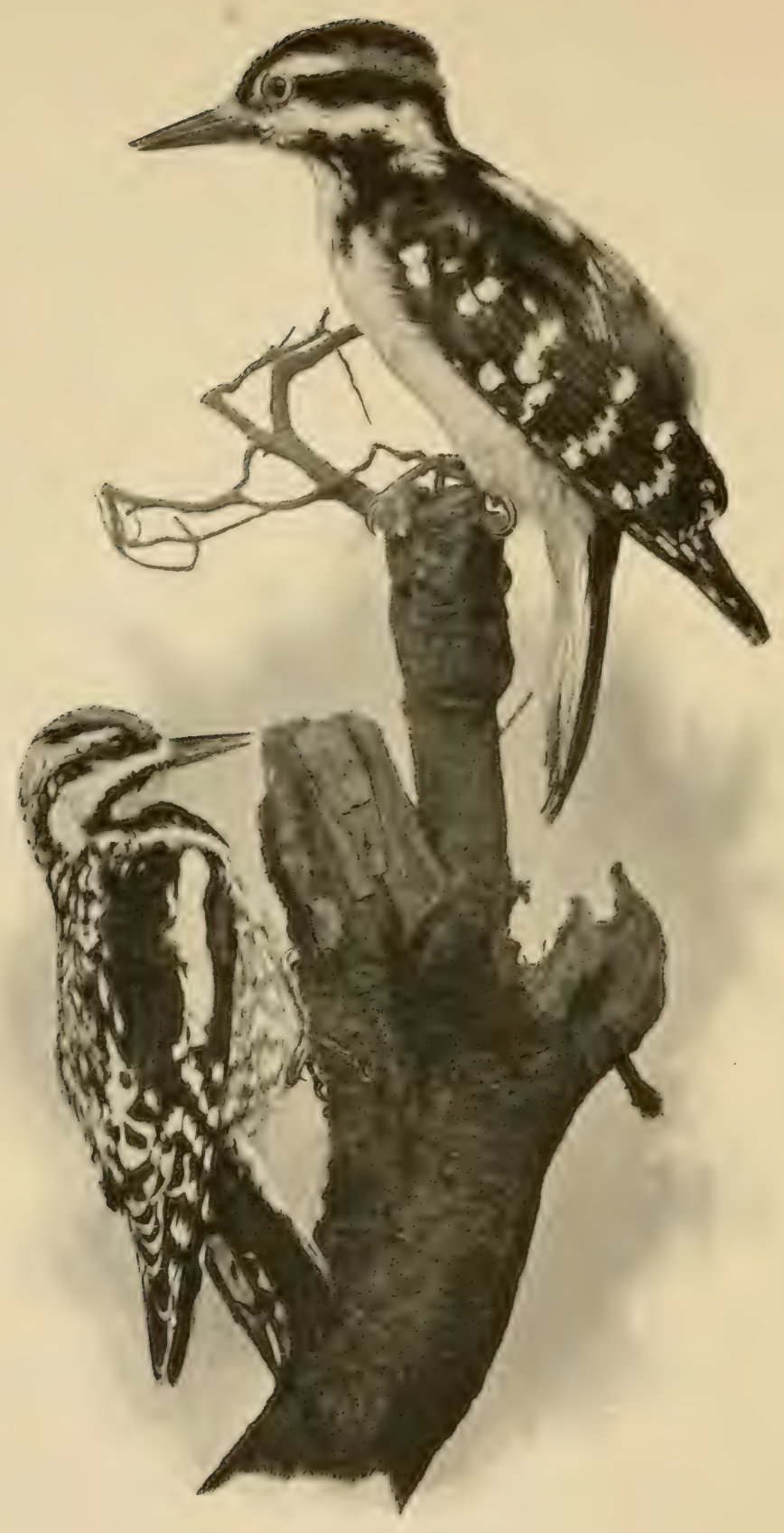

HAIRY WOOJJPERER.

Yellow-Bellied Sapsucker. 
C. Under parts white, or whitish without black strealis or spots.

a. Crown gray, a reddish tinge on the belly.

409. RED-BELLIED WoONPECKER ?.

b. Crown black.

b1. Outer tail-feathers barred with black.

394. DOWNY WOONPECKET \& .

$\boldsymbol{l}_{2}$. Outer tail-featlers white. . . 398. IIAIry Woonpeckers $\delta$. 3936. Southejen IIAmi Woodiecker of .

392. Campephilus principalis (Linn.). IrorY-HILI) WonI)PECKER. A $d$. o.-Upper parts shining black, a large scarlet erest; a white stripe begins below the eye and, passing down the side of the neck, meets its fullow in the middle of the back; ends of the inner primaries and the end half or two thirds of the-secondaries white; outer tail-feathers very short, the central ones elongated and much stiffened; bristles over the nostrils white; bill ivory-white; under parts shining black. Ad. \&.- Similar, but with the crest black. L., 20.00 ; W., $10.00 ;$ T., $6.50 ;$ B., 2.75 .

Range.- "Formerly South Atlantic and Gulf States, from North Carolina to Texas; north in the Mississippi Valley to Missouri, southern Illinois, and southern Indiana. Now restrieted to the (rulf States and the lower Mississippi Valley, whee only locally distributed" (A.O.U.). (See Hasbrouck, Auk, viii, 1891, pp. 174-186, with map.)

Nest, in the higher part of a tree. Eggs, "1.31 $\times .86$ " (Ridgw.). (Sec also Maurice 'Thompson's A Red-headed Family.)

The home of this magnificent Woodpecker is in the almost limitless cypress forests of our southern coasts and river valleys. Even there it is common in but few localities. In Florida it is found chiefly in the western part of the peninsula, and doubtless occurs in greatest numbers in the region between the Suwanee River and the Gulf.

The Irory-bill is a wild, shy bircl. It does not remain long in one place, and during the day ranges over an extended territory. Its call is a high, rather nasal, yop, yolp-yap, somnding in the distance like the note of a penny trumpet.

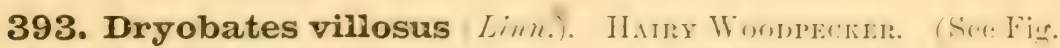
37, a.) Al. 8.-Upper parts black; a searlet band on the nape; middle of the back white; wing-feathers and their coverts spotted with white; middle tail-feathers hlawe thes muter ones white; a white stripes ahere: and amother below the eye; under parts white. $A d$. \&. - Similar, but without searlet on the back of the neck. L., $9.40 ;$ W., $4.78 ;$ T., $3.30 ;$ B., 1.22.

Range.-Eastern United States, from the northern border south to North Carolina.

Washington, rare $P$. R. Sing Sing, rare P. R. Cambridge, uncommon W. V.

Nest, generally in a dead tree. Eggs, four to six, $05 \times \cdot 75$.

This species resmbles the Downy Wormperker in habits, but is less frequently observer out of the woods. Its notes are noticeably louder 
than the Downy's, and when one is familiar with both there is no diffculty in distinguishing the two by their voices.

In speaking of the difference which exists between the rolling tattoo of some Woodpeckers Mr. Brewster says: "Thus, $P$. pubescens has a long, unbroken roll, $P$. villosus a shorter and louder one with a greater interval between each stroke; while $S$. varius, commencing with a short roll, ends very emphatically with five or six distinct disconnected taps. In this latter species I am convinced it is literally a call of recognition, as I have repeatedly seen the bird, after producing it, listen a moment when it would be answered from a distance, and its mate would shortly appear and join it" (Ann. Lyc. Nat. Hist., xi, 1875, p. 144).

393b. D. v. audubonii (Swains.). SoltherN IAARY W (oDpeckir. -Sinzilar to the preceding, but smaller, and with somewhat less white in the plumage. L., $8 \cdot 10 ;$ W., 4.50 ; T., $2 \cdot 80$; B., $1 \cdot 15$.

Range.--South Atlantie and Gulf States north to South Carolina.

This is simply a small southern race of the preceding species. It resembles the northern form in habits, but is much more common, being nearly as numerous as the Downy Woodpecker.

In the northwestern United States and adjoining British provinecs the IIairy Woodpecker reaches its maximum size, and is known as the Northern Hairy Woodpecker (D. v. leucomelas), a form which may occur within our limits.

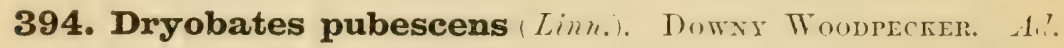
8.-Upper parts black, a scarlet band on the nape; middle of the back white; wing-feathers and their coverts spotted with white: middle tailfeathers black, the outer ones white, barred with black; a white stripe above and another below the eye; under parts white. $A d$. 8 . - Similar, but without searlet on the nape. L., $6 \cdot 83 ;$ W., $3 \cdot 70 ;$ T., $2 \cdot 53 ;$ B., 68.

Remarks.-The Downy and Hairy Woodpeckers differ in coloration only in the markings of the outer tail-feathers, which are white, barred with black in the former, and white without bars in the latter; the difference in size between the two, horrever, is always diagnostic.

Range.-Eastern North America, from Labrador to Florida; resident throughout its range.

Waslington, common P. R. Sing Sing, common P. R. Cambridge, common P. R.

Nest, generally in a dead tree. Eggs, four to six, $15 \times \cdot 60$.

Woodland, orchards. and the shade trees of lawns are alike frequented by this, the smallest and most familiar of our Woodpeckers. Sometimes he tells of his presence by an industrious tap, tap-tapping as he patiently digs out the grubs and larve which form his bill of fare. Again he hails us with a businesslike peek, peek-a note closely resembling the sound produced $1, y$ a marble quarrier's chisel, and which 
sometimes is prolonged into a rattling call. Like other Woodpeckers, in the spring he beats a rolling tatioo on a resonant limb, sounding a reveille which is a credit to so small a drummer.

The Downy is a sociable Woodpecker, and when the gay summer visitors have returned to their southern homes and the wind whistles drearily through the leafless trees, he joins the Chickadees and Nuthatches, and during the winter they are inseparable companions. Perhilps they share with him the snug quarters in some old trunk which he has hollowed out for a winter home.

395. Dryobates borealis (Iieill.). RED-COCKADED WoOdPECkER. Ad. of. -Crown black, a small tuft of scarlet feather's on either side of the back of the head; back barred with black and white; wings spotted with black and white; middle tail-feathers black, outer ones with broken black bars; ear region white, separated from the white throat by a black stripe running from the bill to the shoulder; sides and under tail-coverts spotted and streaked with black; rest of the under parts white. $A d$. $\&$. - Similar, but without scarlet on the head. L., $8 \cdot 40 ;$ W., $4 \cdot 65 ;$ T., $3 \cdot 10 ;$ B., $\cdot 80$.

Range.-Southern United States, westward to Indian Territory, and northward to Tennessee and Virginia.

Nest, in the higher part of a pine tree. Eggs, four to six, $\cdot 91 \times \cdot 68$.

This species is a common inhabitant of the "piny woods." It prefers the higher branches of the trees, and frequently hangs head downward while feeding on a cone at the extremity of a branch. Its callnote suggests the yank, yank, of the White-bellied Nuthatch, but is louder, hoarser, and not so distinctly enunciated.

400. Picoides arcticus (Stcains.). Arctic Three-toed WoodPECKer. (See Fig. 37, b.) Ad. $\delta$.- -Toes three, two in front; middle of the crown with a bright orange-yellow patch; rest of the upper parts shining black; wing-feathers spotted with white; middle tail-feathers black, outer ones white, except at the base; a white line from the nostril passes below the eye; sides barred with black and white; rest of the under parts white. $A d$. 9.- Similar, but without orange-yellow on the crown. L., 9.50; W., 5.10; T., $3.40 ;$ B. from N., 98.

Range.-Northern North America, south to the northern United States.

Nest, within ten feet of the ground. Eggs, four to six, $1.05 \times \cdot 78$.

"It is a restless, active bird, spending its time generally on the topmost branches of the tallest trees, without, however, confining itself to pines. Although it can not be called shy, its habitual restlessness renders it difficult of approach. Its movements resemble those of the Red-cockaded Woodpecker, but it is still more petulant than that bird. ... Its cries also somewhat resemble those of the species abore mentioned, but are louder and more shrill, like those of some small quadruped suffering great pain. . . .

"Its flight is rapid, gliding, and deeply undulating. . . . Now and 
then it will fly from a detached tree of a field to a considerable distance before it alights, emitting at every glide a loud, shrill note" (Audubon).

401. Picoides americanus Brethm. Anerican Three-toed WoodPECKER. Ad. of.-Toes three, two in front; head spotted with white and with an orange-yellow patch on the crown; back barred with black and white; wing-feathers spotted with black and white; middle tail-feathers black, outer ones black and white; region below the eye mixed black and white; sides more or less barred with black and white; rest of the under parts white. $A d$. . - Similar, but crown spotted with black and white, and without yellow. L., 8.75; W., $4.55 ;$ T., 3.10 ; B. from N., 95 .

Range.-Northern North America, south to the northern United States.

Nest, in the lower part of a tree. Eggs, white, $92 \times \cdot 70$ (Merriam, Bull. Nutt. Oru. Club., iii, 1878, p. 200).

"It is said to greatly resemble $P$. villosus in habits, except that it seeks its food principally upon decaying trees of the pine tribe, in which it frequently makes holes large enough to bury itself. It is not migratory" (B., B., and R.).

fo 402. Sphyrapicus varius (Linn.). Tellow-tellied Safsucker. $A d$. s.-Crown deep scarlet, back irregularly barred with black and yellowish white; wing-feathers spotted with white, their coverts mostly white; tail black, the middle feathers with broken black bars, the outer ones with white margins; a white line from the bill passes below the eye; throat cardinal; breast black; sides streaked with black; belly pale yellow. $A d$. . .Similar, but throat white; crown sometimes black; outer tail-feathers with broken white bars. Im.-Similar to atds, but with the crown dull blackish, the breast brownish gray barred with black, the throat whitish. L., 8.56; W., $4.87 ;$ T., $3.20 ;$ B., 92 .

Range.-Eastern North America; breeds from Massachusetts northward, and winters from Virginia to Central America.

Washington, common T. V., Mch. and Apl.; Oct., occasional in winter. Sing Sing, common 'T. V., Apl. 5 to May 13; Sept. 18 to Oct. 23 ; casual in winter. Cambridge, not uncommon 'T. V., Apl. and Oct.

Nest, about forty feet from the ground. Eggs, five to seven, ${ }^{\circ} 87 \times \cdot 67$.

As migrants, Sapsuckers are rather inconspicuons. They frequent living trees, where they are concealed by the foliage and their weak call-note is not likely to attract attention.

On reaching their summer homes in the spring their character changes, and Dr. Merriam speaks of them as "noisy, rollicking fellows; they are always chasing one another among the trees, screaming meanwhile at the tops of their voices" (Bull. Nutt. Orn. Club, iv, 1879, p. 2). Mr. Brewster describes the note of the adults at this season as "a clear, ringing cleur, repeated five or six times in succession"; while young and old utter "a low, snarling cry that bears no very dis- 
tant resemblance to the mew of the Catbird" (Bull. Nutt. Orn. Club, i, 1876 , p. 69).

'The sapsuclier feeds largely on the juices of trees, which it obtaius by perforating the bark. (See Bolles, Auk, viii, 1891, p. 256; ix, 1892, p. 110.)

\& 405. Ceophlœus pileatus (Linn.). Pileated Woonfecker. Ad. of. -Upper parts blackish fuscous; whole top of the head scarlet, the feather's lengthened to form a crest; a narrow white stripe bordering this crest separates it from the fuscous ear-coverts; a stripe beginning at the nostril and passing down the sides of the neck to the shoulders is tinged with yellow betore the eye and is white back of the eye; it is separated from the white throat by a scarlet stripe at the base of the lower mandible; basal half of the wing-feathers white; under parts fuscous, the feathers sometimes lightly margined with white; bill horn-color. $A d$. $q$.- Similar, but without red on the fore part of the crown or at the base of the lower mandible. L., 17.00; W., 8.90; 'T., 6.̊0; B., 1.85.

Range.- "Formerly whole wooded region of North America; now rare or extirpated in the more thickly settled parts of the Eastern States."

Washington, rare $\mathrm{P}$. R.

Nest, twenty-five to eighty feet from the ground. Eggs, four to six, 1.30 $\times \cdot 94$.

This species is common only in the wilder parts of its range. In the hummocks and cypress swarips of Floricla it occurs in numbers. There, contrary to the experience of Audubon, I found it by no means a wild bird. Indeed, Flickers were more difficult to approach. On the Suwanee River. in March, I have called these birds to me by simply clapping my slightly closed palms, making a sound in imitation of their tapping on a resonant limb.

The flight of this species is rather slow, but usually direct, not undulating, as in most Woodpeckers. When under way the white markings of the wings show conspicuously. 'Their usual call-note is a sonorous cou-cou-cow, repeated rather slowly many times, suggesting a somewhat similar call of the Flicker's. Like the Flicker, they have also a wichew note uttered when two birds come together.

406. Melanerpes erythrocephalus ( Limn.). RED-HEADEN W OOrPECKER. Ad.-Head, neck, throat, and upper breast deep red; upper back. primaries, bases of the secondaries, and wing-coverts bluish black; end half of the secondaries, rump, and upper tail-coverts white; tail black, the feathers more or less tipped or margined with white; lower breast and belly white, the middle of the latter generally tinged with reddish. Im.-Red head and neck of the adult replaced by mixed grayish brown and fuscous: upper back bluish black, barred with ashy; primaries and wing-coverts black; end half of the secondaries irregularly barred with black; tail black, generally tipped with white; lower breast and belly white, more or less streaked or spotted with fuscous. L., $9 \cdot 75 ; \mathrm{W}, 5 \cdot 52 ;$ T., $3 \cdot 30 ;$ B., $1 \cdot 17$. 
Range.-Eastern North America; breeds from Florida to northern New York and Manitoba; winters from Virginia, and oceasionally from northern New York southward.

Washington, rather common S. R., rare W. V. Sing sing, rare P. R., common in fall, Aug. 27 to Uet. 12. Cambridge, irregular at all seasons; sometimes common in fall.

Nest, generally in a dead tree. Eggs, four to six, $1 \cdot 00 \times 55$.

Give a bird an abundance of its favorite food, and its morements no longer seem to be governed by the calendar. Red-headed Woodpeckers were supposed to migrate southward in the fall and pass the winter south of Maryland until Dr. Merriam, in his interesting account* of the habits of this species, told us that in Lewis County, northern New York, their abundance in winter was in no way affected by the severity of the weather, but was entirely dependent upon the success of the crop of beechnuts which constitute their food.

Indeed, few birds seem better able to adapt themselves to their surroundings. They change their fare and habits with the season, and to the accomplishments of Woodpeckers add those of Flycatchers and fruit-eaters. We should expect, therefore, to find them very generally distributed, but in the Northern States they show an evident choice for certain localities, and may be wanting over wide stretches of intervening territory.

'They are noisy, active birds, and their loud, rolling, tree-toadlike call, ker-r-ruck, ker-r-ruck, and bright colors combine to render them conspicuous. When on the wing the white secondaries of both adult and immature birds make a striking field mark.

409. Melanerpes carolinus (Linn.). RED-IELLIED WOODPECKER. Ad. s.-Whole top of the head and back of the neck bright scarlet; back regularly barred with black and white; primaries black at the end, white, irregularly barred with black, at the base; secondaries black, regularly spotted and barred with white; upper tail-coverts white, with streaks or arrowheads of black; outer tail-feathers and inner vanes of the middle ones irregularly marked with broken black and white bars; cheeks and under parts dull ashy white, the region about the base of the bill, the micldle of the belly, and sometimes the breast more or less tinged with red. Ad. $q$. - Similar, but with the crown grayish ashy, the scarlet confined to the nape and nostrils. Im.-Similar, but with the belly sometimes tinged with bufly instead of red. L., 9.50; W., 5.00; T., $3 \cdot 40 ;$ B., 1·10.

Range.-Eastern United States, breeding from Florida to Maryland, and in the interior to Ontario and southern Dakota; occasionally strays to Massachusetts; winters from Virginia and southern Ohio southward.

Washington, locally common P. R. Cambridge, A. V., one record.

Nest, in trees, about twenty feet from the ground. Eggs, four to six, $1.05 \times 75$.

* Bull. Nutt. Orn. Club, iii, 18;8, pp. 123-128. 
This is a common bird in our Southern States. It inhabits alike coniferous and deciduous growths, but prefers the latter. It ascends a tree in a curious, jerky fashion, acompanying each upward move by a hoarse chŭh-chŭh.

412. Colaptes auratus (Linn.). Flicier ; Ihth-Hole; Clape: YeLLow-HaMmer; Golden-winged Wooppecker. Ad. of.-Top of the head ashy gray, a bright searlet band across the back of the neck; back, wingcoverts, and exposed part of secondaries brownish gray, barred with black; rump white; primaries black externally, the inner surface of the wing and the shafts of the fsathers yellow; upper tail-coverts barred or streaked with black and white; tail black above, yellow tipped with black below, the outer elges of the feathers slightly margined or barred with white; sides of the head, throat, and upper breast vinaceous; a broad black stripe on either side of the throat from the base of the bill, and a broad black crescent across the breast; rest of the under parts white, more or less tinged with vinaceous, and thickly spotted with black. $A d$. \&. - Similar, but without the black streaks on the side of the throat. L., 12.00 ; W., $6.00 ;$ T., $4.00 ;$ B., 1.40 .

liemarks.-Exceptional specimens have a few red feathers in the throat stripes. A male from Louisiana has this mark entirely red and the head grayish brown, while another specimen from 'Toronto has half the tail orange-red. These un usual markings are supposed to be due to hybridization of our Flicker with the western or Red-shafted Flicker, which resembles the eastern species in pattern of coloration, but has the crown brownish gray or grayish brown, the throat stripes searlet, the throat and breast gray, the under surface of wings and tail dull red, and lacks the red nuchal band. (See an important paper on the relationships of these birds by Dr. J. A. Allen, in the Bull. Am. Mus. Nat. Hist., iv, 1892, pp. 21-44).

Range.-North America, west to the eastern slope of the Rocky Mountains and $A$ laska; breeds throughout its range, and winter's from Illineis and Mansachusetts southward.

W ashington, common S. R., rare W. V. Sing Sing, common S. R., Mch. 25 to Oct. 30 ; a few winter. Cambridge, very common S. R., common W. V.

Nest, in trees, about ten feet from the ground, frequently in orehards. Eggs, five to nine, $1 \cdot 10 \times \cdot 86$.

The habits, notes, and colors of this well-known bird are reflected in the popular names which have been applied to it throughout its wide range. No less than thirty-six of these aliases have been recorded, and many have doubtless escaped the compiler.

The Flicker is a bird of character. Although a Woodpecker. he is too original to follow in the footsteps of others of his tribe. They do not frequent the ground, but that is no reason why he should not humor his own terrestrial propensities, and we maly therefore frequently flush him from the earth, when, with a low chuckle, he goes bounding off through the air, his white rump showing conspicuously as he flies. 
The Flicker, like other Woodpeckers, beats a rolling tattoo in the spring, but his vocal song proper is a rapidly-repeated, mellow cŭh-

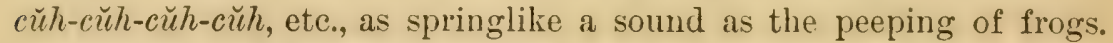
IHis usual note is a vigorous, nasal kìe-yer. It recalls frosty fall mornings when the IIigh-holes are gathering to feed on the woodbine and pepperidge berries. Approaching their feeding grounds, one may hear the "Flicker" note. It can be closely imitated by the swishing of a willow wand: weèchew, weèchew, ueèchew. I never remember hearing a bird utter this note when alone. It is accompanied by the oddest gestures, as with tails stifly spread the birds bob and bow to each other.

\section{ORDER MACROCHIRES. GOATSUCKERS, SWIFTS, HUMMINGBIRDS, ETC.}

\section{Family Caprinulgida. Nighthawks, Whip-Poor-wills, ETC.}

Goatsuckers are found in most parts of the world, but are more numerously represented in the tropics. Some eighty-five species are known, of which about one half are American, though only seven reach North America. Most of the American species are forest-inhabiting, passing the day upon the leaves or perched lengthwise upon the branches of trees, where their dull, blended colors harmonize with their surroundings. The Nighthawks, however, are equally at home in treeless countries. Nighthawks feed high in the air, like Swifts, while other species frequent the borders of forests or clearings, where they feed nearer the ground. All the species capture their food of insects on the wing, their enormous mouths and the long, stiffened bristles, which in some species beset its base, especially adapting them to this mode of feeding. Many of the species are possessed of remarkable vocal powers, and their cries are among the most striking of bird notes.

KEY TO THE SPECIES.

A. A white spot in the wing. 420. Nigutiawk. 420c. Florida Nigntiatik. $B$. No white spot in the wing; primaries spotted with rufous.

a. Wing under 750 . . . . . . . 4 417. Whip-poor-WILL.

b. Wing over 7.50. . . . . . . 416. Chuck-WILl's-Widow.

416. Antrostomus carolinensis (Gmel.). CHuck-WILL's-WIDow. Ad. 8.-Upper parts streaked with black and finely mottled with ochraceousbuffi and black; primaries black, with broken rufous bars; tail mottled with black and ochraceous-buff, the end half of all but the two middle feathers white, more or less washed with buffy on the inner vane; under parts mot- 



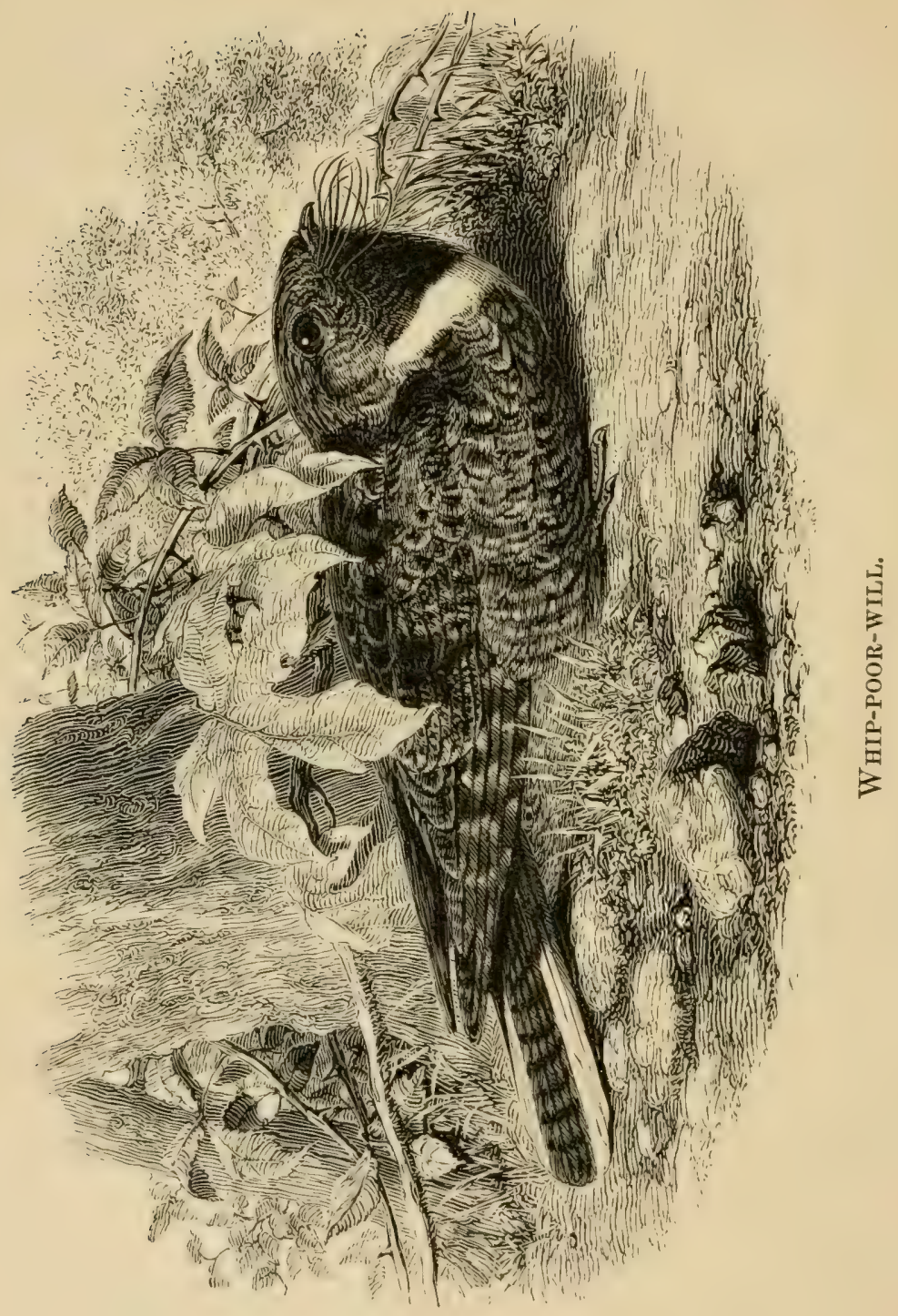


tled with black, ochraceous, and cream-buff; an imperfect whitish band across the upper breast; base of the bill beset with long, stiffened bristles, the basal half of these bristles grown with hairlike brançhes. Ad. \&.-Similar, but with no white patches in the tail, the upper breast with an ochraceousbuff' instead of white band. L., $12 \cdot 00$ : W., $8 \cdot 50 ;$ T., $6 \cdot 00 ;$ B., 40 .

Range.-Eastern United States; breeds from North Carolina and Illinois southward; winters from our southern borders southward; accidental in Massachusetts.

Cambridge, A. V., one record, Dec.

Eggs, two, laid on the ground or leaves, in woods or thickets, dull white, with delicate, obscure pale lilac markings, and a few distinct brownish-gray spots, $1.40 \times \cdot 98$.

Generally speaking, this species resembles the Whip-poor-will in habits. Its notes are quite similar to those of that species, but are louder, less rapidly uttered, and each call has an additional syllable. Its gape is enormous. the wide-open mouth of an adult measuring about two inches from corner to corner. For this reason it can swallow large objects with ease, and both Hummingbirds and Sparrows have been found in C'huck-will's-widow's stomach. Perhaps they were mistaken for large moths.

41\%. Antrostomus vociferus (Wils.). Whip-poor-WILl. Ad. ô. -Upper parts streaked with black, the head finely mottled with black and white, the back mottled with ochraceous-buff and black; primaries black, with broken rufous bars; tail irregularly barred with black and mottled with whitish or cream-butt; end half of three outer feathers white; black on the outer vane of the outer feather extending farther down than on the others; throat and breast blackish, finely mottled with cream-buff or ochraceous-buff; a narrow white band across the upper breast; belly eream-buff, irregularly barred with blackish; base of the bill beset with long, stiffened bristles, which are without hairlike branches. Ad. \&.- Similar, but three outer tailfeathers narrowly tipped with ochraceous-buff; band on the throat creambuff instead of white. L., 9.75 ; W., 6.08 ; T., $465 ;$ B., $\cdot 37$.

Range.-Eastern North America, north to New Brunswick and Manitoba; winters from Florida southward.

Wasliington, common S. R., Apl. 15 to Oct. Sing Sing, common S. R., Apl. 19 to Oct. 17. Cambridge, common S. K., Apl. 28 to Sept. 20.

Eggs, two, laid on the ground or leaves, in woods or thickets; dull white, with delicate, obscure lilac markings and a tew distinet brownish gray spots, $1 \cdot 18 \times \cdot 84$.

In walking through rather densely grown woods I have sometimes been surprised by having a Whip-poor-will fly up from beneath $\mathrm{my}$ feet and disappear in the surrounding growth. I say surprised, because the bird's flight is as noiseless as a moth's, and this unusual, ghostly silence is almost as startling as the whir of a Grouse.

The Whip-poor-will's day begins when the sun goes down. Then 
he passes out into bushy fields near his home, and, flying low, catches his supper on the wing. Between courses he rests on some low perch, and gives utterance to the notes familiar to many who have never seen their author. Whip'-poor-will', whip'-poor-will he calls, rapidly and with unexpected snap and vigor. If one is quite near the singer, a preliminary chuck may be heard before each call. These notes are given for about two hours after sunset and for a short time before sunrise.

It is a singular fact that, in spite of the marked difference in their habits and notes, the Nighthawk and Whip-poor-will are frequently considered to be the same species. It is not the only case, however, where the notes of some species difficult of observation have been attributed to a species whose habits render it conspicuous.

Rf 420. Chordeiles virginianus (Gmel.). Niguthawk; BlLl-bat. (See Fig. 38.) Ad. \&.-Upper parts black, irregularly marked with whitish, cream-buff, or ochraceous-buff ; primaries fuscous, crossed in the middle by a conspicuous white bar which rarely reaches the outer vane of the first primary; tail fuscous or black, with broken bars of cream-buft and a white band near the end on all but the middle feathers; throat with a broad white band; chin and upper breast black, the feathers tipped with ochraceous-buff, creambuff, or white; the rest of the under parts barred with black and white, sometimes tinged with buff. $A d$. \&.- Similar, but with no white on the tail, throat-patch ochraceous-buff, under parts more or less washed with ochraceous-buff. L., $10 \cdot 00$; W., $7 \cdot 85$; 'T., $4.60 ;$ B., $\cdot 25$.

Range.-Eastern North America; breeds from the Gulf States to Labrador; winters in South America.

Washington, not common S. R.; abundant T. V., Apl. 20 to Oct. Sing Sing, common S. R., May 9 to Oct. 11. Cambridge, not uncommon S. R., May 15 to Sept. 25.

Eggs, two, laid on the bare ground or a flat rock in open fields, rarely on the roof of a house, dull white, evenly marked with small, irregularly shaped blotches or fine specklings of grayish brown or brownish gray, $1.20 \times \cdot 86$.

In wooded regions the Nighthawk passes the day perched lengthwise on a limb, but on the plains he roosts upon the ground, where his colors harmonize with his surroundings.

Soon after sunset he mounts high in the air to course for insects. Batlike he flies erratically about, and at more or less regular intervals utter's a loud nasal peent, this call being followed by two or three unustally quick, flitting wing-beats. Long after the light has faded from the western horizon we may hear this voice from the starlit heavens, for the Nighthawk is one of our few truly nocturnal birds.

Occasionally the peents are given more rapidly, and after calling several times in close succession the birl on half-closed wings dives earthward with such speed that one fears for his safety; but just 
before the ground is reached he checks his rapid descent by an abrupt turn, and on leisurely wing again mounts upward to repeat this game of sky-coasting. At the moment the turn is made one may hear a rushing, booming sound, which, as writers have remarked, can be imitated in tone by blowing across the bung-hole of any empty barrel. It is made by the passage of the air through the bird's primaries.

In late summer Nighthawks gather in large flocks and begin their southward migrations. When flying the white mark on their primaries is a conspicuous character, and has the appearance of being a hole in the bird's wing.

420b. C. v. chapmani (Cones). Florida Nighthawk: Bull-bat. -Similar to the preceding, but smaller, and with the white and cream-buff markings of the upper parts more numerous. L., $8 \cdot 60$; W., $7 \cdot 10$; 'T., $4 \cdot 10$.

Range.-Breeds in Florida and westward on the Gulf coast; south in winter to South America.

The Westers Nightuawh (420a. C.v. Tenryi), a near relative of our species, has been recorded from Waukegan, Ill.

\section{Family Micropodide. Swifts.}

The seventy-five known species of Swifts are distributed throughout the greater part of the world. About one half this number are American, but only four are found in North America. Swifts are generally found associated in scattered companies, and when roosting or nesting are eminently gregarious. Hollow trees and caves are their natural retreats, but in some parts of the world chimneys are now used exclusively.

They feed entirely while flying, and with their unusually long wings and small, compactly feathered bodies possess unrivaled powers of flight. Swifts are popularly confused with Swallows, but the resemblance is only superficial and exists chiefly in the similarity of their feeding habits, while the structural differences between the two are numerous and important.

423. Chatura pelagica (Limn.). CHIMner SWIft CHnNeY "Swallow." (See Fig. 39.) Ad.-Entire plumage fuscous, more grayish on the throat; a sooty black spot before the eye; shafts of the tail-feathers extending beyond the vanes. L., 5.43 ; W., 4.94 ; T., 1.90; B. from N., 15.

Range.-Eastern North America; breeds from Florida to Labrador; winters in Central $A$ merica.

Washington, abundant S. R., Apl. 15 to Oet. 10. Sing Sing, common S. R., Apl. 19 to Oct. 23. Cambridge, abundant S. R., Apl. 25 to Sept. 20.

Nest, a bracketlike basket of dead twigs glued together with saliva; attached to the wall of a chimney, generally about ten feet from the top, by 
the grummy secretion of the birl's salivary glands. Egyg, four to six, white, $\cdot 80 \times \cdot 50$.

It is unnecessary to give any aids to the identification of a bird as well known as the Chimney Swift, or, as it is more frequently called, " ('himney Swallow." It is not, howerer, a Swallow, but a Swift, and its structural relations are with the II ummingbirds and not with the Passerine Swallows.

Few sights in the bird-world are more familiar than the bow-andarrow-like forms of these rapially flying birds silhoueted against the sky. 'They are most active early in the morning and late in the afternoon, when one maly hear their rolling twitter as they course about overhead. Sometimes they sail with wings held aloft over-their backs, and sometimes, it is said, they use their wings alternately. It is a common thing to see a trio of birds flying together. but it has never been ascertained that the Chimney Swift is polygamous.

In some localities Chimney swifts congregate in large flocks, making their healquaters in a disused chimney which moming and evening they leave and return to in a body. In perching they eling to the side of the chimney, using the spine-pointed tails, as Woodpeckers do, for a support. The habit of frequenting chimneys is, of course, a recent one, and the substitution of this molern, artificial home for hollow trees, illustrates the realiness with which a bird may take advantage of a faroring change in its environment.

\section{Family Trochilid A. HummingBirds.}

Hummingbirds are found only in the New World. About four hundred species are known. They range from Alaska to Patagonia, but are most numerous in the Andean regions of Colombia and Ecuidor. Seventeen species are found in the United States; only eight of these atrance beyond our Mexican border States. and but one species occurs east of the Mississippi.

Sereral species inhabit the depths of dark tropical forests, but as a rule they are found with the flowers which bloom in the clearings, or far overhead in the sunlight. They are not gregarious, but an abundance of food sometimes brings large numbers of them together, when the air becomes animated with their rapidly moving forms. The smaller species fly so swiftly that their wings are lost in hazy circles. and it is difricult for the human eye to follow their course. The flight of the latrer species is less insectlike, and each wing-beat can be detected. As a rule their voice is a weak squeak or excited chippering. but some of the tropical species have songs of decided character which they sing with much energy.

Hummingbirds feed largely on insects, which ther generally cap- 
ture in flowers, but many species eatch insects on the wing or pick them from beneath leaves. They also feed on the juices of flowers. All the species whose nesting habits are known lay two white eggs.

Strangely enough, these beautiful little creatures are possessed of a most unfortunate disposition which frequently leads them to attack any bird they fancy is trespassing on their domain. 'They know no fear, and with equal courage rush at one of their kind or a passing Hawk.

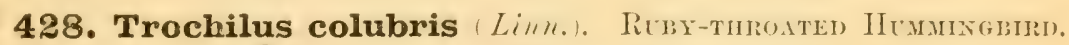
(See Fig. 40.) Ad. j.-Upper parts bright, shining green; wings and tail fuscous, with purplish reflections; throat beautiful metallie ruby-red, bordered on the breast by whitish; rest of the under parts dusky, washed with greenish on the sides. $A d$. \&. - Similar, but without ruby-red on the throat. Im.-Similar to the female, but with the upper parts more bronzy. L., 3.74 ; W., $1.51 ;$ 'T., $1.15 ;$ B., 6 .

Range.-Eastern North America; breeds from Florida to Labrador; winters from southern Florida to Central Ameriea.

Washington, common S. R., Apl. 28 to Sept. Sing Sing, common S. R., Apl. 30 to Oct. 3. Cambridge, uncommon S. R., May 12 to Sept.

Nest, of plant down, covered externally with lichens and firmly wound with almost invisible plant fibers; generally fifteen to twenty-five feet from the ground, saddled on a limb. Eggs, two, white, $\cdot 50 \times \cdot 35$.

The Ruby-throat needs no song. Its beauty gives it distinction, and its wings make music. Its only note, so far as I know, is a squeak, expressive of distrust or excitement. It has no rival in eastern North America, and is to be confounded with nothing but sphinx (humminglird) moths. One hears of "Ilummingbirds" seen in the evening about flower beds. The mistake is not unnatural, and a correction is sometimes received with incredulity. The birds spend but a comparatively small part of the time upon the wing. Whoever watches a female busy about her nest will see her constantly perching here and there in certain branches of the tree, preening her plumage and looking about her. The male, at the same season, forgetful, to all appearance, of his conjugal and parental duties, may be found at home day after day on a dead twig in some tall tree, where he sits so constantly as to make the observer wonder what he can be about, and when, if ever, he takes his food. Further investigation, however, will show that he makes frequent and regular rounds of favorite feeding places. $\Lambda$ tall blueberry bush, for eximple, will be visited at short intervals as long as the observer has patience to stand beside it. The Hummingbird is curiously fearless. Sometimes one will probe a flower held in the haml, and when they fly into houses, as they pretty often do, they manifest but the smallest degree of suspicion, and will feed almost at once upon sngar held between the lips. The old bird feeds 
the young by regurgitation-a frightful-looking act-the food consisting largely of minute insects. The young remain in the nest for some three weeks, and on leaving it are at once at home on the wing.

BradFord 'ToRrey.

\section{ORDER PASSERES. PERCHING BIRDS.}

\section{Family Tyrannid Ae. Flycatchers.}

From the systematist's standpoint Flycatchers are songless Perching Birds. It does not follow that they are voiceless, or even truly songless, but that, having the voice-organ or syrinx less highly developed than other Passeres, they are possessed of comparatively limited vocal powers. This family is peculiar to America. The Old-World Flycatchers belong to the family Muscicapidce and are true Oscines. Some three hundred and fifty species are known. They are most abundant in the tropies, where their services as insect-catchers are in greatest demand. About thirty-five species reach the United States.

Flycatchers are found wherever there are trees. As a rule they are of sedentary and solitary disposition. Their manner of feeding is characteristic. From a farorable perch, hawklike, they await passing insects, and with an aim that rarely misses launch forth into the air; there is a sharp, suggestive click of the broad bill, and, completing their aërial circle, they return to their perch and are again en garde.

I. Wing over $3 \cdot 00$.

KEY TO THE SPECIES.

A. Tail black or blackish, sometimes tipped with white, a concealed orangered crown patch.

a. Under wing-coverts yellowish, no white tip on the tail.

445. Gray KingBird.

b. Under wing-coverts blackish, tail tipped with white . 444. KINGBIRD.

B. Inner vane of tail-feathers pale rufous; throat and breast grayish; belly sulphur-yellow. . . . . . 452. Crested Flycatcher.

C. Tail fuscous, not tipped with white; no crown patch.

a. Entire bill black; tail rarely more than 50 longer than wing; tarsus decidedly longer than bill; under tail-coverts always pale, yellowish white . . . . . . . . . . . . 456. Pппве.

b. Under mandible generally in whole or part pale brownish; wing always more than 50 longer than tail; tarsus about equal to bill; some of under tail-coverts frequently with darker centers.

$b^{1}$. Wing over 350 ; sides and breast, except a narrow whitish line through its center, of the same color as the back.

459. Olive-sided Flycatcher.

b3. Wing under 3.50 ; breast and sides washed with olive-gray.

461. Wond Pewee. 
II. Wing under $3 \cdot 00$.

A. Upper parts between olive-brown and dark olive-green, but with an evident brownish tinge, or lower mandible brownish.

a. Wing over $2 \cdot 60$; lower mandible flesh-color or whitish; under parts with only a very slight tinge of yellow . 466a. 'I'railL's FLycatcher.

$b$. Wing under $2 \cdot 60$; lower mandible rarely clear flesh-color; generally strongly tirged with brownish . . . . 467. Least Flycatcrier.

$B$. Upper parts olive-green without a brownish tinge; lower mandible straw-color.

a. First primary about equal to fifth; under parts white, slightly washed with yellowish on the breast and belly; throat white.

465. Acadian Flycatcher.

b. First primary shorter than fifth; under parts sulphur-yellow; the throat and breast more or less washed with olive-green.

463. Yellow-Bellied Flycatcher.

The Fork-tailed Flidatcher (442. Mitvulus tyrannus), a south American species rarely found north of southern Mexico and the southern Lesser Antilles, has been recorded from Mississippi, Kentucky, and New Jersey.

The Scissor-tailed Flycatcher (443. Milvulus forficatus) is found in the summer as far north as southern Kansas and western Louisiana. It has occurred accidentally near Hudson Bay, in Manitoba, Ontario, Connecticut, New Jersey, Virginia, and Florida. It may be known by its long, deeply forked tail and scarlet sides.

444. Tyrannus tyrannus (Lilln.), KixgBnD. dl.-Lpper parts grayish slate-color, darker on the head and upper tail-coverts; head with a concealed orangered crest; tail black, tipped with white; under parts white, washed with grayish on the breast. Im.-Similar, but without the crown patch, and with the plumage more or less tinged with ochraceous-buff. L., 8.5๊ ; W., 4.64; T., 3.55 ; B. from N., 55 .

hange-North America north to New Brunswick and Manitoba; rare west of the Rocky Mountains; winters in Central and South America.

Washington, common S. R., Apl. 20 to Sept. Sing Sing, common S. R., Apl. 29 to Sept. 10. Cambridge, abundant S. R., May 5 to Sept. 1.

Nest, compact and symmetrical, of weed-stalks, grasses, and moss lined with plant-down, fine grasses, and rootlets, generally at the extremity of a branch fifteen to twenty-five feet up. Eggs, three to five, white, spotted with umber, $1.00 \times \cdot 73$.

The Kingbird is most frequently seen on a fence or a dead twig on a tree, where leaves do not come in the way of his sight. He stands very upright, like a IIawk or an Owl, and, though as quiet as if he had nothing to do, he is keenly awake to every movement about him, and every few minutes he dashes into the air, seizes a passing insect, and returus to the spot from which he started. While his mate is sitting he usually establishes himself near the nesting tree, and spends hour after hour in this apparently monotonous way, varying it only to 
relieve her by watching the nest, and thus give her an opportunity to seek food for hersele. I never saw a Kingbird either assist in brooding or carry food to his mate, but his manners to her are most affectionate, and he is untiring in his labors in the feeding of the young.

This bird is accused of being quarrelsome and aggressive to other birds, and his seientific name means Tyrant Flycutcher, but in my study of his ways I have found him less aggressive than are most birds in the neighborhood of their nest. With the exception of the Crow, against whom he scems to have a special grudge, I have never seen a Kingbird take notice of any bird unless he alighted near his nest, and the meekest creature that wears feathers will try to drive away strangers who approach that sacred spot.

'T'he calls and cries of the Kingbird are generally loud and attractire, if not particularly musical, but while his mate is sitting-and possibly at other times-he indulges in a soft and very pleasing song, which I have heard only in the very early morning.

\section{Olive Thorne Miller.}

445. Tyrannus dominicensis ( $G$ mel.). Grax hingbird. $A d_{-}-$ Upper parts ashy gray; a concealed orange-red crown patch; wings and tail fuscous; under wing-coverts pale sulphur-yellow; under parts white, tinged with grayish on the breast. L., $9 \cdot 00 ; W ., 4 \cdot 60 ;$ T., $3 \cdot 50 ;$ B. from N., $\cdot 80$.

Range.-Breeds from the coast of South Carolina southward through Florida and the Greater Antilles; winters in the Lesser Antilles, Mexico, and Central America; accidental in Massachusetts.

Nest, of grass and weeds, lined with fine grass and rootlets, in bushes. Eggs, four, deep salmon, irregularly spotted and blotehed with umber and lilac, $1.00 \times 75$ (Maynard).

The Gray Kingbird is a common summer resident of parts of our South Atlantic States, arriring early in May. It resembles the Kingbird in appearance, but lacks the white band at the end of the tail, and has quite different notes. Its usual call is a vigorous pitirri, pitirri, which in Cuba gives it its common name.

The Arkansas Kingbird (44\%. Tyrannus verticalis), a western species, has been taken in Iowa, District of Columbia, Maine, New Jersey, and New York.

452. Myiarchus crinitus (Linn.). ('rested Flycatcher; Great Crested Flycatcheis. Ad.-Upper parts grayish brown, washed with olivegreen; outer vane of primaries margined with pale rufous; inner vane of all but the middle tail-feathers pale rufous; throat and breast pearl-gray; belly sulphur-yellow. L., 9.01; W., $4 \cdot 14 ;$ T., $3 \cdot 75$; B. from N., $\cdot 62$.

Range.-Breeds from Florida to New Brunswick; winters from southern Floricla to Central America.

W ashington, very common S. R., Apl. 25 to Sept. Sing Sing, common S. R., May 7 to Sept. 12. Cambridge, uncommon S. R., May 15 to Aug. 
Nest, of grasses, twigs, and rootlets, with generally a piece of a cast snake skin, in a hole in a tree, generally less than twenty feet up. Eggs, three to six, creamy white, streaked longitudinally with chocolate, $\cdot 90 \times \cdot 68$.

During the spring migration each day brings its own surprise and pleasure. The bare, silent woods where I walked alone before are now astir with flitting wings and ringing with glad music. Each morning I hurry out, full of eager anticipation, to be thrilled by the greeting of some old friend come home again.

There are red-letter days, however, even in this calendar. Hark! from the woods a loud whistle pierces far through the clearing. 'The Great-crest has come !

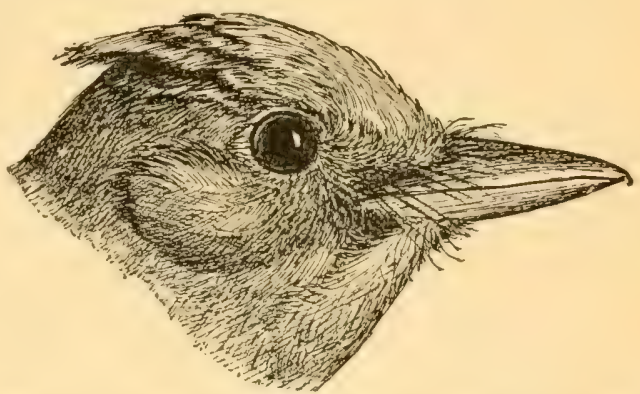

I break away from the

Fig. 75.-Crested Flycatcher. (Natural size.) confusing chorus of small voices and hurry off to the woods for the first sight of the distinguished bird. Full of life and vigror, he flies about in the green tree tops, chattering to himself or calling loudly as he goes.

Not many days pass, however, before he is so taken up with domestic matters that his voice is rarely heard outside the woods. Is he engaged in his fimous pursuit-hunting snake skins to line his nest? Absorber in my daily round of nest ealls, I cherish the memory of each passing glimpse of him. Now I see him launch from a basswood top, with wings and tail spread, to sail down through the air, his tail glowing red against the light. Again, when looking for a rare Warbler, his calls arrest me. In the dead top of the highest tree in sight I find him with his mate. With crests raised, the handsome birds chase each other about the bare branches. Tired of that, they explore the old Woodpecker's holes in the trunk, and one of them walks out of sight down a hollow limb. A Blackbird lights in the tree, and the Great-crest above becomes so agitated that I am convineed his mate has gone to her nest, when lo! both Flycatchers are off and away to another of the great trees that overtop the forest.

Florence A. Merriam.

456. Sayornis phœbe (Lath.). P'нбве. (See Fig. 42.) Ad.-Upper parts grayish brown with an olive-green cast; crown distinctly darker, fuscous; wings and tail fuscous, wing-bars not conspicuous; outer vane of outer tail-feather white or yellowish white, exeept at the tip; under parts white, more or less washed with yellowish, and tinged with brownish gray 
on the breast and sides; bill black. Im.-Similar, but upper parts more olive, under parts more yellow, and wing-bars more distinct. L., 6.99;. W., 3.38; '1., 2.95 ; B. from N., 41 .

Remarks.-The Phobe's principal distinguishing characters are its fuscous crown-cap, white outer vane of the outer tail-feather, and blackish lower mandible.

Range.-Eastern North America; breeds from South Carolina to Newfoundland and Manitoba, and winters from North Carolina to Cuba and Mexico.

Washington, common S. R., Mch. 5 to Oct.; occasionally winters. Sing Sing, common S. R., Mch. 14 to Oct. 29. Cambridge, common S. R., Mch. 25 to Oct. 10.

Nest, bulky, largely moss and mud lined with grasses and long hairs, on a beam or rafter, under a bridge or bank. Eggs, four to six, white, rarely with a few cinnamon-brown spots, $78 \times 59$.

There is something familiar, trustful, and homelike in the Phøbe's ways which has won him an undisputed place in our affections. With an assurance born of many welcomes he returns each year to his perch on the bridge-rail, barnyard gate, or piazza, and contentedly sings his humble, monotonous pewit phobe, pewit phobe-a hopelessly tuneless performance, but who that has hearl it in early spring when the "pussy willow" seems almost to purr with soft blossoms, will not affirm that Phobe touches chords dumb to more ambitious songsters!

Sometimes Phobe is inspired to greater effort, and, springing into the air on fluttering wings, he utters more phobes in a few seconds than he would sing ordinarily in an hour.

Phobe is a devoted parent, and is rarely found far from home. His nest seems to be the favorite abode of an innumerable swarm of parasites which sometimes cause the death of his offspring, and when rearing a second family he changes his quarters.

No other Flycatcher winters in numbers in our Southern States, and Phoebes' notes heard in January in the heart of a Florida " hunmock" seem strangely out of place.

SAY's PIIEBe (45\%. Sayornis saya), a western species, is of accidental occurrence east of the Mississippi. It has been found in northern Illinois; Wisconsin, Iowa, and, more recently, on Cape Cod, Massachusetts (Miller, Auk, vii, 1890, p. 228).

- 459. Contopus borealis (Swaims). Olive-sinen Flycitcher. A $l$. - Upper parts between fuscous and dark olive; wings and tail fuscous ; throat, middle of the belly, and generally a narrow line on the center of the breast white or yellowish white; rest of the under parts of nearly the same color as the back; under tail-coverts marked with dusky; a tuft of fluffy, yellowishwhite feathers on either flank; upper mandible black, lower mandible yellowish or pale grayish brown, the tip darker. Im. - Similar, but with rather 



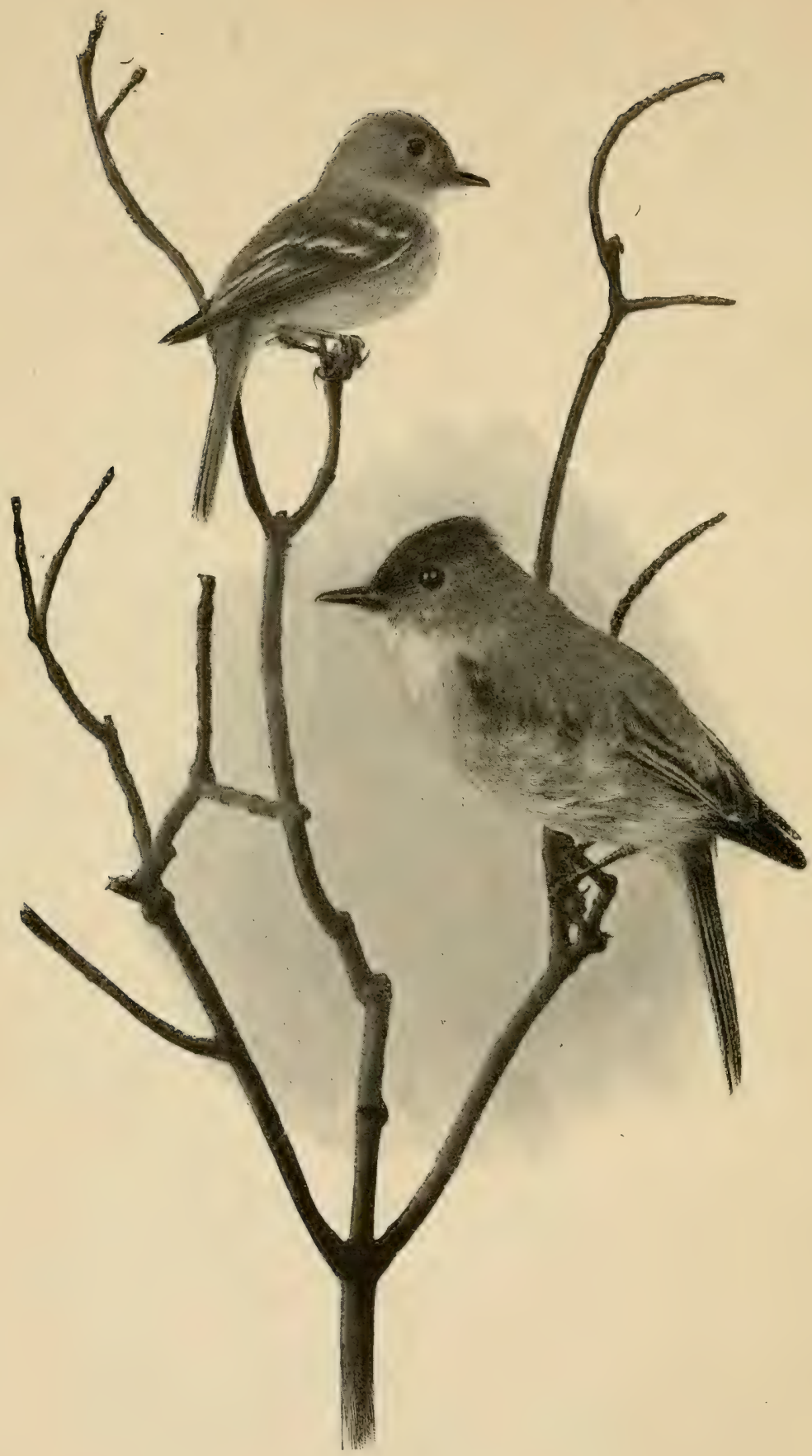

Least Flycatcher.

Ph⿻ве. 
more olive above, more yellow below, and with the wing-coverts edged with ochraceous-butf. L., $7 \cdot 39$; W., $4 \cdot 05$; 'T., $2 \cdot 70 ;$ B. from N., ${ }^{\circ} 54$.

Remarks.-This species may always be known from our other Flycatchers by the comparatively little white on the under parts, and by the tuft of yellowish-white feathers on the flanks. Like the Wood Pewee, it has the wing .50 or more longer than the tail.

Range.-Breeds from Massachusetts and Minnesota northward; winters in Central and South America.

Washington, casual T. V., one instance, Sept. Sing Sing, tolerably com * mon T. V., May 20; Aug. 15 to Sept. 16. Cambridge, T. V., May 20 to May 30 ; Aug.; formerly not uncommon S. R.

Nest, of twigs and moss, in coniferous trees, about twenty-five feet up, near the extremity of a limb. Eggs, three to five, vinaceous-white, spotted, chiefly about the larger end, with distinet and obseure rufous markings, $\cdot 85 \times{ }^{\circ} 62$.

I have seen the Olive-sided Flycatcher only during the migrations, when I look for it on the topmost limb of some high, dead, woodland tree-a commanding position from which it may view its surroundings. Even at a distance it impresses one as being a stout, stocky bird, with a head too large for its body.

During the summer they live among pines or cedars, and are described by Colonel Goss as "bold, quarrelsome, and tyramical, zealously guarding any chosen locality, where they will be found perched upon the tops of the tallest trees, from which they swoop down upon the passing insects, and often repeat their plaintive pu-pu or pu-pip, the males occasionally uttering a loud, whistling call-note."

461. Contopus virens (Linn.). WoOd PEWEe. Al.- - Pper parts very dark, between olive and fuscous, with sometimes a tinge of dark olivegreen; wings and tail fuscous; wing-coverts tipped with whitish, forming two more or less distinct wing-bars; under parts white or yellowish white, washed with olive-gray on the sides of the throat and breast, and, to a less extent, on the center of breast; upper mandible black; lower mandible yellowish or brownish, the tip frequently darker. Im.-Similar. but yellower below, the wing-coverts edged with eream-buff. L., 6.53; W., 3.34; T., 2.62; B. from N., 42 .

Remarks. - The Wood Pewee and the Olive-sided Flycatcher differ from our other Flycatchers in having the wings decidedly longer than the tail, and in their short tarsi. From the species of the genus Empidonax they may be known by these characters and their darker, more fuscous coloration.

Range.-Eastern North America; breeds from Florida to Newfoundland; winters in Central America.

Washington, common S. R., Apl. 28 to Oct. 15. Sing Sing, common S. R., May 10 to Oet. 2. Cambridge, common S. R., May 18 to Sept. 10.

Nest, compact and symmetrical, of fine grasses, rootlets, moss, ete., thickly covered with lichens, saddled on a limb, twenty to forty feet up. Eggs, three to four, white, with a wreath of distinct and obscure umber markings about the larger end, $\cdot 6$ is $\times \cdot 54$. 
'To thoroughly appreciate how well the Pewee's disposition is suited to his haunts and notes, we have only to imagine him taking the Phœbe's place and singing the Phobe's song. Ile was not intended to adorn a bridge or barn, but in the darkened woods, high up in the trees, he finds a congenial home.

His pensive, gentle ways are voiced by his sad, sweet call:

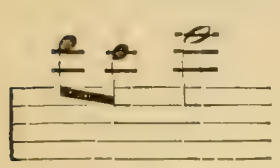

Pee-a - wee The notes are as musical and restful, as much a part of Niture's hymn, as the soft humming of a brook. All day long the Pewee sings; even when the heat of summer silences more vigorous birds and the midday sun sends light-shafts to the ferns, the clear, sympathetic notes of the retiring songster come from the green canopy overhead, in perfect harmony with the peace and stillness of the hour.

463. Empidonax flaviventris Bairl. Tellow-Belled FlYcatcher. $A d$.-Upper parts rather dark olive-green; wings and tail fuscous; greater and lesser wing-coverts tipped with white or yellowish white; under parts sulphur-yellow, the belly pure, the throat, breast, and sides more or less washed with olive-green; upper mandible black, lower mandible whitish or flesh-color; second to fourth primaries of equal length, the first shorter than the fifth. Im.-Yellow of the under parts brighter, wing-bars more yellow, and sometimes tinged with pale ochraceous-buff. L., 5.63 ; W. $2 \cdot 65 ;$ 'T., $2 \cdot 16 ;$ B. from N., 33.

Remarks.-This is the most yellow of our small Flycatchers. In any plunag a the entire under parts, including the throut, are sulphur-yellow or dusky yellowish. In the other eastern species of this genus the throat is white.

Range.-Eastern North America; breeds from Berkshire County, Mass., to Labrador; winters in Central America.

Washington, rather common T. V., May 1 to May 31 ; Aug. 1 to Oet. 1. Sing Sing, common T. V., May 17 to June 4; Aug. 8 to Sept. 20. Cambridge, T. V., sometimes rather common, May 24 to June 5; Aug. 25 to Sept. 10.

Nest, of moss, lined with grasses, on the ground, beneath the roots of a tree or imbedded in moss. Eqgs, four, creamy white, with numerous pale einnamon-brown markings, chiefly about the larger end, $\cdot 68 \times \cdot 54$.

To see this little Flycatcher at his best, one must seek the northern evergreen forest, where, far from human habitation, its mournful notes blend with the murmur of some icy brook tumbling over mossy stones or gushing beneath the still mossier decayed logs that threaten to bar its way. Where all is green and dark and cool, in some glen orerarched by crowding spruces and firs, birches and maples, there it is we find him, and in the beds of damp moss he skillfully conceals his nest. IIe sits erect on some low twig, and, like other Flycatchers, the snap of his bill tells of a sally after his winged prey. He glides quietly away when approached, and his occasional note of complaint 
may be heard as long as one remains in his vicinity. During the migration this species is silent and its several distinctive notes are not available for its identification, and the same thing may be said of our other small Flycatchers. Great similarity in plumage exists between them all, and without the bird in hand identifications are at best questionable.

The song is more suggestive of a sneeze on the bird's part than of any other sound with which it may be compared. It is an abrupt psě-ěl', almost in one explosive syllable, har's like the deeper tones of a House Wren, and less musical than the similar but longer songs of 'Traill's or the Acadian Flycatcher. It is hardly surprising that the birds sing very little when we see with what a convulsive jerk of the head the notes are produced, Its plaintive call is far more melodious -a soft, mournful whistle consisting of two notes, the second higher pitched and prolonged, with rising inflection, resembling in a measure $c h \vec{u}-\bar{e}-\bar{e}^{\prime}-p$.

J. DWIGHT, JR.

465. Empidonaz virescens (Ticill.).* Acadan Flycatcher. Ad.-Upper parts between olive-green and dark olive-green; wings and tail fuscous; greater and lesser wing-coverts yellowish white, forming two conspicuous wing-bars; under parts white, washed with pale yellowish and slightly tinged with greenish on the breast; the throat, and frequently the middle of the belly, pure white; upper mandible black, lower mandible whitish or flesh-color; second to fourth primaries of about equal length, the first and fifth shorter and also of equal length. im.-Upper parts greener; under parts more tinged with yellow; wing-bars and outer edges of the tips of the secondaries ochraceous-buff. L., $5 \cdot 75$; W., 2.85 ; 'T., 2.35 ; B. from N., $\cdot 36$.

Remarks.-This species has the upper parts fully as olive-green as the Yellow-bellied Flycatcher, but the under parts are never entirely yellow, and the throat is always white.

Range.-Eastern United States; breeds from Florida to southern Connecticut and Manitoba; winters in Central America.

Washington, common S. R., May 5 to Sept. 15. Sing Sing, common S. R., May 10 to Aug. 27.

Nest, shallow, of plant stems, grasses, and blossoms, generally on a fork of a beech about eight feet up. Eggs, two to three, creany white, with a few cinnamon-brown spots about the larger end, $74 \times \cdot 56$.

Look for the Acadian Flycatcher in woodlands watered by small streams. It selects a low rather than a high perch, and is rarely seen more than twenty feet from the ground. The frequently uttered calis of this bird are characteristic and will enable you to identify it with more ease in the field than in the study. The most common is a single spee or peet, repeated at short intervals and accompanied by a

* Equivalent to Empidonax acadicus of authors; see Brewster, Auk, xii, April, 1895. 
rapid twitching of the tail. A more peculiar note is a louder pee-eyuk. The bird seems to articulate this note with difficulty, with bill pointed upward and wings trembling like a fledgling begging for food.

Sometimes you may hear only the first call, sometimes only the second, while on other occasions the two may be uttered alternately. A rarer note may be heard when the bird makes a short, fluttering flight. It resembles the soft murmuring of whistling wings.

466a. Empidonax traillii $(A u d$.). Tranll's Flycatener. $4 d$.Upper parts between olive-green and olive or olive-brown; wings and tail fuscous; greater and lesser wing-coverts tipped with brownish ashy; under purts whitish, washed with dusky grayish on the breast and sides and pale yellowish on the belly; throat pure white; upper mandible black, lower mandible whitish or flesh-color. Im.-Similar, but wing-bars ochraceousbuff and under parts slightly yellower. L., $6.09 ; \mathrm{W} ., 2 \cdot 87$; T., 2.33; B. from N., $\cdot 35$.

Remarks.-This is the brownest of our small Flycatchers. The upper parts have an evident tinge of brown or olive-brown, a color entirely wanting in the Acadian and Yellow-bellied Flyeatchers. In this respect it resembles the much smaller Least Flycateher.

Range.-North America; breeds from Arizona, Missouri, southern Illinois, northern New England, and casually Connecticut, north to New Brunswick and Alaska; winters in Central Ameriea.

Washington, irregularly common T. V., May 10 to May 28; Aug. 15 to Sept. 25. Sing Sing, rare T. V., May 19 to May 31; Aug. 29. Cambridge, rare T. V., May 25 to May 31 ; Aug.

Nest, of coarse grasses, plant down, and plant fibers, lined with fine grasses, in the crotch of a small bush or sapling near the ground. Eggs, three to four, creamy white, with cinnamon-brown markings about the larger end, $73 \times \cdot 54$.

While the Yellow-bellied Flycateher is distinctively a bird s? the deep woods, this more abunlant Flycatcher in its summer home resorts to the alder patches of the open country and is seldom found far from their protecting sharle. It flits restlessly about, keeping well out of sight below the waving tops of the bushes, and its presence is betrayed only by a single pĕp of alarm that in no way resembles the mournful wail of the species just mentioned. It, too. is silent when migrating, and on its breeding grounds sings but little, so that if it did not take pains to call out to every one who passes it would not be noticed among the rustling alders. The song most resembles that of the Acadian Flycatcher, an $\bar{e} \bar{e}-z \bar{e} \bar{e}^{\prime}-\bar{e}-\breve{u} p$, with stress on the rasping $z \bar{e} \bar{e}$, the latter part more musical. The performer jerks out the notes rapidly, doubling himself up and fairly vibrating with the explosive effort.

J. Dwight, JR.

NoTE.-In The Auk for April, 1895, Mr. William Brewster shows that the specific name pusillus (Swains.), hitherto applied to the western form of this Fly- 
catcher, is not identifiable. Muscicapa traillii was deseribed by Audubon from Arkansas, and Mr. Brewster considers specimens from Arkansas and the Mississippi Valley south of latitude $42^{\circ}$ as inseparable from those inhabiting the region westward to the Pacific, to which he would therefore apply the name Empidonax traillii. In brief, the form previously known as E. misillus becomes E. traillii, and the Mississippi Valley birds south of latitude $42^{\circ}$, which formerly were considered the same as those from the Atlantic States, are placed with the western rather than the eastern bird. This course leaves the eastern bird without a name, and Mr. Brewster proposes to call it Empidonax traillii alnorum ; Alder Flycatcher.

Western specimens average somewhat browner than eastern ones, ard have slightly larger bills, but, in my opinion, the differences are too slight to warrant their continued separation, and I would apply the name traillii to both.

467. Empidonax minimus Bairl. Least Flycatcher; Cheвec. Ad.-Upper parts between olive-green and olive or olive-brown; wings and tail fuscous; greater and lesser wing-coverts tinged with ashy white; under parts whitish, washed with dusky grayish on the breast and sides and generally with a slight tinge of yellowish on the belly ; lower mandible generally horn-color. Im.-Under parts slightly more yellow. L., 5.41; W., 2.51 ; T., $2 \cdot 21$; B. from N., 31.

Remarks.-This is the smallest of our Flycatchers. Its size, the comparative absence of yellow on the under parts, and the generally horn-colored or brown lower mandible are its chief distinguishing characters.

Range.-Eastern United States; breeds from Pennsylvania to Quebec; winters in Central America.

Washington, common T. V., Apl. 25 to May 25 ; Aug. 28 to Sept. 25. Sing Sing, tolerably common S. K., Apl. 25 to Aug. 26. Cambridge, abundant S. R., May 1 to Aug. 25.

Nest, of plant down, plant fibers, rootlets, fine strips of bark, and long hairs, generally in a crotch five to fifteen feet up. Eggs, three to five, white, unmarked, $\cdot 63 \times 51$.

When music was distributed, I believe most of our Flycatchers had back seats. It was an unfortunate circumstance, for their sedentary habits and apparently thoughtful, serious, even poetic dispositions make one believe that with proper training they might have taken high rank as musicians.

Instead of the simple melody we might expect to hear from the modest Least Flycatcher, he salutes us with a singularly inappropriate, business-like chebéc, chebéc, varying the performance by murderous sallies after passing insects. In crescendo passages he literally rises to the occasion, and on trembling wings sings an absurd "chebéc, tooralooral, chebé, tooral-ooral," with un earnestness deserving better results.

'The Chebec, however, possesses originality; we can not confuse his roice with that of any other lird, and young ornithologists should give him a vote of thanks for his clear enunciation.

He prefers fruit and shade trees to those of forest growth, and is therefore an inhabitant of our lawns and orehards. 


\section{Family Aladdid e. Larks.}

The Horned Larks are the only representatives of this family found in America. About one hundred species, of which the Skylark is the best known, are found in the Old-World.

- They are terrestrial birds, generally colored in harmony with their haunts, and, except during the nesting season, are usually found in flocks.

474. Otocoris alpestris* (Linn.). Horned Lark; Shore Lark. $A d$. o .-Forehead, line over the eye, ear region, and throat sulphur-yellow; fore part of the crown, a tuft of elongated feathers on either side of the head, a mark from the bill below the eye and then downward to the side of the throat, and a patch on the breast black; back of the head and neck and rump vinaceous, more or less washed with grayish brown; back grayish brown, edged with brownish ash and tinged with vinaceous; wing-coverts deep vinaceous; tail black, the outer vanes of the outer feathers maryined with white, the middle feathers broadly margined with brownish and vinaceous; lower breast and belly white, the former more or less soiled with dusky spots; sides vinaceous. $A d . \&$. -Similar, but the markings, especially those of the head, less sharply defined, neck less vinaceous, etc. Fall and winter specimens. -Similar, but with the black markings veiled by yellowish or whitish tips to the feathers. L., $7 \cdot 75$; "W., 4.27; T., 2.84; B. from N., "40" (D,wight).

Range.-Breeds in "northern Europe, Greenland, Newfoundland, Labrador, and Hudson Bay region; southward in winter into eastern United States to about lat. $35^{\circ} "$ (Dwight).

Washington, common W. V., Nov. to Mch. or Apl. Sing Sing, casual W. V. Cambridge, common T. V., Oct. 25 to Nov. 25 ; Mch. 25 to Apl. 5.

Nest, of grasses, on the ground. Eggs, three to four, pale bluish or greenish white, minutely and evenly speckled with pale grayish brown, $84 \times \cdot 60$.

These hardy birds visit us in flocks in the winter. They frequent the vicinity of the seacoast or large, flat, open tracts in the interior, and are rarely found in well-wooded regions. They are terrestrial, and may be seen running over the snow or barren ground in seattered companies. They take wing with a sharp, whistled note, and seek fresh fields or, hesitating, finally swing about and return to near the spot from which they were flushed. They are sometimes found associated with Snowflakes, and flocks may contain numbers of our resident Shore Lark, O. a. praticola.

474b. O. a. praticola Hensh. Prame Horned Lark.-Similar to the preceding species, but smaller and somewhat paler, with the forehead and line over the eye white instead of yellow, the throat but slightly tinged

* See an important paper on the relationships and distribution of the American representatives of this genus, by Dr. J. Dwight, Jr., in The $\Lambda$ uk, vii, 1890 , pp. 138-158. 
with yellow, and sometimes entirely white. L., $7 \cdot 25$; "W., 4.08 ; T., 2.86 ; B. from $N_{.,} \cdot 37 "$ (Dwight).

Range.-Breeds in the upper Mississippi Valley eastward through New York to western Massachusetts and Long Island.

Washington, common W. V., Oct. 25 to Apl.

This is one of the birds that has changed its range since the settlement of America. It is properly a species of the prairies and open birrens, but since the once-continuous forest of the older States and provinces has been broken up, it has made its appearance in the east, wherever the country is suited to its requirements.

It is strictly a ground bird, never perching on trees, though it commonly alights on the top of a fence post or other low, level surface. When encountered on a pathway it often runs before the pedestrian, after the manner of the Vesper Sparrow, from which bird, however, it may be distinguished by the

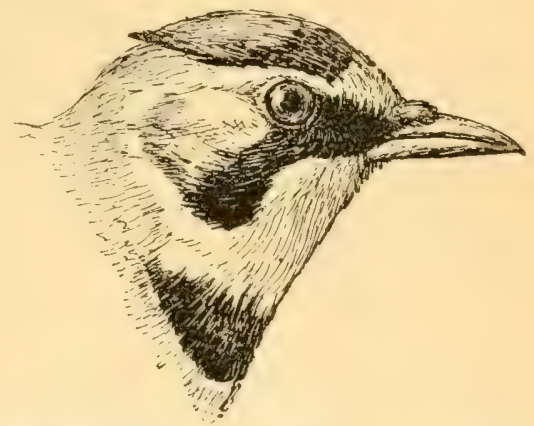

FIG. 76.-Prairie Horned Lark. (Natural size.) black feathers in its tail, by its chocolate back, and by the black marks on its face; also by the fact that it runs, but does not hop, and when it flies it usually utters a whistle, wherews the Vesper Sparrow invariably flies off in silence.

Its chicf song is poured forth in the air as it soars aloft, like a Skylark; but it often utters this same song while perched on some clod or stone, especially just before dawn and after sunset, as well as in the springtime, while the snow is yet on the ground.-Ernest E. Thoupson.

European Skylarks (473. Alauda arvensis) have been introduced several times in this country. In 1887 a small colony had become established near Flatbush, Long Island, where a nest with young was found. (See Dutcher, Auk, v, 1888, p. 180.) After a supposed extinction a singing bird and nest were observed in July, 1895. (See Proctor, Auk, xii, Oct., 1895.)

\section{Family Corvide. Crows, Jays, etc.}

The Corvide are represented in all parts of the world except New Zealand. 'They number' about two hundred species, of which twentyfive are found in North America.

Our ('rows and Jays inhabit wooled regions, and, although migratory to a limited extent, are resident throughout the year, except at the northern limits of their range. They are omnirorous feeders, taking fruits, seeds, insects, eggs, nestlings, etc. 
Crows and Jays exhibit marked traits of character and are possessed of unusual intelligence. Some systematists place them at the top of the Avian tree, and, if their mental derelopment be talien into consideration, they have undoubted claims to this high rank.

A. Plumage black.

KEY TO THE SPECIES.

a. Wing about 15.00 ; bill over 2.50 .

486a. RATE:

b. Wing about $13 \cdot 00$; bill about $2 \cdot 00$.

c. Wing about 11.00 ; bill about 1550 . . . . . . 490. Fish Crow. $B$. Plumage bluish or grayish.

a. Back blue; tail tipped with white; a black breast-patch.

47\%. Blye Jay, 477a. Florida Blue Jat.

b. Back bluish gray; tail not tipped with white; throat and breast indistinctly streaked with whitish . . . . . . . 479. FLORIDA JAY.

c. Back gray; back of head and nape blackish; forehead whitish.

484. Canada Jay. 484c. Labrador Jay.

4y\%. Cyanocitta cristata (Linn.). BLIE JAY. (See Fig. 44, a.) Ad.-Upper parts grayish blue; under parts dusky whitish, whiter on the throat and belly; forehead, and a band passing across the back of the head down the sides of the neck and across the breast, black; head crested; exposed surface of wings blue, the greater wing-coverts and secondaries barred with black and tipped with white; tail blue, all but the outer feathers barred with black, and all but the middle pair broadly tipped with white, this white tip rarely less than 1.00 in width on the outer feather. L., 11.74; W., 5.14; T., $5 \cdot 19 ;$ B., $1 \cdot 04$.

Range.-Eastem North America; breeds from Florida to Newfoundland; generally resident throughout its range.

Washington, rather rare P. R., common T. V., A pl. 28 to May 15; Sept. 1.5 to Oct. 15. Sing Sing, tolerably common P. R. Cambridge, common P. R., abundant T. V., Apl. and May; Sept. and Oct.

Nest, of rootlets, compactly interwoven, generally in a tree crotch fifteen to twenty feet up. Eggs, four to six, pale olive-green or brownish ashy, rather thickly marked with distinct or obscure spots of varying shades of cinnamonbrown, $1 \cdot 10 \times \cdot 85$.

The Blue Jay, I fear, is a reprobate, but, notwithstanding his fondness for eggs and nestlings, and his evident joy in worrying other birds, there is a dashing, reckless air about him which makes us pardon his faults and like him in spite of ourselves.

Like many men, he needs the inspiration of congenial company to bring out the social side of his disposition. Household duties may perhaps absorb him, but certain it is that when at home he is very different from the noisy fellow who, with equally noisy comrades, roams the woods in the fall.

How his jay, jay rings out on the frosty morning air! It is a sig- 
nal to his companions, breakfasting in a near-by oak or chestnut, "Here, here, here's some fun!" and the poor, blinking Owl he has discovered looks helplessly at the blue-coated mob, whose uproar alone is terrifying. Suddenly there is absolute silence; every Jay has disappeared. Some one of them has seen you, and not until your silence reassures the band will they return to the sport of teasing their victim.

The Blue Jay is both a mimic and a ventriloquist. Besides an inexhaustible stock of whistles and calls of his own, he imitates the notes of other species, notably those of the Red-shouldered, Red-tail, and Sparrow Hawks.

47\%a. C. C. florincola Coues. Flomid B bue JAY.-Similar to the preceding species, but smaller, the upper parts somewhat grayer, the white tips to the feathers narrower, those on the outer pair of tail-feathers generally less than 1.00 in width. L., $10.75 ;$ W., 5.15; T., 4.80; B., $\cdot 96$.

Range.-Florida and Gulf coast region to T'exas.

Blue Jays in Florida are much more familiar than our Jays at the north. They are common inhabitants of towns with live-oaks, and hop about the fences and gardens with all the domesticity of the Robins on our lawns. It has always seemed to me that the Florida birds were possessed of greater vocabularies than their northern biethren.

The Magre (475. Pica pica hudsonica) inhabits western North America; stragglers have been recorded from as far east as Montreal and Illinois.

479. Aphelocoma floridana (Bartr.). FloRida JAY. Ad.-Top and sides of the head and neck, wings and tail, grayish blue; back pale brownish gray; under parts dirty white, obscurely streaked on the throat and breast; sides of the breast and faint breast-band grayish blue. L., 11.50; W., $4 \cdot 45 ;$ T., $5 \cdot 40 ;$ B., $\cdot 98$.

Range.-Florida; of local distribution, chiefly along the coasts, between lat. $27^{\circ}$ and $30^{\circ}$.

Nest, of sticks and roots lined with weeds and rootlets, in bushes. Eggs, four, olive-green spotted and blotched with black, 1•17 $\times \cdot 75$ (Maynard).

"The Florida Jays are noisy birds at all times, and the first intimation which one receives of their presence is a harsh scream which is given as a note of alarm. As they usually move in flocks, this cry is taken up by others, and soon the scrub for many rods around will be resounding with these peculiar sounds. When undisturbed they feed on the ground or in bushes, but, upon the approach of an intruder, they will mount the highest point arailable, where they remain until driven away. They are not usually shy, and will allow one to approach them quite closely, but when one or two are shot the survivors usually disappear. . . They will glide through the bushes with remarkable rapility, never once showing themselves, or, if they have an 
open space to cross, dart over it, not in flocks, but singly, and, plunging into the next thicket, they will at once be lost to view" (Maynard).

484. Perisoreus canadensis (Timn.). CANADA JAY; WHiskY JACK; MoosE-BIRD. Ad.-Fore part of the head white, back of the head and nape sooty black, back gray; wings and tail gray, most of the feathers narrowly tipped with white; throat and sides of the neck white, rest of the under parts ashy gray. L., 12.00; W., 5.85; 'T., 5.80; B., 82.

Range.-Nova Scotia, northern New England, and northern New York; west to northern Minnesota; north, in the interior, to the arctic regions.

Cambridge, A. V., one record, Oct.

Nest, of coarse twigs and strips of bark, in conifercus trees. Eggs, four to five, white, distinctly and obscurely spotted with light olive-brown, 1.12 x 81 .

While studying the habits of birds in the great coniferous forest of the north, I soon found that I was very safe in attributing any new strange shrieks or wails, whose origin I was otherwise unable to trace, to the Canada Jay. Many of the notes resemble those of the Blue Jay, but it has a number that are distinctly its own. Some of these are musical, but most of them are harsh and discordant.

In its habits it is much like its blue cousin, but it is less shy, and becomes almost tame if allowed to come ummolested about the camp for a few days in succession. In form it is like a magnified Chickadee, clad in singularly furlike, thick, puffy gray feathers; on its forehead is a white spot, the size of a dime, and its wings and tail are of a much darker gray than the other parts. This description, remembered in conjunction with the habits, will at once identify the species.

It nests early in March-that is, while deep snow still covers the ground and hard frost reigns supreme; and no satisfactory explanation of this strange habit has yet been brought forward. No doubt one or other of the parents always remains with the eggs, but still it is difficult to see how they can keep them from freezing when the surrounding air is chilled to $30^{\circ}$ below zero.

It is a non-migratory species, and it is said that in autumn it provides against the annual famine of winter by laying up a store of nuts and other food.

ERnest E. Thompson.

484c. P. c. nigricapillus Rilgro. LABrador JAY.-Similar to the preceding, but darker, the black of the head and neck extending forward and surrounding the eye.

Range.-Coast region of Labrador.

486a. Corvus corax principalis Rillgw. Nonthers RAven; American Raven. Ad.-Entire plumage black with steel-blue reflections; feathers on the throat narrow, lengthened, and pointed. "L., about. 22.0026.50 ; W., 16.99; T., 9.86; B., 3.03; depth of B. at N., 1.04" (Ridgw.).

R marks.-The Raven differs from the Crow in its much greater size and 
in having long, pointed, instead of the usual short, rounded feathers on the throat.

Range.-Northern North America from Greenland to Alaska, south on the Pacitic coast to British Columbia, and on the Atlantic coast to North Carolina; of local distribution in the eastern United States.

Nest, compact and symmetrical, of sticks lined with grasses, wool, etc., added from year to year, in trees or on clifts. "Eggs, two to seven, pale bluish green, pale olive, or olive spotted or dashed (or both) with olive-brown (sometimes nearly uniform olive from density of markings), $2.02 \times 1.38 "$ (Ridgw.).

"The usual note of the Raven is a hoarse, rolling $c r-r-r-c r u c k$, but he has other cries. ...

"Despite their difference in size and habits, I must confess that I often had difficulty in distinguishing Ravens from Crows. Erery one must have noticed how the apparent size of a Crow will vary under different conditions of the atmosphere; it is the same with the Raven. At times he looks as big as an Eagle; at others scarcely larger than a Fish Crow. But when actually in company with Crows he can not be possibly mistaken, for he then appears, as he is, nearly double the size of any of them. His flight did not seem to me as characteristic as it has been described. True, he sails more than does the Crow, and there is something peculiar in his wing strokes, but the difference is not always appreciable unless there is an opportunity for direct comparison" (Brewster, Birds Observed on Gulf of St. Lawrence. Proc. Bost. Soc. Nat. Hist., xxii, 1883, p. 378).

488. Corvus americanus Aud. Americ.n ('row. (See Fig. 44,b.) $A d$.-Entire plumage black, with steel-blue or deep purplish reflections; the under parts duller than the upper parts; feathers on the neck normal, short, and rounded. L., $19.30 ;$ W., 12.18; T., $7 \cdot 52$; B., $2 \cdot 00$.

Range._. "North America from the fur countries to Mexico"; winters from the northern United States south ward.

Washington, abundant P. R. Sing Sing, common P. R. Cambridge, abundant P. R.

Nest, bulky, of sticks lined with strips of grapevine bark, grasses, moss, etc., in trees, generally about thirty feet up. Eggs, four to six, generally bluish green, thickly marked with shades of brown, but sometimes light blue or eren white with almost no markings, $1.65 \times 1.19$.

'Throughout his wide range the size, color, voice, habits, and abundance of the Crow combine to make him the most conspicuous and consequently the best known of our birds. But in spite of his great circle of acquaintances he has few friends. An unfortunate fondness for corn has placed him under the ban of the agriculturist; there is a price on his head; every man's hand is against him.

Apparently he does not mind this in the least; in fact, he seems to rejoice in being an outlaw. As for fear, I doubt if he knows what 
it means; he has far too much confidence in his undoubted ability to escape his human persecutors. He laughs at their attempts to entrap him; his insolent assurance is admirable. For several centuries man has been his sworn enemy, nevertheless he appears to have held his own, accepting and adjusting himself to every new condition.

Afraid of no one, he migrates boldly by day, and in March and October we may see him with his comrades high in the air, returning to or leaving their summer homes. In winter the Crows are exceedingly abundant along our seacoasts, where they congregate to feed on mollusks, fish, and other sea food.

At this season they roost in colonies. It has been estimated that some roosts contain upward of three hundred thousand birds.* Early in the morning, with regularly executed manœuvres, they start on the day's foraging, flying low, on the lookout for food. Late in the afternoon they return at a much greater height- "as the Crow flies"-and, alighting at some point near the roost, wait the coming of the last stragglers. Then, at a given signal, they all rise and retire for the night.

No one who has listened to Crows will doubt that they have a language. But who can translate it?

488a. C. a. floridanus Buirl. F Forida Crow.-Similar to the preceding, but wings and tail somewhat shorter, and bill and feet slightly larger. L., $20 \cdot 00$; W., $11 \cdot 50-12 \cdot 30$; T., $7 \cdot 00-7 \cdot 70$; B., $2 \cdot 00-2 \cdot 20$; depth of B. at base, 75-・85; Tar., 2·40-2:50 (Ridgw.).

Ringe.-Florida; confined largely to the pine-woods.

490. Corvus ossifragus Wils. Fisir Crow. Adl.-Entire plumage black, with steel-blue or deep purplish reflections, generally more greenish on the under parts. L., $16 \cdot 00$; W., $11 \cdot 00 ;$ T., $6.40 ;$ B., 1.50 .

Remarks.- The Fish Crow may be distinguished from the common Crow (1) by its much smaller size. (2) By the uniform and somewhat richer color of the back. In americanus the feathers of the back have dull tips; when the freshly-plumaged bird is held between the observer and the light these tips give the back a ringed or slightly scaled appearance. In ossifragus these tips are wanting, and the back is uniformly colored. (3) By the brighter color of the under parts. In americanus the under parts are generally much duller than the upper parts; in ossifragus they are nearly as bright.

Range.-Gulf and Atlantic coast, as far north as southern Connecticut; resident except at the extreme northern part of its range.

Washington, rather common P. R. Cambridge, A. V., one reeord, Mch.

Nest, of sticks, lined with strips of grapevine bark, moss, grasses, etc., generally in pines or cedars, twenty to fifty feet up. Eggs, four to six, similar in color to those of $C$. americanus, $1.52 \times 1.06$.

* Rhoads, Crow Roosts and Roosting Crows, Am. Nat., 1886, pp. 691-700, 7r7-787. 
The Fish Crow can be distinguished from the common Crow in life only by its call. Its voice is cracked and reedy, and its notes resemble those of a young common Crow. Instead of the loud, clear, open caw of adults of that species, it utters a hoarser car, as if it talked through its nose! The difference is perhaps not appreciable upon paper, but one who is familiar with their calls need never confuse these two birds in the field.

The Fish Crow, while not confined to the coast or even the vicinity of water, is not found far inland.

\section{Family Sturnid A. Starlings.}

An Old-World family containing some two hundred species. It is represented in America only by the Starling, which has been recently introduced.

493. Sturnus vulgaris Linn. Starling. (See Fig.45.) Atl.summer plumage.-Metallic purplish or greenish ; feathers of the upper parts all tipped with cream-buff spots, feathers of the under parts marked only on the sides; lower belly and under tail-coverts, wings, and tail dark brownish gray, edged with cream-buff'; bill yellow. Ad., winter plumage.-Similar, but the upper parts heavily spotted with brownish crean-buff; the entire under parts hearily spotted with white; bill blackish brown. L., 8.50; W., 5•10; T., 2:50.

Range.-Europe and northern Asia; accidental in Greenland; introduced in New York eity.

Nest, of grasses, twigs, ete., in a crevice in a building or hollow tree. Eggs, four to six, pale bluish, 1.20 $\times \cdot 86$.

This Old-World species has been introduced in eastern North America on several occasions, but only the last importation appears to have been successful. The birds included in this lot, about sixty in number, were released in Central Park, New York eity, in 1890, under the direction of Mr. Eugene Schieffelin. They seem to have left the park and hare established themselves in various farorable places in the upper part of the city. They have bred for three successive years in the roof of the Museum of Natural IIistory and at other points in the vicinity. In the suburbs about the northern end of the city they are frequently observed in flocks containing as many as fifty individuals. These birds are resident throughout the year, and, as they have already endured our most severe winters, we may doubtless regard the species as thoroughly naturalized. Starlings are walkers, not hoppers, and this fact, in connection with the spotted plumage and yellow bill of the adults, makes their identification an casy matter. 


\section{Family ICterid at. Blackbirds, Orioles, etc.}

This distinctively American family is most abundantly represented in the tropics, where the majority of the one hundred and fifty known species are found. With the exception of the Orioles, they are gregarious after the nesting season, while some of the species nest in colonies and are found in flocks throughout the year.

They differ markedly in habits, and are found living in ground of every nature, from dry plains and wet marshes to the densest forest growth. Some species possess marked vocal ability, while the roices of others are harsh and unmusicul. They feed on fruit, seeds, and insects.

\section{KEY TO THE SPECIES.}

\section{With yellow or orange in the under parts.}

A. Throat black.

a. Back black . . . . . . 507. Baltimore Ortole.

b. Back greenish . . . . 506. Orchard Oriole (o im.).

B. A black or blackish crescent on the breast; outer tail-feathers white.

501. Meadowlark: 501a. Western Meadowlark.

C. Entire under parts yellow, yellowish, or orange.

a. Rump and tail orange. . 507. Baltimore Ortole ( $\&$ and im.).

b. Upper parts yellowish green . 506. Orchard OrIOLE ( $q$ and im.).

c. Upper parts brownish, streaked and spotted with black; tail-feathers pointed . . . . . . 494. BовоLink ( 8 and im.).

D. Throat and breast yellow or yellowish; belly black or dark grayish brown. . . . . 497. Yellow-headed Blackbird.

\section{Under parts black, with or without metallic reflec-} tions.

$A$. Outer tail-feathers $\% 5$ or more shorter than middle ones; bill 1.00 or more in length.

a. Tail over 600 . . . . 513. BontT-Talled Grackle $\delta$.

b. T'ail under $6 \cdot 00$.

b1. Back bronzy purple or shining, brassy bluish green, the feathers with iridescent bars . . . . . 511. Púrple Grackle ( $\left.{ }^{*}\right)$. $b^{2}$. Back bronze, without iridescent bars.

511b. Bronzed Grackle of .

$b^{3}$. Back bottle-green, the feathers more purple at their base, and with a narrow iridescent bar near the middle.

511a. Florida Grackle \&.

b4. Back bluish black, with or without iridescent bars.

511. Purple Grackle ( \%). 511a. Florida Grackle \&. B. Outer tail-feathers little if any shorter than middle ones; bill less than 1.00 in length.

a. Entire plumage bluish black, the feathers sometimes tipped with buffy or rufous . . . . . . . 509. Rustx Blackird. b. A red and buffshoulder-pateh. . 498. Ren-wixged Blackemo (o ). 
c. Head and neck all around seal-brown . . . 495. CowBird \&

d. Nape buffy, rump whitish . . . . . . 494. Bobolink ô.

\section{Under parts grayish, slate-color, chestnut, or buffy.}

A. Under parts grayish or slate-color.

a. Under parts grayish; bill finchlike; wing under 4.00.

495. CowBIRD ․

b. Under parts and upper parts slate-color, the feathers sometimes tipped with brownish . . . . . 509. Rustx Blackbird \&.

$B$. Under parts buffy or chestnut.

a. Under parts buffy, generally with a few black streaks.

494. Bobolink \&.

b. Under parts buffy, without black streaks; tail about 5.00.

513. Boat-tailed Grackle \&.

c. Under parts chestnut; throat black.

506. Orchard Oriole ( \& ad.).

\section{Under parts black and white, or black tipped or mar- gined with rusty.}

a. Under parts streaked black and white, or black tipped with white; shoulder generally red or reddish.

498. Red-Winged Blackbird ( $q$ and im.). 498b. Flomida Redwing ( $\%$ and im.).

b. Upper parts and under parts tipped with rusty.

509. Rusty Blackbird (im.).

c. Nape buffy, rump whitish

494. Bobolink o .

494. Dolichonyz oryzivorus (Limn.). Bobolink; ReEDrind; RICEBIRD. Ad. of, breeding plumage.-Top and sides of the head and under parts black, the feathers more or less tipped with a narrow whitish or creambuff fringe, which wears off as the season advances; back of the neck with a large yellowish cream-buff patch; middle of back generally streaked with cream-buff; scapulars, lower back, and upper tail-coverts soiled grayish white; wings and tail black; tail-feathers with pointed tips; bill blue-black. Ad. \&.-Upper parts olive-buff, streaked with black; crown blackish, with a central stripe of olive-buff; nape finely spotted and back broadly streaked with black; wings and tail brownish fuscous; tail-feathers with pointed tips; under parts yellowish or buffy white. Ad. in fall and Im.-Similar to female, but buffier and more olivaceous throughout. L., $7 \cdot 25 ;$ W., $3 \cdot 76$; ' ., $2.73 ;$ B., $\cdot 55$.

Remarks.-The young and adults in fall plumage are known as Reedbirds. Adults aequire this plumage by a complete molt after the breeding season. The breeding plumage is regained by a complete molt in the spring, and not, as has been supposed, by a change in the color of the feathers without molting. Freshly plumaged males have the black veiled by yellow tips to the feathers; these gradually wear off, and by June have almost entirely disappeared (ef. Chapman, Auk, x, 1893, p. 309).

Range.-Breeds from southern New Jersey northward to Nova Scotia, westward to Utah and northern Moptana; leaves the United States by way of Florida, and winters in South America. 
Washington, T. V., common in spring, abundant in fall; May 1 to May 27 ; A ug. 5 to Oct. 1. Sing Sing, tolerably common S. R., May 1 to Oet. 5 . Caubridge, very common S. R., May 8 to Sept. 10.

Nest, of grasses, on the ground. Eggs, four to seven, grayish white, frequently tinged with the color of the numerous irregular spots and blotehes of o.se-brown or umber, $\$ 5 \times \cdot 62$.

In June our fields and meadows echo with the Bobolink's "mad music" as, on quivering wing, he sings in ecstasy to his mate on her nest in the grasses below. What a wonderful song it is! An irrepressible outburst; a flood of melody from a heart overflowing with the joy of early summer.

But this glad season is soon over. Even before the tide of the year is full, the Bobolink begins to prepare for the long journey to his winter resorts. Doffing his jaunty costume of black, white, and buff, he dons the less conspicuous dress of his mate, and travels in disguise under the assumed name of Reedbird or Ricebird. His voice is hushed, save for a single call-note-a metallic chint. He travels both by day and night, and from the sky we hear his watchword as he signals his companions.

The wild-rice marshes of our coasts and rivers are the rendezvous of the countless flocks of Bobolinks, which later will invade South America, stopping en route to visit the rice fields of South Carolina and Georgia. 'They pass the winter south of the Amazon, and in March or April begin their northward journey. The males, in flocks of two or three hundred, precede the females by several days. They reach Florida about April 25, and are then in full song. Only one who has heard the Bobolink sing can form an idea of the effect produced by a flock of three hundred singing in chorus.

495. Molothrus ater (Bold.). Cowrinn. Al. \&.--Mead, neck, and breast coffee-brown; rest of the plumage glossy black, with metallic bluish

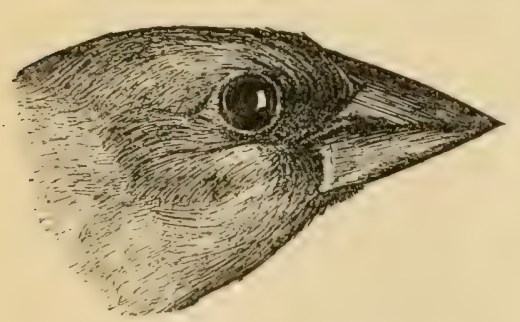

Fig. 77.-Cowbird. (Natural size.) and greenish reflections. Ad. \&.Dark brownish gray, lighter below, especially on the throat. Foung in first plumage.-Similar to the female, but whiter below, all the feathers edged with buffy. This plumage is worn but a short time, and is then changed for that of the adult. of L., $7 \cdot 92 ;$ W., 4.24; T., 3.03; B., $\cdot 67$.

Range.-Breeds from Texas to New Brunswick and Manitoba; winters from southern Illinois southward.

Washington, rather rare P. R., common T. V. Sing Sing, common S. R., Mch. 22 to Nov. 11 . Cambridge, very common S. R., Mch. 25 to Oct. 15; occasional in winter. 


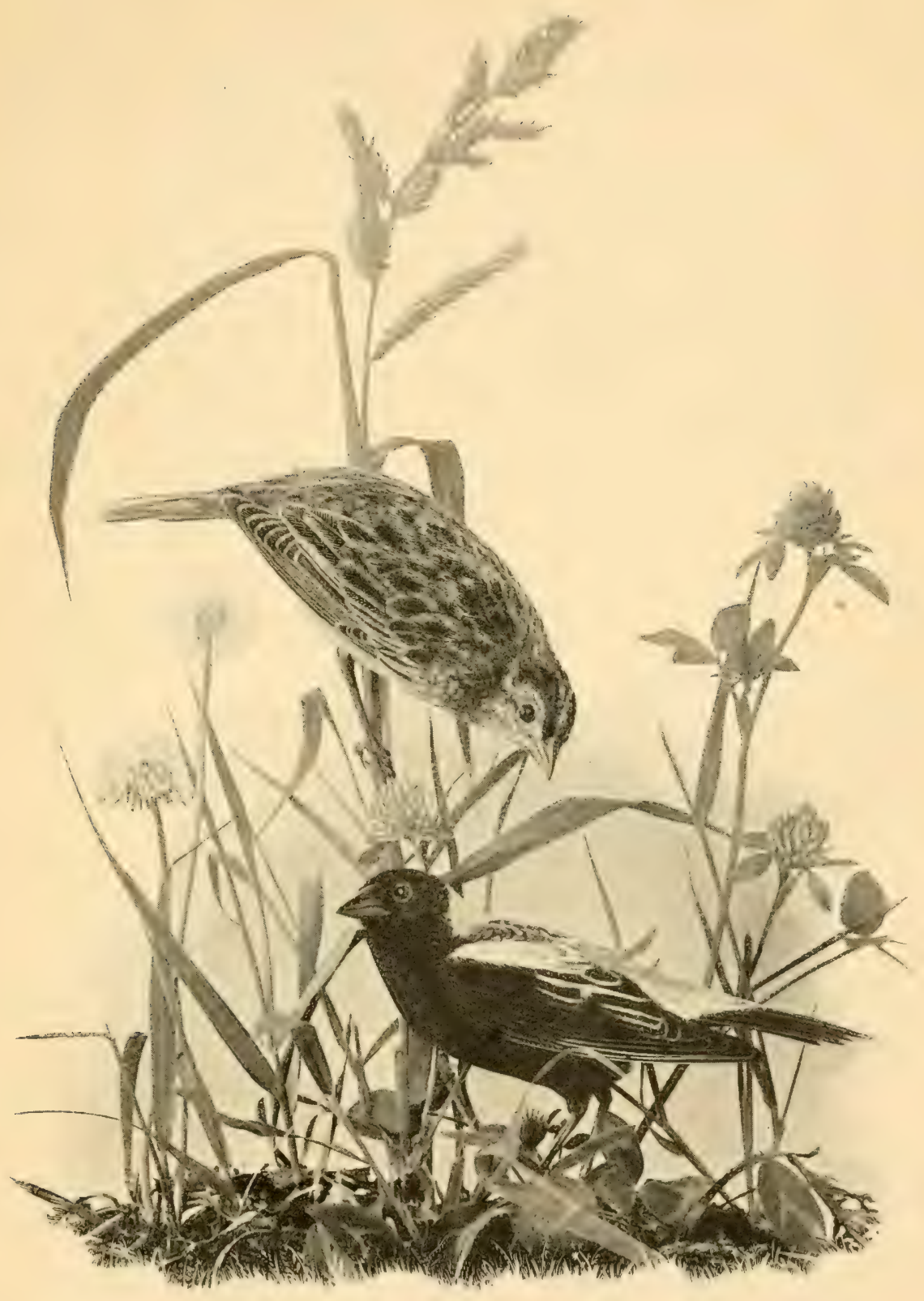

BoBOLINK, MALE AND FEMALE. 
plains, often following and running about with the cattle, in company with Cowbirds; but their natural home is on or about the marshy, weedy grounds, and during the breeding season [they are] seldom to be met with far away. . . .

"Their notes are harsh, and their attempt at song a laborious, whistling, squeaky, chuckling sound" (Goss).

498. Agelaius phœniceus (Linn.). Red-WInged BLACKBIRD. $A d$. o.-Lesser wing-coverts-"shoulders"-bright scarlet; middle wingcoverts varying from ochraceous-buff to buffy' white; rest of the plumage black-in fall and winter specimens more or less tipped with rusty. Im. of.Upper parts margined with rusty and buffy; under parts tipped with whitish ; lesser wing-coverts dull orange-red mixed with black. $A d . \& .-$ Head and back blackish, streaked with rusty and buffy; rump and upper tail-coverts fuscous, more or less edged with ashy; wings fuscous, edged with bufty, the lesser coverts sometimes tinged with reddish; under parts conspicuously streaked with black and white; the throat tinged with orange or yellow. of L., 9.51 ; W., 4.72 ; 'T., $3 \cdot 77$; B., ${ }^{8} 88$.

Range.-Eastern North America; breeds from the Gulf of Mexico to New Brunswick and Manitoba, and winters from Virginia southward.

Washington, common P. R., abundant in migrations. Sing Sing, common S. R., Feb. 25 to Nov. 11. Cambridge, abundant S. R., Mch. to Aug.; a few winter.

Nest, of coarse grasses, weed stalks, etc., lined with finer grasses and rootlets, attached to low bushes or reeds. Eggs, three to five, pale blue, singularly streaked, spotted, or scrawled with dark purple or black, chiefly at the larger end, $1 \cdot 04 \times 72$.

A swiftly moving, compact band of silent birds, passing low through the brown orchard, suddenly wheels and, alighting among the bare branches, with the precision of a trained choir breaks into a wild, tinkling glee. It is quite possible that in the summer this rude chorus might fail to awaken enthusiasm, but in the spring it is as welcome and inspiring a promise of the new year as the peeping of frogs or blooming of the first wild flower.

Plain, streaked Mrs. Redwing, who has been spending the winter in flocks composed only of others of her sex, soon appears, but mating is delayed until late April or early May. Then we find the old homes in the wet meadows and marshes occupied by apparently the same birds which have $d$ welt there for years.

Mounting the topmost branch of a tree not far from the nest, the male hecomes an ever-vigilant sentinel. IHis rich "liong-quěr-rēe," which by association is so strongly suggestive of reedy marshes, is a signal that "all's well." He challenges all suspicious characters by an inquiring chǔt, chuck, and with a long, shrill alarm-note, chee-e-e-e-e, circles out on fluttering wings, his gorgeous crimson epaulets showing conspicuously. 



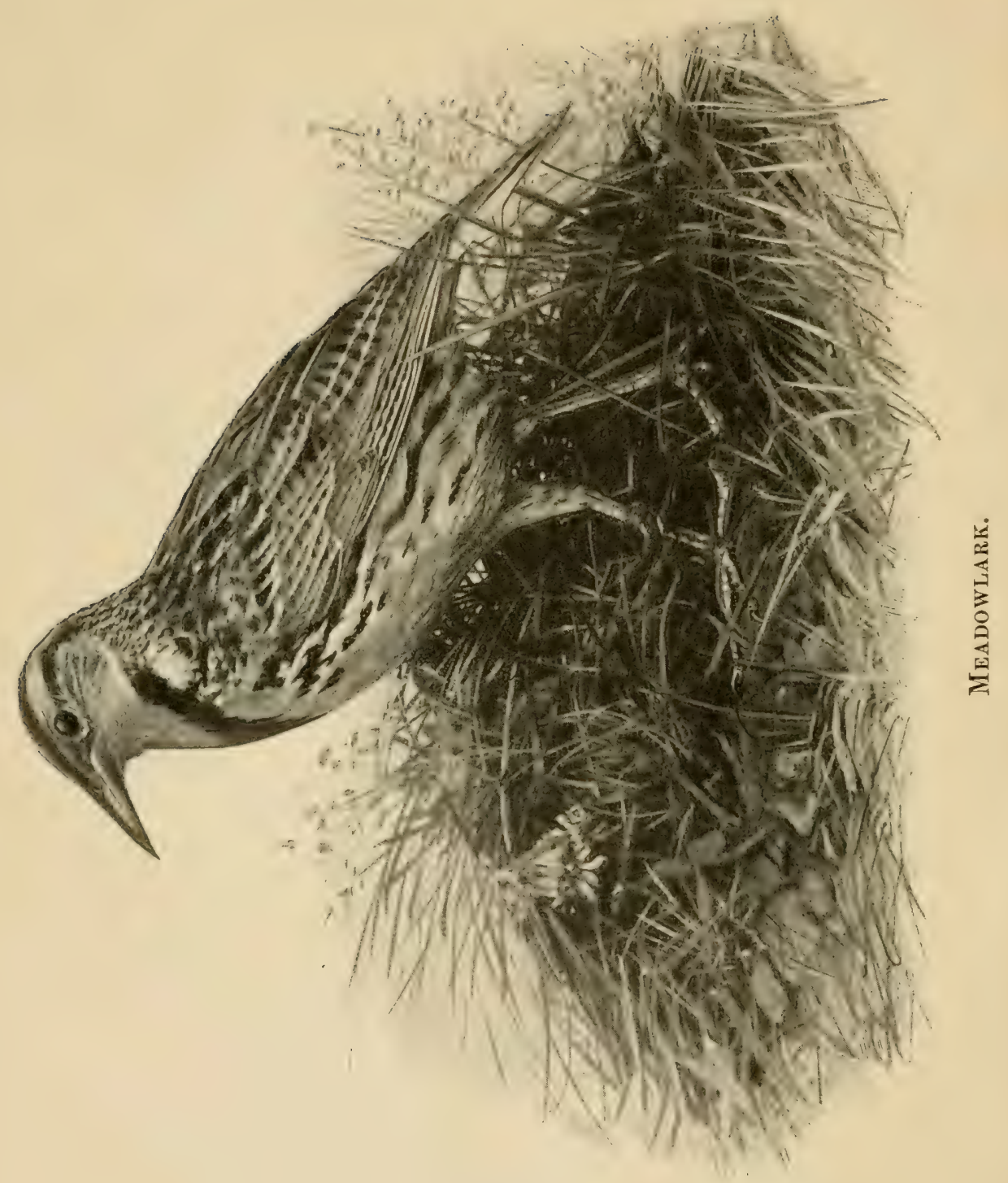


The nesting season is a slort one, and on July young and old begin to gather in flocks in the marshes, where later they will be found, in countless numbers, feeding on the wild rice.

498b. A. p. bryanti Rityw. Florma Rermisi, Sinilar th the preceding, but smaller, the bill much more slender; \& with the under parts less broadly streaked with black. W., $3 \cdot 70$; T., $3 \cdot 50 ;$ B., 90 ; depth of bill at nostril, $\cdot 35$.

Range.-Florida and the Bahamas.

501. Sturnella magna Lihn. Meadomlare: Field Lark. Al. in summer.-Prevailing color of the upper parts black, the crown with a buffy line throus the center, the baok hordered and timed with rufous and huffy: outer tail-feathers motly white, midhle ones with inpurfect, connected bars, not reaching the outer edge of the feather; line from the bill orer the ere rellow; sides of the throat and-ear-corerts whitish; throat, between the lower liranch of the under nandibie. breast. and midle of the umper belly uright rellow: a black cresent on the breast; siles and lower belly whitith. spotted or streaked with black. Winter plumage.-Feathers all much more

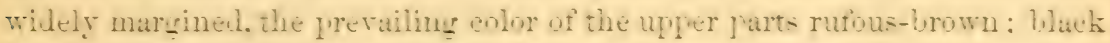
breast crescent reiled with buffy; yellow of under parts duller. L., 1075; W., $4 \cdot 76 ;$ T., $3 \cdot 16 ;$ B., $1 \cdot 30$.

Remarks. - This bird is to be distinguished from the western species by its much darker upper parts, by the imperfect, confluent tail-bars, and more especially by the absence of yellow on the sides of the throat.

Range-Eastern North America; breeds from the Gulf to New Brunswick and Minnesota; winters from Massachusetts and Illinois southward.

Washington, common P. R., less common in winter. Sing Sing, tolerably common S. R., Feb. 20 to Nor. 27; a few winter. Cambridge, common S. R., not common $W$. $V$.

Test, of grasses, frequently arched, on the ground. Eggs, four to six, white, spotted or speckled with cinnamon or reddish brown, $1 \cdot 15 \times \cdot 80$.

In walking through grass fields, meatiows, or marshes, we sometimes flush rather large. brownish birds. which. alternately flapping and sailing. scale away with a flight that suggests a Quail's. Their white outer tail-feathers show conspicuously, and if, instead of returning to the ground. they alight on a fence or the nuter branch of a tree. as they utter a nasal pernt, they will nerrously flit their tails displaying the same white feathers.

When in an exposed position they are wary and difficult to approach, lut when walking about on the ground they trust to the long grasses for protection, and sometimes (d) not take wing until one is within a few feet of them.

In Cuba I noticed that a Xeadomlark, closely related to ours. mas very careful to conceal its brightly colnred breast, with its distinctly marked crescent, and. although eren perching birds were rot shy, they 
would invariably turn their backs upon me as I drew near. Do our Meadowlarks practice the same impolite habit?

The Meadowlark's song is a clear, plaintive whistle of unusual sweetness. It is subject to much variation, both individually and geographically. The birds near my home at Englewood, N. J., generally sing: $\left[\begin{array}{lll}2 & \end{array}\right.$ songs of Florida birds are so different, I hardly recognized them by their notes.

In the fall, Meadowlurks at the north gather in flocks and resort to large marshes.

501a. S. m. neglecta (Aud.). Western Meadowlark; Prairie LARK.-Prevailing color of the upper parts grayish brown, crown with a central buffy stripe; back black, feathers widely margined with grayish brown; rump and upper tail-coverts with narrow black bars; outer tail-feathers mostly white; middle ones brownish gray, barred with black, the bars generally not connected, and as a rule reaching the margins of the feathers; line from the bill over the eye yellow; ear-coverts grayish white; throat yellow, this color reaching up on the sides of the throat and touching the earcoverts; breast and upper belly yellow, a black crescent on the breast; sides and lower belly whitish, spotted or streaked with black. Winter plumage.Upper parts more widely margined with grayish brown, these grayish brown tips with small, broken black bars; yellow of under parts duller, the black crescent veiled with whitish. W., $4 \cdot 60 ;$ T., $3 \cdot 00 ;$ B., 1.25.

Range.-"Western North America, north to British Columbia and Manitoba; east regularly to Dakota, Nebraska, Kansas, and Texas, sparingly to Illinois and Wisconsin; south through western Mexico" (Ridgw.).

The Western Meadowlark resembles the eastern bird in habits but differs from it so decidedly in song that some ornithologists consider it a distinct species and not a geographical race. In his charming biography of the Prairie Lark, Emest E. Thompson writes: "In richness of voice and modulation it equals or excels both Wood Thrush and Nightingale, and in the power and beauty of its articulation it has no superior in the whole world of feathered choristers with which I am acquainted" (Birds of Manitoba).

The Troupras (502. Icterus icterus), a South American species, was recorded by Audubon as accidental at Charleston, South Carolina.

506. Icterus spuxius (Limn.). OrChard OrIole. Ad. \&.--Head, neck, throat, and upper back black; breast, belly, lower back, and lesser wing-coverts chestnut; wings and tail fuscous, more or less edged or tipped with whitish. Ad. \&.- Upper parts srayish olive-green, brighter on the head and rump; wings fuscous, middle ind greater coverts tipped with whitish; tail bright olive-green; under parts dull yellow. Im. of, first year.- 
Similar to the ad. $\$$, but with the back browner. Im. of, second year. - Similar to the ad. $\&$, but with the throat black and occasionally patches of chestnut on the under parts. L., $7 \cdot 32$; W., $3.18 ;$ T., $2 \cdot 92 ;$ B., $\cdot 65$.

Range.-Eastern North America; breeds from the Gulf States to Massachusetts and Ontario, and winters in Central America.

Washington, common S. R., A pl. 28 to Sept. Sing Sing, common S. R., May 2 to Aug. 6. Cambridge, S. R., sometimes rather common, May 15 to July.

Nest, pensile, of grasses interwoven, near the extremity of a $\operatorname{limb}$, ten to fifteen feet up. Eggs, three to five, bluish white, dis-

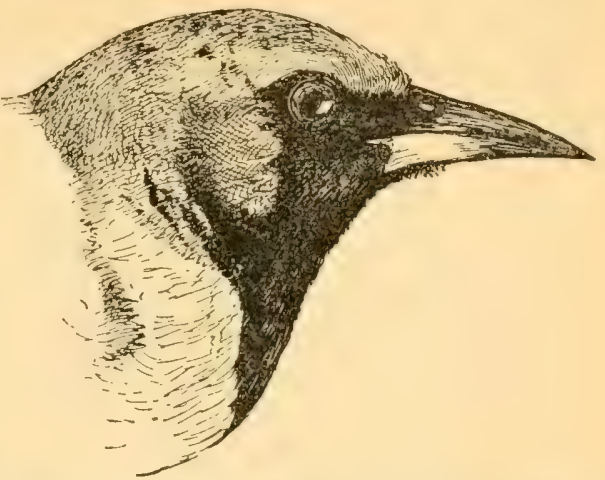

FIG. 78.--Orchard Oriole. (Im., \&, second year.) (Natural size.)

tinctly and obscurely spotted, blotehed, and scrawled with fuscous or black, $.79 \times \cdot 58$.

Although the Orchard Oriole generally frequents apple orchards, he is entirely at home among the shade trees of our lawns.

There is an air of refinement about this bird which seems to pervade his whole life history. He dresses quietly but with excellent taste, his nest is of the choicest materials, while his song suggests the finished effort of a perfectly trained performer. His voice is indeed unusually rich and flexible, and he uses it with rare slill and expression. Words can not describe his song, but no lover of bird-music will be long in the vicinity of a singing Orehark Oriole without learning the distinguished songster's name.

50\%. Icterus galbula (Lim.). Baltimone Oriole; Firebird; Golden Robin; HaNG-Nest. Ad. 8.-Head, neck, throat, and upper back black; breast, belly, lower back, and lesser wing-coverts deep, rich, reddish orange; wings black, the outer margin of the greater coverts and quills edged with white; end half of midale tail-feathers black, base orange; all the others orange, crossed by a black band in the middle. Ad. \&.- Upper parts brownish or grayish orange, brighter on the rump; head and back mottled with black; wings fuscous, greater and middle coverts tipped with white; tail like the rump, the middle feathers stained with black; under parts dull orange, throat sometimes spotted with black. L., 7.53; W., 3.52; T., $2 \cdot 84$; B., $\cdot 70$.

Range.-Eastern North America; breeds from the Gulf States to New Brunswick; winters in Central America.

Washington, rather common S. R., Apl. 28 to Sept. Sing Sing, common S. R., May 2 to Sept. 1. Cambridge, very common S. R., May 8 through Aug.

Nest, pensile, of grasses, bark, plant fibers, hair, strings, etc., firmly interwoven, in fruit or shade trees, near the extremity of a limb twenty to forty 
fect up. Eggs, four to six, white, singularly scrawled with fine, distinct or obscure black or fuscous lines, and with a few spots or blotches, $\cdot 94 \times \cdot 63$.

Sometimes Nature, as if to remind us of the richness of her stores, sends from the tropics a gayly attired bird who seems quite out of place among the more soberly clad inhabitants of northern climes. The genus lcterus contains nearly forty species, all more or less brightly dressed in orange, yellow, and black, but not one is more beautiful than our Baltimore Oriole.

There is reason to believe that he is not unaware of his own charms ; indeed, we may almost suspect him of intentionally displaying them. His splendor is not to be lost in the forest, and, whistling loudly, he flashes through our fruit and shade trees.

He generally leaves to the female the task of constructing their wonderfully made nest, but he seems quite as deeply interested in the performance as if he were a skilled weaver himself; indeed, he would probably assist if he were permitted.

Young Orioles have been well named by Mrs. Olive Thorne Miller the cry-babies of the bird world. Their ceaseless call for food is almost as much a midsummer voice as the song of cicadas. Long after they have left the nest we may find them in the different trees about our lawn calling out monotonously and persistently dee-deedee-dee, until one of the parents arrives and momentarily stops their mouths.

Bullock's Oriole (508. Ieterus bullocki), a species of our Western States, has been taken at Bangor, Maine.

509. Scolecophagus carolinus (Müll.). Ristr Blackind. Ad. s, breeding plumage.-Entire plumage uniform glossy bluish black; tailfeathers of nearly equal length. Ad. o in fall and uinter plumage.-Similar, but the upper parts widely tipped with rufous or rusty, the under parts similarly tipped with ochraceous- or cream-buff; a buffy line over the eye. Ad. o in breeding plumage.-Slate-color, glossy above, duller below; wings and tail darker and more glossy. Ad. $q$ in fall and winter.-Similar, but somewhat lighter, the upper parts widely tipped with rufous or rusty, the under parts similarly tipped with ochraceous- or cream-buff. L., 9.55; W., $4 \cdot 61$; T., $3.52 ;$ B., $\cdot 80$.

Range.-Breeds from New Brunswick and Manitoba northward to Labrador and Alaska; winters from Virginia southward.

Washington, common W. V., Oct. 25 to Apl. 25. Sing Sing, common T. V., Mch. 26 to May 8; Sept. 28 to Nov. 27 . Cambridge, very common T. V., Mch. to May 5 ; Sept. and Oct.

Nest, of twigs and coarse grasses lined with finer grasses, in coniferous trees or on the ground. Eggs, four to seven, grayish green to pale green, thickly blotched with light and dark brown and purple, $1.00 \times 76$ (Chanberlain). 
This bird is found during the migrations in small flocks on freshwater meadows or about open, bushy swamps, feeding on the ground in alder thickets or along the edges of swampy woods. It resembles, more or less, the Rifd-winged Blackbird in size, flight, and notes, but unlike this species, with which it sometimes associates, it is comparatively quict and retiring. Only at times, in the spring, do we find the flocks musical centers, whence issues a confused medley of whistles, sweeter and higher-pitched than the best efforts of the Redwings. Little is known of this Blackbird in its northern home. It gathers into flocks early in the summer, and the most frequently heard note is a "cluck," not in the least characteristic. Its quiet demeanor, paleyellow eye, and uniform color are its chief distinguishing characters in the field, where it may be mistaken for the Bronzed or Purple Grackle. The gray female is unlike the streaked female Redwing.

J. DWIGHT, JR.

Brewer's Blackird (510. Scolecophagus cyanocephalus) inhabits western North America, and is of easual occurrence as far east as Illinois and Louisiana, and has been once recorded from South Carolina. It may be distinguished from $S$. carolinus by its deep violet-purple head and the comparative absence of rusty tips to the feathers.

511. Quiscalus quiscula (Lim.). P'trple Grackle; Crow BlackBIRD. (See Fig. 46, c.) Ad. o. --Head, neck, throat, and upper breast all around varying from brilliant metallic purple to bluish green or steel-blue; back and rump varying from bottle-green to metallie purple or shining brassy green, the feathers with iridescent bars; wings and tail externally metallic purple or bluish black ; lower breast and belly resembling the back but duller. $A d$. o. - Nuch duller than the male, but the feathers of the back generally showing at least traces of iridescence. 8 L., 12.00-13.50; W., 5.66; T., 5•18; B., $1 \cdot 18$.

Remarks.-Intermediates between this and the Bronzed Graekle are found where their ranges adjoin, but typical quiscula always has iridescent bars on the feathers of the back, rump, and belly, while in ceneus these bars are wanting. (On the relationships of this group see Chapman, Bull. Am. Mus. Nat. IIist., iv, 1892, pp. 1-20.)

Riange.-Breeds in the lower Mississippi Valley and east of the Alleghanies from Georgia to Massachusetts; winters in the Southern States.

Washington, common 'T. V. and S. R., Feb. 20 ; a few winter. Sing Sing, tolerably common S. R., Feb. 15 to Nov. 8.

Nest, bulky and compatet, of mud and coarse grasses lined with finer grasses, in colonies, generally in coniferous trees about thirty feet up, sometimes in bushes or holes in trees. Eggs, three to six, very variable, generally pale bluish or bluish green, singularly spotted, blotehed, or scrawled with cinnamon-brown, umber, or black, but sometimes evenly speckled with brownish, and rarely almost solid cinnamon- or rufous-brown, 1.15 × 82 .

When winter gives signs of retreating there comes from the south in sable array the tried adrance guard of the feathered army which is 
impatiently awaiting the order to advance. In close rank they come, phalanx after phalanx, to retake the land which winter-once conquering, now defeated-yields to them. The air resounds to marshal music; their harsh voices, united, rise in an inspiring chorus.

The campaign over, they settle in colonies on their recently acquired possessions, and these careless rover's become so attached to their homes and families that they are rarely seen far from their vicinity. Sometimes we may see them walking sedately over the lawns near their home, their glossy plumage gleaming in the light, and their yellow eyes giving them a peculiar, unbirdlike expression. But when their young are old enough to care for themselves the old habits return, and, leading their offspring into the world, they teach them the ways of wanderers. Mleeting others of their kind, they join forces, and in the fall we find them in hordes ravaging the country.

'The Grackle's disposition is as gloomy as his plumage is aark. Life with him is a serious affair. He seems to utterly lack the Blue Jay's sense of humor. As a parent he is beyond reproach, and every moment is devoted to the care of his young, but it is all done in a joyless way. Eggs and nestlings form part of his fare, and I can imagine bird-mothers frightening their young into obedience by theatened visits from that ogre, the Grackle.

511a. Q. q. aglæus (Buirl). Florida Grackle. A\%. 8.-Head, neck, throat and upper breast all around metallic violet-purple; back and rump rich bottle green, the feathers with more or less concealed iridescent bars; wings and tail externally metallic purple or bluish black; the wingcoverts generally with iridescent tips; lower breast and belly similar to the back but duller. $A d$. \&. - Not distinguishable in color from the of of Q. quiscula, but differing in size. W., $5.38 ;$ 'T., $4.90 ;$ B., 1.25.

Range.-Coast of South Carolina westward through central Georgia to the Mississippi; south through Florida to Key West.

This is a locally abundant bird, and is found in flocks throughout the year. In Florida it sometimes lives in the towns in which liveoaks grow, and it also makes its headquarters in cypress "bays," but its favorite resort is among the cabbage palmettos, upon the berries of which it feeds.

511b. Q. q. æaneus (Rïlgu.). Bronzen Grackle; Crow BlackBIrD. $A d$. of.-Head, neck, throat, and upper breast all around varying from brilliant metallic purple to bluish green or steel-blue; back metallic sealbronze, the feathers without iridescent bars; wings and tail metallic purplish or bluish black; lower breast and belly similar to the back but duller. $A d$. \&.-Much duller, the back and belly brownish, sometimes without metallic reflections and never with iridescent bars. W., 5.62; T., 5.04; B., 1.21.

Range-Breeds from 'Texas to Great Slave Lake, east to the Alleghanies 
as far north as Pennsylvania, and north of this eastward to Connecticut and northward to Labrador; winters in the lower Mississippi Valley.

Washington, rare T. V., between Feb. 20 and Apl. 15. Sing Sing, tolerably common T. V., Apl.; Nov. Cambridge, abundant S. R., Mch. to Oct.; oceasional in winter.

"The general habits of the Bronzed Grackle are in all respects identical with those of the Purple Grackle. ...

. From an almost equal familiarity with the two birds we are able to say that their notes differ decidedly, especially those of the male during the breeding season, the 'song' of the western birds being very much louder and more musical or metallic than those of its eastern relative" (Ridgway).

513. Quiscalus major licill. Boat-Taled Grackle. Ad. o.Glossy bluish black; head, throat, and breast more purplish, wings and tail more blackish. $A d$. \&.-Much smaller, upper parts blackish brown, under parts soiled ochraceous-buff. of L., $16.00 ; \mathrm{W}$., 7.50; T., 7.00; B., 1.55.

Range.-Florida; north along the Atlantic coast to Virginia; west along the Gulf coast to 'Texas.

Nest, bulky and compact, of grasses, seaweed, etc., with a median layer of mud or partially decayed vegetation, in colontes in bushes. Eggs, three to five, pale bluish white, frequently tinged with vinaceous-brown, singularly spotted, blotched, and scrawled with purplish or blackish, 1·32 × 90 .

Boat-tail Grackles are rarely if ever found far from water. Shallow lakes or marshy lagoons grown with aquatic plants are their favorite resorts. Here they may be seen in small grouns, which usually contain more males than females, walking or jumping from plant to plant, sonetimes springing into the air to catch a passing insect, or wading along the shore in search of food.

Their usual notes are hoarse. rather forced whistles; more rarely they utter a singular rolling call, which bears a close resemblance to the sound produced by a Coot in pattering orer the water.

\section{Faimly Fringillid e. Finches, Sparrows, etc.}

This, the largest family of birds, contains some fire hundred and fifty species, which are represented in all parts of the world except the Australian region. Its members present wide diversity of form and habit. but generally agree in possessing stout, conical bills, which are admirably adapted to crush seeds. They are thus chief among seed-eaters, and for this reason are not so migratory as insect-eating species.

The brown. streaked Sparrows are, to a large extent, field- or plaininhabiting, and their neutral colors are therefore a means of protection in the exposed situations they inhabit. The rrighter Grosbeaks 
and Finches are more arboreal. Many species take high rank as songsters, and some of our favorite cage-birds belong to this family.

KEY TO THE SPECIES.

I. Under parts with red.

II. Under parts with no red and without distinet streaks; throat or breast sometimes with a patch or spot.

III. Under parts without red and with numerous streaks.

\section{Under parts with red.}

A. Wing-coverts plainly tipped with white or whitish, or with a white or yellow band in the wing.

a. No red in the upper parts.

$a^{1}$. Back black, rump whitish, throat black, breast and under wingcoverts rosy red . . 595. Rose-breasted Grosbeak (o ad.). $a^{2}$. Back and under parts streaked with black; under wing-coverts rosy red . . . . 595. Rose-breasted Grosbeak (o im.).

b. Red on upper parts confined to crown or forehead, and sometimes a tinge on the rump; wing under $3 \cdot 25$.

$b^{1}$. Kump and flanks generally without blackish streaks; feathers of back generally with whitish borders.

527. Greenland Redpoll. 527 $\alpha$. Hoary Redpoli.

$b^{2}$. Rump and flanks always streaked; feathers of back with little if any white and generally with brownish borders.

528. REDPOLL and races.

b3. Back cinnamon-brown, unstreaked; crown, nape, and sides of the neck black; a yellow band in the wing.

European Goldfinch.

c. Red or pink spread more or less over entire upper parts; wing orer $3 \cdot 25$.

$c^{1}$. Tips of mandibles crossed.

522. White-Tinged Crossbill ( ô ad.).

$c^{2}$. Bill stout; mandibles not crossed. 515. Pine Grosbeak (o ad.).

$B$. Wing-coverts not tipped with white.

a. 'Throat black or blackish; wings and tail red; body red or olive.

593. Cardinal.

b. Throat and more or less of under parts red or greenish red.

b1. Plumage blood-red, brownish red, or greenish red; tips of the mandibles crossed . . . . . . 521. A Mr. Crossbill o.

62. Plumage dull reddish; belly whitish; back indistinctly streaked, with bristly feathers over the nostrils.

51\%: Purple Fincu (o ad.).

$b^{3}$. Head blue; back green; rump red.

601. Painted Buntixg ( o ad.)

\section{Under parts with no red and without distinct streaks; throat or breast sometimes with a patch or spot.}

1. Tail with white spots, bars, or patches.

A. Back plain, without streaks. 
a. Throat and breast black, brown, or slate-color, sharply defined from the white belly.

$a^{1}$. Breast black or brown; sides rufous . . . 587. TowheE. $a^{2}$. Breast slate-color; sides the same, or brownish.

567. Junco. 567e. Carolina Junco.

b. Throat and belly more or less yellow or ashy.

$b^{1}$. Wing over 4.00 ; bill stout, greenish yellow.

514. Evening Grosbeak.

$b^{2}$. Bill small and sharp: back brown; throat yellowish.

529. GOLDFINCII ( $q$ and im.).

b3. Body bright yellow, cap black . . 529. Goldfrncu ( o ad.).

c. Under parts pure white, middle of back black.

B. Back streaked with black, brown, or white.

534. SNOWFLAKE.

a. Bend of the wing yellow; tail under 220.

546. Grasshopper Sparrow.

b. Breast black or blackish; lesser wing-coverts reddish brown.

539. McCown's Longspur ơ .

c. Breast buffy; belly whitish; outer tail-feathers white, next three or four more or less white with a black band at the end; secondaries not entirely white. . . . 539. McCown's Longspur \&.

d. Under parts entirely light brown or buffy, only two outer tailfeathers white: no yellow on the bend of the wing.

587. Suitu's Longspur.

e. Under parts pure white, with a blackish spot on the center of the breast, a black stripe on the siaes of the throat; sides of the crown and ear-coverts chestnut . . . 552. Lark Sparrow.

$f$. Wing slightly over 4.00 ; under parts pure white or washed with rusty; head and rump white or rusty; most of secondaries white.

534. SNOWFLAKE.

2. Tail without large white spots or patches.

A. Back plain, without distinct streaks.

a. Back blue, bluish, or brownish blue.

$a^{1}$. Wing over 3.00 ; lesser wing-coverts chestuut or with broad chestnut tips . . . . . . . . 597. Blue Grosbeak. $a^{2}$. Wing under 3.00 ; lesser wing-coverts blue or bluish, tipped with light brown . . . . . . 598. Indigo Bunting.

b. Back green or greenish, or rump yellow or greenish yellow.

b1. Mandibles not crossed.

62. Back greenish . . . . . 601. Painted Bunting \&.

$b^{3}$. Back and under parts slaty gray; bill black.

515. Pine Grosbenk ( $q$ and im.).

64. Forehead, rump, under parts, and scapulars yellow or brownish yellow; secondaries white; bill yellow.

514. Evening Grosexat of.

$c^{1}$. Mandibles crossed.

$c^{2}$. Wing-bars whitc. . . 522. White-WiNged Crossbill.

$c^{3}$. Without white wing-bars . . . 521. Adr. Crossbill. 
c. Back brown or brownish, ashy, or slate-color.

$c^{1}$. Head and rump yellowish or reddish; wing-bars white; wing over 4.00 . . . . 515. Pine Grosbeak ( $q$ and im.).

$c^{2}$. Under parts brownish cream-buff; wing-coverts with broad chestnut tips; wing over $3 \cdot 00$. . 597. BLvE Grosbear \&.

$c^{3}$. Under parts whitish; wing without yellow and under 3.00 .

598. Indigo Bunting \&.

$c^{4}$. Back ashy; spot before the eye and on bend of wing yellow.

550. Seaside Sparrow.

$B$. Back distinctly streaked.

a. Bend of the wing yellow.

$a^{1}$. Tail over $2 \cdot 20$.

$a^{2}$. A white throat-patch; breast gray; a yellowish line over the eye . . . . . 558. White-throated Sparrow. $a^{3}$. A black spot on the throat; breast yellow, or hoth.

604. DickCissel.

$a^{4}$. No yellow over the eye; breast ashy or buffy; outer tailfeathers much the shortest.

575. Pine-woods Sparrow. 575a. Bachman's Sparrow.

$b^{1}$. Tail under $2 \cdot 20$, the feathers narrow and sharply pointed.

$b^{2}$. Crown olive-brown, a blue-gray line through its center; cheeks and breast ochraceous-buff.

549a. Nelson's Sparrow.

$b^{3}$. Crown blackish, a cream-buff line through its center.

546. Grasshopper Sparrow.

b. Bend of the wing not yellow.

$b^{1}$. Crown bright reddish brown, the feathers sometimes tipped with ashy or brownish, but without black streaks.

$6^{2}$. No white or whitish wing-bars; outer tail-feathers much shorter than middle ones; lesser wing-coverts, upper tailcoverts, and margins of most of the tail-feathers rufous; wing under 250 . . . . . . . 584. Swamp Sparrow.

$b^{3}$. Cheeks and throat ashy, a narrow reddish brown line from back of the eye to the nape, an indistinct black spot in the center of the breast . . . . . 559. Tree Sparrow.

b*. Eye-ring whitish, entire bill brownish flesh-color.

563. Field Sparrow.

$b^{5}$. Rump slaty gray; under parts generally all grayish white; forehead black, with a narrow grayish line in its middle, a narrow black line from back of the eye to the nape.

560. Chipping Sparrow.

c1. Crown streaked or spotted with black or black and white.

$c^{2}$. Crown with chestnut streaks, and sometimes a slight ashy line through its center; no white or whitish wing-bars; outer tail-feathers much shorter than middle ones.

584. SiwaMP Sparrow (Im.).

c3. Crown with reddish brown; rump ashy; wing-bars buffy; middle tail-feathers shortest. 560. Chipping Sparrow (Im.). 
$c^{4}$. Center of crown white; the sides black; wing-bars white.

55̃. White-CROWNED SPARrow.

$c^{5}$. Crown grayish; mandibles crossed . 521. AM. Crossbill.

$d^{1}$. Crown mixed grayish brown and rufous, ashy, or slate-color, without black streaks.

$d^{2}$. Wing 2.50 ; bill brownish flesh-color; back rufous, streaked with black .. . . . . . . 563. Field Sparrow.

$d^{3}$. Wing 3.00 ; center of crown grayish brown, bordered by chestnut-rufous; back grayish brown, spotted with olivebrown . . . . . . 554. White-crowned Sparrow. $d^{4}$. Crown slate-color; a chestnut patch behind the eye; throat black . . . . . . P. 282. English Sparrow o . $d^{5}$. Crown entirely dull brown; lesser wing-coverts broadly tipped with buffy . . . . P. 282. English Sparrow \&.

\section{Under parts without red and with numerous strealss.}

1. Tail-feathers without white or yellow spots or patches, the outer ones little if any shorter than the middle pair.

$A$. Head of about the same color as the back; no yellow over the eye, or on the bend of the wing, or under wing-coverts.

a. Rump yellowish or yellowish green; mandibles crossed.

$a^{2}$. Wing-coverts tipped with white.

522. White-Wingen Crossbill .

$a^{2}$. Wing-coverts not tipped with white - 521. Am. Crossrill q.

b. Mandibles not erossed; rump brown or brownish or sandy like the back; wing under $3 \cdot 25$.

$b^{1}$. Back pale brownish ashy, streaked with brownish; a whitish streak over the eye; legs flesh-color; first primary as long or longer than the second . . . . . . . 541. Ipswich Sparrow.

$t^{2}$. Back and most of under parts streaked with black and reddish brown; upper and under tail-coverts streaked; first primary shorter than second; outer tail-feathers shorter than middle ones.

581. Song Sparrow.

$b^{3}$. Back distinctly streaked; a cream-buff band across the breast.

583. Lincoln's Finch.

64. Back grayish brown, the feathers with or without distinet streaks; first primaries nearly as long or longer than second; outer tail-feathers longer than middle pair; legs and feet blackish; with bristly feathers over the nostrils.

517. Purple Finch \&.

$b^{5}$. Back without streaks; no bristly feathers over the nostrils.

598. Indigo Bunting .

c. Mandibles not crossed; upper tail-feathers and tail bright reddish brown, without black streaks; rump brighter; wing about 3.50 .

585. Fox Sparrow.

$B$. Head of about the same color as the back; a yellow mark before the eye, or on the bend of the wing, or under wing-coverts.

a. Wing about 4.00; under wing-coverts deep yellow.

595. ROSE-rREASTED GROSEEAK \&. 
b. Wing generally under 2.90 ; fenthers of the crown black, bordered by chestnut-brown; a buffy line through the center of crown.

542a. Savanna Sparrow.

c. Wing generally over 2.90 ; feathers of crown with small black centers bordered with cinnamon-brown and pale brownish gray.

541. IPSWICH Sparrow.

d. Wing about 3.00 ; breast washed with yellow . . 604 Dickcissel.

e. Wing about 3.00 ; sides brownish; throat white, quite different from the grayish breast . . . . . 558. White-tinoated Sparrow.

C. A bright red crown-cap; no yellow before the eye or on the bend of the wing.

a. Rump and flanks always heavily streaked with blackish.

528. REDPOLL and races.

b. Rump white, generally without streaks; flanks lightly streaked; more or less white in the feathers of the back.

527. Greenland Reppoll. 527a. Hoary Redpoll.

2. Tail-feathers without white or yellow patches, narrow and generally sharply pointed, the outer feathers always much shorter than the middle pair.

$A$. Crown of a different color from the back, or a buffy line over the eye.

a. Center of crown with a more or less distinct brownish or buffy line. $a^{1}$. Nape dull, pale olive-green, of the same color as the line over the eye, but finely streaked with black; back rufous-brown, streaked with black. . . . . . . 547. IIenslow's Sparrow. $a^{2}$. Nape bright rufous-brown, the feathers bordered by gray; the feathers of the back black, bordered by buffy whitish.

548. Leconte's Sparrow.

b. Center of crown with a more or less distinet stripe of ashy blue.

$b^{1}$. Breast and sides distinctly streaked with black or blackish.

549. Silarp-tailed Sparrow.

$b^{2}$. Breast and sides buffy or brownish, the former generally without distinct black streaks . 549a. Nelson's Sharp-tailed Sparrow.

549b. Acadian Silarp-tailed Spartow.

$B$. Crown of the same color as the back; no buffy line over the eye.

a. A yellow spot before the eye and on the bend of wing.

$a^{1}$. Upper parts very dark brown or black; the feathers edged with olive-gray or ashy, breast generally with black streaks. (Florida.)

550a. Scott's Seaside Sparrow, 551. Dusky Seaside Sparrow. $a^{2}$. Back olive-gray; breast with grayish brown streaks.

550. Seaside Sparrow.

b. No yellow before the eye; bend of the wing yellow.

575. Pine-woods Sparrow. 575a. Bacmuna's Sparrow.

c. No yellow before the eye or on the bend of the wing.

c. A broad cream-buff band across the breast.

583. Lincoln's SPARROW.

$c^{2}$. No cream-buff band on the breast; streaks on the breast tending to form a spot in its middle. . . . . . 581. Sosg Sparrow.

3. Tail with white patches or base of tail yellow. 
A. Base of the tail yellow.

- 533. PiNe Siskin.

B. Outer tail-feathers with white patches.

a. Hind toe-nail shorter than the bill from the nostril.

$a^{1}$. Lesser wing-coverts rufous; breast streaked with black.

540. Vesper Sparrow.

$a^{2}$. Sides of crown and ear-coverts chestnut; a black spot on the center of the breast. . . . . . . . . 552. Lark Sparrow.

b. Hind toe-nail longer than bill from nostril.

61. Under parts cream-buff; two outer tail-feathers mostly white.

537. Suith's Longspur.

62. Under parts whitish; breast streaked or spotted with black or entirely black; second outer tail-feather with but little white.

536. I Lapland Longspur.

\section{A FIeld Key to THE}

Adult Male Finches and Sparrows of the Middle States (Virginia to Massachusetts) in Breeding Plumage.

I. Breast with more or less yellow.

II. Breast blue.

III. Breast or throat red.

IV. Breast without either yellow, blue, or red.

\section{Breast with more or less yellow.}

$A$. Chin white, throat black; haunts grassy ficlds; song an unmusical effort of six or seven notes delivered with great earnestness from a low perch (rare east of the Alleghanies). . . . 604. Dickcrssez.

$B$. Uncler parts and breast pure yellow, crown and wings black; song a sweet canarylike warble; flight undulating, frequently accompanied by the notes chic-o-ree, per-chic-o-ree . . . . 529. GoLdFinch.

\section{Breast blue.}

A. Length over 6.00 ; plumage deep blue, a chestnut bar across the wings (not found north of Virginia) . . . . . 597. Blue Grosbeak.

$B$. Length under 6.00 ; plumage indigo-blue; haunts woody fields, serub or second growth; song clear and musical, generally delivered from a tree-top . . . . . . . . . . . 598. Indigo Bunting.

\section{Breast or thoat red.}

A. Length 8.00 ; throat and region about the base of the bill black, rest of the plumage bright rermilion-red; head with a conspicuous erest; song a rich, musical whistle; call-note an insignificant chepl ; haunts thickets and bushy woodland (rare north of New York eity).

593. Cardinal.

B. Length $7 \cdot 50$; breast rose-red; belly, tip of the tail, rump, and a band in the wings white; rest of the plumage black; haunts wooded growths; song loud, clear, and highly musical; call-note a metallic peek.

595. Rose-breasted Grosbeak.

C. Length under 6.50 ; plumage more or less heavily washed with dull 
reddish; haunts orchards and wooded growths; song a liquid warble; call-note a metallic chink, frequently uttered while on the wing.

517. Purple Finch.

D. Length about 6.00 ; plumage dull blood-red; mandibles crossed at the tips; generally found in small flocks in coniferous woods; utters a clicking or whistled note when on the wing (rarely found south of New England after May.1). . . . . . . . 521. Red Crossbill.

$E$. Breast white, tinged with brown; region about the bill red, a yellow band in the wings (rare except in the vicinity of New York city).

European Goldfinch.

IV. Breast without either yellow, red, or blue.

1. Under parts distinctly streaked or spotted.

A. Outer tail-feathers white, showing conspicuously when the bird flies; haunts dry fields and roadsides; song loud and musical.

540. Vesper Sparrow.

$B$. Outer tail-feathers not white.

a. Song loud and musical; an abundant and familiar bird of general distribution; spots on the breast tending to form one larger spot in the center; crown umber, a whitish line over the eye.

581. Song Sparrow.

b. Song not loud and musical; short and generally unattractive; haunts wet meadows or marshes; passes most of the time on the ground, rarely perching far from it, and when flushed generally returning to it.

61. A buffy line over the eye and at the side of the throat, breast generally washed with buffy; haunts only salt marshes (rarely found far from the vicinity of the seashore.)

549. Sharp-tailed Sparrow.

$b^{2}$. No buff on the sides of the head or breast; upper parts blackish; song tš̌ New York eity; haunts both salt-and fresh-water marshes.

542a. Savanna Sparrow.

$b^{3}$. Back reddish, head and neck buffy olive; haunts generally wet pastures; song an inconspicuous see-wick (rather rare, living in small colonies of local distribution).

547. Henslow's Sparrow.

2. Under parts not distinctly streaked or spotted.

A. Throat pure white, sharply defined from the grayish breast, a yellow spot over the eye; crown black, with a central stripe of white; haunts thickets or bushy woodlands; song a high, elear, musical whistle; call-note a sharp chink.

558. White-thiroated Sparrow.

B. Throat and breast black.

a. Sides of the throat and belly white, crown ash, sides of the head chestnut . . . . . . P. 282. House Sparrow.

b. Length $8 \cdot 00$; sides of the body light rufous, onter tail-feathers tipped with white; haunts thickets and bushy woodlands; callnote a vigorous towhee or chee-wink . . . . 587. Towhen. 
C. 'Ihroat and breast slate-color, like the back; belly and outer tailfeathers white; bill flesh-color (nests in the Middle States only on the higher parts of the Alleghanies) . . . . . . 567. Junco.

$D$. Under parts white or whitish, practically all one color.

a. Haunts wet marshes.

$a^{1}$. Haunts always salt marshes, generally near the sea; back grayish . . . . . . . 550. Seaside Sparrow.

$a^{2}$. Haunts both salt- and fresh-water marshes; back brown, streaked with black; eap and wings chestnut; song a loud, sharp, rapidly repeated weet-weet-weet, etc.

584. SWAMP SPARROW.

b. Haunts dry fields, pastures, roadsides, lawns, thickets, etc.

$b^{1}$. Outer tail-feathers white, middle of the breast with a small black spot (not found east of the Alleghanies).

$c^{1}$. Outer tail-feathers not white.

552. Lark Finch.

$c^{2}$. Upper parts reddish-brown, bill pinkish flesh-color; haunts bushy fields and pastures; song a musical, plaintive cherwee, cher-wee, cher-wee, cheeo-dee-dee-dee-dee-dee.

563. Field Sparrow.

$c^{3}$. Bill dark brown, a buffy line through the center of the ground; song an insect-like pit-tik, zee-zee-zee-zee-zee.

546. Grasshopper Sparrow.

$c^{4}$. Back streaked with black, eap chestnut, a white line over the eye, bill black; song a monotonous chippy-chippychippy, ete. . . . . . 560. Cimpring Sparrow.

$c^{5}$. Larger, length about 7.00 ; crown black, with a white central stripe: throat not noticeably different from the breast; no yellow over the eye (rare; nests north of New England). . . . 554. White-crowned SPArrow.

514. Cocothraustes vespertinus (Coop). Evenivg Grosbeak. Ad. 8.-Forehead yellow, crown black; sides of the head olive-brown, changing to dull yellow on the rump; belly and scapulars, wings and tail black; end half of the secondaries and their coverts white. Ad.. .-Brownish gray, lighter on the under parts, more or less tinged with yellow, especially on the nape; wings black, inner primaries white at the base, secondaries edged with white; tail black, the feathers tipped with white on the inner web; upper tail-coverts black tipped with white. L., 8.00; W., 4.50; T., 3.50; B., 72.

Range.-Interior of North America, from Manitoba north ward; southeastward in winter to the upper Mississippi Valley and easually to the northern Atlantic States.

Cambridge, known to have occurred only in winter of 1889-990.

Nest, known but from few speeimens, composed of small twigs lined with bark, hair, or rootlets, placed within twenty feet of the ground. Eggs, three . to four, greenish, blotched with pale brown (see Davie).

This distinguished inhabitant of the far northwest is a common winter visitant in Manitoba and the contiguous parts of the bordering 
States. At irregular intervals it invades the northern Mississippi Valley in numbers, while still more rarely it extends its wanderings to the north Atlantic States. It travels in flocks of from six or eight to sixty individuals which by their tameness show their ignorance of man and his ways. They feed largely on the buds or seeds of treesmaple, elder, and box elder. Their notes are described by different observers as a shill "cheepy-teet," and a "frog-like peep," while one writer remarks that "the males have a single metallic cry like the note of a trumpet, and the females a loud chattering like the large Cherry Birds (Ampelis garmulus)." Their song is given as a wandering, jerky warble, beginning low, suddenly increasing in power, and as suddenly ceasing, as though the singer were out of breath.

During the winter and early spring of 1890 there was a phenomenal incursion of Evening Grosbeaks into the Northern States, accounts of which, by Amos W. Butler, will be found in 'The Auk, ix, 1892, pp. 238-247; x, 1893, pp. 155-15\%.

515. Pinicola enucleator (Linn.). Pine Grosbear. A A. o.-Slaty gray, more or less strongly washed with rose-red, strongest on the crown, rump, upper tail-coverts, and breast; wings fuscous, their coverts edged with white; tail fuscous. $A d$. o. - Slaty gray, crown, upper tail-coverts, and breast more or less strongly washed with olive-yellow; wings and tail as in the 8. Im:-Resembles the $9 . \quad$ L., $9 \cdot 08 ;$ W., $4 \cdot 36 ;$ T., $3 \cdot 67 ;$ B., ${ }^{\circ} 54$.

Range.- "Northern portions of the northern hemisphere, breeding far north; in winter south, in North America, irregularly to the northern United States."

Washington, casual in winter. Sing Sing, irregular W. V., Dec. 18 to Apl. 12. Cambridge, irregular W. V., frequently common, sometimes abundant, Nov. to Meh.

Nest, of twigs and rootlets lined with finer materials, in coniferous trees a few feet up. Eggs, "pale greenish blue, spotted and blotched with dark brown surface markings and lilae shell spots, $1 \cdot 05 \times \cdot 74 . "$

The Pine Grosbeak, like the Spruce Partridge and Canada Jay, may be said to find its true home in the coniferous forest or Canadian belt, which crosses the continent diagonally from Maine to Alaska.

Like many of its congeners in this inhospitable region, it nests so early in the springtime that the winter's frost and snow are still dominant among the evergreens when the eggs come to claim the attention of the pair.

Its habits at this season are but little known, as very few naturalists have had the opportunity of seeing it in its native pine wood. But in midwinter, when it comes southward in search of food, it is a well-known frequenter, in flocks, of plantations of mountain-ash trees, or groups of sumarh bushes, whose unfallen berries provide it with a bountiful supply of nourishing diet. 
It is said to make an admirable cage-bird, as it readily takes to confinement, and during the springtime has a prolonged and melodious song.

Its form has a general resemblance to that of the common Robin, but its very short, thick beak and its forked tail are striking differences. It is rather slow and inactive when in a tree, and when on the wing it has a loud whistle which is very characteristic; at all times its colors, as above described, should distinguish the bird at a very considerable distance.

Ernest E. Thompson.

51\%. Carpodacus purpureus (Gmel.). PLRPLE FIXCIJ, $A \ell$. $\hat{\delta}$. -Entire body suflused with rose-red, strongest on the head, rump, and breast, more brownish on the back; whiter, generally white, on the belly; wings and tail brownish fuscous, the outer webs of the feathers finely edged with rose-red; a small tuft of bristly feathers over the nostrils; outer tail-feathers longest. $A d$. \&.-Very different, sparrowlike in appearance; upper parts dark grayish brown, finely streaked with black; wings and tail dark grayish brown; under parts white, streaked, or with wedgeshaped spots of fuscous. L., $6 \cdot 22 ; \mathrm{W}$., 3.24; T., $2 \cdot 29$; B., $\cdot 45$.

Remarks. - Females bear a decided resemblance to some Sparrows, but the

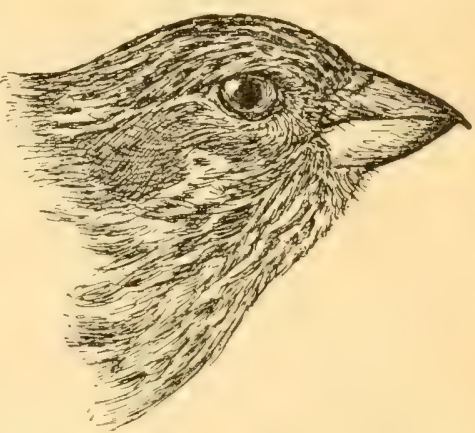

FIG. 79.-Purple Finch. (Natural size.) rounded bill, tufts of feathers over the nostrils, and forked tail are distinguishing characters.

Range.-Eastern North $\Lambda$ merica; breeds from northern Minnesota and Long Island northward; winters from the northern States to the Gulf.

Washington, common W. V., Sept. 15 to May 15, largely a migrant. Sing Sing, rare P. R., common T. V. Cambridge, P. R., very common from Mch. to Oet.; irregular, but sometimes abundant, in winter.

Nest, of twigs, grasses, and rootlets, thickly lined with long hairs, in coniferous trees, five to thirty feet up. Eggg, four to six, blue, spotted about the larger end with fuscous, $79 \times 56$.

During the nesting season the Purple Finch frequently takes up its abode in private grounds, even becoming a familiar garden bird, while others of its race find a congenial home in wild mountain forests, far away from the society of man. 'The rosy plumage of the males makes it attractively noticeable as a garden bird; lut a serious offense must be charged against it-it has far too ready a taste for the blossoms of fruit trees, and is perhaps the most confirmed bud-eater of all our birds. It has naturally a roring disposition, and, in the autumn especially, seems ever to be impelled by some restless impulse. At this 
season it may often be seen descending with airy, sweeping flight into some leafless treetop, as if from a far aïrial journey, its identity made known by its very characteristic utterance, a short, rather dull-sounding note, scarcely metallic - the metal pressed the instant the bell is struck.

Although the Purple Finch often essays to sing in the autumn and earliest spring, its full powers of voice belong alone to the nuptial season. 'Then it easily takes its place among our noteworthy song birds. Its full song is a sweet-toned, carelessly flowing warble-not too brief to miss definite character as a song, and positive enough in modulation and delivery to find ready place in the memory. At times, indeed, its singing is of a character not to be easily forgotten. The song bursts forth as if from some uncontrollable stress of gladness, and is repeated uninterruptedly over and over again, while the ecstatic bird rises high into the air, and, still singing, descends into the trees.

Eugene P. Bickneli.

Passer domesticus (Limn.). House Sparrow; Englisir Sparrow. $A d$. o. - Crown gray, bordered from the eye backward and on the nape by chestnut; lesser wing-coverts chestnut, middle coverts tipped with white; back streaked with black and chestnut; rump ashy; middle of the throat and breast black; sides of the throat white; belly whitish. $A d . \&$. - Head and rump grayish brown; back streaked with black and deep ochraceous-buff; under parts dirty whitish, the breast and sides washed with pale grayish brown. L., $6 \cdot 33$; W., $3 \cdot 01$; 'T., $2 \cdot 30 ;$ B., $\bullet 48$.

Range. - "Nearly the whole of Europe, but replaced in Italy by $P$. italia, extending eastward to Persia and Central Asia, India, and Ceylon " (Sharpe). Introduced and naturalized in America, Australia, New Zealand, etc.

Nest, of any available material in any available place. Eggs, varying from plain white to almost uniform olve-brown, generally white, tiuely and evenly marked with olive, $1.86 \times 62$.

We learn from Bulletin No. 1 of the Division of Economic Ornithology and Mammalogy of the United States Department of Agriculture * that this pest was first introduced into the United States at Brooklyn, New York, in 1851 and 1852. As late as 1870 it was largely confined to the cities of the Atlantic States, but since that date, partly through man's agency and partly through the bird's rapid increase in numbers and adaptability, it has spread over most of the United States and Canada east of the great plains, and isolated colonies are established throughout the west.

* The English Sparrow (Passer domesticus) in North America, especially in its Relations to Agriculture. Prepared under the Direction of Dr. C. Hart Merriam, Ornithologist, by Walter B. Barrows, Assistant Ornithologist, Washington, 1889. 
This report shows that in ten years the progeny of a single pair of Sparrows might amount to $275,716,983,698$ ! It also states that during the year 1886 the Sparrow added approximately 516,500 square miles to the territory occupied by it. The day is evidently near at hand, therefore, when the English Sparrow will be in complete possession of the country.

The European Tree Sparrow (Passer montanus) has become naturalized m and about St. Louis, Missouri.

521. Loxia curvirostra minor ( $B r e h m)$. American Crossbill; Red Crossbill. Ad. o. - Tips of the mandibles crossed; body dull red, brighter on the rump, browner on the back; wings and tail fuscous. $A d . q$. Dull olive-green, yellower on the rump, indistinctly mottled with blackish on the head and back, mixed with whitish on the under parts. Im. 8.- Similar to the \&, or mixed red and green. L., $6 \cdot 19 ;$ W., $3.40 ;$ T., $2 \cdot 13$; B., 66 .

Riange.-Breeds from the Northern States northward, and, in the Alleghanies, southward to the Carolinas; in winter wanders irregularly southward, sometimes reaching the Gulf States.

Washington, irregular W. V., sometimes abundant. Sing Sing, irregular; noted in almost every month. Cambridge, of irregular oceurrence at all seasons.

Nest, of twigs and grasses, lined with bits of moss and rootlets, in coniferous trees, fifteen to thirty feet up. Eggs, three to four, "pale greenish, spotted and dotted about the larger end with various shades of brown and lavender shell-markings, $1.75 \times \cdot 57 . "$

These parrotlike Finches are famous for their erratic wanderings. They seem to have no regard for the laws of migration which regulate the journeys of most birds, and, having no home ties, may linger in regions which offer them abundant fare without much regard to season. They nest early in the spring. sometimes when they are far south of their breeding range, but they seem quite unconcerned by their unusual surroundings, and their young are born and raised in a foreign land.

Coniferous forests form their natural surroundings, and their bills are especially adapted to aid them in forcing off the scales from the cones of these trees to obtain the seed within.

They live in flocks, and when in the trees climb about like Parrots, sometimes exhibiting as little fear of man as Polly on her pedestal. When feeding, they have a short, whistled call-note; they take wing in a body, and their undulating flight is accompanied by a sharp clicking or whistled note. Their song is described as "varied and pleasing, but not powerful or in any respect remarkable."

522. Loxia leucoptera Crmet. White-WIXfen ('mosebill. $A d$. $\delta$. -Tips of the mandibles crossed; body dull pink, brighter on the rump, more 
or less marked with black on the back; belly whitish; wings and tail black, the greater and middle wing-coverts, and sometimes tertials, tipped with white. Ad. \&.-Dull olive-green, yellow on the rump, grayer on the under parts, mottled with blackish on the head and back; wings and tail as in the $\delta$. Im. $\delta$.- Similar to $q$, but passes through a party-colored plumage while becoming mature, and, as in the preceding species, is subject to much variation. L., 6.05 ; IV., 3.27 ; 'T., $2.41 ;$ B., $\cdot 62$.

Range.-Breeds from the Northern States northward; in winter wanders irregularly southward, sometimes reaching Illinois and Virginia.

Washington, casual. Sing Sing, rare T. V., Oct. 29 to Dec. 6. Cambridge, irregular W. V.

Nest, of twigs and strips of birch bark, covered exteriorly with moss (Usnea), and lined with soft moss and hair, on the fork of an evergreen in deep forests. Eggs, three (?), pale blue, spotted and streaked near larger end with reddish brown and lilac, $.80 \times .55$ (Chamberlain).

Colonel Goss writes that in general habits these birds resemble the American Crossbill. Their flight is swift and undulating. While feeding and moving about they are quite noisy, almost constantly uttering a plaintive wheep or cheeping note. Their song is low, soft, and sweet, much like that of the American Goldfinch.

52\%. Acanthis hornemannii (Holb.). Greenland Redpoll.-Similar to the next, but "larger (length about 5.50-6.50), with proportionally thicker and less acute bill. of W., 3.37 ; T., 2.75 ; exposed culmen, 35 ; depth of B. at base, '31."

Range.- "Northern Greenland (breeding from $69^{\circ}-73^{\circ} \mathrm{N}$. latitude) and eastern arctic America, south to Labrador in winter" (Kidgw.).

52ya. A. h. exilipes (Coues). Holry Redpoll. Ad. o. - Bill very sharply pointed, a small tuft of bristly feathers over the nostrils; crown-cap bright red; back dark grayish brown, the feathers more or less margined with white; rump white, generally unstreaked, and tinged with pink; wings and tail brownish fuscous, the feathers all more or less edged with white; middle of the throat blackish, breast tinged with pink, belly white, a few streaks on the side. Ad. \%.- Similar, but with no pink on the rump or breast. Im.Similar to the \&, but without the red crown-cap. L., 5.00; W., 3.00; T., $2 \cdot 30 ; \mathrm{B}, \cdot 30$.

Remarks.-This species is to be distinguished from Acanthis linaria and its races by the greater amount of white in its plumage, its unstreaked rump, and comparatively unstreaked under parts.

Range.-Aretic regions; south in winter rarely to the northern United States.

Cambridge, casual W. V.

Nest, of grass and twigs lined with feathers, in a low tree or on the ground. Eggs, three to five, white, tinged with blue or green, spotted with reddish brown, $\cdot 65 \times \cdot 50$ (Chamberlain).

528. Acanthis linaria $($ Limn.). Renpolt. Ad. ô.-Bill very sharply pointed, a small tuft of bristly feathers over the nostrils; crown-cap 
bright red; back fuscous grayish brown, the feathers margined with ochraceous-buff; rump tinged with pink; wings and tail fuscous, the feathers more or less edged with whitish; middle of the throat blackish, breast suffused with pink, belly white, sides streaked with fuscous. Ad. \& .-Similar, but without pink on the rump or breast, the sides more heavily streaked. Im. -Similar to the $q$, but without a red crowncap. L., $5 \cdot 32$; W., $2 \cdot 80$; T., $2 \cdot 32$; B., $\cdot 36$; depth of $B$. at base, 22 .

Range--Breeds in the northern parts of the northern hemisphere; in winter migrates irregularly southward, in America, to Illinois and Virginia.

W ashington, very rare and irregular W. V. Sing Sing, irregular W. V., Nov. 25 to Mch.

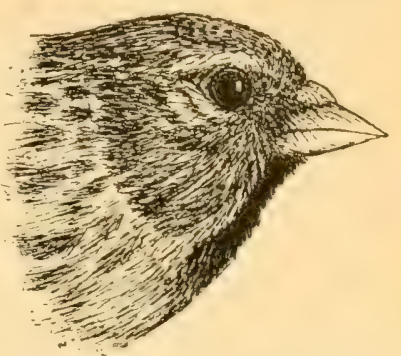

FiG. 80.-Redpoll. (Natural size.)

26. Cambridge, irregular W. V., often very abundant, Oct. 25 to Apl. 10.

Nest, of dry grass and moss lined with hair, feathers, or plant down, in a low tree or tuft of grass. Eggs, four to six, white, tinged with green or blue, spotted with reddish brown, ${ }^{\circ} 65 \times{ }^{\circ} 50$ (Chamberlain).

The little Redpoll is one of those birds that are best known as winter visitors. Sometimes it comes from the north in flocks when driven from home by the annual failure of the food supply, and speedily attracts attention by frequenting the gardens and orchards, even when these are within the limits of a town. In general habits it resembles a Goldfinch, and while with us it finds its wants supplied chiefly by the various grasses and herbs which project through the snow and still retain their seed in spite of wind and weather. It is noted for its affectionate and confiding disposition, and although it is not known to breed in captivity it has always proved an easily tamed and interesting pet.

Ernest E. Thompson.

528a. A. 1. holbollii (Brefum). IIolb(ELL's Redpold.-Similar to A. linaria, but larger, the bill longer. W., 3.20 ; 'T., 2.35 ; B., 38 ; depth of B. at base, $\cdot 22$.

Range._-"Northern coasts of Europe and Asia (Norway to Japan), and portions of Alaska"; casual in eastern North America.

This is an intermediate between $A$. linaria and $A$. l. rostrata, most closely approaching the former, from which it sometimes can with dificulty be distinguished. It is an exceedingly rare bird in eastern North America, where there are but two records of its occurrence: Quebec (Ridgway) and Massachusetts (Brewster).

528b. A. 1. rostrata (Cones). Greater Renpoll.-Similar to A. linaria, but larger, the margin to the feathers of the upper parts averaging darker, the bill shorter and stouter. L., 5.50; W., 3.20; T., 2.55; B., 35 ; depth of $\mathrm{B}$. at base, $\cdot 28$. 
Range.-"Southern Greenland in summer, migrating south, in winter, through Labrador to (sparingly) the northern border of the United States (New England, lower Hudson Valley, northern Illinois, etc.), and west to Manitoba" (Ridgw.).

Sing Sing, A. V. Cambridge, irregular W. V., Nov. to Feb.

"The Greater Redpoll is often rather common, and in February, 1883, it occurred along the seacoast near Boston in positive abundance. On the 19 th of this month $\mathrm{Mr}$. Spelman and I took thirteen specimens at lievere Beach in about two hours; and on the 22d, at Nantasket Beach, two young collectors, by a few random shots into an exceptionally large, mixed flock of Redpolls, secured forty specimens, of which six proved to be $A$. linaria and thirty-four rostrata.

"As one sees them in winter in New England, the forms just mentioned, with A. hornemannii exilipes, do not differ appreciably in notes, habits, or general appearance. It is true that $A$. $l$. rostrate may be often recognized by its superior size, but the birds as a rule are so nervous and restless, and when in large flocks so constantly in motion and so likely to depart altogether at any moment, that a free use of the gun is ordinarily indispensable to positive identification " (Brewster, Minot's Land Birds and Game Birds, 2d ed., App., p. 472).

529. Spinus tristis (Linn.). Amaricax Golnfixch; YellowBIRD; Thistle-BIRD. Ad. \&.-Crown-cap black; back and under parts bright yellow; wings black, the coverts and secondaries tipped with white; tail black, the feathers with white on their inner webs. $A d$. $q .-$ Upper parts grayish brown with an olive tinge; wings and tail as in the $\delta$, but somewhat more dusky and the white markings less distinct; under parts whitish, washed with buffy brown and more or less tinged with yellow, especially on the throat. Ad. of in winter.-Similar to the ad. $\&$, but with the wings and tail as in summer. L., $5 \cdot 10 ;$ W., $2 \cdot 82 ;$ T., $1.95 ;$ B., $\cdot 40$.

Range.-Eastern North America; breeds from South Carolina to southern Labrador; winters from the northern United States to the Gulf.

Washington, common P. R. Sing Sing, common P. R. Cambridge, very common P. R.

Nest, externally of fine grasses, strips of hark, and moss, thickly lined with thistle down, in trees or bushes, tive to thirty feet up. Eggs, three to six, pale bluish white, $\cdot 65 \times \cdot 48$.

Except when nesting, Goldfinches are generally found in small flocks. Few birds seem to enjoy life more than these merry rovers. Every month brings them a change of fare, and in pursuit of fresh dainties the nesting-time is delayed almost until summer begins to wane.

Seed-bearing plants, whether in field or garden, form their larder; the old sunflowers rattle before their rigorous attack; the thistles spring into sudden blossom of black and gold as they swing from the nodding heads. 
Their flight is expressive of their joyous nature, and as they bound through the air they hum a gay

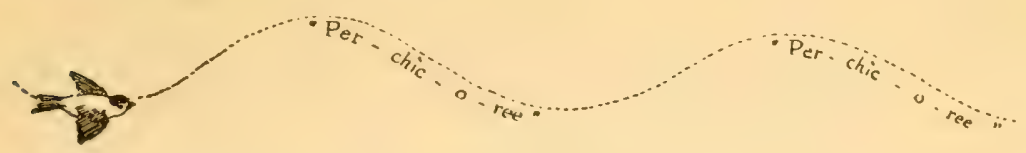

Their love song is delivered with an ecstasy and abandon which carries them off their feet, and they circle over the fields sowing the air with music. The song has a canarylike character, and while it is less varied it possesses a wild, ringing quality wanting in the cage-bound bird's best efforts.

The Black-headed Goldfinch (532. Spinus notatus), a Mexican species, is recorded by Audubon from Kentucky, where its occurrence is, of course, purely aceidental.

533. Spinus pinus (Wits.). Pine Siskin; Pine Finch. Ad.-Bill sharply pointed, a small tuft of bristly feathers over the nostrils; upper parts streaked with black, the feathers margined with buffy; wings fuscous, most of the feathers margined with yellow, and yellow at the base; tail fuscous, all but the middle feathers yellow at the base; under parts white, tinged with buff'y and hearily streaked with black. L., 5.00; W., $2 \cdot 76 ;$ T., $1 \cdot 90 ;$ B., $\cdot 40$.

Remarks. - The yellow markings in the wings and tail of this species will always serve to distinguish it.

Range.-North America generally; breeds mostly north of the United States; winters as far south as the Gulf.

Washington, irregularly abundant W. V., Oct. to Apl. Sing Sing, irregular P. R. Cambridge, irregular W. V., Sept. to May; sometimes very abundant.

Nest, of twigs and rootlets, lined with plant down and long hairs, in coniferous trees. Eggs, four, pale bluish white, thinly spotted with reddish brown, $\cdot 67 \times \cdot 46$.

Like the American Crossbill, this bird is rather erratic in its movements, and its presence or absence at any season can never be predicted with certainty. It resembles the American Goldfinch in habits, but is more often found about coniferous trees, and its notes and song are less musical. It has been found nesting in May at Sing Sing, N. Y. (Fisher), and at Cornwall-on-Hudson (Allen).

Carduelis carduelis ( imm.). Entropean Goldfinch. Al.-Region about the base of the bill bright red; crown, and a stripe extending from it on to the sides of the neck, black; back cinnamon-brown; wings black, crossed by a broad yellow band; tail black, the inner webs of the feathers tipped with white; under parts white, the sides tinged with the color of the back. L., 5.50 ; W., 3.00; T., $2.95 ;$ B., 50 . 
Range.-"Europe generally, except extreme northern part" (Sharpe). Introduced near New York city and Boston.

Nest, externally, of grasses and plant down, lined with plant down, in coniferous trees. Eggs, four to five, white, with purplish spots, $72 \times \cdot 50$.

This European species was introduced into this country at Hoboken, N. J., in 1878. 'The following year it appeared in Central Park, New York city. It has since spread over the northern parts of the city, and in favorable places is a not uncommon permanent resident. It has also been introduced in the vicinity of Boston, Nass., where it is to be found in small numbers. In general habits it resembles its American cousin, with which it sometimes associates.

534. Plectrophenax nivalis (Linn.). SNowflake; SNow BuntING. Ad. of in summer.-Whole head and neck, rump, and under parts white ; back and scapulars black; wings white, the end half of the primaries and inner secondaries black; outer tail-feathers white, inner ones black. $A d$. $₹$ in summer.-Similar, but entire upper parts streaked with black; primaries all fuscous; secondaries more or less tipped with fuscous. of in winter.Upper parts a kind of rusty brown, almost umber on the center of the crown; back streaked with black, caused by the black bases of the feathers showing through their rusty tips; wings and tail much as in summer, but more or less edged with rusty; under parts white, the breast and sides washed with rusty. o in winter. - Similar to of, but the primaries all fuscous. L., 6.88 ; W., 4.07 ; T., $2 \cdot 70 ;$ B., $\cdot 42$.

Range.--"Northern parts of the northern hemisphere, breeding in the arctic regions; in North America, south in winter into the northern United States, irregularly to Georgia, southern Illinois, and Kansas."

Washington, W. V., casual, one instance. Sing Sirig, irregular W. V., Oct. 25 to Mch. 22. Cambridge, common W. V., Oet. 25 to Mch. 25 ; abundant in migrations.

Nest, of grasses, rootlets, and moss, lined with finer grasses and feathers, on the ground. Eggs, four to seven, pale bluish white, thinly marked with umber or heavily spotted or washed with rufous-brown, $85 \times \cdot 64$.

The Snowflake may readily be known by the fact that it is the only one of our sparrowlike birds that has white predominating on its wings and tail, as well as on its body. It feeds exclusively on seeds, and is so much like the Shorelark in habits that the two species oceasionally associate. The Snowflake is also strictly a ground bird, never perching on a tree, though it often does so on a house or fence. It always progresses by walking, not by hopping.

Throughout Canada and the northern tier of States this is the familiar little white bird of winter. As soon as the chill season comes on in icy rigors, the merry Snowflakes appear in great flocks, and come foraging about the barnyards when there is no bare ground left in the adjacent fields. Apparently they get but little to eat, but in reality they always find enough to keep them in health and spirits, and are as 
fat as butter balls. In midwinter, in the far north, when the thermometer showed thirty degrees below zero, and the chill blizzard was blowing on the plains, I have seen this brave little bird gleefully chasing his fellows, and pouring out as he flew his sweet, voluble song with as much spirit as ever Skylark has in the sunniest days of June. As long as the snow lasts the Snowflake stays, and as soon as the ground grows bare and there is promise of better days, this bird of winter betakes himself again to the north, as far as ever human foot has been, and there builds his nest.

Ernest E. Thompson.

536. Calcarius lapponicus (Linn.). Laplayd Longspur. $A d$. $\delta$ in summer.-Hind toe-nail as long as or longer than toe; head, neck, throat, and breast black; a buffy line behind the eye; nape rufous; back streaked with black and ochraceous- and cream-buff; tail fuscous, the two outer feathers with more or less white; belly white; sides streaked with black. $A d$. o. in summer.-Upper parts streaked with black, rufous, ochraceous- and cream-buff; nape ochraceous-buff, the color sometimes concealed by the tips of the feathers; tail fuscous, the outer one or two feathers marked with white; under parts white, the breast and sides streaked with black and ochraceous-buff. os in winter.-Similar to $\&$ in summer, but upper parts blacker, nape

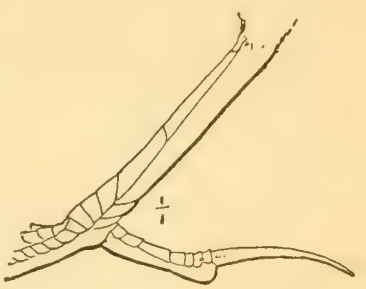

Fig. 81.-Hind toe of Lapland Longspur. more rufous, breast more heavily marked with black, most of the feathers black at the base. o in winter. - Similar to $\$$ in summer, but upper parts duller, nape with little or no ochraceous. $L_{\text {. }}, 6 \cdot 25 ; \mathrm{W}$., $3 \cdot 75 ;$ T., $2 \cdot 55 ;$ B., ${ }^{4} 40$.

Remarks. - In some plumages this bird bears a general resemblance to certain Sparrows, but differs from them in having the hind toe-nail as long as or longer than the toe.

Range.- "Northern portions of the northern hemisphere, breeding far north; in North America, south in winter to the northern United States, irregularly to the Middle States, accidentally to South Carolina."

Washington, W. V., casual, one instance, Dec. Sing Sing, W. V., casual.

Nest, of grasses and moss lined with grasses, on the ground. Eggs, four to six, bluish white, almost obscured by a uniform grayish brown, $82 \times \cdot 60$.

In the east Lapland Longspurs are generally found among flocks of Shorelarks or Snowflakes, but on the western plains they occur in great numbers. "High in the air they fly in long, straggling flocks, all singing together; a thousand voices, a tornado of whistling. ... When in the fields they have a curious habit of squatting just behind some clod, and, as their colors are nearly matched to the soil, they are not easily observed, nor will they move until you are within a few feet; they then run a few feet and squat again. . . ." (Thompson).

53\%. Calcarius pictus (Swains.). Surth's Loxgsper. A 4 . o in summer.-Top and sides of the head black, a line over the eye and the ear-coverts 
white; back and rump streaked with black and ochraceous-buff; lesser wingcoverts black, broadly tipped with white; tail fuscous, the two outer feathers mostly white; nape and under parts ochraceous-buff. Ad. i in summer.Upper parts black, the feathers margined and tipped with pale cream-buff; two outer tail-feathers mostly white; under parts pale cream-buff; breast and sides sometimes lightly streaked with blackish. of in winter.-Similar to ₹ in summer, but with the lesser wing-coverts black, tipped with white. L., $6.60 ;$ W., $3.75 ;$ T., $2.50 ;$ B., $\cdot 42$.

Range--Interior of arctic America (chiefly Mackenzie River Valley) in summer, breeding north to the aretic coast and upper Yukon Valley; south, in winter, over the Great Plains and prairies to Illinois, Texas, etc.

Nesting, similar to that of the preceding.

"Their habits are quite similar to those of $P$. lapponicus while upon the ground... When flushed they invariably uttered a sharp clicking note, rapidly repeated several times. When driven from their feeding place by my approach they would rise in a loose flock, and, after wheeling about a few times, start off in a direct line, gradually rising higher until they disappeared. After a short time their peculiar note would be heard, and, darting down from a considerable height, they would alight near the place from which they were driven" (Nelson).

The Chestnut-collared Longspur (538. Calcarius ornatus), a species of the Great Plains, has been recorded from Massachusetts and Long Island.

McCown's Longspur (539. Rhynchophanes mccownii), a species of the Great Plains of the interior, is of casual occurrence in Illinois.

540. Poocates gramineus (Gmel.). Vesper Sparrow; Baywinged Bunting; Grass Finch. Ad.-Upper parts brownish gray, streaked with black and a little ochraceous-buff; wings fuscous, greater and middle

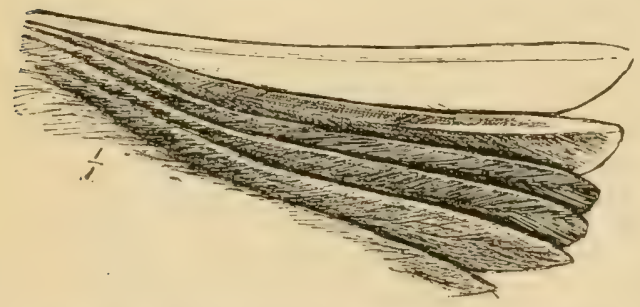

Fig. 82,-Tail-feathers of Vesper Sparrow. coverts tipped with white, lesser coverts bright rufous; tail fuscous, the outer feather mostly white, the next one with much less white; under parts white; the breast and sides streaked with black and ochraceous-buff. L., $6 \cdot 12$; W., 3.06: T., 2.38 ; B., ${ }^{4} 41$.

kemarks.-The white tailfeathers and rufous lesser wing-coverts will always distinguish this species from any of our Sparrows.

Range.-North America; breeds from southern Illinois and Virginia northward to New Brunswick and Manitoba; winters on the Atlantic coast from Virginia southward.

Wrashington, P. R., very common in migrations, less so in summer and 
winter. Sing Sing, tolerably common S. R., Apl. 2 to Nov. 4. Cambridge, very common S. R., Apl. 5 to Oet. 15.

Nest, of rather coarse grass, lined with finer grasses, rootlets, and long hairs, on the ground. Eggs, four to five, bluish white or pinkish white, speckled and spotted with rufous-brown or umber, $1 \cdot 83 \times \cdot 61$.

In walking through dry upland fields or along dusty roadsides a rather pale, streaked Sparrow will sometimes run rapidly ahead of you, wait for you to catch up, then run ahead again. It is best to be content with what measure of his confidence and society he voluntarily grants you, for, if you quicken your steps and try to overtake him, he will rise and bound on before you or swing off to one side, showing, as he flies, the white feathers on either side of his tail.

Frequently he will alight on a fence rail or even the higher branch of a tree, for, although a field Sparrow, he is by no means a purely terrestrial one. When singing, he generally selects an elevated perch and gives himself entirely to his musical devotions. Early morning and late afternoon are his farorite hours, but he can be heard at other times. His song, which is loud, clear, and ringing, may be heard at a distance of several hundred yards. It resembles that of the Song Sparrow, but is sweeter and more plaintive. When heard in the evening it is a truly inspired and inspiring melody.

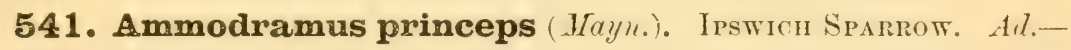
Generally with a spot of sulphur-yellow before the eye and on the bend of the wing; upper parts pale brownish ashy, streaked on the head, back, and upper tail-coverts with black and cinnamon-brown; the nape and rump with few or no streaks; a white line over the eye; wings grayish brown, outer webs of greater coverts and tertials margined with pale ochraceous-buff; tail grayish brown, the outer webs of the feathers margined with brownish ashy ; under parts white; breast and sides lightly streaked with blackish and ochraceous-buff. L., 6.25; W., 3.00; T., 2.25; B., 40.

Range.-Breeds on Sable Island; winters southward along the coast regularly to Virginia and rarely to Georgia.

Cambridge, casual, one instance, Oct.

Those who care to risit in winter the bleak, wind-swept sand hillocks of our Atlantic coast will find this bird much less rare than it was once supposed to be. It never strays far from the waving tufts of coarse beach-grass that scantily cover the sand drifts, and single individuals may be found skulking among such surroundings. They seldom allow a near approach, but fly wildly away to considerable distances, and on alighting run off so rapidly that they are difficult to find a second time. The flight is rapid and irregular, and the birds may easily be mistaken for Saranna Sparrows, with which, during the migrations, they are sometimes associated. On rare occasions a sharp chirp is heard, but as a rule they are silent. 
It is an interesting species, discovered in 1868 , and at first mistaken for Baird's Sparrow of the far west, a species, by the way, that it resembles very little. For many years nothing was known of its breeding range. In 1884 some large eggs from Sable Island, Nova Scotia, supposed to be of the Savanna Sparrow, were unearthed at the National Nuseum, Washington, and later a summer specimen of the Ipswich Sparrow was obtained from this island. Ten years later I had the pleasure of visiting Sable Island and solving all the conjectures that had become current regarding the Ipswich Sparrow's summer home. The bird proved to much resemble the Savanna Sparrow in breeding habits, song, nest, and eggs.

J. DWight, JR.

542a. Ammodramus sandwichensis savanna ( $\left.W^{i} i s.\right) . S_{A-}$ vanNa Sparrow. Ad.-A pale yellow mark over or before the eye and on the bend of the wing; general tone of the upper parts brownish black, the centers of the feathers black, margined first by rufous or ochraceous-buff, then by ashy; wings fuscous, the outer webs of the feathers margined with ochraceous-buff; tail fuscous, the outer web of the feathers margined with whitish: under parts white, heavily streaked with blackish and rufous, the breast feathers tipped with wedge-shaped marks. L., $5 \cdot 68 ;$ W., $2 \cdot 62 ;$ T., $2 \cdot 09 ;$ B., 40 .

Remarks.-Fall specimens are more or less suffused with ochraceous.

Range.-Eastern North America; breeds from Missouri and northern New Jersey north to Labrador and Hudson Bay; and winters from southern Illinois and Virginia southward to Cuba and Mexico.

Washington, abundant T. V., Mch. 20 to May 5; Oct. 14 to Nov. 15; a few winter. Sing Sing, common T. V., Apl. 3 to May 13; Aug. 28 to Oct. 28. Cambridge, abundant 'T. V., Apl.; Oct.; breeds sparingly.

Nest, of grasses and sometimes moss, lined with finer grasses or hair, on the ground. Eggs, four to five, bluish white, thickly marked, sometimes heavily washed, with reddish brown or cinnamon, $78 \times \cdot 56$.

This is essentially a bird of the fields and one of the most abundant species of the Maritime Provinces of Canada-in fact, characteristic of them. The roadsides abound with the birds bobbing up and down on the fence posts and chipping vigorously at every passerby. Their boldness is tempered with a certain timidity that becomes apparent when they are followed, for, dropping into the grass, they will slip away with surprising rapidity. They have a startling way. sometimes, of springing up with a whirr of wings almost from under your very feet as you cross the fields where they have been feeding. At the southern limits of their breeding range they gather into irregularly distributed, isolated colonies frequenting wet, boggy meadows, and exhibit a shyness that is not shared by their northern brethren. In the fall, young and old gather into bands and, joining with other species, form an important part of the large flocks of migrating Sparrors that fill the fields and hedgerows. 
The song is insignificant-a weak, musical little trill following a grasshopperlike introduction is of such small volume that it can be

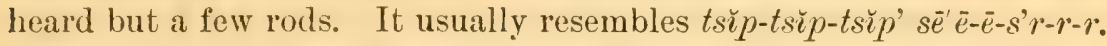
More singing is heard toward sunset, when of a quiet evening the trills are audible at greater distances. Each male seems to have a number of favorite perches, weeds or fence posts, which are visited as inclination dictates, but he is of too restless a disposition to remain long on any of them. The most familiar note is a sharp tšp of alarm or expostulation heard during migration, but so constantly employed by both sexes in the breeding season, even on slight provocation, that one gets to think of them as veritable scolds.

They are more likely to be mistaken for the Vesper Sparrow, which they resemble even in flight, than for any other except perhaps the Ipswich and Sharp-tailed Sparrows.

J. DWIGHT, JR.

546. Ammodramus savannarum passerinus ( $\Pi^{i} i l$.). Grasshopper Sparrow; Yellow-Winged Sparrow. Ad.-Upper parts mixed black, rufous-brown, ashy, and cream-buff ; crown blackish, a cream-buff line through its center; nape rufous-brown, each feather with a small black central spot and bordered by ashy; back black, the feathers bordered by cream-buff' and with a small central tip of rufous-brown; rump rufous-brown and ashy; an orange mark before the eye; bend of the wing yellow, lesser wing-coverts yellowish olivegreen; greater coverts tipped with whit-

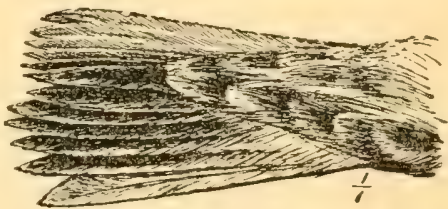

FIG. 83.-Tail of Grasshopper Sparrow. ish; tail-feathers pointed, of about equal length, dark grayish brown, the centers of the feathers darker, the end half of the outer feather generally dusky whitish; under parts generally not streaked; breast and sides buffy; belly white. Young in first plumagt have the breast spotted with blackish. L., $5 \cdot 38 ;$ W., $2 \cdot 38 ;$ T., $1.79 ;$ B., $\cdot 43$.

Remarks. - The yellow on the wing, unstreaked under parts, even, pointed tail, and grayish mark on the outer tail-feather are the principal characters of this species.

Range.-Eastern North America; breeds from the Gulf States northward to Massachusetts and Minnesota; winters from North Carolina to Cuba.

Washington, very common S. R., Apl. 15 to Oet. 25. Sing Sing, common S. R., Apl. 27 to Oet. 23. Cambridge, rare S. R., May 15 to (?).

Nest, of grasses, sometimes lined with hairs, on the ground. Eggs, four to five, white, distinctly spotted and speckled with rufous, ${ }^{7} 73 \times{ }^{\circ} 54$.

Few common birds may be more easily overlooked than the Yellowwinged Sparrow. Its terrestrial habits and weak notes place it among the birls that you are not likely to find unless you know how and where to look for them. I remember once introducing this bird and its song to a visiting ornithological friend. On returning to his home, 
greatly to his surprise, he found it a common resident of the fields about his house, where, owing to his unfamiliarity with its notes and habits, its presence had been before unsuspected.

In the north you will generally find it in old, dry daisy or sorrel fields; in the south it inhabits the broom sedge. It will not take wing until almost stepped upon; then, if bushes are near, it takes refuge in or under them, but out in the open field it flies rapidly some distance and drops to the ground.

Its usual perch, when singing, is a fence rail; and it does not often seek a more elevated position. Its fine, insectlike notes give it the name of Grasshopper Sparrow. They may be written pit-tuck, $z e e-e-e-e=e-e-e-e-e$. Under farorable circumstances they can be heard by an attentive listener at a distance of two hundred and fifty feet, but the casual observer would pass within ten feet of a singing bird and be none the wiser.

54\%. Ammodramus henslowii (Aud.). lienslow's Sparrow. $A d$. - T'op and sides of the head and the nape dull, pale olive-green, more buffy in the fall; side of the erown black; nape finely streaked with black; back rufous-brown, the feathers with narrow, central, wedge-shaped black streaks, and narrow ashy margins; bend of the wing pale yellow; wing-coverts much like the back; tail-feathers very narrow and sharply pointed; middle fenthers rufous-brown; the outer ones much the shortest; under parts white, more or less washed with buffy and streaked with black on the breast and sides. Young in first plumage have no spots on the breast. L., 5.00; W., 2.20; T., $2 \cdot 00 ;$ B., $\cdot 42$.

Remarks. - The peculiar olivaceous color of the head and nape, and the bright rufous-brown color of the back, wing-coverts, and middle tail-feathers are the best distinguishing marks of this species.

Range.-Eastern North America; breeds locally from Missouri and Virginia northward to New Hampshire and southern ()ntario; winters from about the southern limit of its breeding range to the Gulf.

W ashington, common S. R., Apl. 12 to Oct. Sing Sing, rare T. V., Oct. 5 to Oct. 10. Cambridge, very rare S. R.

Nest, of grasses, sometimes lined with hairs, on the ground. Eggs, four to five, grayish white, thickly and evenly speckled with pale rufous-brown, $.75 \times \cdot 57$.

During the summer this species seems to prefer wet meadows, but in the winter it inhabits the dry "old fields" grown with broom sedge, which are so common in the south. It has the secretive habits of the Grasshopper and Leconte's Sparrows, and takes wing only when forced to.

Mr. P. L. Jouy writes of its song: "Besides the characteristic notes of tee-wick, they have quite a song which may be fairly represented by the syllables sis-r-r-rit-srit-srit, with the accent on the first and last 
parts. This song is often uttered while the bird takes a short flight upward; it then drops down again into the tangled weeds and grasses, where it is almost impossible to follow it" (Bull. Nutt. Orn. Club, vi, 1881, p. 57).

548. Ammodramus lecontei ( $A u d$.). Leconte's Sparrow. $A d$.No yellow before the eye or on the bend of the wing; a broad ochraceous-buff line over the eye, and a cream-buff line through the center of the blackish crown; nape rufous-brown, each feather with a small black central spot and an ashy border; back black, the feathers margined first by rufous, then creambutf and whitish; tail grayish brown, with a slight rufous tinge, charker along the shaft: the feathers narrow and sharply pointed, the outer ones much the shortest; breast and sides tinged with buffy, and more or less streaked with black; belly white. L., 5.00; W., 2.00 ; 'T., 2.05 ; B., '35.

Range.- "Great Plains and more western prairies, breeding from Dakota, Minnesota, etc., to Manitoba, migrating southward and eastward, in winter, through Illinois, Iowa, Kansas, ete., to South Carolina, and Gulf States from Florida to Texas" (Ridgw.).

Nest, of fine grasses, on the ground. Eggs, three, delicate pink, lightly spotted with brownish and black near the larger end, $75 \times \cdot 50$ (Thompson).

My experience on the coast of 'Texas with this elusive little Sparrow conforms with that of most observers, and the few specimens I found were in wet marshes. Mr. L. M. Loomis, however, tells us that at Chester, South Carolina, where Leconte's Sparrow is a locally common winter visitant, it shows a marked preference for lry "old fields" of broom sedge (Auk, ii, 1885, p. 190).

Few birds are more difficult to flush. It exhibits a rail-like disinclination to take wing, and, flying low and feebly, makes for the nearest cover. Ernest E. Thompson records it as an abundant summer resident in the willow sloughs and grassy flats of Manitoba, and describes its call-notes as a thin, sharp, ventriloquial tweet, and a single, longdrawn bizz; while its song, which is delivered from some low perch a little above the grass, is a tiny, husky, double-noted reese reese, "so thin a sound and so creaky, that I believe it is usually attributed to a grasshopper.".

+ 549. Ammodramus caudacutus ( (rmel.). Sharp-tailen SpirRow. Ad.-General color of the upper parts a brownish olive-green; crown olive-brown, with a blue-gray line through its center; gray ear-coverts, inclosed by ochraceous-buff lines, one of which passes over the eye and one down the side of the throat; feathers of the back margined with grayish and sometimes whitish: bend of the wing yellow; tail-feathers narrow and sharply pointed, the outer feathers much the shortest; breast and sides washed with buffy, paler in summer, and distinctly streaked with black; middle of the throat and belly white or whitish. "L., 5.85; W., 2.30; T., 1.90; B., $50 "$ (Dwight). 
Remarks.-The chicf points of difference between this and the two following birds are found in the markings of the breast and sides. In the present species these parts are pale ochraceous-buff, distinctly streaked with blackish; in nelsoni they are deep ochraceous-buff, lightly if at all streaked; in subvirgatus they are cream-buff, indistinctly streaked with grayish.

Kange.-Atlantic coast; breeds from South Carolina to New Hampshire, and winters from North Carolina to Florida.

Cambridge, common S. R., May to Sept.

Nest, of grasses and seaweed, lined with fine grasses, on the ground. Eggs, three to four, white or grayish white, finely speckled with cinnamon-brown, especially at the larger end, $\vdash 8 \times 5$.

This species is confined exclusively to the salt-water marshes of our coast, where it may be found in large numbers. It runs about among the reeds and grasses with the celerity of a mouse, and is not apt to take wing unless closely pressed. Mixed flocks of the several varieties of the Sharp-tail, together with the Seaside Sparrow, gather in the fall among the sedges, and may be observed hiding in the grass or clinging to the tall stalks of the cat-tails. In the breeding season it is usually associated with the Seaside Sparrow on the same marsh, but it prefers the drier parts, and builds its nest in the tussocks on the bank of a ditch or in the drift left by the tide, rather than in the grassier sites chosen by its neighbor.

From some bit of driftwood or a convenient stake its infrequent song may be heard morning and evening. It is short and gasping, and only less husky than the somewhat similar performance of the Seaside Sparrow.

J. Dwight, JR.

549a. A. c. nelsoni Allen. Nhlsox's Siarp-talled Sparrow.-Similar to A. caudacutus, but smaller, the upper parts darker, the feathers of the back more olive-brown and more broadly margined with whitish; the throat, breast, and sides deeper ochraceous-buff, very slightly if at all streaked with blackish. "L., $5.50 ;$ W., $2.25 ;$ T., $1.90 ;$ B., 43 " (Dwight).

Range.-Breeds in the marshes of the interior from northern Illinois northward to Dakota and Manitoba; occurs as a migrant on the Atlantic coast, and winters from South Carolina to Texas.

Washington, rare T. V., two instances, Sept. Sing Sing, tolerably common 'T. V., Sept. 28 to Oet. 17.

'This interior representative of the Sharp-tailed Sparrow oceurs on our coasts only as a migrant and winter visitant. It associates with the Sharp-tailed and Acadian Sharp-tailed Sparrow.

549b. A. c. subvirgatus Dright. Acadin Siarp-talled SparRow.-Similar to $A$. caudacutus, but with the throat, breast, and sides washed with cream-buff and indistinctly streaked with ashy. "L., $5 \cdot 55 ; \mathrm{W} ., 2 \cdot 30$; T., 2.00 ; B., *46" (Dwight).

Range.-" MIarshes of southern New Brunswick, Prince Edward Island, 
and probably Nova Scotia, and southward in migration along the Atlantic coast" (D wight).

Sing Sing, rare T. V., Sept. 29 to Oct. 16. Cambridge, very common T. V., May; Sept. and Oet.

Since this race was separated by me in 1887 few new facts have been developed regarding it, except that, as I anticipated, it has been found in other parts of the Maritime Provinees, and never far from salt water. While frequenting brackish or fresh-water marshes, where the grasses grow more luxuriantly than in the haunts of its southern relative, it prefers the more open spots or those where damp ditches make highways of escape for it afoot. It is locally abunclant, particularly in the great marshes that border the Bay of Fundy, but so retiring that, save for its little song, its presence might be casily overlooked. Swaying on a tall stalk of meadow rue or squatting on a convenient fence, the males may be found at all hours of the day repeating their song a few times and then flying to some new perch or burying themselves in the grass. Occasionally toward nightfall one will mount into the air and with set wings float down, fairly gushing with song, a habit shared by the ordinary Sharp-tail and by the Seaside Sparrow as well.

With these birds they associate in autumn, and may be flushed one or two at a time from the strips of grass or reeds that are left on the salt marshes along the ditches after the hay has been cut.

The song is a husky, gasping effort, not very loud, and executed with a nod of the head. It is sung in less than a second, and resembles hish-sh-sh-öolp, the last syllable occupying one fifth of the time and rather musical compared with the harsh lisp that precedes it. 'They also have a tchĕp of alarm, but it is the exception for them to show much anxiety about their nests or young. The nest has never been taken.

J. DwIGHT, JR.

550. Ammodramus maritimus ( Wils.). SEAside Sparrow. Ad. - A yellow line before the eye and on the bend of the wing; upper parts grayish olive-green; tail grayish brown, the outer webs of the feathers margined with olive-greenish; a dusky line from the base of the lower mandible passes down the sides of the tliroat: breast more or less suffused with buffy (wanting in summer specimens), and indistinctly streaked with grayish; throat and middle of the belly white; sides grayish. L., $6.00 ; \mathrm{W} ., 2.50 ;$ 'T., $2 \cdot 20 ;$ B., $\cdot 60$.

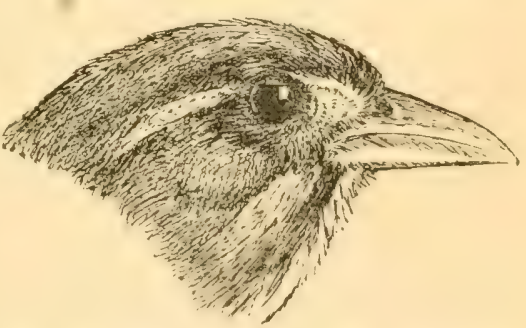

Fra. 84.-Seaside Sparrow. (Natural size.)

Range.-Atlantic coast; breeds from Georgia to Massachusetts, and winters from Virginia to Georgia.

Sing Sing, A. V. 
Nest, of coarse grasses and reed stalks, lined with grasses, on the ground. Eggs, three to four, white or bluish white, clouded or finely speckled with ciunamon-brown, especially at the larger end, ${ }^{-80} \times \cdot 63$.

Like most marsh-loving birds, Seaside Sparrows are so consistent in their choice of a home that it would be quite useless to look for them anywhere but in a marsh, and that a salt one, generally within sound or at least sight of the sea. The baymen call them "Meadow Chippies," and often when Snipe and Plover shooting I have drawn numbers to me by simply squeaking. They tipped all the reeds about iny blind, chirping excitedly at the peculiar sound which aroused their curiosity. They pass much of their time on the ground among the reeds and grasses, but mount a stalk to sing their short, unattractive song of four or five notes. Sometimes they flutter into the air a few feet above the reeds and deliver their song while on the wing.

The absence of distinct streaks on the breast and lack of rufous in their olivaceous or grayish plumage will distinguish them from the Sharp-tailed, Swamp, Savanna, or Song Sparrows, the only ones which are likely to be found in their haunts.

550a. A. ma. peninsulæa Allen. Scott's Seaside Sparrow,-Similar to the preceding, but much darker; prevailing color of the upper parts brownish black, the feathers margined with grayish olive-green; under parts more heavily streaked, the breast and sides streaked with black or blackish. W., $2 \cdot 30 ;$ T., $2 \cdot 00 ;$ B., $\cdot 52$.

Range.-Atlantic coast from northern Florida to South Carolina; Gulf coast from Florida to Texas.

A common southern representative of the Seaside Sparrow.

551. Ammodramus nigrescens Ridgw. D tisky Seaside Sparrow. $A d$.-Upper parts black, narrowly margined with grayish and grayish olivegreen; under parts sharply streaked with black and white in about equal

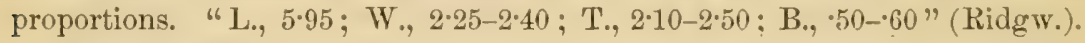

Remarks.-This species is very distinct, and can be at once distinguished from A.m. peninsulke, its nearest known ally, by its much darker upper parts and conspicuously streaked under parts.

Range.-Marshes at the northern end of Indian River, Florida.

Nest and eggs unknown.

Mr. C. J. Maynard, the only collector who has ever met with this species, found a single individual, March 17,1872 , at Salt Lake, near Titusville, while in April it was "quite common on the marshes of Indian River just below Dummett's Grove," and "very abundant on the upper end of Merritt's Island." I have searched for it most carefully, but without success, during February and March in the marshes of the east peninsula of Indian River opposite $\mathrm{Vicco}$, and for a species which is not rare, the Dusky Seaside Sparrow apparently has a more 
restricted range than any other North American bird. Mr. Maynard considers it migratory, and states that it is not found in Florida during the winter. In flight as well as in habits, he says, it resembles the Sharp-tailed rather than the Seaside Sparrow (A. maritimus). Its song of low, sputtering notes is given while the bird hovers in the air, after which it drops quickly into the grass.

552. Chondestes grammacus $(S(a y)$. Lark SPARROW; LarK Fincr. $A d$. - Sides of the crown and ear-coverts chestnut, a whitish line over the eye and through the center of the crown; a black streak on the sides of the throat; upper parts brownish ash; back streaked with blackish; tail fuscous or black, the outer feathers tipped with white; under parts white, a small black spot in the middle of the breast. L., $6.25 ;$ W., $3.50 ;$ T., $2.75 ;$ B., $\cdot 45$.

Range.-Interior of North America, eastward to Illinois; breeds from Texas to Manitoba; aceidental on the Atlantic coast (Massachusetts, Long Island, New Jersey, District of Columbia, Florida).

Washington, A. V., July, Aug., two captures.

Nest, of grasses, lined with rootlets,

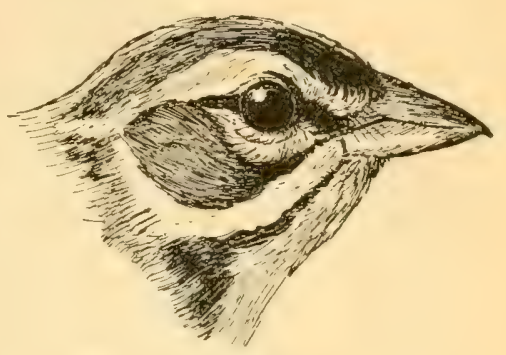

Fig. 85.-Lark Sparrow. (Natural size.) fine grasses, and long hairs, on the ground or in low trees or bushes. Eggs, three to five, white or pinkish white, spotted, blotehed, or serawled with purplish or black, chiefly at the larger end, $\cdot 78 \times \cdot 60$.

This is an exceedingly common bird in the west. It frequents localities of much the same nature as those selected by the Grass Finch, and in its general habits and song reminds one of that species.

554. Zonotrichia leucophrys (Forst.). White-crowned SPARRow. Ad.-No yellow before the eye or on the bend of the wing; center of the crown with a white stripe bordered on either side by black stripes, all of about equal width; no white before the eye; a white line from over the eye passes backward along the side of the head; nape gray; back dark grayish brown, margined with gray; rump dark brownish ash; greater and middle wing-coverts tipped with white; tail fuscous; under parts grayish white on the belly, flanks and under tail-coverts cream-buff. Im.-Generally similar, but sides of the crown rufous-brown, center of the crown pale grayish brown; nape brownish ash; back margined with the same color. L., 6.88; W., 3.03; T., $2.88 ; B ., \cdot 43$.

Range.- "Breeding from higher mountain ranges of western United States, Sierra Nevada, Rocky Mountains, and eastward. north of the Great Lakes, to Labrador; in winter, over whole of United States, and south into Mexico" (Ridgw.).

Washington, irregularly common W. V. and 'T. V., Apl. 15 to May 15; Oct. 15 to Nov. 30. Sing Sing, rare T. V., May 9 to 20 ; Oct. 3 to 30 . Cambridge, uncommon T. V., Nay 12 to 22 ; Oct. 1 to 20. 
Nest, of grasses, on the ground or in bushes. Eggs, four to five, pale greenish blue, speckled and spotted with bay, especially at the larger end, $90 \times \cdot 62$ (Davie).

This is one of the aristocrats of the family. Its size and its handsome markings at once distinguish it from its congeners, and are sure to attract attention. Though its season of love and music is spent in the far north, it often favors us with selections of its melodies as it rests in thickets and hedgerows while slowly passing through our country on its northward pilgrimage. Its usual song is like the latter half of the White-throat's familiar refrain, repeated a number of times with a peculiar sad cadence and in a clear, soft whistle that is characteristic of the group. It resembles its relatives also in singing its sweetest songs in the woods, sometimes during the darkest hours of the night.

ERnest E. 'I'Hompson.

558. Zonotrichia albicollis ( $G$ mel.). WHTE-THIOATED SPARROW; PEABody-Bird. Ad.-A yellow line before the eye; bend of the wing yellow; center of the crown with a white stripe bounded on either side by much wider black stripes; a white stripe from the eye passes backward along the side of the head; back rufous or rufous-brown, streaked with black and slightly margined with whitish; rump grayish brown; greater and middle wing-coverts tipped with white; tail grayish brown; under parts grayish, more so on the breast; throat with a square white patch; belly whitish; flanks and under tail-coverts tinged with grayish brown. Im.-Yellow before the eye, and on the bend of the wing duller; crown streaks brownish ashy and mixed chestnut and black, instead of white and black; throat patch less sharply defined. L., 6.74 ; W., $2 \cdot 89 ;$ T., $2 \cdot 86 ;$ B., $\bullet 44$.

Range.-Eastern North America; breeds from northern Michigan, and occasionally Massachusetts, northward to Labrador; winters from Massachusetts to Florida.

W ashington, very common W. V., Sept. 28 to May 20. Sing Sing, common 'T. V., Apl. 10 to May 21; Sept. 20 to Uet. 30 ; a few winter. Cambridge, very common T. V., Apl. 25 to May 15; Oct. 1 to Nov. 10 ; a few winter.

Nest, of coarse grasses, rootlets, moss, strips of bark, etc., lined with finer grasses, on the ground or in bushes. Eggs, four to five, bluish white, finely and evenly speckled or heavily and irregularly blotched with pale rufousbrown, $\cdot 82 \times \cdot 60$.

In September, when the hedgerows and woodland undergrowths begin to rustle with Sparrows, Juncos, and Towhees, I watch eagerly for the arrival of these welcome fall songsters.

There is little in their modest appearance to tell one, as they feed on the ground near their haunts, of their vocal powers, and one might be pardoned for believing that a feeble tseep was their only note. I whistle a bar or two of greeting in their own language. They are eridently puzzled, but make no reply, for it has apparently been agreed among themselves that singing shall not begin for at least a week after 


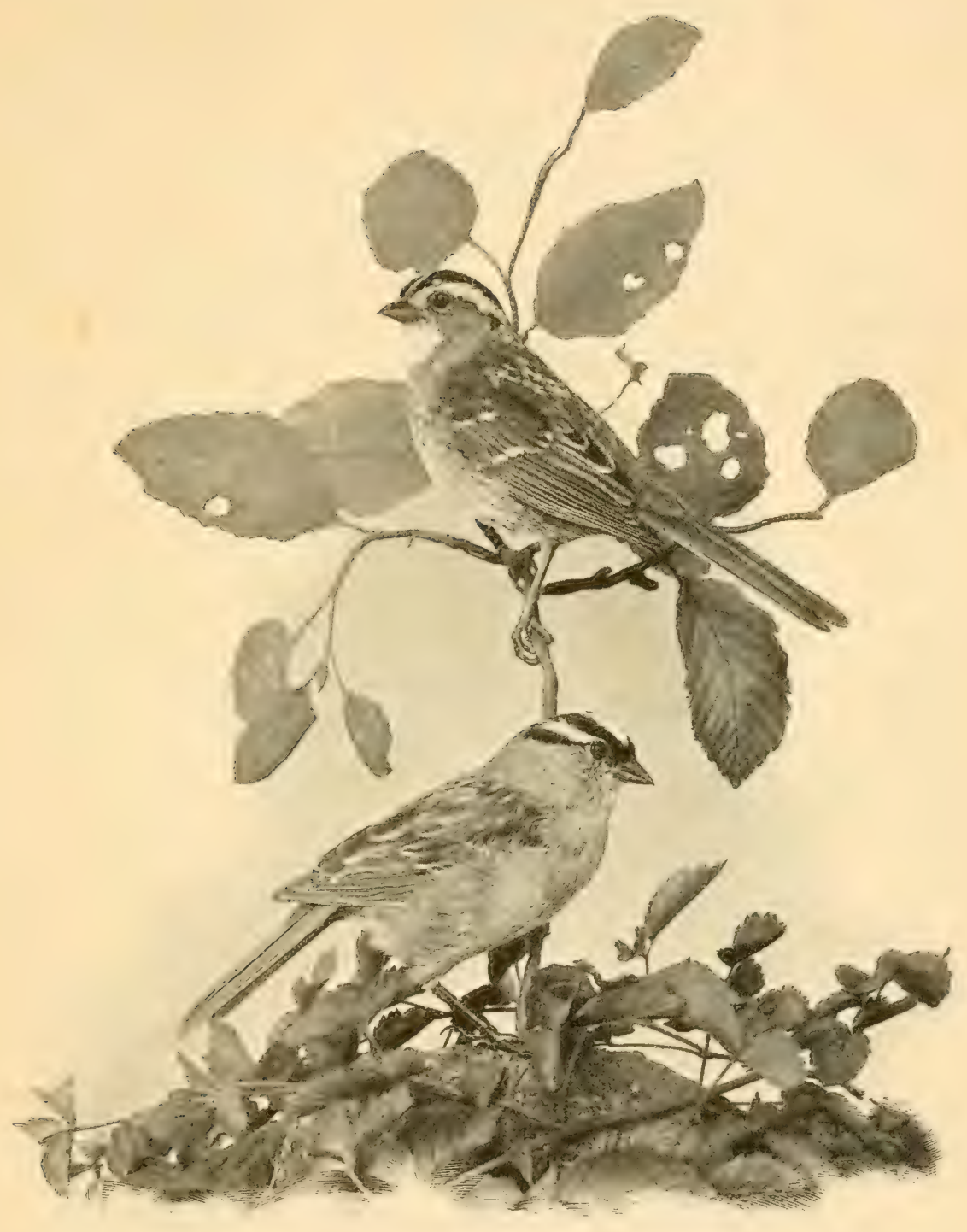

White-throated Sparrow.

White-crowned Sparrow. 

their arrival. Then there are a few sweet, tremulous trials before the plaintive, sympathetic whistle brings cheer to the browning woods:

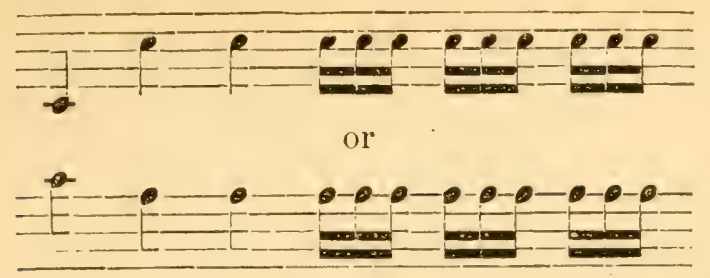

Few birds are more sociable than the White-throats. At this season they are always in little companies, and they frequently roost together in large numbers in the depths of dense thickets or clumps of evergreens. After they have retired one may hear the sharp chink of their "quarrier" chorus, and when darkness comes, with low, brooding notes of cozy companionship they are hushed for the night.

559. Spizella monticola (Gmel.). Tree Sparrow; Winter CnIPpy. Ad.-No black on the forehead; an indistinct black spot on the center of the breast; top of the head rufous-brown, sometimes edged with ashy; a grayish line over the eye and a rufous-brown line behind it; back streaked with rufous-brown, black, and pale ochraceous-buff; rump pale grayish brown; greater and middle wing-coverts tipped with white; outer web of the outer tail-feather whitish; breast grayish white; middle of the belly white; sides tinged with pale grayish brown; upper mandible black, lower, yellow at the base, the tip black. L., $6.36 ;$ W., $2.99 ;$ T., $2.82 ;$ B., 41 .

Range.-Eastern North America; breeds in Labrador and the region about Hudson Bay; south in winter, through eastern United States; west to the edge of the Great Plains.

Washington, abundant W. V., Nov. 1 to Apl. 5. Sing Sing, common W. V., Oct. 10 to Apl. 27. Cambridge, common W. V., abundant T. V., Oct. 25 to Nov. 25 ; Mch. 20 to Apl. 20.

Nest, of grasses, rootlets, and hair, on or near the ground. "Eggs, four to five. pale green or greenish blue, spotted with reddish brown, $75 \times \cdot 60$ " (Chamberlain).

Tree Sparrows wear a small black dot on the center of their otherwise unmarked breasts, a badge which will aid in their identification. They come in flocks when the fields are beginning to look brown and dreary, but seem eontented with the surroundings from which other birds have fled.

They feed on the seeds of weeds and grasses, and even when the snow is deepest always find an abundance of food. I like to see them feasting on the seed stalks above the crust, and to hear their chorus of merry, tinkling notes, like sparkling frost crystals turned to music.

Winter Chippies they are sometimes called, but at this season there 
is little of the Chippy's nature about them. In February or March they begin to sing a song which has been compared to that of a Canary, but is "finer, sweeter, and not so loud."

560. Spizella socialis (Wils.). ('hipping Sparrow; Chippy. Ad. -Forehead black, a short grayish line in its middle; top of the head rufous: the nape generally with a few black streaks: a

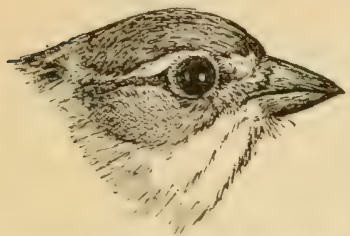

FIG. 86.-Chipping Sparrow. (Natural size.) grayish line over the eye and a black line behind it; back of the neck grayish, separating the rufous crown from the back; back streaked with black, a little rufous, and more pale buffy ochraceous; rump slaty gray; wing-bars not conspicuous ; under parts grayish white, whiter on the throat and belly ; bill entirely black. Imn.-Similar, but no rufous crowncap or black on the forehead; top of the head streaked like the back; bill brownish. Young in first plumage have the breast streaked with black. L., 5.37; W., 2.74; T., $2 \cdot 29 ;$ B., $\cdot 36$.

Remarks.-In adults the rufous crown, black forehead, gray rump, and black bill are characteristic; in the young the gray rump is a good distinguishing mark.

Range.-Eastern North America; breeds from the Gulf States to Newfoundland and Great Slave Lake; winters in the Gulf States and Mexico.

Washington, common S. R., abundant 'T. V., Mch. 15 to Nov, 1, occasionally winters. Sing Sing, common S. R., Apl. 9 to Nov. 7. Cambridge, abundant S. R., A pl. 15 to Oct. 25.

Nest, of grasses, fine twigs, or rootlets, thickly lined with long hairs, in trees or bushes, five to twenty feet up. Eggs, four to five, blue or greenish blue, with cinnamon-brown or blackish markings, chiefly at the larger end, $72 \times 51$.

The Chippy is among Sparrows what the Phobe is among Flycatchers-the humblest, most unassuming member of its family. Both show trustfulness, which, in spite of their unattractive appearance and far from pleasing voices, wins our affection.

Chippy makes his nest in the vines on our piazza, and feeds on the crumbs at our doorstep, quite as though he were a member of the family; and he needs only a little encouragement to give evidence of his entire confidence in our good will by feeding from our hands.

II is song is a monotonous chippy-chippy-chippy-chippy, rather high and wiry and frequently running into an insectlike trill-by no means a musical performance.

In the fall Chippy changes his dress, dons a streaked cap for the one of bright bay, and, with others of his kind, goes to the fields to feast on the year's harrest of seeds. He is generally found near trees and hedgerows, into which, when alarmed, he flies with his companions. 
561. Spizella pallida (Swains.). Clay-Colored Sparrow. Ad.With a general resemblance to immature $S$. socialis, but less rufous above, whiter below, the line over the eye white, and the rump pale grayish brown instead of slaty gray. W., $2 \cdot 40 ;$ T., $2 \cdot 35 ;$ B., $\cdot 34$.

Range.-Interior of North America; breeds from northern Nebraska, central Iowa, and northern Illinois northward; winters from southern Texas southward; accidental in North Carolina.

Nest, of grasses, lined with hairs, on the ground or in bushes. Eggs, three to five, similar to those of S. socialis.

"This pale Sparrow of the plains is very similar in actions to the Chipping Sparrow, but less familiar and confiding in habits" (Goss).

Brewer's SPARrow (562. Spizella breweri), a western species, has been recorded once from Massachusetts.

563. Spizella pusilla (Wils.). Field Sparrow. Ad.--Bill reddish brown; top of the head rufous, a gray line over the eye; nape slightly gray; back like the crown, but finely streaked with black and narrowly edged with brownish ashy; rump brownish ashy; middle and greater wing-coverts tipped with white; under parts white, tinged with ochraceous-buff on the breast and sides. Im.-Similar, but the colors duller, the crown edged with grayish and sometimes a faint grayish line through its center. Ioung in first plumage have the breast streaked with black. L., 5.68; W., 2.50; T., 2.55; B., $\cdot 36$.

Remarks.-This bird may be known by its brightly colored back, buffy breast, and especially by its reddish bill.

Range.-Eastern North America; breeds from southern Illinois and South Carolina to Quebee and Manitoba; winters from Illinois and Virginia southward.

Washington, very common P. R. Sing Sing, common S. R., Apl. 2 to Nov. 7. Cambridge, common S. R., Apl. 15 to Nov. 1.

Nest, of rather coarse grasses, weed stalks, rootlets, ete., lined with fine grasses and long hairs, on the ground or in low bushes. Eggs, three to five, white or bluish white, with numerous rufous markings, chiefly about the larger end, $70 \times \cdot 52$.

Its bright rufous color, the absence of spots on its breast, and especially its flesh-colored bill, are the best field-marks of this misnamed sparrow. He is not a true Field Sparrow, but prefers old pastures dotted with clumps of bushes or young cedars. There is someining winning in lis appearance; he seems such a gentle, innocent, dovelike little bird. His song is in keeping with his character, being an unusually clear, plaintive whistle, sweeter to the lover of birds' songs than the voice of the most gifted songstress. It is subject to much variation. Not only do the same individuals sing several different songs, but two individuals in the same locality rarely sing alike. There is also much variation in the songs of birds from different regions. For this reason it is quite impossible to give a description 
of the song which will apply throughout the bird's range. However,

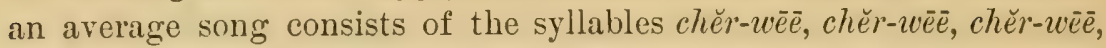
chĕr-wee , chēē-o, de-de-de-de-de, the last notes joined in a trill.

This gives, of course, no idea of the quality of the Field Sparrow's song, but to be convinced of its rare beauty one need only hear it as the sun goes down and the hush of early evening is quieting the earth.

The Western Field Sparrow (563a. Spizella pusilla arenacea) has been recorded from the vicinity of New Orleans.

56\%. Junco hyemalis ( $\operatorname{Linn}$.). J Jinco; SNowbird. $A d$. $\delta$.-Upper parts, throat, and breast grayish slate-color; upper parts more or less washed with grayish brown; belly white, sides grayish; no wing-bars; tail fuscous, the two outer feathers and part of the third white; bill flesh-color. $A d$. . . Similar, but the upper parts browner, throat and breast paler. Young in first plumage resemble the adults, but have the upper parts, throat, and breast streaked with black. L., 6.27 ; W., 3.03 ; 'T., $2 \cdot 71 ;$ B., 441 .

Range.-North America; breeds from northern Minnesota and northern New York northward and southward along the summits of the Alleghanies to Virginia; winters southward to the Gulf States.

Washington, abundunt W. V., Oct. 5 to Apl. 25. Sing Sing, common W. V., Sept. 19 to May 4. Cambridge, rather common W. V., abundant T. V., Sept. 20 to Nov. 25 ; Mích. 20 to Apl. 20.

Nest, of grasses, moss, and rootlets, lined with fine grasses and long hairs, on or near the ground. Eggs, four to five, white or bluish white, finely and evenly speckled or spotted, sometimes heavily blotched, at the larger end with rufous-brown, $\cdot 76 \times \cdot 58$.

When the snow begins to fly you will look out some gray morning to find a flock of small, plump, slate-colored birds hopping about the dooryard, picking up what they can find, or sitting in the bushes with an air of contentment that it is pleasant to see.

Coming, as they do, when most of the home birds have left for the south, they bring their own welcome, and soon seem like old friends. But if you would really know your gentle winter visitors, you must go back into the woods when summer comes and find them in their own homes.

Look for them in a tangle of fallen tree-tops, logs, and upturned ronts. A pair I once surprised in such a place at first sat and chirped at me-with bills full of food-but soon they were flying freely back and forth to the upturned root where they had hidden their nest.

I noticed with surprise that their gray plumage toned in so well with the dark earth that they were hard to see. The sharp horizontal line across the breast where the gray turns abruptly to white added to the disguise, the straight line breaking the round form of the bird.

The 'tsip of the Junco is unmistakable and more often heard than 
his song, but he has both a trill and a low, sweet song as unpretentious and cheery as the friendly bird himself.

Florence A. Merriam.

56\%e. J. h. carolinensis Brevest. Carolina Junco.--Similar to the preceding species, but slightly larger, the upper parts, throat, and breast uniform grayish slate-color without a brownish wash, bill horn-color. W., $3 \cdot 26$ : T., $2 \cdot 85 ; \mathrm{B} ., 43$.

Range.-Mountains of Virginia, North and South Carolina.

This is a common and apparently permanent resident species in the higher parts of the southern Alleghanies.

Shufextid's Junco (56\%b. Junco hyemalis shufeldti), a western species, has been recorded from Illinois, District of Columbia, Maryland, and Massachusetts. It resembles $J$. hyemalis, but has the back browner and the sides brownish vinaceous.

575. Peucra restivalis (Liclit.). PINE-Woods Sparrow. Ad.Upper parts light chestnut, more or less streaked with black and margined with gray; a grayish line over the eye; bend of the wing yellow; tailfeathers narrow, grayish fuscous, the outer ones much the shortest; breast and sides washed with pale brownish ash; breast sometimes with a few black spots; middle of the belly white. L., 5.80 ; W., 2.50 ; T., 2.50 ; B., "45.

Range.-Florida and southern Georgia.

Nest, of fine grasses, on the ground, bencath scrub palmetto. Eggs, three to four, pure white, $72 \times \cdot 61$.

This is a common bird in Florida. It winters in the sonthern part of the State and migrates northward in March. It is found only in pine woods having an undergrowth of scrub palmetto. Here it passes most of its time on the ground, and is difficult to flush.

When singing, it seeks an elerated perch. In my opinion its song is more beautiful than that of any other of our Sparrows. It is very simple, but it possesses all the exquisite tenderness and pathos of the melody of the Hermit Thrush ; indeed, in purity of tone and in execution I should consider the Sparrow the superior songster. It sings most freely very early in the morning and late in the afternoon, when the world is hushed and the pine trees breathe a soft accompaniment to its divine music.

595a. P. æ. bachmanii (Aud.). Bacnins's Sparrow.-Similar to the preceding species, but the upper parts rufous, black streaks generally confined to the back, or absent; line over the eye buffy; breast and sides brownish cream-buff without streaks.

Range.-Lower Mississippi Valley north to southern Indiana and southern Illinois; west to northern 'T'exas ; east to Georgia, South and North Carolina; south in winter, in the Atlantic States, to southern Florida.

Nest, of grasses, domed and cylindrical, on the ground. Eggk, three to four, pure white, ${ }^{\top}+4 \times \cdot 60$ (Bendire, $\Lambda$ uk, v, 1888, p. 356). 
In Florid:, where this bird is not uncommon during the winter, I have found it in pine woods undergrown with turkey oaks, and not in localities frequented by $P$. astivalis. Mr. Ridgway writes that in Illinois this is "emphatically a bird of open oak woods, where large white and post onks prevail, with grass land immediately adjoining, or where the intervals between the trees consist of swarl rather than undergrowth; but neglected fields, grown up to weeds, and in which dead trees are left standing, are also its favorite haunts."

Ile speaks of its song as reminding one somewhat of the plaintive chant of the Field Sparrow, but as far sweeter and louder; " the modulation, as nearly as can be expressed in words, resembling the syllables thééééé-thut, lut, lut, lut, the first being a rich silvery trill, pitched in a high musical key, the other syllables also metallic, but abrupt, and lower in tone."

581. Melospiza fasciata ( $G$ mel.). SONg Sparrow. Ad.-Crown rufous-brown, with a grayish line through its center; a grayish line over the eye; a rufous-brown line from behind the eye to the nape; feathers of the back streaked with black and margined with rufous-brown and grayish; greater wing-coverts with black spots at their tips; no white wing-bars or yellow on the wing; tail rufous grayish brown, the middle feathers darker along their shafts; outer feathers shortest; sides of the throat with black or blackish streaks; breast with wedge-shaped streaks of black and rufousbrown which tend to form one larger bloteh on the center; sides washed with brownish and streaked with black and rufous-brown; middle of the belly white. L., $6 \cdot 30 ;$ W., $2 \cdot 52 ;$ T., $2 \cdot 62 ;$ B., $\cdot 49$.

Range.-Eastern North America; breeds from northern Illinois and Virginia north to Quebee and Manitoba; winters from southern Hlinois and Massachusetts to the Gulf States.

Washington, common P. R., abundant 'T. V., Meh. and, Oct. Sing Sing, common P. R. Cambridge, very abundant S. R., Mch. 10 to Nov. 1; locally common W. V.

Nest, of coarse grasses, rootlets, dead leaves, strips of bark, etc., lined with finer grasses and sometimes long hairs, on the ground, sometimes in bushes. Eggs, four to five, white or bluish white, with numerous rufous-brown markings which sometimes nearly conceal the ground color, $\cdot 76 \times \cdot 60$.

The Song Sparrow's rast range in a dozen varying climates, its readiness to adapt itself to the different conditions in each of the regions it inhabits, its numerical abundance and steady increase while some of its family are dying out, its freedom from disease and vermin, and its perennial good spirits evideneed by its never-failing musicall proclaim that it is indeed one of Nature's successes.

Its irrepressible viracity and good spirits in spite of all circumstances are aptly illustrated by the fact that its song may be heard in every month of the year and in all weathers; also by night as well as by day-for nothing is more common in the darkest nights than to 


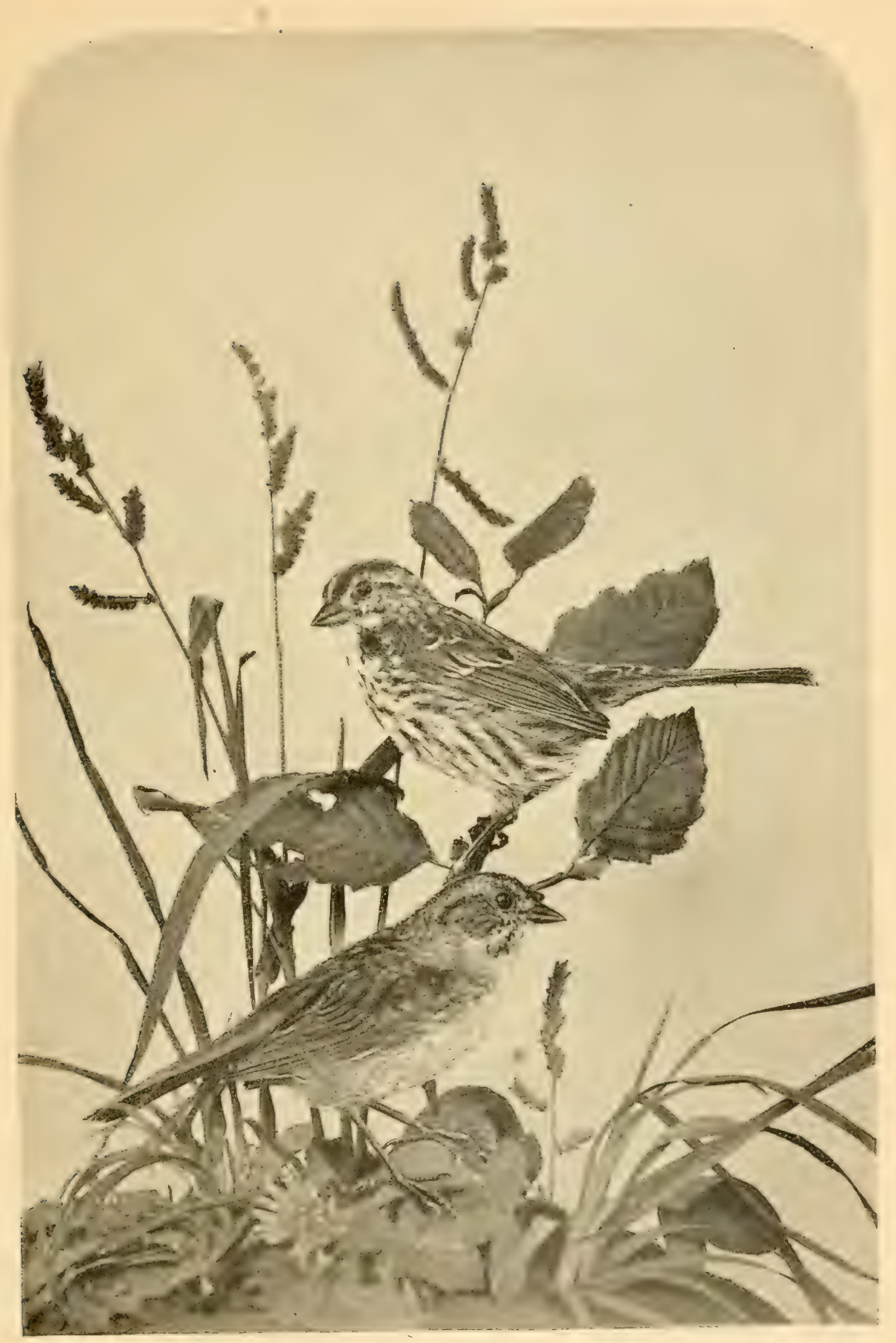

Song Sparrow.

Swamp Sparrow. 

hear its sweet ehant in half-conscious answer to the hooting of the Owl or even the report of a gun.

It is never seen far from water, and when it is alarmed it flies downward or along-never upward-into some low thicket, pumping its tail as it flies.

Its alarm note is a simple metallic chip, which is rery distinctive when once learned. But its merry chant-which has won for it the name of "Song Sparrow"-is its best-known note. It is a volubte and uninterrupted but short refrain, and is perhaps the sweetest of the familiar voices of the meadow lands. The song that it occasionally utters whils on the wing is of quite a different character, being more prolonged and varied.

Though so abundant, it can not be styled a sociable species. Even during the migrations it is never seen in compact flocks like the Redpoll or Snowflake ; at most it will be found forming a part of a long, scattered migrating train that usually includes a number of different but nearly related species.

Ernest E. Thompson.

583. Melospiza lincolni (Aud.). Lincoln's Sparrow. Ad.-. Upper parts streaked with black, brownish gray, and grayish brown; tailfeathers narrow and rather pointed, the outer ones shortest; under parts white, rather finely streaked with black, a broad cream-buff band across the breast, a eream-buff stripe on either side of the throat; sides tinged with cream-buff. L., $5 \cdot 75 ;$ W., $2.50 ;$ T., $2 \cdot 40$; B., $\cdot 41$.

Remarks. - The cream-buff band on the breast is distinctive of this species.

Range.-Eastern North America; breeds from northern Illinois and northern New York northward; winters from southern Illinois to Mexico; rare east of the Alleghanies.

Washington, rare T. V., several records, May and Oet. Sing Sing, rare T. V., Sept. 29 to Oct. 16. Cambridge, uncommon T. V., May 15 to May 25; Sept. 15 to Oct. 5 .

Nest, generally similar to that of $M$. fasciata, on the ground. "Eggs, four to five, pale green or buftish, sometimes almost white, thickly spotted and blotehed with reddish brown and lilac, $80 \times 60 "$ (Chamberlain).

The most striking characteristic about the Lincoln's Sparrow is its shyness, whether migrating in the lavish abundance of the west, straying casually through the States of the Atlantic seaboard, or settled for the summer in a chosen spot of the northern evergreen woods. Scampering like a mouse along some tumble-down stone wall half buried in poison iry, sumach, and all the tangled growth that goes to make up an old hedgerow, or peering out from a clump of lowspreading bushes, this little bird may sometimes be detected; but as he hurries northward late in the migration, when all the woods and fields are ringing with bird music, our attention is seldom directed 
toward the silent straggler, while in the autumn he is lost in the wares of Sparrows that flood the country.

If we follow him northward, we find him irregularly distributed in small colonies or single pairs in damp clearings, perhaps along brooks or ponds, but aroiding almost entirely the wetter, more open localities, where the Swanp Sparrow is at home. Attracted by a sharp chirp which, at times reduplicated, resembles that of a young Chipping Sparrow, we may succeed in catching a glimpse of him as he lurks beneath a little spruce perhaps no bigger than an umbrella.

Sometimes venturing timidly to the outer boughs of a spruce, he surprises the hearer with a most unsparrowlike song. It is not loud, and suggests the bubbling, guttural notes of the House Wren, combined with the sweet rippling music of the Purple Finch, and when you think the song is done there is an unexpected aftermath. The birds sing very little and at long interrals, and are seldom heard during the later hours of the day, ceasing at once if anybody approaches.

J. Dwight, JR.

584. Melospiza georgiana (Lath.). STAMP SPARRow. Ad. in. summer.-Crown chestnut-rufous; forehead black; a grayish line over the eye; a blackish line behind the eye; nape slaty gray with a few black streaks; feathers of the back broadly streaked with black and margined with rufous and eream-buff or ashy buff; wing-coverts rufous, the greater ones with black spots at their tips; rump rufous grayish brown, sometimes streaked with black; tail rufous grayish brown, the middle feathers darker along their shafts; throat and middle of the belly white, breast grayish, sides washed with pale grayish brown. Ad. in winter and Im.-Similar, but the top of the head streaked with black, rufous-brown, and grayish; nape less gray; breast washed with brownish. L., 5.89; W., 2*34; T., 2.32; B., *46.

Range.-Eastern North America; breeds from northern Illinois and Pennsylvania northward to Labrador; winters from southern Illinois and Massachusetts to the Gulf.

Washington, very common T. V., Apl. to May 15 ; Sept. 25 to Oct. 30 ; a few winter. Sing Sing, tolerably common S. K., Apl. 4 to Dec. 2 ; a few winter. Cambridge, abundant S. R., Apl. 12 to Nov. 10 ; a few winter.

Nest, generally similar to that of M. fasciata, on the ground. Eggs, four to tive, similar in color to those of M. fasciata, but the markings are generally inore confluent, $\cdot 76 \times 57$.

While wintering in the south, Swamp Sparrows frequently belie their name, and I have often found numbers of them in dry "old fields" of broom sedge; but at the north they are more consistent, and one rarely sees them beyond the confines of a wet meadow, or, more preferably, a large grassy marsh with reed-bordered streams.

Swamp Sparrows may be distinguished from their cousins, the Song Sparrows, by their unstreaked breasts and totally different notes. Their 
usual call-note is a sharp cheep, not unlike that of the White-throated Sparrow, and quite different from the rather nasal chna of the Song Sparrow. Their song is a simple, sweet, but somewhat monotonous tweet-tweet-tweet, repeated many times, all on one note, and sometimes running into a trill.

585. Passerella iliaca (Merr.). Fox Sparrow. Ad.-Upper parts rufous-brown, the feathers margined by cinnamon-brown; upper tail-coverts and tail bright rufous; wings margined with rufous; under parts heavi$l y$ streaked and spotted with rufousbrown and blackish; middle of the belly white; lower mandible yellowish. L., 7.26 ; W., $3.39 ;$ T., $2 \cdot 85 ;$ B., $\cdot 50$.

Range.-Breeds from the Magdalen Islands and Manitoba to Alaska; winters from Virginia southward.

Washington, very abundant ${ }^{\mathrm{T}} \mathrm{T} . \mathrm{V}$., Feb. to Apl. 5 ; Oct. 25 to Nov.; a few Fig. 87.-Fox Sparrow. (Natural size.) winter. Sing Sing, tolerably common

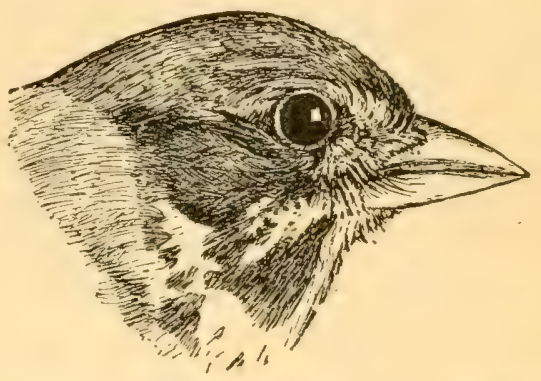

T. V., Mch. 4 to Apl. 20 ; Oct. 14 to Nov. 28. Cambridge, abundant T. V., MIch. 15 to Apl. 20 ; Oct. 20 to Nov. 15.

Nest, of coarse grasses, lined with finer grasses, hair, moss, and feathers, on the ground, and in low trees and bushes. Eggs, four to five, pale bluish, evenly speckled or heavily blotched with umber or vinaceous-brown, $80 \times \cdot 63$ (see Bendire, Auk, vi, 1889, p. 108).

In the early spring the Fox Sparrow is seen mostly about damp thickets and roadside shrubbery; later it takes more to woodsides, foraging on leaf-strewn slopes where there is little or no undergrowth, often assuciated with small parties of Juncos. On its return in the autumn it again becomes a common denizen of hedgerows and thickets, and also invades the weedy grainfielils, rarely, however, straying far from some thickety cover. Sometimes large numbers congregate among withered growths of tall weeds, whence they emerge with a loud whirring of wings as their retreat is invaded, and hie away in tawny clonds, flock after flock. It is a great scratcher among dead leaves, and can make the wood rubbish fly in a way which, in proportion to its size, a barnyard fowl could scarcely excel.

The usual note of the Fox Sparrow is a feeble tseep. A note of excitement is louder and sharper in tone. Its song is not surpassed by that of any of our Sparrows. It is a revelation to hear it at sundown on some vernally softened evening of early springtime; little swarms of gnats hover in the balmy air; from the twilight meadows comes the welcome, half-doubtful piping of the first hylas-no other 
sound. Then perhaps from some dusky thicket a birl's song! An emotional outburst rising full-toned and clear, and passing ail too quickly to a closing cadence, which seems to linger in the silent air. It is the song of the Fox Sparrow with that fuller power and richness of tone which come into it, or seem to, at the sunset hour. It breaks forth as if inspired from pure joy in the awakened season, though with some vague undertone, scarcely of sadness, rather of some lower tone of joy.

Eugene P. Bicknell.

58\%. Pipilo erythrophthalmus ( Limn.). Towné; Chewink; JoREe. $A d$. \$.-Upper parts black, sometimes margined with rufous; throat and breast black, belly white, sides rufous; outer web of primaries mostly white; tail black, the three outer feathers tipped with white; outer web of the outer feather entirely white; iris red. $A d$. o.-Upper parts, wings, throat, and breast bright grayish brown; tail fuseous, the three outer feathers tipped with white; sides rufous, middle of the belly white. Young in first plumage have the back and under parts streaked with black. L., 8.35; W., 3.34; 'T., $3 \cdot 68 ;$ B., $\cdot 55$.

Range.-Eastern North America; breeds from the lower Mississippi Valley and Georgia northward to Maine, Untario, and Manitoba; winters from Virginia to Florida.

Washington, common S. R., very comnon T. V., Apl. 15 to May 15; Sept. to Oct. $15 ;$ a few winter. Sing Sing, common S. R., Apl. 21 to Oet. 31. Cambridge, common S. R., Apl. 25 to Oct. 15.

Nest, externally of dead leaves and strips of bark, lined with fine grasses, on or near the ground. Eqgs, four to five, white, finely and evenly speckled with shades of rufous, sometimes blotched at the larger end, $\cdot 96 \times \cdot 71$.

There is a vigorousness about the 'Towhee's notes and actions which suggests both a bustling, energetic disposition and a good constitution. He entirely dominates the thicket or bushy undergrowth in which he makes his home. The dead leaves fly before his attack; his white-tipped tail-feathers fiash in the gloom of his haunts. He greets all passers with a brisk. inquirmg chewink, towhee, and if you pause to reply, with a fluff-fluff of his short, rounded wings he flies to a nearby limb to better inspect you.

It is only when singing that the Towhee is fully at rest. Then a change comes over him; he is in love, and, mounting a low branch, he gives voice to his passion in song. I have long tried to express the Towhee's song in words, but never succeeded as well as Ernest Thompson when he wrote it chuck-burr, pill-a-will-a-will-a.

- 58\%a. P. e. alleni Coues. White-eyed Towile; Joref.-Similar to the preceding, but with less white on the wings and tail; only two outer tailfeathers tipped with white; iris yellowish or white. L., $8.00 ;$ W., 3.20 ; T., $3 \cdot 60 ;$ B., $\cdot 52$.

Range.-Florida; northward alcng the coast to southern South Carolina. 
This southern race of the Towhee does not associate with the northern bird, which is abundant in the south in the winter.

The latter selects haunts of much the same nature as those in which it passes the summer, while the southern bird lives in heary growths of scrub palmetto. The notes of alleni differ from those of erythrophthalmus; its towhee is much higher, and its song, as Dr. Allen pointed out years ago, is shorter. It is also a shyer bird than its northern cousin.

593. Cardinalis cardinalis $(\operatorname{Linh}$.$) . CARDINAL. All. of.- Throat$ and region about the base of the bill black; rest of the plumage bright rosy red, the upper parts tipped with grayish; a conspicuous crest; bill red. $A d$. 9.-Throat and region about the base of bill grayish black; crest, wings, and tail dull red; upper parts olive brownish ash; under parts buffy ochraceous, lighter on the belly, and sometimes tinged with red on the breast. L., $8 \cdot 25 ;$ W., $3 \cdot 75 ;$ 'T., $4 \cdot 00 ;$ B., $\cdot 64$.

Range.-Eastern United States; breeds from Florida to Iowa and southern New York; resident throughout its range.

Washington, common P. R.; less common than formerly. Sing Sing, A. V. Cambridge, casual, two instances.

Nest, of twigs, rootlets, and strips of bark, lined with grasses and rootlets, in bushes. Eggs, three to four, white or bluish white, speckled or spotted with grayish brown, cinnamon-brown, or umber, 1.00 $\times$ ro.

One's first impression of the Cardinal Grosbeak will usually be that he is rather: a clumsy fellow. His body appears to be stiff, as if it were made of wood, different in every way from the pliant, lithe body of the Catbird, for example. He hops about on the ground with tail held well up out of harm's way, and comes hearily down upon his feet, as if his body were really very solid. In fact, he is not at all a graceful bird.

He is a famous singer, his song being a loud, clear whistle, into which usually enters quite frequently the sound of $q ! q ! q !$ and a peculiar long-drawn-out $e-\bar{e}$ ! sometimes syllabled as "three chēers!" He is'a favorite cage-bird. The female Cardinal is herself a charming singer, more pleasing to many than her mate, her music being softer in tone and otherwise different from his. The common call-note of both is a sharp, abrupt tsip! easily recognized after being once heard.

As the head of a family the Cardinal is admirable, not only in his attentions to his lovely dove-colored mate, but in singing to her by the hour, and in protecting her from intrusion or danger. 'To the young in the nest he is an untiring provider of worms and grubs, and thus most useful in a garden. Nothing can be more comical than his behavior when he first conducts his young family out into the world while his mate is engaged with her second sitting. He is as fussy as any young 
mother, hopping about in great excitement, and appearing to think the whole world thirsting for the life of his pretty little ones.

The Cardinal mother shows the restless manners and anxious spirit of her mate, taking one's intrusion upon her domestic affairs greatly to heart, and being so much disturbed that there is more pain than pleasure in making acquaintance with her nestlings.

\section{Olive 'I'Horne Miller.}

595. Habia Iudoviciana $(\operatorname{Linn}$.). Rose-breasted Grosbeak. $A l$. 8.-Head, throat, and back black; breast and under wing-coverts bright rose-red, this color sometimes extending down the center of the white belly; rump white, tipped with black; wings black; primaries white at the base; tail black, the outer feathers tipped with white on the inner web. $A d$. \&.Upper parts grayish brown, margined with cream-buff and pale grayish brown; a buffy line through the center of the crown, and a conspicuous whitish line over the eye; wings and tail dark grayish brown; wing-coverts tipped with white; under wing-coverts orange; under parts buffy, streaked with dark grayish brown. Im. 3.-Resembles the $q$, but has the under wing-coverts rose-red. L., $8.12 ;$ W., $4.02 ;$ T., $2.99 ;$ B., 69 .

Range.-Eastern North America; breeds from eastern Kansas and the higher altitudes of Virginia and North Carolina northward to Maine and Manitoba; winters in Central and South America.

Washington, rather common T. V., May 1 to 20 ; Aug. 25 to Oct. 1. Sing Sing, tolerably common S. R., May 3 to Oct. 1. Cambridge, common S. R., May 10 to Sept. 10.

Nust, of fine twigs, weed stalks, and rootlets, in bushes or trees, five to twenty feet up. Eggs, four to five, pale blue, with numerous olive-brown or rufous-brown markings, $90 \times \cdot 69$.

Sometimes in passing through young second growths, and more rarely densely undergrown woodland, I hear a singular kind of questioning call-note, not loud, but distinct-a steely peek, peek. It is a signal to me to pause and look for its author; even a glimpse of him is worth several minutes' waiting and watching. There is no mistaking his black, white, and rose costume; but the identity of his more modestly attired mate may long remain an open question. So little does she resemble him that she might pass for an overgrown Sparrow with a rather conspicuous whitish stripe over her eye.

The song of the Rose-breasted Grosbeak is generally compared to that of the Robin, and musical amnotation would doubtless show that the comparison is not misleading. But the similarity is largely one of form; in expression there is no more resemblance in their roices than there is between the birds themselves. There is an exquisite purity in the joyous carol of the Grosbeak; his song tells of all the gladness of a May morning; I have heard few happier strains of bird music. With those who are deaf to its message of good cheer I can only sym- 
pathize, pitying the man whose heart does not leap with enthusiasm at the sight of rival males dashing through the woods like winged meteors, leaving in their wake a train of sparkling notes.

The Black-headed Grosbeak (596. Habia melanocephala), a western species, has been recorded from Michigan.

59\%. Guiraca crerulea (Linn.). Blue Grosbeak. Ad. of.-Decp blue; lores and chin black; back blackish; wings and tail black, slightly edged with blue; middle wing-coverts widely, and greater coverts narrowly tipped with chestnut-rufous. Ad. \&.--Upper parts grayish brown; in some specimens more or less blue about the head and rump and lesser wing-coverts; rump inclined to ashy; wings fuscous, the greater and middile coverts tipped with ochraceous-buff; tail fuscous, slightly margined with bluish gray ; under parts brownish cream-buff, the feathers of the breast sometimes blue at the base. Im. \&.--Resembles the o. L., $7 \cdot 00 ; \mathrm{W} ., 3 \cdot 50 ;$ 'T., $2 \cdot 75 ;$ B., $\cdot 65$.

Range.-United States; breeds from about latitude $38^{\circ}$ southward into Mexico; winters south of our limits.

Washington, very uneommon S. R., May 1 to Sept. 30. Cambridge, A. V., one instance, May.

Nest, of grasses, in bushes or high weedy growths. Eggs, three to four, pale bluish white, $\cdot 84 \times \cdot 65$.

"Unless seen under the most favorable circumstances the adult male does not appear to be blue, but of an ill-defined, dusky color, and may easily be mistaken for a Cow Blackhird (Molothrus ater), unless most carefully watched; besides, they usually sit motionless, in a watchful attitude, for a considerable length of time, and thus easily escape observation.

"The Blue Grosbeak frequents much the same localities as those selected by the Indigo Bird and Field Sparrow-viz., the thickets of shrubs, briers, and tall weeds lining a stream flowing across a meadow or bordering a field, or the similar growth which has sprung up in an old clearing. The usual note is a strong, harsh ptchick, and the song of the male is a very beautiful though rather feeble warble, somewhat like that of the Purple Finch, but bearing a slight resemblance also to that of the Rose-breasted Grosbeak" (Ridgway).

598. Passerina cyanea (Lim.). Indigo Buntina; Indigo-biri). $A d$. o.--Rich blue, deeper on the head, brighter on the back; lores blackish; wings and tail black, margined with blue. $A d$. \&.-Upper parts uniform grayish brown without streaks; wings and tail fuscous, sometimes lightly margined with bluish; wing-coverts margined with grayish brown; under parts whitish, washed with grayish brown and indistinctly streaked with darker; belly whiter. Im.-Resembles the 8 , but is darker. $A d$. of in winter.-Resembles the $\&$, but has more or less blue in the plumage. L., 5.59 ; W., $2.58 ;$ 'T., $2 \cdot 11 ;$ B., $\cdot 41$. 
Remarks. - The female of this species is rather a puzzling bird, and may be mistaken for a Sparrow. Its unstreaked back and the slight tinge of blue generally present on the outer web of the wing-and tail-feathers should serve to distinguish it.

Range.--Eastern United States; breeds as far north as Minnesota and Nova Scotia; winters in Central America.

Washington, common S. R., A pl. 28 to Oct. 15. Sing Sing, common S. R., May 4 to Oct. 17. Cambridge, rather common S. R., May 15 to Sept. 25.

Nest, of grasses, bits of dead leaves, and strips of bark, lined with fine grasses, rootlets, and long hairs, generally in the croteh of a bush near the ground. Eggs, three to four, pale bluish white, $\cdot 73 \times \cdot 57$.

In walking among clumps of bushes in clearings or old pastures. look sharp if a small brown bird flies before you, especially if she calls cheep and twitches her tail nervously from side to side. Though she be a sparrowy-looking bird, look well to her shoulders and tail. If you discover a glint of blue and her eries call her mate, you will ever after be a more trustworthy observer-for his brilliant coat is unmistakable.

Having made sure of your birds, watch them to their nest-a compactly made cup-too cleverly hidden in the dense green thicket to be easily discovered. The color of the eggs will again test your accuracy of observation; in varying lights they look green, blue, and white.

The female Indigo is so suspicious that it is hard not to be vexed with her, but the primary virtues of an observer are conscientiousness and patience; so take your hard cases as a means of grace.

However distrustful the poor mother bird is, her mate's cheery son $x$ makes up for it all. After most birds have stopped singing for the year, his merry voice still gladdens the long August days.

I well remember watching one Indigo-bird who, day after day, used to fly to the lowest limb of a high tree and sing his way up from branch to branch, bursting into jubilant song when he reached the topmost bough. I watched him climb as high into the air as he could, when, against a background of blue sky and rolling white clouds, the blessed little songster broke out into the blithest round that ever bub. bled up from a glad heart.

Florence A. Merriam.

The Varied Bunting (600. Passerina versicolor), a species of our Mexican border, has been once recorded from Michigan.

601. Passerina ciris (Limu.). Panted Bunting; Nonpareil. Ad. 8.- Head and sides of the neck indigo-blue; back golden green; rump dull red; under parts bright red; wings and tail tinged with dull red; greater wing-coverts green. $A d . \& .-$ Upper parts bright olive-green; under parts white, washed with greenish yellow; wings and tail fuscous, margined with olive-green. I., $5 \cdot 25 ;$ W., $2 \cdot 70 ;$ T., $2 \cdot 15 ;$ B., $\cdot 42$.

Range.-Breeds from the Gulf States northward to Kansas, southern Illinois, and North Carolina; winters in the tropies. 
Nest, similar to that of $P$. cyanea, in bushes or low trees. Eggs, three to four, white or bluish white, with numerous chestnut or rufous-brown markings, $.78 \times .56$.

Mr. Maynard found this species in southern Florida in January, but it does not migrate northward until about May 1. He writes that it " is always shy and retiring, seldom appearing in the open, but remaining in the dense, thorny undergrowth which covers all waste places in Florida, especially if the soil has been cultivated. Whenever the birds perceive an intruder they retire into the depths of these fastnesses, and it requires considerable beating to drive them out, when they at once dart into the nearest cover. The adult males are especially shy, and seldom show themselves. Even while singing they remained concealed. and, although we were thus furnished with a clew to their whereabouts, it was with the utmost difficulty that we caught sight of the author's of the harmonious strains which nearly always greeted our ears when we were in the vicinity of their homes" (Birds of Eastern North America.)

"I'heir notes very much resemble those of the Indigo-bird, but lack their energy and are more feeble and concise" (B., B., and R.).

The Grassquit (603. Euetheia bicolor) and the Melodiovs Grassquit (603.1. E. canora), West Indian species, have each been recorded once from the Florida Keys.

604. Spiza americana (Gmel.). Dickcissel; Biaci-thronten Bunting. Ad. o.-Head and sides of the neck ashy gray; forehead tinged with yellow; a yellow line over the eye and one on the side of the throat; a black pateh on the throat; chin white; breast yellow, spreading down on to the white belly; back streaked with black and pale grayish brown; rump brownish ash; lesser wing-coverts rufous; wings and tail fuscous. $A d$. \&.Similar, but the head grayish brown, streaked with blackish, and with no black patch on the throat

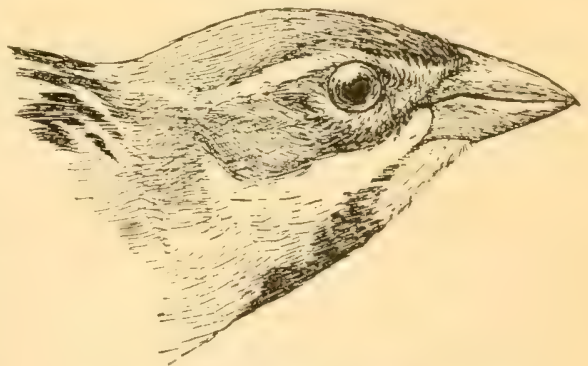

Fig. 88.--Dickcissel. (Natural size.) and less yellow on the breast, which is sometimes lightly streaked with black. Ad. in fall.-Much brighter, and with some rufous in the back. L., $6 \cdot 00 ;$ W., $3 \cdot 20 ;$ T., $2.35 ;$ B., 55 .

Range.-Eastern United States, mostly in the Mississippi Valley; breeds from Texas to Minnesota; winters in Central and South America; breeds east of the Alleghanies now only rarely and locally.

Washington, very rare S. R., a few seen each year; formerly "very abundant." Cambridge, casual, found nesting at Medford, June 9, 1877, where 
several birds were observed; not uncommon in 1833-'34 (see Bull. Nutt. Orn. Club, iii, 1878, pp. 45, 190).

Nest, bulky, of coarse grasses and leaves, lined with finer grasses and sometimes long hairs, on the ground or in low trees or bushes. Eggs, four to tive, pale blue, $\cdot 80 \times \cdot 60$.

Thirty to forty years ago these birds were more or less common in the middle Atlantic States, but they are now of rare occurrence east of the Alleghanies. In T'exas I have seen them migrating in closely massed flocks of several hundred individuals, all silent, except for an occasional cack. They alight on the prairie to feed; birds in the rear are constantly arising and passing to the front; there is ceaseless motion.

In the summer Dickcissel makes his home in grassy fields and pastures, and from a weed stalk or bordering fence, with uplifted head, he announces his presence as though life itself depended on his rocal exertions. It is a poor song from a musical standpoint, but pleasing because of the singer's earnestness:

The Lark Bunting (605. Calamospiza melanocorys), a western species, has been recorded from Massachusetts, Long Island, and South Carolina.

\section{Family Tanagrid}

The Tanagers form a distinctively American family, and are most abundant in the tropies. About three hundred and fifty species are known, of which only five reach the United States. They are remarkable, as a whole, for the brilliancy of their plumage, and our Scarlet Tanager is therefore no exception to the rule.

They are arboreal and for the most part forest-inhabiting, feeding on flowers, fruit, and insects. The tropical species are of a roving disposition, and wander through the forests in search of certain trees bearing ripe fruit, near which they may always be found in numbers.

As a rule they are not musical. A few species have more or less pleasing songs, but the voices of the majority are weak and squeaky.

$$
\text { KEY TO TIE SPECIES. }
$$

$A$. With red in the plumage.

a. Wings and tail black. . . . . 608. Scarlet Tanager 8 .

b. Wings and tail like the body. . . . 610. Summer Tanager 8 .

- $B$. Without red in the plumage.

a. Under parts, including under wing-coverts, dull buffy yellow.

610. Summer TaNager \%

b. Under parts greenish yellow, under wing-coverts white.

608. Scarlet 'Tanager 9. 
608. Piranga erythromelas Vieill. Scarlet Tanager. (See Fig. 48.) $A d$. o. - Bright scarlet, wings and tail black, under wing-coverts white. $A d$.. .-Upper parts light olive-green; wings and tail fuscous, lightly margined with olive-green; under parts greenish yellow. Im. o and $A d$. o in winter.-Similar to the $\&$, but wings and tail black. L., $7 \cdot 25$; W., $3 \cdot 75$; 'T., 2.09 ; B. from N., 46.

Range.-Eastern North America; breeds from southern Illinois and Virginia to Manitoba and New Brunswick; winters in Central and northern South America.

Washington, common T. V., rare S. K., Apl. 28 to Oct. 7. Sing Sing, eommon S. R., May 4 to Oct. 9. Cambridge, rather common S. R., May 12 to Oct. 1.

Nest, of fine twigs and weed stalks, lined with vine tendrils and blossom stems, generally near the end of a horizontal limb, seven to twenty feet up. Eygs, three to four, pale bluish white or greenish blue, with numerous rufous or rufous-brown markings, $\cdot 88 \times \cdot 68$.

In watching birds, there are certain sights and sounds that make a day memorable much as a beautiful sunset does. I say to myself, "I have seen a Scarlet Tanager to-day!" or, "I have listened to a Hermit Thrush this evening."

High among the tree tops of the cool green woods the Tanager sings through the summer days. Hidden by the network of leaves above us, we often pass him by; but once discovered he seems to illuminate the forest. We marvel at his color. He is like a Bird of Paradise in our northern landscape.

We are first guided to him by his cali and song. They are peculiar, and both have a rare woods flavor. The call is a distinctly uttered chip-chirr. The song is a loud, cheery, rhythmical carol, suggesting the song of the Robin.

Inside the green woods the Tanager spends the summer, flying down to visit his nest in the fresh young undergrowth or to bathe in the still forest pools, and hunting and singing in the tree tops high overhead.

Florence A. Merriam.

610. Piranga rubra $(\operatorname{Linn}$.). Scmuer Tanager. Ad. 8.-Rosered, brighter below; wings fuscous, margined with rose-red. $A d$. ㅇ.-Upper parts orange olive-green; under parts yellowish orange. Im. $\delta$.- -Resembles the o. L., $7 \cdot 50 ; W ., 3 \cdot 75:$ T., $2.90 ;$ B. from N., 55 .

Range.-Eastern United States; breeds from Florida to southern New Jersey, wandering casually to Nova Scotia; winters in Central and South America.

Washington, uneommon S. R., Apl. 28 to Sept. 15.

Nest, of leaves, strips of bark, etc., generally near the extremity of a limb, about twenty feet up. Egys, three to four, bluish white or greenish blue, with numerous cinnamon- or olive-brown markings, $\cdot 96 \times \cdot 68$.

This is a common summer resident of our Southern States, arriving in Florida early in April. It frequents open, rather than dense woods, 
and is particularly numerous in pineries having an undergrowth of oaks. It may be easily identified, not alone by its color but by its unique call-note-a clearly enunciated chicky-tucky-tuck. Its song bears a general resemblance to that of the Scarlet 'Tanager, but to my ear is much sweeter and less forced.

The Louisiana Tanager (60\%. Piranga ludoviciana), a species of our Western States, has been recorded from Massachusetts, Connecticut, and New York.

\section{Family Hirundinid $æ$. Swallows.}

About eighty species of Swallows are known. They are distributed throughout the world. In their long, powerful wings and small, weak feet Swallows present an excellent illustration of the effects of use and disuse. The greater part of their day is passed on the wing, and in alighting they select a perch which they can grasp with ease.

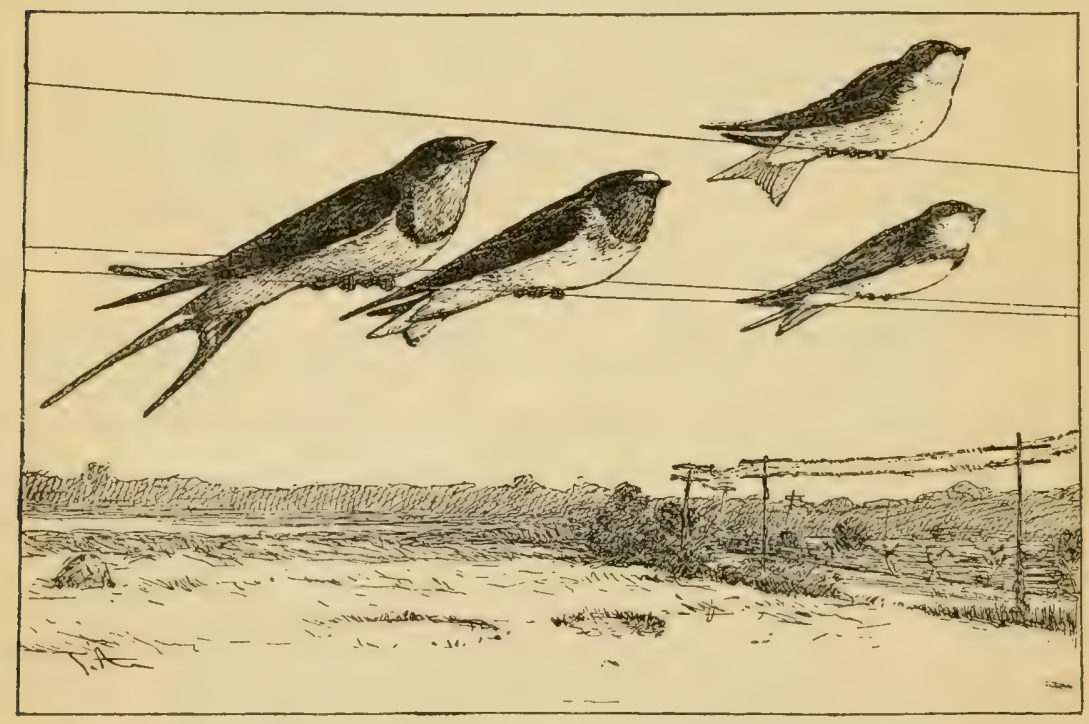

FIG. 89,-Barn Swallow. Cliff Swallow.

Tree Swallow.

Bank Swallow.

Swallows live almost exclusirely upon insects, which they capture on the wing, their large mouths, as in the case of the Swifts and Goatsuckers, being especially adapted to this mode of feeding.

They nest both in pairs and colonies, and during their migrations associate in countless numbers at regularly frequented roosting places or migration stations, which are sometimes in trees, but more often in marshes, and to which they regularly return each night. They migrate, as far as known, entirely by day, their wonderful power of flight enabling them to escape the dangers which beset less rapid fliers. 
KEY TO THE SPECIES.

A. Upper parts with metallic reflections.

a. Under parts steel-blue.

$a^{1}$. Feathers on the belly fuscous at the base - 611. Purple Martin \&

$a^{2}$. Feathers on the belly white at the base. 611.1. Cuban Martin of.

b. Throat chestnut, rufous, or brownish.

$b^{1}$. Upper tail-coverts the same as the back; tail with white spots.

613. Barn Swallow.

62. Upper tail-coverts rufous or buffy; no white in the tail.

c. Throat gray or white.

612. Cliff Swallow.

$c^{1}$. Entire under parts white. . . . . . 614. Tree Swallow.

$c^{2}$. Throat and breast brownish gray . . . 611. Purple Martin.

$c^{3}$. 'Throat, breast, and sides sooty brownish gray.

$B$. Upper parts without metallie reflections.

611.1. Cuban Martin.

a. Under parts entirely white. . . . . . 614. Tree Swallow.

b. Throat and breast brownish gray . . 617. Rough-winged Swallow.

c. 'Throat and belly white; a brownish gray band across the breast.

616. Bank Swallow.

611. Progne subis (Linn.). Pirple Mantin. Al. o.-Shining blue-black; wings and tail duller. Ad. $\%$.-Upper parts glossy bluish black, duller than in the $\delta$; wings and tail black; throat, breast, and sides brownish gray, more or less tipped with white; belly white. im.-Resembles the $\&$. L., 8.00; W., 5.80: 'T., 2.90 ; B. from N., 32.

Range.-North America, north to Newfoundland and the Saskatchewan; breeds throughout its range; winters in Central and South America.

Washington, rather common S. R., Apl. 12 to Sept. 5. Sing Sing, tolerably common S. R., Apl. 27 to Sept. 11. Cambridge, locally common S. R., A pl. 20 to $\mathrm{Aug} .25$.

Nest, of straws, twigs, ete, in houses or gourds erected for the purpose. Eggs, four to five, white, $1.00 \times \cdot 73$.

The Purple Martin is very common throughout the south, and breeds wherever gourds or boxes are erected for its occupation. In the Northern States it is a comparatively rare bird of local distribution, and is apparently decreasing in numbers each year.

In Forest and Stream, vol. xxii, 1884, p. 484, Mr. Otto Widmann, of Old Orchard. Missouri, presents an interesting table showing how often young Martins are fed. Me watched a colony of sixteen pairs of birds from 4 A. . . to 8 P.M., during which time the parents visited their offspring $3,2 \%$ times, or an average of 205 times for each pair. The males made 1,454 , the females 1,823 visits.

611.1. Progne cryptoleuca Baim. Cirin Martin. dil. o."Similar to $P$. subis, but feathers of ventral region marked beneath surface, with a broad spot or bar of white." Ad. \& and $\mathrm{im}$. $\delta$.- Similar to those of 
$P$. subis, but "whole under portion and sides of head and reck, chest, sides, and flanks uniform sooty grayish brown, in marked contrast with pure white of belly, anal region, and under tail-coverts. L., 7.60; W., 5.50; T., $3 \cdot 10 "$ $($ Ridgw.).

Kange.-Southern Florida south to Cuba and probably Central America. Nesting similar to that of $P$. subis.

A common summer resident in Florida from Pasco County southward, arriving in March. It resembles $P$. subis in habits.

612. Petrochelidon lunifrons (Say). Cliff Swallow; Eave Swallow. $A d$.-Forehead whitish, crown steel-blue, throat and sides of the head chestnut; a brownish gray ring around the neck; breast brownish gray, tinged with rufous and with a steel-blue patch in its center; belly white; back steel-blue, lightly streaked with white; shorter upper tailcoverts pale rufous; tail fuscous, the feathers of nearly equal length. Im.Similar, but upper parts duller ; throat black, sometimes mottled with white. L., 6.01 ; W., 4.34 ; T., $2 \cdot 01$; B. from N., 20 .

Remarks.-The Cliff Swallow may be known from our other Swallows by its rufous upper tail-coverts.

Range.-North America, north to Labrador, and, in the interior, to the Arctic Ocean; breeds throughout its range; winters in the tropics.

Washington, rare S. R., Apl. to Sept. Sing Sing, common S. R., May 1 to Sept. 12. Cambridge, S. R., much less common than formerly, Apl. 28 to Sept. 1.

Nest, of mud, generally retort-or pocket-shaped, beneath clifts or the eaves of a barn or other building. Eggs, four to five, white, with numerous spots of cinnamon-, olive-, or rutous-brown, $\cdot 81 \times \cdot 55$.

During the nesting season these Swallows are of very local distribution. They will return year after year to their rows of mud tenements beneath the eares of some barn or outbuilding, and, although familiar birds to residents of the immediate vicinity, they may be entire strangers to those who have never had a colony of these birds settled near them.

Like Barn Swallows, they are masons, and they may be seen on muddy shores rolling the little pellets of clay which enter into the construction of their nest.

In the fall they are found in flocks with other Swallows, but at all times they may be readily identified by their pale rufous upper tailcoverts, which make a conspicuous field-mark.

The Cuban Cliff Swallow (612.1. Petrochetidon, fulva) has been once recorded from the Dry Tortugas, Florida (Scott, Auk, vii, 1890, p. 265).

613. Chelidon erythrogaster (Bold.). BARN SWALLow. Ad.Forehead, throat, and upper breast chestnut-rufous; rest of the under parts washed with the same color; upper parts steel-blue; tail deeply forked, all but the middle feathers with white spots on their inner webs. Im.-Upper 
parts mixed with dusky, forehead and throat paler: outer tail-feathers shorter. L., 6.95 ; W., 4.67 ; T., 3.30 ; B. from N., $\cdot 24$.

Range.-North America, north to Greenland and Alaska; breeds throughout the greater part of its range; winters as far south as southern Brazil.

Washington, common S. R., more abundant 'T. V., Mch. 28 to Sept. Sing Sing, common S. R., Apl. 15 to Sept. 22. Cambridge, common S. R., but fast decreasing, Apl. 20 to Sept. 10.

Nest, of mud and grasses, lined with grasses and feathers, generally on the rafter of a barn or other building. Eggs, four to six, white, with numerous spots of cinnamon-, olive-, or rufous-brown, generally smaller than the eggs of $P$. lunifrons, $77 \times 54$.

Barn Swallows nest both in pairs and colonies, and during the breeding season are more generally distributed than any of our Swallows. Almost every old-fashioned barn with its great doors hospitably opened is cheered by their sweet call-notes and happy twittering song as they dart in and out on their errands of love.

Barn Swallows take first rank among a family of birds famous for their power of flight. While their relatives are circling about feeding on insects in the air above, they capture their prey nearer the ground, skimming low over the fields, turning quickly to right or left, up or down, and pursuing their erratic course with marvelous ease and grace.

614. Tachycineta bicolor (Fieill.). Tree Swallow; WhiteBELLied Swallow. Ad.-Upper parts steel-blue or steel-green; under parts pure white; outer tail-feathers somewhat longer than the middle ones. Im. -Upper parts brownish gray; under parts pure white. L., 5.90; W., 4.70; T., 2.35 ; B. from N., 22.

Range.-North America, north to Labrador and Alaska; breeds locally throughout its range; winters from South Carolina southward.

Washington, common T. V., Apl. 1 to May 25 ; July 10 to Sept. Sing Sing, common T. V., Apl. 4 to May 26; Aug. 4 to Oct. 16. Cambridge, S. R., formerly commion, now common only as a migrant, Apl. 5 to Oct. 12.

Nest, of coarse grasses and feathers, in a hollow tree or bird-box. Eggs, four to seven, white, $\cdot 74 \times \cdot 55$.

While our eastern Barn and Eave Swallows have abandoned their primitive methods of nesting in caves or beneath cliffs, and the Bank Swallows still adhere to the customs of their ancestors, Tree Swallows are passing through a transition period in their history. Some accept the houses or boxes erected by man as substitutes for the holes in trees or stumps which others still use.

Near New York city they are the first birds to flock after the nesting season, and they begin to gather in our marshes as carly as July 1. Their numbers rapidly increase, and the maximum of abundance is reached about August 15, when they outnumber all other Swallows together by at least three to one. They return to their roosts in the 
reeds with great regularity every night, and early in the morning fly out over the country to feed. Their flight in the evening is comparatively low, at an average height of thirty to forty feet. They sail about in circles more than other Swallows, and many pause to rest on telegraph wires, where their pure white breasts easily distinguish them from the Swallows which may be associated with them. In the morning their flight is much higher and more direct. They migrate by day, leaving their roosting ground in flocks, which sometimes contain myriads, and, after attaining a great height, pursue their journey to the south. When migrating along the coast they sometimes collect in large numbers in bayberry bushes (Myrica cerifera) and feed on their fruit.

The Bahama Swallow (615.1. Callichelidon cyaneoviridis) has been once recorded from the Dry 'Tortugas, Floricla, and may oecur more or less regularly in the keys off southeastern Florida (Scott, Auk, vii, 1890, p. 265).

616. Clivicola riparia (Limu.). Bank Swallow. Ad.-Upper parts brownish gray; throat white; a brownish gray band on the breast; outer vane of first primary without recurved hooklets; a small tuft of feathers above the hind toe. L., $5 \cdot 20 ; \mathrm{W} ., 3 \cdot 95 ;$ T., $2 \cdot 00 ;$ B. from N., $\cdot 18$.

Range.-North America, north to Labrador and Alaska; breeds locally throughout its range; winters as far south as Brazil.

Washington, common S. R., more common T. V., Apl. 15 to Sept. 25. Sing Sing, common S. R., Apl. 18 to Oct. 1. Cambridge, common S. R., Apl. 28 to Sept. 1:

Nest, of grasses and feathers, in a hole in a sand bank, two to three feet from the entrance. Eggs, four to six, white, $\cdot 68 \times \cdot 48$.

This is a locally distributed species breeding in colonies only where sand banks offer it a favorable nesting site. Probably for the reason that such banks are more frequently found bordering streams than inland, the birds are more numerous in the vicinity of water.

Bank Swallows may be readily known from other Swallows, excepting the Rough-winged, by their nesting habits, small size, and absence of metallic coloring.

From the Rough-wing they differ in having the under parts white, with a conspicuous band across the breast, and in their somewhat quicker movements.

61\%. Stelgidopteryx serripennis $(A u d$.$) . Rol'H-TINGED SwAL-$ Low. $A d$.-Upper parts brownish gray; throat and breast pale brownish gray; belly white; outer web of first primary with a series of recurved hooklets; no tuft of feathers above the hind toe. Im.-Similar, but without recurved hooklets on the first primary; throat and breast more or less washed and wing-coverts edged with rufous. L., $5.75 ; \mathrm{W} ., 4 \cdot 35 ;$ 'T., $2 \cdot 10: \mathrm{B}$. from N., $\cdot 19$. 
Range.-North America; breeds as far north as British Columbia, Minnesota, and Connecticut; winters in the tropics.

Washington, common S. R., Apl. 5 to Sept. Sing Sing, common S. R., Apl. 17 to Aug. 12 .

Nest, of coarse grasses and feathers, under bridges, in stone walls, or a hole in a bank. Eggs, four to eight, white, $72 \times 5 \overline{1} 1$.

Rough-winged Swallows resemble Bank Swallows both in habits and appearance. 'They do not, however, always nest in holes in banks, but are sometimes founa nesting about bridges, railway trestles and their abutments.

With the Bank Swallow this bird differs from our other Swallows in the absence of metallic colors, while from the

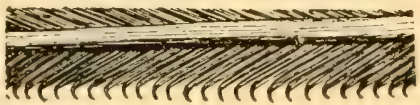

FIg. 90.-Section of outer primary of adult Rough-winged Swallow. (Enlarged.) Bank Swallow it is to be distinguished by its plain, pale brownish gray, uniformly colored throat and breast, and somewhat slower, less erratic flight.

\section{FAmily Ampelid Ae. Waxwings.}

This small family contains the two known species of Waxwings, with which some ornithologists class several peculiar American tropical species whose exact relationships are not thoroughly understood.

618. Ampelis garrulus (Limn.). Bonemin Waxwing. Ad.Forehead, chin, and line through the eye.velvety black; a conspicuous crest; front of crown chestnut-rufous; upper parts rich grayish brown; upper tailcoverts, wings, and tail grayish; primary coverts and secondaries tipped with white, the latter with small, red, seed-shaped sealing-wax-like tips; all but the outer primaries tipped with yellow or white on the outer web; end of tail with a yellow band; breast like the back, grayer on the belly; under tailcoverts chestnut-rufous. L., $8 \cdot 00$; W., $4 \cdot 60 ;$ T., $2 \cdot 60$ : B. from N., 29.

Range.-Northern parts of the northern hemisphere; in North America south in winter, irregularly, to the northern United States; recorded from as far south as Kansas, Illinois, and Pennsylvania.

Nest, of twigs, roots, moss, etc., in trees. Eggs, similar in color to those of A. cedrorum, $92 \times \cdot 65$.

The distribution of this bird in the United States is not unlike that of the Evening Grosbeak. It is exceedingly rare and irregular in the Atlantic States, but occurs with some frequency in the northem Mississippi Valley. In notes and habits it is said to resemble its small cousin, the Cedar Waxwing.

619. Ampelis cedrorum (Tirill.). CEDAI WAXTING; CEDAR-13IRD; Cherry-Bird. (See Fig. 50.) Ad.-Forehead, chin, and a line through the eye velvety black; a conspicuous erest; upper parts rich grayish brown; upper 
tail-coverts, wings, and tail gray ; secondaries, and sometimes tail, with small, red, seed-shaped, sealing-wax-like tips; tail with a yellow band at its end; breast like the back, changing gradually into yellowish on the belly; under tail-coverts white. L., $7 \cdot 19$; W., 3.70; T., $2 \cdot 37$; B. from N., 26.

Range.-North America; breeds from Virginia and the highlands of South Carolina north to Labrador; winters from the northern United States to Central America.

Washington, very common P. R., less so in winter. Sing Sing, common P. R. Cambridge, not common P. R., common S. R., abundant 'T'. V. in spring, Feb. 1 to Apl. 25.

Nest, bulky, of strips of bark, leaves, grasses, twigs, rootlets, moss, and sometimes mud, lined with finer materials of the same nature, in fruit or shade trees, five to twenty feet up. Eggs, three to tive, pale bluish gray or putty color, distinctly and obscurely spotted with black or umber, $\cdot 88 \times \cdot 62$.

When the spring migration is over and the home birds have gone to nest-building, small flocks of Goldfinches and Waxwings-two peculiarly gentle, attractive birds-may still be seen wandering about the country. The squads of Cedar-birds fly evenly, on a level with the tree tops, in close ranks, often of five, seven, or nine. Frequently, when under full headway, they suddenly wheel and dive down to an apple tree for a meal of canker worms.

In following the beautiful Waxwings about one listens in vain for a song, but soon comes to relish their two peculiar calls-a hushed whistle and the subrlued call Thoreau describes as their "beady note," a succession of short notes strung together-for they both seem to harmonize with the quiet reserve of the delicately tinted birds.

In July, when the wandering flocks are no longer seen, a walk through the neighboring orchards may show where both tardy builders have at last gone to nesting, and few bird homes afford pictures of such human tenderness and devotion. If there is an evergreen in the vicinity, the Ceclar-bird mounts guard upon its tip, but occasionally relieves the monotony of his watch by flying up in the air for light luncheons of passing insects.

'The strong individuality of the Waxwings make them interesting birds to the field student. The use of their crests in expressing emotion, and the protective attitudes they assume when watched at their nests, throw much light upon bird psychology.

To the bird-lover, however, the Cedar-birds have their own attraction; their proverbially gentle, refined ways make them scem superior creatures of the air to whom he can but yield his affection.

I shall never forget a pair that I once found by a clear mountain lake. They were perched upon two evergreen spires that guarded a silent bay, whose dark water was gilded by the lingering light of the setting sun.

Florexce A. Merriam. 


\section{Family Lanidd}

The Shrikes, numbering about two hundred species, are largely confined to the Old World. Only two species are found in America, both member's of the subfamily Laniince or true Shrikes. Their characteristic habits are described under their respective names.

621. Lanius borealis Fieill. Northern Shrike; Butcher-bird. $A d$.-Upper parts gray; wings and tail black; primaries white at the base, secondaries tipped with white or grayish; outer, sometimes all, the tailfeathers tipped with white, the outer feather mostly white; forehead whitish; lores grayish black; ear-coverts black; under parts white, generally finely barred with black; bill hooked and hawklike. Im.-Similar, but entire plumage more or less heavily barred or washed with grayish brown. L, 10.32; W., 4.5̌ ; T., 4.00; B. from N., ,55.

Range.-Breeds in the interior in the far north (Fort Anderson, MacFarlane), and migrates southward in winter as far as Kansas and Virginia.

Washington, rare and irregular W. V.; Nov, to Feb. Sing Sing, tolerably common W. V., Oet. 26 to Apl. 17. Cambridge, common W. V., Nov. 1 to Apl. 1.

Nest, of twigs, grasses, ete., in low trees or hushes. Eggs, similar in color to those of $L$. ludovicianus, $1.05 \times 76$.

This bird may be known at once by his colors-gray, black, and white-by the consternation his appearance causes among the Sparrows, and by his peculiar flight, which is steady and straightforward, with much flapping, and close to the ground till he nears his intended perch, which is reached at the last moment by a sudden upward turn.

He is so well known as a bird of hawklike, sanguinary character that most students are astonished when they find out that toward springtime he develops into a vocalist of no mean powers. Often in the warm days of March he may be heard singing on the top of some tail tree, a song that would do credit to a Catbird-indeed, it recalls strongly that loquacious songster. He is, I think, a better singer than his southern cousin, but resembles him in habitually impaling his prey on a thorn, a fence barb, or a forked twig. His food consists chiefly of mice, noxious insects, and the equally noxious English Sparrow, so that the Shrike is a bird worthy of all protection.

\section{Ernest E. Thompson.}

622. Lanius ludovicianus Linn. LoggfneAd SHRIKe. (See Fig. 51.) $A d$.-Upper parts gray, wings and tail black, primaries white at the base, secondaries tipped with white; outer, sometimes all, the tailfeathers tipped with white; the outer feather mostly white; lores black, connected by a narrow black line on the forehead at the base of the bill; ear-coverts black; under parts white, sometimes tinged with gray. L., 9.00; 
W., 3.82 ; 'I., 3.87 ; B. from N., 48 ; depth of B. at N., 35 (average of nine Florida specimens).

Komarks.-Specimens from the Mississippi Valley, western Pennsylvania, New York, and northern New England average lighter in color and have, as a rule, smaller bills than specimens from the south Atlantic States. They are thus intermediate between ludovicianus and excubitorides, but the differences between them are too slight and inconstant to warrant me in including excubitorides on the basis of specimens which are quite as near ludovicianus as they are to typical examples of the western form.

Range--Eastern North America west to the edge of the plains; breeds, east of the Alleghanies, as far north as Virginia; west of the Alleghanies breeds northward to the Great Lakes and eastward through central New York to Vermont and Maine.

Washington, rare W. V., Aug. 11 to Apl. 6. Sing Sing, A. V. Cambridge, rare in fall and winter.

Nest, of strips of bark, small twigs, and vegetable fibers, lined with grasses, in thorny hedges or low trees, about seven feet up. Eggs, three to five, dull white or creamy white, thickly marked with cinnamon-brown and lavender, $98 \times 78$.

Like some of the Hawks and Flycatchers, the Loggerhead does not search for his prey, but waits for it to come within striking distance. It is of importanee, therefore, that his perch should command an uninterrupted view of his surroundings. For this reason one rarely or never sees a Shrike in a tree, but always on its ontermost or highest branches. He will fly directly toward its center, but just as he reaches it swing up and light on its top. He also selects telegraph wires, peaks of houses, and especially the apex of a lightning rod or weather vane.

From his point of vantage he maintains a constant outlook for any unsuspecting grasshopper, small snake, or lizard which may appear below. 'The distance at which he can detect these gives evidence of his power of sight. I have seen Shrikes fly fifty yalds with the evident object of capturing a grasshopper which they undoubtedly saw before starting.

Like the Butcher-bird, the Loggerhead frequently impales its prey on a convenient thorn or spike. Doubtless this habit aids him in dissecting his food, but I do not think that he does it for this reason alone. 'The bird's vigilance, like that of the waiting IIawk, is probably attended by varying results. One hour may yield excellent returns, the next may be fruitless. But under any circumstances he can not resist taking advantage of an opportunity to secure food. Sometimes the opportunities exceed the demands of his stomach, and then, after capturing his unfortunate victim, he simply impales and leaves it.

If perseverance deserved success, the Loggerhead would take high rank as a songster. But his notes are harsh and unmusical. They 
consist of a series of guttural gurgles, squeaky whistles, and shrill pipes, some of which might be attributed to the creaking weather vanes he so often chooses as a perch.

\section{FAMily Vireonid A. VIREOS.}

The Virecs, numbering about fifty species, are peculiar to America, most of them being confined to Central and South America. Some fifteen species, all belonging to the genus Vireo, reach the United States.

Vireos are for the most part arboreal, though several species haunt the lower, rather than the higher growth. For small, insect-eating birds they are rather slow in their movements. We do not see them darting out after insects as do the Flycatchers, nor do they flit through the foliage after the manner of many Warblers, but patiently glean their food from the under surfaces of leaves, crevices in the bark, etc. They are more musical than the small Warblers; all our species have pleasing songs, and some of them are especially gifted.

KEY TO THE SPECIES.

A. With distinct white or yellowish white wing-bars.

a. Eye-ring, or line from eye to bill, yellow.

$a^{1}$. Throat and breast bright yellow; rump gray.

628. Yellow-thronted Vireo.

$a^{2}$. Under parts white or whitish; sides and sometimes breast washed with greenish yellow; rump olive-green.

631. White-Eyed Vireo. 631a. Key West Vireo.

b. Eye-ring and line from eye to bill white.

$b^{1}$. Head lead-blue; wing over 250 .

629. Blue-headed Vireo. 629a. Mountain Vireo.

62. Head grayish, nearly like back; wing under 2.50).

B. Without white wing-bars.

633. BelL's VIREO (Illinois).

a. Under parts yellowish; first primary as long as fifth.

626. Philadelpiita Vireo.

b. Under parts white; sides washed with yellowish; first primary 75 long.

627. Watbling Vireo.

c. Under parts white, with little if any yellowish on sides; head with a lead-gray cap, bordered by narrow black lines over the eye.

624. Red-eyed Vireo. 623. Black-Whiskered Vireo.

623. Vireo calidris barbatulus $(r a b$.$) . BLACK-THISKERED$ Vireo. Ad.-Similar to the next species, but somerwat duller above and with a fuscous streak on either side of the throat.

Range.-Cuba, Bahamas, and southern Florida; southward to Central America in winter.

Nest, pensile, of dry grasses, shreds of bark, cotton, lichens, and spiders? web, lined with soft, cottonlilie fibers, suspended from a forked branch, fivo 
to twenty fect up. Eggs, three to four, white, with a pinkish hue, speckled and spotted, chiefly at the larger end, with reddish brown, $78 \times \cdot 55$.

'This is a not uncommon summer resident in southern Florida, arriving from its winter home in Central America early in May. Its song resembles that of the Red-eyed Vireo, but is somewhat more hesitating and emphatic.

624. Vireo olivaceus (Linn.). RED-EYED VIREo. Ad.-Crown slaty gray, bordered on either side by blackish; a conspicuous white line over the eye; rest of the upper parts, wings, and tail light olive-green; no wing-

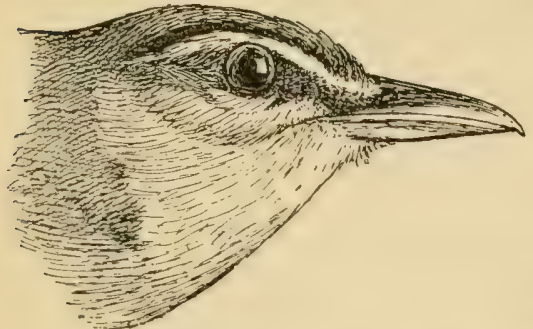

FIG. 91.-Red-eyed Vireo. (Natural size.) bars ; under parts pure white. L., 6.23 ; W., $3 \cdot 20$; T., $2 \cdot 20$; B. from N., 40 .

Remarks.-The well-defined slatygray cap, bordered by narrow black lines, are the best distinguishing marks of this species.

Range.--Eastern North America; westward to British Columbia; breeds from the Gulf States to Labrador and Manitoba; winter's in Central and South America.

Washington, very common S. R., Apl. 25 to Oct. 15. Sing Sing, common S. R., Apl. 29 to Oct. 19. Cambridge, abundant S. K., May 10 to Sept. 10.

Nest, pensile, of strips of bark, bits of dead wood, paper, and plant down, firmly and smoothly interwoven, lined with finer strips of bark and vine tendrils, suspended from a forked branch, five to forty feet up. Eggs, three to four, white, with a few black or umber specks or spots about the larger end, $.85 \times \cdot 55$.

'This, the most common and generally distributed of our Vireos, is found alike in the shade trees of our lawns, in orchards, or woodlands. The conspicuous white line over the eye, with its black border, and the bird's red eye, are good characters by which to distinguish it f:om its relatives.

Wilson Flagg's description of the Red-eye to my mind exactly reflects the character of the bird and its song: "The Preacher is more generally known by his note, because he is incessant in his song, and particularly vocal during the heat of our long summer days, when only a few birds are singing. Ilis style of preaching is not declamation. Though constantly talking. he takes the part of a deliberative orator, who explains his subject in a few words and then makes a pause for his hearers to reflect upon it. We might suppose him to be repeating moderately, with a pause between each sentence, "You see it-you know it-do you hear me?-do you believe it?' All these strains are delivered with a rising inflection at the close, and with a pause, as if waiting for an answer." 
The Yellow-green Vimeo (625. V.flavoviridis), a Mexican and Central American species, has been once recorded from Godbout, Province of Quebec.

626. Vireo philadelphicus (Cass.). Philadelpina Vireo. Ad.Upper parts light olive-green; the crown sometimes grayish; a whitish line over the eye; wings and tail edged with olive-green; no wing-bars; first primary nearly as long as second; entire under parts nearly uniform pale, greenish yellow. L., 4.75 ; W., $2 \cdot 60$; 1'., 1.95; B. from N., 26.

Remarks.-The pale, greenish-yellow color spread almost uniformly over the entire under parts distinguishes this bird from our other Vireos.

Range.-Eastern North America; breeds in Manitoba, Maine, and probably north to Labrador; and winters in the tropies.

Washington, very rare 'T. V., May 17. Sing Sing, rare T. V., Sept. 20 to Oct. 20. Cambridge, very rare T. V. in Sept.

Nest, pensile, of fine grass and birch bark, suspended from a forked branch about eight feet from the ground. Eggs, four, similar in color to those of $r$. olvvaceus (Thompson).

This species resembles the Red-eyed Vireo in habits, and Mr. Brewster writes that its song is so nearly identical with the song of that species " that the most critical ear will, in many cases, find great difficulty in distinguishing between the two. The notes of philadelphicus are generally pitched a little higher in the scale, while many of the utterances are feebler and the whole strain is a trifle more disconnected. But these differences are of a very subtile character, and, like most comparative ones, they are not to be depended upon unless the two species can be heard together. The Philadelphia Vireo has, however, one note which scems to be peculiarly its own, a very abrupt, doublesyllabled utterance with a rising inflection, which comes in with the general song at irregular but not infrequent intervals. I have also on one or two occasions heard the male when in pursuit of his mate utter a soft pseno, similar to that sometimes used by Fireo olivaceus, and both sexes when excited or angry have a harsh, petulant note exactly like that of $V$.gilvus" (Bull. Nutt. Orn. Club, v, 1881, p. 5).

62\%. Vireo gilvus (Tieill.). W ARBLIN⿴囗VIrEo. Al.-Upper parts ashy olive-green; no wing-bars; wings and tail edged with the color of the back; first primary very short, not more than 1.00 in length; under parts white slightly washed with yellowish. L., $5 \cdot 80$; W., $2 \cdot 85 ;$ T', $2 \cdot 14 ;$ B. from N., 30 .

Range.-North Amer-

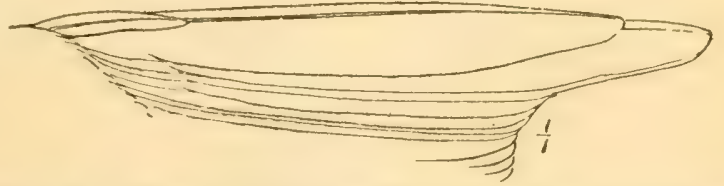

Fia. 92.-Wing of Warbling Vireo, to show short first primary.

ica; breeds as far north as the Hudson Bay region; winters in the tropics.

Washington, rather common S. R., Apl. 28 to Sept. 10. Sing Sing, tolera- 
bly common S. R., May 3 to Sept. 18. Cambridge, common S. R., May 10 to Sept. 25.

Nest, pensile, of grasses and plant fibers, firmly and smoothly interwoven, lined with fine grasses, suspended from a forked branch eight to forty feet up. Eggs, three to four, white, with a few specks or spots of black, umber, or rufous-brown, chiefly about the larger end, $76 \times \cdot 55$.

Unlike its cousin, the Preacher, the Warbling Vireo is not generally distributed, but shows a decided preference for rows of shade trees, particularly rows of elms. It passes the greater part of its time in the upper branches, and is more often heard than seen.

Although resembling the Red-eye in general appearance, its song is so different that singing birds need never be mistaken for that species. Instead of the Red-eye's broken, rambling recitative, the song of the Warbling Vireo is a firm, rich, continuous warble with a singular alto undertone.

628. Vireo flavifrons rieill. Yellow-thronted Vireo. Ad.Upper parts bright olive-green, changing to gray on the rump and upper tailcoverts; greater and middle wing-coverts tipped with white, forming two distinct wing-bars; outer web of inner seconduries white; eye-ring, throat, and breast bright yellow; belly white. L., 5.95 ; W., 3.05 ; T., 2.10 ; B. from N., $\cdot 36$.

Range.-Eastern North America; breeds from Florida to Newfoundland and Manitoba; winters in the tropics.

Washington, common S. R., Apl. 20 to Sept. 15. Sing Sing, tolerably common S. R., Apl. 30 to Sept. 7. Cambridge, common S. R., May 8 to Sept. 1.

Nest, pensile, of strips of bark, plant fibers, etc., interwoven, lined with fine grasses and covered externally with lichens, suspended from a forked branch ten to thirty feet up. Eggs, three to four, white, with a few specks or spots of black, umber, or rufous-brown, chiefly about the larger ends, $.80 \times \cdot 60$.

The Yellow-throated Vireo is a dweller in tree tops, and whether in woodland, orchard, or lawn, he seldom comes below the upper story of his home. But even at a distance his bright yellow breast is a conspicuous mark, at once distinguishing him from other members of his family.

If the Red-eyed Vireo is a soprano, the Yellow-throat is a contralto. He sings much the same tune, but his notes are deeper and richer, while they are uttered more deliberately and with greater expression than those of his somewhat too voluble cousin. "See me; I'm here; where are you?" he calls, and at intervals repeats his question in varying forms. Sometimes he astonishes us by an intricate liquid trill which suggests the wonderful song of the Ruby Kinglet, but which unfortunately is sometimes marred by the scolding notes that precede or follow it. 


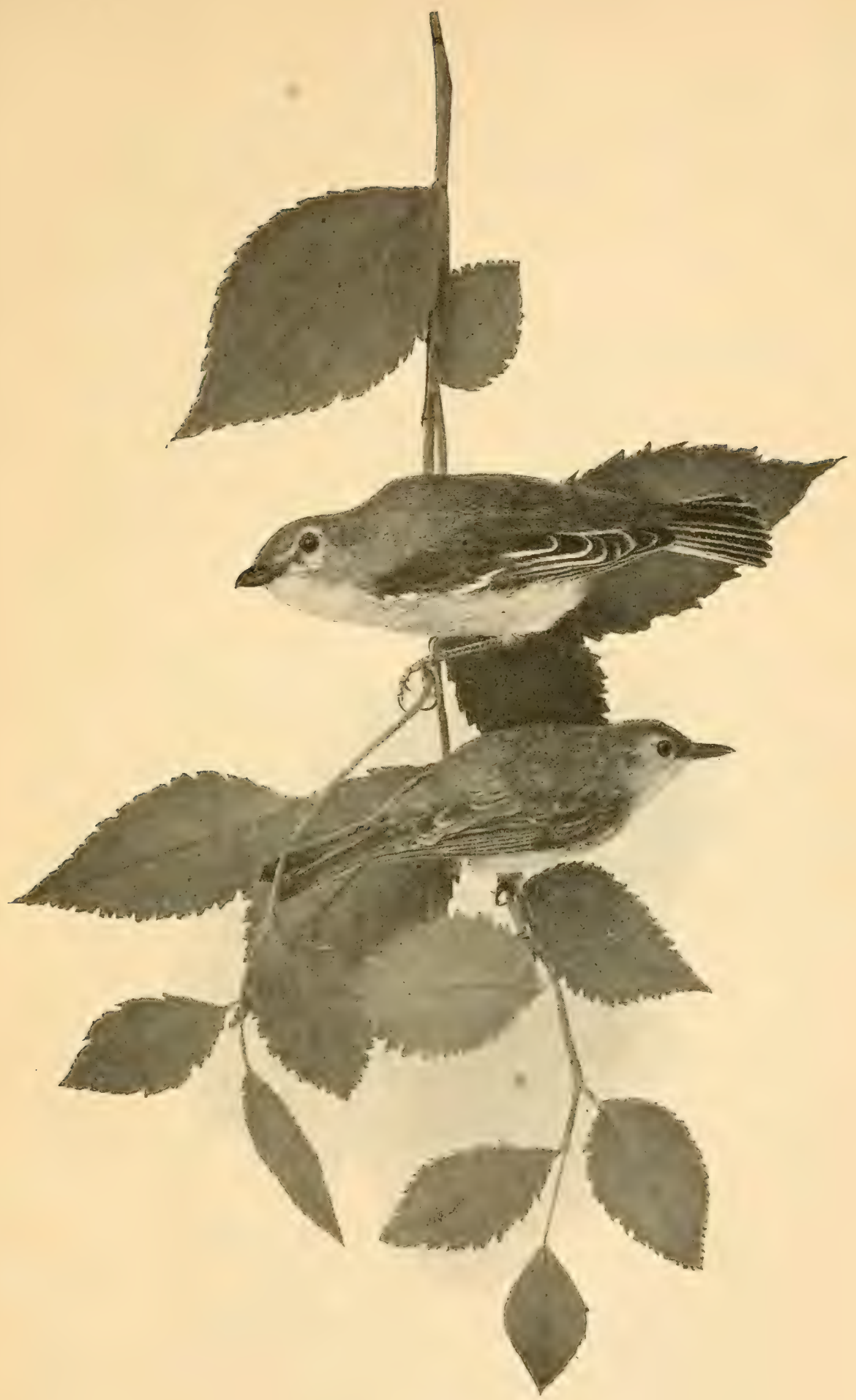

Yellow-throated Vireo.

Warbiting Vireo. 

629. Vireo solitarius (Wils.). Blechended Vireo. (Sce Fin. 52.) $A d$. -Top and sides of the head bluish gray; eye-ring and lores white; back olive-green; greater and middle wing-coverts tipped with white, forming two distinct wing-bars; outer web of inner secondaries white; under parts white; sides washed with greenish yellow. L., $5 \cdot 61 ;$ W., $2.96 ;$ 'Г., $2 \cdot 15 ; 13$. from N., $\cdot 28$.

Remarks. - This species may be known by its white lores and eye-ring, and bluish-gray cheeks and crown.

Range.-Eastern North America; breeds from Connecticut (and southward along the crest of the Alleghanies) northward to New Brunswick and Nanitoba; winters from Florida south ward.

Washington, common T. V., Apl. 10 to May 10; Sept. to Oct. 26. Sing Sing, tolerably common 'T. V., Apl. 23 to May 14; Sept. 8 to Oct. 20. Cambridge, common T. V., rather rare S. R., $\Lambda$ pl. 25 to Oct. 5.

Nest, pensile, of pine needles, plant down, etc., firmly interwoven, suspended from a forked branch tive to ten feet up. Eggs, three to four, white, with a few specks or spots of black, umber, or rufous-brown, chiefly at the larger end, $\cdot 80 \times 55$.

This large and handsome Vireo-a bird of the woods-is the first of its family to reach the Northern States in the spring and the last to depart in the autumn. Like its congeners, but unlike birds in general, it sings at its work. In form its music resembles the Red-eye's, the Philadelphia's, and the Yellow-throat's; but to me it is more varied and beautiful than any of these, though some listeners may prefer the Yellow-throat for the richness and fullness of its "organ tone." The Solitary's song is matchless for the tenderness of its cadence, while in peculiarly happy moments the bird indulges in a continuous warble that is really enchanting. It has, too, in common with the Yellowthroat, a musical chatter-suggestive of the Baltimore Oriole's-and a pretty trilled whistle. Its most winning trait is its tameness. Wood bird as it is, it will sometimes permit the greatest familiarities. 'Two birds I have seen which allowed themselves to be stroked in the freest manner while sitting on the eggs, and which ate from my hand as readily as any pet canary; but $I$ have seen others that complained loudly whenever I approached their tree. Perhaps they had had sad experiences.

BRADFORd TORREY.

A single specimen of the Plumbeos Vireo (699b. $\quad$. $. s . p l u m b e u s)$, a western species, has been taken at Peterboro, N. Y. (Miller, Auk, xi, 1894, p. 79).

629c. V. S. alticola Brenst. Morntain Sol.ttare Vireo.-Similar to the preceding, but with a much larger bill, and the back generally with more or less slaty blue. W., 3.15; T., $2 \cdot 25$; B. from N., $\cdot 35$; depth of B. at N., $\cdot 20$.

liamge.-Higher portions of the Alleghanies in North and South Carolina; southward in winter to Florida. 
This race of the Blue-hearled Vireo is a common summer resident in the southern Alleghanies (see Loomis, Auk, viii, 1891, p. 329).

631. Vireo noveboracensis (Gmel.). WhitE-Eyed V'IREo. Ad.Upper parts, including upper tail-coverts, bright olive-green, more or less washed with grayish; greater and middle wing-eoverts tipped with yellowish white, forming two distinct wing-bars; outer web of inner secondaries whitish; lores and eye-ring yellow; throat white or whitish; belly white; breast and sides washed with greenish yellow; iris white, hazel in the young. L., $5 \cdot 2 \tau$; W., 2.37; 'T., 1.95; B. from N., 29.

Range.-Eastern United States; breeds from Florida to New Hampshire and Minnesota; winters from Florida southward.

Washington, common S. R., Apl. 20 to Oct. 7. Sing Sing, common S. R., Apl. 29 to Oct. 3. Cambridge, rather rare S. R., May 8 to Sept. 20 ; formerly common.

Nest, generally similar to that of $V$. olivaceus, suspended from a forked branch in thickets. Eggs, three to four, white, with a few specks of black, umber, or rufous-brown at the larger end, $\cdot 75 \times \cdot 55$.

If birds are ever impertinent, I believe this term might with truth be applied to that most original, independent dweller in thickety undergrowths, the White-eyed Vireo. Both his voice and manner say that he doesn't in the least care what you think of him; and, if attracted by his peculiar notes or actions, you pause near his haunts, he jerks out an abrupt "Who are you, eh?" in a way which plainly indicates that your presence can be dispensed with. If this hint is insufficient, he follows it by a harsh scolding, and one can fancy that in his singular white eye there is an unmistakable gleam of disapproval.

I have always regretted that the manners of this Vireo hare been a bar to our better acquaintance, for he is a bird of marked character and with unusual vocal talents. He is a capital mimic, and in the retirement of his home sometimes amuses himself by combining the songs of other birds in an intricate potpourri.

631a. V. n. maynardi Brewst. KeY West VIreo.-Searcely distinguishable in color from the preceding, but averaging somewhat paler and less yellow below, and with a larger bill. L., $5 \cdot 12 ;$ W., $2 \cdot 40 ;$ T., $2 \cdot 12 ; \mathrm{B}$. from N., $\cdot 35$.

Range.-Southern Florida.

This closely related race of the White-eyed Vireo is a common permanent resident in southern Florida.

633. Vireo belli Aud. BeLL's Vireo. Ad.-Crown ashy gray, changing to olive-green on the rump; greater and middle wing-coverts narrowly tipped with white; lores and eye-ring whitish; under parts white, breast and sides washed with greenish yellow. L., 4.75; W., 2.20; T., 1.80; B. from N., $\cdot 28$. 
Range.-Interior of North America, from Texas north to Minnesota, east to Illinois.

Nest, pensile, of strips of bark and plant fibers firmly and smoothly interwoven, lined with finer grasses, etc., in bushes or low trees. Eggs, four to six, white, with a few specks of black, umber, or rufous-brown at the larger end, $\cdot 66 \times \cdot 50$.

This is a common bird in its range, and is locally not uncommon as far east as Illinois." "In their food, habits, and actions they are very similar to the White-eyed. 'Their call- and alarm-notes are not quite so harsh, and their song is delivered in a less emphatic manner; an indescribable sputtering, that does not rank it high in the musical scale" (Goss).

The Bahana Honey Creeper (635. Coreba bahamensis) was found by Dr. Würdemann in January, 1858, on Indian Key, southeastern Florida, but has not, to my knowledge, been taken by subsequent observers. The upper parts are sooty black, the rump and middle of the under parts yellow, and a line over the eye, the throat, and the lower belly are white or whitish; length about 4.50 .

\section{Family Mniotiltid Ae. Wood Warblers.}

The Wood Warblers are found only in America, and are most numerously represented in eastern North America. About one hundred species are known, of which seventy visit the United States, while the remaining thirty are tropical.

With three or four exceptions they are inhabitants of woodland, but during their migrations may be found in the trees of lawns or orchards. They feed almost exclusively upon insects, and are thus highly migratory, thousands of miles frequently separating their summer and winter homes.

The majority are among the last of the spring arrivals; their coming caps the climax of the migration, and the first severe frost leaves but few with us. They migrate by night, and are chief among the victims of lighthouses and electric-light towers. When migrating, they are generally found in straggling companies composed of a number of species, which during the day travel slowly through the woods from tree to tree.

They capture their insect food in a variety of ways. Some species flit actively from branch to branch, taking their prey from the more exposed parts of the twigs and leaves; others are gleaners, and carefully explore the under surfaces of leaves or crevices in the bark; while several, like Flycatchers, capture a large part of their food on the wing. As a rule, they are arboreal, but many are thicket-haunting, and some are terrestrial. 
Several species have remarkable vocal ability, but, generally speaking, they have rather weak voices, and take low rank as songsters.

Warblers are at once the delight and the despair of field students. To the uninitiated their existence is unknown, and when search reveals the before unsuspected fact that our woods are thronged with birds as exquisitely colored as the daintiest tropical forms, we feel as though a new world were opened to us.

A bsent to-day, present to-morrow, the Warblers come and go under cover of the night, and we may give a lifetime to their study, and then know we have not mastered the laws which govern their movements.

Entering an apparently deserted bit of woods, we hear faint voices, lisping tseeps, and soon discover that the tree tops are animated with flitting forms. What limitless possibilities there are in a flock of Warblers! Who can say what rare species may be among them ?-perhaps the bird we have long vainly looked for; perhaps a stranger from another clime!

$$
\text { KEY TO THE SPECIES. }
$$

First Group.-Throat yellow, yellowish, or orange.

I. Under parts without streaks or spots.

II. With black or brown streaks on the breast or sides, or (in one species) a blackish brown band across the throat, or (in one species) a black patch on the breast.

Second Group.-Throat black, gray, ashy, white, whitish, brown, or buffy.

I. Throat and upper breast one color, black, gray, ashy, or brown, very different from the white or yellow belly.

II. 'Throat white or whitish, with or without streaks or spots; rest of under parts streaked or spotted with black, bluish, chestnut, or yellow.

III. Under parts white, whitish, or buffy, without streaks, spots, or patches.

$$
\text { First Group. }
$$

\section{Under parts without strealss or spots.}

1. Tail with conspicuous white spots or patches.

$A$. Wings with white wing-bars.

$a$. Under parts entirely pure yellow.

$a^{1}$. Forehead yellow; a black line through the eye; rump same as back . . . . . . 641. BLUE-WINGED WARBLER. $a^{2}$. Crown ashy; rump yellow - 657. Magnolia Warbler (Im.).

b. Throat bright yellow; belly white or whitish.

b1. Back olive-greenish . . . . 671. Pine Warbler. $b^{2}$. Back bluish, with a yellowish patch in the middle.

648. Parula Warbler ( $\operatorname{Im}_{\text {. }}$.

c. Under parts pale yellowish white or buffy; throat not brighter than belly.

$c^{1}$. Back olive-green, slightly streaked with black.

$c^{2}$. Under parts pale cream-buff, stronger on the flanks.

660. Bay-breasted Warbler (Im.). 
$c^{3}$. Under parts pale yellowish white.

661. BlaCK-POLL WARBler (Im.). d1. Back olive-green, without streaks. - 671. Pine Warbler 8 . $e^{\gamma}$. Back with a bluish tinge and without streaks.

B. Without white wing-bars.

658. Cervlean Warbler (Im.).

a. Under parts bright orange or orange-yellow; wings, tail-coverts, and tail bluish gray. . . . . 637. Prothonotary Warbler.

b. Under parts pure yellow; wings, rump, and tail greenish; head sometimes blackish; inner web of outer tail-feathers white.

684. HoOded WARBLER ( $q$ and im.).

c. Under parts pale yellowish; head ashy: rump olive-green; small white tail-spots, not reaching to ends of feathers.

640. Bachuan's Warbler ( $\&$ and im.).

d. Under parts pale vellowish; entire upper parts olive-green; a white spot at the base of the primaries.

654. Black-throated Blue Warbler .

2. Tail without white spots or patches; wings without white wing-bars.

A. Cap, or forehead, or cheeks black or blackish.

a. Cap black; forehead and cheeks yellow.

685. WilsoN's WARBLER.

b. Band on the forehead and eheeks black or blackish; no yellow line over the eye. . . 681. Maryland Yellow-throat of. 681b. Flotida Yellow-throat of .

c. Forehead or crown and cheeks black or blackish; a clear yellow line over the eye . . . . . . . 677. Kentuckr Warbler.

$B$. No black on forehead; crown ashy, of a very different color from the olive-green back, or with the bases of the crown feathers rufousbrown or chocolate.

a. Crown plain ashy; tunder tail-coverts white.

640. BaCmMAN'S W ARBLER.

b. Crown ashy; bases of feathers chestnut; eye-ring distinctly white; most of under parts and under tail-coverts bright yellow.

645. Nashville Warbler.

c. Crown of nearly the same color as the back; the feathers with rufous-brown bases; under parts dull greenish yellow.

646. Orange-Crowned Warbler.

$C$. Crown of the same color as the back; forehead the same, or yellowish, or brownish.

a. Under parts bright yellow.

a1. Upper parts bright olive-green; forehead yellowish; short bristles at base of bill; tail greenish brown.

685. WiLson's WARBLER (Im.).

$a^{2}$. L pper parts bright greenish yellow; inner web of tail-feathers yellow . . . . . . . . 652. Yellow Warbler \&. $a^{3}$. Upper parts ashy greenish; eye-ring white.

645. Nashtille Warbler (Im.).

b. Throat and breast yellow; belly white or whitish. 
$b^{1}$. A black spot before the eye and a white line over it; wing 3.00 . 683. Yellow-Breasted Chat.

$b^{2}$. Legs flesh-color; outer tail-feathers shortest; forehead sometimes brownish . . . 681. Maryland Yellow-throat. 681b. Florida Yellow-throat .

$b^{3}$. Legs blackish; tail-feathers even; wing under 3:00.

645. Nashyille Warbler (Im.).

c. Under parts uniform yellow or yellowish.

$c^{2}$. Under parts dull greenish yellow, obscurely streaked with dusky; back ashy greenish.

646. ORANGE-CROWNED WARBLER (Im.).

$c^{2}$. Under parts yellowish or buffy yellowish; outer tail-feathers decidedly shortest; legs flesh-color.

681. Martland Yellow-throat $\$$. 681b. FLORIDA YELLOW-TIIROAT $\%$;

$c^{3}$. Breast somewhat yellower than rest of under parts; flankis brownish; legs blackish; tail-feathers of same length.

645. Nashville Waibler (lm.).

$c^{4}$. Inner margins of tail-feathers yellow.

652. YELLOW WARBLER $\%$

$c^{5}$. Back bright olive-green; under tail-coverts white.

647. Tennessee Warbler (Im.).

$c^{6}$. A small white spot at the base of the primaries.

654. Black-throated Blue Warbler \&.

\section{With black or brown streaks on the breast or sides, or (in one species) a blackish brown band across the throat, or (in one species) a black patch on the breast.}

1. Under parts streaked with rufous-brown.

A. Crown chestnut.

a. Entire under parts rich yellow - 672a. Yellow Palm Warbler.

b. Throat and breast bright yellow; belly yellowish white.

672. Palm Warbler.

$B$. No chestnut crown-cap.

a. Under parts yellowish white; eye-ring yellowish.

672. PalM Warbler (Im.).

b. Under parts yellow, washed with brownish; eye-ring yellowish.

672a. Yellow Palm W arbler (Im.).

c. Under parts bright yellow; forehead yellow; inner webs of tailfeathers yellow. . . . 652. Yellow Warbler (Ad.).

2. Under parts streaked or spotted with black.

A. Back unspotted, the same as the head, olive-green or olive-brown.

a. Under parts pale sulphur-yellow, streaked with black; no wingbars; wing 3.00 or over.

675. Water Thrush. 675a. Grinnell's Watrr Thrush.

b. Under parts bright yellow; no black streaks on the flanks; wing nearly 3.00 . . . . . . . . . 6r1. Pine Warbler.

c. Under parts bright yellow; sides streaked with black; wing about 2.00. . . . . . . 673. Pralrie Warbler ( $q$ and im.). 
d. Throat pale yellow, indistinctly spotted or streaked; belly whitish; cheeks bright yellow; outer web of outer tail-feather white at the base.

667. Black-throated Green Warbler (Im.).

e. Throat and breast yellow, distinctly spotted; median wing-coverts white . . . . .650. Cape May Warbler ( $q$ and im.).

$B$. Back streaked or spotted with black, or center of crown orange.

a. Under parts pale yellow; black spots confined to sides; no white wing-bars . . . . . . . 670. Kirtland's Warbler.

b. Under parts pale yellow, indistinctly streaked with blackish; two white or whitish wing-bars.

661. Black-Poll Warbler (Im.).

c. Throat orange or yellow, without streaks; ear-coverts gray or black; center of crown yellowish or orange.

662. Blackburnian Warbler.

d. Under parts streaked with black; ear-coverts rufous; cap black.

650. Cape May Warbler.

e. Head bluish gray or ashy; rump bright, yellow; eye-ring white; white tail-spots not reaching to ends of feathers.

657. Magnolia Warbler.

C. Back ashy gray.

a. Throat yellow; belly white; wing-bars and tail-spots white. $a^{1}$. A yellow line from the bill to the eye.

663. Yellow-throated Warbler. $a^{2}$. A white line from the bill to and over the eye.

663a. Sycamore W ARBLER.

b. Entire under parts yellow; breast with a neeklace of black spots ; no wing-bars or tail-spots . . . 686. Canadian W Arbler.

D. Center of back brick-red; under parts yellow; sides streaked with black. . . . . . . . . . 673. Pratrie Warbler.

3. Throat yellow; breast with a band of copper or blackish chestnut; upper parts blue; center of back greenish yellow.

648. Parula Warbler.

4. Throat and forehead yellow; breast and crown-cap black.

640. BACHMAN'S W ARBLER.

Second Group.

\section{Throat and upper breast one color, black, gray, ashy, or brown, very different from the white or yellow belly.}

A. Belly white or whitish.

a. Back gray or greenish gray, crown yellow, cheeks black or gray, wing-bars yellow . . . . 642. Golden-winged WARbLer.

b. Back and crown bright olive-green, cheeks yellow, wing-bars white. . . . . . 667. Black-thro.ten Green Warbler.

c. Back and crown dark blue, a white spot at the base of the primaries. 
d. Back streaked with gray and black; cap, throat, and sides chestnut. 660. BAY-BREASTED WARBLER of.

e. Back streaked with black and white, a white line through the center of the crown . . . 636. Black and White Warbler of. $f$. Back black; sides, center of wings, and base of tail salmon-red.

687. Redstart o .

B. Belly yellow.

a. Throat black.

$a^{1}$. Cheeks bright yellow, black crown-cap connected with black throat by a black line, end half of inner web of outer tail-feathers white............ 684. Hooded Warbler. $a^{2}$. Cheeks dull greenish yellow, black crown-cap not connected with black throat, white tail-spots not reaching to the ends of feathers . . . . . . . 640. Bachuan's Warblel. $a^{3}$. A black streak through the eye, wing-bars white.

$641+642$. Lawrence's Warbler.

b. Throat bluish gray, ashy, or brownish.

$b^{1}$. A white eye-ring . . . . 678. Connecticet Warbler.

$b^{2}$. No white eye-ring. . . . . 679. Mourning Warbler.

\section{Throat white or whitish, with or without streaks or spots; rest of the under parts spotted or streaked with black, bluish, chestnut, or yellow.}

A. Back streaked with black.

a. With chestnut streaks on the sides, under tail-coverts white. $a^{1}$. Wing over 250 , head with chestnut or black streaks or spots, wing-bars white . . . 660. Bay-Breasted Warbler \&. $a^{2}$. Wing under 250 , head and wing-bars yellow or yellowish.

659. Chestnut-sided Warbler.

b. With black or bluish streaks on the sides or entire under parts.

b1. Cap solid black. . . . 661. BLACK-POLL WARbLer \&. $b^{2}$. Crown, rump, and sides of the breast with a yellow patch or spot.

655. Mrrtle Warbler.

$b^{3}$. Cap black, with a white streak through the center.

636. Black aND White Warbler ?. $b^{4}$. Crown olive-green, with small black streaks.

661. Black-Poll Warbler \&.

$b^{5}$. Crown blue, a bluish-black band across the breast.

658. Cerulean Warbler \& .

$b^{6}$. Crown brownish, under tail-coverts yellow.

672. Palm Wareler (Im.).

$B$. Back without streaks or spots.

a. With white or yellow spots in the tail.

$a^{1}$. Wing-bars white, cheeks yellow, back greenish.

667. Black-throated Green Warbler (Im.).

$a^{2}$. Wing-bars, cheeks, and back grayish, under tail-coverts white.

650. Cape May Warbler ( $\$$ and im.).

$a^{3}$. Back brownish, under tail-coverts yellow.

672. Palu Warbler (Im.). 
$a^{4}$. Sides of breast, band in wings, and base of tail yellow.

b. Without white or yellow spots in the tail.

687. REDstart ( $\%$ and im.).

b1. A pale rufous streak bordered by black through the center of the crown . . . . . . . . 674. OveN-BIRD.

62. A white line over the eye, throat generally without spots, wing over $3 \cdot 00$, bill over 50 . . . 676. Louisiana WAter-'Turush.

$b^{3}$. $\Lambda$ buffy line over the eye, throat with small black spots, wing under 3.00 , bill under 50 . . . . . 675. WAter-Thrush.

$675 \alpha$. Grinnell's Water-'Thrish.

\section{Under parts white, whitish, or buffy, without streaks, spots, or patches.}

A. Tail with white or yellow spots or patshes.

a. Wing-bars white or grayish.

$a^{1}$. Under parts pure white, back greenish yellow, cheeks gray, wing under 2.50 . . 659. Chestnut-sibed Warbler (Im.). $a^{2}$. Under parts tinged with buffy, back and cheeks olive-green, with generally distinet black streaks, wing over 2.50 .

660. Bay-breasted Warbler (Im.).

$a^{3}$. Under parts soiled whitish, back brownish or grayish green, eyering white, wing-bars grayish, wing over 250 .

671. Pine Warbler ( $\&$ and im.).

a. Under parts white, back streaked with pure black and white.

636. BLACK AND White Warbler ?.

b. Wing-bars yellowish, greenish, or absent.

$b^{1}$. Back and head bright greenish yellow, cheeks gray, under parts pure white. . . 659. Chestnut-sided Warbler (Im.).

62. Back, head, and cheeks yellowish green, under parts yellowish, inner margins of tail-feathers yellow.

652. Yellow Warbler (Im.).

$b^{3}$. Back gray or grayish, a black line through the eye.

$641+642$. Brew'WTER's W ARBLER.

64. Back and head brownish, wings and base of tail with a yellow band . . . . . . . . 687. Kedstart ( $\&$ and im.).

65. Back bright green, head and cheeks grayish, a small black spot in front of the eye . . . . 647. Tennessee Warbler of .

$B$. Tail without white or yellow spots or patches.

a. Under tail-coverts yellow.

$a^{1}$. Back olive-green, outer tail-feathers shortest, legs flesh-color.

681. Maryland Yellow-throat ( $q$ and im.).

681b. Florida Yeliow-throat.

$a^{2}$. Back grayish olive-green, tail-feathers of equal length, legs blackish . . . . . . 646. OraNge-Crowned WARBLER.

万. Under tail-coverts white or whitish.

b. Head plain brown, a whitish line from the bill over the eye.

638. SwaIson's WARBLER.

b2. Center of crown and line from the bill over the eye buffy, bordered by black stripes . . . 639. Woru-EATING WARBLER. 
$b^{3}$. Crown greenish, a small white spot at the base of the primaries almost concealed by wing-coverts.

654. Black-tiroated Blue Warbler ( $q$ and im.).

$b^{4}$. Crown grayish, bend of the wing yellow.

640. BaChMAN's Warbler .

\section{A Field Key to THe}

\section{Adult Male Warblers of Eastern North AMierica iN Spring and Summer Plumage.}

I. Throat yellow, white, or whitish; under parts without streaks or patches.

II. Throat black, brown, or slate-color.

III. Throat yellow or orange, under parts with streaks. (In one species a blackish-brown band across the breast.)

IV. Throat white or whitish, with streaks or spots on the under parts. (In two species a yellow patch on the sides of the breast.)

\section{Throat yellow, white, or whitish; under parts without streaks or patches.}

1. Throat yellow.

$A$. Length over 6.00 , the largest of the Warblers; haunts dense thickets in second growth; song, a peculiar mixture of whistles, chucks, and crow-calls, delivered from the undergrowth, from the trees above, or on the wing, when the bird resembles a bunch of falling leaves . . . . . . 683. Yellow-breasted Chat.

$B$. Length under $6 \cdot 00$.

a. Head and neck bright golden yellow like the breast; tail-feathers white, except at the tip; haunts near the water, especially low bushes and willows hanging over streams and ponds; call, a sharp peek; range, from Virginia southward.

63\%. Prothonotary Warbler.

b. Forehead and cheeks black, a yellow line over the eye; song, a low whistled eall of five to seven notes; haunts near the ground; ranga from lower Hudson Valley southward.

677. KeNTUCKY WARBLER.

c. Forehead and cheeks black, bordered by grayish; no line over the eye; haunts undergrowth; call, a frequently repeated chack; song, a loud, rapid I beseech you, I beseech you, I beseech you, or witch-e-wè̀-o, witch-e-wè-o, witch-e-wè-o; movements restless ; abundant . . . . . 681. Maryland Yellow-throat. 681b. Florida Yellow-thront (Fla.).

d. Head and back olive-green; wings with two white bars; outer tail-feathers white; haunts pine woods; song, a musical trill.

671. Pine Warbler.

e. Crown bluish ash, eye-ring white; call-note sometimes like the sound produced by striking two pebbles together.

645. Nashville Warbler. 
$f$. Forehead yellow, a small black mark in front of the eye; wings with two white bars; outer tail-feathers white; song, sweè-chee,

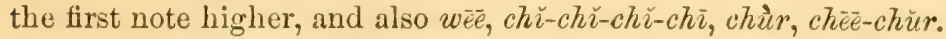

641. Blue-Winged Warbler.

g. Forehead yellow; crown-cap black; cheeks yellow; wings and tail unmarked; rather rare . . . 685. WILSON's W ARBLER.

2. Throat white or whitish.

A. Length 5.00; crown brown or with blackish and buffy stripes.

a. A conspicuous whitish line through the center of the crown, bordered by black lines; not common.

639. WorM-EATING WARBLER.

b. Crown plain brown: range, North Carolina and southward.

$B$. Length 4.50 ; crown ashy or forehead yellow.

638. SWaINSON's WarBLER.

a. Forehead yellow.

$a^{1}$. Breast white, with a barely perceptible tinge of yellow; wingbars white or yellow, a black mark in front of the eye; rare.

$641+642$. Brewster's Warbler.

b. Forehead not yellow.

61. Breast white, crown plain bluish ashy, clearly defined from the bright olive-green back . . 647. Tennessfe W Arbler.

$b^{2}$. Breast whitish, tinged with yellow and indistinctly streaked with dusky; crown dull ashy, not clearly defined from the back and with a partly concealed patch of rufous-brown; very rare in the Atlantic States north of South Carolina.

646. Orange-Crowned Warbler.

\section{Throat black, brown, or slate-color.}

1. Belly white.

a. Back blue, a white spot near the outer edge of the wing; common.

654. Black-throated Blue Warbler.

b. Back green, cheeks yellow; song, a buzzlike zee repeated five or six times, the next to last note the highest; common.

667. Black-throated Green Warbler.

c. Back grayish, forehead yellow, a black mark through the eye and a white line below it; a large patch of yèllow on the wings; song, $z e e-z e e-z e e-z e e$, all on the same note: not common.

642. Golden-winged Warbler.

d. Back black; sides of the breast, middle of the wing, and base of the tail-feathers reddish orange; movements active, tail frequently spread, the reddish color showing conspicuously; abundant.

687. Redstart.

e. Back streaked with black and white; song fine and wiry; movements like those of a Creeper; common.

636. Black and White Warbler.

$f$. Back streaked with buffy and black; forehead and cheeks black; crown-cap, throat, upper part of the breast, and sides chestnut; rather rare . . . . . 660. BAY-BREAsted WARBLER. 
2. Belly yellow.

A. Throat slate-color; haunts near the ground.

a. Breast showing traces of black, no white eye-ring; rare in most places . . . . . . . . . 679. Mourning Warbler.

b. Breast with no traces of black, a white eye-ring; eall a sharp peek; very rare in the spring . . 678. Connecticut Watebler.

B. Throat black.

a. Forehead and crown yellow, wings with white bars, a black line through the eye; very rare.

$641+642$. LAwRENCE'S WARBLER.

b. Forehead and cheeks yellow, rest of the head and sides of the neck black; outer tail-feathers almost entirely white; haunts near the ground, generally in wet woods; movements active, the white tail-feathers showing conspicuously in flight; lower Hudson V alley southward; common . . . . . 684. Hooded Warbler.

c. Forehead yellow, a small black patch on the crown, white patches on the tail not reaching to the ends of the feathers; range, South Carolina southward . . . . 640. Bachman's Warbler.

\section{IIL. Throat yellow or orange, under parts with streaks. (In one species a blackish brown band across the breast.)}

1. Belly white, with or without black streaks.

a. Throat rich orange; back, black streaked with white; tolerably common . . . . . . . 662. Blackburnian Warbler.

b. Throat bright yellow, back grayish; range, Virginia southward; abundant . . . . . 663. Yellow-throated Warbler.

663a. Sycamore Warblel:.

c. Throat yellow, with a blackish band crossing the upper part of the breast; abundant . . . . . . 648. Parula Warbleir.

2. Belly yellow, with streaks or spots on the breast or sidus.

A. With black streaks or spots on the under parts.

a. Back grayish, unstreaked; a neck]ace of black spots on the breast; no streaks on the sides or white on the wings or tail; common.

686. Canadian Warbler.

b. Back black, crown grayish, a black stripe through the eye; breast and sides streaked with black; end of tail black, a white band across its middle; common . . . 657. Magnolia Warbler.

c. Back streaked with white, center of the crown and line over the eye orange . . . . . . 662. Blackburnian Warbler.

d. Back greenish, streaked with hlack: crown black, a rufous earpatch, a white patch on the wings, rump yellow; rare.

650. Cape May Warbler.

e. Back greenish, with a patch of rufous-brown; haunts second growths and old bush-grown pastures; common in sorne places.

673. Prairie Warbler.

f. Back grayish, streaked with black; crown bluish; no conspicuous white marking on the wings; very rare in the United States.

(i)0. Kirtland's Warbler. 
B. Under parts with rufous-brown streaks.

a. Crown yellow, back greenish, inner border of tail-feathers yellow; general appearance that of a yellow bird; haunts lawns, orchards, and second growths; rarely seen in deep woods; abundant . . . . . . . . . 652. Yellow Warbler.

b. Crown chestuut, back brownish, outer tail-feathers tipped with white; haunts near the ground, frequently seen along roadsides and in old fields; movements leisurely, constantly wags its tail; common . 672. Palm Warbler. 672a. Yellow Palm Warbler.

\section{Throat white or whitish, with streaks or spots on the under parts. (In two species a yellow patch on the sides of the breast.)}

1. A patch of yellow on the sides of the breast.

a. Back grayish, streaked with black; rump and a partly concealed crown-patch yellow; note, a loud teleip, generally uttered during flight; abundant . . . . . . 650. Mrrthe Wander.

b. Back brown, breast more or less spotted with black; a yellow band across the middle of wings and tail; movements active, tail frequently spread, the yellow band showing conspicuously; abundant.

687. Redstart (Im.).

2. No yellow patch on the sides of the breast.

$A$. With wing-bars; back streaked with black; haunts in trees.

a. Back bright blue; very rare near the Atlantic coast.

658. Cerulein Warbler.

b. Back grayish, crown black; movements slow; abundant.

661. Black-Poll Warbler.

c. Back greenish yellow, crown bright yellow, sides chestnut; common . . . . . . . 659. Chestnut-sided W Areler.

$B$. Without wing-bars; back not streaked; haunts on or near the ground; walkers, not hoppers.

a. Crown pale rufous, bordered by black streaks : song, a loud teacher, repeated eight or nine times and increasing in volume; common.

674. OVENBIRD.

b. Crown like the back, breast with a tinge of sulphur-yellow, an inconspicuous buffy line over the eye; bill less than 50 in length ; common . . . . . . . . . . 675. Water Thrush.

c. Crown like the back, breast and particularly flanks tinged with buffy, a conspicuous white line over the eye; bill nearly 75 in length; a far shyer bird than the preceding; song loud and ringing; not common . . . . 676. Lovisiana Water 'linusi.

636. Mniotilta varia $(\operatorname{Linn}$.). BLACK AND WHITE WARHLER; BLACK and White Creeper. (Fig. 93.) Ad. 8.-No yellow anywhere; upper parts streaked with black and white; ear-coverts black; inner webs of outer tailfeathers with white patches; wing-coverts black, tipped with white; throat and upper breast black or black and white; sides streaked with black and white: middle of the belly white. Ad. \&.- Similar, but the under parts with fewer black streaks; sides washed with brownish. Im. \$.-Similar to 
the \&, but with more streaks on the under parts. L., 5.30 ; W., 2.73 ; T., 2.02 ; B. from N., 37 .

Range.-Eastern North America; breeds from the Southern States north to Fort Simpson; winters from Florida southward.

Washington, abundant T. V., less common S. R., Apl. 12 to Oct. 15. Sing Sing, common S. R., Apl. 18 to Oct. 1. Cambridge, very conmon S. R., Apl. 25 to Sept. 5.

Nest, of strips of bark, grasses, etc., lined with rootlets or long hairs, on the ground at the base of a stump, log, or rock. Eggs, four to five, white, spotted and speckled with cinnamon-brown to umber, chiefly in a wreath at the larger end, $\cdot 68 \times \cdot 54$.

None of our Warblers can be more readily identified than this conspicuously marked creeper. It is genelally distributed throughout woodland, and climbs with even more agility than a true Creeper, hanging from the under surface of branches and twigs, and flitting actively from tree to tree after apparently the most superficial examination.

It is a generally silent bird, intent on food-getting, and its thin, wiry notes, ste-see-see-see, are not frequently uttered.

- 63y. Protonotaria citrea (Bodl.). Prothonotary Warbler. Ad. o.-Whole head, neck, and under parts rich orange, lighter on the belly ; back greenish yellow, changing to bluish gray on the rump; wings and tail ashy; inner webs of all but the middle tail-feathers white, except at the tip ; no wing-bars. $A d$. \&.- Similar, but the yellow is paler, the belly with more white. L., 5.50; W., 2.90 ; T., 1.85 ; B. from N., 42 .

Range.-Eastern United States; breeds from the Gulf States to southern Illinois and Virginia; wanders casually to Maine; winters in the tropics.

Washington, of irregular occurrence in summer.

Nest, of rootlets, fine twigs, and moss, plant down or feathers, in a hole in a stub or stump, generally of a willow tree. Eggs, four to six, white, thickly and rather coarsely marked distinctly and obscurely with cimnamon-brown, chestnut, or rufous-brown, $\cdot 69 \times \cdot 56$.

This exquisite Warbler frequents bushes and low trees-particularly willow trees-hanging over the water. Its call-note so closely resembles that of a Water 'Thrush (Seiurus), I have sometimes mistaken it for that species. Its usual song, as Mr. Brewster remarks in his admirable biography* of this species, "sounds at a distance like the call of the Solitary Sandpiper, with a syllable or two added-a simple peet, tweet, tweet, tweet, given on the same liey throughout. . . . Nearer at hand, however, the resemblance is lost, and a ringing, penetrating quality becomes apparent in the Warbler's song."

To thoroughly appreciate the Prothonotary's radiant beauty, one 
should float quietly in a canoe past its haunts. Its color shows to best advantage against the dark background of its home, and its every movement is a delight to the eye.

638. Helinaia swainsonii Aud. SwaINSON's Warbler. Ad.Crown cinnamon-brown; a whitish line over the eye ; back, rump, wings, and tail olive grayish brown without white; under parts soiled yellowish white, grayer on the sides. L., $5 \cdot 00 ;$ W., $2 \cdot 75 ;$ T., $1 \cdot 90 ;$ B. from N., 46 .

Range.-Southern United States, north to North Carolina and Missouri; south in winter to the tropics.

Nest, externally of leaves, lined with pine needles and rootlets, in bushes, canes, palmettos, and clumps of vines, from three to ten feet above the ground or surface of the water. Eggs, three to four, white, with a faint bluish tinge, $.75 \times .54$ (Davie).

The history of Swainson's Warbler is very similar to that of Bachman's Warbler. It was discovered by Dr. Bachman near Charleston, South Carolina, in 1832, and for somewhat over fifty years was practically a lost species, but proves now to be a common bird in some parts of its range. Its rediscovery near Charleston by Mr. A. T. Wayne and Mr. Brewster is recounted by the latter in an article * which adequately portrays the bird, its habits and haunts. It lives on and near the ground, and, according to Mr. Brewster's cxperience, four things seem indispensable to its existence-"water, tangled thickets, patches of cane, and a rank growth of semi-aquatic plants." Its song, which is highly rentriloquial, is described by the same author as "a series of clear, ringing whistles, the first four uttered rather slowly and in the same key, the remaining five or six given more rapidly, and in an evenly descending scale. ... In general effect it recalls the song of the Water Thrush (Seiurus noveboracensis). It is very loud, very rich, very beautiful, while it has an indeseribable tender quality that thrills the senses after the sound has ceased."

639. Felmitherus vermivorus ( $G m e l$.). Wori-EATING Warbler. (Fig. 94.) Ad.-A black line from the eye to the nape, and two on the crown from either nostril; an olive-buffy line over either eye, and a third through the center of the crown; back, wings, and tail olive-green without white; under parts whitish eream-buff, whiter on the throat and belly. L., 5.51; W., $2 \cdot 78$; 'T., $2 \cdot 05$; B. from N., $: 39$.

Range.-Eastern United States; breeds from the Gulf States north to southern Illinois and southern Connecticut; winters in the tropies.

Washington, quite common S. R., Apl. 28 to Sept. Sing Sing, common S. R., May 7 to Aug. 23. Cambridge, A. V., one instance, Sept.

Nest, of rootlets, leaves, and bark, on the ground. Eggs, four to six, white, speckled, spotted, or bloteherl with einnamon- or rufous-brown, $\cdot 68 \times \cdot 54$.

* The Auk, ii. 1885 , pp. 65-80 ; see also ibid., pp. 346- 44 , and also Perry, Orn.

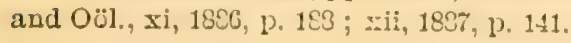


This comparatively rare, retiring Warbler may be found on dry wooded slopes, hillsides, and ravines, generally where there is a rather dense undergrowth, but occasionally where the ground is quite clear and open. It lives on or near the ground, and in its slow, deliberate actions resembles a Vireo more than the usually active Warblers. Its call-note is a sharp chip, while its song, as all observers agree, closely resembles that of the Chipping Sparrow, but is somewhat weaker.

- 640. Helminthophila bachmani (Aud.). BACHMN's W $A d$. o.-Forehead yellow, bordered by a black patch on the crown; back of the head bluish gray; back and rump bright olive-green; lesser wing-coverts yellow; tail grayish, all but the middle feathers with white patches on their inner web near the tips; throat and belly yellow, a large black patch on the breast. $A d$. o.-Crown grayish; forehead yellowish; back, wings, and tail as in the $\delta$; under parts whitish, washed with yellow on the throat and breast; bend of the wing yellow. L., $4 \cdot 25 ;$ W., $2 \cdot 40 ;$ 'T., $1 \cdot 80 ;$ B. from N., $\cdot 32$.

Range.-Southeastern United States, west to New Orleans, north to South Carolina; south in winter to Cuba, and probably Central America; accidental in Virginia.

"Nest, in low trees. Eggs, four," dull grayish white, heavily blotched with umber in the form of a broken band about the larger end, a few spots and specks of the same color, and numerous irregular, obscure lavender markings are distributed over the remaining surface, $\cdot 74 \times \cdot 60$. (Described from only known specimen, collected by Dr. S. W. Wilson on St. Simon's Island, Georgia, April 30, 1854; see Bailey, Bull. Nutt. Orn. Club, viii, 1883, p. 38.)

Bachman's Warbler was described by Audubon from a pair of birds taken by Dr. Bachman at Charleston, South Carolina, in July, 1833. Several specimens were subsequently taken in the West Indies during the winter, but over fifty years passed before the species was again found in the United States. It proves now to be a common bird in parts of its range, and has been found in large numbers near New Orleans, and on the Suwance River in Florida in March and April, and at Key West in late July and August. At each of these places, however, it has been observed only as a migrant, and its breeding home is still unknown.

Mr. Brewster and myself had excellent opportunities to study its habits on the Suwance River, and in The Auk for 1891, pp. 149-15\%, will be found a detailed account of our observations written by Mr. I3rewster. It was migrating with other Warklers, and kept to the tops of the highest trees. It is not improbable, however, that when in its breeding haunts it may prove to be a low-ranging bird like most of the members of this genus. Its movements were rather leisurely, and resembled those of $H$. pinus or $H$. celata. Its song, which only Mr. Brewster was fortunate enough to hear, is described by him as resembling the song of the Parula Warbler. 
641. Helminthophila pinus ( $\lim n_{*}$ ). Blte-WINGEI) Warbler. (Fig. 95.) $A d$. o .-Crown and entire under parts bright yellow, a black line through the eye; back and rump bright olive-green; wings and tail bluish gray; greater and middle wing-coverts tipped with white or yellowish white; outer three tail-feathers with large white patches on their inner webs, fourth feather with a much smaller patch. $A d . \&$. - Similar, but yellow on the head confined to the forehead; under parts duller. L., 4.80 ; W., 240 ; T., 1.80; B. from N., $\cdot 33$.

Remarks.-The only variation of note in the plumage of otherwise typical specimens of this species occurs in the color of the wing-bars, which in some specimens are tinged with yellow. A specimen in Mr. Brewster's collection (No. 25,511, Seymour, Conn., June 11, 1889, E. A. Eames) shows this variation carried to an extreme, and has the wing-bars as broadly yellow as in H. chrysoptera, though in every other respect it is typical pinus. Between this species and $H$. chrysoptera there exists a complete set of intergrades, which are variously called $H$. leucobronchialis and $H$. lawrencei. They are generally considered to be hybrids, and it has also been suggested that dichromatism may aid in producing their coloration. Their relationships will be found discussed under the following references: Brewster, Bull. Nutt. Orn. Club, vi, 1881, p. 218; Ridgway, Auk, ii, 1885, p. 359; Manual N. A. Birds, 1887, p. 486 .

Range.-Eastern United States; breeds as far north as southern Minnesota and Connecticut; winters in the tropics.

Washington, rather uncommon T. V., Apl. 28 to May 25; Aug. 5 to Sept.; a few breed. Sing Sing, common S. R., May 4 to Sept. 7.

Nest, of bark and leaves, lined with fine strips of bark and tendrils, and firmly wrapped with numerous leaves, whose stems point upward, on the ground, generally in or at the border of second growth. Eggs, four to six, white, thinly speckled with rufous, cinnamon-brown, or rufous-brown, $.62 \times \cdot 50$.

This species may be found in scrubby second growths, woodland borders, or even the lower trees of dense woods. Its movements are rather slow and leisurely, and, like a Chickadee, it may sometimes be seen hanging head downward while searching for food.

It is at times a rather persistent songster, and its peculiar song is not likely to be mistaken for that of any other Warbler. As a rule, it consists of the two drawled, wheezy notes swēe-chee ; the first inhaled, the second exhaled. A less common song, uttered later in the season,

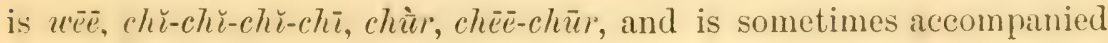
by peculiar kit notes.

Helminthophila leucobronchialis (Brewet.). BhEW BLER. Ad. of.-Forehead and fore part of the crown yellow, a black line from the bill through the eye: rest of the upper parts bluish gray; wingbars broadly yellow; tail like the back, three to four outer feathers marked with white; under parts pure white, faintly washed with yellow on the breast. Fall specimens are more heavily washed with yellow, and the upper 
parts are margined with olive-green. Ad. \&.- Similar, but wing-bars white, and crown not so bright.

Remarks.-The descriptions are from typical specimens of the puzzling bird known as Helminthophila leucobronchialis. Between it and H. pinus there are specimens showing every degree of intergradation. Typical examples are comparatively rare, and the most common form has the breast heavily washed with yellow, the back tinged with olive-green, and the white wingbars washed with yellow; in other words, about intermediate between typical leucobronchialis and typical pinus.

This hybrid, color phase, or species-I do not presume to say what it is, for I think some day we may understand its relationships more fully-has been found in Louisiana, from Virginia northward to Connecticut, and as far west as Michigan. Its breeding range apparently coincides with that of $H$. pinus. Upward of one hundred specimens, representing typical leucobronchialis and various phases of its intergradation with pinus are known, and in the Connecticut River Valley the bird is stated to be more frequent than $H$. chrysoptera. In general habits it resembles both pinus and chrysoptera. Some individuals sing like the former, some like the latter, while others have notes of their own. (See Fisher, Bull. Nutt. Orn. Club, iv, 1879, p. 234 : vi, 1881, p. 245; Auk, ii, 1885, p. 378; Chapman, ibid., iv, 1887, p. 348 ; ix, 1892, p. 302 ; Eames, ibid., v, 1888, p. 427; vi, 1889, p. 305 ; Bishop, ibid., vi, 1889 , p. 192 : Sage, ibid., vi, 1889 , p. $279 ;$ x, 1893, p. 208.)

Helminthophila lawrencei (Herrick). Lawrence's Warbler.$A d$. o.-Forehead and fore part of the crown yellow, rest of the upper parts bright olive-green; wing-bars white; tail bluish gray, the three to four outer feathers marked with white; a black pateh on the cheek divided by a yellow line from the black patch on the throat and upper breast; lower breast and belly yellow, under tail-coverts white. Ad. \&.-Forehead dingy yellow, rest of the upper parts bright olive-green; wing-bars white, tinged with yellow; tail as in the $\delta$, black patches of the o replaced by dusky olive-green.

Remarks. -This bird combines the characters of pinus and chrysoptera; it has the black cheek-patches and breast-patch of the latter, but in other respects resembles the former, and is doubtless a hybrid between the two. lts history and a discussion of its relationships will be found under the references given above. It is a much rarer bird than Brewster's Warbler, and less than a dozen specimens have been recorded.

642. Helminthophila chrysoptera (Linn.). GoLdEN-Wragen W ARBLER. (Fig. 96.) Ad. o. -Crown bright yellow; rest of the upper parts bluish gray, sometimes washed with greenish; a large black patch about the eye, separated from another on the throat by a white stripe; a white line over the eye; wings and tail bluish gray; tips of middle wing-coverts and outer webs of greater ones bright yellow, forming a large yellow patch on the wing: outer three tail-feathers with large white patehes on their inner webs at the 
tip, fourth feather with a smaller patch; lower breast and belly white; sides grayish. Ad. $\%$.- Similar, but the crown duller, the patch on the sides of the head and throat grayish instead of black. L., $5 \cdot 10$; W., $2 \cdot 46$; ' I., 1.94; B. from N., 34 .

Range.-Eastern United States; breeds from Indiana and northern New Jersey north to Michigan, southern Ontario, and Vermont; south along the Alleghanies to South Carolina; winters in Central America.

Washington, uncommon T. V., May 1 to 28 ; A ug. Sing Sing, rare S. R., May 8 to Aug. 25. Cambrictge, not uncommon S. R., May 12 to Aug. 25.

Nest, much like that of $H$. pinus, on or near the ground, in second growths or bushy fields. Eggs, four to six, white, speckled and spotted, chiefly about the larger end, with cinnamon-brown, chestnut, or umber, $\cdot 62 \times \cdot 50$.

In their actions and choice of haunts the Golden-winged resemble the Blue-winged Warblers. Their song is of much the same quality, but the notes are all of the same kind and length, and the bird utters a rather lazy zec-zee-zee-zee, at once distinguisliable from the song of pinus.

645. Helminthophila ruficapilla (Tils.). Nasuvile WARBLER. Ad.-T'op and sides of the head bluish gray, a partially concealed chestnut patch in the center of the erown; back and rump bright olive-green; wings and tail edged with the same and without white; under parts bright yellow, whiter on the belly. Im.-Upper parts dull olive-green, more or less washed with brownish; rump brighter; wings and tail as in the ad.; sides of the head brownish ashy, eye-ring white; under parts yellowish, brighter on the breast; sides brownish. L., 4.77; W., 2.33 ; T., 1.81 ; B. from N., 28.

Range-Eastern North America; breeds from northern Illinois and Connecticut northward to Labrador and the fur countrics; winters in the tropics.

Washington, uncommon T. V., May 5 to 20 ; Sept. 5 to -0 . Sing Sing, tolerably common T. V., May 7 to 27 ; Aug. 11 to Oct. 4 ; may breed. Cambridge, rather common S. R., May 5 to Oct. 1 , more common T. V.

Nest, of grasses and moss, lined with finer grasses and fine, hairlike rootlets, on the ground, in partial clearings or tree-grown pastures. Eggs, four to five, white, thickly speckled, chietly at the larger end, with rufous or cinnamon-brown, $\cdot 61 \times \cdot 48$.

This Warbler is an inhabitant of rather open woodland, young second growth, or tree-bordered fields. In addition to the usual chip, it has a sharp, characteristic call-note, while its song is about as likely to attract attention as that of the Chestnut-sided Warbler. Minot writes it "weé-see-r'eé-see, wit'-a-vit'-a-vit'," while Langille gives it as "ke-tsee-ke-tsee-ke-tsee-chip-ee-chip-ee-chip-ee-chip," and compares the first half to the penetrating notes of the Black and White Warbler, and the last half to the twitter of the Chipping Sparrow. 
646. Helminthophila celata (Say). OrANGE-croWNed WARter. Ad.-Upper parts rather ashy olive-green; feathers of the crown orangerufous at the base; wings and tail edged with olive-green and without white: eye-ring yellow: under parts greenish yellow, obscurely streaked with dusky on the breast. Im.- Similar, but without orange-rufous in the crown; upper parts more ashy; under parts duller; eye-ring white. L., 5.00; W., 2.50; T., $1.95 ;$ B. from N., 31.

Range.-Breeds in the interior of British Columbia, and as far north as the "Yukon and Mackenzie River districts, and southward through the Rocky Mountains; winters in the South Atlantic and Gulf States and Mexico."

Washington, casual T. V., one instance, Oct. Sing Sing, A. V. Cambridge, rare 'T'. V., in fall, Sept. 30 ; Oct. 2.

Nest, of leaves and fine grasses, on or near the ground. Eggs, four to five, white, with specks or spots of cinnamon-brown or rufous, more numerous at the larger end, $63 \times \cdot 49$.

Orange-crowned Warblers are rare in the North Atlantic States. In Florida, where they are common in the winter, they evidently prefer the densely foliaged live and water oaks. 'Their sharp chip is sufficiently characteristic to be recognized after one has become thoroughly fumiliar with it. Their song. which I have never heard, is described by Colonel Goss as consisting of "a few sweet trills uttered in a spirited manner, and abruptly ending on a rising scale."

64\%. Helminthophila peregrina (Wils.). Texnessee Warbler. (See Fig. 53, a.) Ad. $\delta$.- Top and sides of the head bluish gray, sharply defined from the bright olive-green back and rump; wings and tail edged with olive-green; no white wing-bars; inner margin of inner vane of outer tailfeathers generally white at the tip; under parts white, sometimes tinged with yellow. Ad. 8.-Similar, but crown tinged with greenish and under parts washed with yellowish. Im.-Upper parts uniform olive-green; under parts washed with yellowish; under tail-coverts white. L., 5.00; W., 2.63; T., 1.69; B. from N., 32 .

Remarks.-The adults of this and the two preceding species may be distinguished with ease; immature birds, however, are frequently confused. The Nashville is distinctly yellow on the breast and under tail-coverts; the Orange-crowned is pale greenish yellow, with dusky streaks and yellow under tail-coverts; the Tennessee is pale greenish yellow, without streaks, and with the under tail-coverts white.

Range.-Eastern North America; breeds from Minnesota, northern New York, and New Brunswick northward; winters in Central America.

Washington, T. V., not observed in spring; occasionally common in fall, Aug. 25 to Oct. 15 . Sing Sing, rare 'T. V., May 22 to 27 ; Aug. 22 to Oct. 2. Cambridge, rare T. V., May 15 to 28 ; Sept.

Nest, of fine hempen fibers, grasses, and moss, lined with hair, in low bushes near the ground. Eggs, pearly white, with a circle of brown and pur. plish spots about the larger end, $\cdot 60 \times \cdot 50$ (B., B., and K.). 


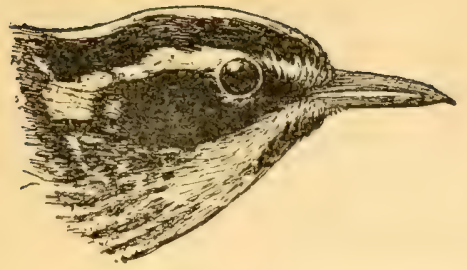

Fig. 93.-Black and White Warbler.

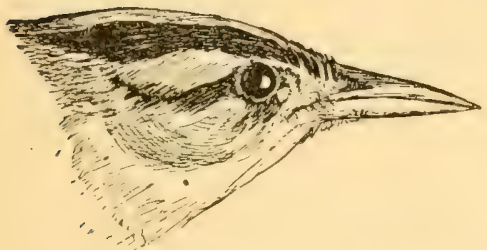

Fig. 94.-Worm-eating Warbler.

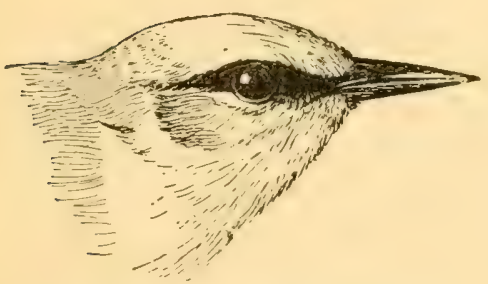

Frg. 95.-Blue-winged Warbler.

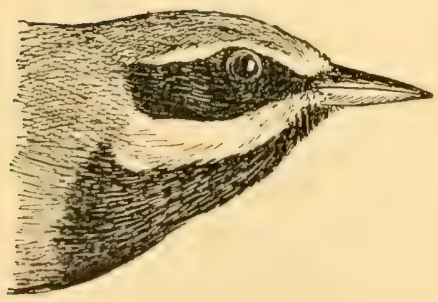

FiG. 96.-Golden-winged Warbler.

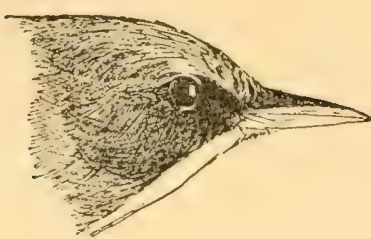

FIG. 97.-Parula Warbler.

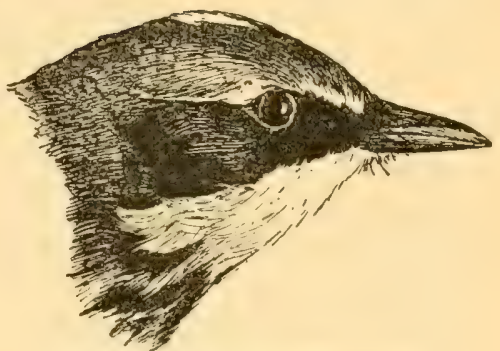

Fia. 98.-Myrtle Warbler.

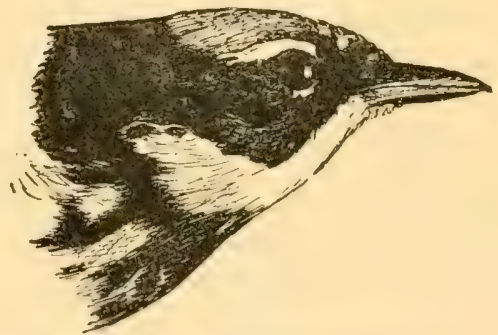

FIG. 99. --MIagnolia Warbler.

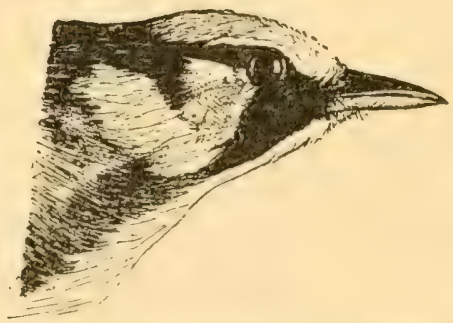

FIG. 100.-Chestnut-sided Warbler.

Figs. 93-100.-Heads of Warblers. (Natural size.) 
This bird has the general habits of the Orange-crowned or Nashville Warblers. Ernest Thompson describes its song as beginning with a note like chipiti, chipiti, repeated a dozen or more times, with increasing rapidity, then suddenly changed into a mere twitter. Bradford Torrey says the Tennessee's song "is more suggestive of the Nashville's than of any other, but so decidedly different as never for a moment to be confounded with it," and adds a detailed description (The Footpath Way, p. 8).

648. Compsothlypis americana (Limn.). Partla Warbler; Blue Yellow-BACKed WARBLer. (Fig. 97.) $A d$. of.-Upper parts grayish blue; a greenish-yellow patch in the middle of the back; greater and lesser wing-eoverts tipped with white; outer tail-feathers with a white patch near the end; throat and breast yellow, more or less marked with pale rufous, $a$ black, or bluish black, or rufous band across the breast; belly white; sides sometimes marked with rufous. $A d$. . q. - Similar, but the rufous color and band on the breast sometimes absent. Im.-Like the \&. L., 4.73; W., $2 \cdot 40$; T., $1.76 ;$ B. from N., $\cdot 32$.

Range.-Eastern North America; breeds from the Gulf States northward to Anticosti; winters from Florida south ward.

Washington, abundant T. V., Apl. 20 to May 20; Aug. 20 to Oct. 15; a few breed. Sing Sing, common T. V., May 2 to 28 ; Sept. 21 to ()ct. 7. Cambridge, common T. V., May 1 to 28 ; Sept. 10 to 30.

Nest, generally in bunches of Usnea "moss." Eggs, four to five, white, with rufous markings, chiefly in a wreath about the larger end, $\cdot 66 \times 47$.

During its migrations the Parula is rery generally distributed, but when nesting it selects localities in which there is an abundance of Spanish or Usnea "moss."

In Florida the Parula's notes mark the beginning of a new ornithological year, and its song is so associated in my mind with the beauties of a southern spring that in describing it as a short, insectlike buzz I realize how largely its charm is borrowed from its surroundings. When the cypresses are enveloped in a haze of lacelike blossoms, and the woods are fragrant with the delicions odor of yellow jasmine, the dreamy softness of the air is voiced by the Parula's drowsy song.

650. Dendroica tigrina $(G m e$.). Cape Mar Wardeer. (See Fig. 1.) Ad. of.-Crown black, slightly tipped with greenish; ear-coverts rufous, bounded behind by a large yellow patch on the side of the neck; back olive-green, broadly streaked with black; rump yellow or greenish yellow; a large white patch on the wing-coverts; outer tail-feathers with a large white pateh on their inner webs, near the tip; under parts yellow, heavily streaked with black; lower belly and under tail-coverts whitish. $A d$. \&.Upper parts grayish olive-green; rump yellowish; a yellow line over the eye; middle wing-coverts with narrow white tips; outer tail-feathers with a white pateh on their inner webs near the tip; under parts yellow, streaked with 
black; belly and under tail-coverts whiter. Im. o.--Resembles the \&, but the wing-coverts have more white. Im. \&.- Similar to ad. \&, but with little or no yellow on the under parts. L., $5 \cdot 00$; W., $2 \cdot 61 ;$ T., $1 \cdot 88 ;$ B. from N., $\cdot 30$.

Range.-Eastern North America; breeds from northern New England north tu Hudson Bay; winters in the tropics.

Washington, sometimes very common, usually uncommon T. V., May 5 to 20; Aug. 25 to Oct. 7. Sing Sing, tolerably common T. V., Aug. 20 to Oct. 1. Cambridge, rare T. V., May 15 to 25 ; Aug. 25 to Sept. 15.

Nest, partially pensile, of twigs and grass fastened with spiders' webbing, lined with horsehair, on a low branch of a small tree in pasture or open woodland. Eggs, three to four, dull white or buffy, slightly specked, and wreathed around the larger end with spots of brown and lilac, $70 \times .50$ (Chamberlain).

During its migrations this generally rare Warbler may be found associated with its wood-inhabiting congeners. In the summer it haunts the higher branches of coniferous trees. Mr. Chamberlain describes its song as somewhat resembling "the simple lay of the Nashville, though its voice is neither so full nor so sweet, recalling the thin, wiry tones of the Black and White Creeper."

652. Dendroica astiva (Gmel.). Yellow Warbler. Ad. ô.Upper parts bright greenish yellow, brighter on the crown; wings edged with yellow ; tail fuscous, the inner vanes of the feathers yellow; under parts bright yellow, streaked with rufous. Ad. o.- Upper parts uniform yellowish olivegreen; tail as in the $\delta$; wings fuscous, edged wiih yellow; under parts bright yellow, slightly, if at all, streaked with rufous on the breast and sides. Im. o . -Similar to the ?. Im. \&.-Upper parts light olive-green; tail fuscous, the inner margins of the inner vanes of the tail-feathers yellow; under parts uniform dusky yellowish. L., $5 \cdot 10$; W., $2 \cdot 40$; 'T., 1.89 ; B. from N., $\cdot 33$.

Remarks. - In any plumage this bird may be known by the yellow on the inner vanes of the tail-feathers.

Range.-North America, except Southwestern States; breeds northward to the aretic regions; winters as far south as northern South America.

Washington, common S. R., abundant 'T. V., Apl. 18 to Sept. 30. Sing Sing, common S. R., Apl. 30 to Sept. 27. Cambridge, abundant S. R., May 1 to sept 30 .

Nest, of fine grasses and hempen fibers, with a conspicuous amount of plant down, lined with plant down, fine grasses, and sometimes long hairs, in the shrubs or trees of lawns or orchards. Eggs, four to five, bluish white, thickly marked with cinnamon-and olive-brown, with frequently a wreath about the larger end, $\cdot 70 \times \cdot 50$.

When any one tells me he has seen a "Wild Canary," I feel reasonably sure he refers to the Yellow Warbler, for the casual observer at once betrays his inexperience by entirely overlooking the bird's streaked breast and slender bill.

It has, it is true, the general appearance of a yellow bird, and its 
bright colors and preference for gardens, orchards, the shrubbery of our lawns or bushy brooksides, instead of the woods, frequently brings it to the attention of those to whom most birds are strangers.

It is an active bird, and its song-wee-chee, chee, chee, cher-weethough simple, has a pleasing, happy ring.

654. Iendroica carulescens ( $G$ mel.). Black-THRoAted Blte WARBLER. Ad. 8.-Upper parts grayish blue, back sometimes blackish; wings and tail edged with blue; base of the primaries white, forming a white spot on the wing at the end of the primary coverts; inner vanes of outer tail-

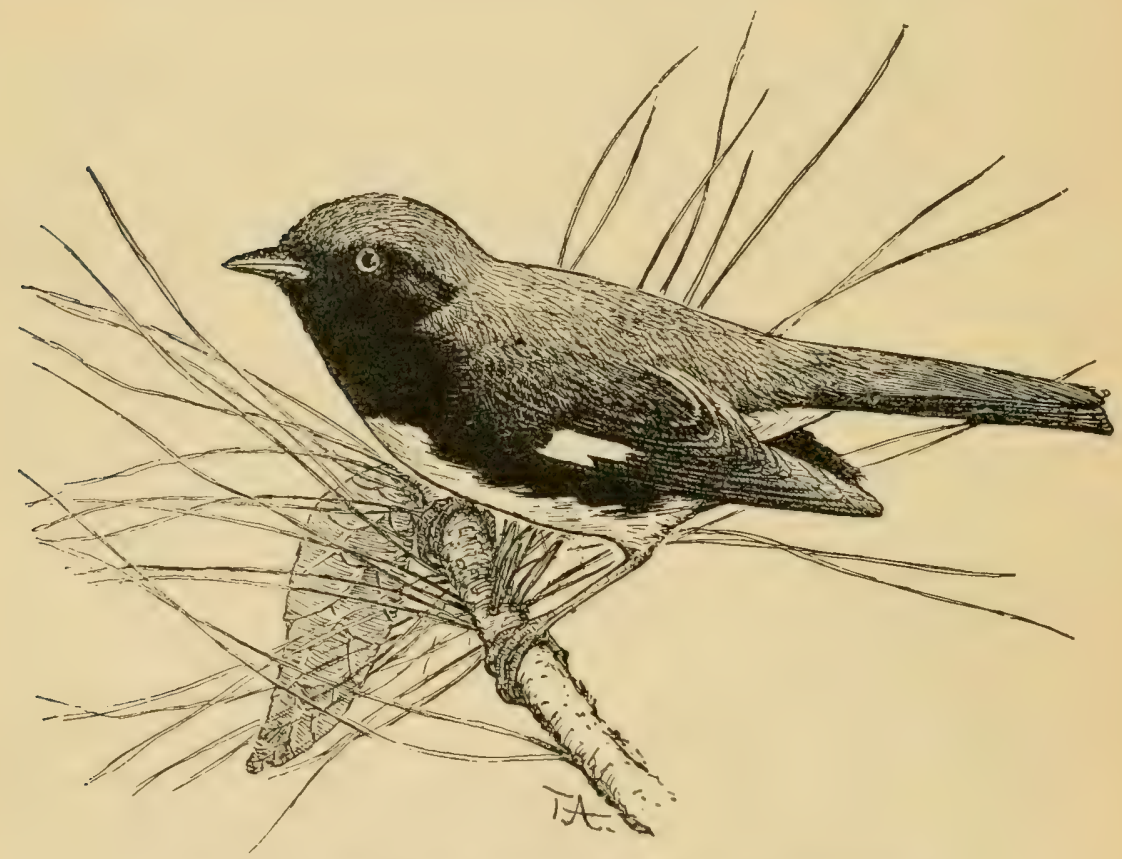

FIG. 101-Black-throated Blue Warbler. (Reduced.)

feathers with a white patch near their tips; sides of the head and throat black; sides mixed black and white; breast and belly white. $A d . q .-$ Upper parts uniform olive-green; tail generally with a faint bluish tinge, the white patch on the outer feathers scarcely distinguishable; white at the base of the primaries much reduced and sometimes concealed by the primary coverts; ear-coverts dusky gray; under parts soiled butfy yellowish. Im. 8.--Similar to ad. $\delta$, but the upper parts washed with greenish, the throat tipped with white, and less black on the sides. Im. \&. - Similar to ad. \&, but somerwhat yellower. L., 5.28; W., 2.52; T., 2.06; B. from N., $\cdot 29$.

Remarks.-The white spot at the base of the primaries is the distinguishing mark of this species.

liange-Eastern North America; breeds from northern Minnesota (prob- 
a!ny) and Connecticut (rarely) northward to Labrador, and south along the crest of the Alleghanies to Georgia; winters in the tropics.

Washington, very common T. V., Apl. 25 to May 25; Aug. 27 to Oct. 18. Sing Sing, common 'T. V., Apl. 25 to May 28; Aug. 26 to Oct. 10. Cambridge, rather common T. V., May 10 to 25 ; Sept. 20 to Oct. 10.

Nest, of strips of bark, fine grasses, and pine needles, lined with hairlike black rootlets, in the heavier undergrowth of dense woods, usually within two feet of the ground. Eggs, three to five, grayish white, with distinct and obscure olive-brown markings, chiefly about the larger ends, $\cdot 68 \times \cdot 50$.

The male Black-throated Blue Warbler can be identified at sight, but his obscurely colored mate has been the cause of many a field student's neckache. When flitting about with other Warblers it is diffieult to observe any positive character by which to distinguish her; but the white spot at the base of the primaries is an unmistakable mark, if one can see it clearly.

When nesting, the birds seem to require woods with rather heary undergrowth. Their call-note is a sharp, recognizable chip. The song of the male is generally written zuee-zwee-zuee, but both callnotes and song are subject to variation.

655. Dendroica coronata $($ Linn.). Mrrtle Waliler; YellowrUMPed Warbler. (Fig. 98.) Ad. o. - A yellow patch on the crown, rump, and either side of the breast; upper parts bluish gray, streaked with black; two white wing-bars; outer tail-feathers with white spots on their inner vanes near the tip; throat white; breast and upper belly heavily marked with black; lower belly white. $A d$. $\&$.- - Similar, but with less black below; breast simply streaked with black; upper parts browner. Im. and ads. in winter.-Yellow crown patch more or less concealed by brownish tips to the feathers; rump bright yellow; yellow on the sides of the breast much reduced; upper parts grayish brown, streaked with black; wing-bars grayish; tail with white patches; under parts soiled white, streaked with black. L., $5 \cdot 65 ; \cdot$ W., $2 \cdot 85$; 'T., $2 \cdot 25$; B. from N., $\cdot 29$.

Remarks.-The yellow patches on the crown, rump, and sides of the breast are characteristic of this species.

Kange.-Eastern North America; breeds from northern Minnesota and northern New England northward; winters from the Middle States southward.

Washington, abundant W. V., Sept. 28 to May 20. Sing Sing, common T. V., Apl. 13 to May 28; Aug. 16 to Nov. 11; a few winter. Cambridge, abundant 'T. V., Apl. 18 to May 20 ; Sept. 20 to Nov. 3; a few winter.

Nest, of vegetable fibers lined with grasses, in coniferous trees five to ten feet up. Eggs, four or five, white or grayish white, distinctly and obscurely spotted and speckled or blotehed with olive-brown or rufous-brown, $1.50 \times 52$.

These strong, harly Warblers leave their cousins of the woods and in loose companies forage in old fields and scrubby growths among the bayberry or myrtle (Myrica cerifera) bushes, which bear 
their favorite food. So fond are they of these berries that their morements are largely governed by the success or failure of the bayberry crop. Near my home at Englewood, N. J., Nyrtle Warblers are always common during the winter if there is an abundance of bayberries and always absent when the berries are wanting.

No Warbler is more easily identified than this bird with its four distinct patches of yellow. The yellow rump is conspicuous in life, and, in connection with the bird's characteristic tchip, forms an excellent field-mark.

Audubon's Warbler (656. Dendroica auduboni), a species of the Western States, has been once recorded from Massachusetts and Pennsylrania.

65\%. Dendroica maculosa (Gmel.). Mhanolia Warbler; Black ANd Yellow Warbler. (Fig. 99.) Ad. o. -Crown bluish gray, cheeks and forehead black, a white line behind the eye ; back black, bordered with olivegreen, a large white patch on the wing-coverts; rump yellow, tail black, inner vanes of all but the central feathers with white patehes on their middle, the end third of the feather being entirely black; throat yellow, breast and sides heavily streaked with black. $A d$. o. - Similar, but with the colors duller and less sharply defined; back greener. Im.-Top and sides of the head ashy; back olive-green, with nearly concealed black spots; two narrow wing-bars; rump yellow; tail as in the adults; under parts yellow; whiter on the belly; sides with a few black streaks. L., $5 \cdot 12 ;$ W., $2 \cdot 30 ;$ T., $2 \cdot 00 ; \mathrm{B}$. fron N., $\cdot 30$.

Remarks. - In any plumage this bird may be known hy the white patehes on the tail being near the middle instead of at the tip of the feathers.

Range.-Eastern North America; breeds from northern Michigan and northern New England to IIudson Bay and southward along the crests of the Alleghanies to Pennsylvania; winters in Central America.

Washington, common 'T. V., Apl. 28 to May 30 ; Aug. 15 to Oct. 10. Sing Sing, common T. V., May 9 to 28; Aug. 13 to Oct. 11. Cambridge, common T. V., May 12 to 25 ; Sept. 20 to Oct. 5.

Nest, of fine twigs, leaf stems, etc., lined with hairlike rootlets, in conifcrous trees, usually three to six feet up. Eggs, three to five, white, marked with cinnamon- and olive-brown, chiefly in a wreath about the larger end, $\cdot 66 \times \cdot 48$.

Adult Magnolia Warblers are so distinctly marked that ordinarily they may be identified at sight. Immature birds are less strikingly colored, but in any plumage the species may be known by having the white tail-spots nearer the middle than the ends of the feathers. Seen from below, the birds thus appear to have a white tail broadly banded with black.

The Magnolia's summer home is among the spruces and hemlocks. Its song, which is of somewhat the same character as that of the Tellow Warbler, is desc:ibed by Mr. Langille as "a loud, clear whistle, 
which may be imitated by the syllables chee-to, chee-to, chee-tee-ee, uttered rapidly and ending in the falling inflection.

6a8. Dendroica carulea (Tils.). Cerbulean Warbler. $A d$. o. - Upper parts bright blue, the sides of head and back streaked with black; wings and tail edged with blue; two white wing-bars; inner vanes of all but the central tail-feathers with white patches at their tips; under parts white, a bluish black band across the breast; sides streaked with bluish black. Ad. . - - Upper parts bluish olive-green: wings and tail as in the $\delta$; under parts white, generally more or less tinged with pale yellow. Im.--Similar to ad. \&, but yellower. L., 4.50; W., 2.65; B. from N., '31.

Range.-Breeds in the Mississippi Valley as far north as Minnesota, and eastward as far as Lockport, N. Y. (Davison); winters in the tropies.

Washington, very rare 'T. V., two instances, May.

Nest, of tine grasses bound with spiders' silk, lined with strips of bark and fine grasses and with a few lichens attached to its outer surface, in a tree, twenty-five to fifty feet from the ground. Eggs, four, creamy white, thickly covered with rather heavy blotuhes of reddish brown, $\cdot 60 \times 47$ (Allen, Bull. Nutt. Orn. Club, iv, 1879, p. 26).

In writing of this species as observed by him in Ritchie County, West Virginia, Mr. Brewster says:

"Decidedly the most abundant of the genus here. The first specimen taken May 5. They inhabit exclusively the tops of the highest forest trees, in this respect showing an affinity with D. blackbumice. In actions they most resemble $D$. pensyleanica, carrying the tail rather high and having the same 'smart bantamlike appearance.' Were it not for these prominent characteristics they would be very difficult to distinguish in the tree tops from Parula [= Compsothlypis] americana, the songs are so precisely alike. That of the latter bird has, however, at least two regular variations: in one, beginning low down, he rolls his guttural little trill quickly and evenly up the seale, ending apparently only when he can get no higher: in the other the commencement of this trill is broken or divided into syllables, like zee, $z e e, z e e, z e-e e-e e-e е p$. This latter variation is the one used by D. carmlea, and I could detect little or no difference in the songs of dozens of individuals. At best it is a modest little strain and far from deserving the encomium bestowed upon it by Audubon, who deseribes it as 'extremely sweet and mellow'; decidedly it is neither of these, and he must have confounded with it some other species. In addition to the song they utter the almost universal Dendroicine lisp and also the characteristic tehep of $D$. coronate, which I had previously supposed entirely peculiar to that bird."

659. Dendroica pensylvanica (Limn.). (HESTNT-SINED WARBLER. (Fig. 100.) Ad. o.-Crown bright yellow, a black line behind the cye; front part of the cheeks black; ear-coverts white; back streaked with 
black and margined with bright olive-green; wing-bars yellowish white; tail black, the outer feathers with white patches on their inner vanes at the tip; under parts white, the sides chéstnut. Ad. \&.- Similar, but somewhat duller in color. Im.-Very different; upper parts bright yellowish olivegreen, back sometimes streaked with black; wing-bars yellowish white; under parts pure, silky white, the sides sometimes with spots or patches of chestnut. I., 5•14; W., $2 \cdot 45 ;$ T., $2 \cdot 00 ;$ B. from N., 29 .

Range.-Eastern North America; breeds from central Illinois and northern New Jersey north to Manitoba and Newfoundland, and southward along the Alleghanies to South Carolina; winters in the tropies.

Washington, abundant T. V., Apl. 28 to May 30; Aug. 10 to Sept. 30. Sing Sing, tolerably common S. R., May 2 to Sept. 24. Cambridge, common S. R., May 5 to Sept. 10.

Nest, of strips of bark, leaf stems, etc., lined with tendrils and rootlets, in bushes, about three feet up. Eggs, four to five, white, with numerous distinct and obseure cinnamon- and olive-brown narkings, chiefly in a wreath about the larger end, $\cdot 69 \times 50$.

When settled for the summer, Chestnut-sided Warblers may be found in second growths, scrubby clearings, or the bushy borders of woodlands. 'There is a suggestion in their movements of the restless activity of the Redstart, as with drooped wings and slightly raised tail they flit among the lower growth. They have two songs, both of which closely resemble that of the Yellow Warbler, though a practiced ear can at once recognize the song of either.

Adults of this species are too conspicuously marked to be mistaken for any other Warbler, but in the fall have a care in identifying the very differently colored young.

660. Dendroica castanea (Iils.). BAY-mpeasten WARBLER. $A d$. o.-Forchead and cheeks black, a cream-buff patch on the sides of the neck; crown chestnut; throat, upper breast, and sides chestnut-rufous; back brownish ashy, streaked with black; two white wing-bars; inner vanes of outer tail-feathers with white patches at their tips; lower breast and belly buffy white. $A d$. $9 .-$ Crown olive-green, streaked with black and with generally some chestnut; rest of upper parts as in the $s$; under parts buffy white; breast and sides more or less stained with rufous. Im.-Upper parts bright olive-green, indistinctly streaked with black; wings and tail much as in the ads. : under parts white, tinged with cream-buff, especially on the flanks. L., $5 \cdot 63 ;$ W., $2.95 ;$ T., $2 \cdot 12 ;$ B. from N., $\cdot 30$.

Range.-Eastern North America; breeds from northern Michigan and northern New England northward to Hudson Bay and Labrador; winters in Central America.

Washington, sometimes abundant, usually uncommon T. V., May 10 to 20 ; Aug. 28 to Oct. 20. Sing Sing, tolerably common T. V., May 14 to 28 ; A ug. 5 to Sept. 26. Cambridge, rather rare T. V., May 15 to 25 ; Sept. 12 to 28.

Nest, of grasses and plant fibers, lined with plant down and long hairs, in coniferous trees, five to twenty feet up. Eggs, four to five, white, finely 
marked, chiefly at the larger end, distinetly and obseurely with cinnamon-, olive-, or rufous-brown, $72 \times \cdot 52$.

During its migrations this tastefully marked Warbler is generally uncommon enough to be consiclered somewhat of a prize, though at irregular intervals it becomes comparatively common. It is said to be much rarer in fall than in spring, but the immature Bay-breasts so closely resemble the usually abundant young Black-polls that it is sometimes difficult to determine specimens, while living birds could not possibly be distinguished.

In the summer the Bay-breasts inhabit the northern coniferous forests, living, it is said, in the tree tops. Mr. Langille writes: "Their song, said to begin like that of the Black-poll and end like that of the Redstart, bears to my ear no resemblance whatever to either, but is a very soft warble, somewhat resembling the syllables tse-chee, tse-chee, tse-chee, tse-chee, tse-chee, but far too liquid to admit of exact spelling."

661. Dendroica striata (Furst.). Black-poll Warbler. (Fig. 102.) Ad. 8.-Crown black; ear-coverts white; nape streaked, black and white; back and rump ashy, streaked with black; two white wing-bars; inner vanes of outer tail-feathers with white patches at their tips: under parts white, streaked with black, the streaks most numerous on the sides, and wanting on the middle of the breast and belly. $A d . \&$.- Upper parts olive-green, distinctly streaked with black; wings and tail as in the $\delta$; under parts white, tinged with yellow, the breast and sides distinctly streaked with black. Im.- Similar to $\&$, but the upper parts brighter and not distinctly streaked, the under parts yellower and not distinctly streaked. L., 5.56; W., 2.92 ; T., $2 \cdot 05$; B. from N., 30 .

Remarks.-No two of our Warblers more closely resemble each other than do immature examples of this and the preceding species. 'There is no difference in the color of the upper parts, but castanea has the under parts tinged with delicate eream-buff, strongest on the flanks, while striata is distinetly yellowish below.

Range.- "Eastern North America to the Rocky Mlountains, north to Greenland, the Barren Grounds, and Alaska, breeding from northern New England northward: south in winter to northern South America" (A. O. U.).

Washington, abundant T. V., May 1 to June 5; Sept. 5 to Oct. 20. Sing Sing, common T. V., May 7 to June 6 ; Aug. 30 to Oct. 16. Cambridge, abundant T. V., May 12 to June 5 ; Sept. 8 to Oct. 15.

Nest, of twigs, moss, rootlets, ete., lined with fine grasses and tendrils, generally in spruce trees, about six feet up. Eggs, four to tive, white, more or less speckled and spotted, and generally heavily blotehed at the larger end with cinnamon-, olive-, or rufous-brown, $\cdot 70 \times \cdot 54$.

Black-polls are rather more leisurely in their movements than most of their congeners. Adults should be identified without diffieulty, but the immature birls, which are generally abundant in the fall, may occasion some trouble. Mr. Iangille describes their song as one of the 
most slender and wiry in all our forests, and as distinguishable as the hum of the cicada or the shrilling of the katydid. "Tree-tree-tree-treetree-tree-tree-tree, rapidly uttered, the monotonous notes of equal length, beginning very softly, gradually increasing to the middle of the strain, and then as gradually diminishing, thus forming a fine musical swell, may convey a fair idea of the song. There is a peculiar soft and tinkling sweetness in this melody, suggestive of the quiet mysteries of the forest, and sedative as an anodyne to the nerves."

662. Dendroica blackburniz (Gmel.). Blackburnian WarBLER. Ad. $\delta$.-Center of the black crown, a line over the eye, patch behind the black ear-coverts, throat, and breast beautiful rich orange; back black, streaked with whitish; wing-coverts white, forming a large white patch on the wing ; inner vane of most of the tail-feathers almost entirely white, except at the tip; the outer vane of the outer feather white at the base; belly tinged with orange, sides streaked with black. $A d$. q.- Resembles the ${ }^{\circ}$, but the orange markings are duller, the upper parts are ashy olive-green streaked with black and whitish; the white on the wings an i tail is less extensive. Im. of.-Resembles the $q$, but has the orange markings dull yellow, the crown-pateh nearly absent. Im.. .- Similar to the im. $\delta$., but the yellow markings much paler, nearly buffy, the back browner. L., 5.25; W., $2 \cdot 71 ;$ T., $1 \cdot 96$; B. from N., $\cdot 31$.

Remarks.-In connection with other markings the large amount of white in the tail, appearing on even the outer vane of the outer feather, is characteristic of this species.

Range.-Eastern North America: breeds from northern Minnesota and southern Maine northward to Labrador and southward along the Alleghanies to South Carolina; winters in the tropies.

Washington, common 'T. V., May 5 to 20; Aug. 20 to Oet. 5. Sing Sing, common 'T. V., May 10 to 29 ; Aug. 15 to Oct. 15 . Cambridge, uneommon T. V., May 12 to 22 ; Sept. 15 to 30.

Nest, of fine twigs and grasses, lined with grasses and tendrils, in coniferous trees, ten to forty feet up. Eggs, four, grayish white or bluish white, distinctly and obscurely spotted, speckled, and blotehed with cinnanon-brown or olive-brown, $68 \times \cdot 50$.

The Blackburniun is uncommon enough to make us appreciate his unusual beauty. Coming in May, before the woods are fully clarl, he seems like some bright-plumaged tropical bird who has lost his way and wandered to northern elimes. The summer is passed among the higher branches in coniferous forests, and in the early fall the bird returns to surroundings which seem more in keeping with its attire.

Mr. Ninot describes its summer song as resembling the syllables wee-seé-uce-sée-uee-seé (uree-sée-ick), while in the spring its notes may be likened to wee-see-wee-see, tsee-tsee, tsee, tsee, tsee-tsee, tsee, tsee, the latter syllables being on ascending scale, the very last shrill and fine. 
663. Dendroica dominica $($ Linn.). Yellow-throated Warbler. Ad.-A yellow line in front of the eye and a white line over it; upper parts gray, forehead blackish; wings and tail edged with grayish, two white wingbars; outer tail-feathers with white patches near their tips; cheeks and sides of the throat black; a white patch on the side of the neck; throat and breast yellow, belly white, sides streaked with black. L., 5.25; W., $2 \cdot 60$; 'T., 2.01 ; B., 49 .

Range.-Southern United States; breeds as far north as Virginia; winters from Florida southward; accidental in New York and Massachusetts.

Washington, rare S. R., rather common in late July; may breed.

Nest, of twigs, strips of bark, and Tillandsia "moss," lined with vegetable down, thirty to forty feet from the ground, in pines or live-oaks, sometimes in a bunch of Tillandsia "moss." Eggs, four to five, white or grayish white, with numerous distinct and obscure cinnamon- or olive-brown markings, sometimes evenly distributed, sometimes in a wreath at the larger end, $\cdot 74 \times \cdot 52$.

Some birds are so characteristic of certain places that wherever heard or seen they recall their accustomed haunts. I have only to remember the song of the Yellow-throated Warbler to give form to a mental picture of some tree-bordered stream or bayou in the south. The song bears some resemblance to that of the Indigo Bunting, but has a wilder, more ringing quality. It is to some extent ventriloquial, and this in connection with the rather deliberate morements of the birds, and the fact that they resort to the upper branches, makes it sometimes difficult to locate the singer.

663a. D. d. albilora Riden. Sycamore W preceding, but with a smaller bill and the line in front of the eye white in stead of yellow. W., $2 \cdot 60 ;$ T., $2 \cdot 00 ;$ B., $\cdot 45$.

Range.-Breeds in the Mississippi Valley north to Kansas, southern Indiana, and southern Illinois; east to western South Carolina; migrates southward, chiefly along the west Gulf coast, to Mexico and Central America.

"The Sycamore Warbler is a common summer resident in the bottom-lands: [of Illinois], where, according to the writer's experience, it lives chiefly in the large sycamore trees along or near the water courses. On this account it is a difficult bird to obtain during the breeding season, the male usually keeping in the topmost branches of the tallest trees, out of gunshot and often, practically, out of sight, although its presence is betrayed by its loud, very unwarblerlike song" (Ridgway).

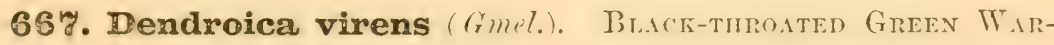
BLER. A $d$. of - Upper parts bright olive-green, back sometimes spotted with black; line over the eye and cheeks bright yellow, ear-coverts dusky; two white wing-bars; inner vanes of outer tail-feathers entirely white, outer web white at the base; throat and breast black; belly white, sometimes tinged with yellow; sides streaked with black. $A d . \&$.- Similar, but the black of 
throat and breast more or less mixed with yellowish. Im.--Similar to the \&, but with more yellow on the throat, the black sometimes being almost entirely hidden or wanting. L., $5 \cdot 10$; W., $2 \cdot 46$; 'T., 1.99 ; B. from N., $\cdot 25$.

Remarks.-The bright yellow checks of this species, in connection with the large amount of white in the tail, will serve to distinguish it in any plumage.

Range.-Eastern North America; breeds from northern Illinois and Connecticut northward to Hudson Bay and southward along the Alleghanies to South Carolina; winters in the tropics.

Washington, very commion T. V., Apl. 25 to May 28 ; Aug. 28 to Oct. 21. Sing Sing, common T. V., Apl. 30 to June 3 ; Sept. 1 to Oct. 26 ; a few breed. Cambridge, very common S. R., May 1 to Oct. 15.

Nest, of small twigs and moss, lined with rootlets, fine grasses, and tendrils, in coniferous trees, fifteen to fifty feet from the ground. Eggs, four, white, distinctly and obscurely spotted and speckled with olive-brown or umber, chiefly at the larger end, ${ }^{\circ} 65 \times \cdot 46$.

When migrating this species joins the ranks of the Warbler army and visits wooded land of almost any kind. When nesting it prefers coniferous forests, where it is a dweller among the tree tops.

While resembling its congeners in general habits, the song of the Black-throated Green is so unlike their generally humble ditties that the bird seems possessed of more character than they impress us with having. Mr. Burroughs graphically represents its notes by straight lines: - - V which nevertheless will aid one in recognizing the bird's song. There is a quality about it like the droning of bees; it seems to voice the restfulness of a midsummer day.

Townsend's Warbler (668. Dendroica townsendi), a species of western North America, has been once recorded from Pennsylvania.

6\%0. Dendroica kirtlandi Baird. Kirtland's Warbler. Ad.Head bluish gray, sometimes spotted with black; lores and sicles of the throat black; back brownish ashy, spotted with black: no white wing-bars; outer tail-feathers with white patches on their inner webs at the tips; under parts pale yellow; sides streaked and spotted with black. L., 5.75 ; W., $2 \cdot 75$; 'I., $2 \cdot 30 ;$ B. from N., 32 .

Kange.-Migrates through southeastern United States and Mississippi Valley (South Carolina, Virginia, Missouri, Ohio, Michigan, WViseonsin, Illinois, Minnesota); summer home unknown; winters in the Bahamas.

Washington, casual T. V., one record, Sept. 25, 1887.

The dozen or more specimens of this rare Warbler which have been taken in the United States were captured in late April and May and late September and October. Six specimens have been recorded from Michigan, all taken in May, and it is possible these birds were en route to a nesting ground in the Hudson Bay region. It is not uncommon in winter in the Bahamas. 
6y1. Dendroica vigorsii ( $A u d$.). Pine Warbler. (See Fig. $53, b)$. Ad. o.--Upper parts bright olive-green, sometimes washed with ashy; two whitish wing-bars; outer tail-feathers with white patches on their inner vanes near the tip ; under parts bright yellow, more or less washed with ashy, turning to white on the lower belly and under tail-coverts; sides sometimes with a few black streaks. $A d$. $q$. - Similar, but upper parts brownish olivegreen; under parts soiled whitish ; breast tinged with yellow. L., 5.52; W., $2 \cdot 81$; T., $2 \cdot 25 ;$ B. from N., $\cdot 33$.

Range.-Eastern North America; breeds from Hayti (?), the Bahamas, and Florida north to Manitoba and Maine; winters from southern Illinois and North Carolina southward.

Washington, quite uncommon S. R., Mch. 25 to Oct. 25 ; abundant in fall. Sing Sing, casual. Cambridge, common S. R., Apl. 10 to Oct. 20.

Nest, of strips of bark, leaves, plant fibers, etc., in pines or cedars, thirty to fifty feet up. Eggs, four to five, white or grayish white, with numerous distinct and obscure cinnamon-brown to umber markings, chiefly in a wreath or band at the larger end, $\cdot 70 \times \cdot 52$.

True to its name, the Pine Warbler is rarely found outside of pine woods. In the south, where pineries may extend over half a State, it is an abundant and generally distributed bird; in the more northern part of its range it is, from lorce of circumstances, a local species, occurring only with the pines.

In the winter it is found in small flocks, which may contain a few Myrtle or Palm Warblers, and at this season it lives on or near the ground. In the summer it is more arboreal. Its habit of clinging to the trunk of a tree, or hopping along a limb while searching for insects in erevices in the bark, has given it the misnomer of Pine Creeping Warbler.

Its song is a clear, sweet trill. Southern birus, in my experience, have more musical voices, and their notes suggest those of the Field Sparrow, while the song of northern birds has more the quality of the Chipping Sparrow's.

692. Dendroica palmarum (Gmel.). Palar Warbler; Ren-port WARBLER. Ad.-Crown chestnut; back olive grayish brown, indistinctly streaked; rump olive-green; no wing-bars; tail black, the outer feathers with white patches on their inner vanes at the tips; a yellow line over the eye; throat and breast bright yellow; belly soiled whitish, tinged with yellow; sides of the throat, the breast, and sides streaked with chestnut-rufous; under tail-coverts yellow. $A d$. in winter and Im.-Crown-cap partly concealed by brownish tips to the feathers and sometimes wanting; line over the eye and eye-ring white; under parts soiled whitish, more or less tinged with yellow; breast streaked with dusky. L., 5•25; W., 2.64; T., 2·10; B. from N., $\cdot 32$.

Range.-Breeds in the interior of British America north of Manitoba and west of Iludson Bay ; minrates southwarl through the Mississippi Valley and winters in the South Atlantic and Gulf States, West Indies, and Mexico; rare in the North Atlantic States. 
Washington, rare T. V., Apl. 29 to May 18; Sept. Sing Sing, rare T. V., Apl. 29 ; Sept. 30 to Oct. 12. Cambridge, uncommon T. V., in fall, Sept. 25 to Uet. 10.

This interior race of the Yellow Palm Warbler is occasionally met with in the North Atlantic States, while in Florida it is much more common than the eastern form. Sometimes the two birds may be seen in the same flock, when the brighter colors of hypochrysea are at once apparent.

6y2a. D. p. hypochrysea Riilgw. Yellow Palm Warbler; YeLLOW ReD-PoLt. Ad.-Crown chestnut; back brownish olive-green; rump olive-green; no white wing-bars; secondaries sometimes tinged with chestnut; tail edged with olive-green, the outer feathers with white spots on their inner vanes near the tips; line over the eye and eye-ring yellow ; under parts entirely bright yellow; sides of the throat, the breast, and sides streaked with chestnut-rufous. Ad. in winter and Im.-Crown-cap partly concealed by the brownish tips to the feathers and sometimes wanting; line over the eye and eye-ring yellowish; entire under parts uniform yellow, washed with ashy; the sides of the throat, the breast, and sides streaked with chestnutrufous or dusky. L., $5 \cdot 43$; W., $2 \cdot 61 ;$ T., $2 \cdot 10 ;$ B. from N., $\cdot 31$.

Remarks. - In any plumage this bird may be distinguished from the preceding species by its uniform yellow under parts.

Range.-Eastern North Ainerica; breeds from Nova Scotia northward east of Hudson Bay; migrates southward through the Atlantic States, and winters in the Gulf States.

Washington, common T. V., Mch. 28 to Apl. 29 ; Oct. Sing Sing, tolerably common T. V., Apl. 11 to May 5; Sept. 20 to Nov. 8. Cambridge, abundant T. V., A pl. 15 to May 5 ; Oct. 1 to 15.

Nest, of rather coarse grasses lined with finer grasses, on or near the ground. Eggs, four to five, white or buffy white, with some distinct and obscure cinnamon- or olive-brown markings, chiefly at the larger end, $\cdot 65 \times \cdot 51$.

The Red-poll is a renegade Dendroica. He has no liking for the wood, and even trees in the open do not seem to attract him. His tastes bring him to fields and roadsides, where he lires on or near the ground, but is ever active and much on the move. During the winter in the south he is a common bird in the streets and gardens of towns, and like a Chippy hops familiarly abont piazzas.

He has the same nervous peculiarity which, irrespective of family, seems to affect some birds, and, as though life were a matter of beating time, never ceases to wag his tail. His fine chip is recognizable after one has become familiar with it, while his song is described as a simple trill.

6y3. Dendroica discolor (Tieill.). Pramie Warbler. (Fig. 103.) Ad. ô.-Upper parts bright olive-green; back spotted with chestnut-rufous; wing-bars yellowish; outer tail-feather's with large white patehes at their tips, 
the outer vane of the outer feather white at the base; a yellow line over the eye; lores and a crescent below the eye black; under parts bright yellow; sides heavily streaked with black. $A d$. $₹$.- Similar, but with less, and sometimes no chestnut-rufous in the back. Im.-Upper parts uniform ashy olivegreen; no apparent wing-bars; outer tail-feathers with white on their inner webs at the tips; ear-coverts ashy; under parts yellow; sides indistinctly streaked with blackish. L., $4 \cdot 75$; W., $2 \cdot 20$; T., $1 \cdot 95$; B. from N., $\cdot 28$.

Remarks. - The chestnut-rufous patch in the back at once identifies the adults; but the young are puzzling birds, to be known chiefly by their small size, absence of wing-bars and streaks on the sides.

Range.-Eastern United States; breeds from Florida to Michigan and Massachusetts; winter's from southern Florida southward.

W ashington, very common S. R., Apl. 20 to Sept. Sing Sing, rare S. R., May 2 to Sept. 14. Cambridge, locally common S. R., May 8 to Sept. 15.

Nest, of plant fibers and plant down, lined with rootlets and long hairs, in briary bushes. Eggs, four to five, white, spotted distinctly and obscurely with cinnamon- or olive-brown, or chestnut, chicfly in a wreath at the larger end, $\cdot 61 \times \cdot 48$.

The Yellow, Palm, and Prairie Warblers are the three "Wood Warblers" that are rarely found in the woods. The latter, however, differs decidedly in habits from either of the former. It is a rather retiring inhabitant of scrubby clearings, bushy fields, and pastures, or thickets of young pines and cedars. But while the Prairie, if silent, might readily escape observation, no one with an ear for bird music will pass within sound of a singing bird without at least trying to solve the mystery of its peculiar notes, a series of six or seven quickly repeated zees, the next to the last one the highest.

6y4. Seiurus aurocapillus (Limn.). OVEN-BIRn; GOLDEN-CROWNED Timush. (Fig. 104.) Ad.-Center of the crown pale rufous or ochraceousbuff', bordered on either side by black lines; rest of the upper parts, wings, and tail brownish olive-green; no wing-bars or tail-patches; under parts white; the sides of the throat, the breast, and sides streaked with black. L., 6.17 ; W., $3 \cdot 00$; T., $2 \cdot 15$; B. from N., 35 .

Range.-Eastern North America; breeds from Kansas and Virginia northward to Manitoba and Labrador, southward along the Alleghanies to South Carolina; winters from Florida southward.

Washington, very common S. R., Apl. 20 to Oct. 15. Sing Sing, common S. R., Apl. 27 to Oct. 10. Cambridge, abundant S. R., May 6 to Sept. 15.

Nest, bulky, covered, the entrance at one side, of coarse grasses, weed stalks, leaves, and rootlets, on the ground. Eggs, four to five, white, speckled or spotted with cinnamon- or rufous-brown markings, sometimes finely distributed, sometimes confluent about the larger end, $80 \times \cdot 60$.

During the nesting season Oren-birds are among our commonest woodland birds. We hear them everywhere; one singer scarcely ceases before another begins. But when the song period has passed how 


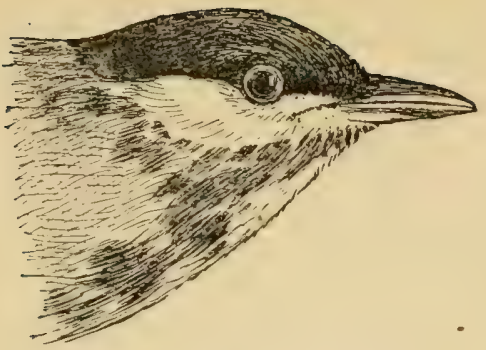

FIG. 102.-Black-poll Warbler.

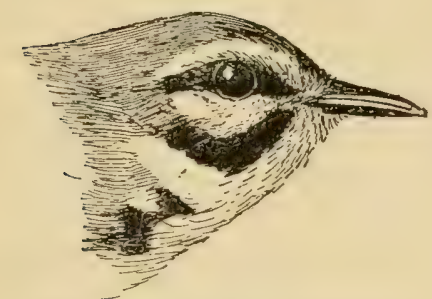

Fig. 103.-Prairie Warbler.

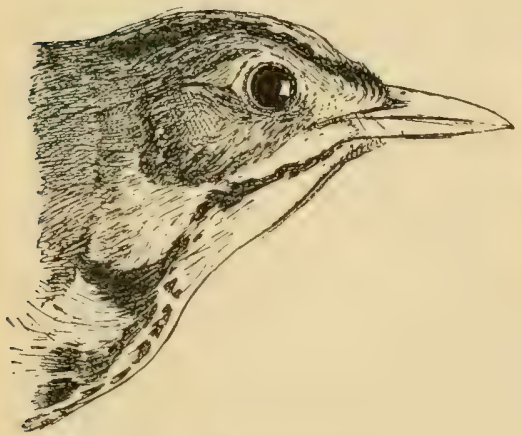

FIG. 104.-Oven-bird.

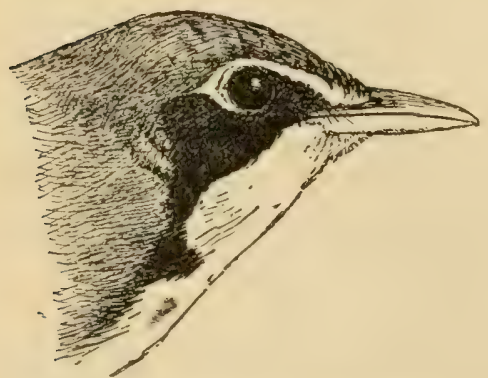

Fig. 105.-Kentucky Warbler.

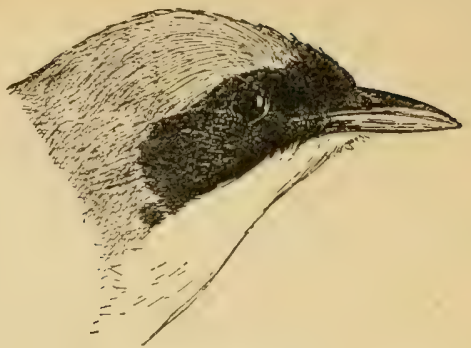

Fig. 1C6.-Maryland Yellow-throat.

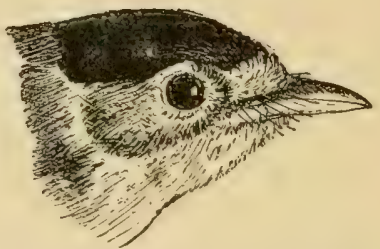

Fig. 107.-Wilson's Tarbler.

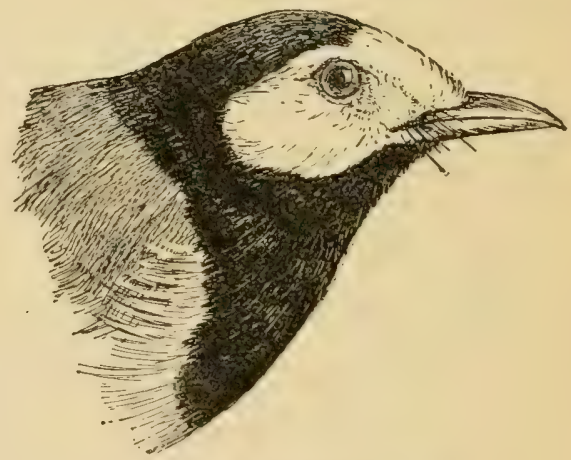

Fig. 108.-Hooded Warbler.

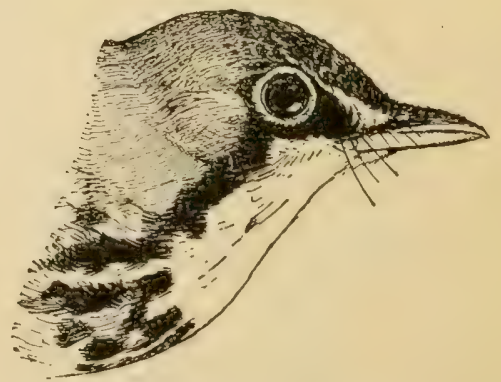

Fra. 109.-Canadian Warbler.

Figs. 102-109.-Heads of Warblcrs. (Natural size.) 
comparatively rare they become! The reason is not hard to find. At most times the Oven-bird is somewhat of a recluse. He passes much of his time on or near the ground, generally where the woods are more or less undergrown. Only the practiced car will detect his sharp, weak cheep.

If there be such a thing as inspiration, I believe the Oven-bird sings under its influence. Not that his usual song is in the least remarkable, but because the bird is so obviously moved by a spirit which demands utterance. Watch him now as he is about to sing. Flying up from the ground, how cautiously he hops from branch to branch, and, with crest slightly erect, walks carefully along a limb, when, suddenly overcome by the music in his soul, he throws fear to the winds and lifts up his voice in a crescendo chant which vibrates through the woods. Teacher, teacher, TEACHER, TEACHER, TEACHER, Mr. Burroughs writes it, and the description is difficult to improve upon.

The bird fairly quivers with the violence of his effort. The result seems inadequate; we feel that he is striving for something better, and, in truth, as Mr. Bicknell says, he sometimes breaks the bonds that ordinarily beset his expression, and "bursts forth with a wild outpouring of intricate and melodious song," the very force of which carries him up into the air among the tree tops.

635. Seiurus noveboracensis (Gmel.). Water THRLin. Al.Upper parts, wings, and tail uniform olive; no wing-bars or tail-patches; a buffy line over the eye; under parts white, tinged with pale sulphur-yellow, and everywhere-including throat-streaked with black. L., 6.04; W., 2.99; T., $2 \cdot 11 ;$ B. from N., $\cdot 31$.

Range.-Eastern North America; breeds from northern Illinois and northern New England northwarl; winters from the Gulf States to northern South America.

Washington, common T. V., Apl. 25 to May 25 ; July 20 to Sept. Sing Sing, tolerably common T. V., May 11 to 21 ; July 28 to Oct. 3. Cambridge, very common T. V., May 8 to 25 ; A ug. 10 to Oct. 10.

Nest, of moss, lined with tendrils and fine rootlets, in a mossy bank or under the roots of a fallen tree. Eggs, four to five, white or buffy white, with numerous cinnamon-brown markings, chiefly about the larger end, $\cdot 76 \times \cdot 59$.

In general habits this bird resembles its southern relative, the Louisiana Water-Thrush, but during its migrations it is frequently found some distance from water, and I have known birds spend several days beneath erergreen trees on a lawn a quarter of a mile from the wonds. It is, too, much less shy than motacilla, and one can generally approach closely enough to take note of the characters which distinguish it from that species-a smaller bill and yellower under parts.

I have heard it sing only as a migrant, when its song lacked the wildness of that of $S$. motacilla. 
6r5a. S. n. notabilis (Ridgw.). Grinnell's Water-Thrush.-Similar to the preceding, but slightly larger, upper parts darker, under parts and line over the eye whiter. W., $3 \cdot 10 ;$ T., $2 \cdot 20 ;$ B. from N., $\cdot 37$.

Range.-" United States, from Illinois westward to California, and north into British America"; eastward during the migrations to Virginia and the South Atlantic States, casually to New Jersey; winters from the Gulf States to northern South America.

Washington, casual, two instances, May.

6\%6. Seiurus motacilla ( Tieill.). Lolisiana Water-Tirush. $A d$. -A conspicuous white line over the eye; upper parts, wings, and tail olive; no wing-bars or tail-patches; under parts white, tinged with cream-buff, especially on the flanks, and streaked with black, except on the throat and middle of the belly. L., $6 \cdot 28$; W., $3 \cdot 23$; T., 2.14 ; B. from N., 40 .

Remarks. - Aside from its larger size, this bird may be known from the two preceding by the whiter, more conspicuous line over the eye, buffy instead of yellowish tinge on the under parts, and absence of spots on the throat.

Kange--Eastern United States; breeds as far north as Minnesota and Connecticut; winters in the tropies.

Washington, rare S. R., Apl. 14 to Sept. 5. Sing Sing, common S. R., Apl. 9 to Aug. 24.

Nest, of leaves, twigs, and rootlets, under a bank or the upturned roots of a fallen tree. Eygs, four to six, white, evenly speckled or spotted, distinctly and obscurely, with cinnamon- or rufous-brown, $\cdot 75 \times \cdot 60$.

Few birds are more particular in their choice of homes than the Water-Thrush. He lives where dashing brooks leap down wooded hillsides, or, more rarely, where quieter streams flow through the lowland forests. He is a wild, shy bird, and his never-ceasing alertness surgests the watchfulness of the sarage. Approach as quietly as you will, the Water-Thrush knows of your coming. With a tilting motion he wallis on ahead, springs from rock to rock, or with a sharp, metallic chink of alarm takes wing and darts through the woods so low you scarcely get a glimpse of him. From a distant limb near the ground he watches you, constantly teetering his body as though even when resting he must find some outlet for his surplus nervous energy.

As a songster the Water-Thrush is without a rival. His song is not to be compared with the clear-voiced carol of the Rose-breasted Grosbeak, the plaintive chant of the Field Sparrow, or the hymnlike melody of the true Thrushes; it is of a different kind. It is the untamable spirit of the bird rendered in music. There is an almost fierce wildness in its ringing notes. On rare occasions he is inspired to voice his passion in a flight-song, which so far exceeds his usual performance that even the memory of it is thrilling.

6yy. Geothlypis formosa (Tils.). Kentéci WArbler. Ad. o.(Fig. 105.) A yellow line from the bill passes over and around the back of 


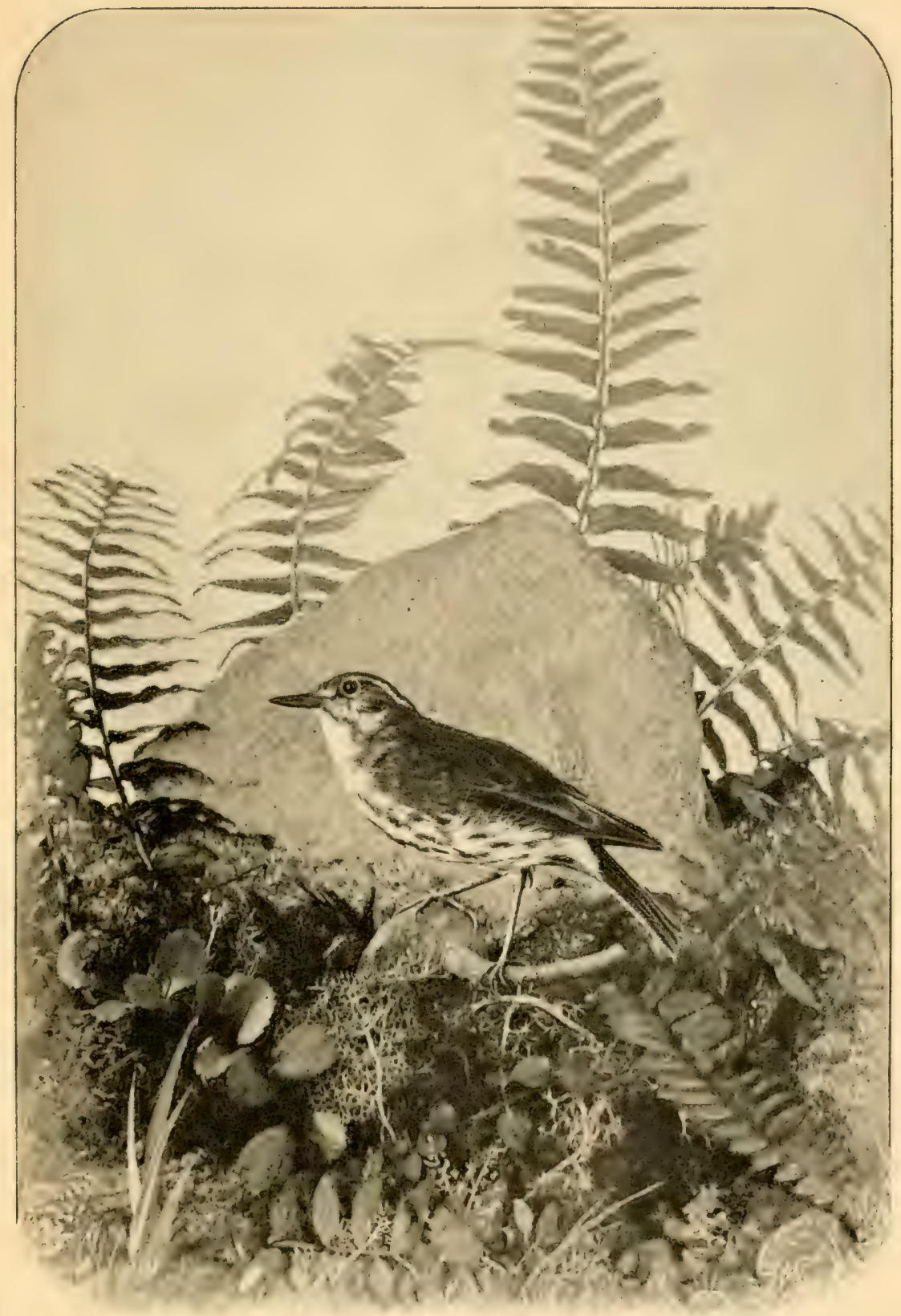

LOUISIANA WATER-'T'HRUSH. 

the eye; crown, region below the eye, and the side of the throat black; rest of the upper parts, wings, and tail olive-green; no wing-bars or tail-patches; under parts bright yellow. Ad. . - Similar, but the black areas more grayish and less clearly defined. L., 5*40; W., $2 \cdot 60 ;$ T., 1.90; B. from N., 32 .

Runge.-Eastern United States; breeds from the Gulf States to Iowa and Connecticut; winters in Central America.

Washington, not very uncommon S. R., May 3 to Sept. 5. Sing Sing, common S. R., May 2 to Aug. 27.

Thest, bulky, of twigs and rootlets, firmly wrapped with several thicknesses of leaves, lined with fine rootlets, on or near the ground. Eggs, four to five, white or grayish white, finely and evenly speckled or coarsely blotehed with rufous to umber, $\cdot 72 \times \cdot 58$.

The Kentucky Warbler frequents rather densely grown, wellwatered woods. Here he may be found, on or near the ground, hopping from limb to limb or ualking about searching for food. When singing, he generally mounts to the lower branches of the higher trees. His song is entirely unlike that of any other Warbler. It is a loud, clearly whistled performance of five. six. or seven notes-tur-dle, turdle, tur-dle-resembling in tone some of the calls of the Carolina Wren. Eren in the roods it may be heard at a distance of about one hundred and fifty yards.

In the height of the breeding season this Warbler is a most persistent singer. On one occasion, at Englewood, N. J., I watched a male for three hours. During this period, with the exception of five interruptions of less than forty-five seconds each, he sang with the greatest regularity once every twelre seconds. Thus, allowing for the brief intervals of silence, he sang about 875 times, or some 5,250 notes. I found him singing, and when I departed he showed no signs of ceasing.

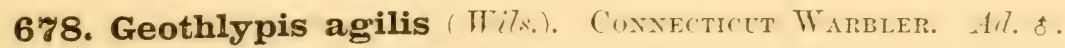
-Head, neck, and breast bluish gray, lighter on the throat; crown in the fall tipped with olive-green; eye-ring white; rest of upper parts, wings, and tail olive-green; no wing-bars or tail-patches; belly yellow; sides washed with olive-green. $A d$. $q$ and $I m$.- Similar to the $\hat{o}$, but upper parts uniform oliveereen; throat and breast pale grayish brown; belly pale yellow. L., 5.40; W.. $2 \cdot 90:$ T., 1:90; B. from N., 32 .

Pange.-Eastern North America; breeds, as far as known, in Manitoba; winters in northern South America.

Washington, T. V., very rare in spring, late May : common from Aug. 28 to Oct. 15. Sing Sing, rare T. V., Aug. 26 to Oct. 9. Cambridge, fall 'T. V., sometimes locally abuudant, Sept. 10 to 30.

Nest, of dry grasses, on the ground. Eggs, four, white, with a few spots of lilac-purple, brown, and black about the larger end, $75 \times \cdot 60$ ('Thompson, Auk, i, 1884, p. 192).

"Connecticut Warbler" is an unfortunate mismomer for this spe- 
cies. "Swamp" or "Tamarac Warbler," or "Bog Black-throat," would have been much more truly descriptive.

In the cold, boggy tamarac swamps of Manitoba, where I found it breeding, it was the only one of the family, and almost the only bird, whose voice broke the silence, of those gray wastes. Its loud song was much like the "teacher, teacher" chant of the Oven-bird, but it also uttered another, which I can recall to mind by the aid of the syllables "free-chapple, free-chapple, free-chapple, wногт."

The nest was placed on the ground, or, rather, in the moss which everywhere covered the ground to a depth of a foot or two, and was composed of fine vegetable fibers.

This species has somewhat the manners of the Vireos but is much more active and sprightly in its movements. During the migrations it is generally found on or near the ground, in the undergrowth of low, damp woods, and also in bordering, weedy fields, where it sometimes announces its presence by a sharp peek. Ernest E. Thompson.

6\%9. Geothlypis philadelphia (Wils.). Mourning Warbler. $A d$. o. - -Head, neck, and throat bluish gray, changing to black on the breast; no white eye-ring; rest of upper parts, wings, and tail olive-green : no wingbars or tail-patches; belly yellow. $A d$. \& and Im.-Similar, but upper parts olive-green, slightly grayer on the head; breast grayish, throat whiter. L., $5.63 ;$ W., $2.56 ;$ T., $2 \cdot 13$; B. from N., $\cdot 32$.

Remarks.-This species bears a general resemblance to the preceding, but may always be distinguished from it by the absence of a white eye-ring.

Range.-Eastern North America; breeds from eastern Nebraska, northern New York, and Nova Scotia northward, and southward along the Alleghanies to Pennsylvania; winters in the tropies.

Washington, very rare T. V., May 15 to 30 ; Aug. Sing Sing, rare T. V., May 28 to $29 ;$ Aug. 18 to Oct. 1. Cambridge, rare 'T. V., May 22 to June 6 ; Sept. 12 to 30 .

Nest, of strips of bark and other fibrous materials, lined with hair, on or near the ground. Eggs, four, white, sprinkled with reddish dots near the larger end, $\cdot 71 \times \cdot 54$ (Davie).

The Mourning Warbler inhabits the undergrowth, choosing situations not unlike those selected by the Maryland Yellow-throat.

"Its common song consists of a simple, clear, warbling whistle, resembling the syllables 'truée, 'triée, 'trúe, 'trú, 'toó, the voice rising on the first three syllables and falling on the last two.

"Sometimes, when otherwise occupied, the first, or first two, syllables are omitted. All through the breeding season, and till late in $\mathrm{July}$, they have a very characteristic habit of perching, at frequent intervals during the day, on some branch, generally a dead one, and commonly ten or fifteen feet from the ground, and singing for half an hour at a time" (Merriam, Birds of Connecticut, p. 24). 
681. Geothlypis trichas (Linn.). Marylani Yellow-throat. (Fig. 106.) $A d$. of. $-A$ broad band across the forehead, and on the cheeks and ear-coverts black, bordered behind by grayish; rest of the upper parts, wings, and tail olive-green, sometimes tinged with brownish; no wing-bars or tailpatches; throat and breast bright yellow, changing to whitish on the belly; sides washed with brownish; under tail-coverts yellow. Ad. of in fall.Similar, but browner above; black mask tipped with grayish; belly more yellow; sides browner. Im. of.-Similar, but the black mask more concealed, sometimes merely indicated by a dusky area. $A d . \& .-$ No black mask; upper parts, wings, and tail olive-green, the forehead sometimes tinged with rufous; throat and breast yellowish, changing to whitish on the belly; under tail-coverts yellow; sides brownish. L., 5.33; W., $2 \cdot 20$; T., $2 \cdot 04$; B., ${ }^{\circ} 42$.

Range.-Eastern North America, west to the Plains; breeds from the Gulf States to Manitoba and Labrador; winters from the Gulf States southward.

Washington, abundant S. R., Apl. 18 to Oet. 20. Sing Sing, common S. R., Apl. 28 to Oct. 23. Cambridge, abundant S. R., May 5 to Oct. 20.

Nest, bulky, of strips of bark, coarse grasses, and clead leaves, lined with fine grasses, tendrils, and rootlets, on or near the ground. Eggs, three to five, white, rather thinly speckled and spotted with rufous to umber, chicflysometimes entirely - at the larger end, $\cdot 70 \times \cdot 53$.

One of the first acquaintances you will make, when you begin to look for birds, will be this black-masked inhabitant of thickets and bushes. Indeed, you have only to pause near his home, when he will meet you halfway. He announces his coming by an impatient, quickly repeated chack, varying to chit, pit, quit, as, hopping from twig to twig, he finally appears for a moment and then darts back into the cover of his haunts.

His song is characteristic of his active, nervous nature, and is delivered with much force and energy. It varies greatly with locality. a fact which may account for the quite different descriptions given of it by authors. Sometimes it is written wichity, wichity, wichity, wichity; again, rapity, rapity, etc. : but the birds near New York eity seem to me to say $I$ beseech you, I beseech you, I beseech you, I beseech you; though, to be sure, the tone is far from pleading.

They sing throughout the summer, and in August add a flight song to their repertoire. This is usually uttered toward evening, when the bird springs several feet into the air, hovers for a second, and then drops back to the bushes.

681b. G. t. ignota rhapm. Florima lelelow-throat; Palmetto BirD.-Similar to the preceding, but with longer tarsus, tail, and bill; yellow of under parts of a deeper shade and of greater extent; flanks of a much darker eolor; upper parts browner; black mask wider, its ashy border (in summer specimens) slightly paler and of greater extent: first primary shorter, equaling the eighth instead of the sixth. WV., $2 \cdot 17$; T., 2.18; B., 47 .

Range.-Florida and southern Georgia. 
This southern representative of the Maryland Yellow-throat is usually found in dense rrowths of scrub palmetto. Its song is quite unlike that of the northern bird.

683. Icteria virens $(\operatorname{Linn}$.$) Y Yellow-blieastel) Chat. A d$ - Isargest of the Warblers; upper parts, wings, and tail olive-green; line from the eye to the bill, one on the side of the throat, and eye-ring white; throat,

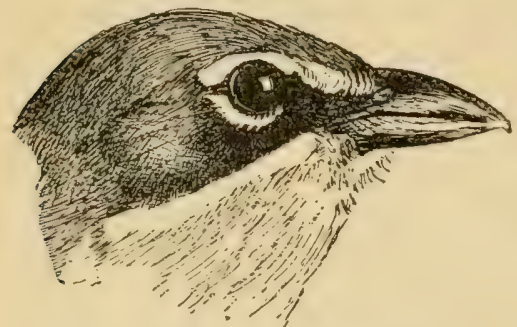

Fig. 110.-Yellow-breasted Chat. (Natural size.) breast, and upper belly bright yellow; lower belly white; sides grayish. L., $7 \cdot 44$; W., 3.00; T., 3.07; B. from N., 41 .

Range._-Eastern United States; breeds as far north as southern Minnesota and Massachusetts; and winters in Central America.

Washington, common S. R., Apl. 29 to Sept. Sing Sing, common S. R., Apl. 28 to Aug. 29. Cambridge, rather rare S. R., May 15 to (?).

Nest, rather bulky, of coarse grasses, leaves, and strips of bark well interwoven, lined with finer grasses, in a crotch near the ground. Eggs, three to five, white, rather evenly speckled and spotted with rufous-brown, $990 \times 66$.

Bushy undergrowths or thickets in partial clearings form the home of the Chat. After an acquaintance of many years I frankly confess that his true character is a mystery to me. While listening to his strange medley and watching his peculiar actions, we are certainly justified in calling him eccentric, but that there is method in his madness no one who studies him closely can doubt.

Is the odd jumble of whistles, chucks, and caws uttered by one bird in that copse yonder, or by half a dozen different birds in as many places? Approach cautiously, and perhaps you may see him in the air-a bunch of feathers twitched downward by the queer, jerky notes which animate it. One might suppose so peculiar a performance would occupy his entire attention, but nevertheless he has seen you; in an instant his manner changes, and the happy-go-lueky clown, who a moment before was turning aërial somersaults, has become a shy, suspicious haunter of the depths of the thicket, whence will come his querulous chŭt, chŭt as long as your presence annoys him.

684. Sylvania mitrata ( $G$ mel.). Ilonded Warbler. (Fig. 108.) Ad. 8.-Forehend and cheeks bright yellow; crown black, connected behind with the black throat; upper parts, wings, and tail olive-green; outer tailfeathers with inner vane mostly white; breast and belly yellow; bill with evident bristles at its base. Ad. \&.-Similar, but with the black on head and breast somewhat restricted and less sharply defined. Im. $\delta$.- Similar to ad. $\delta$, but the black feathers with yellow tips. Im.. . - Similar to ad. $\&$, but 
with no black on the head or breast. L., 5.67 ; W., 2.58 ; T., $2.30 ;$ B. from N., 31 .

Range.-Eastern United States; breeds as far north as southern Michigan and southern Connecticut, and winters in Central America.

Washington, rare 'T. V., may breed; May 1 to 30 ; Aug. 15 to Sept. 15. Sing Sing, rare S. R., to Sept. 1 .

Nest, of leaves, strips of bark, and rootlets, lined with fine grasses and rootlets, in the croteh of a bush or sapling, about four feet up. Eggs, four to five, white or creamy white, rather thinly speckled or spotted with rufous or rufous-brown, generally in a wreath at the larger end, $\cdot 71 \times \cdot 53$.

'This beautiful bird is a lover of well-watered, rather densely grown woods. It is a bird of the lower growth rather than the trees, but is not a thicket-haunter, and its habit of flitting restlessly from bush to bush renders it easily observed. When on the wing its white outer tail-feathers are conspicuously displayed. and, with the striking markings of the head, make an excellent field mark.

The song of the Ilooded Warbler is sweet and graceful. It is subject to much variation, but as a rule consists of eight or nine notes. To my ear the bird seems to say, "You must come to the woods, or you won't see me."

Its call-note is a sharp, characteristic cheep, frequently uttered when the bird is anxious for the safety of its nest or young, and accompanied by a flit of the tail, which reveals the white outer tail-feathers.

685. Sylvania pusilla (WiT.s.). Frilsox's Warnler (Fig. 107.) Ad. S.-Forehead yellow, crown black; rest of the upper parts, wings, and tail bright olive-green; no wing-bars or tail-patches; under parts bright yellow; bill with bristles at its base. Ad. \&. - Similar, but generally without the black cap. Im.-Similar, but without black cap. L., 5.00; W., 2.21 ; 'I', 2.03 ; B. from N., 25.

Kange.-North America; breeds from British Columbia, Minnesota, and Nova Scotia northward; winters in Central America.

Washington, rather common T. V., May 8 to 23 ; Aug. 28 to Sept. 15. Sing Sing, tolerably common T. V., May 9 to 30 ; Aug. 10 to Sept. 9. Cambridge, common 'T. V., May 12 to 25 ; Sept. 1 to 20.

Nest, of leaves and grasses, lined with fine grasses and hairs, on the ground. Eggs, four to five, white, speckled with cinnamon-rufous and lavender-gray, $59 \times \cdot 48$ (Davie).

The Black-cap frequents the lower woodlund growth, and is gencrally found near water. Like other members of this genus, it has decided talents as a flycatcher, and eaptures much of its prey on the wing, darting out into the air, but does not, like a true Flycatcher, return to the same perch.

Its song is compared by Minot to that of the Redstart or Yeliow Warbler, while Nuttall writes it "'tsh-'tsh-'tsh-'tshea," and to Goss it sounds like "zee-zee-zee-zee-e." 
686. Sylvania canadensis (Lini.). CANADLAN WARBLets. (Fị. 109.) $A d$. $\delta$.- -Upper parts, wings, and tail gray; no wing-bars or tail-patehes; crown spotted with black; line from the bill to the eye and under parts yellow; sides of the neck black; a necklace of black spots across the breast; under tail-coverts white; hill with evident bristle at its base. $A d$. \& and Im.-Similar, but with no black on the head or sides of the throat; necklace inlicuted by dusky spots. L., $5 \cdot 61$; W., $2 \cdot 53 ;$ T., $2 \cdot 23$; B. from N., $\cdot 31$.

Range.-Eastern North America; breeds from northern Michigan and Milsisthusetts to Manitoba and Labrador, and winters in Central and South America.

Washington, very common T. V., May 5 to 27 ; Aug. 7 to Sept. 25. Sing Sing, common 'T. V., May 6 to June 2; Aug. 10 to Oct. 11. Cambridge, common T. V., May 18 to 28 ; Sept. 1 to 20.

Nest, of strips of bark, bits of dead wood, and moss wrapped in leaves, and lined with tine rootlets, in mossy banks or under roots. Eggs, four to tive, white, speckled and spotted, chiefly at the larger end, with rufous or rufousbrown, $\cdot 66 \times \cdot 51$.

Although when associated with other migrating Warblers this bird may be found in woodland of varied character, it prefers low, wet woods, in which, like Wilson's Black-cap, it frequents the lower growth. Like that bird also it is an expert flycatcher.

Its song is sweet, loud, and spirited. Thompson writes it " rup itche, rup-it-che, rup-it-chitt-it lit."

68\%. Setophaga ruticilla (Linn.). American Redstart. (Nien Fig. 53, c.) Ad. of.-Upper parts, throat, and breast shining black; basal half of the wing-feathers salmon, end half and wing-coverts black; basal two thirds of all but the middle tail-feathers salmon, end third and middle feathers black; sides of the breast and flanks deep reddish salmon; belly white, tinged with salmon; bill with prominent bristles at its base. $A d$. \&. - Salmon of the $\delta$ replaced by dull yellow; head grayish; back ashy, with a greenish tinge; under parts, except where marked with yellow, white. Im.-Resemble the $q$; the $\delta$ acquires his full plumage the third year, and the second year has the plumage mottled with black. L., 5.41; W., 2.57; T., 2.27; B. from N., $: 27$.

Range.-North America; breeds from Kansas and North Carolina north to Labrador and Fort Simpson; winters in the tropies.

Washington, very abundant T. V., Apl. 18 to May 28; Aug. 19 to Sept. 25; a few breed. Sing Sing, common S. R., May 1 to Oct. 3. Cambridge, very common S. R., May 5 to Sept. 20.

Nest, of fine strips of bark, leaf stalks, and plant down, firmly interwoven, lined with tendrils and fine rootlets, in the crotch of a sapling, five to twenty feet up. Eggs, four to five, grayish white or bluish white, spotted and blotched, chiefly at the larger end, with cinnamon- or olive-brown, $68 \times 50$.

If this active, brilliantly colored inhabitant of woodlands was as rare as he is beautiful, we woulc? consider a meeting with him an crent 
demanding at least a page in our journals. In Cuba most of our Wood Warblers are known simply as "Mariposas"-butterflies; but the Redstart's bright plumage has won for him the name "C'andelita" - the little torch that flashes in the gloomy depths of tropical forests.

Ching, ching, chee; ser-wee, swee, swee-e-e he sings, and with wings and tail outspread whirls about, daneing from limb to limb, darting upward, floating downward, blown hither and thither like a leaf in the breeze. But the gnats dancing in the sunlight and the caterpillars feeding in the shade of the leaves know to their sorrow that his erratic course is guided by a purpose.

\section{Family Motacillide. Wagtails and Pipits.}

Only three of the sixty odd species in this family inhabit North America, and but one is found in the Eastern States. They are all terrestrial birds, and have been named from their habit of wagging their tails.

69\%. Anthus pensilvanicus (Lath.). American l'ipit: Titlark. (See Fig. 54.) Ad.-U pper parts dark brownish gray; wings and tail fuscous; wing-coverts tipped with whitish or buffy; end half of outer tail-feather white, next one tipped with white; a white or buffy line over the eye; under parts white or buffy, streaked with fuscous, except on the throat and middle of the belly; hind toe-nail the longest, as long as or longer than its toe. I., $6.38 ;$ W., 3.50 ; T., $2 \cdot 69 ;$ B., $\cdot 47$.

Range.- "North America at large, breeding in the higher parts of the Rocky Mountains and subarctic distriets, and wintering in the Gulf States, Mexico, and Central America "(A. O. U.).

Washington, W. V., sometimes abundant, Oct. 15 to Apl. 25. Sing Sing, common T. V., March 26 to (?); Sept. 24 to Nov. 16. Cambridge, T. V., abundant Sept. 20 to Nov. 10; less common A pl. 10 to May 20.

Nest, of grasses, on the ground. Eggs, four to six, bluish white or grayish white, thickly and evenly speckled with cinnamon- or vinaceous-brown, $.78 \times \cdot 57$.

Large, open tracts in the ricinity of the coast are the localities in which Titlarks are most common, but they are also found in numbers in old fields, meadows, and pastures inland. A recently burned or newly plowed field is a good place in which to look for them. Once seen, there is little difficulty in identifying these graceful uraliers, as they run on before you, or with constantly wagging tail await your approach. The individuals of a flock are generally scattered over a varying space while feeding, but when flushed they rise together and, with a soft dee-dee, dee-dee, mount high in the air as though bound for parts unknown, but often, after horering above you for several 
seconds in an undecided way, they will return to or near the place from which they rose.

Their flight is light and airy, and in loose companies they undulate gently throngh the air without apparent effort, uttering their faint dee-dee as they fly.

Sprague's Pipit (700. Anthus spragueii), a species of the Great Plains, has been once recorded from near Charleston, S. C. (Wayne, Auk, xi, 1894, p. 80).

The European White Wagtail (694. Motacilla alba) and European Meadow Pipit (698. Anthus pratensis) have been recorded as of accidental occurrence in Greenland.

\section{:- Family Troglodytid ze. Thrashers, Wrens, etc.}

T'wo quite different subfamilies are included under this head, the Thrashers and Mockingbirds, numbering some fifty species, and comprising the subfamily Mimino, and the subfamily Troglodytina, which includes the one hundred and fifty known species of Wrens. The former is a distinctively American group, most numerously represented in the tropical and subtropical parts of the continent, only a dozen species reaching the United States. Generally speaking, they are inhabitants of scrubby growths and bushy borders of woods. They are possessed of remarkable vocal ability, and the Mockingbirds, of which there are sixteen species, are universally conceded first rank among cur song birds so far as powers of execution are concerned.

The Wrens have a few representatives in the Old World, but by far the greater number inhabit $\Lambda$ merica, where they are most abundant in the tropics. Wrens, as a rule, are thicket haunters. They are active, nervous, excitable birds, and most of the species have characteristic scolding notes with which they express displeasure or alarm. The majority are highly musical.

KEY TO THE SPECIES.

A. Wing over 3.50 ; tail without black bars.

a. Back slate-color; cap black; under tail-coverts rufous-brown.

704. Catrirn.

b. Back and crown grayish; under parts whitish; outer tail-feathers white. 703. Mockingirird.

c. Back rufous; under parts spotted with black . 705. Brown Thrasuer. $B$. Wing less than $3 \cdot 00$; tail with numerous small bars.

a. Upper parts rufous, a long, conspicuous whitish line over the eye; under parts cream-buff or ochraceous-buff; wing $2 \cdot 25$ or over.

718. Carolina Wren. 718a. Florida Wren.

b. Upper parts uniform dark, reddish olive-brown; back without white streaks. 
61. Under parts whitish; primaries finely barred; no white line over the eye. . . . 721. House Wren. 721b. Western House Wren. $\iota^{2}$. Under parts whitish; primaries not barred; a white line over the eye. 719. BEWICK'S WREN.

$b^{3}$. Under parts brownish, finely barred with black. 722. WINTER W BEN. c. Back with white streaks.

$c^{1}$. White streaks confined to the center of the back; a white line over the eye . . . . . T25. Long-billed Marsh Wren and races. $c^{2}$. Crown, back, and wing-coverts streaked with white.

724. Sholit-Billed Marsh Wren.

y03. Mimus polyglottos (Linn.). Mockingrind. Al.-Upper parts ashy; wings and tail fuscous; basal half of the primaries white; outer tailfeather white, next mostly white, third about half white; under parts soiled white. L., 10.50 ; W., 4.50 ; T., 4.90 ; B., $\cdot 70$.

Remarks. - The sexes can not be distinguished in color.

Range.-Breeds from the Bahamas and Mexico to southern Illinois and northern New Jersey, and rarely to Massachusetts; winters from Virginia southward.

Washington, uncommon P. K., less numerous in winter. Cambridge, rare S. R., Mch. to Nov.

Nest, of coarse twigs, weed stalks, etc., lined with rootlets, cotton, etc., in thickets, orange trees, etc. Eggs, four to six, pale greenish blue or bluish white, sometimes with a brownish tinge, rather heavily spotted and blotehed, chiefly at the larger end, with cinnamon- or rufous-brown, $1.00 \times 72$.

The Mockingbird might be called our national song-bird; his remarkable vocal powers have made him famous the world over, while our more retiring Thrushes are scarcely to be found mentioned outside the literature of ornithology. He is a good citizen, and courting rather than shumning public life, shows an evident interest in the affairs of the day. He lives in our gardens, parks. and squares, and even in the streets of the town, and is always alert and on the qui vive; a selfappointed guardian, whose sharp alarm note is passed from bird to bird like the signals of watchmen.

In Florida, Mockinghirds begin to sing in February, and by March 1 the air rings with music. 'The heat of midday is insufficient to quell their ardor, and on moonlight nights many birds sing throughout the night.

It is customary to consider the Mcckingbird a musician possessed of marrelous technique, but with comparatively little depth of feeling. He is said to create intense almiration without reaching the soul. But listen to him when the world is hushed, when the air is heary with the rich fragrance of orange blossoms and the dewy leares glisten in the moonlight, and if his song does not thrill you then confess yourself deaf to Nature's voices.

Writers have compared the Mockingbird's song with that of ofher 
renowned songsters-the Nightingale, for instance-but Dr. R. W. Shufeldt, writing in Prof. Newton's Dictionary of Birds, puts it very nicely when he says: "I believe, were he successfully introduced into those countries where the Nightingale flourishes, that princely performer might some day wince as he was obliged to listen to his own most powerful strains poured forth with all their native purity by this king of feathered.mockers. ..."

Nevertheless, it must not be supposed that every Mockingbird is a mocker; there is much variation in their imitative gifts. Mr. L. M. Loomis tells me of a Mockingbird he once heard singing in South Carolina who imitated the notes of no less than thirty-two different species of birds found in the same locality, and this during ten minutes' continuous singing! 'This was a phenomenal performance, one I have never heard approached, for in my experience many Mockingbirds have no notes besides their own, and good mockers are exceptional.

y04. Galeoscoptes carolinensis (Linn.). Catвird. (See Fig. $55, b) A$.$d .-Crown and tail black; under tail-coverts chestnut, sometimes$ spotted with slaty, and rarely largely slaty; rest of the plumage slaty gray. L., 8.94; W., 3.54 ; 'T., $3.65 ;$ B., 60 .

Range--North America; breeds in the eastern United States from the Gulf States to New Brunswick and northwestward to the Saskatchewan and British Columbia; winters from Florida southward.

Washington, abundant S. R., Apl. 20 to Oct.; occasionally winters. Sing Sing, common S. R., A pl. 28 to Oct, 25. Cambridge, abundant S. R., May 6 to Sept. 30.

Nest, of twigs, grasses, and leaves, lined with rootlets, in thickets or densely foliaged trees. Eggs, three to five, rich greenish blue, $94 \times \cdot 67$.

The Catbird is one of the most intelligent birds in North America. He is inclined to be very friendly to man, and where he is well treated and his confidence won he likes to nest near our homes, showing himself delightfully familiar, coming around the door steps, answering one's calls and talk, and singing by the hour for our entertainment. In the garden and orchard he is as useful as he is enchanting, for he is an untiring devourer of insects, and his value in preserving our fruits can hardly be overrated. In this way he earns his full share of the fruit protected, and it should not be grudged to him when he proceeds to take it, as he surely will.

It is not generally known that the Catbird is a charming singer, for the reason, probably, that his song is rarely loud, and is preferably given from the depths of the thickest shrub he can find. One more often hears than sees him sing, and will miss even the hearing unless quite near, and gifted with a listening ear, ever open to bird notes.

The Catbird mother is one of the most anxious and devoted. If 
her nest is discovered, she exhibits so much distress that one sympathetic to bird griefs has no heart to pursue investigations.

The Catbird is generous and helpful to others of his kind in trouble of any sort, feeding and caring for deserted or orphaned young ones of any species, and always ready to aid distracted parents in the defense of their home and little ones.

He is of a lively and restless temperament, entirely lacking the serene repose of his near relatives, the Thrushes. He is always tossing upward or spreading his tail, jerking his lithe body about, now crouching like a cat ready to spring, then straightening himself up very tall; one moment puffing his feathers out till he looks like a ball, and the next holding them closely against his body. He is very playful, full of droll pranks and quaint performances. I know of no bird better worth cherishing and cultivating than the Catbird.

\section{Olive Thorne Miller.}

y05. Harporhynchus rufus (Limn.), Brown Thrasher; Brown Thrusir. (See Fig. $55, a_{\text {. }}$ ) $A d$.-Upper parts, wings, and tail rufous; wingcoverts tipped with whitish; under parts white, heavily streaked with black, except on the throat and middle of the belly. L., 11.42 ; W., 4.06; T., 5.03; B., $\cdot 96$.

Range.-Eastern North America; breeds from the Gulf States to Manitoba, Maine, and Montreal: winters from Virginia southward.

Washington, very common S. R., A pl. 5 to Oet. 15 ; occasionally winters. Sing Sing, common S. R., A pl. 22 to Oct. 28. Cambridge, very common S. R., Apl. 25 to Oct. 15 .

Nest, of twigs, coarse rootlets, and leaves, lined with finer rootlets, in bushes, thickets, or on the ground. Eggs, three to six, bluish white or grayish white, thickly, evenly, and minutely speckled with cinnamon- or rufousbrown, $1.08 \times \cdot 80$.

Hedgerows, shrubbery about the borders of woods, scrubby growth, or thickets in dry fields, are alike frequented by the Thrasher. Generally speaking he is an inhabitant of the undergrowth, where he passes much time on the ground foraging among the fallen leaves. He is an active, suspicious bird, who does not like to be watehed, and expresses his annoyance with an unpleasant kissing note or sharply whistled whè̀u.

Like many thicket-haunting birds, who ordinarily shun observation, he seeks an exposed position when singing. Morning and evening he mounts to a farorite perch-generally in the upper branches of a tree-and deliberately gives his entire attention to his song. This is repeated many times, the bird singing almost continuously for an extended interval. He is a finished musician, and, although his repertoire is limited to one air, he rivals the Mockinghird in the richness of his tones and execution. I never listen to the Thrasher's song with- 
out involuntarily exclaiming, "What a magnificent performance!" Nevertheless, there is a certain consciousness and lack of spontaneity about it which makes it appeal to the mind rather than to the heart.

r18. Thryothorus ludovicianus (Lath.). Carolina Wren. (See Fig. 55, c.) Ad.-Upper parts rufous-brown; feathers of the rump with conccaled downy white spots; a long, conspicuous whitish line over the eye; wings and tail rufous-brown, finely barred with black; under parts ochraceous-buff or cream-buff', whiter on the throat; flanks sometimes with a few blackish bars. L., $5 \cdot 50$; W., $2 \cdot 30$; T., $2 \cdot 00 ;$ B., 60 .

Range.-Eastern United States; breeds from the Gulf States to southern Iowa, northern Illinois, and southern Connecticut; resident, except at the northern limit of its range.

Washington, common P. R.

Nest, bulky, of grasses, feathers, leaves, etc., lined with finer grasses, long hairs, etc., in holes in trees or stumps, nooks and crevices about buildings, etc. Eggs, four to six, white or ereamy white, with numerous cinnanon-, rufous-brown, and lavender markings, sumetimes wreathed about the larger end, $\cdot 75 \times \cdot 58$.

The cozy nooks and corners about the home of man which prove so attractive to the House Wren have no charms for this bird. His wild nature demands the freelom of the forests, and he shows no disposition to adapt himself to new conditions. Undergrowths near water, fallen tree tops, brush heaps, and rocky places in the woods where he can dodge in and out and in a twinkling appear or disappear, like a feathered Jack-in-the-box, are the resorts he chooses.

The nervous activity so characteristic of all Wrens reaches in him its highest development. Whatever he may be when alone, he is never at rest so long as he imagines himself observer. Now he is on this side of us, now on that: a moment later, on a stump before us, bobbing up and down and gesticulating wildly with his expressive tail; but as a rule he is seldom in sight more than a second at a time.

Of course, so excitable a nature must find other than physical outlet for his irrepressible energy, and he accompanies his movements by more or less appropriate notes: scolding cacks, clinking, metallic rattles, musical trills, tree-toadlike krrrings-in fact, he possesses an almost endless vocabulary. He is sometimes called Mocking Wren, but the hundreds of birds I have heard were all too original to borrow from others. In addition to his peculiar calls he possesses a variety of loud, ringing whistles, somewhat similar in tone to those of the Tufted Titmouse or Cardinal, and fully as loud as if not louder than the notes of the latter. The more common ones resemble the syllables whee-udel, whee-udel, whee-udel, and tea-kettle, tea-kettle, tea-kettle. 
y18a. T. 1. miamensis Rillgw. Florida Wren,-Similar to the preceding, but larger; upper parts darker; under parts more deeply colored. W., $2 \cdot 46 ;$ 'I., $2 \cdot 19 ;$ B., $\rightarrow 70$.

Range.-Florida, from Pasco and Brevard Counties southward.

y19. Thryothorus bewickii (Aud.). BEWICK's W IREN. Ad.Upper parts dark cinnanion-brown; feathers of the rump with concealed, downy white spots; primaries not barred; central tail-feathers barred; outer ones black, tipped with grayish; a white line over the eye; under parts grayish white; flanks brownish. L., 5•00; W., $2 \cdot 30 ;$ 'T., $2 \cdot 10 ;$ B., $\cdot 50$.

Range.- "Eastern United States, rare and local east of Alleghanies and north of $40^{\circ}$; west to edge of Great Plains; winters in more southern districts (Georgia to eastern T'exas)" (Ridgw.).

Washington, rare T. V., may winter, A pl. 4 to 22 ; Nov. 24 to Dec. 22.

Nest, resembles that of T. aedlon; location the same. Eggs, four to six, white, speckled with cinnamon-, rufous-brown, or lavender, evenly, or in a wreath at the larger end, $\cdot 66 \times \cdot 50$.

"No bird more deserres the protection of man than Bewick's Wren. He does not need man's encouragement, for he comes of his own accord and installs himself as a member of the community wherever it suits his taste. He is found about the cow-shed and barn along with the Pewee and Barn Swallow; he investigates the pig-sty, then explores the garden fence, and finally mounts to the roof and pours forth one of the sweetest songs that ever was heard. Not . . . like the House Wren's merry roundelay, but a fine, clear, bold song, uttered as the singer sits with head thrown back and long tail pendent-a song which may be heard a quarter of a mile or more, and in comparison with which the faint chant of the Song Sparrow sinks into insignificance. The ordinary note is a soft, low plit, uttered as the bird hops about, its long tail carried erect or even leaning forward, and jerked to one side at short intervals. In its movements it is altogether more deliberate than either T. ludovicianus or T. aёdon, but nothing can excel it in quickness when it is pursued" (Ridgway).

y21. Troglodytes aëdon Tieill. IIOt'se WrEN. Ad.-- l Pper parts cinnamon olive-brown, more rufous on the rump and tail; baek generally with indistinct bars; feathers of the rump with concealed, downy white spots; wings and tail finely barred; under parts whitish, sides or flanks with numerous blackish bars. L., 5.00; W., 1.97; T., 1·71; B., 50 .

Range.-Enstern North Ameriea; breeds as far north as Manitoba, Montreal, and Maine; and winters from South Carolina southward.

Washington, common S. R., Apl. 15 to Sept. Sing Sing, common S. R., Apl. 23 to Oet. 14 . Cambridge, loeally common S. R., May 1 to Sept. 25.

Nest, of twigs lined with grasses, generally filling the hole in a tree, birdbox, erevice, etc., in which it is placed. Eggs, six to eight, vinaceous, uniform, or minutely speckled, with generally a wreath of a decerer shade at the larger end, $\cdot 65 \times 51$. 
It has been claimed that the name House Wren is a misnomer, because in the south during the winter these birds are found in the forests miles from the nearest habitation. This, however, is owing to circumstances over which the House Wren has no control. He is just as much of a House Wren in the south as he is in the north; you will find a pair in possession of every suitable dwelling. The difficulty is that in the winter there are more House Wrens than there are houses, and, being of a somewhat irritable disposition, the House Wren will not share his quarters with others of his kind. Late comers, therefore, who can not get a snug nook about a house or outbuilding, are forced to resort to the woods.

In the summer, when they are spread over a much greater area, House Wrens are very particular in their choice of haunts, and for this reason are locally distributed. Having selected a nesting site, they become much attached to it, and return to the same place year after year. It may be a bird-box, a crevice in a building, a hollow in an apple tree, or hole in a fence rail; wherever it is, it is theirs, and they will fight for it against all comers.

The song of the House Wren is delivered with characteristic energy-a sudden outpouring of music which completely dominates the singer, who with raised head and drooped tail trembles with the violence of his effort.

y21b. T. a. aztecus (Baird). W Estern Horse Wren.-Similar to the preceding, but upper parts lighter and less rufous, the back and rump generally distinctly barred with blackish.

'Range.-Interior of' North America, east to the Mississippi Valley; Minnesota, Illinois.

r22. Troglodytes hiemalis rieill. WINTER Wren. Ad.-Upper parts dark einnamon-brown; feathers of the rump with concealed, downy white spots; wings and tail barred; under parts washed with pale cinnamonbrown, the lower breast, sides, and belly more or less heavily barred with black. L., $4 \cdot 06$; W., $1.89 ;$ 'T., $1.24 ;$ B., .55.

Range.-Eastern North America; breeds from the Northern States northward, and southward along the Alleghanies to North Carolina; winters from Massachusetts and Illinois to Florida.

Washington, rather common W. V., Sept. 25 to May 1. Sing Sing, tolerably common W. V., Sept. 18 to Apl. 27. Cambridge, T. V., rather common, Sept. 20 to Nov. 25; rare, Apl. 10 to May 1: a very few winter.

Nest, of small twigs and moss, lined with feathers, in the roots of a tree, brush-heap, or similar place. "Eggs, five to seven, white or creamy white, finely but rather sparingly speckled with reldish brown, sometimes nearly immaculate, $\cdot 69 \times \cdot 50 "$ (Ridgw.).

When looking for a Winter Wren during the fall migration I go to an old raspberry patch, and in the woods watch the stumps and 
fallen trees. In the shadow of the woods it is easy to overlook the small dark bird creeping under a log or clambering over an old stump. But often, when sitting alone in the deserted patch, my heart has been warmed by the sudden apparition of the plump little Wren atilt of a dry golden-rod stalk close beside me, his tail standing straight orer his back and his head cocked on one side. He would bow to me with a droll bobbing motion, but his hearty quip-quap and the frank look of interest in his bright eyes showed that he was quite ready to make friends. Many a dull morning has been gladdened by such an encounter.

Perhaps my choicest memories, however, are of a Wren who left his usual home in the dark coniferous forest for our brighter woodlands of maple and beech. He built his nest in an upturned root on the edge of a bit of marshy land, helping himself to some feathers the Scarlet Tanager had left at his bath in the swamp behind.

I had never before had a chance to listen to his famous song, and it was the event of the summer in the woods. Full of trills, runs, and grace notes, it was a tinkling, rippling roundelay. It made me think of the song of the Ruby-crowned Kinglet, the rolume and ringing quality of both being startling from birds of their size. But while the Kinglet's may be less hampered by considerations of tune, the Wren's song has a more appealing human character. It is like the bird himself. The dark swamps are made glad by the joyous, wonderful song.

Florence A. Merriam.

724. Cistothorus stellaris (Licht.). Shomt-billed Marsi Wran. Ad.-Entire upper parts streaked with white, black, and ochraceous-buff; wings and tail barred; under parts white, washed with ochraceous-buff on the breast, sides, and under tail-coverts. L., 4.00; W., 1.75; T., 1.41; B., 42 .

Range.-Eastern North America; breeds as fur north as Manitoba and Massachusetts; winters from the Gulf States southward.

Washington, very rare T. V., two instances, May. Sing Sing, rare S. R., to Oct. 16. Cambridge, locally common S. R., May 15 to Oct. 1.

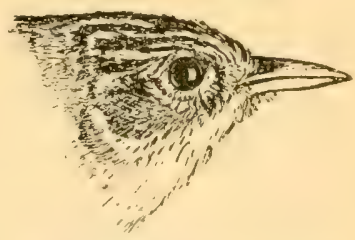

FIG. 111. - Short-billed Marsh Wren. (Natural size.)

Nest, globular, the entrance on one side, of grasses, lined with plant down, on or near the ground, in a tussock of tall grass. Eggs, six to eight, pure white, rarely with a few lavender spots, $\cdot 62 \times \cdot 47$.

This bustling, energetic little creature will much more often be heard than seen. Its ordinary call-note, like the somin of two pebbles struck together, may be heard in a dozen directions for a quarter of an hour before one of the birds comes in view, so careful are they to licep concealed among the protecting serlge. The ordinary song of 
the species has much the same timbre as the call-note; it resembles the syllables chap-chap-chap-chap, chap chap-chap-chap-p-p-rrrr; but during the height of the love season it vents its feelings in a much more ambitious refrain, one which, while it is everywhere varied and in parts very musical, is still conspicuous for the amount of chappering that enters into its composition. While singing, it is usually seen clinging to the side of some tall swaying reed with its tail. bent forward so far as almost to touch the head, thus exhibiting in an exaggerated manner a characteristic attitude of all the Wrens.

This is less a species of the deep-water marshes than is the longbilled member of the gentis, and often it will be found in places that are little more than damp meadows. It is remarkably mouselike in its habits and movements, and can be flushed only with extreme difficulty.

ERnest E. Thompson.

y25. Cistothorus palustris ( $W i l s_{\text {. }}$ ). Long-billed M Marsi Wren. $A d$.-Crown olive-brown, blacker on the sides, a white line over the eye;

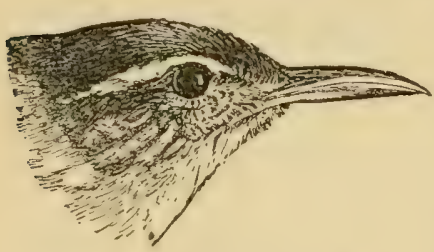

Fig. 112.-Long-billed Marsh Wren. (Natural size.) back black, streaked with white; rump cinnamon-brown; wings and tail barred; under parts white; sides washed with grayish brown. L., $5.20 ;$ W., 1.95 ; T., $1.68 ;$ B., 52 .

Range.-Eastern North America; breeds from the Gulf States to Manitoba and Massachusetts; winters from the Gulf States, and locally farther north, southward to Mexico.

Washington, very numerous S. R., Apl. 30 to Oct. 30 . Sing Sing, common S. R., May 10 to Oct. 28. Cambridge, locally abundant S. R., May 15 to Oct.; sometimes a few winter.

Nest, globular, the entrance at one side, of coarse grasses, reed stalks, etc., lined wtth fine grasses, attached to reeds or bushes. Eggs, five to nine, uniform, minutely speckled or thickly marked with cinnamon- or olive-brown, $\cdot 65 \times \cdot 49$.

If you would make the acquaintance of this Marsh Wren, you have only to visit his home in the cat-tails and tall, reedy grasses bordering rivers, creeks, and sloughs. It will be unnecessary to announce yourself; he will know of your presence long before you know of his, and from the inner chambers of his dwelling will proceed certain scolding, cacking notes before this nervous, excitable bit of feathered life appears on his threshold. With many flourishes of the tail and much bobbing and attitudinizing, he inquires your business, but before you have had time enough to inspect him he has darted back into his damp retreats, and you can tell of his frequently changing position only by his scolding, grumbling notes.

All this time his neighbors-and he generally has numbers of 
them-have doubtless been charming you with their rippling, bubbling, gurgling song. It is quite beyond their control; they seem filled to overflowing with an inexhaustible supply of music. Sometimes, like a mine of melody, it explodes within them and lifts them from the dark recesses of the flags up into the air above.

g25b. C. p. griseus Brewst. Wortinngton's IIARsil Wren."Black of upper parts much duller and less extended than in palustris, usually confined to the extreme sides of the crown and a short, narrow area in the middle of the back, and in extreme specimens almost wholly absent. Brown of sides, flanks, and upper parts pale and grayish. Dark markings of the under tail-coverts, flanks, sides, and breast taint, confused, and inconspicuous, sometimes practically wanting." W., 1.80 ; T., 1.53; B., "50 (Brewster, Auk, x, 1893, p. 218).

Range.-Coast of South Carolina and Georgia.

r25.1. C. p. mariana (Scott). Marian's Marsh Wren.-Similar to C.palustris, but with the upper parts darker, the sides and flanks of about the same color as the rump; the under tail-coverts, and sometimes the breast, barred or spotted with black. W., 1.85 ; T., 1.75 ; B., 52.

Range.-Gulf coast of Florida, and probably westward to Louisiana.

\section{Family Certhidd}

This is an Old-World family, numbering about twelve species, of which only one is found in America. Our bird and its several races belong to the northern group containing the species with stiffened tails. It is a true tree-creeper, and, like a Woodpecker, uses its tail as a prop in climbing.

126. Certhia familiaris americana (Bonap.). Brown C'reeper. (See Fig. 56.) $A d$.-Upper parts mixed white, fuscous, and ochraceous-buff; rump pale rufous; wings with a band of cream-buff; tail pale grayish brown, the feathers stiffened and sharply pointed; under parts white; bill slightly curved. L., $5 \cdot 66 ;$ W., 256 ; T., $2 \cdot 65 ;$ B., ${ }^{\circ} 63$.

Range.-Eastern North America; breeds from Minnesota and Maine northward; migrates south in winter as far as the Gulf States.

Washington, common W. V., Sept. 25 to Apl. 25. Sing Sing, tolerably common W. V., Sept. 20 to May 7. Cambridge, common T. V., rather common W. V., Sept. 25 to May 1.

Nest, of twigs, strips of bark, bits of dead wood, moss, ete., placed behind the loose bark of a tree. Eggs, five to eight, white, spotted and speckled with cinnamon-or rufous-brown and lavender, chiefly in a wreath at the larger end, $\cdot 62 \times \cdot 47$ (Brewster, Bull. Nutt. Orn. Club, iv, 1879, p. 199).

The facts in the case will doubtless show that the patient, plodding Brown Creeper is searching for the insects, eggs, and larre which are hidden in crevices in the bark; but after watching him for several minutes one becomes impressed with the thought that he has lost the 
only thing in the world he ever cared for, and that his one object in life is to find it. Ignoring you completely, with scarcely a pause, he winds his way in a preoccupied, near-sighted manner up a tree trunk. Having finally reached the top of his spiral staircase, one might suppose he would rest long enough to survey his surroundings, but like a bit of loosened bark he drops off to the base of the nearest tree and resumes his never-ending task.

He has no time to waste in words, but occasionally, without stopping in his rounds, he utters a few screeping, squeaky notes, which are about as likely to attract attention as he is himself. As for song, one would say it was quite out of the question; but Mr. Brewster,* in his biography of this bird, tells us that in its summer home, amid the northern spruces and firs, it has an exquisitely pure, tender song of four notes, "the first of moderate pitch, the second lower and less emphatic, the third rising again, and the last abruptly falling, but dying away in an indescribably plaintive cadence, like the soft sigh of the wind among the pine boughs."

\section{Family Paride. Nuthatches and Tits.}

Two well-marked subfamilies are included here, the Sittince, or Nuthatches, and Parince, or Chickadees. They are distributed throughout the temperate parts of the northern hemisphere. About twenty species of Nuthatches are known, of which four are American. They are all climbers, but, unlike the Woodpeckers and Creepers, climb downward as well as upward, and do not use their tails as a support. Their name is derived from their habit of wedging nuts (with our species, usually beechnuts) in a crevice in the bark and then hatching them by repeated strokes with their bills.

The subfamily Parine contains some seventy-five species, of which no less than fifty, including the thirteen North American species, belong in the genus Parus. Both our Nuthatches and Chickadees are migratory at the northern parts of their range. After the migration they are generally found in small groups, composed probably of the members of a family, which wander through the woods within certain definite limits.

A. Throat black.

KEY TO THE SPECIES

a. Crown brown: sides chestnut . . . 740. Hudsonian Chickadee.

b. Crown black; outer margin of greater wing-coverts distinctly whitish ; wing generally over 250 . . . . . . . 735. CHickadee.

c. (rown black; greater wing-coverts without white margins; wing under 250 . . . . . . . . . 736. Camolina Chickadee. 
B. Throat not black.

a. Under parts more or less washed with rufous; a black or gray streak through the eye . . . . . . 728. Red-breasted Nuthatch.

b. Under parts white or whitish; under tail-coverts more or less rufous; tail with white spots.

727. White-breasted Nuthatch. 727b. Florida Nuthatch.

c. Under parts white or whitish; flanks with rufous; no white in the tail; head crested. . . . . . . . . . -731. Tufted Titmouse.

d. Whole top of the head brown . . . 729. Brown-meaded Nuthatch.

r2\%. Sitta carolinensis Lath. Wnite-Breasted Nuthatch. $A d$. s.--Top of the head and front part of the back shining black; rest of the upper parts bluish gray; imner secondaries bluish gray, marked with black; wing-coverts and quills tipped with whitish; outer tail-feathers black, with white patches near their tips; middle ones bluish gray; sides of the head and under parts white; lower belly and under tail-eoverts mixed with rufous. $A d$. $q$. - Similar, but the black of the head and back veiled by bluish gray. L., 6.07 ; W., 3.48 ; T., $1.92 ;$ B., 76 .

Range.-Eastern North America; breeds from the Gulf States to Minnesota and New Brunswick; generally resident throughout its range.

Washington, common T. V. and W. V., less common S. R. Sing Sing, common P. R. Cambridge, P. R., rare in summer, uncommon in winter, common in migrations; most numerous in Oct. and Nov.

Nest, of feathers, leaves, ete, in a hole in a tree or stump. Eggs, five to eight, white or creamy white, thickly and rather evenly spotted and speckled with rufous and lavender, $75 \times \cdot 57$.

When the cares of a family derolve upon him, the Nuthatch eschews all society and rarely ventures far from his forest home. But in the winter I believe even the birds are affected by the oppressive loneliness; the strangers of summer become for a time boon companions, and we find Downy Woodpeckers, Chickadees, and Nuthatches wandering about the woods or visiting the orchards on apparently the best of terms.

Few birds are easier to identify: the Woodpecker pecks, the Chickadee calls "chickadee," while the Nuthatch, running up and down the tree trunks, assumes attitudes no bird outside his family would think of attempting. His powers of speech are in no wise disturbed by his often inverted position, and he accompanies his erratic clamberings by a conversational twitter or occasionally a loud. nasal yank, yank, which frequently tells us of his presence before we see him.

$\mathrm{He}$ is not too absorbed in his business to have a mild interest in yours, and he may pause a moment to look you over in a calm kind of way, which somehow makes one feel that perhaps, after all, Nuthatches are of as much importance as we. But his curiosity is soon satisfied; affairs are evidently pressing, and with a yank, yank, he resumes his 
search for certain tidbits in the shape of grubs or insects' eggs hidden in the bark.

'There is such a lack of sentiment in the Nuthatch's character, he seems so matter-of-fact in all his ways, that it is difficult to imagine him indulging in anything like song. But even he can not withstand the all-conquering influences of spring, and at that season he raises his voice in a peculiar monotone-a tenor hah-hah-hah-hah-hahsounding strangely like mirthless laughter.

g2\%b. S. c. atkinsi scott. Florida White-breasted Nuthatch.Similar to the preceding, but somewhat smaller, the wing-coverts and quills but slightly or not at all tipped with whitish, the $\&$ with the top of the head and nape black, as in the s. W., $3 \cdot 32$; T., $1 \cdot 80$; B., $\cdot 70$.

Range.-Florida, northward on the Atlantic coast to southern South Carolina.

r28. Sitta canadensis Linn. Red-breasted Nuthatci. Ad. \&.Top of the head and a wide stripe through the eye to the nape shining black;

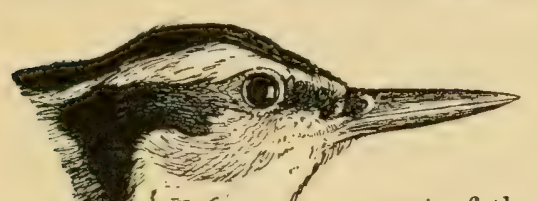
a white line over the eye; upper parts bluish gray; no black marks on the secondaries; outer tail-feathers black, with white patches near their tips; middle ones bluish gray; throat white; rest of the under parts ochracesus-buif' or rufous. $A d .9$. - Similar, but the top of the head and stripe through the eye bluish gray, like the back; under parts paler. L., $4.62 ;$ W., $2 \cdot 66 ;$ T., $1.58 ;$ B., $\cdot 50$.

Fic. 113. - Red - breasted

Range.-North America; breeds from ManiNuthatch. (Natural size.)

toba and Maine northward, and southward along the Alleghanies to Virginia; winters from about the southern limit of its breeding range to the Gulf States.

Washington, irregularly abundant W. V., sometimes rare, Sept. 15 to May 10. Sing Sing, irregular W. V., A ug. 8 to May 8. Cambridge, irregular 'T. V. and W. V., Sept. 15 to Nov. 25; Nov. 25 to A pl. 1, or rarely May 5.

Nest, of grasses, in a hole in a tree or stump. Eggs, four to six, white or creamy white, speckled with cinnamon-, rufous-brown, and lavender, $60 \times \cdot 47$.

While resembling the White-breasted Nuthatch, this more northern species differs from it sufficiently both in notes and appearance to be easily distinguished. Its black face-stripe is a noticeable character, while to the trained ear its higher, finer, more nasal, slightly drawled yna. yna is quite unlike the White-breast's vigorous yank, yank. The Red-breast has an evident partiality for pine trees, and may be seen hovering about the cones while looking for a foothold from which to extract their seeds.

y29. Sitta pusilla (Lath.). BRowN-HEADED Niethatch. Ad.-Top and back of the head dark grayish brown; a whitish patch on the nape; no 
white over the eye; rest of upper parts bluish gray; outer tail-feathers black, tipped with grayish, middle ones bluish gray; under parts grayish white. L., 4.50; W., 2.60; 'T., 1.25; B., 52.

Range.-South Atlantic and Gulf States, north to Virginia; accidentally to Missouri and New York.

Nest, of feathers, grasses, ete., generally near the ground, in a hole in a tree or stump. Eggs, five to six, white or creamy white, heavily spotted or blotched with cinnamon- or olive-brown, $\cdot 56 \times \cdot 46$.

This little Nuthatch, the Red-cockaded Woodpecker, and Pine Warbler, are characteristic birds of the great pineries in our Southern States. Frequently they are found associated. The Woodpeckers generally lieep to the tree tops, the Warblers live on or near the ground, while the Nuthatches scramble actively about from the base of the trunk to the terminal twigs. The only note I have heard them utter is a conversational tnee, tnee. They are talkative sprites, and, like a group of school children, each one chatters away without paying the slightest attention to what his companions are saying.

731. Parus bicolor (Linn.). 'Tuften 'Titmozse. All-Forehcad black; rest of the upper parts, wings, and tail gray; under parts whitish; sides washed with rufous; a conspicuous crest. L., $6.00 ;$ W., $3 \cdot 10 ;$ 'T., $2 \cdot 70$; B., 42 .

Range.-Eastern United States; breeds from the Gulf States to southern Iowa and northern New Jersey: resident throughout its breeding range.

Washington, very common P. R., more so in winter.

Nest, of leaves, moss, strips of bark. feathers, etc., in Woodpeckers' deserted holes, stumps, etc. Eqgs, five to eight, white or creamy white, rather coarsely and evenly marked with rufous-brown, Frg. 114.-Tufted Titmouse. (Natural $\cdot \% 1 \times 55$.

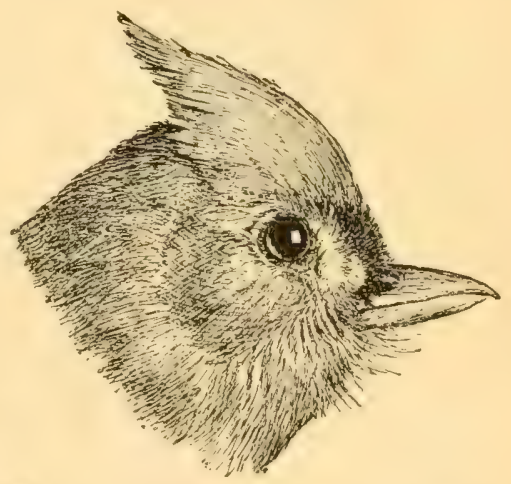

The Tufted Titmouse is a bird of very general distribution in wondlands, where its presence is always made known by its notes. Its common call is a loud, clearly whistled peto, peto, peto, peto, which may be repeated by the same individual for hours at a time. Occasionally the key is changed, and at first the notes are decidedly pleasing, but the bird finally wearies one by its monotonous repetition.

It utters also other whistled calls, and a de-de-de-de, much like the notes of the Chickadee, though somewhat louder and hoarser.

The 'Tufted T'it is not a shy bird and may be approached with ease. Its conspicuous crest is an excellent field mark. 
y35. Parus atricapillus (Linn.). ChickadeE. (See Fig. 5\%,b.) Ad.-Top of the head, nape, and throat shining black; sides of the head and ncck white; back ashy; outer vanes of greater wing-coverts distinctly margined with white; wing and tail-feathers margined with whitish; breast white; belly and sides washed with cream-buff. L., 5.27 ; W., 2.53 ; T., 2.43 ; B., 37.

Kange.-Eastern North America; breeds from southern Illinois and Pennsylvania northward to Labrador, and southward along the Alleghanies to North Carolina; in winter migrates a short distance below the southern limit of its breeding range.

Washington, rare and irregular W. V., Dec. to Apl. 15. Sing Sing, tolerably common P. R. Cambridge, very common P. R., more numerous in fall and winter.

Nest, of moss, grasses, feathers, and plant down, in old stumps, holes in trees, etc., not more than fifteen feet up. Eggs, five to eight, white, spotted and speckled, chiefly at the larger end, with cinnamon- or rufous-brown, $\cdot 60 \times \cdot 48$.

When most birds were strangers to me, I remember thinking what a blessing it would be if every one spoke his name as plainly as does this animated bunch of black and white feathers. No need of a textbook to discover his name; with winning confidence he introduced himself, and probably for this reason he has always been my best friend among birds. I never hear his voice in the woods without answering him:

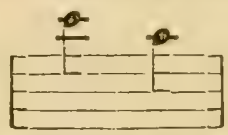

or

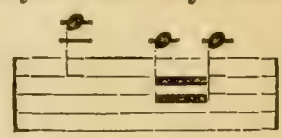
Soon he comes to me, mildly inquisitive at first, looking about for the friend or foe whose call has attracted him. In an unconcerned way he hops from limb to limb, whistling softly the while, picking an insect's egg from beneath a leaf here or larva from a crevice in the bark there, all the time performing acrobatic feats of which an accomplished gymnast might be proud. Finally his curiosity becomes aroused, he ceases feeding, and gives his entire attention to the discovery of the bird who so regularly replies to him. Hopping down to a limb within three feet of my head, he regards me with puzzled intentness; his little black eyes twinkle with intelligence, he changes his call, and questions me with a series of chick- $\breve{a}$-dēes, liquid gurgles, and odd chuckling notes which it is beyond my power to answer, and finally, becoming discouraged, he refuses to renew our whistled ccnversation and retreats to the woods.

On two occasions Chickadees have flown down and perched upon my hand. During the few seconds they remained there I became rigid with the emotion of this novel experience. It was a mark of confidence which seemed to initiate me into the ranks of woodland dwellers. 
y36. Parus carolinensis Aud. Carolina Chickadee.-Similar to the preceding species, but smaller; greater wing-coverts not margined with whitish; wing and tail-feathers with less white on their outer vanes. L., 4.06-4.75; W., 2.20-2*48; T., 1.88-2.12; B., •30-32.

Range.-Southeastern United States, north to middle New Jersey and Illinois; resident from southern New Jersey southward.

Washington, very common $\mathrm{P} . \mathrm{K}$., particularly in winter.

Nest, of grasses, fine strips of bark, feathers, hair, etc., in holes in trees, stumps, etc. Eggs, five to eight, similar in color to those of P. atricapillus.

My experience with this southern Chickadee has been confined largely to Fiorida. There I found it a comparatively shy bird, with notes quite unlike those of $P$. atricapillus. Instead of the two clear whistles which atricapillus in New Jersey utters, the Florida bird repeats four rather tremulous notes, and there is also a substantial difference in its other calls, one of which resembles the words my watcher key, my watcher key.

Mr. C. W. Richmond writes me that at Washington the chick- $\breve{\imath}-(7 \bar{e} \bar{e}$ call of carolinensis is higher pitched and more hurriedly given than that of atricapillus, and that the whistle consists of three notes.

Writing from the mountains of North Carolina, where both species occur together, Mr. Brewster says: "In one place a male of each species was singing in the same tree, the low, plaintive tsuce-dee-tuseedee of the $P$. carolinensis, contrasting sharply with the ringing te-derry of its more northern cousin" (The Auk, vol. iii, 1886, p. 177).

y40. Parus hudsonicus Forit. Ilcdsonian Chickadee. Ad.Crown dull, dark brownish gray; back brownish ashy; wings and tail grayish; throat black; ear-coverts, sides of the neck, breast, and belly white; sides rufous.

Range.-Northern North America, from Nova Scotia, northern New England, and northern Michigan northward; south in winter rarely to Massachusetts.

Cambridge, rare, perhaps only casual, W. V., Nov. 1 to Apl. 1.

Nest, of moss and felted fur, in holes in trees and stuinps. Eggs, six to seven, not distinguishable from those of $P$. atricapillus, $\cdot 61 \times \cdot 50$.

This northern Chickadee is frequently found associated with $P$. atricapillus, which it resembles in habits, though its notes are quite unlike the notes of that species.

\section{Family Sylvimde. Old-World Warblers, Kinglets, and GNATCATCHERS.}

This family is divided into three subfamilies: (1) The Sylriince, or Old-World Warblers, numbering one hundred species, confined exclusively to the Old World, with the exception of one species found in Alaska; $(2)$ the Reguline, or Kinglets, of which three of the seren 
known species are found in the New World; (3) the Potioptitince, or Gnatcatchers, an American group containing about fifteen species, three of which are found in the United States.

The Kinglets and Gnatcatchers are active little birds, and constantly flit from limb to limb in their search for food. They are possessed of decided character, build remarkably beautiful nests, and some species are noteworthy songsters.

\section{KEY TO THE SPECIES.}

A. With a bright-colored crest.

a. Crest ruby, without black - 749. Ruby-crowned Kinglet (Ad. $\delta$ ).

b. Crest yellow, or orange and yellow, bordered by black.

748. Golden-crowned Kinglet.

B. Without a colored crest.

$a$. Back ashy blue; outer tail-feathers white.

751. Blue-gray Ginatcatcher.

b. Back olive-green; no white in tail. Rubx-crowned Kinglet ( $\&$ and im.).

748. Regulus satrapa Licht. Golden-Crowned Kinglet. Ad. ô. - Center of crown bright reddish orange, bordered by yellow and black; a whitish line over the eye; rest of upper parts olive-green; wings and tail fuscous, margined with olive-green; tail slightly

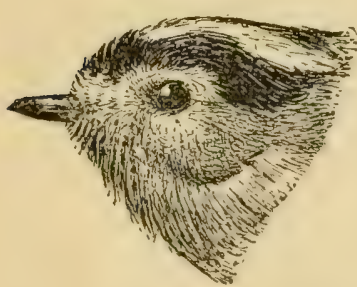

Fis. 115.--Golden-crowned Kinglet. (Natural size.) forked; under parts soiled whitish. Ad.q.-Similar, but crown without orange, its center bright yellow, bordered on either side by black. L., 4.07; W., $2 \cdot 14 ;$ 'T., $1 \cdot 75 ;$ B., 28.

Range.-North America; breeds from the northern United States northward, and southward along the Rockies into Mexico, and in the Alleghanies to North Carolina; winters from the southern limit of its breeding range to the Gulf States.

Washington, abundant W. V., Oct. 5 to Apl. 27. Sing Sing, common W. V., Sept. 20 to Apl. 28. Cambridge, very common T. V., common W. V., Sept. 20 to Apl. 25.

Nest, generally pensile, of green mosses, lined with fine strips of soft inner bark, fine black rootlets, and feathers, in coniferous trees, six to sixty fect from the ground. Eggs, nine to ten, creamy white to muddy cream-color, speckled and blotehed with pale wood-brown, and, rarely, faint lavender, $.55 \times$ ×44. (See Brewster, Auk, v, 1888, p. 337.)

This Kinglet resembles in habits its Ruby-crowned cousin, with which during the migrations it is frequently associated. Its notes, however, are quite unlike those of that species, its usual call-note being a fine, high $t i-t i$, audible only to practiced ears. In his extended account of the nesting habits of this species, as observed by him in Worcester County, Mass. (Auk, l.c.), Mr. Brewster writes that its song "begins with a succession of five or six fine, shrill, high-pitched, some- 
what faltering notes, and ends with a short, rapid, rather explosive warble. The opening notes are given in a rising key, but the song falls rapidly at the end. The whole may be expressed as follows: tzee, tzee, tzee, tzee, $t i, t i$, ter, $t i-t i-t i-t i . "$

Muffled in its thick coat of feathers, the diminutive Golderest braves our severest winters, living evidence that, given an abundance of food, temperature is a secondary factor in a bird's existence.

949. Regulus calendula (Linn.). Ruby-crowned Kinglet. (Sce Fig. 58, a.) Ad. 8. -Crown with a partly concealed crest of bright red; rest of upper parts grayish olive-green, brighter on the rump ; wings and tail fuscous, edged with olive-green; two whitish wing-bars; tail slightly forked, the middle feathers shortest; under parts soiled whitish, more or less tinged with buffy. $A d . q$ and Im.-Similar, but without the red crown-patch. L., $4 \cdot 11 ;$ W., $2 \cdot 24 ;$ T., $1 \cdot 73 ;$ B., $\cdot 29$.

Remarks.-Females and young are warblerlike in general appearance, but note the short first primary, barely one inch in length.

Range.-North America; breeds from the northern border of the United States northward; winters from South Carolina southward into Mexico.

Washington, abundant T. V., Apl. 5 to May 10 ; Sept. 25 to Nov. 1; oceasionally winters. Sing Sing, common T. V., Apl. 8 to May 13; Sept. 16 to Nov. 3. Cambridge, rather common T. V., Apl. 10 to May 5; Oct. 10 to Nov. 5.

Nest, usually semipensile, of moss, fine strips of bark, neatly interwoven, lined with feathers, in coniferous trees, twelve to thirty feet from the ground. Eggs, five to nine, dull whitish or pale buffy, faintly speckled or spotted with pale brown, chiefly at the larger end, $\cdot 55 \times \cdot 43$ (Davie).

When the leaves begin to turn you will notice numerous very small, olive-green birds flitting about the terminal twigs of the trees and lower growth, in the woods, orchards, or hedgerows. They resemble Warblers, but are much tamer-you can almost touch themand have a habit of nervously flitting their wings every few seconds, perhaps accompanying the action by a wrenlike scolding note. You will not often hear them sing at this season, and there is little in their voice or appearance to tell you that they are among the most famous of feathered songsters.

The May morning when first I heard this Kinglet's song is among the most memorable of my early ornithological experiences. The bird was in the tree tops in the most impassable hit of woods near my home, The longer and more eagerly I followed the unseen singer the greater the mystery became. It seemed impossible that a bird which I supposed was at least as large as a Bluebird could escape observation in the partly leared trees. The song was mellow and flutelike, and lond enough to be heard several hundred yards; an intricate warble past imitation or deseription, and rendered so admirably that I never 
hear it now without feeling an impulse to applaud. The bird is so small, the song so rich and full, that one is reminded of a chorister with the roice of an adult soprano. To extend the comparison, one watches this gifted but unconscious musician flitting about the trees with somewhat the feeling that one observes the choir-boy doffing his surplice and joining his comrades for a gane of tag.

751. Polioptila cærulea (Limn.). Blue-gray Gratcatcher. (See Fig. 58, b.) Ad. of.-Upper parts bluish gray ; forehead and front of the head narrowly bordered by black; wings edged with grayish, the secondaries bordered with whitish; outer tail-feathers white, changing gradually until the middle ones are black; under parts dull grayish white. $A d$.. .-Similar, but without the black on the head. L., $4.50 ;$ W., 2.05 ; 'T., $2 \cdot 00$; B., 40 .

Range.-Eastern United States; breeds from the Gulf States to northern Illinois, southern Ontario, and New Jersey, and wanders rarely to Minnesota and Maine; winters from Florida southward.

Washington, rather common S. R., Apl. 5 to Sept.

Nest, of tendrils, fine strips of bark, and fine grasses firmly interwoven and covered externally with lichens, on a horizontal branch or in a crotch, ten to sixty, usually thirty feet up. Eggs, four to five, bluish white, thickly spotted and speckled with cinnamon-, rufous-brown, or umber, $56 \times{ }^{*} 46$.

The Blue-gray Gnatcatcher frequents rather densely foliaged trees, generally in the woods, showing a preference for the upper branches. He is a bird of strong character, and always seems to me like a miniature Mockingbird with some of the habits of Kinglets.

His exquisitely finished song is quite as remarkable as the ordinary performance of his large prototype, but is possessed of so little volume as to be inaudible unless one is quite near the singer. His characteristic call-note-a rather sudden ting, like the twang of a banjo string - can be heard at a greater distance.

\section{Family. Turdide. Thrushes, Bluebirds, etc.}

The three hundred species included in this large family are placed by systematists in several subfamilies. About one hundred and fifty are true Thrushes belonging in the subfamily Turdince. These are distributed throughout the world, some twelve species inhabiting the United States. As a rule, they inhabit wooded regions, are migratory, and gregarious or sociable to a greater or less extent during their migrations and in winter.

As songsters they are inferior to some of our birds in power of execution, but their voices are possessed of greater sweetness and expression, and they are conceded first rank among song-birds by all true lovers of bird music. 



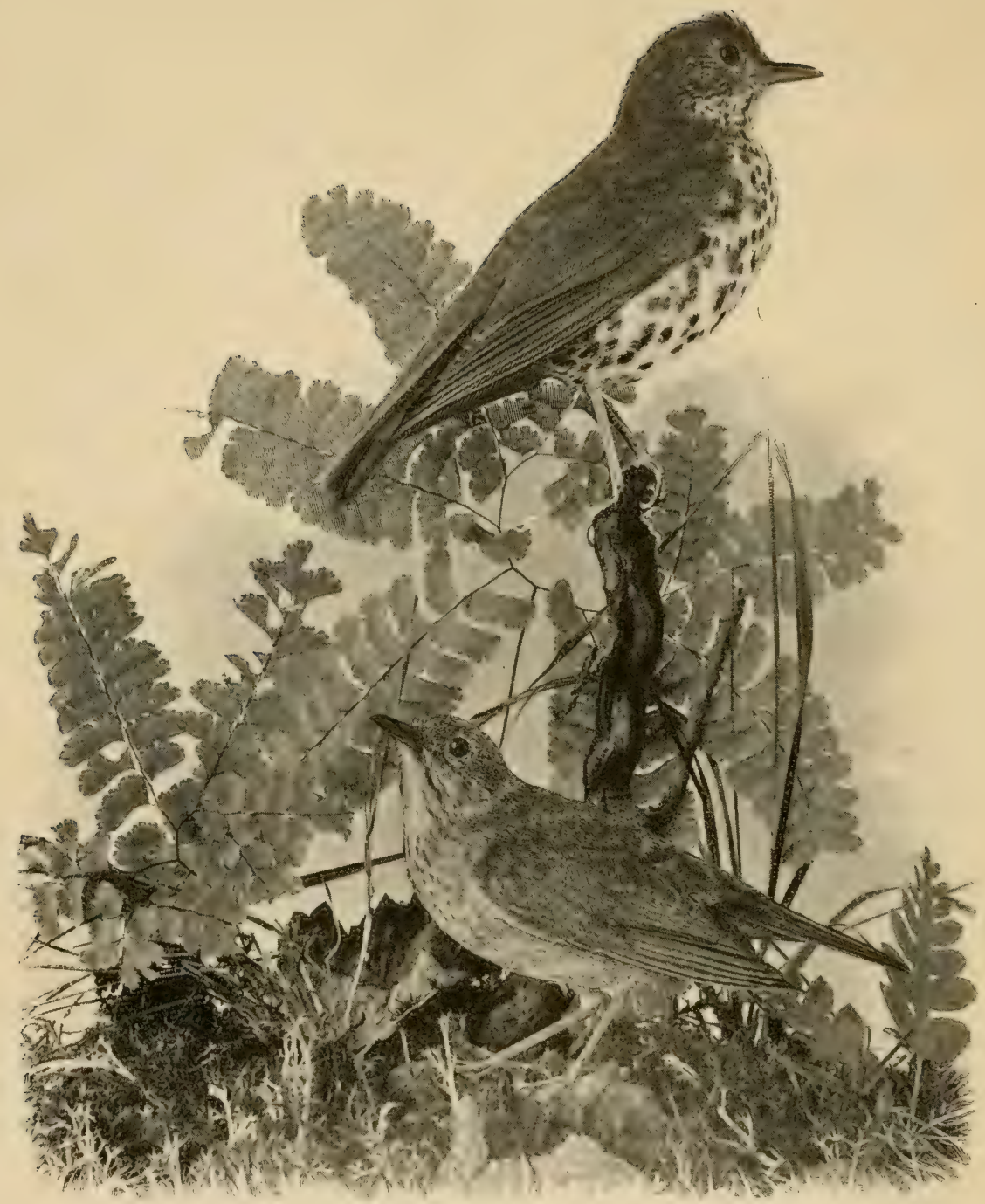

WOOD THRush.

Wilson's 'Thrush. 
KEY TO THE SPECIES.

A. 'Tail blue; back blue or bluish . . . . . . . 766. Bluertrd.

B. Tail black or blackish, tipped with white . . ., . . 761. Rosin.

C. Tail white, tipped with black. . . . . . 765. WheAtear.

$D$. Tail olive-brown or rufous, without white spots.

a. Upper parts cinnamon-brown; tail not brighter than the back.

$\alpha^{1}$. Entire under parts, including sides, more or less heavily marked with round, black spots; back brighter than tail . . 755. Woon THrush.

$a^{2}$. Throat and upper breast pale buffy, with small, cinnamon-brown, wedge-shaped spots; belly pure white; sides with a barely perceptible grayish wash . . . . . . . 756. W ILson's THRush.

b. Upper parts olive; back and tail nearly the same color.

$b^{1}$. 'Throat, breast, cheeks, eye-ring, and lores deep cream-butf.

758a. Olive-Backed Thrush.

$b^{2}$. Throat, breast, cheeks, eye, and space before the eye white, with only a very slight buffy tinge.

757. Gray-cheeted Turvsh. 757a. Bicknell's 'Turush.

c. Upper parts olive-brown, sometimes inclining to einnamon; upper tailcoverts and tail rufous . . . . . . . 759b. Hermit Thrush.

y55. Turdus mustelinus Gmel. Wood Trinusir. Ad.--Upper parts bright cinnamon-brown, brightest on the heed, and changing gradually to pale olive-brown on the upper tail-coverts and tail; under parts white, thickly marked with large, round black spots except on the throat and middle of the belly. L., 8.29; W., 4.44; T., $2.92 ;$ B., 65 .

Remarks. - The Wood Thrush may be distinguished from our other Thrushes (1) by its larger size; (2) by its brighter, more rufous color above; and (3) especially by the numerous large, round black spots on its under parts. These cover not only the breast, but are equally numerous on the sides, where they extend well up under the wings.

Range.-Eastern United States; breeds as far north as Minnesota, Vermont, and Quebec; winters in Central America.

Washington, common S. R., Apl. 20 to Oet. 15. Sing Sing, common S. R., Apl. 30 to Oct. 2. Cambridge, rather common.S. R., May 12 to Sept. 15.

Nest, of leaves, rootlets, fine twigs, and weed stalks, firmly interwoven, with an inner wall of mud and lining of fine rootlets, generally in saplings, about eight feet up. Eggs, three to five, greenish blue, lighter and with less green than those of the Catbird, averaging lighter, but not certainly distinguishable in color from those of the Robin, $1.05 \times \cdot 76$.

The Wood Thrush is not so distinctively a bird of the woods as the Veery. Well-shaded lawns are sometimes graced by his presence, and at all times he is more familiar and easier to observe than his retiring relative. His large size, bright cinnamon upper parts, and especially his conspicuously spotted breast and sides, are his most striking field characters.

When excited, his usual call-note, pit-pit, is rapidly repeated until 
it resembles the sound produced by striking large pebbles together, quite unlike the whistled whèeu of the Veery. The Wood Thrush is a lovable bird, with a voice suited to his gentle disposition, but when his young are in real or fancied danger his sharp alurm-note gives painful evidence of his fear and anxiety.

The songs of the Wood and Hermit Thrushes are of the same character, but, while the Hermit is the more gifted performer, the Wood Thrush does not suffer by the comparison. Ilis calm, restful songr rings through the woods like a hymn of praise rising pure and clear from a thankful heart. It is a message of hope and good checr in the morning, a benediction at the close of day:

The flutelike opening notes are an invitation to his haunts; a call from Nature to yield ourselves to the ennobling influences of the forest.

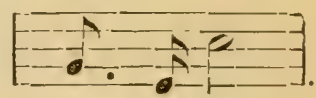

Come to me.

956. Turdus fuscescens Steph. Wrlsox's Thrusir; Veeri. Ad. -Upper parts, wings, and tail nearly uniform cinnamon-brown, not so bright as in the Wood Thrush; center of the throat white; sides of the throat and breast with a delicate tinge of cream-buff, spotted with small wedge-shaped spots of nearly the same color as the back; belly white; sides white, with only a faint tinge of grayish: L., $7.52 ;$ W., $3.84 ;$ T., $2.87 ;$ B., 53.

Remarks. - The Veery's distinguishing characters are (1) its uniform cinnamon-brown upper parts; (2) its delicately marked breast; and (3) particularly its almost white sides. The Wood Thrush has the sides heavily spotted, and the other Thrushes have this part more or less strongly washed with grayish or brownish.

Range.-Eastern North America; breeds from northern Illinois and Pennsylvania to Nanitoba and Newfoundland, and southward along the Alleghanies to North Carolina; winters in Central America.

Washington, common 'T. V., Apl. 26 to May 28; Aug. 20 to Sept. 30. Sing Sing, common S. R., Apl. 29 to Sept. 5. Cambridge, very common S. R., May 10 to Sept. 8.

Nest, of strips of bark, rootlets, and leaves, wrapped with leaves and lined with rootlets, on or near the ground. Eggs, three to five, greenish blue, of the same shade as those of the Wood Thrush, $: 88 \times \cdot 65$.

The Veery's home is in low, wet, rather densely undergrown woodlands. He is a shyer, more retiring bird than the Wood Thrush; he lives nearer the ground and is less likely to leave the cover of his haunts. For this reason, even in localities where both are equally common, the Wood Thrush is more frequently observed.

The Veery's usual call-note is a clearly whistled wheeu, which can be closely imitated; his song is a weird, ringing monotone of blended alto and soprano tones. Neither notes nor letter's ean tell one of its peculiar quality; it has neither break nor pause, and seems to emanate from no one place. If you can imagine the syllables $2 \cdot e e-r-r-h u$ re- 
peated eight or nine times around a series of intertwining circles, the description might enable you to recognize the Veery's song.

The Veery has a double personality, or he may repeat the notes of some less vocally developed ancestor, for on occasions he gives utterance to an entirely uncharacteristic series of cacking notes, and even mounts high in the tree to sing a hesitating medley of the same unmusical cacks, broken whistled calls, and attempted trills. Fortunately, this performance is comparatively uncommon, and to most of us the Veery is known only by his own strange, unearthly song. His notes touch chords which no other bird's song reaches. The Water'I'hrush is inspiring, the Wood and Hermit Thrushes "serenely exalt the spirit," but the Veery appeals to even higher feelings; all the wondrous mysteries of the woods find a voice in his song; he thrills us with emotions we can not express.

756a. T. f. salicicolus (Ridgw.). Willow Turesir-Similar to the preceding, but with the upper parts slightly darker.

Range.-Rocky Mountains, north to British Columbia; south in winter to the tropies; migrates as far east as Illinois and, casually, South Carolina.

15\%. Turdus alieiæ Bairl. Gray-cheeked Thrush. Ad.-Upper parts uniform olive, practically no difference between the colors of the back and tail ; eye-ring whitish, lores grayish; middle of the throat and middle of the belly white; sides of the throat and breast with a very faint tinge of cream-buff; the feathers of the sides of the throat spotted with wedge-shaped marks, those of the breast with half-round black marks; sides brownish gray or brownish ashy. L., 7.58; W., 4.09; T., $2 \cdot 96 ;$ B., $\cdot 55$.

Remarks.-The uniform olive of the upper parts of this species at once separates it from our eastern Thrushes except its subspecies bicknelli and the Olive-backed Thrush. From the latter it may be known by the comparative absence of buff on the breast and sides of the throat, by its whitish eye-ring and grayish lores.

Range.-North America; breeds in Labrador and northwestward to Alaska; migrates through eastern North America to Central America.

Washington, rather common T. V., May 10 to June 5; Sept. 10 to Oct. 10. Sing Sing, tolerably common T. V., May 15 to June 1; Sept. 20 to Oct. 17. Cambridge, uncommon T. V., May 15 to 25 ; Sept. 25 to Oct. 6.

Nest, of grasses, leaves, strips of fine bark, ete., lined with fine grasses, in low trees or bushes. Eggs, four, greenish blue, spotted with rusty brown, $.92 \times \cdot 67$.

During its migrations Alice's Thrush may be found associated with the Olive-backed Thrush, from which it can be distinguished in life only by an expert. It is a rather shy bird, and is apt to fly up from the ground to some low limb, and, after a moment's pause, seek a more distant perch before one reaches fair opera-glass range.

This species has been so long confused with Bicknell's Thrush that 
in many cases it is impossible to say to which birds certain records apply. Doubtless there is little difference in their notes or habits, but our knowledge of alicice in its summer home is too limited for us to say much about it (see, however, Nelson, Rep. on Nat. Hist. Collections made in Alaska, p. 216).

7579. T. a. bicknelli Ridgw. Bickneli's Thrusi.-Similar to the preceding, but averaging somewhat brighter and constantly smaller. L., 6.25-7.25; W., 3.40-3.80; T., 2·60-2·70; B., $500-52$ (Ridgw.).

Range.-Breeds in the higher parts of the Catskills and northward to the White Mountains and Nova Scotia ; winters in the tropies.

Washington, apparently rare T. V., two instances, May. Cambridge, rather common T. V., May 15 to May 25 ; Sept. 25 to Oct. 6.

Nest, essentially like that of T. swainsonii, both in construction and position. Eggs, greener and more finely spotted than those of swainsonii (Brewster, Minot's Land Birds and Game Birds, 2d ed., appendix, p. 468).

"In northern New England Bicknell's Thrush breeds from an altitude of about three thousand feet (scattered pairs may be found lower than this) to the extreme upper limits of tree growth, but most abundantly among the dwarfed, densely matted spruces and balsams which cover such extensive areas on the upper slopes and ridges of our higher mountains. Here, in an atmosphere always cool and ordinarily saturated with moisture from passing clouds, it spends the summer in company with such birts as Swainson's Thrushes, Winter Wrens, Yellow-rumped and Black-poll Warblers, Juncos, White-throated Sparrows, and Yellow-bellied Flycatchers. In many places it is quite as numerous as any of these species, and in certain favored localities it probably outnumbers them all put together. Nevertheless one may spend hours in its chosen haunts without getting a fair view of a single individual, for, despite (or perhaps really because of) the fact that these solitudes are rarely invaded by man, Bicknell's Thrush is, while breeding, one of the very shyest of our smaller birds. . . .

"The song is exceedingly like that of the Veery, having the same ringing, flutelike quality; but it is more interrupted, and it ends differently, - the next to the last note dropping a half tone, and the final one rising abruptly and having a sharp emphasis. The ordinary calls are a whistled pheu practically identical with that of $T$. fuscescens, a harsh note which recalls the cry of the Night Hawk, a low cluck much like that of the Hermit Thrush, and a pip or peenk similar to that of Swainson's Thrush. The last is rarely heard" (Brewster, l. c., p. 467).

y58a. Turdus ustulatus swainsonii ( $C a b$.). (OLIVE-BACKED Thrush; Swainson's Thrush. $A d$.-Upper parts uniform olive; back and tail practically the same color; eye-ring deep, cream-buff, lores the same; whole throat and breast with a stroing tinge of deep cream-buff or even ochra- 
ceous-buff; the feathers of the sides of the throat with wedge-shaped black spots at their tips, those of the breast with rounded black spots at their tips; middle of the belly white; sides brownish gray or brownish ashy. L., $7 \cdot 17$; W., 3.93 ; T., 2.76 ; B., 50 .

Remarks.-This bird will be confused only with the Gray-cheeked and Bicknell's Thrushes, from which it differs in the much stronger suffusion of butf on the throat and breast, its buff eye-ring and lores.

Range.-Breeds from Manitoba, northern New England, and New Brunswick to Alaska and Labrador, and southward in the Rocky Mountains, and along the Alleghanies to Pennsylvania; winters in the tropies.

Washington, common T. V., May 4 to 28 ; Sept. 22 to Oct. 25. Sing Sing, tolerably common 'T. V., May 2 to 30 ; Sept. 19 to Oct. 22 . Cambridge, common T. V., May 12 to June 3 ; Sept. 10 to Oct. 5.

Nest, of coarse grasses, moss, rootlets, leaves, and bark, lined with rootlets and grasses, in bushes or small trees, about four feet up. Eggs, three to four, greenish blue, more or less spotted and speckled with cinnamon-brown or rufous, $990 \times \cdot 64$.

Passing northward in the spring, in small, silent bands, scattered through the woodland undergrowth, whence they quietly slip away, if disturbed, often to the higher branches of the trees, these birds easily escape observation. In late September or early October their loud, metallic call-notes ma be recognized overhead at night, and during the day the birds themselres may be found on the edges of the woods or along tangled hedgerows, associated with Sparrows and other migrants. Their summer home is in the coniferous forest of the north, although they do not confine themselves strictly to the evergreen woods, and, aroiding its depths, seek rather the vicinity of clearings well grown up with firs and spruces. Here, day after day, the same musician may be seen pouring forth his ringing song from some commanding elevation-preferably a dead tree top. If approached, he promptly dives down into the underbrush, where he is very likely joined by his mate, and both proceed to scold, in a mild way, the chance intruder. Little is ever seen of these shy birds, but fortunately their notes are quite characteristic, and the sole obstacle in distinguishing them from those of the Hermit Thrush, a bird frequenting the same localities, lies in the difficulty of tracing them to their source.

The effect of its loud and beantiful song is much enhanced by the evening hush in which it is most often heard. It lacks the leisurely sweetness of the Iermit Thrush's outpourings, nor is there pause, but in lower key and with greater energy it bubbles on rapidly to a close rather than fading out with the soft melody of its renowner rival. There are also a variety of other notes, the most frequent being a pruk of alarm, pitched higher than a corresponding cluck of the IIermit 'Thrush.

J. DWight, JR. 
Y59b. Turdus aonalaschkre pallasii ( $C a b$.$) . IIERMit Thrush.$ Ad.--Upper parts olive-brown, sometimes cinnamon-brown; tail pale rufous, of a distinctly different color from the back; throat and breast with a slight buffy tinge; feathers of the sides of the throat with wedge-shaped black spots at their tips; those of the breast with large, rounded spots; middle of the belly white; sides brownish gray or brownish ashy. L., 7•17; W., 3.56; T., $2 \cdot 74 ;$ B., $\cdot 51$.

Remarks.-The Hermit Thrush may always be easily identified by its rufous tail. It is the only one of our 'Thrushes which has the tail brighter than the back.

Range.-Eastern North America; breeds from northern Michigan and Massachusetts northward, and southward along the Alleghanies to Pennsylvania; winters from southern Illinois and New Jersey to the Gulf States.

Washington, very common T. V., sometimes not uncommon W. V., Apl. 4 to May 15; Oct. 15 to Nov. Sing Sing, common T. V., Apl. 5 to May 9; Oct. 18 to Nov. 26. Cambridge, very common T. V., Apl. 16 to May 5 ; Oct. 5 to Nov. 15; occasionally one or two may winter.

Nest, of moss, coarse grasses, and leaves, lined with rootlets and pine needles, on the ground. Eggs, three to four, greenish blue, of a slight]y lighter tint than those of the Wood Thrush, $88 \times \cdot 69$.

This Thrush comes to us in the spring, when the woods are still bare, and lingers in the autumn until they are again leafless-the earliest as it is the latest of our Thrushes. It is common on its migrations, but attracts little notice, for, though not really a shy bird, its disposition is retiring, and it is most at home in secluded woodland and thickety retreats. Still, it often finds seclusion enough along shrubby roadsides, and may so far doff its hermit traits as to approach dwellings, where its attractive lightness of motion and ease of manner may be observed from indoors. It frequently descends to the ground, but is soon back again in the branches, making short flights from perch to perch, often with long, quiet pauses in the intervals. It may be known at sight by its habit of lifting its tail slightly, especially after alighting. This action is usually accompanied by the bird's customary note-a low chuck, which sounds scarcely thrushlike.

The Hermit Thrush bears high distinction among our song birds. Its notes are not remarkable for variety or volume, but in purity and sweetness of tone and exquisite modulation they are unequaled. Some, indeed, have deemed the Wood Thrush not inferior : but though. the Wood Thrush at its best seems sometimes to touch the very highest chords of bird music, the strains of its wilder cousin, in tranquil clearness of tone and exalted serenity of expression, go beyond any woods music we ever hear.

While traveling, the Iermit Thrush is not in full voice, and he who would know its song must follow it to the mossy forests, which are its summer home.

Eugeite P. Bicknell. 
The Red-winged Thrusn (760. Turdus iliacus), a European species, is of accidental occurrence in Greenland.

761. Merula migratoria (Limn.). Amenican Rogin. (See Fig. $59, \alpha) \quad A d$..8 .- Top and sides of the head black, a white spot above the eye; rest of the upper parts grayish slate-color; margins of wings slightly lighter; tail black, the outer feathers with white spots at their tips; throat white, spotted with black; rest of the under parts rufous (tipped with white in the fall), becoming white on the middle of the lower belly. A $\%$. - Similar, but back of head tipped with grayish; back, tail, and under parts lighter. Young in nestling plumage.-Back and under parts spotted with black. L., 10.00; W., $4.96 ;$ T., $3.87 ;$ B., $\cdot 84$.

Range.- "Eastern North America to the Rocky Mountains, including eastern Mexico and Alaska. Breeds from near the southern border of the United States north ward to the arctic coast; winters from southern Canada and the Northern States (irregularly) seuthward" (A. O. U.).

Washington, rather common S. R., abundant 'I. V., from Feb. to Apl.; irregularly common W. V. Sing Sing, common S. R., Mch. 4 to Oct. 30 ; a few winter. Cambridge, very abundant S. K., common but irregular W. V.

Nest, of coarse grasses, leaves, rootlets, etc., with an inner wall of mud and lining of fine grasses, most frequently in fruit or shade trees, five to thirty feet up. Eggs, three to five, greenish blue, very rarely with brownish markings, $1.14 \times 80$.

While the few Robins that have the courage to winter with us are seeking protection from chilling winds in the depths of friendly evergreens, their comrades who extended their journey to the south are holding carnival under sunny skies. In Florida, during the winter, Robins may be found in enormous flocks, feeding on the berries of the China tree, holly, and mistletoe. Occasionally they give roice to a half-suppressed chorus, as though rehearsing for the approaching season of song.

Robins migrate in flocks, and the arrival of the adrance guard makes the dreariest March day seem bright. It is a question whether these pioneers are summer residents or transients en route to a more northern summer home, but in my experience they make the sunny side of some woods their headquarters and remain there until paired. 'They are then in full song, and we see them in their aecustomed haunts about our lawns and orchards.

Toward the last of June the roung of the first brood, with the old males, resort in numbers nightly to a roosting place. These roosts are generally in deciduous seennd growths, usually in low, but sometimes on high ground. The females are now oceupied with the cares of a second family, and the males are said to return each dily to assist them in their duties.*

* See studies of Robins' roosts, by William Brewster, in Auk. $\mathbf{x}, 1890$, pp. 360-373, and Bradford Torrey in The Foot-path Way, 1892, pp. 153-175. 
Early in September, when the nesting season is over, Robins gather in large flocks, and from this time until their departure for the south roam about the country in search of food, taking in turn wild cherries, dogwood and cedar berries.

The songs and call-notes of the Robin, while well known to every one, are in reality understood by no one, and offer excellent subjects for the student of bird language. Its notes express interrogation, suspicion, alarm, caution, and it signals to its companions to take wing; indeed, few of our birds have a more extended vocabulary.

The VARIEd Thrush (763. Hesperocichla navia), a species of western North America, has been recorded from Massachusetts, Long Island, and New Jersey.

765. Saxicola œenanthe (Linn.). Wheatear; Stone-chat. Al. $\delta$. - Upper parts light gray; forehead and upper tail-coverts white; cheeks and wings black; the basal two thirds of the tail white, the end black; under parts whitish, more or less washed with buffy. $A d$. \&.--Similar, but duller, the black grayer, the white parts more buffy. Ad. in winter and Im.-Upper parts cinnamon-brown, wings edged with lighter; upper tail-coverts and base of the tail white; end of the tail black, tipped with buffy; under parts ochraceous-buff. L., $6.25 ;$ W., $4.00 ;$ T., $2 \cdot 20 ;$ B., $\cdot 50$.

Range.-" Europe, North Africa, Asia, Alaska, Greenland, and Labrador, straggling south to Nova Scotia, Maine, Long Island, and the Bermudas" (A. O. U.).

Nest, of moss and grasses, usually in crevices among rocks. Eggs, four to seven, bluish white, $\cdot 81 \times \cdot 59$.

This European species is a common summer resident in Greenland. It has been found nesting in Labrador, and there is evidence of its having bred at Godbout, Province of Quebec (see Nerriam, Auk, ii, 1885, p. 305; Comeau, ibid., vii, 1890, p. 294). South of these points it is of accidental occurrence.

Mr. Saunders writes: "From early spring onward the Wheatear is to be seen, jerking its white tail as it flits along, uttering its sharp chack, chack, on open downs, warrens, and the poorer land; ascending the mountains almost to the highest summits. . . .

"The song of the male is rather pretty, and the bird also displays considerable powers of imitating other species."

r66. Sialia sialis (Limn.). Bluebird. (See Figs. 2 and 5?, a.) $A d$. o.-Upper parts, wings, and tail bright blue, tipped with rusty in the fall; throat, breast, and sides dull cinnamon-rufous; belly white. Ad. \&.Upper parts with a grayish tinge; throat, breast, and sides paler. Young in nestling plumage.-Back spotted with whitish; the breast feathers margined with fuscous. L., 7.01; W., 3.93; T., 2.58; B., 47 .

Range.-United States; breeds from the Gulf States to Manitoba and 
Nova Scotia; winters from southeru Illinois and southern New York southward.

Washington, common P. R. Sing Sing, common P. R. Cambridge, common S. R., Mch. 6 to Nov. 1; more numerous during migrations, in Mch. and Nov.

Nest, of grasses, in hollow trees or bird-houses. Eggs, four to six, bluish white, sometimes plain white, ${ }^{\circ} 85 \times{ }^{\circ} 65$.

A bird so familiar as the Bluebird needs no introduction; in fact, he seems so at home in our orchards and gardens or about our dwellings that one wonders what he did for a home before the white man came.

In the winter, it is true, Bluebirds are greater rovers, and one may see them in the Southern States whirling through the woods in great flocks or feeding on the berries of the mistletoe. But the warmth of returning spring reminds them of cozy bird-boxes or hospitable pear or apple trees, and soon we see them inspecting last summer's home, evidently planning repairs and alterations.

The Bluebird's disposition is typical of all that is sweet and amiable. Ilis song breathes of love; even his fall call-note-tir -wee, tùrwee-is soft and gentle. So associated is his voice with the birth and death of the seasons that to me his song is freighted with all the gladness of springtime, while the sad notes of the birds passing southward tell me more plainly than the falling leaves that the year is dying. 


\section{APPENDIX.}

\section{A Field Key to OUR Commoner Eastern Land Birds.}

Actrva upon a suggestion, I have prepared as an Appendix to the Handbook the following field key to those birds which, either because of their abundance or conspicuous colors, most frequently attract our attention. With the object of making it as brief, and consequently as simple, as possible, I have omitted species which can be referred to their respective families without difficulty-for example, Hawks, Owls, Woodpeckers, and Swallows. It is designed simply as an aid to the first steps of the beginner, who will soon graduate from it to the more detailed keys in the body of the book. Like the field keys to Finches and Sparrows, and Warblers, after which it is modeled, it is based largely upon adult males. Its use will be found fully explained on page 34 .

First Group.-With yellow or orange in the plumage.

Second Group.-With red in the plumage.

Third Group. - With blue in the plumage.

Fourth Group.-Plumage conspicuously black, or black and white.

Fifth Group.-Without either yellow, orange, red, or blue in the plumage; not conspicuously black, or black and white.

\section{First Group.-With yellow or orange in the plumage.}

I. Throat yellow.

A. Throat and breast pure yellow, without streaks or spots.

a. Length 5.00; cap, wings, and tail black; back yellow; song canarylike, sometimes uttered on the wing: Hight undulating, frequently accompanied by the notes chic-o-ree, per-chic-o-ree.

529. AM. GoLDFincir.

b. Length 5.50 ; lower belly and wing-bars white; back olive-green; frequents the upper branehes, generally in woodland; actions deliberate; song loud and musical, uttered slowly, often with pauses: "See me? I'm here; where are you?" . . 628. Yellow-throated Vireo.

c. Length 5.25 ; cheeks and forehead black bordered by ashy; upper parts olive-green; no wing-bars; haunts thickets and undergrowth; movements nervous and active; call-note, pit or chack ; song, a vigorous, rapid witch-e-wiee-o, witch-e-wèe-o, witch-e-wèe-o.

681. Maryland Yellow-throat. 
d. Length 7.25; upper parts olive-green; no wing-bars; a white line before the eye; haunts thickets and undergrowth; song, a striking mixture of whistles, chucks, and caws, sometimes uttered on the wing.

683. Yhllow-breasted Chat.

$B$. Under parts streaked with rufous-brown; length 5.00: general appearance of a yellow bird; haunts shrubbery of lawns, orchards, second growths, and particularly willows near water; song, rather loud, weèe, chèe-

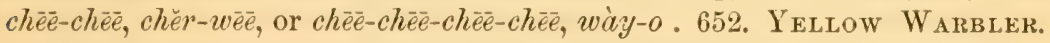

C. Breast yellow, with a conspicuous black crescent; length $10^{\circ} 00$; haunts fields and meadows, largely terrestrial; flight quail-like, outer white tailfeathers showing when on the wing; song, a loud, musical whistle.

II. Throat white.

501. Meadowlark.

A. With yellow on the sides.

a. Length 5.50; rump yellow: breast streaked or spotted with black; tail-feathers marked with white; note, a characteristic tchip ; sept. to May, usually rare or local in winter . . . 655. Myrtle Warbler.

b. Length 5.00; no streaks on under parts or white in the tail; yellow extending along the whole sides; back olive-green, iris white; haunts thickets; call, an emphatic "Who are you, eh?"

631. White-EYED ViREo.

c. Length $5 \cdot 25$; tail and wings banded with yellow, showing conspicuously in flight; haunts woodland; movements active, much in the air, tail frequently spread . . . . . . . 687. Redstart.

$B$. No yellow on sides.

a. Length 6.75 ; a yellow line from the bill to the eye; crown black, with a white stripe through its center; haunts in and about thickets and bushy woodlands; song, a high, clear, musical whistle; call-note; chink.

558. White-throated Sparrow.

b. Length 4.00 ; a yellow or yellow and orange crown-pateh, bordered by black; flits restlessly about outer limbs of trees and bushes; note, a fine $t i$-ti; Oct. to Apl. . . . . 748. Golden-Crowned Kinglet.

III. Throat vinaceous; length 12.00 ; a black breast-patch; belly white, spotted with black; rump white, showing conspicuously in flight; linings of wings yellow; call-note, a loud kee-yer . . . . . . . 412. Flicker.

IV. Throat and head black; length 7.50 ; breast, belly, and lower back deep orange; an active inhabitant of fruit and shade trees; song, a loud, ringing whistle. . . . . . . . . . . 507. Baltimore Oriole.

V. Throat and upper breast ashy; length 9.00 ; erested; belly yellow, tailfeathers largely pale rufous; haunts upper branches in woolland; note, a loud questioning, or grating whistle . . . 452. Crested Flycatcher.

VI. Grayish brown; length 7.00 ; crested; tip of tail yellow.

619. WAXWING.

\section{Second Group.-With red in the plumage.}

1. With red on the under parts.

A. Throat red.

a. Length 7.00 ; wings and tail black; rest of plumage bright scarlet; eall-note, chip-chirr . . . . . . 608. Scarlet Tanager. 
b. Length 6.00 ; dull, pinkish red, wings and tail brownish; frequently seen feeding on buds or blossoms; call-note, a sharp chink, often uttered during flight; song, a sweet, flowing warble.

517. Purple Finch.

c. Length 6.00 ; dull red or green tinged with red; mandibles crossed; generally seen in flocks feeding on pine cones . 521. Ar. Crossbill.

d. Length 5.00 ; a red crown-cap; back streaked black and brown; breast rosy; feeds on seeds or catkins; Nov, to Mch. . . . 528. REDPoLl. B. Throat black.

a. Length 8.00 ; breast rose-red, rest of plumage black and white; song loud and musical; call-note, peek. . 595. Rose-Breasted Grosbeak.

b. Length 8.00 ; a conspicuous erest; region about the base of the bill black; rest of the plumage and bill red; song, a clear whistle.

593. Cardinal.

c. Length 5.50 ; wings and tail banded with orange-red, showing conspicuously in flight; movements active; much in the air; tail frequently spread; haunts woodland . . . . . 687. REDstart.

II. No red on the under parts.

A. Length 9.00 ; black; shoulders red; haunts marshes; migrates in flocks. 498. Red-WINGED BLACKBIRD.

B. Length 5.25 ; crown-cap red; chin black; rest of under parts streaked with blackish; feeds on seeds and catkins; Nov. to Mch.

528. REDPOLL (Im.).

$C$. Length 4.00; under parts whitish; back olive-green; a ruby crownpatch; cye-ring white; movements restless, wings flitted nervously; callnote, cack ; song remarkably loud and musical; Sept. and Oct.; Apl. and May. . . . . . . . . . 749. RubY-Crowned Kinglet.

\section{Third Group.-With blue in the plumage.}

I. Length 11.50 ; a conspicuous crest; upper parts dull blue; under parts whitish; a black patch on the breast . . . . 477. BLuE JAY.

II. Length 7.00 ; upper parts bright blue; under parts cinnamon-rufous.

766. BLUEBIRD.

III. Length 5.50; entire plumage indigo-blue . . . 598. Indigo Buating.

\section{Fourth Group.-Plumage conspicuously black, or black and white.}

I. Black and white birds.

A. Throat black.

a. Length over 6.00 .

$a^{1}$. Entire under parts black; nape buffy; rump white; a musical $\mathrm{d}$ weller of fields and meadows; frequently sings on the wing.

494. BовоLink.

$a^{2}$. Breast rose-red; rest of the plumage black and white; song rapid, loud, and musical; call-note, peek; a tree dweller in rather open woodland . . . . . 595. Rose-Breasted Grosbeak. $a^{3}$. Sides rufous: rest of the plumage black and white; call-note, chewink or towhee; inhabit the undergrowth . . . 587. TowneE. 
b. Length under 6.00 .

b1. Crown black: cheeks white; back ashy; unstreaked; call, chick- $a$ dee, or a musical, double-noted whistle . . . . 735. СиickadeE.

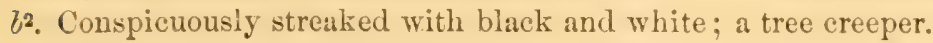

636. B LACK AND White WARBLER.

B. Under parts white or whitish.

a. Length 8.00; upper parts grayish slate-color; tail tipped with white; a bird of the air, catching its insect food on the wing, and occasionally sallying forth from its exposed perch in pursuit of a passing Crow ; note, an unmusical, steely chatter . . . . . . 444. KingBiRD.

b. Length $5 \cdot 75$; crown black; back bluish gray; a tree ereeper; call-note, yank, yank . . . . . . 727. White-Breasted Nuthatch.

c. Length 6.50 ; upper parts washed with rusty ; generally seen in flocks; terrestrial; Nov, to Mch. . . . . . . . . 534. SNowflake.

II. No white in the plumage.

A. Length 19.00; jet black . . . . . . . . $45 S$ Am. Crow.

B. Length $12 \cdot 00$; black with metallic reflections; iris yellowish; migrates in flocks; nests usually in colonies in coniferous trees; voice eracked and reedy; tail "keeled" in short flights; a walker.

511. Purple Grackle. 511b. Bronzed Grackle.

C. Length 9.50 ; shoulders red; haunts marshes; call, kong-quěr-rēé.

498. Red-Winged Blackbird

D. Length 7.50; head and neck coffee-brown; frequently seen on the ground near cattle. . . . . . . . . 4 495. Cowbrrd.

Fifth Group.-Without either yellow, orange, red, or blue in the plumage; not conspicuously black, or black and white.

I. Under parts all one color, without streaks or spots.

1. Back without streaks or spots.

A. Under parts white or whitish; length under $7 \cdot 50$.

a. Back olive, olive-green, or slaty fuscous.

$a^{1}$. No white line over the eye; flycatchers, capturing their proy on the wing and returning to their perch, where they sit quietly until making a fresh sally.

$a^{2}$. Crown blackish; frequently found nesting under bridges or about buildings; tail wagged nervously; note, peuit-phabe.

456. PHEBE.

$a^{8}$. Wing-bars whitish; haunts orchards, lawns, and open woodland; note, chebec, chebèc. . . . . 467. Least Flycatcher. $a^{4}$. Haunts woodlands; generally frequents the upper branches; note, a plaintive pee-a-wee . . . . .461. Wood Pewee.

$b^{1}$. A white line over the eye, or wing-bars white; gleaners; patiently exploring the foliage for food or flitting about the outer branches.

63. White line over the eye bordered by a narrow black one; cap gray; iris red; song, a rambling recitative: "You see it-you know it-do you hear me?" etc. . . . 624. Red-eYed Vireo. 63. White line over the eye not bordered by black; prefers the 
upper branches of rows of elms and other shade trees; song, a rich, unbroken warble with an alto undertone.

627. Warbling Vireo.

$b^{4}$. No white line over the eye; eye-ring and wing-bars white; length 4.00; a tiny, unsuspicious bird; flits about the outer branches of trees and shrubs; wings twitched nervously; note, cack; song, a remarkably loud, musical whistle.

749. Ruby-CRowned Kinglet.

b. Back gray or bluish gray.

b1. Crown black; cheeks white; a tree creeper; note, yank, yank.

727. White-Breasted Nuthatch.

62. A gray, crested bird; forehead black; no white in the tail; note, a whistled peto, peto, or hoarse $d e-d e-d e-d e . ~ .731$. 'I'ufted ''iт.

c. Back cinnamon-brown; length 4.75 ; a nervous, restless, excitable bird; tail carried erect; song sweet, rapid and rippling, delivered with abandon .......... . 721. House Wren.

$B$. Under parts white or whitish; length over 7.50 .

a. Upper parts grayish slate-color; a white band at the end of the tail; a concealed orange-red crest; a bird of the air, catching its insect food on the wing, and occasionally sallying forth from its exposed perch in pursuit of a passing Crow; note, an unmusical, steely chatter. . . . . . . . . . . 444. KingBrrd.

b. Length 12.00; slim, brownish birds with long tails; Hight short and noiseless; perch in a tree, not in an exposed position; note, tuttut, cluck-cluck, and cow-cow.

387. Yellow-Billed Cuckoo. 388. Black-billed Cuckoo.

C. Under parts not white.

a. Slate-color; cap and tail black; inhabits the lower growth; call-note, nasal; song highly musical and varied; length 8.50 . 704. Catrird.

b. Grayish brown; conspicuously crested; a black line through the eye; tail tipped with yellow; generally seen in small flocks; note thin and weak; length $7 \cdot 00$. . . 619. Cedar WAXwing.

c. Under parts cream-buff; a conspicuous whitish line over the eye; upper parts rufous-brown; movements active; tail carried erect; haunts lower growth; notes loud and striking; length 5.50.

718. Carolina Wren.

2. Back streaked.

A. Crown rufous or chestnut without streaks.

a. Length 5.25; bill black; a whitish line over the eye; a familiar bird of lawns and door-yards; song, a monotonous chippy-chippy-chippy.

560. Chipping Sparrow

b. Length 5.50; bill reddish brown, back rufous, or rufous-brown; wing-bars and eye-ring whitish; haunts dry, bushy fields and pastures; song, a musical, plaintive cher-wee, cher-wee, cher-wee, cheen, dee-dee-dee-dee. . . . . . . . 563. Field Sparrow.

c. Length 5.50 ; forehead black; crown and wings chestnut-rufous; flanks pale grayish brown; haunts marshes; song, a rapidly repeated weet-weet-weet, etc. . . . . . . 584. Swamp SParrow. 
B. Crown not rufous or chestnut.

a. Length $6 \cdot 75$; crown, blackish with a central whitish stripe; throat white; breast gray; a yellow spot before the eye; haunts in and about thickets and bushy woodlands; song, a high, clear, musical whistle; call-note, chink . . . 558. White-turoated Sparrow.

b. Length 5.50 ; crown finely streaked; a tree climber, winding patiently up tree trunks in search of food; tail-feathers pointed.

726. Brown Creeper.

c. Length 5.50; bill slender; a white line over the eye; tail carried erect; haunts reedy marshes; call-note scolding; song rippling.

725. Long-Billed Marsi Wren.

II. Under parts white or whitish, streaked or spotted.

1. Back streaked.

A. Crown streaked; under parts conspicuously streaked.

a. Outer tail-feathers white, showing conspicuously when the bird flies; length 6.00 ; haunts dry tields and roadsides; song loud and musical.

b. Outer tail-feathers not white.

540. Vesper Sparrow.

b1. Length 6.00 ; plumage with a rufous-brown cast; spots on the breast tending to form one large spot in its center; haunts on or near the ground, generally in the vicinity of bushes; call-note, a characteristic chă ; song musical . . . . 581. Song Sparrow.

$b^{2}$. Length 6.00 ; no rufous in the plumage; spots on the under parts evenly distributed; frequently seen feeding on buds or blossoms; call-note, a sharp chink, often uttered during flight; song, a sweet, flowing warble . . . . . . 517. Purple Finch (Im.).

B. Crown not streaked, rufous-brown; under parts whitish with an indistinct blackish spot in the center of the breast; Oct. to Apl.

559. Tree Sparrow.

2. Back not streaked.

A. Upper parts rufous, olive-brown, or cinnamon-brown.

a. Bill slender and thrushlike; breast spotted with blackish.

$a^{1}$. Length 11.00 ; tail 5.00; wing-bars white; upper parts, wings, and tail uniform rufous; haunts undergrowth; sings from an exposed and generally elevated position; song loud, striking, and continuous. 705. Brown 'Turasher.

31. Length under 9.00 ; tail under 3.00 ; no wing-bars.

$b^{2}$. Breast and sides heavily marked with large, round, black spoti; head and upper back brighter than lower back and tail ; call-note, a sharp pit or liquid quirt . . . . 755. Wood Trrusu.

$b^{3}$. Breast with wedge-shaped black spots; sides unspotted, washed with brownish ashy; tail rufous, brighter than back; call-note, a low chuck. . . . . . . . 759b. Hermit Thrusir.

64. Upper breast lightly spotterl with small, wedge-shaped, blackish spots; tail the same color as the back; sides white; callnote, a clearly whistled whein. . . . 756. Wrlsox's Turisu.

b. Bill short and stout; breast and sides heavily spotted with rufous; length 7.00; haunts on or near the ground; generally in 
or about shrubbery; call-note, tseep; song loul, ringing, and musical . . . . . . . . . . : 585. Fox Sparrow.

B. Back olive-green; center of crown pale rufous, bordered by black; length 6.00 ; haunts on or near the ground in woodland; a walker ; song, a ringing teacher, teacher, TEACHER, TEACIIER, TEACHER.

674. OVEN-BIRD.

III. Throat and upper breast black or slate-color, very different from the white or chestnut belly.

A. Throat black.

a. Belly and rump chestnut; head, wings, and tail black; haunts orchards, shade trees, etc.; song highly musical.

506. ORCHARD ORIOLE.

b. Belly white; sides rufous; tail black and white; haunts undergrowths; call-note, chewink or towhee. . . . . 587. TowneE.

B. Throat slate-color.

a. Back and wings slate-color; outer tail-feathers and belly white; haunts generally on or near the ground about shrubbery; Oct. to $A$ pl. . . . . . . . . . . . . 567. Junco.

IV. Throat streaked with black and white; rest of under parts rafous; upper parts grayish slate-color; length 10.00 . . . . . . 761. Rodin. 


\section{LIST OF WORKS TO WIICII REFERENCE IS MOST FREQUENTLY MADE IN THIS VOLUME.}

The Auk, a Quarterly Journal of Ornithology. Editor, J. A. Allen; Associate Editor, Frank MI. Chapman. Published for the American Ornithologists' Union. New York [35 Pine Street]: L. S. Foster.

As the official organ of the American Ornithologists' Union The Auk is the leading ornithological journal of this country. Volumes I to VIII, 1876-83, were published as the Bulletin of the Nuttall Ornithological Club (Cambridge, Mass.), the present name being adopted upon the founding of the Union. Each volume of The Auk contains about four hundred octavo pages and four colored plates; price per volume, $\$ 3$; per number, 75 cents.

Baird, S. F., Brewer, T. M., and Ridgway, R. A History of North American Birds. . . . Land Birds [Vols. I to III]. Illustrated by sixty-four colored plates and five hundred and ninety-three woodcuts. Boston: Little, Brown \& Company. 3 vols., 4to, 1874. Vol. I. Turdide-Fringillida, pp. 1-596; Vol. II. Fringillide-Picidee, pp. 1590 ; Vol. III, Strigide-Perdicidce, pp. 1-560. (Issued also with uncolored plates.) Water Birds [Vols. I and II]. Published as Vols. XII and XIII of the Memoirs of the Museum of Comparative Zoölogy (Cambrilge). Issued in continuation of the publications of the Geological Survey of California. Boston: Little, Brown \& Company. 2 vols., 4to, numerous woodents, mostly colored, 1884. Vol. I, ArdeideAnatince, pp. 1-537; Vol. II, Anatince-Alcido, pp. 1-552.

Bexdre, Charles. Life IIistories of North American Birds, with Special Reference to their Breeding IIabits and Eggs. With twelve lithographic plates. 4to, pp. i-viii : 1-414. Washington, 1892. Published as Vol. XXVIII of the Smithsonian Contributions to Knowledge, and as Special Bulletin No. 1 of the United States National Museum.

The authority upon the groups of which it treats.

Bulletin of the Nuttall Ornithological Club. A Quarterly Journal of Ornithology. Editor, J. A. Allen. Associate Editors, S. F. Baird 
and Elliott Coues. Cambridge, Mass.: Published by the Club. Vols. I to VIII, 1876-'83. (Address C. F. Batchelder, Treasurer, C'ambridge, Mass.)

Continued as The Auk, which see.

Cunaberain, Montague. A Popular Handbook of the Ornithology of the [Eastem] United States and Canada, based on Nuttall: Manual. ... Vol. I, The Land Birds, pp. i-xlviii, 1-473; Vol. II, Game and Water Birds, pp. i-vii, 1-431. 8ro, numerous illustrations.

The Code of Nomenclature and Check-List of North American Birds, adopted by the American Ornithologists' Union. Being the Report of the Committee of the Union on Classification and Nomenclature. . . New York: American Ornithologists' Union, 1886. 8ro, pp. i-viii, 1-392.

This edition is now out of print; a revised edition, without the Code of Nomenclature, will appear during the present year. An abridged edition, giving only the systematic and English names, was published in 1889 .

Coues, Elliotr. Key to North American Birds, . . . with which are incorporated General Ornithology, an Outline of the Structure and Classification of Birds; and Field Ornithology, a Manual of Collecting, Preparing, and Preserving Birds. Profusely illustrated. Boston : Estes \& Lauriat, 1884. Royal 8vo, pp. i-xxx, 1-862.

This is issued as the second edition of the "Key" published in 1872 , but is really the first edition of the new "Key." Several reprints, with an appendix giving newly described birds, recent changes in nomenclature, etc., have appeared. The influence of this work in promoting ornithological research in America can not be overestimated. To one intending to enter upon the scientific study of birds it is indispensable.

Davie, Ourver. Nest and Eggs of North American Birds. Third edition, revised and augmented. Introduction by J. Parker Norris. Columbus [Ohio]: Hann \& Adair, 1889. 8vo, pp. i-xii, 1-455. Thirteen plates.

Fisher, A. K. The Hawks and Owls of the United States in their Relation to Agriculture Prepared under the Direction of Dr. C. Hart Merriam, (hief of Division. Bulletin No. 3, Division of Ornithology and Mammalogy, United States Department of Agriculture: Washington, 1893. 8vo, pp. 1-210. Twenty-five colored plates.

Viewed from whatever standpoint, this is a model work.

Goss, N. S. History of the Birds of Kansas. Illustrating Five Hundred and Twenty-nine Birds. Topeka, Kansas: George W. Crane \& Co., 1891. Royal 8vo, pp. 1-692. Thirty-five plates. 
A work of far wider interest than the title implies. Colonel Goss studied birds in many lands, and his pages testify to the keenness of his observation.

Langille, J. Hibber't. Our Birds in their Haunts: A Popular Treatise on the Birds of Eastern North America. Boston: S. E. Cassino \& Co., 1884. 12mo, pp. 1-624.

Maynard, C. J. The Birds of Eastern North America. With Original Descriptions of all the Species which occur East of the Mississippi River between the Aretic Circle and the Gulf of Mexico, with Full Notes on their Habits, etc. Containing thirty-two plates drawn on stone by the author. Newtonville, Mass.: C. J. Maynard \& Co. 4to, pp. 1-532.

This is the final title-page; the first three parts (i-iii, 1872-'74) were issued as The Birds of Florida, ete. ; the next six (iv-ix, 1878) as The Birds of Florida with the Water and Game Birds of Eastern North America; and the concluding seven ( $\mathrm{x}-\mathrm{xvi}, 1879-92)$ with the title as quoted in full ahove.

Mrnot, II. D. The Land Birds and Game Birds of New England. with Deseriptions of the Birds, their Nests and Eggs, their Habits and Notes. With Illıstrations. Salem, Mass., Naturalists' Ageney. Boston: Estes \& Lauriat, 187\%. 8vo, pp. i-xvi, 1-456.

A second edition, edited by William Brewster, published by Houghton, Mifflin \& Co., of which I have seen advance sheets of the Editor's Appendix, is issued as these pages go to press.

Nelson, Edward W. Report upon Natural History Collections made in Alaska between the Years 1877 and 1881. . . Edited by Henry W. Henshaw. . . . No. III. Aretic Series of Publications, issued in Connection with the Signal Service, Cnited States Army. With twenty-one Plates. Washington: Government Printing Office, $188 \%$. 4to. Birds, pp. 35-226, twelve colored plates.

Ridgway, Robert. A Manual of North American Birds. Illustrated by Four IIundred and Sixty-four Drawings of the Generic Characters. Philadelphia: J. B. Lippincott Company, 188\%. Royal 8vo, pp. i-xi, 1-631. One hundred and twenty-four plates.

Our standard systematic work.

Ridgway, Robert. The Ornithology of Illinois. Part 1. Descriptive Catalogue. Vol. I [Land Birds exchusive of the Gallime]. Publisherl by authority of the State Legislature. Springfield, I1l.: II. W. Rokker, Printer and Binder, 1889. Royal 8vo, pp. i-viii, 1-520. Colored frontispiece. Thirty-two plates. 
Saunders, Howard. An Illustrated Manual of British Birds. . . . With Illustrations of nearly Every Species. London: Gurney \& Jackson, 1 Paternoster Row, 1889. 8vo, pp. i-xl, 1-754.

Thompson, Ernest E. The Birds of Manitoba. Proceedings of the United States National Museum, xiii, 1891, pp. 45\%-643. 


\section{N D E X.}

Abrreviations, list of, 40 .

Acanthis hornemannii, 284. hornemannii exilipes, 284. linaria, 284.

linaria holbollii, 285.

linaria rostrata, 285.

Accidental visitants defined, 12 .

Accipiter atricapillus, 199. cooperi, 199. velox, 198

Actitis macularia, 169.

Agialitis hiaticula, 175.

meloda, 175.

meloda circumeincta, 175.

montana, 176.

semipalnıata, 174 .

vocifera, 173.

wilsonia, $170^{\circ}$.

Estrelata hasitata, 89. scalaris, 89.

Agelaius phœniceus, 264.

phoniceus bryanti, 265.

Aix sponsa, 107 .

Ajaja ajaja, 126.

Alauda arvensis, 253.

Alaudidx, 252.

Albatross, Wandering, 86. Yellow-nosed, 86.

Alea torda, 32.

Alcedinidæe, 226.

Alcidæ, 60.

Alle alle, 64 .

American Ornithologists' Union, 32.

Ammodramus caudacutus, 295. caudacutus nelsoni, 296. caudacutus subvirgatus, 296. henslowii, 294.

lecontei, 295.

maritimus, 297.

maritimus peninsulæ, 298.

nigrescens, 298.

princeps, 291.

sandwichensis savanna, 292.

savannarum passerinus, 293.

Ampelidæ, 323.

Ampelis cedrorum, 323. garrulus, 323.

Anas americana, 103.
Anas boschas, 101. earolinensis, 104. crecea, 105. cyanoptera, 105. discors, 105 . fulvigula, 102 . obscura, 102. penelope, 103. strepera, 103.

Anatidæ, 97.

Anatinæ, 100.

Anhinga anhinga, 93.

Anhingidæ, 93.

Ani, 226 .

Anous stolidus, 85.

Anser albifrons, 122.

albifrons gambeli, 121.

Anseres, 97.

Anserinæ, 119.

Anthis pensylvanicus, 375 . pratensis, 376 . spraguei, 376 .

Antrostomus carolinensis, 236. vociferus, 237.

A phelocoma floridana, 255.

A phrizidæ, 176 .

Aquila chrysaëtos, 206.

Aramidæ, 138.

Aramus giganteus, 139.

Archibuteo ferrugineus, 206. lagopus sancti-johannis, 205.

Ardea candidissima, 134.

cinerea, 133.

coerulea, 135.

egretta, 133 .

herodias, 132.

occidentalis, 131.

pealei, 134.

rufescens, 134.

tricolor ruficollis, 135.

virescens, 136 .

wardi, 132.

wuerdemanni, 131.

Ardeidæ, 128.

Ardetta exilis, 130. neoxena, 131.

Arenaria interpres, 177.

Asio accipitriuus, 215 . 
Asio wilsonianus, 214.

Asturina plagiata, 205.

Auk, Great, 64.

Razor-billed, 63.

The, 32.

A vocet, American, 149.

Aythya attinis, 112.

americana, 110.

collaris, 112.

marila nearetica, 111.

vallisneria, 110 .

Baldpate, 103.

Bartramia longicauda, 167.

Beetlchead, 172 .

Bittern, American, 129. Cory's, 131.

Least, 130.

Bicknell, Eugene P., biographical sketches by, 281, 309, 400.

observations by, 14 .

Biographies, plan of, 38 .

Birds, collecting, 22.

color of, 4.

distribution of, 3 .

how to identify, 10 .

migration of, 5,15 .

nesting of, 3, 19 .

origin of, 3 .

sexing, 27.

skinning, 24.

study of, out-of-doors, 10.

when to find, 12.

Blackbird, Brewer's, 269.

Crow, 269, 270.

Florida Red-rving, 265.

Red-winged, 264.

Rusty, 268.

Yellow-headed, 263.

Blackbreast, 161.

Blackhead, 111.

Little, 112.

Bluebill, 111.

Little, 112.

Bluebird, 402.

Blue Peter, 146.

Bobolink, 261.

Bob-white, 178.

Florida, 179 .

Bonasa umbellus, 180.

umbellus togata, 182.

Booby, 92.

Blue-faced, 92.

Red-footed, 92 .

Botaurus lentiginosus, 129.

Brant, 123.

Black, 123.

Branta bernicla, 123.

canadensis, 122.

Branta canadensis hutchinsii, 122. canadensis minima, 122.
Branta leucopsis; 124.

nigricans, 123.

Brant-bird, $17 \%$.

Brewster, William, biographical sketches by, 142, 155 . observations by, 38.

Broadbill, 111. Creek, 112.

Bubo virginianus, 219. virginianus saturatus, 220 . virginianus subarcticus, 220 .

Bubonidæ, 213.

Buftlehead, 114.

Bull-bat, 238, 239.

Bulweria bulweri, 89 .

Bunting, Bay-winged, 290. Black-throated, 315 .

Indigo, 313.

Lark, 316.

Painted, 314.

Snow, 288.

Varied, 314.

Burgomaster, 70 .

Butcher-bird, 325.

Buteo borealis, 200.

borealis calurus, 201.

borealis harlani, 201.

borealis kriderii, 201.

brachyurus, 204.

buteo, 201.

latissimus, 204.

lineatus, 201.

lineatus alleni, 203.

swainsoni, 203.

Butter-ball, 114.

Buzzard, European, 201. Turkey, 191.

Calamospiza melanocorys, 316 .

Calcarius lapponicus, 289.

ornatus, 290.

pictus, 289.

Calico-back, 17 .

Calidris arenaria, 163 .

Callichelidon cyaneoviridis, 322 .

Campephilus principalis, 229.

Camptolaimus labradorius, 115.

Canary, Wild, 353.

Canvasback, 110.

Caprimulgidæ, 236.

Caracara, Audubon's, 211.

Cardinal, 311.

Cardinalis cardinalis, 311.

Carduelis carduelis, 287.

Carpodacus purpureus, 281.

Cataloguing birds, 28 .

Catbird, 378 .

Catharista atrata, 192.

Cathurtes aura, 191.

Cathartidø, 191.

Cedar-bird, 323. 
Ceophlœus pileatus, 233.

Cepphus grylle, 61.

mandtii, 62.

Certhia familiaris americana, 385.

Certhiidæ, 385.

Ceryle alcyon, 226 .

Chrtura pelagica, 239.

Charadriidæ, 171.

Charadrius apricarius, 173. dominieus, 173. squatarola, 172.

Charitonetta albeola, 114.

Chat, Yellow-breasted, 372.

Chebec, 251.

Chelidon ery throgaster, 320.

Chen corulescens, 121.

hyperborea, 120 . nivalis, 120.

Cherry-bird, 323.

Chewink, 310.

Chickadee, 390.

Carolina, 391.

Hudsonian, 391.

Chippy, 302. Winter, 301.

Chondestes grammacus, 299.

Chordeiles virginianus, 238 . virginianus chapmani, 239. virginianus henryi, 239.

Chuck-will's-widow, 236.

Ciconiidæ, 127.

Circus hudsonius, 197.

Cistothorus palustris, 384 . palustris griseus, 385 . palustris marianæ, 385 . stellaris, 383 .

Clangula hyemalis, 114.

Clape, 235.

Clivicola riparia, 322.

Cocothraustes vespertinus, 279 .

Coccyges, 224.

Coccyzus americanus, 225. erythropthalmus, 226. minor, 224.

minor maynardi, 225.

Coereba bahamensis, 333 .

Colaptes auratus, 235.

Colinus virginianus, 178. virginianus floridanus, 179 .

Collecting birds, 23. egrss, 29 . nests, 29.

Collections, care of, 29.

Color chart, 39.

Columba leucocephala, 187.

Columbæ, 187.

Columbidæ, 187.

Columbigallina passerina terrestris, 190.

Colymbus auritus, 3 . holballii, 56 .
Compsothlypis americana, 352.

Contopus borealis, 246.

virens, $24 \pi$.

Conurus carolinensis, 222.

Coot, American, 146.

Black, 117.

European, 147.

Sea, 118.

White-winged, 118.

Cormorant, 94 .

Double-crested, 94.

Florida. 95.

Mexican, 95.

Corvidæ, 253.

Corvus americanus, $25 \%$.

americanus floridanus, 258.

corax principalis, 256.

ossifragus, 258.

Coturnix coturnix, 180.

Courlan, 139.

Cowbird, 262.

Crake, Corn, 144.

Spotted, 144.

Crane, Blue, 132.

Brown, 138.

Little Brown, 138.

Sandhill, 132, 138.

White, 137.

Whooping, 137.

Creeper, Bahama Honey, 333.

Black and White, 343 .

Brown, 385.

Crex crex, 144.

Crossbill, American, 283.

Red, 283.

White-winged, 283.

Crotophaga ani, 226.

Crow, American, 257.

Fish, 258.

Florida, 258.

Crying-bird, 139.

Crymophilus fulicarius, 147.

Cuckoo, Black-billed, 226.

Mangrove, 224.

Maynard's, 225.

Yellow-billed, 225.

Cuculidæ, 224.

Curlew, Eskimo, 170.

Hudsonian, 170 .

Jack, 170.

Long-billed, 170.

Pink, 126.

Spanish, 126.

Cyanocitta cristata, 254.

cristata florincola, 255 .

Cygninæ, 124.

Cymodroma grallaria, 91.

DABCHICK, 57.

Dafila acuta, 106.

Definition of terms, 32 . 
Dendragapus canadensis, 180.

Dendroica aestiva, 353.

auduboni, 3556 .

blackburniæ, 360 .

cærulea, 357.

cærulescens, 354.

castanea, 358.

colonata, 355 .

(iiscolor, 364 .

dominica, 361.

dominica albilora, 361.

kirtlandi, 362.

maculosa, 356 .

palmarum, 363.

palmarum hypochrysea, 364 .

pensylvanica, 357 .

striata, 359 .

tigrina, 352 .

townsendi, 362 .

vigorsii, 363.

virens, 361 .

Dickcissel, 315.

Diedapper, 57.

Diomedea exulans, 86 .

Diomedeidæ, 86.

Diving birds, 56 .

Dolichonyx oryzivorus, 261.

Doughbird, 170.

Dove, Blue-headed Quail, 191.

Ground, 190.

Mourning, 188, 190.

Quail, 190.

Kuddy Quail, 191.

Sea, 64.

White-winged, 190.

Zenaida, 189.

Dovekie, 64.

Dowiteher, 155 .

Long-billed, 156.

Western, 156.

Dryobates borealis, 231 .

pubescens, 230.

villosus, 229 .

villosus audubonii, 230.

villosus leucomelas, 230

Duck, American Scaup, 111.

Black, 102

Broad-bill, 111.

Crow, 146.

Dusky, 102.

Florida, 102.

Gray, 103.

Greater Scaup, 111.

Harlequin, 115 .

Labrador, 115.

Lesser Scaup, 112.

Masked, 119 .

Pied, 115 .

Ring-necked, 112.

Ruddy, 119.

Rufous-crested, 109.
Duck, Scaup, 111.

Spirit, 114.

Steller's, 116.

Wood, 107.

Dunlin, 161.

Dutcher, William, observations by, 38.

Dwight, J., Jr., biographical sketches by, $248,250,268,290,293,296,297$, 308,399 .

EAGLe, Bald, 207.

Golden, 206.

Gray Sea, 207.

Eetopistes migratorius, 187.

Eggs, collecting, 29. descriptions of, 38 : preserving, 30 .

Egret, American, 133. Peale's, 134.

Reddish, 134.

Snowy, 134.

Eider, American, 116. Greenland, 116.

King, 116.

Elanoides forficatus, 196.

Elanus leucurus, 196.

Empidonax acadicus, 249.

flaviventris, 248 .

mininıus, 251.

pusillus, 251 .

traillii, 250.

traillii alnorum, 251.

virescens, $24 \%$.

Eniconetta stelleri, 116.

Ereunetes pusillus, 161. occidentalis, 162.

Erismatura rubida, 119.

Euetheia bicolor, 315 . canora, 31 .

Falco columbarius, 210. islandus, 208. mexicanus, 209. peregrinus anatum, 209. regulus, 211.

rusticolus, 208. rusticolus gyrfalco, 209. rusticolus obsoletus, 209. sparverioides, 211. sparverius, 211. tinnunculus, 211.

Falcon, Peregrine, 210. Prairic, 209.

Falconidæ, 193.

Feathers, markings of, 32.

Field-glass, use of, 11.

Finch, Grass, 290.

Lark, 299.

Pine, 287.

Purple, 281. 
Firebird, 267.

Fisher, Dr. A. K., observations by, 38.

Flamingo, 125.

Flicker, 235.

Florida Yellow-throat, 371.

Flycatcher, Acadian, 249.

Alder, 251.

Crested, 244.

Fork-tailed, 243.

Great-crested, 244.

Least, 251.

Olive-sided, 246.

Scissor-tailed, 243.

Traill's, 250.

Yellow-bellied, 248.

Fratercula aretica, 60 . arctica glacialis, 61 .

Fregata aquila, 97.

Fregatidæ, 97.

Frigate-bird, 97.

Fringillidæ, 271.

Fulica americana, 146. atra, 147.

Fuligulinæ, 10 \%.

Fulmar, 87. Lesser, 87.

Fulmarus glacialis, 87. glacialis minor, 87 .

Fute, 170 .

Gadwall, 103.

Galeoscoptes carolinensis, 378.

Gallinæ, 178.

Gallinago delicata, 154 . gallinago, 155.

Gallinula galeata, 145.

Gallinule, Florida, 145. Purple, 145.

Gannet, 92.

Gavia alba, 68.

Gelochelidon nilotica, 78 .

Geothlypis agilis, 369. formosa, 368 . philadelphia, 370 . trichas, 371. trichas ignota, 371 .

Geotrygon martinica, 190. montana, 191.

Glaucionetta clangula americana, 113. islandica, 113.

Gnateateher, Blue-gray, 394.

Goatsuckers, 236.

Godwit, Black-tailed, 164. Hudsonian, 164.

Marbled, 163.

Golden-eye, American, 113. Barrow's, 113.

Goldfinch, American, 286. Black-headed, 287.

European, 287.
Goosander, 98.

Goose, American White-fronted, 121.

Barnacle, 124.

Blue, 120.

Cackling, 122.

Canada, 122.

European White-fronted, 122.

Greater Snow, 120.

Hutchins's, 122.

Lesser Snow, 120.

Goshawk, American, 199.

Grackle, Mexican, 205.

Boat-tailed, 271.

Bronze, 270.

Florida, 270.

Purple, 269.

Grassquit, 315.

Melodious, 315.

Greenback, 173.

Greenshank, 165.

Grebe, Holbœell's, 56.

Horned, 57.

Pied-billed, 57.

Grosbeak, Black-headed, 313.

Blue, 313.

Evening, 279.

Pine, 280.

Rose-breasted, 312.

Grouse, Canada, 180.

Canadian Ruffed, 182.

Prairie Sharp-taled, 185.

Ruffed, 180.

Gruidæ, 137.

Grus americana, 137. canadensis, 138. mexicana, 138.

Guara alba, 126. rubra, 127.

Guillemot, Black, 61.

Mandt's, 62.

Guiraca cærulea, 313.

Gull, American Herring, 72.

Black-headed, 74 .

Bonaparte's, 75 .

European, 73.

Franklin's, 74.

Glaucous, 70.

Great Black-backed, 71 .

Iceland, 71 .

Herring, 72 .

Ivory, 68 .

Kumlien's, 71.

Laughing, 74 .

Little, 76 .

Mew, 74 .

Ring-billed, 73 .

Ross's, 76.

Sabine's, 76 .

Siberian, 72.

Gun, kind of, 23.

load for, 24. 
Gyrfalcon, 209.

Black, 209.

Gray, 208.

White, 208.

Habia LUdoviciana, 312. melanocephala, 313.

Hæmatopodidr, 177.

Hæmatopus ostralegus, 177. palliatus, 177.

Hagdon, 88. Black, 89.

Haliæetus albicilla, 207. leucocephalus, 207.

Hang-nest, 267.

Harporhyncus rufus, 379 .

Harrier, 197.

Hawk, American Rough-legged, 205. American Sparrow, 211.

Broad-winged, 204.

Chicken, 200, 201.

Cooper's, 199.

Cuban sparrow, 211.

Duck, 209.

Ferruginous Rough-leg, 206.

Fish, 212.

Florida Red-shouldered, 203.

Harlan's, 201.

Hen, 200, 201.

Killy, 211.

Krider's, 201.

Marsh, 197.

Pigeon, 210.

Red-shouldered, 201.

Red-tailed, 200.

Rough-legged, 205.

Sharp-shinned, 198.

Short-tailed, 204.

Snail, 197.

Sparrow, 211.

Swainson's, 203.

Heath Hen, 185.

Helinaia swainsonii, 345 .

Hell Diver, 57.

Helminthophila bachmani, 346 .

celata, 350 .

chrysoptera, 348 .

lawrencei, 348 .

leucobronchialis, 347 .

peregrina, 350.

pinus, 347.

ruficapilla, 349 .

Helmitherus vermivorus, 345 .

Hen, Heath, 185.

Hen, Prairie, 184.

Herodiones, 125.

Heron, Black-crowned Night, 136.

European Great Blue, 133.

Great Blue, 132.

Great White, 131.

Green, 136.
Heron, Little Blue, 135.

Little Green, 136.

Louisiana, 135.

Snowy, 134 .

Ward's, 132.

Würdemann's, 131.

Yellow-crowned Night, 137.

Hesperocichla nevia, 402 .

High-hole, 235.

Himantopus mexicanus, 150 .

Hirundinidæ, 318.

Histrionicus histrionicus, 115.

Honey Creeper, Bahama, 333.

Hummingbird, Ruby-throated, 241.

Hydrochelidon leucoptera, 85. nigra surinamensis, 84 .

IBIDID E, 126.

Ibis, Glossy, 127.

Scarlet, 127.

White, 126.

White-faced Glossy, 127.

Wood, 128.

Icteria virens, 372 .

Icteridæ, 260.

Icterus bullocki, 268 .

galbula, 267.

icterus, 266.

spurius, 266.

Ietina mississippiensis, 196.

Illustrations, 39 .

Indigo-bird, 313.

Ionornis martinica, 145.

JAEGER, LoNG-TAILED, 66.

Parasitic, 66.

Pomarine, 65.

Jay, Blue, 254.

Canada, 256.

Florida, 255.

Florida Blue, 255

Labrador, 256.

Joree, 310.

Journals, 21.

Junco, 304.

Carolina, 305.

hyemalis, 304 .

hyemalis carolinensis, 305 .

hyemalis shufeldti, 305 .

Shuf'eldt's, 305.

Slate-colored, 304.

Kestrel, 211.

Keys, use of, 32.

Killdeer, 173.

Kingbird, 243.

Arkansas, 244.

Gray, 244.

Kingtisher, Belted, 226.

Kinglet, Ruby-crowned, 393.

Golden-crowned, 392. 
Kite, Everglade, 197.

Mississippi, 196.

Swallow-tailed, 196.

White-tailed, 196.

Kittiwake, 69.

Knot, 157.

Krieker, 158.

LABELING BIRDS, 28.

Labels, 28.

Lagopus lagopus, 182.

lagopus alleni, 182.

rupestris, 182.

rupestris reinhardti, 183.

welchi, 183.

Lamellirostral Grallatores, 125.

Swimmers, 97.

Lanius borealis, 325 .

ludovicianus, 325 .

ludovicianus excubitorides, 326.

Laniidæ, 325.

Lapwing, 172.

Lark, Field, 265.

Horned, 252.

Meadow, 265.

Prairie, 266.

Prairie Horned, 252.

Shore, 252.

Western Meadow, 266.

Laridæ, 67.

Larinæ, 67.

Larus affinis, 72.

argentatus, 73 .

argentatus smithsonianus, 72 .

atricilla, 74 .

canus, 74 .

delawarensis, 73 .

franklini, 74 .

glaucus, 70 .

kumlieni, 71.

leucopterus, 71 .

marinus, 71 .

minutus, 76 .

philadelphia, 75 .

Leadback, 160.

Limicolæ, 147.

Limosa fedoa, 163.

hæmastica, 164.

limosa, 164.

Limpkin, 139.

Loggerhead, 325.

Longipennes, 65.

Longspur, Chestnut-collared, 290. Lapland, 289.

McCown's, 290.

Sinith's, 289.

Long-winged Swimmers, 65 .

Loon, 58.

Black-throated, 59.

Red-throated, 59.

Lophodytes cucullatus, 99.
Loxia curvirostra minor, 283. leucoptera, 283.

Macrorhampus griseus, 155. scolopaceus, 156.

Macrochires, 236.

Magpie, 255.

Mallard, 101.

Man-of-War Bird, 97.

Marsh Hen, 129, 140.

Marlin, Brown, 163. King-tailed, 164.

Martin, Cuban, 319. Purple, 319.

Maryland Yellow-throat, 371.

Meadowlark, 265. W estern, 266.

Measurements of birds, 37 .

Megalestris skua, 65 .

Megascops asio, 218. asio tloridanus, 219.

Melanerpes carolinus, 234. erythrocephalus, 233.

Meleagris gallopavo, 186. gallopavo osceola, 186.

Melopelia leucoptera, 190.

Melospiza fasciata, 306. georgiana, 308.

lincolni, 307 .

Merganser americanus, 98. serrator, 99.

Merganser, American, 98. Hooded, 99.

Red-breasted, 99.

Merginæ, 98.

Merlin, 211.

Merriam, Florence A., biographical sketches by, $245,304,314,317,324$, 382.

Merula migratoria, 401.

Micropalama himantopus, 156.

Micropodidæ, 239.

Migration of birds, 5 . tables of, 15 .

Milvulus forficatus, 243. tyrannus, 243.

Miller, Olive 'Thorne, biographical sketches by, 243, 311, 379.

Mimus polyglottos, 377 .

Mniotilta varia, 343.

Mniotiltidæ, 333.

Mockingbird, 377.

Molothrus ater, 262.

Moose-bird, 256.

Motacilla alba, 376 .

Motacillidæ, 375.

Mother Carey's Chicken, 91.

II ud Ilen, 146.

Murre, 62 .

Brünnich's, 63.

Myiarchus crinitus, 244. 
Nesting season, 13, 19, 20.

Nests, collecting, 29. descriptions of, 38 . preserving, 31.

Netta rutina, 109.

Night Hawk, 238. Florida, 239.

Western, 239.

Noddy, $85,87$.

Nomenclature, 5, 32.

Nomonyx dominicus, 119.

Nonpareil, 314.

Note-books, 21.

Numenius borealis, 1 to

hudsonicus, 170 .

longirostris, 170 . phæopus, 171.

Nuthatch, Brown-headed, 388. Florida White-breasted, 388.

Red-breasted, 388.

White-breasted, 387.

Nyctala acadica, 217. tengmalmi richardsoni, 217.

Nyctea nyctea, 220.

Nyeticorax nyeticorax nævius, 136. violaceus, 137.

Oceanites oceanicus, 90.

Oceanodroma leucorhoa, 89 .

Odontoglossæ, 125.

Oidemia americana, 117.

deglandi, 118.

fusca, 118.

perspicillata, 118.

Old squaw, 114.

Wife, 114.

Olor buceinator, 124

columbianus, 124.

cygnus, 125.

Opera-glass, use of, 11.

Oriole, Baltimore, 267.

Bullock's, 268.

Orchard, 266.

Ornithology, economic, 6 .

philosophic, 3.

sentiment of, 8 .

study of, 1.

systematic, 2.

Osprey, American, 212.

Otocoris alpestris, 252.

alpestris praticola, 252 .

Oven-bird, 365 .

Owl, Acadian, 217.

American Barn, 213.

American Hawk, 221.

American Long-eared, 214.

Barn, 213.

Barred, 215.

Burrowing, 221.

Dusky-horned, 220.

Florida Barred, 216.
Owl, Florida Burrowing, 221.

Florida Screech, 218.

Great Gray, 217.

Great Horned, 219.

Hawk, 221.

Hoot, 215.

Long-eared, 214.

Monkey-faced, 213.

Richardson's, 217.

Saw-whet, 217.

Screech, 218.

Short-eared, 215.

Snowy, 220.

Western Horned, 220.

Oxeye, Meadow, 160.

Sand, 161.

Oyster-catcher, American, 177.

European, 177.

Palmetto Bird, 371.

Paludicolæ, 137.

Pandion haliaëtus carolinensis, 212.

Paridæ, 386.

Paroquet, Carolina, 222.

Parrot, Sea, 60.

Partridge, 178, 179, 180, 182. Spruce, 180.

Parus atricapillus, 390. bicolor, 389.

carolinensis, 391.

hudsonicus, 391.

Passer domesticus, 282. montanus, 283.

Passerella iliaca, 309.

Passeres, 242.

Passerina ciris, 314. cyanea, 313.

versicolor, 314.

Pavoncella pugnax, 167.

Peabody-bird, 300.

Pediocæetes phasianellus campestris, 185.

Peep, 160, 161.

Pelagodroma marina, 91.

Pelecanidie, 95.

Pelecanus erythrorhynchus, 95 .

fuscus, 96 .

Pelican, Brown, 96.

White, 95.

Perisoreus canadensis, 256.

canadensis nigricapillus, 256 .

Permanent residents defined, 12. list of, 13.

Petrel, Black-capped, 89.

Bulwer's, 89.

Leach's, 89.

Scaled, 89.

Stormy, 89.

White-bellied, 91.

White-faced, 91.

Wilson's, 90. 
Petrochelidon fulva, 320. lunifrons, 320.

Peucsea restivalis, 305. restivalis bachmanii, 305 .

Pewee, Wood, 247.

Phaëthon æthereus, 91. flavirostris, 91.

Phaëthontidæ, 91.

Phalacrocoracidæ, 94.

Phalacrocorax carbo, 94. dilophus, 94. dilophus floridanus, 95 . mexicanus, 95.

Phalarope, Gray, 147. Northern, 148. Red, 147. Wilson's, 148.

Phalaropodidæ, 147.

Phalaropus lobatus, 148. tricolor, 148.

Phasianidæ, 185.

Philohela minor, 153.

Phoebe, 245. Say's, 246.

Phœenicopteridæ, 125.

Phonicopterus ruber, 125.

Pica pica hudsonica, 255.

Pici, 227.

Y'icidæ, $22 \%$.

Picoides americanus, 232. areticus, 231.

Pigeon, Passenger, 187. Sea, 61 .

White-crowned, 187.

Wild, 187.

Pinicola enucleator, 280.

Pintail, 106.

Pipilo ery throphthalmus, 310. erythrophthalmus alleni, 310.

Pipit, American, 375.

Meadow, 376.

Sprague's, 376.

Piranga ery thromelas, 317.

ludoviciana, 318.

rubra, 317.

Plataleidæe, 125.

Plautus impennis, 64.

Plectrophenax nivalis, 288.

Plegadis autumnalis, 127. guarauna, 127.

Plover, American Golden, 173.

Belted Piping, 175.

Black-bellied, 172.

European Golden, 173.

Field, 167.

Golden, 173.

Mountain, 176 .

Piping, 175 .

Ring, 175 .

Semipalmated, 174.

Upland, 167.
Plover, Wilson's, 176.

Podicipida, 56.

Podilymbus podiceps, 57 .

Poke, 136.

Polioptila cærulea, 394.

Polyborus cheriway, 211.

Poocretes gramineus, 290.

Porzana carolina, 143.

jamaicensis, 144.

noveboracensis, 144 .

porzana, 144.

Prairie Hen, 184.

Procellaria pelagica, 89 .

Procellariidæ, 86 .

Progne cryptoleuca, 319. subis, 319.

Protonotaria citrea, 344.

Psittaci, 222.

Psittacidæ, 222.

Ptarmigan, Allen's, 182.

Greenland, 183.

Reinhardt's, 183.

Rock, 182.

Welch's, 183.

Willow, 182.

Puftin, 60.

Large-billed, 61.

Puttinus auduhoni, 88.

borealis, 88 .

major, 88 .

puffinus, 88 .

stricklandi, 89.

Pygopodes, 56.

Quart, 178, 179.

European, 180.

Migratory, 180.

Quawk, 136.

Quiscalus major, 271.

quiscula, 269.

quiscula seneus, 270 .

quiscula aglæus, 270.

RACES, gEOgRAPIICAL, 4 .

Rail, Black, 144.

Carolina, 143.

Clapper, 140.

Florida Clapper, 141.

King, 140.

Little Black, 144.

I. ouisiana Clapper, 141.

Virginia, 141.

Yellow, 144.

Rallidæ, 139.

Rallus elegans, 140.

longirostris erepitans, 140.

longirostris saturatus, 141.

longirostris scottii, 141 .

virginianus, 141 .

Range of birds, 37.

Raptores, 191. 
Raven, Northern, 256.

Recurvirostra americana, 149.

Recurvirostridæ, 149.

Redback, 161.

Redhead, 110.

Redpoll, 284.

Greater, 285.

Greenland, 281.

Hoary, 284.

Holboll's, 285.

Redstart, 374 .

Redtail, Western, 201.

Reedbird, 261.

Regulus calendula, 393. satrapa, 392.

Rhodostethia rosea, 76 .

Rhyncophanes mecownii, 290.

Rice-bird, 261.

Richmond, C. W., observations by, 37 .

Ring-neck, 174.

Rissa tridactyla, 69.

Robin, American, 401. Golden, 267.

Rostrhamus sociabilis, 197.

Rutt, 167.

Rynchopidæ, 85.

Rynchops nigra, 86 .

SADDLEBACK, 71 .

Sanderling, 163.

Sandpiper, Baird's, 159.

Bartramian, 167.

Buff-breasted, 168.

Curlew, 161.

Green, 165.

Least, 160.

Pectoral, 158.

Purple, 157.

Red-backed, 160.

Semipalmated, 161.

Solitary, 166.

Spotted, 169.

Stilt, 156.

Western Semipalmated, 162.

White-rumped, 158.

Sapsucker, Y ellow-bellied, 232.

Saxicola onanthe, 402.

sayornis phobe, 245. saya, 246.

Seissor-bill, 86.

Scolecophagus carolinus, 268. cyanocephalus, 269.

Scolopacidre, 150.

Scolopax rusticola, 154 .

Scoter, American, 117.

Surf, 118.

Velvet, 118.

White-winged, 118.

Scotiaptex cinereum, 217.

Sea Parrot, 60.

Sea Pigeon, 61.
Sea Swallow, 80.

Seiurus aurocapillus, 365 . motacilla, 368. noveboracensis, 367 .

noveboracensis notabilis, 368 .

Setophaga ruticilla, 374 .

Sexing birds, 27.

Sexual organs, 28.

Shag, 94 .

Shearwater, Audubon's, 88.

Cory's, 88.

Greater, 88.

$\operatorname{Manx}, 88$.

Sooty, 88.

Shelldrake, 98, 99.

Shore Birds, 147.

Shoveler, 105.

Shrike, Loggerhead, 325.

Northern, 325.

Sialis sialis, 402 .

Sickle-bill, 170 .

Siskin, Pine, 287.

Sitta canadensis, 388. carolinensis, 387. carolinensis atkinsi, 388. pusilla, 388.

Skimmer, Black, 86.

Skinning birds, 24.

Skua, 65.

Skylark, 253.

Snakebird, 93.

Snipe, English, 154.

European, 155.

Grass, 158.

Gray, 157.

Robin, 157.

Rock, 158.

Surf, 163 .

Wilson's, 154

Winter, 158.

Snowtlake, 288.

Somateria dresseri, 116.

mollissima borealis, 116 . spectabilis, 116 .

Song season, 14.

Sora, 143.

South Southerly, 114.

Sparrow, Acadian Sharp-tailed, 296.

Bachman's, 305.

Brewer's, 303.

Chipping, 302.

Clay-colored, 303.

Dusky Seaside, 298.

English, 282.

European 'Tree, 283.

Field, 303.

Fox, 309.

Grasshopper. 293.

Henslow's, 294.

House, 282.

Ipswich, 291. 
Sparrow, Lark, 299.

Leconte's, 295.

Lincoln's, 307.

Nelson's Sharp-tailed, 296.

Pine-woods, 305.

Savanna, 292.

Scott's Seaside, $29 \mathrm{~S}$.

Seaside, 297.

Sharp-tailed, 295.

Song, 306.

Swamp, 308.

'I'ree, 301.

Vesper, 290.

Western Field, 304.

White-crowned, 299.

White-throated, 300.

Yellow-winged, 293.

Spatula clypeata, 105 .

Speoty to cunicularia floridana, 221. cunicularia hypogæa, 221.

Sphyrapicus varius, 232.

Spinus notatus, 287.

pinus, 287.

tristis, 286.

Spiza americana, 315 .

Spizella breweri, 303.

monticola, 301.

pallida, 303.

pusilla, 303.

pusilla arenacea, 804.

socialis, 302.

Spoonbill, Roseate, 126.

Sprigtail, 106.

Spring migration, 15.

Starling, 259.

Starnoenas eyanocephala, 191.

Steganopodes, 91.

Stelgidopteryx serripennis, 322.

Stercorariidre, 65.

Stercorarius longicaudus, 66 .

parasiticus, 66 . pomarinus, 66 .

Sterna anæthetus, 84 .

antillarum, 84 .

dougalli, 83.

forsteri, 80 .

fuliginosa, 84 .

hirundo, 81 .

maxima, 79 .

paradisæa, 82 .

sandvicensis acuflavida, 80 .

trudeaui, 80 .

tschegrava, 79 .

Sterninæ, 76.

Stilt, Black-necked, 150.

Stone-chat, 402.

Strigidæ, 213.

Strix pratincola, 213.

Sturnella magna, 265. magna neglecta, 266.

Sturnidx, 259.
Sturnus vulgaris, 259.

Sula bassana, 92.

cyanops, 92 .

sula, 92.

piscator, 92 .

Sulidæ, 92.

Summer residents defined, 12.

list of, 18.

Surnia ulula caparoch, 221.

Swallow, Bahama, 322.

Bank, 322.

Barn, 320.

Chimney, 239.

Cliff, 320.

Cuban Cliff, 320.

Eave, 320.

Rough-winged, 322.

'Tree, 321.

White-bellied, 321.

Swan, 'Trumpeter, 124.

Whistling, 124.

Whooping, 125.

Swift, Chimney, 239.

Sylvania canadensis, 374 .

mitrata, 372.

pusilla, 373.

Sylviidæ, 391.

Symphemia semipalmata, 166 . semipalmata inornata, 167.

Syrnium nebulosum, 215. nebulosum alleni, 216 .

TACHYCINETA BICOLOR, 321.

'Tanager, Louisiana, 318.

Scarlet, 317.

Summer, 317.

'Tanagridæ, 316 .

Tantalus loculator, 128.

Taxidermy, 27.

Teal, Blue-winged, 105.

Cinnamon, 105.

European, 105.

Green-winged, 104.

Terms used in description, 32 .

Tern, Aretic, 82.

Black, 84.

Bridled, 84.

Cabot's, 80.

Caspian, 79.

Conmon, 81 .

Forster's, 80 .

Gull-billed, 78 .

Least, 84 .

Marsh, 78.

Roseate, 83.

Royal, 79.

Sooty, 84.

Trudeau's, 80.

White-winged Black, 85.

Wilson's, 81 .

Tetraonidæ, 178. 
Thalassogeron culminatus, 86 .

Thistle-bird, 286.

Thompson, Ernest E., biographical sketches by, 181, 197, 253, 256, $280,285,289,300,306,325,369$, 383.

Thrasher, Brown, 379.

'Thrush, Alice's, 397.

Bicknell's, 398.

Brown, 379.

Golden-crowned, 365.

Gray-cheeked, 397.

Grinnell's Water, 368.

Hermit, 400.

Louisiana Water. 368.

Olive-backed, 398.

Red-winged, 401.

Varied, 402 .

Water, 367.

Willow, 397.

Wilson's, 396.

Wood, 395.

Thryothorus hewickii, 381.

ludovicianus, 380 .

ludovicianus miamensis, 381 .

Tinker, 63.

Titlark, 375 .

'Titmouse, Tufted, 389.

Torrey,Bradford, biographical sketches by, $129,243,331$.

Totanus Havipes, 165.

melanoleucus, 164.

nebularius, 165 .

ochropus, 165.

solitarius, 166 .

'Totipalmate Swimmers, 91.

Towhee, 310.

White-eyed, 310.

Transient visitants defined, 12.

Tringa alpina, 161.

alpina pacifica, 160 .

bairdii, 159.

canutus, 157.

ferruginea, 161 .

fuscicollis, 158.

maritima, 157.

maculata, 158.

minutilla, 160 .

Trochilidæ, 240.

Trochilus colubris, 241.

Troglodytes aëdon, 381 .

aêdon aztecus, 382.

hiemalis, 382.

Troglody tidæ, 376 .

Tropic-bird, Red-billed, 91. Yellow-billed, 91.

Troupial, 266.

'T'ryngites subruficollis, 168.

'T'ube-nosed Swimmers, 86 .

Tubinares, 86 .

T'urdidæ, 394.
Turdus aliciæ, 397.

aliciæ bicknelli, 398.

aonalaschkæ pallasii, 400 .

fuscescens, $396^{\circ}$.

fuscescens salicicolus, 397.

iliacus, 401.

mustelinus, 395 .

ustulatus swainsonii, 398.

'Turkey, Water, 93.

Florida Wild, 186.

Wild, 186.

Turnstone, 177.

Tympanuchus americanus, 184. cupido, 185.

Tyrannidæe, 242.

Tyrannus dominicensis, 244. tyrannus, 243. verticalis, 241.

Uria LOMVIA, 63. troile, 62.

Urinator arcticus, 59 .

imber, 58.

lumme, 59.

Urinatoridæe, 58 .

VANellus vanellus, 172.

Veery, 396.

Vireo belli, 332 .

calidris barbatulus, 327 .

flavifrons, 330 .

flavoviridis, 329 .

gilvus, 329.

noveboracensis, 332 .

noveborucensis maynardi, 332.

olivaceus, 328.

philadelphicus, 329.

solitarius, 331.

solitarius alticola, 331 .

solitarius plumbeus, 331 .

Vireo, Bell's, 332.

Black-whiskered, 327.

Blue-headed, 331.

Key West, 332.

Mountain Solitary, 331.

Philadelphia, 329.

Plumbeous, 331.

Red-eyed, 328.

Warbling, 329.

White-eyed, 332.

Yellow-green, 329.

Yellow-throated, 330.

Vireonidæ, 327.

Vulture, Black, 192.

T'urkey, 191.

W AGtaIL, White, 376.

W arbler, Audubon's, 356.

Bachman's, 346.

Bay-breasted, 358.

Black and White, 343 . 
Warbler, Black and Yellow, 356.

Blackburnian, 360 .

Blackpoll, 359.

Black-throated Blue, 354.

Black-thiroated Green, 361.

Blue-winged, 347.

Blue Yellow-backed, 352.

Brewster's, 34?.

Canadian, 374.

Cape May, 352.

Cerulean, 357.

Chestnut-sided, 357.

Connecticut, 369.

Golden-winged, 348.

Hooded, 372 .

Kentucky, 368.

Kirtland's, 362.

Lawrence's, 348.

Magnolia, 356.

Mourning, 370.

Myrtle, 355 .

Nashville, 349.

Orange-crowned, 350.

Palm, 363.

Parula, 352.

Yine, 363.

Prairie, 364.

Prothonotary, 344.

Redpoll, 363.

Summer Yellow, 353.

Swainson's, 345 .

Sycamore, 361.

Tennessee, 350.

Townsend's, 362.

Wilson's, 373.

Worm-eating, 345.

Yellow, 353.

Yellow-palm, 364.

Yellow Redpoll, 364.

Yellow-rumped, 355.

Yellow-throated, 361.

Water Witch, 57.

Waxwing, Bohemian, 323. Cedar, 323.

Wheatear, 402.

Whimbrel, 171.

Whip-poor-will, 237.

Whisky Jack, 256.

Whistler, 113.
Widgeon, American, 103.

European, 103.

Willet, 166.

Western, 16 个.

Winter visitants defined, 12.

list of, 13.

Woodcock, American, 153.

European, 154.

Woodpecker, American Three-tocd, 232.

Arctic Three-toed, 231.

Downy, 230.

Golden-winged, 235.

Hairy, 229.

Ivory-billed, 229.

Pileated, 233.

Red-bellied, 234.

Red-cockaded, 231.

Red-headed, 233.

Southern Hairy, 230.

Wren, Bewick's, 381.

Carolina, 380.

Florida, 381.

House, 381.

Long-billed Marsh, 384.

Marian's Marsh, 385.

Mocking, 380.

Short-billed Marsh, 383.

Western House, 382 .

Winter, 382.

Worthington's Marsh, 385.

Xanthocephalus Xanthocephalus, 263.

Xema sabinii, 76.

YELLOW-BIRD, 286.

Yellow-hammer, 235.

Yellow-legs, 165.

Greater, 164.

Lesser, 165.

Summer, 1 ti5.

Yellow-throat, Florida, 371.

Marylaud, 371.

Zenaida Zenaina, 189.

Zenaidura macroura, 188.

Zonotrichia albicollis, 300 . leucophrys, 299. 







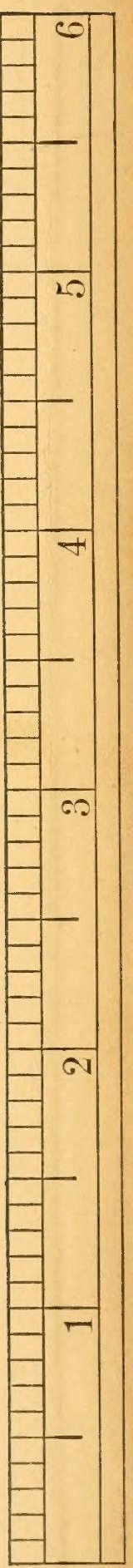


